\title{
De Grondwet en delegatie : het delegatievraagstuk in constitutioneel perspectief
}

Citation for published version (APA):

Derks, J. M. E. (1995). De Grondwet en delegatie : het delegatievraagstuk in constitutioneel perspectief. [Doctoral Thesis, Maastricht University]. Koninklijke Vermande. https://doi.org/10.26481/dis.19951116jd

Document status and date:

Published: 01/01/1995

DOI:

10.26481/dis.19951116jd

Document Version:

Publisher's PDF, also known as Version of record

\section{Please check the document version of this publication:}

- A submitted manuscript is the version of the article upon submission and before peer-review. There can be important differences between the submitted version and the official published version of record.

People interested in the research are advised to contact the author for the final version of the publication, or visit the DOI to the publisher's website.

- The final author version and the galley proof are versions of the publication after peer review.

- The final published version features the final layout of the paper including the volume, issue and page numbers.

Link to publication

\footnotetext{
General rights rights.

- You may freely distribute the URL identifying the publication in the public portal. please follow below link for the End User Agreement:

www.umlib.nl/taverne-license

Take down policy

If you believe that this document breaches copyright please contact us at:

repository@maastrichtuniversity.nl

providing details and we will investigate your claim.
}

Copyright and moral rights for the publications made accessible in the public portal are retained by the authors and/or other copyright owners and it is a condition of accessing publications that users recognise and abide by the legal requirements associated with these

- Users may download and print one copy of any publication from the public portal for the purpose of private study or research.

- You may not further distribute the material or use it for any profit-making activity or commercial gain

If the publication is distributed under the terms of Article $25 \mathrm{fa}$ of the Dutch Copyright Act, indicated by the "Taverne" license above, 
DE GRONDWET EN DELEGATIE

HET DELEGATIEVRAAGSTUK

IN CONSTITUTIONEEL PERSPECTIEF 


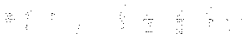

$\begin{array}{lll}- & +\quad \\ \cdots & +\end{array}$ 


\section{De Grondwet en delegatie}

\section{Het delegatievraagstuk in constitutioneel perspectief}

PROEFSCHRIFT

ter verkrijging van de graad van doctor aan de Rijksuniversiteit Limburg te Maastricht op gezag van de Rector Magnificus, Prof. mr. H. J. Cohen volgens het besluit van het College van Dekanen in het openbaar te verdedigen op donderdag 16 november 1995 om 16.00 uur

door

JOHANNA MARIA ELISABETH DERKS 
Promotor: Prof. mr. M. J. Cohen

Co-promotor: Mr. A. W. Heringa

beoordelingscommissie: Prof mr. F. A. M. Stroink (voorzitter)

Prof. mr. C. Flinterman

Prof mr. A. Q. C. Tak

Prof. mr. dr. I. C. van der Vlies

(Universiteit van Amsterdant) 


\section{Voorwoord}

In de meeste proefschriften is het voorwoord vooral een dankwoord. Dat is ook in dit boek het geval.

Dank ben ik verschuldigd aan mijn beide promotoren Aalt Willem Heringa en Job Cohen voor hun steeds getoonde betrokkenheid bij de voortgang van het onderzoek. Hun vertrouwen in een goede afloop van dit project heb ik als zeer stimulerend ervaren.

Dank past ook (schoon)ouders, familie, buren, vrienden en collega's, voor goede raad en bijstand op momenten dat het nodig was. In het bijzonder dank ik Malva Driessen voor het laatste jaar samen op een kamer, en Nettie Litjens voor het camera-ready maken van deze tekst.

Dank ook is er aan 'de mannen' thuis, Roel en Niels, die me de ruimte gaven én aanmoedigden om dit boek af te ronden.

Als 'jonge moeder' kon ik me alleen concentreren op de laatste loodjes ondat ik wist dat Niels in goede handen was (dank je wel, Ilona) en dat het huis leefbaar werd gehouden (dank je wel, Silvia).

De meeste dank gaat uit naar Rie Bost met wie ik zes jaar een kamer deelde. Lieve Rie, sommige contacten met collega"s groeien uit tot vriendschappen. Van sommige vriendschappen hoop je dat ze een leven lang mogen duren. Jouw steun is voor de totstandkoming van dit boek écht onmisbaar geweest.

Aan jou is dit boek opgedragen.

De tekst van dit boek is op 1 mei 1995 afgesloten.

Maastricht/Elsloo, september 1995

Annemiek Derks 



\section{Lijst van gebruikte afkortingen}

AA

Afd.

AG

AMVB

APV

ARP

ABRS

AGRS

ARRS

Awb

Bijl.

CBB

CDA

$\mathrm{CHU}$

CPN

CRvB

D'66

diss.

e.a.

EG

EK

EV

EVRM

GPV

Gst.

Gw

Hand.

HR

I

II

IVBPR

JB

$\mathrm{KG}$
Ars Aequi

Afdeling

Advocaat-Generaal

Algemene maatregel van bestuur

Algemene politie verordening/Algemene plaatselijke verordening

Anti-Revolutionaire Partij

Afdeling bestuursrechtspraak Raad van State

Afdeling geschillen van bestuur Raad van State

Afdeling rechtspraak Raad van State

Algemene wet bestuursrecht

Bijlage

College van Beroep voor het Bedrijfsleven

Christen Democratisch Appèl

Christelijk Historische Unie

Communistische Partij van Nederland

Centrale Raad van Beroep

Democraten "66

dissertatie

en anderen

Europese Gemeenschappen

Eerste Kamer

Eindverslag

Europees Verdrag voor de Rechten van de Mens

Gereformeerd Politiek Verbond

De Gemeentestem

Grondwet

Handelingen

Hoge Raad

Eerste Kamer

Tweede Kamer

Internationaal Verdrag inzake Burger en Politieke Rechten

Jurisprudentie Bestuursrecht

Kort Geding 


$\begin{array}{ll}\text { KVP } & \text { Katholieke Volkspartij } \\ \text { m.nt. } & \text { met noot } \\ \text { MvA } & \text { Memorie van Antwoord } \\ \text { MvT } & \text { Memorie van Toelichting } \\ \text { NA } & \text { Nieuwsbrief Awb } \\ \text { NJ } & \text { Nederlandse Jurisprudentie } \\ \text { NJB } & \text { Nederlands Juristenblad } \\ \text { NJV } & \text { Nederlandse Juristenvereniging } \\ \text { nr } & \text { nummer } \\ \text { NTvOR } & \text { Nederlands Tijdschrift voor Onderwijsrecht } \\ \text { NTB } & \text { Nederlands Tijdschrift voor Bestuursrecht } \\ \text { p. } & \text { pagina } \\ \text { PPR } & \text { Politieke Partij Radicalen } \\ \text { Pres. } & \text { President } \\ \text { Rb } & \text { Rechtbank } \\ \text { red. } & \text { redactie } \\ \text { RO } & \text { Rechterlijke Organisatie } \\ \text { RvO } & \text { Reglement van Orde } \\ \text { PvdA } & \text { Partij van de Arbeid } \\ \text { RvS } & \text { Raad van State } \\ \text { SEW } & \text { Sociaal-economische Wetgeving } \\ \text { Stb. } & \text { Staatsblad } \\ \text { Stcrt. } & \text { Staatscourant } \\ \text { TAR } & \text { Tijdschrift voor Ambtenarenrecht } \\ \text { TK } & \text { Tweede Kamer } \\ \text { TvO } & \text { Tijdschrift voor openbaar bestuur } \\ \text { VAR } & \text { Vereniging voor Administratief Recht } \\ \text { VV } & \text { Voorlopig Verslag } \\ \text { VVD } & \text { Volkspartij voor Vrijheid en Democratie } \\ \text { Vz } & \text { Voorzitter } \\ \text { W. } & \text { Weekblad van het recht } \\ & \end{array}$




\section{Inhoudsopgave}

\section{Hoofdstuk 1 Inleiding}

1.1 Omschrijving van de onderzoeksdoelen 1

1.2 Afbakening van het onderzoeksterrein 2

1.2.1 Geen rechtsvergelijking 2

1.2.2 Beperkte aandacht voor de positie van lagere overheden 2

1.2.3 Uitwoeringswetgeving in de marge belicht 3

1.3 Plan van behandeling 3

Hoofdstuk 2 Begrippen

$2.1 \quad$ Omschrijving van begrippen 5

2.1.1 Inlleiding 5

2.1.2 De delegatieterminologie 5

2.1.3 Regelgevende bevoegdheid 6

2.1.4 Bestuursbevoegdheid 6

2.1.5 Regelgeving-uitvoering 8

2.1.6 Algemeen verbindend voorschrift 9

2.1.7 Beleidsregel 9

2.2 Toedeling van bevoegdheid; attributie-delegatiemandaat 9

2.2.1 Inleiding 9

2.2.2 De oorsprong van bevoegdheden 11

2.2.3 Attributie-delegatie-mandaat van regelgevende

2.2.3.1 Attributie van regelgevende bevoegdheid 12

2.2.3.2 Delegatie van regelgevende bevoegdheid 15

2.2.3.3 Mandaat van regelgevende bevoegdheid 18

2.2.4 Attributie-delegatie-mándaat van bestuursbevoegdheid 19

2.2.4.1 Attributie van besturursbevoegdheid 19

2.2.4.2 Delegatie van bestuursbevoegdheid 20

2.2.4.3 Mandaat van bestuursbevoegdheid 22

$\begin{array}{ll}2.2 .5 & \text { Verschillen tussen attributie-delegatie-mandaat } \\ & \text { van regelgevende en bestuursbevoegdheid? }\end{array}$ 
Inhoudsopgave

2.3 De regeling van mandaat en delegatie in het wetsvoorstel van de Derde tranche van de Algemene wet bestuursrecht

2.3.1 Beschrijving van de regeling 24

$\begin{array}{lll}2.3 .1 .1 & \text { Mandaat } & 24\end{array}$

2.3.1.2 Delegatie 28

2.3.2 Commentaren 30

2.3.3 De regeling van mandaat en delegatie en de grondwettelijke delegatieterminologie

Hoofdstuk 3 Schets van het delegatieyraagstuk tot 1983

3.1. Inleiding 39

3.2 Addens, Delegatie van wetgevende macht, 1884

3.2.1 Beschrijving 40

3.2.2 Bespreking 43

3.2.3 Commentaar van Van der Pot 45

3.3 Van der Pot, Wet en Algemeene maatregel van bestuur in het Nederlandsche Staatsrecht, 1916

3.3.1 Beschrijving 46

3.3.2 Bespreking 51

$3.4 \quad$ Handelingen NJV 1951

3.4.1 Beschrijving preadvies Stellinga $\quad 53$

3.4.2 Beschrijving preadvies Donner 58

$\begin{array}{lll}3.4 .3 & \text { Beschrijving discussie } & 62\end{array}$

3.4.4 Bespreking 62

3.5 Van Driel, De ministeriële verordening, 1956

3.5.1 Beschrijving 64

3.5.2 Bespreking 68

3.6 Van der Hoeven, De plaats van de grondwet in het

$\begin{array}{lll}3.6 .1 & \text { Beschrijving } & 70\end{array}$

$\begin{array}{lll}3.6 .2 & \text { Bespreking } & 75\end{array}$

$\begin{array}{lll}3.6 .3 & \text { Recensies } & 76\end{array}$

$\begin{array}{lll}3.7 & \text { Lijnen in de geschiedenis } & 79\end{array}$ 
Hoofdstuk 4 De invoering van de delegatieterminologie in de Grondwet van 1983; het delegatievraagstuk na 1983

4.1 Inleiding

4.2 De delegatieterminologie in de parlementaire geschiedenis van de Grondwet 1983

4.2.1 Inleiding

4.2.2 De terminologie in de voorbereidende rapporten op de grondwetsherziening

De terminologie in de wetsontwerpen op de grondrechten

De terminologie en de bevoegdheden van lagere overheden

4.2.4.2 De terminologie en de bevoegdheden van lagere overheden 92

4.2.4.3 Het onderscheid regelgeving-uitvoering 92

4.2.5 De betekenis van de terminologie, voorlopige conclusie 93

4.3

De delegatieterminologie in regeringsrapporten na 1983

De Aanwijzingen voor de regelgeving 1993

4.5.1 De invloed van de delegatieterminologie op het delegatievraagstuk

4.5.2 De invloed van het delegatievraagstuk op de delegatieterminologie

4.6.2 Grenzen aan delegatie in de Aanwijzingen voor de regelgeving 1993 
4.7 En nog steeds: zoeken naar waarborgen 118

$\begin{array}{ll}4.7 .1 \text { Inleiding } & 118\end{array}$

$\begin{array}{ll}\text { 4.7.2 Delegatie onder voorbehoud } & 119\end{array}$

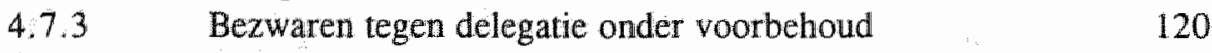

$\begin{array}{lll}\text { 4.7.4 Samenvatting } & 121\end{array}$

4.8 Samenvatting $\quad 122$

Hoofdstuk 5 Enkele relativeringen van de delegatieterminologie

5.1 Inleiding 125

5.2. De terminologie geldt niet voor enkele 'oude' artikelen 125

5.2.1 Artikel 23 Grondwet 125

5.2.2 Artikelen 97-102 Grondwet 126

5.3 De terminologie is niet consequent toegepast 127

$\begin{array}{lll}\text { 5.3.1 Artikel 36 Grondwet } & 127\end{array}$

$\begin{array}{lll}5.3 .2 & \text { Artikel } 104 \text { Grondwet } & 128\end{array}$

5.4 Invloed van EG-regelgeving: bij implementatie grondwettelijke delegatieterminologie toepassen? 130

5.4.1 De Aanwijzingen voor de regelgeving $1993 \quad 130$

$\begin{array}{lll}5.4 .2 & \text { Meningen van enkele schrijvers : } & 132\end{array}$

$\begin{array}{lll}5.5 & \text { Samenvatting } & 134\end{array}$

Hoofdstuk 6 Uitwerking van de delegatieterminologie in wetgeving en jurisprudentie
6.1
Inleiding
6.2
Delegatieterminologie en uitvoeringswetgeving
6.2.1
Artikel 2 Grond wet
6.2.2 Artikel 6 en artikel 9 Grondwet
Artikel 10 lid 2 en 3 Grondwet
6.2 .4
Artikel 18 lid 2 Grondwet
Artikel 79 Grondwet
6.2.6 Artikel 80 lid 2 Grondwet
Artikel 91 lid 1 en 2 en artikel 95 Grondwet
6.2 .9
Conclusie
6.3
Delegatieterminologie en jurisprudentie 
6.3.2 Strijd met het delegatieverbod?

6.3.3 Een specifieke wettelijke basis ontbreekt

6.3.4 De delegatieterminologie in horizontale verhoudingen 155

6.3.5 Toetsing van lagere regelingen 156

$\begin{array}{lll}6.3 .6 & \text { Conclusie } & 157\end{array}$

$\begin{array}{lll}6.4 & \text { Conclusie } & 158\end{array}$

Hoofdstuk 7 Het onderscheid regelgeving-uitvoering

$7.1 \quad$ Inleiding

7.2 Het onderscheid regelgeving-uitvoering in parlementaire stukken op de grondwetsherziening

7.2.1 Het onderscheid regelgeving-uitvoering in parlementaire stukken

Nadere beschouwing

Het onderscheid regelgeving-uitvoering in de jurisprudentie

172

7.3.1 Inleiding Jurisprudentie betreffende gemeentelijke bevoegdheden Jurisprudentie betreffende ministeriële bevoegdheden

Hoofdstuk 8 Het onderscheid beleidsregels-algemeen verbindende voorschriften

8.1

Inleiding 
8.2.5 Beleidsregels in het wetsvoorstel van de Derde tranche van de Algemene wet bestuursrecht $\quad 212$

8.2.5.1 Beschrijving van de regeling 212

$\begin{array}{ll}\text { 8.2.5.2 Enkele opmerkingen } & 213\end{array}$

8.3 Belleidsregel en algemeen verbindend voorschrift . 216

8.3.1 Inleiding 216

8.3.2 De term algemeen verbindend voorschrift 217

$\begin{array}{ll}\text { 8.3.2.1 Omschrijvingen } & 217\end{array}$

$\begin{array}{ll}\text { 8.3.2.2 Algemeenheid } & 219\end{array}$

8.3.2.3 Vereiste van een wettelijke grondslag 225

8.3.3 Beleidsregel-algemeen verbindend voorschrift; overeenkomsten $\quad 226$

8.3.4 Beleidsregel-algemeen verbindend voorschrift; verschillen 228

8.3.4.1 Een specifieke wettelijke grondslag 229

8.3.4.2 Inherente afwijkingsbevoegdheid 230

$\begin{array}{ll}\text { 8.3.4.3 Burgers bindende bepalingen } & 231\end{array}$

$\begin{array}{ll}\text { 8.3.4.4 Het beperken van grondrechten } & 232\end{array}$

8.3.4.5 Het toedelen van bevoegdheden 233

8.3.5 Implementatie van EG-recht 234

8.3.6 Conversie 235

8.3.7 Belleidsregels en algemeen verbindende voorschriften dezelfde status geven? 238

8.3.7.1 Beleidsregels krijgen de status van algemeen verbindend voorschrift

8.3.7.2 Algemeen verbindendle voorschriften krijgen de status van beleidsregel

$\begin{array}{ll}\text { 8.3.7.3 Gedeeltelijke gelijkstelling } & 241\end{array}$

$\begin{array}{lll}\text { 8.3.7.4 Conclusie } & 242\end{array}$

8.4 Relatie algemeen verbindend voorschrift-beleidsregeldelegatievraagstuk-delegatieterminologie $\quad 242$

8.4.1 Inleiding 242

8.4.2 Gevolgen van de opkomst van de beleidsregel voor het delegatievraagstuk en de delegatieterminologie 242

$\begin{array}{lll}\text { 8.4.2.1 Beleidsregel en delegatievraagstuk } & 242\end{array}$

8.4.2.2 Beleidsregel en delegatieterminologie 243

8.4.3 Gevolgen van een gelijke status voor het delegatievraagstuk en de delegatieterminologie

8.4.3.1 Gelijkstelling van beleidsregels aan algemeen verbindende voorschriften 
8.4.3.2 Gelijkstelling van algemeen verbindende voorschriften aan beleidsregels

8.5 Conclusie

Hoofdstuk 9 Legaliteitsbeginsel, materieel wetsbegrip en delegatieterminologie

9.1 Inleiding

9.1.1 Onderzoeksvragen

9.1.2 Legaliteitsbeginsel en materieel wetsbegrip: twee kanten van dezelfde medaille

9.2 Opvattingen over her legaliteitsbeginsel en materieel wetsbegrip in de parlementaire stukken op de grondwetsherziening

9.2.1 Inleiding

9.2.2 Korte schets van opvattingen over het legaliteitsbeginsel en materieel wetsbegrip voor 1983

9.2.3 Een formeel of materieel wetsbegrip in artikel $81 \mathrm{Gw}$ ?

Op zoek naar criteria in de parlementaire stukken

Conclusie

Opvattingen over de inhoud van het legaliteitsbeginsel na 1983

9.3.1 Opvattingen in handboeken

9.3.2 Een veranderende inhoud?

9.3.2.1 Een wettelijke grondslag voor de presterende functie van de overheid?

9.3.2.2 Geldt het legaliteitsbeginsel voor privaatrechtelijk handelen van de overheid?

9.3.2.3 Kunnen bestuursbevoegdheden ontleend worden aan ongeschreven recht?

9.3.2.4 Geldt het legaliteitsbeginsel ook yoor de wetgever?

9.3 .2 .5 Conclusie

9.4.2 Orde in de regelgeving 1985 en Regelgeving centrale overheid 1987

9.4.3 De Aanwijzingen voor de regelgeving 1993 


\section{Hoofdstuk 1}

\section{Inleiding}

\subsection{Omschrijving van de onderzoeksdoelen}

Onder de 'oude' Grondwet (de Grondwet naar de tekst van 1972) was niet steeds duidelijk of delegatie van regelgevende bevoegdheid door de formele wetgever was toegestaan. Bij de grondwetsherziening die heeft geleid tot de Grondwet van 1983 is geprobeerd deze onduidelijkheid te ondervangen door het invoeren van een delegatieterminologie. Deze terminologie beoogt in de redactie van een artikel duidelijk te maken of delegatie van regelgevende bevoegdheid is toegestaan dan wel verboden.

De terminologie is (in het kort) als volgt opgezet. Wanneer in een grondwetsbepaling een vorm van het werkwoord 'regelen' of eén van de zelfstandige naamwoorden 'regels' of 'regeling' wordt gebruikt, dan is delegatie van regelgevende bevoegdheid toegestaan. Dat geldt ook bij het hanteren van de term 'bij of krachtens'. Wordt niet één van deze woorden gebruikt dan is delegatie verboden.

Het eerste doel van deze studie is om te onderzoeken welke betekenis de grondwettelijke delegatieterminologie precies heeft en of de terminologie op consequente wijze in de Grondwet is neergelegd. Als bronnen worden hiervoor gehanteerd de tekst van de Grondwet zelf en de parlementaire stukken van de grondwetsherziening.

Het tweede doel is om na te gaan welke ontwikkelingen zich in het delegatievraagstuk hebben voorgedaan voor en na 1983 en welke plaats de invoering van de grondwettelijke delegatieterminologie daarbinnen heeft.

De wijze waarop formele wetgever en rechter de delegatieterminologie toepassen is het derde doell van deze studie.

Het vierde doel is om na te gaan of en op welke wijze het delegatievraagstuk in het algemeen en als uitvloeisel hiervan de delegatieterminologie in het bijzonder, beïnvloed worden door een aantal leerstukken in het staats- en bestuursrecht die de bevoegdhedenverdeling raken. Hierbij gaat het enerzijds om een leerstuk dat al geruime tijd speelt: het onderscheid regelgeving-uitvoering. Anderzijds gaat het om vrij recente, actuele leerstukken, die bij de grondwetsherziening nog volop in ontwikkeling waren, en die een belangrijke invloed op het delegatievraagstuk hebben of kunnen gaan hebben. Het betreft de vraag naar het onderscheid tussen beleidsregels en algemeen verbindende voorschriften en de vraag naar de inhoud van het legaliteitsbeginsel en een (nieuw), materieel wetsbegrip. 


\section{Hoofdstuk 1}

Het laatste doel van dit onderzoek is tenslotte om na te gaan of het gebruik van de delegatieterminologie in de huidige Grondwet geslaagd te noemen is en of het aanbeveling verdient om bij een volgende integrale grondwetsherziening opnieuw een delegatieterminologie op te nemen.

\subsection{Afbakening van het onderzoeksterrein}

\subsubsection{Geen rechtswergelijking}

Een eerste grens die getrokken wordt om dit onderzoek af te bakenen is een letterlijke: de 'landsgrens'. In dit onderzoek komt buitenlands recht niet of nauwelijks aan bod. Slechts incidenteel is buitenlandse literatuur geraadpleegd. Gekozen is om de delegatieterminologie in de Nederlandse Grondwet en daarmee samenhangend het delegatievraagstuk in de Nederlandse context te behandelen en te confronteren met zich in dit land voordoende staats- en bestuursrechtelijke ontwikkelingen.

\subsubsection{Beperkte aandacht voor de positie van lagere overheden}

De positie van de lagere overheden (met name provincies en gemeenten) is er wat betreft hun eigen regelruimte met de introductie van de delegatieterminologie niet duidelijker op geworden. ${ }^{1}$ De delegatieterminologie gaat ervan uit dat er steeds sprake is van een wet in formele zin, waarin, als delegatie in het grondwetsartikel is toegestaan, regelgevende bevoegdheden kunnen worden gedelegeerd aan bijvoorbeeld provincies en gemeenten. Provincies en gemeenten zijn afhankelijk van die wet in formele zin en mogen niet 'op eigen houtje' een onderwerp regelen waar de grondwet een formele wet vereist. Zo luidde de uitleg van de delegatieterminologie op dit punt in het wetsontwerp op de klassieke grondrechten. ${ }^{2}$ Hier speelde met name de vrees voor een zelfstandige beperking van die grondrechten door lagere overheden een belangrijke rol.

Bij de behandeling van het wetsontwerp op de sociale grondrechten echter bleek de regering de deur naar een eigen regelruimte voor provincies en gemeenten bij de uitwoering van sommige grondwetsbepalingen toch op een kier te zetten. In bepaalde omstandigheden mogen lagere overheden, buiten een wet in formele zin om, voorzieningen voor burgers treffen of anderszins een regeling treffen ter uitvoering van een grondwetsartikel.

1. Zie ook Kortmann $1987 a$, p.343 e.w.

2. Zie hoofdstuk 4. 
In het licht van de onderzoeksdoelen van deze studie past slechts een beknopte analyse van de lagere overhedenproblematiek.

\subsubsection{Uitvoeringswetgeving in de marge belicht}

Een manier om de delegatieterminologie en de uitvoerbaarheid ervan te evalueren is door wetgeving, die de Grondwet van 1983 uitvoert, te onderzoeken op bepalingen die regelgevende of bestuursbevoegdheden overdragen of toedelen. Zo kan bijvoorbeeld gecontroleerd wordlen of een delegatieverbod wordt overtreden. Is delegatie toegestaan dan kan gekeken worden hoe de uitvoeringswetgever daarmee omgaat: veel of weinig delegatiebepalingen, aan wie, met welke inhoud. Gezien echter de grote omvang van de uitvoeringswetgeving is afgezien van een uitputtende studie hiernaar. Aan de hand van enkele voorbeelden wordt een indruk gegeven van de wijze van uitvoering van de delegatieterminologie.

\subsection{Plan van behandeling}

Na dit inleidend hoofdstuk wordt in hoofdstuk 2 noodzakelijk 'voorwerk' verricht. Zo bevat de eerste paragraaf 'werkdefinities' van in dit boek centraal staande begrippen. De tweede paragraaf is gewijd aan manieren om bevoegdheden toe te delen: attributie-delegatie-mandaat. De (toekomstige) regeling van mandaat en delegatie in de Algemene wet bestuursrecht volgt in paragraaf 2.3. In hoofdstuk 3 worden enkele historische lijnen van het delegatievraagstuk geschetst. Daaruit zal blijken hoe steeds de uitvoeringskant van de delegatie voor de nodige problemen heeft gezorgd. Deze uitwoeringsproblematiek is de rode draad van de rest van dit onderzoek.

De delegatieterminologie zelf en haar betekenis komen uitgebreid aan bod in hoofdstuk 4. De betekenis wordt afgeleid uit de parlementaire stukken van de grondwetsherziening. Verder wordt in dit hoofdstuk ingegaan op het delegatievraagstuk na 1983. Een aspect daarbij is de wederzijdse beïnvloeding van ontwikkelingen binnen het delegatievraagstuk en de grondwettelijke delegatieterminologie.

In hoofdstuk 5 komen enkele 'relativeringen' van de delegatieterminologie aan de orde. De terminologie geldt namelijk niét voor alle artikelen en zij is niet steeds op consequente wijze in de Grondwet opgenomen.

De toepassing van de grondwettelijke delegatieterminologie door formele wetgever en rechter staat centraal in hoofdstuk 6.

In de hoofdstukken 7,8 en 9 worden enkele leerstukken besproken die nauw verbonden zijn met het delegatievraagstuk en die in de afgelopen decennia meer of 


\section{Hoofdstuk 1}

minder ontwikkeling hebben doorgemaakt. Zo komt in hoofdstuk 7 het onderscheid regelgeving-uitvoering aan bod. In hoofdstuk 8 volgt een bespreking van het onderscheid tussen beleidsregels en algemeen verbindende voorschriften en de gevolgen van een eventuele gelijke status van de regels voor het delegatievraagstuk en de grondwettelijke delegatieterminologie.

In hoofdstuk 9 wordt het delegatievraagstuk benaderd vanuit de vraag naar de invulling van het legaliteitsbeginsel en cen (nieuw) materieel wetsbegrip. Onderzocht wordt in hoeverre de parlementaire stukken van de grondwetsherziening aanwijzingen geven voor de inhoud van het legaliteitsbeginsel en een (nieuw) materieel wetsbegrip.

In hoofdstuk 10 tenslotte worden de conclusies gepresenteerd. 


\section{Hoofdstuk 2}

\section{Begrippen}

\subsection{Omschrijving van begrippen}

\subsubsection{Inleiding}

In dit onderzoek wordt gewerkt met centrale begrippen die een wisselende betekenis kunnen hebben. Om de duidelijkheid van het geschrevene voor de lezer te bevorderen, en als handvat voor het onderzoek in de volgende hoofdstukken volgen hier 'werkdefinities' van enkele centrale begrippen. In de meeste gevallen zal later nog tot in detail op de desbetreffende begrippen worden ingegaan.

\subsubsection{De delegatieterminologie}

Uitgangspunt van dit onderzoek is de delegatieterminologie zoals die is neergelegd in de Grondwet van 1983. De terminologie beoogt in de redactie van een artikel duidelijk te maken of delegatie van regelgevende bevoegdheid door de formele wetgever is toegestaan of verboden. De terminologie is in het kort als volgt opgezet. Wanneer in een grondwetsbepaling een vorm van het werkwoord 'regelen' of één van de zelfstandige naamwoorden 'regels' of 'regeling' wordt gebruikt, dan is delegatie van regelgevende bevoegdheid door de formele wetgever toegestaan. Dat geldt ook bij het gebruik van de term 'bij of krachtens'. Is geen van deze woorden gebruikt, dan dient de formele wetgever de wezenlijke bepalingen in de wet zelf op te nemen. De regelling van detailpunten mag aan lagere regelgevers overgelaten worden. Er mogen geen ruime (discretionaire) bestuursbevoegdheden geattribueerd worden waardoor in feite de normstelling toch overgedragen wordt. ${ }^{1}$ Deze uitleg van de betekenis van de delegatieterminologie zal nader worden geanalyseerd in hoofdstuk 4.

De delegatieterminologie geldt alleen voor de bepalingen in de Grondwet en niet voor andere wetten of wettelijke regelingen.

1. Kamerstukken II 1976-1977, 13990, nr 6 MvA, p.8; in Kamerstukken II 1975-1976, $13872, \mathrm{nr} 3$ MvT, p. 22-24 werd het delegatieverbod strikter witgelegd en was elke delegatie van regelgevende bevoegdheid verboden. 


\section{Hoofdstuk 2}

\subsubsection{Regelgevende bevoegdheid}

Een regelgevende bevoegdheid ${ }^{2}$ houdt in een bevoegdheid om algemeen verbindende voorschriften te stellen. Deze bevoegdheid is verkregen krachtens attributie, delegatie, of (zij het in zeer uitzonderlijke gevallen) mandaat ${ }^{3}$.

\subsubsection{Bestuursbevoegdheid}

Een bestuursbevoegdheid is een bevoegdheid van een bestuursorgaan, uitgezonderd het vaststellen van algemeen verbindende voorschriften ${ }^{4}$ en het plegen van rechterlijke handelingen. ${ }^{5}$ De bevoegdheid van het bestuur tot het vaststellen van algemeen verbindende voorschriften (bestuurswetgeving) ${ }^{6}$ beschouw ik als een regelgevende bevoegdheid.

Een omschrijving van 'bestuursorgaan' kan ontleend worden aan artikel 1:1 lid $1 \mathrm{Awb}^{7}$ :

'Onder bestuursorgaan wordt verstaan: a. een orgaan van een rechtspersoon die krachtens publiekrecht is ingesteld, of b. een ander persoon of college, met enig openbaar gezag bekleed.'

2. De omschrijving van de begrippen regelgevende en bestuursbevoegdheid zijn niet op deze wijze in de parlementaire stukken van de grondwetsherziening terug te vinden.

3. Aan de termen attributie-delegatie-mandaat is paragraaf 2.2 gewijd.

4. Het hier gemaakte onderscheid gaat ervan uit dat er steeds een duidelijk onderscheid te maken is tussen de verschillende soorten besluiten (bijwvoorbeeld beschikkingen, algemeen verbindende voorschriften en (andere) besluiten van algemene strekking). De jurisprudentie lat evenwel zien dat de verschillen kleiner worden. Zie L.J.A. Damen, De beschikte weekmarkt van Maassluis, annotatie bij ARRS 11 juni 1992, AA 1993, p.732-737.

5. Ontleend aan Van Wijk/Konujnenbelt 1990, p.56: Onder bestuursbevoegdheden worden verstaan: "bevoegdheden tot het verrichten van bestuurshandelingen, dit zijn alle andere overheidshandelingen dan besluiten die algemeen verbindende regels inhouden of rechterlijke activiteiten betreffen." Een bredere definitie hanteren zij in de achtste druk (1993, p. 126): 'de bevoegdheid tot het nemen van andere besluiten dan algemeen verbindende voorschriften'. Een bredere definitie hanteert ook Goorden 1990, p.79: "Bestuursrechtelijke bevoegdheid is het geheel wan rechten en plichten dat, hetzij expliciet door de wetgever aan publiekrechtelijke rechtssubjecten is toegekend, hetzij impliciet ligt besloten in een op de wet gebaseerde tak die dient ter behartiging van openbare belangen."

6. Term ontleend aan Van Male 1988, p.4.

7. Zie voor een behandeling van de te onderscheiden categorieën bestuursorganen onder de Awb Küper/Boxum 1993 p.279. 
Met deze definitie zijn weer nieuwe problemen in huis gehaald waaraan ik hier echter voorbij ga. Zo kan de vraag gesteld worden wat publiekrecht inhoudt ${ }^{8}$, en wanneer er sprake is van openbaar gezag. ${ }^{9}$

In lid 2 van artikel 1:1 Awb worden uitzonderingen gemaakt op het gestelde in lid 1: 'De volgende organen, personen en colleges worden niet als bestuursorgaan aangemerkt:

a. de wetgevende macht;

b. de kamers en de verenigde vergadering der Staten-Generaal;

c. onafhankelijke, bij de wet ingestelde organen die met rechtspraak zijn belast;

d. de Raad van State en zijn afdelingen;

e. de Algemene Rekenkamer;

f. de Nationale ombudsman en de substituut-ombudsmannen;

g. de voarzitters, leden, griffiers en secretarissen van de in de onderdelen $b$ tot en met $f$ bedoelde organen, de procureur-generaal en de advocaten-generaal bij de Hoge Raad, alsmede de commissies wit het midden van de in de onderdelen $b$ tot en met $f$ bedoelde organen. 10

In relatie tot de Algemene wet bestuursrecht is de hier gegeven definitie van bestuursbevoegdheid verouderd. Tot de bevoegdheid van een bestuursorgaan onder de Awb valt in elk geval ook het nemen van besluiten als bedoeld in artikel 1:3 Awb. Een besluit is in het eerste lid omschreven als. 'een schriftelijke beslissing van een bestuursorgaan, inhoudende een publiekrechtelijke rechtshandeling'. Deze schriftelijke beslissingen kunnen beschikkingen en besluiten van algemene strekking (waaronder algemeen verbindende voorschriften) inhouden.

In het kader van deze studie, waarin de grondwettelijke delegatieterminologie een belangrijke plaats inneemt, wil ik echter aan een strikt onderscheid tussen regel-

8. Zie voor een behandeling van het onderscheid publiekrecht - privaatrecht de dissertatie van Simon 1993, p.73 e.4. en de door hem aangehaalde literatuur.

9. Zie over de term openbaar gezag Van Male 1988, p.4: "Van enig openbaar gezag is sprake wanneer een persoou of college een in het publiekrecht erkende bevoegdheid heeft om eenzijdig de rechtspositie wan andere rechtssubjecten te bepalen." In deze zin ook Verheij 1992a, p. 165: Er is sprake van openbaar gezag. "indien het orgaan ter uitwoering van een taak die de overheid aan zich heeft getrokken, is bekleed met de bevoegdheid om eenzijdig rechtsposities van burgers te bepalen." In artikel $2: 1 \mathrm{BW}$ wordt aan openbare lichamen rechtspersoonlijktheid verleend.

10. Lid 3 bepaalt voorts nog: 'Een ingevolge hei tweede lid uitgezonderd orgaan, persoon of college wordt wel als bestuursorgaan aangemerkt, voor zover het orgaan, de persoon of het college bestuiten neemt of handelingen ver richt ten a anzien van een miet voor het leven benoemde ambtenaar als bedoeld in artikel 1 van de Ambtenarenwet als zodanig, zijn nagetaten betrekkingen of zijn rechtverkrijgenden." Zie over artikel 1:1 Awb nog Simon 1993, p.63 e.v. en Tak 1994, p.53. 


\section{Hooflstuk 2}

gevende bevoegdheid en bestuursbevoegdheid zoals in deze en de vorige paragraaf gedefinieerd vasthouden.

\subsubsection{Regelgeving-uitvoering}

De begrippen regelgeving-uityoering hangen nauw samen met de termen regelgevende bevoegdheid-bestuursbevoegdheid. Vooral het onderscheid tussen de begrippen regelgeving en uitvoering heeft tot veel misverstanden aanleiding gegeven. "In plaats van het woord 'regelgeving' werd en wordt ook vaak het woord 'regeling' gebruikt. Dit begrip en de term 'uitvoering' hebben allebei een dubbele betekenis gekregen en kunnen zodoende gemakkelijk tot misverstanden leiden. 'Regeling' in ruime betekenis betekent het 'regelen' van een bepaalde kwestie. Dit regelen kan zowell het stellen van algemeen verbindende voorschriften inhouden als het creëren van bestuursbevoegdheden of het op andere wijze 'regelen' van een onderwerp. 'Regeling' in enge zin houdt in het stellen van algemeen verbindende voorschriften.

Ook het begrip 'uitvoering' heeft een ruime en beperkte betekenis. Uitvoeren in ruime zin omvat zowel het geven van beschikkingen als het nemen van besluiten van algemene strekking (waaronder het stellen van algemeen verbindende voorschriften). ${ }^{12}$

Uitvoering in beperkte zin is nauw gekoppeld aan de beschikkingsbevoegdheid van een bestuursorgàan. ${ }^{13}$ De regels die het bestuursorgaan in dat kader stelt (in de meeste gevallen als beleidsregels te kwalificeren) vat ik onder het beperkte begrip uitvoering.

In het navolgende zal ik het woord regelgeving gebruiken voor het stellen van algemeen verbindende voorschriften. Het woord regeling wordt in ruime zin gebruikt en kan dus 'van alles' inhouden. Wordt een regeling bedoeld die algemeen verbindende voorschriften bevat (omdat dat nu eenmaal ook tot de gang-

11. Aan dit onderscheid is hoofdstuk 7 gewijd.

12. Kortmann 1994, p.37. Vergelijk Oud 1970, deel II, p.81: "Uitvoeren is een zeer algemeen begrip. Een daad van uitvoering kan tegelijk een daad van wetgeving zijn." Zie ook Donner 1980, p.227: "Wat het politiek gezag van het bestuur verlangt is 'uitwoering' en die oude term omvat, zoals Van Wijk het uitdrukte, zowel algemene als indíviduele normstelling. Het bestuur geeft zowel voorschriften als beschikkingen."

13. Zie over de verhouding bestuur - uitwoering Phaf 1962, , p. 83 , "Bestuur valt derhallve niet samen met uitworing. Het is enerzijds ruimer, ondat bestuur ook handelingen omvat, die niet als uitvoering van enige regeling zijn te beschouwen, anderzijds enger, omdat uitwoering ook daden van wetgeving kan omvatten." In dit citaat is uitvoering in de ruime betekenis gebruikt. 
bare juridische terminologie behoort, bijvoorbeeld in de term ministeriële regeling), dan worden de woorden "wettelijke regeling" gebruikt.

Het begrip uitwoering zal hierna vooral nog aan bod komen in hoofdstuk 7 , het onderscheid regelgeving-uitvoering. In dit hoofdstuk zal het begrip uitvoering vooral als tegenpool van het begrip regelgeving gehanteerd worden. Uit de context zal blijken of uitvoering in ruime dan wel enge zin aan de orde is.

\subsubsection{Algemeen verbindend voorschrift}

Als werkomschrijving voor de term algemeen verbindend voorschrift kan aangesloten worden bij de omschrijving uit de Memorie van Toelichting van het wetsvoorstel Derde tranche Awb: 'naar buiten werkende, voor de daarbij betrokkenen bindende regels, uitgegaan van het openbaar gezag dat de bevoegdheid daartoe aan de wet ontleent'. ${ }^{14}$

Als synoniem voor het begrip algemeen verbindend voorschrift kan de term wettelijk voorschrift gehanteerd worden. ${ }^{15}$

\subsubsection{Beleidsregel}

Ingevolge het wetsvoorstel Derde tranche $A w b$, wordt aan artikel 1:3 een vierde lid toegevoegd, waarin een beleidsregel wordt omschreven als: "een besluit, niet inhoudende een algemeen verbindend voorschrift, dat een algemene regel geeft omtrent de afweging van belangen, de vaststelling van feiten of de uitleg van wettelijke voorschriften bij het gebruik van een bevoegdheid van een bestuursorgaan. ${ }^{10}$

Deze omschrijving hanteer ik voorlopig als werkdefinitie. Nadere bespreking vindt plaats in hoofdstuk 8 .

\subsection{Toedeling van bevoegdheid; attributie-delegatie-mandaat}

\subsubsection{Inleiding}

In een studie die de grondwettelijke delegatieterminologie als uitgangspunt heeft, werdienen de begrippen attributie-delegatie-mandaat, die in het staats- en bestuursrecht vaak in één adem genoemd worden, een nadere beschouwing.

14. Kamerstukken II 1993-1994, 23700, nr 3 MvT, p.105.

15. Hirsch Ballin 1989, p.23. Van Wijk/Konijnenbelt/Van Male 1994, p.253.

16. Kamerstukken II 1993-1994, 23700, nr 2 Voorstel wan wet. 


\section{Hoofdstuk 2}

Wanneer gekeken wordt naar de uitleg van de grondwettelijke delegatieterminologie valt op dat daarin nauwelijks wordt ingegaan op het begrip attributie en helemaal niet op het begrip mandaat. De begrippen worden bekend verondersteld, ze worden niet afgebakend (ook niet ten opzichte van elkaar).

Een beschouwing in deze studie gewijd aan attributie, delegatie én mandaat heeft meerdere rechtvaardigingsgronden.

Op de eerste plaats hebben de drie begrippen met elkaar gemeen dat ze alle drie een vorm van bevoegdheidsverkrijging zijn. Het is van belang om de verschillen (en overeenkomsten) tussen de drie vormen op te sporen om zo het delegatiebegrip goed te kunnen afbakenen.

Op de tweede plaats speelt deze studie zich af in het staats- én bestuursrecht. In het staatsrecht komen vooral attributie en delegatie van regelgevende bevoegdheden voor. In het bestuursrecht speelt, naast attributie en delegatie van bestuursbevoegdheden (ook) mandaat een belangrijke rol: reden om alle drie begrippen te behandelen.

I k kies ervoor om de begrippen attributie-delegatie-mandaat afzonderlijk te onderzoeken voor regelgevende bevoegdheden en bestuursbevoegdheden, ${ }^{17}$ De delegatieterminologie zoals gehanteerd door de grondwetgever heeft voornamelijk betrekking op regelgevende bevoegdheden. In de terminologie spelen echter ook bestuursbevoegdheden een rol (zie paragraaf 2.1 .2 ). Nu verder een belangrijk deel van dit onderzoek ook bestuursbevoegdheden betreft, namelijk hoofdstuk 7 over het onderscheid regelgeving-uitvoering en hoofdstuk 8 over het onderscheid beleidsregels-algemeen verbindende voorschriften, is het wenselijk te beschrijven

17. Anders bijwoorbeeld Stroink/Steenbeek 1993, p. 17 e.v. die voor een dergelijk onderscheid geen reden zien. $Z_{j j}$ geven op deze en de volgende bladzijden een overzicht van definities van statsrecht en bestuursrecht. Ik (onder)scheid de begrippen attributie-delegatie-mandat niet naar staats- en bestuurstecht omdat de grenzen tussen deze twee rechtsgebieden diffuus zijn; ik onderscheid wel regelgevende en bestuursbevoegdheden (paragraaf 2.1.3 en 2.1.4). Vergelijk werder Van Wijk/Konijnenbelt 1990, p.56, die constateert dat er "een grote verwantschap' is tussen attributie-delegatie-mandaat van wetgevende bevoegdheden en attributie-delegatie-mandaat wan besturirsbevoegdheden. Er zijn echter kennelijk wel verschillen: "Voor delegatie en mandaat van wetgevende bevoegdheid gelden niet geheel dezelfde regels." (Van Wijk/Konijnenbelt 1990, p.69). Van Wijk/Konijnenbelt 1993 bevat deze opmerking niet meer.

Koopmans 1994,p.24-25 maakt ook geen onderscheid tussen regelgevende en bestuursbevoegdheden bij de bespreking van attributie-delegatie-mandaat:

Van Maarseveen 1991, p.82: "Er zitten aan deze rechtsfiguren (delegatie en mandaat, JD) problemen vast die in literatuur en rechtspraak anders worden behandeld naargelang het bevoegdheden betreft die door middel van regelgeving dan wel beschikkingneming worden uitgeoefend." Hij gaat daar overigens niet verder op in. 
wat de begrippen inhouden voor regelgevende $(2.2,3)$ en bestuursbevoegdheden (2.2.4). Zijn er verschillen (2.2.5)?

Voordat ik met een behandeling van deze vragen begin, behandel ik in paragraaf 2.2.2 de vraag waar de bevoegdheden vandaan komen, die krachtens atuributie, delegatie of mandaat verdeeld worden.

Een beschrijving van het wetsontwerp tot codificatie van de begrippen (attributie)-delegatie-mandaat in de Algemene wet bestuursrecht vindt plaats in paragraaf 2.3. Ook de commentaren op het (voor)ontwerp komen hier aan bod.

\subsubsection{De oorsprong van bevoegdheden}

In de literatuur wordt verschillend gedacht over de oorsprong van bevoegdheden. In de opvatting van Kortmann worden bevoegdheden door de constitutie geschapen en komen ze 'uit het niets? 18 De constitutie is de bron van alle bevoegdheden. Dit betekent dat bevoegdheden zowel aan de (geschreven) Grondrecht als aan het (ongeschreven) overige constitutionele recht ontleend kunnen worden. Deze opvatting strookt niet met die van Koopmans, die de Grondwet als bron van bevoegdheden aanwijst: "Zo kunnen in een pre-constitutionele fase alle bevoegdheden toekomen aan éến orgaan (bijv. absoluut vorst), maar zodra er een grondwet is, vestigt deze een hiërarchie van organen en voorziet deze elk van eigen bevoegdheden. ${ }^{19}$ In deze opvatting lijken bevoegdheden niet ontleend te kunnen worden aan het ongeschreven recht. ${ }^{20} \mathrm{Zo}$ ook Van der Vlies: publieke be-

18. Kortmann 1994, p.33.

19. Koopmans $1994, p_{2} 24$.

20. Hier rijst er een probleem waar het gaat om onderwerpen die níet in de Grondwet geregeld zijn. Waar halen de verschillende overheidsinstanties (wetgever; bestuur, rechter) hun bevoegdheden vandaan? Wat betreft de rechter lijken er de minste problemier te zijn. diens bewoegdheid is geregeld in de Grondwet in de artikelen 12-113. Een algemene bevoegdheid voor de (formele) wetgever kan ontleend worden aan artikel $81 \mathrm{Gw}$. In dit artikel wordt dan (ook) een materieel wetsbegrip gelezen. De (formele) wetgever kan zich elk onderwerp ter regeling aantrekken (mits geen strijd met de Grondwet of algemene rechtsbeg inselen ontstaat).

Een algemene bevoegdheid voor het bestuur is in de Grondwet niet aan te wijzen (het vroegere artikel $56 \mathrm{Gw}$ is vervallen bij de grondwetsherziening van 1983; in plats daarvan wordt wel een beroep gedaan op artikel $42 \mathrm{Gw}$ ). De bevoegdheden van het bestuur zullen vaak in een formele wet terug te vinden zijn. Krachtens de klassieke opvatting wan het legaliteitsbeginsel is voor benadelend bestuurshandelen een wettelijke basis nodig (zie paragraaf 9.2). Begunstigend ingrijpen kan echter plaatsvinden op basis van het ongeschreven recht. 


\section{Hoofdstuk 2}

voegdheden mogen àlleen door de wet of Grondwet in het leven geroepen worden. $^{21}$

Zowel in de opvatting van Kortmann als in de opvatting van Koopmans en Van der Vlies is de Grondwet dus ến van de bronnen van bevoegdheden. Ook aan andere wetten kunnen bevoegdheden ontleend worden. ${ }^{22}$ En daarnaast is er (bij Kortmann) nog een (bescheiden) rol weggelegd voor ongeschreven constitutioneel recht: Ik sluit mij aan bij de opvatting van de laatste omdat die het meest recht doet aan de constitutionele werkelijkheid. ${ }^{23}$

\subsubsection{Attributie-delegatie-mandaat van regelgevende bevoegdheid}

\subsubsection{Attributie van regelgevende bevoegdheid}

In een uitgebreide beschrijving van het begrip attributie onderscheidt Kortmann de volgende kenmerken ${ }^{24}$ Het eerste is dat de constitutie bevoegdheden attribueert die er eerder nog niet waren. ${ }^{25}$

Het tweede kenmerk is dat bij attributie bevoegdheden worden gecreëerd die de attribuerende instantie niet zelf bezit. Als voorbeelden hierbij noemt hij: attributie (door de grondwetgever) aan de regering van de bevoegdheid om algemene maatregelen van bestuur vast te stellen en attributie aan de rechterlijke macht van de bevoegdheid om recht te spreken. ${ }^{26}$

Een derde kenmerk is dat de attribuerende bevoegdheid zelf vatbaar is voor overdracht, de grondwetgever kan dus attribuerende bevoegdheid aan bijvoorbeeld de wetgever 'attribueren': de wetgever mag op zijn beurt bevoegdheden toekennen aan andere organen.

21. Van der Vlies 1991, p.90.

22. Zile ook Strounk/Steenbeek 1993, p.46.

23. In paragraf 9.2 zullen we zien dat in bijzondere gevallen bestuursbevoegdheden ontleend kunnen worden aan het ongeschreven recht.

24. Kontmann 1994, p.33-35.

25. Kortinann 1994, p.33.

26. Kortmann 1994, p.33-34. Met deze voorbeelden kan ik instemmen. Maar hoe zit het met enige andere bepalingen? Is er geen sprake van attributie wanneer de grondwetgever aan de wetgever opdratgt on de goedkeuring van verdragen te regelen (zie artikel $91 \mathrm{Gw}$ )? En geld ditzelfde voor de opdracht aan de wetgever om de eedsaflegging door kamerleden te regelen (artikel $60 \mathrm{Gw}$ )? Beide zijn een voorbeeld van een materie die in de Grondwet naar de tekst van 1972 nog zelf door de grondwetgever geregeld was. (Zie voor de goedkeuring van verdragen de artikelen 61,62 en $64 \mathrm{Gw} 1972$ en voor de eedsaflegging van kannerleden de artikelen 97 en 101 lid $2 \mathrm{GW}$ 1972.) Is hier dan sprake van een overdracht van een bevoegdheid en niet zozeer van een opdracht, zodat we zouden moeten spreken van delegatie (van regelgevende) bevoegdheid? 
De vierde karakteristiek is, dat de attributie limitatief is. "Overheidsbevoegdheden bestaan rechtens slechts krachtens uitdrukkelijke toekenning of erkenning ervan door de constitutie:" 27

Als laatste aspect stelt Kortmann dat er een onderscheid gemaakt moet worden tussen het stellen van taken en het attribueren van bevoegdheden. Het stellen van taken, bijvoorbeeld het stellen van een doel, komt volgens hem voor bij de sociale grondrechten. Daarmee is nog geen bevoegdheid gegeven hoewel taken en bevoegdheden nauw samenhangen, ze zijn niet goed denkbaar zonder elkaar. ${ }^{28}$ Koopmans geeft als omschrijving: "Van attributie is sprake als een wetgever aan een orgaan van een lichaam een nieuwe eigen bevoegdheid toekent, die het op eigen gezag en daarmee onder eigen verantwoordelijkheid gaat uitoefenen. ${ }^{29}$ En: "Behalve de Grondwet kunnen ook andere wettelijke regelingen aan organen van lagere publiekrechtelijke lichamen eigen bevoegdheden toekennen (bijv. de gemeentewet aan de burgemeester, vgl. art. 175): "30

Het aantrekkelijke van de laatste omschrijving is zijn beknoptheid. Ik zou die omschrijving dan ook willen volgen waarbij ik een verruiming aanbreng: 'attri. butie is het toedelen van nieuwe bevoegdheden door de Grondwetgever of de wetgever aan een orgaan dat die bevoegdheid onder eigen gezag en verantwoordelijkheid gaat uitoefenen. Voorts kan in bijzondere gevallen de bevoegdheid ook voortkomen uit het ongeschreven constitutionele recht. ${ }^{31}$

27. Kortmann 1994, p.34. Een vraag die rijst is hoe uitdrukkelijk de toekenning van een bevoegdheid is wanneer die ontleend wordt aan het ongeschreven recht.

28. Kortmann 1994, p.34-35. Kortmann merkt op dat wanneer taken (bijvoorbeeld sommige sociale grondrechten) opgevat worden als bevoegdheden, het limitatieve karakter van de bewoegdheidsverdeling doorbroken wordt. Enerzijds zou te verdedigen zijn dat die doorbreking ondervangen wordt door in artikel $81 \mathrm{Gw}$ een algemene bevoegdheid voor de wetgever aan te wijzen om onderwerpen te regelen en in een formelle wet regelgevende en bestuursbevoegdheden te attribueren. Anderzijds kan daar tegenin gebracht worden dat dan het limitatieve karakter van de bevoegdheidsverdeling toch wordt doorbroken doordat er geen specifieke bevoegdheid aan te wijzen valt.

29. Koopmans 1994, p.24. Zo ook Van der Vlies 1991, p.90.

30. Koopmans 1994, p. 24.

31. In deze omschrijving kunnen de woorden 'nieuwe bevoegdheid' de vraag oproepen in hoewerre het attribuerende orgaan de bevoegdheid zelf had kunnen uitoefenen. Dit speelt vooral bij onderwerpen die de Grondwet ter regeling opdraagt aan de wetgever. Zou men tot de conclusie komen dat de grondwetgever het onderwerp zelf had kunnen regelen (vergelijk de Grondwetten van 1972 en 1983 en de deconstitutionalisering) dan zou het overdragen van die regelingsbevoegdheid aan de wetgever als delegatie bestempeld kunnen worden. Draagt de formele wetgever op zijn beurt weer regelgevende bevoegdheid over, dan zou van subdelegatie gesproken moeten worden. Dit nu is niet de weg die gevolgd is bij de uitleg van de grondwettelijke delegatieterminologie. llk acht deze weg 


\section{Hoofdstuk 2}

Ook problematische kanten van het begrip attributie komen we tegen in de literaturur. ${ }^{32}$

Zo betwijfelt Van Maarseveen of wel van attributie gesproken kan worden. "Als de grondwetgever bevoegdheden opdraagt aan de regering kan men stellen dat het de grondwetgewer vrij stond om die bevoegdheden zelf uit te oefenen. Geen orgaan kail meer bevoegdheid toekennen aan een ander orgaan dan het zelf heeft en op grond van die redenering zou men kunnen stellen dat attributie niet kan voorkomen en er alleen sprake kan zijn van overgang van bevoegdheid. " ${ }^{33}$

Anderen gaan minder ver, maar signaleren wel problemen in het onderscheid tussen attributie en delegatie. ${ }^{34}$

Of een toedeling van een bevoegdheid attributie dan well delegatie genoemd wordt kan, naast de hierboven genoemde reden, onder andere afhangen van de interpretatie die wordt gegeven aan artikel $81 \mathrm{Gw}$. De aanhangers van een formeel wetsbegrip zien er uitsluitend een vormvoorschrift in: wetten worden vastgesteld in een procedure waarbij regering en Staten-Generaal betrokken zijn. Het artikel behelst geen bevoegdheidstoewijzing.

Aanhangers van een materieel wetsbegrip gaan er van uit dat in artikel $81 \mathrm{Gw}$ de wetgever een algemene wetgevende bevoegdheid heeft gekregen. De wetgever is ook bevoegd om zonder uitdrukkelijke grondwettelijke aanwijzing een onderwerp te regelen. De bevoegdheid van de wetgever is echter niet onbegrensd maar wordt beperkt door bepalingen van internationale verdragen en algemene rechtsbeginselen. ${ }^{35}$

ook niet zinvol: het betekent dat (afhankelijk wan het onderwerp) de Grondwet in het ene geval bevoegdheden attribueert en in het andere gevall delegeert. Ik stel voor om de toedeling wan bewoegdheden door de Grondwet in alle gevallen attributie te noemen.

32. Niet voor niets noemen De Goede/Van den Brink 1986, p.56 attributie "een juridische kunstgreep".

33. Van Maarseveen 1991, p.81.

34. Zo bijwootbeeld Stroink/Steenbeek 1993, p.48: "In bepaalde gevallen kan men van mening verschillen of er sprake is van attributie en delegatie. Belangrijker dan de vraag of er in een bepaald geval nu sprake is wan atributie of delegatie, is of er een rechtens juiste bevoegdheid bestat." Zie ook Van der Vlies 1991, p.90-91. Een dergelijke opvatting komen we ook tegen in de parlementaire stukken op de grondwetsherziening. Volgens regeringscommissaris Simons hangt de kwalificatie attributie of delegatie vaak af van wilens kant men de bevoegdheid bekijkt. Degene die de bevoegdheid overdraagt, zal dat als delegatie beschouwen, degene die de bevoegdheid ontvangt kan er meer attributie in zien. Handelingen III 1978-1979, p.4042.

35. Stroink/Steenbeek 1993, p.33. Ook geldt de grondwettelijke delegatieterminologie die bepalt of de formele wetgever bevoegdheden mag dellegeren. 
Hoe deze verschillende opvattingen kumnen leiden tot een interpretatie van toedeling van een bevoegdheid als attributie of delegatie lezen we bij Stroink/Steenbeek: "Een voorbeeld van door elkaar halen van attributie en delegatie vindt men in de algemeen ingeburgerde term 'delegatie van wetgevende (regelgevende) bevoegdheid', namelijk door de formele wetgever aan de Kroon. Strikt genomen is deze terminologie alleen juist indien er sprake is van organieke wetgeving omdat daarbij deze constellatie zo is dat de grondwetgever de regeling toevertrouwt aan de formele wetgever. In alle andere gevallen is er sprake van attributie van regelgevende bevoegdheid. " ${ }^{36}$ Uit dit citaat blijkt dat Stroink/Steenbeek uitgaan van een formeel wetsbegrip in artikel $81 \mathrm{Gw}$.

Mijn eigen opvatting, die inhoudt dat ik (ook) een materieel wetsbegrip in artikel $81 \mathrm{Gw}$ besloten acht, heeft als consequentie dat steeds van delegatie van regelgevende bevoegdheid sprake is wanneer de formele wetgever een regelgevende bevoegdheid overdraagt, ongeacht of het een organieke of andere formele wet betreft.

Dat de grondwetgever spreekt over delegatieterminologie is begrijpelijk: de Grondwet attribueert regelgevende bevoegdheden aan de formele wetgever, en de overdracht van die bevoegdheden wordt delegatie genoemd.

\subsubsection{Delegatie van regelgevende bevoegdheid}

Van der Vlies constateert dat in de doctrine delegatie van wetgevende bevoegdheid en delegatie van regelgevende bevoegdheid vaak aan elkaar wordt gelijk gesteld. ${ }^{37}$ Dat kan volgens haar wanneer er van uitgegaan wordt dat wetgeving het stellen van algemene (in veel gevallen de burgers bindende) regels inhoudt. Ook in deze studie wordt het delegatievraagstuk behandeld voor regelgevende bevoegdheid. Voor de achterliggende opvatting, dat het de taak van de wetgever is om algemene regels te geven, wordt steun gevonden in de toelichting op de grondwettelijke delegatieterminologie. ${ }^{38}$ De kritiek van Van der Vlies dat hiermee geen criterium is gegeven in welke mate delegatie is toegestaan is terecht. ${ }^{39}$

36. Stroink/Steenbeek 1993, p.48.

37. Van der Vlies 1984, p.132.

38. Op sommige platatsen in de Grondwet is de wetgever echter een beschikkende taak opgedragen, bijwoorbeeld artikel 37 lid 2 Gw: 'De regent wordt benoemd bij de wet. De StatenGeneraal beraadslagen en besluiten terzake in verenigde vergadering. " De hier opgedra. gen bevoegdheid mag niet gedellegeerd worden door de wetgever.

39. Het door Van der Wlies gehanteerde wetsbegrip: de formele wetgever dient zich te beperken tot het nemen van ingrijpende besluiten, leidt tot de opvatting dat deze bevoegdheid niet gedelegeerd kan worden: "De exclusieve bevoegcheid van de wetgever mag de wetgever niet delegeren. En aangezien de bevoegdheid van de wetgever beperkt is tot het 


\section{Hoofdstuk 2}

In de Aanwijzingen voor de regelgeving 1993 zijn dan ook bepalingen opgenomen die zulke criteria pogen aan te reiken (zie voor een bespreking hoofdstuk 4).

Delegatie van bevoegdheid kan, voor de invoering van de delegatieterminologie en de daarmee mogelijk gepaard gaande verandering in het vraagstuk, ${ }^{40}$ bondig omschreven worden als " (...) de overdracht van een eigen bevoegdheid aan een ander om die op eigen naam en onder eigen verantwoordelijkheid uit te oefenen. ${ }^{\text {"4l }}$ Voor delegatie van regelgevende bevoegdheid betekent dat dus dat een regelgevende bevoegdheid wordt overgedragen, (en geen beschikkingsbevoegdheid). ${ }^{42}$

Triepel onderscheidt in zijn werk, Delegation und Mandat im öffentlichen Recht, echte en onechte delegatie. ${ }^{43}$ Bij echte delegatie kan de delegans (degene die de bevoegdheid overdraagt) de bevoegdheid niet meer zelf uitoefenen. Waar het gaat om regelgevende bevoegdheden gaat dit, voor het Nederlandse recht, niet steeds op. Zo is er in de literatuur consensus over dat de formele wetgever een gedelegeerde regelgevende bevoegdheid ook weer zelf kan uitoefenen, zonder dat de delegatiebepaling herroepen wordt, of zonder dat daartoe uitdrukkelijk een voorbehoud is gemaakt. ${ }^{44}$

nemen van ingrijpende besluiten, mag hij nooit delegeren." Van der Vlies 1984, p.133.

40. Er is reden om an te nemen dat de reikwijdte van delegatie van regelgevende bevoegdhe id veranderd is met de invoering van de grond wettelijke delegatieterminologie: delegatie

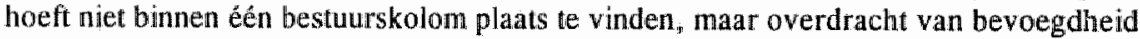
is ook mogelijk van rijksorgan naar gedecentraliseerd orgaan; ook het attribueren vart (discretionaire) bestuursbevoegdheden valt onder het grond wettelijke delegatiebegrip. Zie Kortmann 1987a, p.25 e.v; Van der Pot/Donner/Prakke 1989, p.528; Konijnenbelt 1993, p. 119. Een bespreking vindt plaats in hoofdstuk 4.

41. Donner 1981b, p.381. Na 1983: Van der Vlies 1984, p.131; Koopmans 1994, p.24.

42. Er kunnen well andere bevoegdheden zoals bijvoorbeeld beschikkingsbevoegdheden worden geattribueerd.

43. In de Nederlandse literatuur wordt het onderscheid echte-onechte dellegatie niet gemaakt. Triepel begint zijn werk met een histor̈̈sch onderzoek van de begrippen delegatie en mandaat, die een oorsprong blijken te hebben in het Romeinse recht. Zie vooral zijn hoofdstuk 2.

44. Donner 1951, p.151; Van der Vlies 1984, p.131. Het wetsvoorstel Derde tranche Awb makt aan deze praktijk een einde, althans voor zover het om delegatie van bevoegdheid door bestuursorganen gaat (de wetgevende macht, hier te lezen als synoniem voor formele wetgever is geen bestuursorgaan in de zin van de $\mathrm{Awb}$, zie artikel 1:1 lid $2 \mathrm{Awb}$ ). In artikel 1A.1.2.5 wordt bepaald dat een bestuursorgaan een gedelegeerde bevoegdheid niet meer zelf kan uitoefenen. In het voorontwerp van de Derde tranche was hierbij een uitzondering gemaakt voor het stellen van algemeen verbindende voorschriften. Zie paragraaf 2.3 . 
Donner verklaart dit als volgt: "Uitoefening van de gedelegeerde bevoegdheid door den delegant is ook wetgeving en heeft als zodanig gelij]ke qualiteit als de delegatie. Is zij aan de delegatie posterieur, dan zal zij moeten worden beschouwd als een stilzwijgende intrekking of beperking daarvan. "45.

Triepel noemt deze vorm van (in zijn beschrijving onechte) delegatie 'conserverende' of 'concurrerende' delegatie: de delegans draagt de bevoegdheid over, maar behoudt zich het recht voor, in voorkomende gevallen ook zelf de bevoegdheid uit te oefenen. ${ }^{46}$

Ook wat betreft de rechtskracht van het produkt van de gedelegeerde bevoegdheid is een 'onzuiverheid' waar te nemen: de produkten van de regelgevende bevoegdheden die de formele wetgever delegeert aan bijvoorbeeld regering of minister hebben niet de status van (formele) wet. ${ }^{47}$

De hoofdregel is dat delegatie van regelgevende bevoegdheid moet berusten op een grondslag in een formele wet. ${ }^{48}$ Er wordt echter wel een uitzondering gemakt voor delegatie door een lagere regelgever van een bevoegdheid die past bij de taak van het ontvangende orgaan, en die beperkt is tot details. Een dergelijke delegatie mag zonder wettelijke grondslag plaatsvinden. ${ }^{49}$

45. Donner 1951, p.153.

46. Triepel 1942, p.53-54.

47. Van der Pot/Donner 1972, p.385. Zij voegen eraan toe: tenzij witdrukkelijk de bevoegdheid is verleend om bij algemene maatregel van bestuur van de wet af te wijken of bepaald is, dat de algemene maatregel dezelfde kracht heeft als een wet. Deze problematiek heeft tot discussie geleid over de vraag of deze algemene matregelen wan bestuur getoetst konden worden aan de Grondwet. Heersende leer is dat door de formele wet gedelegeerw de, strikt gebonden regelgeving, niet getoetst mag worden aan de Grond wet Zie hierover de discussie tijdens grondwetsherziening: Kamerstukken II 1975-1976, 13872, nr 6 VV, p. 12-13 en Kamerstukken II 1976-1977, 13872, nr 7 MWA, p.9. Zie woorts Böhtlingk/Logemann 1966, p. 150; Van der Vlies 1984, p.71; Van der Pot/Donner/Prakke 1989, p.527 maken niet het voorbehoud dat het bij het toetsen van gedelegeerde regelingen moet gaan om strikt gebonden regelingen.

48. Stroink/Steenbeek 1993 , p.46. In de veel voorkomende omschrijving van delegatie van regelgevende bevoegdheid vinden we het vereiste van een wettelijke grondslag niet terug. Ook is hierin niet opgenomen aan welk orgaan gedelegeerd mag worden. In sommige bestuursrecht-handboeken wordt gesteld dat delegatie van regelgevende bevoegdheid zonder wettelijke grondslag aanvaardbaar is, mits is voldaan aan bepaalde voorwaarden. Zie Rapport ABAR 1984, p.32; De Goede/Van den Brink 1986, p.65; minder stellig: De Haan/Drupsteen/Fernhout 1986, 1, p.209-210. Vaak ontbreken echter verwijzingen naar bronnen.

49. Rapport ABAR 1973, p.30; 1984, p.32. Zie echter ook paragraaf 7.3. 
Subdelegatie vindt plaats wanneer een gedelegeerde bevoegdheid weer wordt overgedragen aan een lager orgaan. Ook voor subdelegatie van regelgevende bevoegdheid is een formeel-wettelijke basis nodig.

\subsubsection{Mandaat van regelgevende bevoegdheid}

Aan mandaat van regelgevende bevoegdheid wordt in de literatuur slechts weinig aandacht besteed. Dat zou de indruk kunnen wekken dat de figuur in de rechtspraktijk nauwelijks voorkomt. ${ }^{50}$ Donner wijdt er een passage aan: "Al aanstonds kan worden gezegd, dat op het terrein der regeling het zuivere mandaat een uitzondering vormt. Regelende bevoegdheden plegen niet te worden opgedragen aan ondergeschikte organen. Kroon noch Minister kunnen zonder meer als ondergeschikten van den wetgever worden beschouwd. B. en W. zijn evenmin als ondergeschikten van den Gemeenteraad te qualificeren. Zij plegen de hun gegeven regelgevende bevoegdheden dan ook op eigen naam en naar eigen inzicht uit te oefenen. Hun regelingen bezitten de kracht, welke zíj eraan kunnen geven; meer niet. " $\$ 1$

Daarna ontbreekt in de staatsrechtelijke literatuur aandacht voor de figuur van mandaat van regelgevende bevoegdheid. ${ }^{52}$

Wel vinden we deze mandaatsfiguur geregeld in de Aanwijzingen voor de regelgeving 1993. Aanwijzing 33 luidt: 1. 'Mandaat van de bevoegdheid tot het bij ministeriële regeling stellen van algemeen verbindende voorschriften is niet toege-

50. Zie echter de opmerking in de MvT bij het wetsontwerp Derde tranche Awb (Kamerstukken II 1993-1994, 23700, nr 3 MvT, p.171): "De figuur van mandaat tot het vaststellen van algemeen verbindende voorschriften aan een secretaris-generaal of een directeur-generaal komt in de huidige bestuurspraktijk (...) nog al eens voor. Een dergelijk mandaat is naar onze mening echter over het algemeen niet wenselifk en ook niet nodig. Het is van belang dat de politiek verantwoordelijke bewindspersoon zelf de regeling vaststelt."

51. Donner 1951, p.151.

52. Zo bespreekt Koopmans 1994, p.25 kort mandat in het bestuursrecht; zie ook Kortmann 1994, p.36-37 (verwijzend naar Rapport ABAR 1984, p.36 en Duk 1988, p.12-13): "Van delegatie is wel te onderscheiden het mandaat. Hier vindt formeel geen owerdracht van bevoegdheden plaats, daar het besluit van de mandataris op naam blijft staan van de verantwoordelijke mandans. (...) Mandlat komt in ambtelijk-hiërarchische verhoudingen voor. Dit type verhoudingen treft men meer in het bestuursrecht dan het statstecht aan. Mandaat is dan ook meer een bestuursrechtelijk dan een staatsrechtelijk verschijnsel. "Van der Pot/Donner/Prakke 1989, p.480 bespreken de bestuursrechtelijke "mandaatbeschikking' op rijksniveau (de verhouding minister - lagere ambtenaren betreffend). Ook (alleen) over bestuursrechtelijk mandaat Belinfante/De Reede 1991, p.120: "bij mandaat treedt de gemandateerde op in naam en onder verantwoordelijkheid van degeen die een taak gemandateerd heeft (mandans)." Zie voorts paragraaf 2.3: in de Awb wordt mandaat geregeld. 
staan, tenzij bij de toekenning van die bevoegdheid uitdrukkelijk in de mogelijkheid van mandaatverlening is voorzien.

2. Ondermandaat van de bevoegdheid tot het vaststellen van algemeen verbindende voorschriften is niet toegestaan."

De Toelichting luidt: "Onder mandaat van regelgevende bevoegdheid is te verstaan dat een bestuursorgaan aan een onder zijn verantwoordelijkheid werkzame functionaris de bevoegdheid verleent om uit zijn naam en voor zijn verantwoordelijkheid regels te stellen. Mandaat onderscheidt zich van delegatie doordat een gedelegeerde bevoegdheid tot regelgeving meebrengt dat uit eigen naam en voor eigen verantwoordelijkheid van de delegataris regels worden gesteld. De aanwijzing ziet niet op rechtspositionele regelingen ten aanzien van overheidspersoneel aangezien deze in belangrijke mate een intern karakter hebben."

\subsubsection{Attributie-delegatie-mandaat van bestuursbevoegdheid}

\subsubsection{Attributie van bestuursbevoegdheid}

De omschrijvingen van attributie van bestuursbevoegdheid zijn vrijwel dezelfde als die van attributie van regelgevende bevoegdheid. Zo bijvoorbeeld Van Wijk/ Konijnenbelt/Van Male: "een wetgever schept een (nieuwe) bestuursbevoegdheid en kent die toe aan een bestuursorgaan. Dat kan een bestaand bestuursorgaan zijn, of een voor de gelegenheid nieuw geschapen bestuursorgaan (...)." ${ }^{\text {53 }} \mathrm{Zij}$ onderscheiden 'originaire' en 'gedelegeerde' wetgevers, die tot attributie bevoegd zijn. ${ }^{54}$ Tot de 'originaire' wetgevers behoren: de grondwetgever, de formele wetgever, de Kroon wanneer deze een zelfstandige algemene maatregel van bestuur uitvaardigt en organen van lagere publiekrechtelijke lichamen, voor zover zij een autonome verordeningsbevoegdheid hebben.

Gedelegeerde wetgevers zijn de Kroon wanneer die een algemene maatregel van bestuur uitvaardigt die op een formele wet berust, ministers die een ministeriële regeling tot stand brengen en organen van lagere publiekrechtelijke lichamen die een 'medebewinds'verordening uitvaardigen. ${ }^{5 s}$

53. Van Wijk/Konijnenbelt/Van Male 1994, p.131. In dezelfde zin Nicolaï e.a. 1994, p.83; Rappont ABAR 1984, p.12; De Goede/Van den Brink 1986, p.57 en p.59, die ook attributie krachtens ongeschreven recht mogelijk achten.

54. Dit onderscheid komen we bij attributie wan regelgevende bevoegdheid niet tegen, hetgeen echter geen wezenlijk verschil maakt.

55. Van Wijk/Konijnenbelt/Van Male 1994, p.131. 
Ook hier komen we het kenmerk tegen dat het om een nieuwe bevoegdheid gaat, die het attribuerende orgaan niet zelf bezat. ${ }^{56}$

Attributie van bestuursbevoegdheid komt veelvuldig voor in materiële wetgeving, ${ }^{57}$

\subsubsection{Delegatie van bestuursbevoegdheid}

In 1965 verscheen van de Commissie Prins een rapport inzake delegatie en mandaat van bestuursbevoegdheden.$^{58}$ De Commissie verstaat onder delegatie van bestuursbevoegdheid: "1. de overdracht van bestuursbevoegdheid, 2 . door het bestuursorgaan waaraan deze bestuursbevoegdheid is gegeven, 3 . aan een ander, 4. die de overgedragen bevoegdheid op eigen gezag en onder eigen verantwoordelijkheid zal uitoefenen." "ss

Van Wijk/Konijnenbelt/Van Male maken onderscheid tussen auto-delegatie (waarbij het oorspronkelijk bevoegde orgaan zelf een bevoegdheid overdraagt) en allo-delegatie (waarbij de overdragende instantie een ander is dan het orgaan waaraan de bevoegdheid oorspronkelijk was geattribueerd). Het delegerende orgaan kan de bevoegdheid gedeeltelijk overdragen, of geclausuleerd, maar

56. Zie De Goede/Van den Brink 1986, p.60: "Bij attributie gaat het om een originele wijze van bevoegdheidsverkrijging: een orgaan verkrijgt een bevoegdheid, die nog niet aan een ander behoorde. Donner drukt dit aldus uit, dat bij attributie bevoegdheden in het geding zijn die tevoren niet bij het toekennende orgaan berustten. Phaf voegt daaraan toe, dat de betrokken bevoegdheid weliswaar niet bij het toekennende orgaan berustte in die zin, dat dit ongaan haar zelf harteerde, maar dat het blijkbaar wel de mogelijkheid heeft tot het toekenmen ervan. Koopmans levert het sluitstuk: 'Zo kunnen in een pre-constitutionele fase alle bevoegdheden toekomen aam éen orgaan (bijv. absoluut vorst), maar zodra er een grondwet is, vestigt deze een hierarchie van organen en voorziet deze elk van eigen bevoegcheden." Verwijingen: Donner 1951, p.153-157, Phaf 1962, p.82 en Koopmans 1983, p. 22

57. Bestuursbevoegdheden worden veelvuldig geattribueerd aan ambtenaren. Zie Nicolaïe.a. 1994, p.89: "De heersende opvatting is dat toekenning van een eigen bestuursrechtelijke bevoegdheid aan een ambtenaar, tenzij uit de toepasselijke wettelijke regeling het tegendeel blijkt, niet de hier rarchische bevoegdheid tot het geven van algemene en bijzondere aanwijzingen doorbreekt." Zie ook Konijnenbelt 1992a, p.41.

58. De Commissie us ingesteld naar aanleiding van de VAR-preadviezen van Leemans en Phaf uit 1962, over 'Figuren als overdracht, machtiging en opdracht met betrekking tot bestuursbevoegdheden" alsnede de beraadslagingen over die preadviezen.

59. Rapport Commissie Prins 1965, p.6. Zie in gelijke zin Donner 1981 b, p.381; Nicolaïe.a. 1994, p.92; Van Wijk/Konijnenbelt/Van Malle 1994, p.135. 
voorzover de bevoegdheid is overgedragen is de delegans hem kwijt. De delegataris hanteert deze dan ook als een eigen bevoegdheid. ${ }^{60}$

Algemeen wordt aangenomen dat een wettelijke basis voor delegatie van bestuursbevoegdheid is vereist: delegatie doorbreekt de door de wetgever gewilde bevoegdheidsverdeling. ${ }^{61}$ Daarbij is delegatie van bestuursbevoegdheid slechts toegestaan voorzover de wet daartoe de bevoegdheid geeft. ${ }^{62}$ Voor de delegatieverlening is een besluit nodig. ${ }^{63}$ Delegatie aan ondergeschikten komt in de be-

60. Nicolaï e.a. 1994, p. 92 ; Van Wijk/Konijnenbelt/Van Male 1994, p.136. Vergelijk Donner 1981 b, p. 381: "Wil de delegans de gedelegeerde bevoegdheid zelf (weer) uitoefenen, dan is daarvoor maar één mogelijkheid: de delegatie zelf ongedaan maken door het delegatiebesluit in te trekken; eventueel door het zo te wijzigen, dat de delegans zich het recht voorbehoudt in voorkomende gevallen de bevoegdheid zelf te hanteren."

61. Rapport Commissie Prins 1965, p.9; Rapport ABAR 1984, p.33; De Goede/Van den Brink 1986, p.65; Nicolaî e.a. 1994, p.94; Van Wijk/Konijnenbelt/Van Male 1994, p.137; ARRS 28 oktober 1988, AB 1989, 153, m.nt. PvB: ook voor delegatie van beschikkingsbevoegdheid is wettelijke grondslag nodig. Zie voorts ARRS 16 oktober 1992, AB 1993, 328, m.nt. PvB: Besluit van de gemeenteraad tot delegatie aan b en w van bevoegdheid om bestemmingsplan te herzien mist rechtskracht. Wettelijke grondslag ontbreekt: niet in de WRO of andere wet is af te leiden dat bevoegdheid gedelegeerd zou kunnen worden door gemeenteraad. Nu in casu de herziening van het bestemmingsplan één perceel betrof is hier sprake van een beschikkingsbevoegdheid.

62. Nicolaï e.a. 1994, p.94. Zie bijvoorbeeld artikel 166 Gemeentewet. In de Gemeentewet komt ook een figuur voor die lijkt op attributie ên delegatie, Nicolaï/Olivier 1991, p.35: "Het gaat om gevallen waarin een bestuursorgaan een aan een ander orgaan toekomende bevoegdheid kan overhevelen naar een door hem aan te wijzen orgaan. Van delegatie in strikte zin is dan geen sprake: het bevoegdheid verlenende orgaan draagt geen hem zelf toekomende bevoegdheid over." Zie bijvoorbeeld artikel 165 Gemeentewet.

Is enerzijds het onderscheid delegatie-attributie soms moeilijk te maken, ook het onderscheid delegatie-mandaat levert soms problemen op. Zie ARRS 5 januari 1986, AB 1987, 278 m.nt. Van Buuren, Gst. 6836, m.nt. Kan en ARRS 29 oktober 1988, AB 1989, 153, m.nt. Van Buuren. Opvallend is dat met name op gemeentelijk niveau regelmatig problemen opduiken rond de atbakening delegatie-mandaat. Zie ook Goorden 1993, p.227-229, die een overzicht geeft van recente jurisprudentie over delegatie en mandaat.

63. Eer eventueel gebrekkig delegatiebesluit wordt soms door de rechter 'gedekt', zie $\mathrm{Vz}_{\mathrm{z}}$ ARRS 24 september 1992, AB 1993, 266, m.nt. NV, Gst. 6968, nr 10, m.nt. Goorden: "Wij vragen ons af of ten dele wel van een voldoende omschreven delegatie van beslissingsbevoegdheid sprake is. Wij zijn evenwel woorshands bereid het betrokken besluit het voordeel van de twijfel te geven. Wij nemen daarbij in aanmerking dat verzoekster met een schorsing van bedoeld besluit onder de bepaling dat de raad der gemeente terzake een beslissing dient te nemen, thans niet is geholpen." Zie ook ARRS 23 matart 1993, AB 1993,489 , m.nt. S.E. Zijlstra. Ondanks onbevoegdheid geen vęrinietiging van het bestreden besluit ondat het besluit berust op een uitvoerig advies van de commissie voor beroep- en bezwaarschriften, die appellant heeft gehoord. Appellant is door de gang van 


\section{Hoofdstuk 2}

stuurspraktijk veelvuldig voor. De meeste auteurs nemen aan dat de delegans aan een ondergeschikte ambtenaar algemene en bijzondere aanwijzingen kan geven met betrekking tot de gedelegeerde bevoegdheid. ${ }^{64}$

Van belang is dat door delegatie (of mandaat) de rechtsbeschermingsmogelijkheden kunnen veranderen: er kunnen andere bezwaar- en beroepsinstanties bevoegd worden. ${ }^{65}$

Subdelegatie houdt in dat de delegataris een aan hem overgedragen bevoegdheid weer delegeert aan een ander orgaan dat die bevoegdheid op eigen naam en verantwoordelijkheid gaat uitoefenen. ${ }^{66}$ Subdelegatie vereist eveneens een wettelijke grondslag. ${ }^{67}$

\subsubsection{Mandaat van bestuursbevoegdheid}

De Commissie Prins omschrijft mandaat als: "1. de overdracht van bestuursbevoegdheid, 2. door het bestuursorgaan waaraan deze bestuursbevoegdheid is gegeven, 3 . aan een ander, 4 . die de overgedragen bevoegdheid uit naam en onder verantwoordelijkheid van het eerstbedoelde orgaan zal uitoefenen. ${ }^{\text {68 }}$ Mandaat kan zowel plaatsvinden aan ondergeschikten als aan niet-ondergeschikten. Dit laatste dient in een wettelijke regeling mogelijk te zijn gemaakt en bovendien dient de niet-ondergeschikte het mandaat uitdrukkelijk te aanvaarden. ${ }^{69}$

zaken niet in zijn processuele belangen geschaad.

64. Rapport ABAR 1984, p.31: Scheltema 1975, p.238 acht delegatie aan ondergeschikten een contradictio in terminis. "De Commissie meent echter dat hierin geen beletsel behoeft te zijn gelegen om van delegatie te spreken: de delegatie leidt tot overgang van verantwoordelijk beid, maar de bestaande hiërarchische verhouding leidt ertoe dat het besturrsorgaan net als bij attributie van beschikkingsbevoegdheid aan een ambtenaar - een politieke verantwoordelijkheid behoudt." Nicolail/Olivier 1991, p.34 achten eveneens delegatie en alanwijzingsbevoegdheid aan ondergeschikten mogelijk. In de voorstellen voor regeling vandelegatie in de Awb wordt delegatie aan ondergeschikten niet toegestaan (zie paragrataf 2.3.1.2).

65. Nicolati e.a. 1994, p.98.

66. Nicolail e.a. 1994, p.95. Zij hanteren de term 'onderdelegatie',

67. Rapport Commissie Prins 1965, p.11; Nicolai e.a. 1994, p.95.

68. Rapport Commissie Prins 1965, p.6. In haar definitie hanteert de Commissie de term overdracht: "als gevolg van een mandaat (krijgt) een voorheen onbevoegde de macht (...) tot het vertichten van bestuurshandelingen." Voor mandaat wordt ook wel het woord opdrach gebruikt: De Goede/Van den Brink 1986 p.68 "Mandaat is de figuur, waarbij een orgaan (de mandans) een ander orgaan (de mandataris) opdraagteen bestuursbevoegdheid van de mandans uit te oefenen in diens naam en onder diens verantwoordlelijkheid." $\mathrm{Zij}$ wijden nog een aantal pagina's aan de 'onvaste' terminologie (p.73-74).

69. Rapport Commissie Prins 1965, p.15 en p.17. Zie ook Rapport ABAR 1984, p.47; De Goede/Van den Brink 1986, p.72. 
Voor mandaat aan ondergeschilkten is geen wettelijke grondslag vercist. Een negatief vereiste geldt wel. Mandaatverlening mag niet door een wetsbepaling worden uitgesloten en ook mag de aard van de bevoegdheid zich niet tegen de verlening verzetten. ${ }^{70}$

Er worden twee 'soorten' mandaat onderscheiden: afdoeningsmandaat en ondertekeningsmandaat. In de praktijk lopen deze twee vormen nogal eens door elkaar. $^{\text {n }}$

In tegenstelling tot bij delegatie blijft de mandaatgever verantwoordelijk voor de uitoefening van de gemandateerde bevoegdheid en kan hij die in voorkomende gevallen ook zelf uitoefenen. Ook kan hij de mandataris algemene en bijzondere aanwijzingen geven. ${ }^{72}$

Ondermandaat is toegestaan wanneer de mandaatverlening daarin voorziet. Bij ondermandaat wordt de gemandateerde bevoegdheid niet uitgeoefend door de mandataris, maar draagt deze op zijn beurt de bevoegdheid weer op aan een ander. ${ }^{73}$

\subsubsection{Verschillen tussen attributie-delegatie-mandaat van regelgevende en bestuursbevoegdheid?}

Tussen attributie van regelgevende bevoegdheid en attributie van bestuursbevoegdheid blijkt geen yerschil te bestaan.

Delegatie van regelgevende bevoegdheid blijkt een vorm van 'onechte' delegatie te zijn, in de woorden van Triepel 'conserverende' of 'concurrerende' delegatie. De bevoegdheid wordt overgedragen, maar de delegans kan de bevoegdheid ook nog zelf uitoefenen. ${ }^{74}$ Bij delegatie van bestuursbevoegdheid is de delegans de bevoegdheid echter helemaal kwijt, in Triepels beschrijving is dit 'echte' delegatie.

Mandaat van bestuursbevoegdheid komt veel voor en is zonder wettelijke grondslag aan ondergeschikten toegestaan. Mandaat van regelgevende bevoegdheid wordt in de Aanwijzingen voor de regelgeving 1993 niet wenselijk geacht en dient dan ook, als zij al voorkomt, een wettelijke grondslag te hebben.

70. HR 1 april 1966, NJ 1966, 455. Zie ook Rb Almelo 5 augustus 1992, NJ 1993, 43 en CRvB 10 november 1994 , NJB-katern 1995, p.105, or 2.

71. De Goede/Van den Brink 1986, p.71.

72. De Goede/Van den Brink 1986, p.70; Nicola e.a. 1994, p.110.

73. Rapport Commissie Prins 1965, p.18; Rapport ABAR 1984, p.49.

74. Anders: het wetsvoorstel Derde tranche Awb. 


\section{Hoofdstuk 2}

2.3 De regeling van mandaat en delegatie in het wetsvoorstel van de Derde tranche van de Algemene wet bestuursrecht

\subsubsection{Beschrijwing van de regeling ${ }^{75}$}

In het wetsvoorstel van de Derde tranche Algemene wet bestuursrecht (Awb) ${ }^{76}$ worden mandaat en delegatie geregeld, attributie ontbreekt daarbij. De bepalingen krijgen een plaats in een nieuw hoofdstuk 10 "Bepalingen over bestuursorganen". Zowel bij mandaat als delegatie wordt gesproken over bevoegdheden met betrekking tot besluiten; daaronder vallen zowel algemeen verbindende voorschriften als besluiten van algemene strekking en beschikkingen.

De regeling is volgens de MvT in hoge mate 'een neerslag van geldend recht'. Op onderdelen neemt de wettelijke regeling een standpunt in waarover in jurisprudentie en literatuur nog verschil van inzicht bestaat. ${ }^{77} \mathrm{Bij}$ de beschrijving van de regeling volg $i \mathrm{k}$ het wetsvoorstel: daarin wordt eerst mandaat geregeld, daarna delegatie.

\subsubsection{Mandaat}

Onder mandaat verstaat het wetswoorstel: "de bevoegdheid om in naam van een bestuursorgaan besluiten te nemen" (artikel 1A.1.1.1). Die bevoegdheid wordt steeds aangenomen, tenzij bij wettelijk voorschrift anders is bepaald of de aard van de bevoegdheid zich ertegen verzet (artikel 1A.1.1.2 lid 1). Het tweede lid somt enkele bevoegdheden op die niet gemandateerd mogen worden: de bevoegdheid tot het vaststellen van algemeen verbindende voorschriften (tenzij bij toekenning van die bevoegdheid in mandaat is voorzien); de bevoegdheid tot het nemen van een besluit dat met versterkte meerderheid genomen moet worden of waarvoor anderszins een bijzondere procedure voorgeschreven is; de bevoegdheid tot het beslissen op een beroepschrift; de bevoegdheid tot het vernietigen van of tot

75. Het ingediende wetsvoorstel wijkt slechts marginal af van het voorontwerp. De meeste hierna aangehaalde auteurs bespreken het voorontwerp van de Derde tranche.

76. Kamerstukken II 1993-1994, 23700, nr 2, Voorstel van wet.

77. Kamerstukken II 1993-1994, 23700, nr 3 Mv'1, p. 165. Zie ook Verheij 1992a, p.172: de regeling heeft 'in hoofdzaak een codificerend karakter". Verwijzingen in de jurisprudentie naa de Derde tramehe Awb (mandaat): Rb Den Bosch 19 februari 1993, TAR 1993, 86, in de uitspraak wordt werwezen naar artikel 1A.1.1.7 Awb; CRvB 11 maart 1993, AB 1993, 341, m.nt. HH ower mandaat (artikel 1A.1.1.2 Awb); CRvB 8 april 1993, AB 1993,392, m.nt. $H H$ over delegatie (artikel 1 A.1.2.2 Awb). Verder nog CBB 31 januari 1995, JB 1995/61 (mandaat) en Rb Utrecht 27 januari 1995, JB 1995/55, m.nt. FAMS (mandaat). 
het onthouden van goedkeuring aan een besluit van een ander bestuursorgaan. Krachtens het derfe lid mag de bevoegdheid tot het beslissen op een bezwaar schrift wel gemandateerd worden, maar niet aan degene die het bestreden besluit krachtens mandaat heeft genomen.

Het besluit dat door een gemandateerde (binnen de grenzen van zijn bevoegdheid) wordt genomen geldt als een besluit van de mandaatgever (artikel 1A.1.1.1a, in het voorontwerp was dit artikel 1A.1.1.3).

Mandaat zal in veel gevallen plaatsvinden aan ondergeschikten. Wordt gemandateerd aan een niet-ondergeschikte, dan dient deze in te stemmen met de mandaatverlening, alsmede degene onder wiens verantwoordelijkheid hij werkt (artikel 1A.1.1.4). Mandaat kan zowel voor een bijzonder geval als in het algemeen verleend worden. Een algemeen mandaat dient schriftelijk verleend te worden (artikel 1A.1.1.5).

De mandaatgever kan zowel algemene als bijzondere aanwijzingen geven (artikel 1A.1.1.6) en de mandaatverlening te allen tijde beëindigen (artike 1A.1.1.8). Ook blijft de mandaatgever bevoegd om de gemandateerde bevoegdheid zelf uit te oefenen (artikel 1A.1.1.7).

Ondermandaat kan worden verleend als de mandaatgever dat toestaat. De bepalingen over mandaat worden in dat geval van overeenkomstige toepassing verklaard (artikel 1A.1.1.9).

In het krachtens mandaat genomen besluit wordt vermeld namens welk bestuursorgaan het besluit wordt genomen (artikel 1A.1.1.10). Voor een ondertekenings'mandaat' bevat artikel 1A.1.1.11 de volgende regeling: een bestuursorgaan kan bepalen dat een door hem genomen besluit namens hem wordt ondertekend (tenzij bij wettelijk voorschrift anders is bepaald of de aard van de bevoegdheid zich ertegen verzet). Uit het besluit moet wel blijken dat het door het bestuursorgaan zelf genomen is.

Tenslotte verklaart artikel 1A.1.1.12 de regeling van mandaat van overeenkomstige toepassing op de gevallen waarin het bestuursorgaan een ander (werkzaam onder zijn verantwoordelijkheid) volmacht verleent (tot het verrichten van privaatrechtelijke rechtshandelingen), of machtigt (tot het verrichten van handelingen die noch een besluit, noch een privaatrechtelijke rechtshandeling zijn).

In de MvT wordt gesteld dat mandaat te beschouwen is "als de publiekrechtelijke tegenhanger van de volmacht uit het privaatrecht. "78 $\mathrm{Bij}$ mandaat blijven verantwoordelijkheid en zeggenschap over de gemandateerde bevoegdheid bij de man-

78. Kamerstukken II 1993-1994, 23700, nr 3 MvT, p. 165; zie voor een vergelijking van mandaat en volmacht De Groot/Van Rossum 1993, p. 127-141. 


\section{Hoofdstuk 2}

daatgever. ${ }^{79}$ De kern van de mandaatsuitoefening is volgens de MvT gelegen in artikel 1A.1.1.1a: een besluit van de gemandateerde geldt als een besluit van de mandaatgever, wanneer deze handelt binnen de grenzen van de gemandateerde bevoegdheid. Het vertrouwensbeginsel kan bescherming bieden aan degene die op een geldig mandaat mocht vertrouwen. ${ }^{80}$ Er is vanaf gezien om wettelijk te regelen in welke gevallen die toerekening aan de mandaatgever plaatsvindt. ${ }^{81}$

Wel worden in de MvT, op basis van de jurisprudentie, de voorwaarden besproken waaronder een dergelijke toerekening kan plaatsvinden. "Allereerst moet het bestuursorgaan door zijn gedrag het vertrouwen hebben gewekt dat er een rechtsgeldig mandaat bestond. Het gaat daarbij in beginsel niet om gedrag van de gemandateerde, maar om dat van het bestuursorgaan in wiens naam is gehandeld. In de tweede plaats zal vast moeten staan dat de wederpartij in redelijkheid op de gewekte schijn van bevoegdheid heeft mogen afgaan." 82 "Wanneer het om een gunstig besluit gaat voor de burger kan deze zich op het vertrouwensbeginsel beroepen. De omgekeerde situatie, dat een besluit minder gunstig is voor de burger, komt, althans in de jurisprudentie, vaker voor. De burger beroept zich dan op een gebrekkig mandaat. Voor die gevallen geldt artikel 1A.1.1.1a en zal van een onbevoegd genomen besluit sprake zijn. ${ }^{83}$

In een aantal gevallen is mandaat niet toegestaan, die gevallen zijn (niet-limitatief) opgesomd in artikel 1A.1.1.2 lid 2. Terwijl mandaat van het stellen van algemeen verbindende voorschriften in beginsel niet is toegestaan is volgens de MvT mandaat van het stellen van beleidsregels wel mogelijk. Daarbij is denkbaar dat de gemandateerde bevoegdheid zelf weer wordt ondergemandateerd (bijvoorbeeld aan verschillende ambtenaren). Het stellen van de beleidsregels mag daarbij echter volgens de MvT niet ondergemandateerd worden, om te voorkomen dat er verschillende beleidsregels over de toepassing van één bevoegdheid ontstaan. ${ }^{84}$

De Mv'T vermeldt verder dat overwogen is een vijfde uitsluitingsgrond op te nemen: mandaat van de bevoegdheid tot het beperken van grondrechten. In

79. Kamerstukken II 1993-1994, 23700, nr 3 MvT, p. 165 .

80. Kamerstukken II 1993-1994, 23700, nr 3 MvT, p.168.

81. Kamerstukken II 1993-1994, 23700, Nader rapport, p.8.

82. Kamerstukken II 1993-1994, 23700, nr 3 MvT, p. 169.

83. Kamerstukken III 1993-1994, 23700, nr 3 MvT, p. 169. Soms kan daarbij het besluit nog (door het bevoegde orgaan) bekrachtigd worden.

84. Kamerstukken II 1993-1994, 23700, nr 3 MvT, p.170-171. 
sommige gevallen kan die bevoegdheid niet gemandateerd worden ${ }^{85}$, maar volgens de toelichting is denkbaar dat er gevallen zijn waarin wel gemandateerd mag worden ${ }^{86}$ Criteria om deze gevallen te onderscheiden geeft de toelichting overigens niet.

Voor mandaat aan een niet-ondergeschikte is geen bijzondere wettelijke grondslag vereist. Wel eist het wetsvoorstel de instemming van de gemandateerde. Daarmee verplicht deze zich de bevoegdheid uit te oefenen en daarbij de aanwijzingen van de mandaatgever in acht te nemen. De instemming hoeft overigens niet schriftelijk te worden gegeven. ${ }^{87}$ Nieuw ten opzichte van het voorontwerp is de bepaling dat ook degene onder wiens verantwoordelijkheid de gemandateerde werkt, moet instemmen met het mandaat. Als bij wettelijk voorschrift in mandaatverlening aan een niet-ondergeschikte is voorzien is geen instemming nodig van de gemandateerde en degene onder wiens verantwoordelijkheid hij werkt. $^{88}$

Dat de mandaatgever een gemandateerde bevoegdheid zelf steeds kan blijven uitoefenen wordt een 'wezenskenmerk' van mandaat genoemd. ${ }^{89}$

Afdoen en ondertekenen horen in principe in één hand thuis. Bij ondertekening kan echter moeilijk van mandaat gesproken worden, nu volgens de regeling mandaat ziet op het nemen van besluiten. Omdat in de praktijk toch behoefte is aan een ondertekeningsbevoegdheid is deze geregeld in artikel 1A.1.1.11.

85. Kamerstukken II 1993-1994, 23700, nr 3 MvT, p.172, noemt als voorbeelden Vz ARRS 31 juli 1989, AB 1990, 315 en Hof Amsterdam 4 mei 1990, AB 1991, 30. In beide gevalllen ging het om beperking van het recht op bewegingsvrijheid.

86. Bijvoorbeeld bij bepaalde bevoegcheden die de burgemeester toekomen op grond van de Wet Openbare Manifestaties of de Zondagswet. (Zie ook paragraaf 5.3.) Kamerstukken II 1993-1994, 23700, nr $3 \mathrm{MvT}_{\text {, p. } 172 .}$

87. Kamerstukken II 1993-1994, 23700, ni 3 MvT, p.172.

88. Kamerstukken II 1993-1994, 23700, nr 3 MvT, p. 172-173.

89. Kamerstukken II 1993-1994, 23700, nr 3 MvT, p.174.

90. Kamerstukken II 1993-1994, 23700, nr $3 \mathrm{MvT}$, p.175-176. Zie voor cen voorbeeld van ondertekeningsmandaat in strijd met de wet: Vz AGRS 19 februari 1991, AB 1991, 305. m.nt. PJS. De gemeentesecretaris had in casu niet de bewoegdheid om te ondertekenen. Vernietiging wegens strijd met de wet (artikel 75 Gemeentewet oud). Zie ook ABRS 5 januari 1995, NA 1995, 45: de primaire besluiten zijn uitsluitend door de griffier ondertekend en niet ook door de Commissaris der Koningin. Van een door Gedeputeerde Staten aan de griffier verleend ondertekeningsmandaat is geen gebruik gemaakt. Dit is in strijd met de ondertekeningsvoorschriften in de artikelen 74 lid 2 en 102 lid 1 Provinciewet. De Afdeling acht hier niet slechts een administratief verzuim aan de orde. Door ondertekening is immers gewaarborgd dat het besluit door de daartoe bevoegde instantie is genomen. 


\section{Hoofdstuk 2}

\subsubsection{Delegatie}

Telde de titel over mandaat nog 12 artikelen, de regeling van delegatie moet het stellen met 8 artikelen. Het wetsvoorstel definieert delegatie als: 'het overdragen door een bestuursorgaan wan zijn bevoegdheid tot het nemen van besluiten aan een ander die deze onder eigen verantwoordelijkheid uitoefent.' (artikel 1.A.1.2.1) Afwijkend van geldend recht tot nu toe is de bepaling in artikel 1A.1.2.2 dat delegatie niet wordt verleend aan ondergeschikten. Voorts is voor delegatie een grondslag in cen wettelijk voorschrift nodig (artikel 1 A.1.2.3). Voor de uitoefening van een gedelegeerde bevoegdheid kan een bestuursorgaan uitsluitend beleidsregels geven (artikel 1A.1.2.4 lid 1). ${ }^{91}$ Lid 2 bevat een inlichtingenplicht voor degene aan wie de bevoegdheid is gedelegeerd. Het bestuursorgaan kan de gedelegeerde bevoegdheid niet meer zelf uitoefenen (artikel 1A.1.2.5) ${ }^{92}$ Het bestuursorgaan kan te allen tijde de delegatie beëindigen (artikel 1A.1.2.6). Een besluit dat genomen is krachtens een gedelegeerde bevoegdheid, vermeldt het delegatiebesluit en de vindplaats daarvan (artikel 1A.1.2.7).

Artikel 1A.1.2.8 tenslotte bevat een regeling voor de overdracht van een bevoegdheid die een ander bestuursorgaan toebehoort. Dit artikel was nog niet in het voorontwerp opgenomen. ${ }^{93}$ Lid 1 bepaalt dat afdeling 10.1 .2 van overeenkomstige toepassing is behalve artikel 1A.11.2.4 (het stellen van beleidsregels en de inlichtingenplicht). Daarvoor in de plaats zijn de leden 2 en 3 opgenomen. Lid 2 luidt: 'Bij wettelijk voorschrift of bij het besluit tot overdracht kan worden bepaald dat het bestuursorgaan wiens bevoegdheid is overgedragen beleidsregels over de uitoefening van die bevoegdheid kan geven. ' Lid 3 behelst een uitbreiding van de inlichtingenplicht: 'Degene aan wie de bevoegdheid is gedelegeerd, verschaft het overdragende en het oorspronkelijk bevoegde bestuursorgaan op hun verzoek inlichtingen over de uitoefening van de bevoegdheid."

91. Kritisch hierover Goorden 1992, Beleidsregels bij mandaat en delegatie, en Kortmann 1995, Delegatie, beleidsregeis en decentralisatie.

92. In het voorontwerp was hierbij een uitzondering gematakt voor de bevoegdheid om aligemeen verbindende voorschriften te stelten: die bevoegdheid zou het bestuursorgaan behouden. Natar anleiding van het Advies wan de Raad van State is deze uitzondering geschrapt. Kamerstukken II 1993-1994, 23700, nr 3 Mv'T, Nader rapport, p.13. De Raad meende dat deze uitzondering in strijd was met de definitie van delegatie en wilde delegatie van het vaststellen wan algemeen verbindende voorschriften niet regelen in deze afdeling. Zie hierover ook Velman 1994, p.129.

93. Kamerstukten II 1993-1994, 23700, nr 3 MvT, p. 178: dit artikel is mede natar aanleiding van het advies van de Raad van State opgenomen. Een verwijzing naar dit artikel geeft Pres. Rb Den Haag 27 januari 1995, NA 1995, 107. 
Volgens de MvT is thans volgens de heersende leer delegatie aan ondergeschikten mogelijk, waarbij de delegatie de ondergeschiktheidswerhouding niet doorbreekt. ${ }^{94}$ Het wezenskenmerk van delegatie, de zelfstandige bevoegdheidsuitoefening, ontbreekt hierbij echter. Dit is voor de opstellers van het wetsvoorstel reden om delegatie aan ondergeschikten uit te sluiten. Wordt een ondergeschikte ingeschakeld dan is mandaat de aangewezen figuur..$^{95}$

Opmerking verdient verder dat een regeling van subdelegatie ${ }^{96}$ ontbreekt. "Dit is ook niet nodig, omdat in tegenstelling tot mandaat voor delegatie een wettelijke grondslag vereist is. Dit brengt mee dat de wet regelt in hoeverre onderdelegatie is toegestaan. Is over onderdelegatie niets bepaald, dan is zij ingevolge artikel 1A.1.2.3 niet toegestaan. ${ }^{\text {"97 }}$

Het vereiste van een wettelijke grondslag voor (sub)delegatie (van wetgevende bevoegdheid) wordt in de toelichting geillustreerd aan de hand van een drietal arresten van de Hoge Raad: HR 25 januari 1926, NJ 1926, blz.246 (Jamin), HR 19 januari 1931, NJ 1932, p.439 (snoekvissen) en HR 26 januari 1957, NJ 1958, 53 (vuurwerk; bedoeld is HR 26 november 1957, NJ 1958, 53). ${ }^{98}$

Als er geen wettelijke basis voor subdelegatie van wetgevende bevoegdheid is kunnen wel uitvoerende taken aan bestuursorganen toebedeeld worden. Het bestuursorgaan mag dan geen algemeen verbindende voorschriften stellen, maar kan wel besluiten van algemene strekking nemen. Volgens de toelichting sluit deze benadering aan bij de jurisprudentie van de Hoge Raad in deze (HR 8 mei 1953, NJ 1953, 614 en HR 11 januari 1977, NJ 1977, 467) "al werd in die jurisprudentie het onderscheid tussen algemeen verbindend voorschrift en besluit van algemene strekking niet als zodanig gemaakt. " 99

De basis voor delegatie kan zowel gelegen zijn in een specifiek als een algemeen wettelijk voorschrift. ${ }^{100}$

94. Kamerstukken II 1993-1994, 23700, nr 3 MvT, p.177, onder verwijzing naar Rapport ABAR 1984, p.30-31. Zie bijvoorbeeld ook ARRS 23 maart 1993, AB 1993,489 , m.nt. S.E. Zijlstra.

95. Kamerstukken II 1993-1994, 23700, nr 3 MwT, p. 177-178. In aanpassingswetgeving zal voorgesteld worden on de thans in de Gemeentewet en Provinciewet opgenomen artikelen die delegatieverlening aan ambtenaren mogelijk maken (de artikelen 166 en $\$ 77$ Gemeentewet en 164 en 177 Provinciewet), te wijzigen en met de regeling in de Awb in overeenstemming te brengen.

96. De MvT, p.178, spreekt van 'onderdelegatie'.

97. Kamerstukken II 1993-1994, 23700, nr 3 MvT, p.178.

98. Zie over deze arresten verder paragraf 7.3 .

99. Kamerstukken II 1993-1994, 23700, nr 3 MvT, p.179. Op de problematiek van het onderscheid "regelgeving-uitwoering" wordt uitgebreid ingegaan in hoofdstuk 7.

100. Kamerstukken II 1993-1994, 23700, nr 3 MvT, p.179. 


\section{Hoofdstuk 2}

De delegans kan de gedelegeerde bevoegdheid niet meer zelf uitoefenien. In het voorontwerp was hierbij nog een uitzondering gemaakt voor delegatie van het stellen van algemeen verbindende voorschriften. Die uitzondering komt niet meer voor in het wetsvoorstel. "Het is ongewenst dat twee bestuursorganen tegelijkertijd bevoegd zijn over dezelfde materie besluiten te nemen; dit geldt voor besluiten tot regelgeving evenzeer als voor andere besluiten." ${ }^{101}$ Wil het delegerende bestuursorgaan zelf toch de regelgevende bevoegdheid uitoefenen dat kan het de delegatie intrekken. ${ }^{102}$

Een besluit waarbij een bevoegdheid wordt gedelegeerd is volgens de toelichting een algemeen verbindend voorschrift. ${ }^{103}$

\subsubsection{Commentaren}

De voorgestelde regeling is kritisch ontvangen in de literatuur. ${ }^{104}$ De meeste commentaren zijn gebaseerd op het voorontwerp. Ik volsta met het bespreken van de, in het kader van dit onderzoek, meest interessante bezwaren.

\section{Het ontbreken van een regeling van attributie}

Attributie is niet geregeld in het wetsvoorstel. De MvT geeft daarvoor als verklaring dat het zowel bij mandaat als delegatie om een bestaande bevoegdheid gaat. Attributie vindt plaats in de bijzondere wet en gaat aan mandaat en delegatie vooraf. Later kan bekeken worden of attributie (bijvoorbeeld van bestuursorgaan aan ondergeschikte) toch regeling in de Awb behoeft. ${ }^{105}$ Mijns inziens blijkt hieruit (nog steeds) niet waarom niet nu al een wettelijke regeling wordt voorgesteld. Oudshoorn denkt dat de opstellers van het (voor)ontwerp attributie bewust niet geregeld hebben omdat daarbij de provinciale en gemeentelijke autonomie met betrekking tot regelgeving en uitvoering van de eigen huishouding van provincies en gemeenten in het geding zou kunnen zijn. ${ }^{106}$ Deze beweegreden is echter niet in de MvT terug te vinden.

Kritisch op dit punt (het niet regelen van attributie) is ook Stroink in zijn commentaar op het voorontwerp. Zijns inziens is welliswaar het onderscheid attribu-

101. Kamerstukken II 1993-1994, 23700, nr 3 MvT, p.180.

102. Kamerstukken II 1993-1994, 23700, nr 3 Mv'T, p.180-181.

103. Kamerstukken II 1993-1994, 23700, nr 3 MvT, p.181.

104. Zie over het onderwerp mandaat-delegatie uit de Derde tranche o.a.: Langbroek e.a 1992, Stroink 1992, Van der Burg 1992, Goorden 1992, Hennekens 1992, Konijnenbelt 1992b, Oudshoorn 1992, De Groot/Van Rossum 1993, Ter Schegget/Herwejjer 1993. Konijnenbelt 1993 en Van der Vlies 1994.

105. Kamerstukken II 1993-1994, 23700, nr 3 MvT, p.3.

106. Oudshoorn 1992, p.272. 
tie-delegatie niet altijd scherp te maken, maar dat is ook niet zo belangrikk: primair gaat het in zijn ogen om een rechtsgeldige bevoegdheid. ${ }^{107}$ Ter Schegget/ Herweijer hanteren als argument vöor regeling de systematiek van het recht: eerst zou gesproken moeten worden over het ontstaan van bevoegdheden voordat de overdracht ervan aan de orde is. Zij voegen er echter aan toe dat attributie door de formele wetgever ${ }^{108}$ hier niet aan de orde is, nu de Awb niet op de wetgevende macht van toepassing is. Wel zou voor attributie door de materiële wetgever iets geregeld moeten worden, bijvoorbeeld of attributie aan ondergeschikten is toegestaan. Delegatie aan ondergeschikten is immers niet toegestaan. ${ }^{109}$ De Raad voor het binnenlands bestuur bepleitte onder meer een regeling van attributie aan ambtenaren. ${ }^{110}$

Een ander standpunt wordt ingenomen door Van der Vlies. Een regeling voor attributie is volgens haar terecht niet in de Awb opgenomen. De formele wetgever valt buiten de delegatiedefinitie nu de $A w b$ niet van toepassing is op de wetgevende macht. Daaruit concludeert zij dat de toedeling van (regelgevende) bevoegdheden door de formele wetgever aan de regering attributie is (in plaats van delegatie) en vervolgens de toedeling door de regering aan de minister delegatie (in plaats van subdelegatie). ${ }^{11}$ Naast deze uitleg van de 'Awbdelegatiedefinitie' zou volgens haar over delegatie door de formele wetgever gesproken kunnen worden. ${ }^{112}$ "Dat spoort echter niet met de aigemene wijze waarop met de begrippen van de Awb wordt omgegaan: een begrip heeft alleen betekenis voor de Awb. "113

Ik vraag me af of het éen uit het ander zou moeten volgen. De Awb geldt inderdaad niet voor de formele wetgever, maar zou de definitie van delegatie niet (mutatis mutandis) van toepassing kunnen zijn op de formele wetgever? En het feit dat een bepaaid begrip gedefinieerd wordt in de Awb hoeft toch niet te betekenen dat dat begrip buiten de Awb niet meer kan voorkomen, of dat het buiten de Awb niet dezelfde betekenis kan hebben?

107. Stroink 1992, p.478.

108. In de toelichting op artikel $1: 1 \mathrm{Awb}$ worden wetgevende macht en wetgever in formele zin als synoniemen gebruikt. Zie Kamerstukken II 1988-1989, 21221, nr 3 MvT, p.29.

109. Ter Schegget/Herweijer 1993, p.308. Zie ook Stroink 1992, p.479. Hennekens 1992, p.613 wil attributie aan ondergeschikten uitsluiten wanneer er een verbod geldt om te delegeren aan die ondergeschikten.

110. Raad yoor het binnenlands bestuur 1992, p.8. In gelijke zin Van Wijk/Konijnenbellt 1993, p. 129.

111. Van der Vlies 1994, p.416.

112. Ik zie niet zo goed in welke gevallen dat het geval zou kunnen zijn.

113. Van der Vlies 1994, p.417. 


\section{Hoofdstuk 2}

Regeling van attributie van bestuursbevoegdheden door de formele wetgever acht Van der Vlies niet passend in de Awb. Een dergelijke regeling behoort in beginsel in de Grondwet plaats te vinden. ${ }^{114}$ Een regeling van attributie door lagere regelgevers is volgens haar in strijd met het legaliteitsbeginsel. "Volgens het legaliteitsbeginsel behoort een publiekrechtelijke bevoegdheid op een wet te berusten. (...) Ter vermijding van misverstanden zou kunnen worden geregeld dat bestuursorganen niet kunnen attribueren." 115

Wat zou er in de Awb over attributie geregeld kunnen worden? ${ }^{116}$ De Awb heeft (onder andere) betrekking op bestuursorganen met regelgevende bevoegdheid zoals de regering, ministers, provinciale staten en de gemeenteraad. In de regelingen die deze organen tot stand brengen kunnen bevoegdheden worden geattribueerd: aan andere bestuursorganen of aan ambtenaren. ${ }^{117} \mathrm{Bij}$ delegatie en mandaat is duidelijk dat bestaande bevoegdheden in het geding zijn. Bij attributie gaat het over nog niet bestaande bevoegdheden. Dan kan men zich afvragen welke bevoegdheden geattribueerd kunnen worden, en aan wie.

114. Van der Whies 1994, p.417. Een dergelijke regeling is er voor een deel ook: zie de grondwettelijke delegatieterminologie en de uitleg erwan (paragraaf 4.2).

115. Van der Vlies 1994, p.418.

11.6. Zie ook Konijnenbelt 1992 b, p.15 die in een alternatief voorstel twee artikelen heeft opgenomen die attributie aan ondergeschikten regelen. Artikel 1A.1.1.1 luidt: 1. 'Slechts bij de wet of bij algemeen verbindend voorschrift krachtens de wet wordt de bevoegdheid tor het nemen van bestuiten aan andergeschikten van een bestuursorgaan toegekend. 2 . Tenzij de wet anders bepaalt, wordt aan een ondergeschikte niet de bevoegdheid toegekend tot het nemen wan besluiten die een algemeen verbindend voorschrift inhouden. Artikel 1A.1.1.2: 'Het bestuursorgaanaan welks ondergeschikte en bevoegdheid rechtstreeks is toegekend, kan ter zake wan de uitoefening vandie bevoegdheid geen bijzondere aanwijzingen geven."

Enkele opmerkingen over deze artikelen: op de eerste plaats gaat de Awb niet over formele wetten. De verwijzing in artikel 1A.1.1.1 lid 1 nar de formele wetgever ("slechts bij de wet") is dus niet relevant. Op de tweede plaats is opmerkelijk dat attributhe aan ondergeschikten in dit voorstel wel mogelijk wordt terwijl de bepaling dat detegatie aan ondergeschikten niet plaats vindt gehandhaafd wordt. Op de derde plaats zou hier een verwijzing naar de delegatieterminologie thuis horen: de Grondwet bepaalt of voor sommige onderwerpen attributie mogelijk is en zo ja van welke bevoegdheden (in de zin varn gebonden dan wel discretionaire bevoegdheden). En verder rijst er nog een terminologische kwestie: kan de toekenning wan de bevoegdheid tot het stellen van algemeen verbindende woorschriften wel attributie genoemd worden wanneer die bevoegdheid wordt toegekend aan een ondergeschikte? Is er dan, met andere woorden, niet veel eerder sprake van delegatie?

117. Ter Schegget/Herweijer 1993, p.308. 
Wat betreft de eerste vraag lijkt het duidelijk dat regelgevende bevoegdheden niet geattribueerd kunnen worden: dat vindt immers plaats op het niveau van de Grondwet of de formele wet. In een lagere regeling kunnen regelgevende bevoegdheden dan 'slechts' gedelegeerd worden, en delegatie is wel geregeld in de Awb.

Bestuursbevoegdheden, zoals omschreven in paragraaf 2.1 , zouden wel geattribueerd kunnen worden. ${ }^{118}$

De tweede vraag is aan wie geattribueerd zou kunnen worden. Aansluiting kan gezocht worden bij de regeling van delegatie, waarbij delegatie aan ondergeschikten wordt uitgesloten. Nu deze bepaling in het wetsvoorstel is gehandhaafd zou ook attributie aan ondergeschikten verboden moeten worden. ${ }^{119}$

\section{Mandaat van regelgevende bevoegdheid}

Mandaat van regelgevende bevoegdheid is niet toegestaan, tenzij er een wettelijke basis is (artikel 1A.1.1.2 lid 2 aanhef en onder a). Een voorbeeld van een wettelijke regeling waarin mandaat van regelgevende bevoegdheid wordt toegestaan is artikel 29a Bijstandswet (oud). ${ }^{120}$ Het niet toestaan van mandaat van regelgevende bevoegdheid behoudens een wettelijke basis spoort met artikel 33 van de Aanwijzingen voor de regelgeving 1993. ${ }^{121}$

Volgens De Groot/Van Rossum is mandaat van regelgevende bevoegdheid (met name voor ministeriële regelingen) in huidig recht toegestaan. Zij vinden het niet

118. De door Stroink 1992, p.478 voorgestelde bepaling voor de regeling van attributie behoeft aanpassing. Hij stelt het volgende voor: "Onder attributieverlening wordt werstaan: het toekennen door een bestuursorgæan van een bevoegdheid tot het nemen van besluiten aan een ander orgaan. " Deze bepaling is te ruim: onder het nemen van besluiten walt immers tevens het vaststellen van algemeen verbindende voorschriften. Stroinks voorstel zou als volgt aangevuld kunnen worden, (..), met uitzondering van het vaststelJen van algemeen verbindende voorschriften.

119. Ter Schegget/Herweijer 1993, p.308.

120. Voorbeeld ontleend aan Oudshoorn 1992, p.273.

121. Aanwijzing 33 luidt: '1. Mandaat van de bevoegdheid tot het bij ministerielle regeling stellen van algemeen verbindende voorschriften is miet toegestaan , tenzij bij de toekenning wan die bevoegdheid aitdrukkelijk in de mogelijkheid var mandaatverlening is voorzien.

2. Ondermandaat van de bevoegdheid tot het vaststellen van algemeen verbindende voorschriften is niet toegestaan.' In deze aanwijzing wordt gesproken van mandaat door een minister. Nu de Aanwijzingen betrekking hebben op regelingen die onder ministeriele verantwoordelijkheid tot stand komen (aanwijzing 1) is deze beperking begrijpelijk. 


\section{Hoofdstuk 2}

consequent om dit enerzijds te verbieden en anderzijds toch mogelijk te maken. ${ }^{122}$

Van der Vlies bepleit (analoog aan het verbod van mandaat om algemeen verbindende voorschriften te stellen) een verbod voor mandaat van het stellen van beleidsregels. Een betere oplossing is volgens haar misschien nog om voor 'eenvoudige' wijzigingen van algemeen verbindende voorschriften, beleidsregels of plannen wel mandaat toe te laten. ${ }^{13}$

\section{Beperking wan grondrechten door mandaat}

Zoals in paragraaf 2.3.1.2 omschreven is mandaatverlening van de bevoegdheid om grondrechten te beperken volgens de toelichting in sommige gevallen toegestaan. Zo'n mandaat werd toegestaan in een uitspraak van de Centrale Raad van Beroep. In geding was hier een beperking van het recht om in vrijheid zijn woonof verblijfplaats te kiezen (artikel 2 lid 1 Vierde Protocol EVRM; artikel 12 lid 1 IVBPR). ${ }^{124}$

Een dergelijk mandaat werd niet toegestaan bij een beperking van het grondrecht op bewegingsvrijheid. ${ }^{125}$

\section{Het delegatieverbod aan ondergeschikten}

Het delegatieverbod aan ondergeschikten is volgens Verheij 'in afwijking van de heersende leer". ${ }^{126}$ In de literatuur wordt vooral de relatie met attributie aan ondergeschikten aan de orde gesteld. In de meeste commentaren wordt een delegatieverbod aan ondergeschikten geaccepteerd. ${ }^{127}$

122. De Groot/Van Rossum 1993, p.135, werwijzend naar Hennekens 1992, p.642, die tegen mandat van regelgevende bevoegdheid is.

123. Van der Vlies 1994, p.414-415.

124. CRvB 25 juli 1991, AB 1991, 656, m.nt. HH.

125. Zie Vz ARRS 31 juli 1989, AB 1990, 315. Zie ook De Groot/Van Rossum 1993, p.134, verwijzend nar Hof Amsterdam 4 mei 1990, AB 1991, 30; Vz ARRS 11 januari 1989, AB 1989, 424: "Mandat is in deze gevallen niet mogelijk als bij de uitoefening van de gemandateerde bevoegdhe id sprake is van beoordelingsvrijheid van de betrokken ambtemaren. "Zie voorts nog ARRS 17 december 1991, AB 1992, 550, m.nt. JHydV: mandaat wan burgemeester aan politiefunctionarissen om straatverbod op te leggen aan 'balletjeballetje'spelers toegestaan.

126. Verheij 1992a, p.173.

127. Zie Hennekens 1992, p.614 en Konijnenbelt 1993, p.121. De Raad voor het binnenlands bestuur betreurt echter dat delegatie aan ondergeschikten niet meer mogelijk is, terwijl dat nu in praktijk wel mogelijk en geaccepteerd is. Raad voor het binmenlands bestuur 1992, p. 10 . 
Is een delegatiebesluit een algemeen verbindend woorschrift?

De MvT merkt een besluit waarbij een bestursorgaan delegeert aan als een algemeen verbindend voorschrift. Dit standpunt is omstreden. Van der Burg acht een delegatiebesluit een beslissing ad hoc en daarom geen algemeen verbindend voorschrift. ${ }^{128}$ Volgens Stroink en Hennekens werkt een delegatiebesluit niet naar buiten en is het op die grond geen algemeen verbindend voorschrift.

Hennekens maakt vervolgens een onderscheid tussen delegatie van regelgevende bevoegdheid en delegatie van bestuursbevoegdheid. De delegatiebevoegdheid om algemeen verbindende voorschriften te stellen moet zijn opgenomen in een wet in materiële zin en het delegatiebesluit, daarop gebaseerd, is dan een algemeen verbindend voorschrift. Anders ligt dat wanneer er op grond van een wettelijk voorschrift een bestuursbevoegdheid gedelegeerd wordt. Dan heeft men te maken met een besluit van algemene strekking (niet zijnde een algemeen verbindend voorschrift), wanneer het delegatiebesluit op meerdere gevallen betrekking heeft of met een (bundel) beschikkingen wanneer het delegatiebesluit een bepaald geval betreft. ${ }^{129}$ Konijnenbelt deelt dit standpunt. Hij ziet in een delegatiebesluit ook geen algemeen verbindend voorschrift behalve wanneer het delegatie van algemeen verbindende voorschriften betreft. ${ }^{130}$

$\mathrm{Ik}$ sluit mij aan bij deze redenering. Een algemeen verbindend voorschrift is in paragraaf 2.1.6 omschreven als: een krachtens een regelgevende bevoegdheid genomen besluit, inhoudende een of meer algemene, naar buiten werkende regels. Wanneer een bevoegdheid tot het stellen van algemeen verbindende voorschriften gedelegeerd wordt, is dat krachtens een regelgevende bevoegdheid. Het besluit werkt naar buiten nu met de delegatie de verantwoordelijkheid voor de uitvoering van de bevoegdheid overgaat. Ook kan de delegatie gevolgen hebben voor de beroeps- en bezwaarmogelijkheden van de burger.

De delegatie van een bestuursbevoegdheid wordt niet genomen op grond van een regelgevende bevoegdheid en kan zodoende niet als algemeen verbindend voorschrift worden gekenmerkt.

128. Van der Burg 1992, p.273.

129. Stroink 1992, p.479; Hennekens 1992, p.610 en p.615. Van der Vlies 1994, p.423: "Een delegatiebeslunt is in beginsel regelgevend van ard. Dit spoort met de praktijk: de delegatiebepaling is meestal in een regel opgenomen."

130. Konijnenbelt $1992 \mathrm{~b}, \mathrm{p} .20$. 


\section{Hoofdstuk 2}

\subsubsection{De regeling van mandaat en delegatie en de grondwettelijke delegatieterminologie}

Een bespreking van de relatie tussen de voorgestelde regeling van mandaat en delegatie en de grondwettelijke delegatieterminologie kan hier niet achterwege blijven. Is er een relatie en hoe ziet die eruit?

Verschillende auteurs noemen de delegatieterminologie in hun commentaar. Zo merkt Stroink op dat hij een verwijzing naar de delegatieterminologie mist in de toelichting. "Deze terminologie geldt weliswaar alleen voor organieke, d.w.z. door de Grondwet voorgeschreven formele wetten $(. .$.$) , maar in de toelichting$ mag een verwijzing daarnaar toch niet ontbreken." ${ }^{\text {"yi }}$ Het is niet duidelijk hoe Stroink zelf deze verhouding ziet.

Ook Konijnenbelt betrekt de delegatieterminologie in zijn beschouwing. Hij "vertaall" een door de Grondwet toegestane delegatiemogelijkheid als 'een bevoegdverklaring tot normstelling', omdat dan mogelijk is om enerzijds regelgevende bevoegdheid over te dragen, en anderzijds bestuursbevoegdheid (bijvoorbeeld beschikkingsbevoegdheid) te attribueren. Dit maakt echter de confrontatie tussen de delegatieterminologie en de regeling van mandaat en delegatie in zijn ogen 'ingewikkeld'. ${ }^{132}$

De relatie tussen de regeling van mandaat en delegatie en de grondwettelijke delegatieterminologie behoeft nadere analyse. Er zitten meerdere kanten aan deze relatie.

De eerste kant is die tussen artikel 107 lid 2 Gw ('De wet stelt algemene regels van bestuursrecht vast.') en de Awb: de Awb is een op de Grondwet gebaseerde wet. Uit artikel 107 lid 2 blijkt dat delegatie is toegestaan omdat in de bepaling het woord 'regels' voorkomt. Tijdens de parlementaire behandeling is hierover opgemerkt dat de formele wet de hoofdregels dient vast te stellen. Aan lagere bestuursorganen kan op onderdelen een meer gedetailleerde regeling worden overgelaten. ${ }^{\text {in }}$

In de Awb wordt terughoudend gebruik gemaakt van de delegatiemogelijkheid. In de artikelen 5.1.2 en 5.1.9 wordt gedelegeerd aan de Minister van Justitie. In artikel 8.2.1.1 vindt delegatie aan de regering plaats: overigens een mooi voor-

13.. Stroink 1992, p.478.

132. Konijnenbelt 1992b, p. 10 .

133. Zie Kamerstukken II 1977-1978, 15046, n 3 MvT, p.6; Kamerstukken II 1978-1979, 15046, nr 6 VV, p.6 en Kamerstukken II 1979 1980, 15046, nr 7 MvA, p.11. Zie ook Akkermans/Koekkoek 1992, p.957. 
beeld van een algemene maatregel van bestuur die een wettelijke bepaling mag wijzigen (in casu de hoogte van het griffierecht).

De tweede kant heeft betrekking op de dellegatieterminologie en de voorgestelde regeling van mandaat en delegatie. Het is van belang om eerst nader vast te stellen waar beide concepten precies betrekking op hebben.

De grondwettelijke delegatieterminologie geldt voor organieke wetten en de eventueel daarop gebaseerde lagere regelgeving.

Is delegatie volgens de terminologie verboden dan mag geen regelgevende bevoegdheid worden overgedragen, en mogen slechts sterk gebonden bestuursbevoegdheden worden geattribueerd. De normstelling dient daarbij in de formele wet plaats te vinden.

Is delegatie toegestaan dan kan de formele wetgever zowel regelgevende bevoegdheden delegeren als (discretionaire) bestuursbevoegdheden attribueren (zie paragraaf 2.1.2 en hoofdstuk 4). ${ }^{134}$

De Awb geldt in ieder geval niet voor de formele wetgever en diens besluiten (artikel 1:1 lid 2 aanhef en onder a). Besluiten (waaronder algemeen verbindende voorschriften) afkomstig van lagere bestuursorganen vallen er echter wel onder. Of er in een lagere regeling gedelegeerd mag worden is echter afhankelijk van de formele wet en, wanneer er sprake is van een organieke wet, van de Grondwet. Een verwijzing hiernaar had in de Memorie van Toelichting niet mogen ontbreken, of had zelfs een plaats in de Awb zelf moeten krijgen.

Het wetsvoorstel gaat uit van een basis voor delegatie in een wettelijk voorschrift. Daaronder worden niet alleen formele wetten verstaan "maar ook regels gesteld door organen die aan Grondwet of wet regelgevende bevoegdheid kunnen ontlenen." 135

Stroink merkt op dat dit maar de 'halve waarheid' is: "Uiteindelijk moet de grondslag tot de wet in formele zin te herleiden zijn, in ieder geval in die situaties dat aan de burgers verplichtingen worden opgelegd (beginsel van wetmatigheid van bestuur)." 136 En mijns inziens zou hier nog aan toegevoegd moeten

134. Een eerste "probleem" van de term delegatieterminologie blijkt lhier: een "delegatie" kan zowel betrekking hebben op delegatie als op attributie.

135. Kamerstukken II 1988-1989, 21221, nr 3 MvT, p.17 (Eerste tranche Awb).

136. Stroink 1992, p.478 en verder P. van Buaren, Dellegatie en het legaliteitsbeginsel, in NJB 1995, p.532. Ook Hennekens 1992, p.611 gaat op deze kwestie in. Volgens hem bepaalt de Grondwet wie tot materiële wetgeving bevoegd is. Soms attribueent de Grondwet rechtstreeks die bevoegdheid, soms via de formele wet. "Dit systeem heeft tengevolge dat andelegaile van wetgevende bewoegdheid de formele wetgever per bevoegde 


\section{Hoofdstuk 2}

worden: er moet in elk geval voldaan zijn aan de grondwettelijke delegatieterminologie. Want geldt er een delegatieverbod dan kunnen slechts regelgevende bevoegdheden worden overgedragen voor zover het detailpunten betreft. En toegekende bestuursbevoegdheden mogen niet zo discretionair zijn dat het bestuur in feite de norm stelt. ${ }^{137}$ Wel kan dan gebruik gemaakt worden van de mandaatfiguur (bij bestuursbevoegdheden).

Is delegatie door de Grondwet toegestaan dan kan de formele wetgever bestuursbevoegdheden attribueren of regelgevende bevoegdheden delegeren aan lagere bestuursorganen. Deze organen hebben (voor zover zij bestuursorgaan zijn in de zin van de Awb) wel te maken met de bepalingen over mandaat en delegatie in de Awb bij hun handelen. ${ }^{138}$

De conclusie kan zijn dat de voorgestelde regeling van mandaat en delegatie in de Awb een aanvulling is op de bespreking van het delegatievraagstuk tijdens de grondwetsherziening.

materiële wetgever inhoud kan geven. (...) "De voorgestelde regeling doorbreekt in wezen dit systeem door in algemene zin de mogelijkheid te creëren bij wettelijk voorschrift delegatie van materièle wetgeving mogelijk te maken." (curs. in orig.). Mij lijkt dat deze opwatting van Hennekens niet houdbaar is. De Awb zal de grondwettelijke delegatieterminologie en de uitwerking daarvan niet kunnen doorkruisen, men mag althans aannemen dat dat niet de bedoeling is.

137. Zie paragraaf 4.2 .

138. Voor de volledigheid: er is een groot aantal wetten dat niet is gebaseerd op de Grondwet. Voor die wetten hoeft geen rekening te worden gehouden met de grondwettelijke delegatieterminologie. 


\section{Hoofdstuk 3}

\section{Schets van het delegatievraagstuk tot 1983}

\subsection{Inleiding}

Het delegatievraagstuk kent een lange geschiedenis .Vanaf het moment dat, in de eerste (voor het nu Nederlands grondgebied geldende) constitutionele regelingen, de scheiding der machten meer of minder expliciet werd vastgelegd deed zich het probleem voor dat ten aanzien van het uitoefenen van de wetgevende macht de praktijk andere eisen stelde dan in theorie verantwoord was. Op een enkel vroeg moment is het probleem onderkend: de constitutie van 1806 bevatte in artikel 51 de volgende bepaling. 'De Wet wordt in Holland vastgesteld door zamenstemming van den Koning en het Wetgevend Ligchaam. De Koning kan in sommige gevallen door de Wet speciaal worden geautoriseerd, om het Wetgevend gezag, zonder de medewerking der Vergadering van Hun Hoog Mogende, uit te oefenen." In latere regelingen is deze mogelijkheid er weer uitgelaten en kwam de vraag op naar de grondwettigheid van delegatie van wetgevende macht.

Een steeds weer terugkerende discussie rond het delegatievraagstuk is de vraag of er in de grondwetsbepaling 'De vaststelling van wetten geschiedt door de regering en Staten-Generaal gezamenlijk' ${ }^{2}$ een materieel dan wel formeel wetsbegrip besloten ligt. Deze vraag houdt voor- en tegenstanders van delegatie verdeeld, zoals hieronder zal blijken.

Een andere discussie vindt plaats over kernbegrippen uit het delegatievraagstuk, de termen 'regeling' en 'uitvoering'. Beide termen kunnen voor onduidelijkheid en misverstanden zorgen. In paragraaf 2.1 zijn omschrijvingen van beide begrippen opgenomen. In de hier volgende paragrafen zal nog eens duidelijk worden dat 'regeling' en 'uitvoering' allebei in een dubbele betekenis gehanteerd kunnen worden. 'Regeling' in ruime betekenis betekent het 'regelen' van een bepaalde kwestie. Dit regelen kan zowel het stellen van algemeen verbindende voorschriften inhouden als het creëren van bestuursbevoegdheden. 'Regeling' in enge zin houdt in het stellen van algemeen verbindende voorschriften. Ook 'uitvoering" heeft een ruime en een enge betekenis. Uitvoering in ruime zin omvat zowel het geven van beschikkingen als het nemen van besluiten van algemene strekking.

1. Van Hasselt 1987, p.159-160. Zie ook Addens 1884, p.20.

2. Artikel $81 \mathrm{Gw} 1983$. In soortgelijke woorden komt deze bepaling sinds 1815 in de Grondwet voor. Zie Akkermans/Koekkoek 1992, p.738. 


\section{Hoofdstuk 3}

Uitvoering in enge zin is nauw gekoppeld aan de beschikkingsbevoegdheid van een bestuursorgaan, en kan gezien worden als het toepassen van een wettelijke regeling op her concrete geval. In de hieronder besproken literatuur is niet steeds duidelijk wat bedoeld wordt.

Het ligt niet in de bedoeling om in dit hoofdstuk uitputtend de historie van het delegatievraagstuk te behandelen. In plaats daarvan kies ik enkele werken uit die (bijna allemaal) het delegatievraagstuk als onderwerp hebben en die ik als ijkpunt neem om de stand van het delegatievraagstuk op dat moment te meten. In een eerste subparagraaf wordt steeds deze stand beschreven, in een tweede wordt deze becommentarieerd. De laatste paragraaf van dit hoofdstuk worden enkele lijnen van het delegatievraagstuk geschetst.

In sommige commentaren wordt de lijn doorgetrokken naar de (totstandkoming van de) Grondwet van 1983. De geschiedenis van die totstandkoming en de opvattingen over het delegatievraagstuk na 1983 zullen in het volgende hoofdstuk aan bod komen.

\subsection{Addens, Delegatie van wetgevende macht, 1884}

\subsubsection{Beschrijving}

Het eerste hier te bespreken werk is de vrij onbekende dissertatie "Delegatie van wetgevende macht' van Addens uit 1884 . Uit de beschrijving van de verschillende hoofdstukken in het voorwoord wordt duidelijk dat hij onderzoekt in hoeverre delegatie van wetgevende macht toelaatbaar is. De inhoud van zijn boek is verdeeld in vijf hoofdstukken. Het eerste behandelt de vraag of delegatie van wetgevende macht geoorloofd is. In het tweede komen de grenzen tussen de wetgevende en uitvoerende macht aan de orde. In hoofdstuk 3 komen gevallen aan de orde "waarin men met meer of minder recht van delegatie zou kunnen spreken. ${ }^{3}{ }^{3}$ Het vierde hoofdstuk is gewijd aan de provinciale en gemeentelijke wetgevende en uitvoerende macht en het laatste hoofdstuk behandelt de jurisprudentie. Omdat de kern van Addens', betoog in het eerste en tweede hoofdstuk is gelegen bespreek ik deze wat uitgebreider. Op de overige hoofdstukken ga ik nauwelijks meer in.

Addens behandelt in hoofdstuk 1 de vraag of delegatie van wetgevende macht aan de Kroon. Hij onderscheidt twee "soorten' algemene maatregel van (inwendig) bestuur: die waarbij wetgevende macht wordt gedelegeerd en die waarbij uitvoe-

3. Addens 1884, p.2. 
ring aan de Koning wordt opgedragen. De laatste vorm is grondwettig volgens Addens, in de Grondwet is de Koning immers de uitvoerende macht opgedragen. Delegatie van wetgevende macht is volgens Addens echter niet toegestaan. Hij baseert zich op auteurs die het standpunt innemen dat (door het volk) aan de wetgevende macht opgedragen bevoegdheden niet overgedragen mogen worden aan de Koning. Het belangrijkste argument hierbij is dat met die overdracht de waarborgen in het proces van wetgeving tegen willekeur en machtsmisbruik verloren gaan. ${ }^{4}$

Twijfel is er volgens Addens bij sommigen, waaronder Buys, over delegatie van wetgeving betreffende ondergeschikte zaken. Buys bepleit een delegatiemogelijkheid voor bijzondere gevallen die de wet niet zelf kan voorzien. ${ }^{5}$ Addens deelt die twijfel niet. Voor hem is delegatie van wetgevende macht in alle gevallen ongeoorloofd. ${ }^{6}$

In zijn tweede hoofdstuk onderzoekt Addens de grenzen tussen de wetgevende en de uitvoerende macht. Hij toont zich voorstander van een formeel wetsbegrip, zich baserend op Thorbecke. ${ }^{7}$ Dat leidt hem tot de overtuiging dat wanneer de Grondwet een onderwerp niet aan de wetgever opdraagt, en de wetgever het ook nog niet naar zich toegetrokken heeft, de Koning het onderwerp mag regelen. ${ }^{8}$ Heeft de wetgever het onderwerp geregeld, daarbij aan de Koning een deel van de materie ter nadere regeling overlatend, dan kan er volgens Addens toch niet gesproken worden van delegatie van wetgevende macht, en deze constructie is in zijn ogen dus toegestaan. In een dergelijk geval mag de wetgever desnoods alles aan de Koning overlaten.

Addens stelt ook de situatie aan de orde dat de Grondwet regeling bij wet voorschrijft en de wetgever vervolgens nadere regeling aan de uitvoerende macht overlaat. ${ }^{10}$ Mag dat? Dat hangt van de redactie van het grondwetsartikel af. ${ }^{11}$

4. Addens 1884, p.5-10. Addens baseert zich op: Locke, Treatise of civil government (Book II, Chap. XI); A.A. de Pinto, Verslagen en Mededeelingen van de Akadenie van Wetenschappen, afd. letterkunde (VIII, blz. 333); Levy. Nieuwe Bijdr. woor Rechtsgel. en Wetg. Nieuwe Reeks (VI, blz. 117 e.v.); Quarles van Ufford, Diss. Algemeene matregelen van inwendig bestuur, Leiden 1881 (blz. 79 en 80 ).

5. Addens 1884, p.10-12. Aangehaald wordt Buys, Bijdr. wan 't Staatsbest. XIX. Nieuwe Reeks (blz, 165) en Toelichting en Kritiek der Grondwet (I, blz. 279).

6. Addens 1884, p. $19-20$.

7. Addens 1884, p. 27 , citeert Thorbecke, Aanteekening op de Grondwet, 1, blz.283.

8. Addens 1884, p. 27-28.

9. Addens 1884, p.28. We kunnen dan denken aan de ons bekende 'kaderwetgeving".

10. Addens 1884, p. 28 . 
Als de tekst van de grondwetsbepaling ruimte biedt mag aan de uitvoerende macht een deel van het onderwerp overgelaten worden. De vraag is daarbij wat er onder het begrip 'uitwoering' valt.

Voor het antwoord op deze wraag gaat Addens te rade bij Laband. Deze kent wee betekenissen toe aan het woord 'uitvoering'. Enerzijds kan het gaan om voorschriften (algemene regels) die wettelijke regels verder verfijnen; anderzijds kan het aanwijzingen betreffen om de wet uit te voeren (bijvoorbeeld concrete bevelen). ${ }^{12}$

Ook onze Grondwet hanteert volgens Addens het begrip uitvoering in twee betekenissen. Een algemene maatregel van inwendig bestuur kan zowel nadere regeling als 'concrete' uilvoering bevatten. ${ }^{13}$

Hoeveel mag er overgelaten worden aan de Koning ter regeling? Addens kan daarvoor in de Grondwet geen aanknopingspunten vinden: er ontbreekt een materieel wetsbegrip in de Grondwet, en de grenzen tussen wetgevende en uitvoerende macht zijn niet scherp afgebakend. Als de Grondwet hierover geen duidelijkheid biedt kan de vraag naar de omvang van delegatie niet uit rechtskundig oogpunt beantwoord worden maar wordt het een doelmatigheidskwestie. En die afweging is voorbehouden aan de wetgever zelf. ${ }^{14}$ Richtlijnen die de wetgever zou kunnen hanteren ontleent Addens aan Vivien. Deze acht het doelmatig de regeling over te laten aan een Koninklijk Besluit wanneer: ${ }^{15}$

- er veel technische kennis nodig is, of

- er voortdurend behoefte is aan herziening, of

- het iets locaals betreft, of

- het een tijdelijke en voorbijgaande regeling betreft.

Er kunnen volgens Addens ook andere omstandigheden van invloed zijn op de omvang van de bevoegdheden van de uitvoerende macht, zoals het vertrouwen dat de uitwoerende macht geniet of problemen bij de behandeling van wetsontwerpen waardoor er meer aan de uitvoerende macht wordt overgelaten "vooral in een tijd, waarin de grenzen der staatszorg meer en meer worden uitgezet. "16

11. Addens geeft verderop (p.59) het volgende voorbeeld. Eist de Grondwet een wetboek dan is er geen enkele ruimte om een deel wan de materie ter nadere regeling aan een KB over te laten. Wordt het woord "wet' gebruikt (en wordt er een 'eenvoudige' wet gewraagd) dan zou dat wel mogen.

12. Addens 1884, p.30, citeert Laband, Das Staatsrecht des Deutschen Reiches, II, blz.70.

13. Addens 1884, p. 31 .

14. Addens 1884, p. 34.

15. Addens 1884 , p. 35, haalt Vivien aan, Etudes administratives, I, blz. 5 e.v., Parijs 1845.

16. Addens 1884, p. 36 . 
Tot slot van deze beschrijving nog een voorbeeld dat Addens in zijn derde hoofdstuk behandelt. Het gaat over artikel 1 van de wet van 28 juni 1876 (Stb 150), "houdende maatregelen tegen het gevaar, hetwelk door den in-, door- en vervoer van vergiftige stoffen kan ontstaan". Artikel 1 luidt: "Door Ons kunnen bij algemeenen maatregel van inwendig bestuur de in-, door-en vervoer van bepaald daarbij aangewezen vergiftige stoffen verboden, of aan zoodanige voorschriften onderworpen worden, als in het belang der openbare gezondheid noodig voorkomen.' In artikel 2 wordt overtreding van het bepaalde in de algemene maatregel van bestuur strafbaar gesteld. ${ }^{17}$ In deze overdracht van bevoegdheid ziet Addens geen delegatie van wetgevende macht omdat het hier om een wet gaat die niet door de Grondwet wordt yoorgeschreven: de Koning had het onderwerp ook zelf kunnen regelen. ${ }^{18}$ Voor Addens is dit dan ook geoorloofde uitvoering.

\subsubsection{Bespreking}

Het delegatievraagstuk stond ook in Addens' tijd al volop in de belangstelling, waarbij het vraagstuk door sommigen formeel, en anderen materieel benaderd werd. Addens kiest voor de formele benadering: een formeel begrip wetgeving (dat wil zeggen dat hij alleen een regeling als wet aanmerkt wanneer die door regering en Staten-Generaal gezamenlijk vervaardigd is) en een formeel begrip uitvoering (dat 'al het andere' inhoudt).

Zijn standpunt dat in alle gevallen delegatie van wetgevende macht verboden is (want 'publiek recht is publieke plicht'), leidt mijns inziens tot enkele ongelukkige 'oplossingen' van verwante problemen.

Zo kan er volgens Addens alleen gesproken worden van delegatie van wetgevende macht wanneer het een grondwettelijk genoemd onderwerp betreft. Bij onderwerpen die buiten de Grondwet om door de wetgever ter hand worden genomen doet zich het vraagstuk van delegatie van wetgevende macht niet voor.

Dit standpunt kan ik niet onderschrijven. De regeling van onderwerpen in de Grondwet is een $\min$ of meer toevallige. Om in het ene geval wel het delegatievraagstuk 'toe te passen' en in het andere geval niet kan dan misschien formeel en in theorie wel kloppen, maar materieel natuurlijk niet. Zo kan in het ene geval aan de Koning overgelaten nadere regeling 'ongeoorloofde delegatie' zijn, in het andere geval dezelfde soort regeling 'geoorloofde uitvoering' ${ }^{19}$ Het door Ad-

17. Addens 1884, p.78.

18. Addens 1884, p.79.

19. Een zelfde probleem in een modern jasje is het onderscheid algemeen verbindend woorschrift - beleidsregel. Ook hier kunnen het dezelfde soort regels betreffen. De afkomst is echter doorslaggevend voor de jurid ische betekenis. Zie hoofdstuk 8. 


\section{Hoofdstuk 3}

dens in zijn derde hoofdstuk besproken en hierboven weergegeven voorbeeld geeft voor mij deze inconsequenties duidelijk weer.

Het aanhaken bij de Grondwet om het delegatievraagstuk vorm te geven gebeurt ook in de Grondwet van 1983. De delegatieterminologie daarin geldt alleen voor grondwettelijke bepalingen en uitvoeringswetgeving. Voor alle andere wetten en wettelijke regelingen is niets bepaald over delegatie. Daar gelden alleen de 'normale.' grenzen van delegatie. ${ }^{20}$ Wel lijkt er ook buiten de grondwettelijke delegatieterminologie consensus te bestaan over gebruikte termen. Zo duiden de woorden 'bij wet' of 'bij algemene maatregel van bestuur' op een delegatieverbod en staat de term "bij of krachtens" juist delegatie toe. ${ }^{21}$ Aan de grenzen van te delegeren bevoegdheden komt Addens niet toe nu in zijn visie immers delegatie van wetgevende macht steeds verboden is. In zijn opvatting is er wel een grens aan datgene wat ter uitvoering overgelaten mag worden bij een grondwettelijk genoemd onderwerp: de wetgever mag in geen geval de zelfstandige regeling van het onderwerp geheel overlaten. ${ }^{22}$

Addens' opvatting leidt op de tweede plaats tot een zeer ruim begrip "uitvoering'. Daaronder valt zowel het uitvoeren van de wet, door die toe te passen op het concrete geval, als het geven van een nadere regeling in de vorm van algemeen verbindende voorschriften. Hierdoor vervagen de begrippen 'wetgeving' en 'uitvoering' en raken ze hun onderscheidend vermogen kwijt. Ook zijn poging om de grenzen van de uitvoerende en wetgevende macht af te bakenen levert praktisch weinig op. En wanneer hij kiest voor het criterium "doelmatigheid" om te bepalen wat er aan de uitvoerende macht mag worden overgelaten werkt hij dat niet verder uit: dat is aan de wetgevende macht. Ook de rechter mag zich er niet mee bemoeien.

Op de derde plaats acht ik het standpunt van Addens over de bevoegdheden van de Koning opmerkelijk in het licht van het Meerenbergarrest. ${ }^{23}$ Addens betoogt

20. Zie paragraf 4.6 .

21. Ook hier doen zich echter uitzonderingen voor. Zie bijvoorbeeld Pres. Rb Den Haag 22 juni 1982, NJ 1983, 175 . In de Wet op het Voortgezet Onderwijs is de overurenregeling gedelegeerd aan de Kroon (door het gebruik van de woorden "bij algemene maatregel van bestuur"). De President achte het vervolgens geoorloofd dat in het Rechtspositiebesluit Onderwijspersoneel (de AMvB) de regeling van het maximum aantal leseenheden aan de minister werd (sub)gedelegeerd.

22. Addens 1884, p.33.

23. HR 13 januari 1879, W. 4330. 
dat een onderwerp waarover niets in de Grondwet is bepaald, zowel door de wetgever als de Koning (zelfstandig!) geregeld kan worden. De kern van het Meerenbergarrest is nu juist dat de Koning alleen die (regelgevende) bevoegdheden toekomen die hem uitdrukkelijk in de Grondwet of wet zijn toegekend. Addens bespreekt slechts kort dit arrest ${ }^{24}$, maar gaat daarbij niet in op de consequenties van deze uitspraak voor de door hem aangehangen theorie. Dat is spijtig, want volgens mij conflicteert zijn opvatting met die van de Hoge Raad.

\subsubsection{Commentaar van Van der Pot}

In zijn dissertatie 'Wet en Algemeene maatregel van bestuur in het Nederlandsche Staatsrecht" wijdt Van der Pot enkele bladzijden aan het werk van Addens. ${ }^{25}$ Hij besteedt vooral aandacht aan het door Addens" gehanteerde begrip 'uitvoering' dat Addens ontleent aan Laband: uitvoering in de zin van het stellen van nadere voorschriften en uitvoering in de zin van het toepassen van de wet in het concrete geval. Hier maakt Addens volgens Van der Pot een fout: Addens neemt het uitvoeringsbegrip over van Laband maar gaat van een andere delegatietheorie uit. Laband acht delegatie van wetgevende macht geoorloofd terwijl voor Addens delegatie verboden is. ${ }^{26}$

Laband spreekt vervolgens over 'Ausführungsverordnungen', die echter ook wetgeving in materiële zin kunnen inhouden. ${ }^{27}$ "De zaak is dat mr. Addens zich door den term 'Ausführung' ten eenen male op een dwaalspoor laat brengen. "28 Van der Pot laat de feilen van Addens' systeem zien: Addens erkent dat er zowel zelfstandige algemene maatregelen van bestuur kunnen zijn die rechtsvoorschriften inhouden, als algemene maatregelen van bestuur ter uitvoering van een wet. Die algemene maatregelen van bestuur brengt Addens echter allemaal onder het begrip uitvoering. "Om maar te kunnen vasthouden, dat ook daar, waar de Grondwet uitdrukkelijk een wet eischt, regeling van onderdeelen den Koning reeds als hoofd van het uitvoerend orgaan toekomt, zoodat de bevoegdheid daartoe hem niet 'opgedragen' maar bloot 'overgelaten' behoeft te worden, geeft mr. Addens aan het begrip 'uitvoering' een geheel onnatuurlijke materieele beteekenis, welke daaraan de tegenstelling tot het begrip 'wetgeving' ontneemt." ${ }^{29}$

24. Addens 1884, p.48-49.

25. Van der Pot 1916, p.324-327.

26. Van der Pot 1916, p. 325.

27. Van der Pot 1916, p.325-326.

28. Van der Pot 1916, p. 326.

29. Van der Pot 1916, p.326-327. 


\section{Hoofdstuk 3}

Addens loopt vast in zijn volharding dat delegatie van wetgevende macht ongeoorloofd is, terwijl hij wel ziet dat de praktijk niet zonder een dergelijke constructie kan. ${ }^{3 a}$ En dat kan dan als de verdienste van Addens beschouwd worden, zij het misschien een magere gezien de gebrekkige theoretische uitwerking.

\subsection{Van der Pot, Wet en Algemeene maatregel van bestuur in het Nederlandsche Staatsrecht, 1916}

\subsubsection{Beschrijving}

Het werk van Van der Pot is door zijn omvang (het telt 394 bladzijden) en vooral gedegenheid niet direct geschikt om 'in vogelvlucht" weer te geven. Ik beperk me daarom tot de twee laatste hoofdstukken (hoofdstuk IV Het nieuwe grondwetsartikel en hoofdstuk V Het vraagstuk in den tegenwoordigen tijd). Daarmee wordt de aansluiting gemaakt met de door Addens beschreven periode met als laatste belangrijke wapenfeit, het Meerenbergarrest uit 1879. Een overzicht van de inhoud van de dissertatie van Van der Pot ziet er als volgt uit.

In de Inleiding verantwoordt Van der Pot het onderwerp en zijn aanpak. "De staatsrechtelijke strijdvraag, waarnaar de titel verwijst, verdient ook thans nog de aandacht" en "Het vraagstuk eischt een historische behandeling. Bezwaren tegen een behandeling volgens de dogmatische methode. "31 Hoofdstuk I gaat over de "Invloeden uit den tijd vóór 1814". Hoofdstuk II bespreekt het delegatievraagstuk vóór 1887 . In zijn derde hoofdstuk vat Van der Pot het voorgaande samen en geeft hij er kritiek op. Het 'nieuwe' grondwetsartikel uit 1887 staat centraal in het vierde hoofdstuk, waarna Van der Pot toe is aan de behandeling van het vraagstuk in zijn tijd.

Met het Meerenbergarrest was duidelijk geworden dat de positie van de Koning wat betreft het (zelfstandig) kunnen regelen en uitvoeren ook grondwettelijk verduidelijkt diende te worden. Over de precieze redactie van het nieuw op te nemen artikel is uitvoerig gedebatteerd. ${ }^{32}$ Uiteindelijk werd in 1887 een nieuw artikel 56 in de Grondwet opgenomen waarvan de tekst luidde: 'Door den Koning worden algemeene maatregelen van bestuur vastgesteld. Bepalingen, door straf-

30. Van der Pot 1916, p.327.

31. Van der Pot 1916, p.LX.

32. Van der Pot 1916, p.291-308. 
fen te handhaven, worden in die maatregelen niet gemaakt, dan krachtens de wet. De wet regelt de op te leggen straffen. ${ }^{33}$

Van der Pot begint zijn vijfde hoofdstuk met de vraag of dit nieuwe artikel in de praktijk heeft voldaan. ${ }^{34}$ Op twee manieren zoekt hij een antwoord op deze vraag. De eerste manier is door de voorstellen tot grondwetsherziening na 1887 te bekijken. Het artikel komt in de ontwerpen van de vierde herziening (van 1910-1913) aan de orde, maar een wezenlijke verandering van het artikel wordt daarbij niet voorgesteld. Het artikel blijft onveranderd.

Daarna bespreekt Van der Pot de praktijk en komt het delegatievraagstuk aan de orde in het licht van de 'onzelfstandige reglementaire macht des Konings'. ${ }^{35}$

In de Tweede Kamer stond het vraagstuk na 1875 meer en meer in de belangstelling. Vooral commotie was er in dat jaar over artikel 3 Spoorwegwet waarbij de regeling van een burgerrechtelijk onderwerp (het uitsluiten van aansprakelijkheid door vervoerders) aan een algemene maatregel van bestuur werd opgedragen. Als belangrijkste argument tegen deze delegatie werd genoemd de onvervreemdbare bevoegdheid die door de constitutie aan de wetgever was opgedragen. De voorstanders vonden echter een wettelijke basis voor de algemene maatregel van bestuur voldoende, haalden aan dat de praktijk niet buiten nadere regelling (en dus delegatie) kon en kwamen met voorbeelden uit andere landen. $\mathrm{Zij}$ wonnen de discussie. ${ }^{36}$

De grondwettellijke bezwaren tegen delegatie die steeds aangevoerd waren, zijn met het opnemen van artikel $56 \mathrm{Gw} 1887$ volgens Van der Pot ondervangen. "Wat nu voortaan 'niet dan krachtens de wet' mocht geschieden, d.w.z. een regeling onder strafbedreiging, dat was krachtens de wet, dus bij delegatie, zonder eenigen twijfel geoorloofd. De omstandigheid, dat bij de beraadslaging over art. 56 niemand deze gevolgtrekking met zooveel woorden makte, kan bezwaarlijk aan iets anders worden toegeschreven dan hieraan, dat ieder haar als vanzelf sprekend aanvaardde. " Hooguit kan in een individueel geval de mate van delegatie nog een strijdpunt opleveren. ${ }^{37}$ Daarbij speelt ook het onderwerp van

33. Het werkwoord 'regelen' geeft de wetgever de vrijheid om te volstaan met het vaststellen van een maximumstraf, die in een algemene maatregel van bestuur lager gesteld kan worden. Van der Pot 1916, p.345.

34. Van der Pot 1916, p.308.

35. Van der Pot 1916, p.317.

36. Van der Pot 1916, p.327-328.

37. Van der Pot 1916, p.329. 


\section{Hoofdstuk 3}

de te regelen materie een rol. In de Arbeidswet en Veiligheidswet werd veel opgedragen aan de algemene maatregel van bestuur, maar werd over deze delegatie nauwelijks gesproken: de Kamerleden waren te druk bezig met het 'nieuwe' van het onderwerp (de sociale wetgeving) om aandacht te schenken aan de verhouding tussen de staatsmachten. ${ }^{38}$

Rond 1910 duikt; door een toenemende behoefte aan specialisatie, in ontwerpwetgeving de figuur van delegatie aan andere organen (met name lagere ambten) dan de Kroon op. Van der Pot laat zien hoe hier verzet tegen rijst, en hoe de discussie verschuift: deze delegatie was "toch nog heel wat anders dan regelingen door constitutioneel daarvoor aangewezen organen, welke de Grondwet zelf met zekere waarborgen had omringd," en "zoo werd al de toorn, welke vermeende grondwetsschennis in staat is op te wekken, ten slotte uitsluitend tegen den nieuwen, althans nog weinig gebruikelijken vorm van delegatie gericht." Delegatie aàn de Kroon was 'plotseling' constitutioneel, delegatie aan ambtenaren verwerpelijk. ${ }^{39}$

Ook Van der Pot gaat in op de termen 'regeling' en 'uitvoering'. ${ }^{40}$ Veel van de discussie over het delegatievraagstuk is volgens hem vertroebeld door verhullend taalgebruik. Door bijvoorbeeld het woord 'overlaten' te gebruiken, wanneer een bevoegdheid feitelijk wordt overgedragen, lijkt het of er geen sprake is van delegatie, maar in feite gebeurt dat wel en had beter gesproken kunnen worden van 'overdragen'. De fout die steeds gemaakt is, is volgens hem 'het willen trekken van dezelfcle grenslijn tussen twee naar haar wezen verschillende onderdelen van de staatstaak en tussen de competentie van twee organen' ${ }^{41}$

In het vervolg van zijn betoog toont Van der Pot zich een voorstander van delegatie. Zijn opvatting is mede gebaseerd op zijn standpunt dat er in de Grondwet een formeel wetsbegrip lag besloten. Het stellen van algemene regels is niet uitsluitend voorbehouden aan de formele wetgever, maar kan ook gebeuren door de Koning. ${ }^{42}$ De Grondwet staat delegatie toe, het gaat er alleen in het concrete

38. Van der Pot 1916, p.330.

39. Vander Pot 1916, p.349.

40. Van der Pot 1916, p.333 e,w.

41. Van der Pot 1916, p.336.

42. Recensent Van Gelein Vitringa besteedt hieraan ruim aandacht en bestrijdt de opvatting van Van der Pot. Volgens Van Gelein Vitringa zijn er ook aanwijzingen voor een materiele opvatting van het wetsbegrip in de Grondwet. Zie Van Gelein Vitringa 1917, p.330343. 
geval om of de delegatie praktisch gezien 'oorbaar' is. ${ }^{43}$ Daarbij speelt het motief van de delegatie een belangrijke rol. "Uit heuschheid, uit zucht om welwillendheid te betoonen, uit oogendienarij is delegatie nooit geoorloofd $(\ldots)^{\prime \prime}{ }^{44}$ Het argument tegen delegatie 'publiek recht is publieke plicht' is volgens hem twijfelachtig. " $(. .$.$) is het dan 'publieke plicht' om regelen, die er nu eenmaal$ blijken te moeten zijn, zelf te geven, als men er de zaakkennis voor mist of als die regelen daardoor zullen blijven gelden, ook wanneer hun onbillijke, ja slechte werking reeds zonneklaar is aan den dag gekomen door dat een wetswijziging altijd geruimen tijd vergt?" 45

Delegatie aan de Kroon is daarom toelaatbaar én doelmatiger, in het bijzonder in de volgende gevallen: de materie ligt niet meer binnen het bereik van de volksvertegenwoordiging; wijziging op korte termijn is noodzakelijk; de regeling bevat veel details waardoor de wetsvorm minder bruikbaar is. ${ }^{46}$ De wetsvorm heeft echter ook voordelen: de voorbereiding is grondiger, de 'aanraking met het rechtsbewustzijn des volks is nauwer" en het gezag van de regeling is groter. ${ }^{47}$

Desalniettemin acht Van der Pot delegatie in sommige gevallen doelmatiger. Hij vraagt zich af of er in de toekomst niet een grotere rol voor de zelfstandige algemene maatregel van bestuur weggelegd kan zijn. Om die vraag te beantwoorden gaat hij in op de verhouding tussen de staatsmachten. ${ }^{48}$

Als belangrijkste van de drie machten (rechter, uitvoerder en wetgever) in de staat ziet hij de wetgever: Kroon tezamen met Staten-Generaal. Uiteindelijk is de volksvertegenwoordiger hiervan het belangrijkste, maar die mag niet bij elk conflict haar zin doordrijven. ${ }^{49}$

De positie van de Koning op regelgevend vlak is dat diens zelfstandige regelgevende bevoegdheid weinig voorstelt, en dat de 'onzelfstandige' bevoegdheid steeds door de wetgever gegeven moet worden. De wetgever is dus steeds bij de rechtsvorming betrokken. "Een zelfstandig, naast den wetgever optredend, voor bepaald aangewezen gevallen recht vormend orgaan, zij het dan ook dat dit recht op grond van de onderlinge verhouding der organen door den wetgever elk oogenblik door van hem afkomstig recht kan worden vervangen, kennen wij niet

43. Van der Pot 1916, p.340.

44. Van der Pot 1916, p.357.

45. Van der Pot 1916, p.357.

46. Van der Pot 1916, p.359-360.

47. Van der Pot 1916, p.360.

48. Van der Pot 1916, p. 362 e.v.

49. Van der Pot 1916, p.367. 


\section{Hoofdstuk 3}

meer. Ik geloof dat dit zeer te betreuren is. " 50 Van der Pot voert hiervoor aan dat het parlement steeds meer ongeschikt is voor zijn wetgevende taak.

Wetten maken vereist juridische vaardigheden die nu eenmaal moeilijk op te brengen zijn in een vergadering van 100 personen. Bovendien bestaat het parlement, door uitbreiding van het kiesrecht, uit steeds minder juristen. En een goed voorbereid ministerieel wetsontwerp is ook al geen garantie voor een (juridisch) goede wet nu de Tweede Kamer geneigd is veel te amenderen. De toenemende ingewikkeldheid van te regelen materie en maatschappelijke verhoudingen zijn daar mede debet aan..$^{31}$

Als oplossing voor dit probleem van legislatief onvermogen stelt hij 'radicale genezing' voor: het parlement ontheffen van een taak waarvoor het steeds minder berekend is. Het parlement dient zich te beperken tot een debat over de beginselen van de wet die samengevat zijn in stellingen. De nadere uitwerking ervan wordt in handen gelegd van een bureau van wetgeving. ${ }^{52}$

Bij die uitwerking kan aan de Kroon meer regelgevende bevoegdheid worden gegeven. Artikel 56 lid 2 Gw $1887^{53}$ is daarbij een 'sta in de weg': dat artikel dateert nog uit een tijd dat de ministeriële verantwoordelijkheid niet ten volle tot ontwikkeling was gekomen. Het artikel is echter volgens Van der Pot overbodig geworden: de volksvertegenwoordiging kan immers wanneer (de inhoud van) een algemene maatregel van bestuur niet bevalt de betrokken minister vragen de regeling in te trekken dan wel te wijzigen, of zelf een wet indienen, 'op straffe van' het naar huis sturen van de minister ${ }^{54}$

Wanneer artikel 56 lid 2 Gw 1887 zou vervallen, dan zou de vraag nog zijn waar de grens ligt tussen dat wat de Koning met medewerking van de Staten-Generaal en zonder die medewerking mag regelen. "Wat nimmer onderwerp van andere dan wettelijke regeling mag zijn, bijv. het privaatrecht, het worde door de Grondwet als zoodanig aangewezen. Wijziging van de bestaande wet blijve als altijd slechts door de wet geoorloofd. Overigens beslisse de behoefte. ${ }^{155}$

50. Van der Pot 1916, p.368.

51. Van der Pot 1916, p.368-370.

52. Van der Pot 1916, p.371.

53. Artikel 56 Gw 1887 luidt: "1. Door den Koning worden algemeene maatregelen van bestuur wastgesteld. 2. Bepalingen, door straffen te handhaven, worden in die maatregelen niet gemaakt, dan krachtens de wet. 3. De wet regelt de op te leggen straffen."

54. Van der Pot 1916, p.373-374.

55. Van der Pot 1916, p. 375. 
De voordelen van algemene maatregelen van bestuir $z i j n$ duidelijk: ze kunnen sneller tot stand gebracht worden; wijzigingen kumnen sneller verwerkt worden wanneer blijkt dat het recht nog 'in beweging", nog niet helemaal uitgekristalliseerd, is; en ze zijn geschikter wanneer de regeling veel technische kennis vereist. ${ }^{56}$

De zelfstandige algemene maatregel van bestuur heeft als bijkomend voordeel dat een moeizame discussie over het al dan niet toestaan van de delegatie in de formele wet niet gevoerd hoeft te worden. ${ }^{57}$ Maar, zo kan de tegenwerping luiden volgens Van der Pot: wordt hiermee de rechtsstaat gediend? Hij beantwoordt de vraag bevestigend.

Ideaalbeeld van de rechtsstaat is dat steeds gerechtigheid wordt gedaan. Om aan dat streven te voldoen is, bij steeds sneller veranderende levenshoudingen, nodig dat 'het recht' mee verandert. En dan is de inhoud van dat recht het belangrijkste, niet de afkomst of de vorm waarin het tot stand is gekomen. ${ }^{58}$

Daarbij is de rol van de vertegenwoordiger niet meer doorslaggevend. "Mogelijk is er een tijd geweest, toen terecht kon gemeend worden, dat slechts één enkele vorm warborg voor deugdelijken inhoud tood, nl die vorm, welke de medewerking eener volksvertegenwoordiging insloot. In dat geval bracht toen de rechtstaatsgedachte mede, die medewerking te beschouwen als eisch voor het in het leven treden van elke norm van stellig recht. Maar - nog eens - die tijd is voorbij. ${ }^{.59}$

\subsubsection{Bespreking}

Van der Pot heeft een gedegen werk geschreven. ${ }^{60} \mathrm{Ik}$ wil hier slechts kort ingaan op zijn pleidooi voor een uitbreiding van de regelgevende macht van de Kroon, door het schrappen van artikel 56 lid $21887 \mathrm{Gw}$. Daarmee zouden in een zelfstandige algemene maatregel van bestuur ook door straffen te handhaven bepalingen mogelijk zijn. De waarborg tegen 'misbruik' van deze bevoegdheid van de Koning ziet Van der Pot in het instituut ministeriële verantwoordelijkheid. Dat biedt de Staten-Generaal immers de mogelijkheid de verantwoordelijke minister 'aan te pakken' wanneer de inhoud van een algemene maatregel van bestuur niet bevalt.

56. Van der Pot 1916, p.379.

57. Van der Pot 1916, p.380.

58. Van der Pot 1916, p.387.

59. Van der Pot 1916, p.388.

60. Zie ook de recensies van J. van Gelein Vitringa 1917, en H. Vos 1918. Beide auteurs bestrijden de opwatting van Van der Pot dat de Grondwet geen materieel wetsbegrip kent. 


\section{Hoofdstuk 3}

Hoe sterk is deze waarborg? Van der Pot geeft geen voorbeelden van ministers die door de volkswertegenwoordiging naar huis zijn gestuurd. Hij geeft deze waarborg als theoretisch verhaal. Tegen zijn standpunt pleit de volgende passage uit zijn boek waarin hij ingaat op de verhouding Kroon-Parlement. "Dat, als eenig meeningsverschil op haren en snaren gezet wordt, de wil des Konings wijken moet voor dien der volksvertegenwoordiging, is m.i. voor ons land en voor dezen tijd een niet te loochenen feit." ${ }^{61}$ Maar bij dit standpunt past een zekere relativering: "Zeker, tegenover een op haar stuk staande Kamer kan de Koning een minister niet handhaven. Hoe vaak echter komt en blijft een minister aan het bewind, terwijl de op hem gevallen keuze de Kamer in haar meerderheid zeer bepaald tegen den zin is. Door het recht van amendement en het vervallen van het sanctierecht tot een bloote formaliteit ontvangt de wet van de volksvertegenwoordiging haar definitieven inhoud. Hoe dikwijls is echter niet een wet in het Staatsblad gekomen, waarvan duidelijk gebleken was, dat de meerderheid der Tweede Kamer er niet mee instemde. Een minister blijft aan het roer, omdat men wan zijn val een ongewenschte verzwakking van de Regeering in haar geheel vreest, omdat onder bepaalde omstandigheden 's lands belang een portefeuillewisseling schijnt te verbieden, omdat de kamer, hoe ook ontstemd over zijn beleid, van een ultimum remedium als het verwerpen zijner begrooting terugschrikt. Een wet gaat er door, omdat haar verwerping den minister, dien men om andere redenen wenscht te behouden, hoogst waarschijnlijk zou doen aftreden of omdat het belang, dat er een regeling van de zaak komt, op dat oogenblik over de bezwaren, die men tegen de wijze van regelen heeft, zuchtend doet heenstappen. ${ }^{162}$

Deze constatering van Van der Pot over de rol van het parlement en de ministeriële verantwoordelijkheid bij het totstandkomen van de formele wet, geldt mijns inziens a fortiori voor de zelfstandige algemene maatregel van bestuur. Daar heeft het parlement immers helemaal geen zeggenschap over gehad: er is geen formele wet die voor de algemene maatregel van bestuur de basis biedt, en waarin de inhoud van de regeling (al enigszins) bepaald zou kunnen worden.

Bovenvermelde passage verzwakt Van der Pots betoog voor een grotere rol van de zelfstandige algemene maatregel van bestuur, waarbij de ministeriële verantwoordelijkheid als waarborg kan gelden tegen bevoegdheidsmisbruik, in mijn ogen dan ook aanzienlijk.

61. Van der Pot 1916, p.365.

62. Van der Pot 1916, p.365-366. 


\subsection{Handelingen NJV 1951}

\subsubsection{Beschrijving preadvies Stellinga}

In 1951 komt het delegatievraagstuk (naast het onderwerp 'bewijsrecht') aan de orde op de vergadering van de Nederlandse Juristen Vereniging. De twee preadviseurs, Stellinga en Donner, krijgen de volgende vragen voorgelegd. "Welke beginselen behoren de delegatie van regelende bevoegdheid aan uitvoerende organen te beheersen? Behoren deze beginselen te worden vastgelegd, hetzij in de grondwet, hetzij in de delegerende wet?"63

Stellinga opent zijn preadvies met de opmerking dat de opstellers van de vragen er kennelijk van uitgaan dat delegatie van regelgevende bevoegdheid geoorloofd is. Hij zet hier vraagtekens bij, omdat de bevoegdheid tot delegeren eerder een in de praktijk gegroeide bevoegdheid is dan een positief-rechtelijk verankerde. ${ }^{64}$ Volgens Stellinga is er sprake van delegatie "wanneer het ene orgaan een bepaalde verrichting, welke tot zijn eigen competentie behoort, aan een ander orgaan overdraagt" ${ }^{65}$ Die overdracht vindt vaak plaats aan een uitvoerend orgaan. ${ }^{66}$ Hij bepleit vervolgens een scheiding van functies in plaats van een scheiding van machten.

Een wetgevend orgaan kan een deel van zijn taak overdragen, maar die taak blijft wetgevend van inhoud. "In dit opzicht heeft men niet altijd de juiste kijk op de dingen gehad, hetgeen voornamelijk in de hand gewerkt is door het hanteren van het begrip uitvoering. Dit werd dan uitgelegd in deze zin, dat het stond tegenover de functie wetgeven. Dit gaat echter, al was het wellicht door Montesquieu zo bedoeld, niet geheel en al op, omdat uiteraard een wettelijke regeling ook kan worden uitgevoerd door het maken van een nadere regeling. "67 (...) "Wanneer derhalve uitvoeren mede het maken van nadere regelen kan omvatten, dan zal aanstonds duidelijk zijn, dat uitvoering en delegatie dicht bij elkaar liggen. Het is zelfs de vraag, of hetgeen men in de wandeling delegatie pleegt te noemen, wel allemaal echte delegatie is, en of het niet voor een deel onder het begrip uitvoering is te brengen." ${ }^{68}$

63. Stellinga 1951, p.110.

64. Stellinga 1951, p. 110.

65. Stellinga 1951, p.111.

66. Stellinga 1951, p. 112.

67. Stellinga 1951, p. 113.

68. Stellinga $1951, p .114$. 


\section{Hoofdstuk 3}

Stellinga onderzoekt vervolgens de delegatie bij provincie en gemeente. De rechter heeft hier de grenzen van de delegatie kunnen controleren en vaststellen. ${ }^{69}$ Vooral de verhouding gemeenteraad-B en W gaf aanleiding tot juridische twisten. Dat kwam door het systeem van de gemeentewet. In artikel 168 werd de gemeenteraad een regelgevende bevoegdheid toegekend en in artikel $209 \mathrm{a}$ een daanuit voortyloeiende bevoegdheid aan $\mathrm{B}$ en $\mathrm{W}$ tot uitvoering van die raadsbesluiten. De jurisprudentie liet nadere regeling door $\mathrm{B}$ en $\mathrm{W}$ toe ${ }_{\text {, }}$ zolang dat onder 'uitvoering' was te brengen. ${ }^{70}$

De problemen die dit systeem met zich mee bracht werden in 1931 opgelost door de invoering van een nieuw artikel 169 Gemeentewet: 'Hij (de gemeenteraad) kan in die verordeningen burgemeester en wethouders bevoegd verklaren nadere regels te stellen nopens bepaalde, in die verordening aangewezen, onderwerpen'. "I

Overstappend naar de grenzen van delegatie bij de centrale overheid constateert Stellinga dat de problematiek hier diffuser ligt. Dit komt zijns inziens door artikel 124 lid 2 Gw 1938: 'De wetten zijn onschendbaar'. Volgens Stellinga betekent het ontbreken van rechterlijke controle niet dat de wetgever nu maar ongestoord mag delegeren.

De wetgever krijgt volgens hem in artikel $112 \mathrm{Gw} 1938$ ('De wetgevende macht wordt gezamenlijk door den Koning en de Staten-Generaal uitgeoefend') een wetgevende bevoegdheid opgedragen die hij, zij het niet onbeperkt, mag overdragen. ${ }^{72}$ In artikel $112 \mathrm{Gw} 1938$ is volgens hem een materieel wetsbegrip neergelegd: het materiẻle ligt in de 'regeling' van een onderwerp. ${ }^{73}$

De historische achtergrond van de algemene maatregel van bestuur ziet Stellinga in het uitvoeren van de wet. Het artikel waarin de Koning tot het stellen van algemene maatregelen van bestuur bevoegd wordt gemaakt is niet te zien als een vrijbrief voor delegatie aan de algemene maatregel van bestuur in de formele wet, of de vaststelling van zelfstandige algemene maatregelen van bestuur. ${ }^{74}$

Stellinga wijst op het onderscheid dat in de delegatie-literatuur gemaakt wordt tussen een wet die geëist wordt door de Grondwet en een wet die buiten de Grondwet om tot stand komt. In het eerste geval zijn velen van mening, dat dele-

69. Stellinga 1951, p.115.

70. Stellinga 1951, p.116-117.

71. Stellinga $₫ 951, \mathrm{p} .118$.

72. Stellinga 1951, p.122 e.v.

73. Stellinga 1951, p. 120 .

74. Stellinga 1951, p. 123-125. 
gatie slechts tot op zekere hoogte mogelijk is, in het tweede geval zou de wetgever geheel vrij zijn om te delegeren. ${ }^{75}$

Stellinga is het hier niet mee eens. Zijn opvatting over het materieel wetsbegrip brengt mee dat er geen onderscheid in 'status' tussen organieke en andere wetten gemaakt dient te worden. ${ }^{76}$

Stellinga bespreekt de meningen van verschillende auteurs. Van der Pot noemt de mate waarin gedelegeerd kan worden een interpretatiekwestie: heeft de Grondwet een uitputtende regeling bedoeld dan is delegatie niet toegestaan: in het andere geval is delegatie van details toegestaan. ${ }^{77}$ Zo ook Duynstee die in het geval dat de Grondwet een opdracht aan de wetgever verstrekt de geoorloofdheid van delegatie tot een rechtsvraag bestempelt. Komt een wet buiten de Grondwet om tot stand dan is het in zijn ogen een beleidskwestie om gebruik te maken van delegatie. ${ }^{78}$

Oud neemt een ander standpunt in. Die is van mening dat delegatie is toegestaan wanneer de Grondwet een opdracht aan de wetgever geeft. Stellinga geeft de woorden van Oud weer. "Wanneer de Grondwet de koninklijke macht heeft beperkt, dan is dat z.i. geschied, omdat zij niet wenste, dat belangrijke zaken zouden kunnen worden geregeld zonder de medewerking der volksvertegenwoordiging. Zij wilde de rechten dier vertegenwoordiging waarborgen tegen mogelijke willekeur des Konings. Maar de Grondwetgever bedoelde volgens Oud niet wijzer te zijn dan die volksvertegenwoordiging zelf. Hij wilde haar niet tegen haar eigen zwakheden in bescherming nemen. Waarom zou dan de volksvertegenwoordiging niet, indien zij daarvoor voldoende vertrouwen in de Regering stelt, de zaken, waarvoor zij dit doelmatig acht, aan de Regering mogen overlaten? " $^{\text {79 }}$

Stellinga is het niet eens met Oud. "Dat men onbeperkte delegatie kan leren in die gevallen, waarin de wetgever niet uitdrukkelijk tot regeling wordt geroepen, is nog begrijpelijk, maar dat men daartoe ook kan komen, als de Grondwet zelf regeling bij de wet eist, is m.i. volkomen onaanvaardbaar. Het betekent immers, dat men practisch alle waarde aan de Grondwet ontneemt en het gehele staatsbestel op losse schroeven zet. ${ }^{180}$

75. Stellinga 1951, p. 125 .

76. Stellinga $1951, \mathrm{p} .125$.

77. Stellinga 1951, p.125, verwijzend naar Van der Pot, Handboek, blz. 330.

78. Stellinga 1951, p.126, verwijzend naar Duynstee, NJB 1949, blz, 15.

79. Stellinga 1951, p.126-127, verwijzend nalar Oud, Constitutioneel recht II, blz.215-237.

80. Stellinga 1951 , p. 128. 


\section{Hoofdstuk 3}

\subsubsection{Beschrijving preadvies Donner}

Donner begint zijn preadvies met het onderzoeken van de grenzen tussen delegatie en mandaat en tussen delegatie en attributie. Voor de eerste kwestie zoekt hij aansluiting bij de Duitse geleerde Triepel. ${ }^{96}$ Deze beschrijft delegatie als overdracht van bevoegdheden door het ene orgaan aan een ander, dat de bevoegdheid onder eigen verantwoordelijkheid gaat uitoefenen. Bij mandaat gaat het om een opdracht van een bevoegdheid van een orgaan aan een lager orgaan, dat de bevoegdheid gaat uitoefenen onder de verantwoordelijkheid van het hogere orgaan. Kenmerk van delegatie is verder dat de delegans de mogelijkheid om zijn bevoegdheid uit te oefenen kwijt raakt, zolang de delegatie niet is ingetrokken. In het algemeen acht Triepel delegatie ongeoorloofd, en mandaat toegestaan. ${ }^{97}$ Donner wijst erop dat het gemaakte onderscheid, hoewel verdienstelijk, niet in alle gevallen duidelijkheid schept. Bovendien gaat Triepel niet in op de grens tussen delegatie en attributie. ${ }^{98}$

Donner gaat die grens vervolgens onderzoeken. Hij komt tot de volgende omschrijving: delegatie vindt slechts plaats "bij overdracht door het tot de uitoefening dier bevoegdheden aangewezen orgaan," want de regelgevende bevoegdheden die de wetgever aan andere organen toekent, zullen niet steeds bevoegdheden zijn waarvoor de wetgever zelf aangewezen is. ${ }^{99}$

Dat betekent dat de grens tussen delegatie en attributie gezocht moet worden in het geldende recht: de bepalingen die bevoegdheden verdelen.

"Beogen die voorschriften, waar zij een bevoegdheid geven, dat deze ook door het ontwangen orgaan zelf wordt uitgeoefend, dan kan het delegatie-vraagstuk rijzen. Is dat doel dien voorschriften vreemd, dan late men voor het doorgeven van de verleende bevoegdheid de benaming delegatie achterwege. "100

Wanneer komt een orgaan een bevoegdheid toe, in het bijzonder, wanneer kornt de wetgever een regelgevende bevoegdheid toe? Om hierop een antwoord te kunnen geven, behandelt Donner de vraag of de Grondwet een materieel wetsbegrip huldigt. Hij onderzoekt dit aan de hand van het onderscheid wetgeving-

96. Donner 1951 , p. 149, verwijzend naar H. Triepel, Delegation und Mandat im öffentlichen Recht, Stuttgart \& Berlijn 1942.

97. Donner 1951, p. 149.

98. Donner 1951, p.150.

99. Donner 1951, p.153.

100. Donner 1951, p.156-157. 
uitvoering, en de kwestie in hoeverre dit onderscheid kan worden gebaseerd op het positieve Nederlandse staatsrecht. ${ }^{101}$

Hij komt tot de conelusie dat de begrippen wetgevende macht en uitvoerende macht niet gekoppeld zijn aan de specifieke functies wetgeving en uitvoering. Zowel de Kroon als de formele wetgever kunnen als taak hebben om algemene regels te stellen. De Grondwet eist ter waarborging van vrijheden van burgers (slechts) dat bepaalde onderwerpen door de (formele) wetgever worden geregeld. ${ }^{102}$

Volgens Donner ligt er in artikel 112 van de toenmalige Grondwet over de wetgevende macht ${ }^{103}$ een formeel wetsbegrip besloten. Welke consequenties heeft deze opvatting voor het delegatievraagstuk? Het feit dat in Donners ogen in de Grondwet niet aan de wetgevende macht een 'algemeen geldende' regelende bevoegdheid wordt opgedragen, betekent dat de wetgever dus ook niet steeds het aangewezen orgaan is om een onderwerp te regelen. In de gevallen waarin dat niet zo is, dient dan ook niet van delegatie van regelgevende bevoegdheid te worden gesproken, als de wetgever bevoegdheden overlaat aan een ander orgaan. $^{104}$

"In het kader van de Grondwet kan dan ook alleen van delegatie in den vollen zin van dat woord sprake zijn in die gevallen, waar de wetgever wordt aangewezen tot het nemen van bepaalde besluiten of het treffen van een regeling voor een met name aangewezen onderwerp. Intussen is ons staatsrecht niet tot de Grondwet beperkt. Van delegatie zal ook sprake zijn in die gevallen waar de wetten zelf de wetgever of andere organen voor de uitoefening van bepaalde bevoegdheden aanwijzen." ${ }^{\text {105 }}$

In hoeverre is delegatie echter geoorloofd? Donner haalt Oud aan, in diens betoog over de Noodwet Indonesië. Oud is voorstander van ruime delegatie. ${ }^{106}$ Niet iedereen is het met Oud eens. Zo ook Anema die drie belangrijke drijfveren ziet voor delegatie: "de sociale wetgeving, het verkeersrecht en de gespannen internationale verhoudingen. "107

101. Donner 1951, p.157-158.

102. Donner 1951, p.164.

103. "De wetgevende macht wordt gezamenlijk door den Koning en de Staten-Generaal uitgeoefend."

104. Donner 1951, p.165.

105. Donner 1951, p.165.

106. Donner 1951, p. 166.

107. Donner 1951, p.168, verwijzend naar Handelingen Eerste Kamer 1948-1949, p. 25 e.v. 


\section{Hoofdstuk 3}

Voor wat betreft de mate van delegatie maakt Anema onderscheid tussen de verschillende grondwetsbepalingen. Als het gaat over fundamentele vrijheden en over gezag (zoals bij grondrechten en de artikelen over een "organieke staatsregeling") dan mag de wetgever niet delegeren en zal hij het onderwerp zelf moeten regelen. ${ }^{108}$ Donner erkent deze drijfveren maar tekent erbij aan dat er juist op deze terreinen geen grondwettelijke belemmeringen lagen. ${ }^{109}$

Maar welke onderwerpen zijn aan de wetgever opgedragen om door hem zelf geregeld te worden? Het probleem van het door Anema aangelegde criterium is volgens Donner dat niet duidelijk is wat er precies onder valt, dat hangt mede af van iemands persoonlijke inzichten. ${ }^{110}$

Donner zoekt het antwoord in een analyse van de tekst van de verschillende grondwetsartikelen. Het woord 'regelen' speelt in deze teksten een belangrijke rol. Is hier dit woord gebruikt in de zin van het stellen van algemene regels? ${ }^{111}$ Donner wijst erop dat dit gebruik van het woord 'regelen' vrij 'modern' is, en dus niet zomaar toegepast kan worden op de tekst van de al veel oudere Grondwet. ${ }^{1 / 2}$

Zijn conclusie luidi dan ook dat delegatie wel geoorloofd lijkt wanneer de Grondwet het woord 'regelen' of een vervoeging daarvan hanteert, maar dat de mate waarin dat mag een rechtsvraag is. Waar de grens tussen toegestane en verboden delegatie ligt, is niet duidelijk aan te geven. ${ }^{113}$

"Intussen moet wel worden toegegeven: ten eerste, dat het gebrek aan systematiek in de woordenkeus der Grondwet het trekken van een althans enigszins verantwoorde grenslijn bemoeilijkt; ten tweede, dat de wijzigingen in de staatstaak ertoe hebben geleid, dat er zeer vele minstens even belangrijke, zo niet belangrijker zaken zijn, waarover de Grondwet zich geheel niet uitspreekt en waarvoor dus aan de 'delegatiebevoegdheid' géên grens is gesteld. "1/4

108. Donner $195 !$, p.168-169.

109. Donner 1951, p.170.

110. Donner 1951, p.171.

111. Donner 1951, p.172. Donner haslt de wolgende definitie van wetgeving aan (verwijzend nat Van der Pot, Handboek, Se dr., Zwolle, 1950, blz. 286 en de aldaar aangehaalde platsen bij Van Vollenhoven, Statsiecht Overzee): "het vaststellen wan algemeen werkende regelen, waarbij dus niet iets bepaald wordt voor eén persoon of voor enige bepaaldelijk aangeduide personen of voor éen concreet, voorliggend geval, maar voor een te voren onbekende reeks van personen of gevallen."

112. Donner 1951, p.171-173.

113. Donner 1951, p.177.

114. Donner 1951, p. I78. Hij voegt eraan toe: "In beide opzichten zou een komende Grondwetsherziening verbetering kunnen brengen." 
Hij bespreekt vervolgens aan wie er mag worden gedelegeerd. Krachtens artikel 57 lid $2 \mathrm{Gw} 1938^{115}$ (over strafbepalingen die alleen in een algemene matregel van bestuur opgenomen mogen zijn wanneer er een wettelijke grondslag is) mag er aan de Kroon worden gedelegeerd, maar dat sluit volgens Donner niet uit dat ook aan de minister bevoegdheden mogen worden overgedragen. Dit laatste is gezien de toenemende druk op de wetgever onvermijdelijk. ${ }^{116}$ Een bevoegdheid tot delegatie zal in het algemeen een wettelijke basis moeten hebben. ${ }^{117}$

Donner wijst op een recente discussie waarbij de vraag centraal staat of de $\mathrm{Ka}$ mers de gedelegeerde regeling op de een of andere manier niet kunnen controleren. ${ }^{118}$ Dit zou bijwoorbeeld kunnen geschieden door het gedurende een bepaalde termijn ter inzage leggen van een regeling, waarna die in werking kan treden tenzij één van de Kamers bezwaar heeft gemaakt. ${ }^{119}$

Donner is geen voorstander van dit voorstel. Want al verschuift de werkzaamheid van de Staten-Generaal van medewetgever naar controleur, dat kan niet beletten dat de macht van de Kroon toeneemt. Deze trend moet niet worden doorgezet. ${ }^{120}$

Hij toont zich dan ook geen voorstander van het voorstel van Van der Pot in diens dissertatie gedaan om de Kroon meer zelfstandige algemene maatregelen van bestuur te laten stellen. "Men kan wel aanvoeren, dat de Staten-Generaal in hun contrôlerecht over voldoende middelen beschikken om een gebruik van die bevoegdheid, waarin zij geen vertrouwen hebben, tegen te gaan, maar dat is slechts ten dele juist. Vertrouwensquaesties stelt een Kamer niet graag en de voorgestelde oplossing zou dan ook beslist geen versterking van haar positie zijn, vergeleken bij de huidige toestand, waaronder, krachtens art. 57, 2e lid, haar instemming meestal te voren moet zijn verworven en waarbij het haar veel makkelijker valt waarborgen te verkrijgen voor een regelingsbeleid, dat haar instemming heeft. Het bezwaar tegen de huidige situatie, dat men telkens met 'lege wetten' te maken krijgt, moet niet te zwaar worden geteld; eigenlijk valt zulk een bezwaar alleen te plaatsen in een opvatting, die bij de uitdrukking wetgevende macht nog altijd een materieel wetsbegrip in het achterhoofd heeft." 121

115. Het vroegere artikel $56 \mathrm{Gw}$.

116. Donner 1951, p. 180-181.

117. Donner 1951, p.181-182.

118. Donner 1951, p.186.

119. Donner 1951, p. 187 . Voorstel gedaan door Van der Goes van Naters, wolgens Donner aan de Engelse praktijk ontleend.

120. Donner 1951, p.188-189.

121. Donner 1951, p. 190. 


\section{Hoofdstuk 3}

En dat leidt hem tot de conclusie dat er geen vaste beginselen voor het hanteren van het delegatievraagstuk aan te wijzen zijn, "althans niet, wanneer men de probleemstelling van de liberale triasleer verwerpt."

\subsubsection{Beschrijving discussie}

De discussie in de vergadering van de NIV naar aanleiding van beide preadviezen was weinig opwindend en wordt hier daarom niet uitgebreid weergegeven. Er kwamen op hoofdzaken nauwelijks nieuwe aandachtspunten naar voren. Donner vatte in zijn reactie op de woordvoerders de discussie samen in de vraag: "Waarom is er over dat hele delegatievraagstuk zoveel herrie?" En het antwoord ziet hij in de opmerkingen van Van Dullemen besloten: " (...) de burger moet zich zelf regeren." Angst en bezorgdheid voor een te eigenmachtig optreden van het ambtelijk apparaat houden het delegatievraagstuk levend. ${ }^{123}$

Aan het eind van de vergadering van de NJV is er gestemd over de vraagpunten. De stemming viel als volgt uit. De wetgever mag, zij het niet onbeperkt, delegeren; hij moet er naar streven om hoofdlijnen in de wet zelf vast te leggen; de Grondwet moet voorschrijven in welke gevallen niet gedelegeerd mag worden, en eventueel delegatiebepalingen met (procedurele) voorwaarden omkleden. De krachtens delegatie tot stand gekomen lagere regelingen moeten door de rechter getoetst kunnen worden. ${ }^{124}$

\subsubsection{Bespreking ${ }^{125}$}

De verschillende opvattingen van de beide preadviseurs over de betekenis van artikel $112 \mathrm{Gw} 1938$ heeft gevolgen voor de vraag in hoeverre zij delegatie geoorloofd achten.

Donner; aanhanger van een formeel wetsbegrip, kijkt naar de tekst van de Grondwet om te kunnen bepalen of de wetgever een hem opgedragen taak mag delegeren. Als uit de tekst van een Grondwetsartikel blijkt dat de grondwetgever regeling van een bepaalde materie door de wetgever verlangt is delegatie niet toegestaan. In alle andere gevallen is delegatie wel toegestaan.

122. Donner 1951, p.193.

123. Handelingen NJV 1951, p.137.

124. Handelingen NJV 1951, p.150-152.

125. De preadviezen zijn ook besproken door J.V. Rijpperda Wierdsma in NJB 195 1, p.509. 519. 
Stellinga, aanhanger van een materieel wetsbegrip, kijkt naar de taak van de wetgever, het regelen van een onderwerp, en leidt daar uit af dat de wetgever zelf steeds de hoofdzaken moet regelen.

Het standpunt van Donner, dat delegatie slechts plaatsvindt wanneer een aangewezen orgaan een bevoegdheid overdraagt, leidt tot een 'enge' delegatiedefinitie. Nu is daar op zichzelf niets tegen, maar welk criterium is er om een onderscheid te maken tussen regelgevende bevoegdheden waarvoor de wetgever zelf aangewezen is, en regelgevende bevoegdheden waarvoor de wetgever niet zelf aangewezen is? Donner neemt daarvoor de tekst van de Grondwet als uitgangspunt, maar het is in mijn ogen de vraag of de toenmalige grondwetgever zo bewust het onderscheid heeft gemaakt.

Als we de inhoud van de preadviezen vergelijken met het werk van Addens en Van der Pot, besproken in de paragrafen 3.2 en 3.3 , dan vallen enkele overeenkomsten en verschillen op.

Nog steeds speelt het artikel over het vaststellen van algemene maatregelen van bestuur door de Koning (artikel $56 \mathrm{Gw}$ 1887, artikel $57 \mathrm{Gw}$ 1938) een belangrijke rol in het delegatievraagstuk. Ook de Grondwet neemt een centrale positie in. De discussie over een formeel dan wel materieel wetsbegrip woedt nog volop en is van belang voor een delegatiestandpunt. En evenals Van der Pot zoeken wetenschappers en politici naar wegen om de waarborgen tegen al te vergaande delegatie te vergroten, hoewel de inhoud van de voorstellen daarwoor verschilt. Van der Pot wil een groter beroep op de ministeriële verantwoordelijkheid door de Kamers, de voorstellen nu gedaan willen door maatregelen als ter inzage legging meer inspraak voor de Staten-Generaal.

Daarnaast en daarmee samenhangend kunnen we een verschuiving constateren in de opvatting of delegatie is toegestaan. Delegatie wordt steeds meer geoorloofd geacht. Simons verwoordde het in de vergadering van de NJV aldus: delegatie is noodzakelijk, maar geen noodzakelijk kwaad. ${ }^{126}$ Delegatie komt meer en meer voor; in de preadviezen komt (voor het eerst) delegatie aan anderen dan de Kroon ter sprake en valt de term 'subdelegatie'. Ook voor de laatste vorm wordt een wettelijke basis noodzakelijk geacht.

126. Handelingen NJV 1951, p.110. 


\subsection{Van Driel, De ministeriële verordening, 1956}

\subsubsection{Beschrijwing}

Uit het feit dat de dissertatie van Van Driel in 1956 over de ministeriële verordening gaat, kunnen we afleiden dat (sub)delegatie naar het niveau van de minister een belangrijke plaats heeft ingenomen. ${ }^{127}$ Van Driel constateert dat wetgeving op rijksniveau ('Den Haag') "behalve uit wetten en algemene maatregelen van bestuur, voor een niet onbelangrijk deel uit ministeriële beschikkingen met algemene werking bestaat". ${ }^{128}$ De plaats van die ministeriële beschikking in het (Nederlandse) staatsrecht en haar rechtskracht zijn het belangrijkste onderwerp van studie. ${ }^{129}$

Van Driel bespreekt het verschijnsel en de naam ministeriële verordening in hoofdstuk I en de geschiedenis ervan in hoofdstuk II. In de hoofdstukken III tot en met $\mathrm{V}$ wordt de rechtskracht van de ministeriële verordening behandeld: de grondslag, het begin en einde, en de inhoud ervan. Hoofdstuk VI heeft de vooren nadelen van regeling bij ministeriële verordening als onderwerp en hoofdstuk VII toetsing van de ministeriële verordening. Hoofdstuk VIII tenslotte is getiteld 'Samenvatting der conclusies'.

Het stellen van regels bij ministeriële verordening "is een gebruikelijke methode geworden om principieel weinig belangrijke en vaak tot in details tredende regelingen vorm te geven. " ${ }^{130}$ De verordening steunt dikwijls op een wet of algemene maatregel van bestuur en wordt in de Staatscourant gepubliceerd.

Van Driel onderscheidt vier soorten ministeriële regelingen: 1. die waarin de rechtstoestand van de burger direct geregeld wordt; 2 . die waarin interne aanwijzingen worden gegeven aan ambtenaren, die materieel echter de rechtstoestand van de burger kunnen beïnvloeden; 3 . die waarin het stellen van normen aan derden wordt overgelaten en 4 . die waarin subsidievoorwaarden zijn opgenomen

127. Het niveau waarnaur gedelegeerd wordt is steeds 'lager" geworden. Nadat in 1916 de verhouding wet-algemene maatregel van bestuur door Van der Pot in kaart is gebracht, koml veertig jaren later de ministeriële verordening aan de beurt. En deze ontwikkeling doortrekkend is het niet meer dan vanzelfsprekend dat weer een "lagere" soont regels, namelijk beleidsregels, een kleine vier decennia later onderwerp van een dissertatie is: Van Kreveld 1983. Zie hoofdstuk 8.

128. Van Driel 1956, p.1.

129. Van Driel 1956, p.1.

130. Van Driel 1956, p.2. 
waardoor de minister "subsidie-lustigen volkomen naar zijn milde hand (kan) zetten". 131

De juridische handboeken besteden volgens Van Driel nauwelijks aandacht aan de ministeriële verordening. Wel constateert zij eensgezindheid in de doctrine op twee punten: de minister vaardigt in sommige ministeriële beschikkingen voorschriften uit die algemeen werken; de bevoegdheid daartoe ontleent de minister meestal aan een specifieke wettelijke bepaling. ${ }^{1.32}$ Als benaming stelt zij voor om de 'ministeriële beschikking met algemene werking' ministeriële verordening te noemen. ${ }^{133}$ Haar definitie ervan luidt: "de ministeriële verordening is een algemeen werkend overheidsbesluit dat van de minister afkomstig is". ${ }^{134}$ Historisch gezien krijgt de minister in de periode 1798 (de Staatsregeling voor het Bataafse volk) tot 1840 geen (grond)wettelijke wetgevende bevoegdheid toegekend. ${ }^{135}$ De minister treedt wel feitelijk regelend op, maar dat valt onder de uitvoeringsbevoegdheid van de minister. ${ }^{136}$ In de periode daarna wordt wel in afzonderlijke wetten regelgevende bevoegdheid gedelegeerd aan de minister. ${ }^{137}$

In de volgende hoofdstukken onderzoekt Van Driel de rechtskracht van de ministeriële verordening. Een grondslag daarvoor treft zij in de toenmalige Grondwet niet aan. Zij vraagt zich af waarom die ontbreekt. "Toch niet, omdat de ministeriële wetgeving een nieuw instituut zou zijn. Reeds meer dan honderd jaar zijn wetgevende maatregelen bij ministeriële verordening tot stand gebracht." ${ }^{138}$ Overigens blijkt Van Driel verderop in haar boek geen voorstander te zijn van een dergelijke grondwettelijke rechtsgrond. Volgens haar hangt de behoefte aan regeling door een mınister samen met de behoefte aan maatschappelijke ordening. Dit laatste kan verschillen naar tijd en plaats. Het gaat te ver om daar dwingende grondwettelijke regels voor op te nemen. "Gezien de grote rol, die het behoefte-element in deze speelt, meen ik, dat aan de minister, wiens eerste

131. Van Driel 1956, p.8.

132. Van Driel 1956, p.10-11.

133. Van Driel 1956, p.25. De benaming is mede een probleem omdat de Grondwet de term 'ministeriële beschikking' niet kent. Van Driel 1956, p.11.

134. Van Driel 1956, p.28. De eis wan wettelijke grondslag wordt hier niet genoemd.

135. Van Driel 1956, p.29 e.v.

136. Van Driel 1956, p.49-51.

137. Van Driel 1956, p.51. Zij geeft onder andere voorbeelden uit 1902 (betreffende de Boterwet) en 1919 (betreffende de Arbeidswet).

138. Van Driel 1956, p.54. 


\section{Hoofdstuk 3}

taak het is te zorgen, dat de wetten worden toegepast, geen grondwettelijke bevoegdheid moet worden verleend." ${ }^{139}$

Een voorwaarde voor verbindende kracht van de ministeriële verordening is een (behootlijke) afkondiging. Van Driel pleit voor een algemene bekendmakingsplicht. Afkondiging en bekendmaking zou in de Staatscourant of het Staatsblad kunnen, maar ook in een departementaal in te stellen bekendmakingsblad. $\mathrm{Zij}$ stelt voor aansluiting te zoeken bij de regeling voor bekendmaking van algemene maatregelen van bestuur. ${ }^{140}$

Aan de rechtskracht van een ministeriële verordening kan op vier verschillende manieren een einde komen. 1. Door tijdsverloop: in de wet, algemene maatregel van bestuur of ministeriële verordening zelf kan een bepaling opgenomen zijn dat de verordening slechts een bepaalde tijd van kracht is. 2 . Door ingrijpen door een hogere wetgever. 3. Door intrekking door de minister zelf (deze mogelijkheid verdient de voorkeur). 4 . Door vernietiging. ${ }^{141}$

Bij het bespreken van de wettelijke grondslag van de ministeriële verordening komt het delegatievraagstuk aan de orde. De wetgever kan zowel in beperkte als in ruime mate wetgevende bevoegdheid delegeren (binnen de grenzen door de Grondwet gesteld). ${ }^{142}$ Vooral voor onderwerpen waarvoor specifieke technische kennis is vereist, als voor zaken die geregeld kunnen worden buiten een formele wet om, is de ministeriële verordening geschikt. ${ }^{143}$

Van Driel bespreekt ook het verschijnsel subdelegatie: dat vindt plaats wanneer de ministeriële verordening een grondslag heeft in een algemene maatregel van bestuur. Ontbreekt daartoe een in de formele wet opgenomen mogelijkheid dan is volgens haar de verordening onverbindend wanneer die ingrijpt in de rechten en plichten van de burgers. ${ }^{144}$

Voordelen van regeling door de minister zijn volgens Van Driel: a. een grotere soepelheid in totstandkoming en wijziging van de regeling; $b$. voorkoming van overbelasting van regering en parlement door de regeling van details over te laten

139. Van Driel 1956, p.56.

140. Van Driel 1956, p.66-69.

141. Van Driel 1956, p.70-74.

142. Van Driel 1956, p.56.

143. Van Driel 1956, p. 70.

144. Van Driel 1956, p.58. 
aan de minister; c. bevordering van de overzichtelijkheid van wetgeving (de grote lijnen staan bij elkaar in de wet, details in de ministeriële verordening). ${ }^{145}$ Nadelen zijn: a. bedreiging van het evenwicht tussen de hoogste staatsorganen: vooral de Staten-Generaal verliezen invloed (het controlerecht achteraf kan het medebeslissingsrecht vooraf niet vervangen); $b$. het ontbreken van adviesinstanties en c. de zeer gemakkelijke wijzigingsprocedure. ${ }^{146}$

Het eerste gevaar van ministeriële regelgeving: verstoring van het evenwicht kan op een aantal manieren ondervangen worden. Bijvoorbeeld door het terrein waarop en de gevallen waarin de minister verordenende bevoegdheden krijgt te beperken. Ook begrenzing van de bevoegdheid kan hier deel van uit maken: mag de minister strafbepalingen opnemen of mag hij subdelegeren? Tenslotte kan er ook een grens gesteld worden aan de geldigheid in tijd van de ministeriële verordening. ${ }^{147}$

Voor het ondervangen van het tweede nadeel, het ontbreken van adviesorganen, ziet Van Driel twee manieren: door toezicht te houden op de ministeriële verordening (dat kan zowell voor- als achteraf) of door het inwinnen van advies zoveel mogelijk te bevorderen. ${ }^{148}$ Haar vcorkeur heeft stilzwijgende goedkeuring achteraf door de Minister-President (in hoofdzaak voor de formele kant) en vooraf verplicht inwinnen van advies bij instanties waarin betrokkenen vertegenwoordigd zijn (van belang voor de inhoudelijke kant). ${ }^{149}$

Voor het derde nadeel, een te gemakkelijke wijzigingsprocedure, acht Van Driel geen goede remedie voorhanden. Het gevaar van een zwaardere procedure kan het voordeel van een grotere soepelheid teniet doen. ${ }^{150}$

In het laatste hoofdstuk bespreekt Van Driel de rechterlijke toetsing van de ministeriële verordening. Belangrijkste vraag is of een ministeriële verordening aan te merken is als 'wet' in de zin van artikel 99 Wet RO. Aan de eisen die de Hoge Raad daarvoor stelt, voldoet de verordening niet steeds. Het moet in de ogen van de Hoge Raad gaan om: "naar buiten werkende, dus tot een ieder gerichte algemeene regelingen, welke zijn uitgegaan van een openbaar gezag, dat de bevoegdheid daartoe aan de wet, in den zin van eene regeling door de wetgevende macht, ontleent." Onder het 'naar buiten werken' valt volgens de Hoge Raad

145. Van Driel 1956, p. $80-82$.

146. Van Driel $1956, \mathrm{p} .82-85$.

147. Van Driel 1956, p.86-89.

148. Van Driel 1956, p.89-96.

149. Van Driel 1956, p. 97.

150. Van Driel 1956, p.96-97. 


\section{Hoofdstuk 3}

"afkondiging in eenig voor publiekmaking van regelingen van het Staatsbestuur aangewezen orgaan." is!

Ministeriële verordeningen voldoen vaak niet aan de eis van algemene regeling tot een teder gericht, en aan de eis van voldoende bekend gemaakt zijn. Van Driel bepleit een versoepeling van de criteria van de Hoge Raad. Toetsing door de Hoge Raad kont immers de rechtsbescherming van de burger en de eenheid van het recht ten goede. ${ }^{152}$

\subsubsection{Bespreking}

Op heldere en systematische wijze brengt Van Driel het onderwerp 'ministeriële verordening' in kaart. De door haar voorgestelde term ministeriële verordening heeft het niet 'gemaakt'. Thans wordt veelal gesproken van ministeriële regeling. ${ }^{153}$

Haar bevindingen over het toekennen van wetgevende bevoegdheid aan de minister (bijwoorbeeld in de sociale wetgeving) ${ }^{154}$ komen overeen met de bevindingen in de vorige paragraaf in de preadviezen van Stellinga en Donner, waar voor het eerst subdelegatie ter sprake kwam.

De constatering van Van Driel dat een grondwettelijke basis voor de ministeriële regeling ontbreekt, is ook onder de Grondwet van 1983 nog actueel. Ook hier is geen rechtstreekse verwijzing te vinden. Ministeriële regelingen kunnen wel vallen onder artikel 89 lid $4 \mathrm{Gw}$ : 'Het tweede en derde lid zijn van overeenkomstige toepassing op andere vanwege het Rijk vastgestelde algemeen verbindende voorschriften: Hiermee is vastgelegd dat ministeriële regelingen die door straffen gehandhafd worden een wettelijke grondslag dienen te hebben. Ook bekendmaking en inwerkingtreding dienen wettelijk geregeld te worden. ${ }^{155}$ Dit geldt uiteraard alleen voor zover de ministeriêle regeling algemeen verbindende voor-

151. Van Driel 1956, p.98-99.

152. Van Driel 1956, p. 102 .

153. De Grond wet wan 1983 kent de term niet. Wel treffen we de 'ministeriele regeling' aan in artikel 4 lid 1 (amnhef eny sub a Bekendmakingswet.

154. Van Driel 1956, p.51.

155. Zie de artikelen 4 en 5 Bekendmakingswet 1988. 
schriften inhoudt. ${ }^{156}$ Van Driels pleidooi om aansluiting te zoeken bij de regeling van de algemene maatregel van bestuur is hiermee gehonoreerd. ${ }^{157}$

Van Driel toont zich geen voorstander van grondwettelijke regeling van de ministeriële verordening omdat dit volgens haar te sterk samen hangt met de maatschappelijke behoefte aan ordening. Gezien de toegenomen betekenis van de ministeriële regeling was opneming in de Grondwet van 1983 wellicht op zijn plaats geweest.

Bij Van Driels beschrijving van de voor- en nadelen van (sub)delegatie aan de minister past een enkele kanttekening. De eerste twee voordelen: een soepeler totstandkoming van regelgeving en het tegengaan van overbelasting van het parlement gelden nog steeds. Het derde voordeel: het vergroten van de overzichtelijkheid van de regelgeving lijkt zichzelf achterhaald te hebben en omgeslagen te zijn in een nadeel.

In de jaren ' 90 van de twintigste eeuw (maar ook al daarvoor) duiken regelmatig klachten op over de grote hoeveelheid en ondoorzichtigheid van de regelgeving. Mocht het argument van Van Driel in de jaren ' 50 nog gelding hebben (hetgeen ik overigens moeilijk kan beoordelen door mijn hedendaags getinte bril), tegenwoordig wordt het niet meer als voordeel van delegatie genoemd. In Koopmans” Compendium wordt in de veelheid van regels die zonder openbare behandeling zijn vastgesteld, een gevaar voor de rechtszekerheid van de burger gezien. ${ }^{158}$

Daarentegen lijkt een door Van Driel gesignaleerd nadeel (het ontbreken van adviesinstanties) ondervangen te zijn. Door Koopmans wordt als een voordeel van delegatie beschouwd dat er meer mogelijkheden zijn om belanghebbenden te horen (soms is deze inspraak zelfs voorgeschreven). ${ }^{159}$

156. Hierbaj tekent Kortmann 1987a, p.268, het volgende aan. "Er zijn talloze ministeriële besluiten die stoffen, plaatsen, tijden e.d. aanwijzen met betrekking tot welke door de aanwijzing een wettelijk verbod van toepassing wordt. Ook zelfstandige ministerièle subsidieregelingen roepen de nodige vragen op. Hoewel de jurisprudentie deze tot op heden niet beschouwt als algemeen verbindende voorschriften, doch als bekendmaking van te voeren beleid, kwalificeerde de memorie van antwoord (TK 1979-1980, 15047 (R1099), $\mathrm{nr} 8, \mathrm{blz} .20)$ zelfstandige ministerièle subsidievoorschriften als verordeningen." Het onderscheid algemeen verbindend woorschrift - beleidsregel komt in hoofdstuk 8 aan bod.

157. Van Driell 1956, p.77-79.

158. Koopmans 1994, p.131.

159. Koopmans 1994, p.131. 


\section{Hoofdstuk 3}

Van Driel stelt aan het eind van haar boek voor om het wetsbegrip in artikel 99 Wet RO te verruimen zodat (meer) ministeriële verordeningen in cassatie getoetst kunnen worden. Die werruiming heeft in de Wet RO en jurisprudentie inderdaad plaatsgevonden. In 1963 is het woord 'wet" in artikel 99 Wet RO vervangen door het woord 'recht'. En daarnaast is de Hoge Raad andere eisen gaan stellen aan het zijn van 'reeht' in de zin van artikel 99 Wet RO. De Hoge Raad noemt nu een regeling 'algemeen', als die voor de betrokkenen naar buiten werkt. De regeling moet betrekking hebben op herhaalbare gevallen en geen geindividualiseerde personen. ${ }^{160}$

Hierdoor zullen nu vele ministeriële regelingen die algemene regels bevatten in cassatie te toetsen zijn.

\subsection{Van der Hoeven, De plaats van de grondwet in het constitutionele recht, $1958^{161}$}

\subsubsection{Beschrijving}

De dissertatie van Van der Hoeven heeft als ondertitel 'Enkele opmerkingen over betekenis en functie van de grondwet in het geheel der constitutionele verhoudingen'. Het werk gaat dan ook over véél meer dan het delegatievraagstuk.

$\mathrm{Na}$ een eerste inleidend hoofdstuk maakt hij in hoofdstuk II 'Enkele opmerkingen over de waarden van het staatsbegrip voor het constitutionele recht' en in hoofdstuk III 'Enkele opmerkingen over het constitutionele en over het grondwettelijke recht in het algemeen'. Hoofdstuk IV handelt over 'De grondwet en de soevereiniteit-dragende instellingen'. In hoofdstuk $V$ komt aan de orde 'De praktische betekenis der grondwet voor het functioneren van de soevereiniteit-dragende instellingen'. Het is in dit kader dat hij de delegatie van wetgevende bevoegdheid bespreekt. Hoofdstuk VI is gewijd aan 'De grondwet en de grondrechten' en hoofdstuk VII tenslotte aan 'De grondwet en soevereiniteitsdaden'.

Het delegatievraagstuk (en enkele andere kwesties, zoals het recht van interpellatie en het recht van enquête, het ministerieel contraseign en het recht van kamerontbinding) bespreekt Van der Hoeven als voorbeeld van hoe (grondwettelijke)

160. HR 25 aprï 1969, NJ 1969, 303. Aangehaald bij Van der Vlies 1991, p.115. Zie voor jurisprudentie van de Hoge Raad op artikel 99 Wet RO over beleidsregels hoofdstuk 8.

161. In deze paragraaf is gebruik gemaakt van de in 1988 aangevulde heruitgave van het proefschrift van Van der Hoeven. Als literatururverwijzing zall dan ook steeds gegeven worden: Van der Hoeven 1988. 
regels en feitelijke ontwikkelingen zich kunnen verhouden en elkaar beïnvloeden. Zijn gedachte hierbij is "dat het vraagstuk van de gelding van een rechtsregel slechts kan worden beantwoord aan de hand van een analyse van de onderliggende verhouding, van de menselijke relatie, welke het rechtsvoorschrift wil regelen en ordenen". ${ }^{162}$

Van der Hoeven brengt een onderscheid aan tussen regels die de soevereiniteitsdistributie als onderwerp hebben ("de verhouding tussen de grote constitutionele instellingen"), en regels die de vrijheidsrechten betreffen ("de verhouding tussen de enkeling en zijn vrije groeperingen tegenover de soevereiniteitsdragers"), ervan uitgaande "dat de vragen rond het heerschappij-uitoefenen-als overheid de eigenlijke kernproblemen vormen" van het publiekrecht. In dit onderscheid ligt de verdeling van de heerschappij besloten én de grenzen ervan. ${ }^{163}$

In (onder andere) het delegatievraagstuk komt dit onderscheid tot uiting. De verhouding tussen de constitutionele organen verschuift doordat de wetgever niet meer in staat is alles zelf te regelen en dientengevolge regelgevende bevoegdheden overdraagt op andere organen. ${ }^{164}$ Van der Hoeven constateert in de wetenschappelijke beschouwingen over het delegatievraagstuk een tweezijdige benadering: enerzijds vindt er rechtsverfijning plaats, wordt er gezocht naar de precieze betekenis van de bepalingen; anderzijds worden bepalingen geformaliseerd en kunnen ze daardoor (inhoudelijk) diverse ladingen dekken. ${ }^{165} \mathrm{Hij}$ geeft als voorbeeld van rechtsverfijning de "thans veelal gevolgde leer (die) stelt, dat de geoorloofdheid van delegatie door de wetgever aan andere organen beoordeeld moet worden naar de bedoeling van de grondwettelijke bepaling waarin de opdracht tot regeling aan de wetgever is vervat $(\ldots)^{\prime \prime}{ }^{166}$

Van der Hoeven bespreekt het delegatievraagstuk niet uitputtend maar tegen de achtergrond van de vraag naar de verhouding tussen de feitelijk bestaande constitutionele relaties en de grondwetsartikelen die die relaties beogen te regelen. In

162. Van der Hoeven 1988, p.121.

163. Van der Hoeven 1988, p.121.

164. Van der Hoeven 1988, p. 123.

165. Van der Hoeven 1988, p. 123 . Een woorbeld hiervan is artikel $81 \mathrm{Gw} 1983$ 'De vaststelling van wetten geschiedt door de regering en de Staten-Generaal gezamenlijk." Dit artikel wordt, zoals ook reeds uit de vorige paragrafen bleek, zowel formeel als materieel geinterpreteerd.

166. Van der Hoeven 1988, p.123-124. Voor de onderbouwing van de thans veelal gevolgde leer" verwijst hij naar C.W. Van der Pot, Handboek wan het Nederlandse Staatsrecht, Se druk. Zwolle 1953, p.342 e.v. 


\section{Hoofdstuk 3}

de Grondwet van 1956 bepaalde alleen artikel 57 lid 2 iets over delegatie: 'Bepalingen, door straffen te handhaven, worden in die maatregelen niet gemaakt, dan krachtens de wet." "Maar de zeer verbreide gedachte, dat een publieke bevoegdheid tevens een plicht inhoudt, die niet op eigen gezag aan een ander kan en mag worden overgedragen (verwijst hier in noot naar diverse auteurs, JD), een typisch materieel normatief beginsel, brengt mee dat het delegatievraagstuk bij uitstek een vraagstuk van grondwetshantering is, nu de grondwet immers zo talrijke opdrachten aan verschillende instellingen, waaronder de wetgever, verstrekt en hun bevoegdheden omschrijft. ${ }^{167}$

Bij de totstandkoming van de Grondwet in 1814-1815 werd het delegatievraagstuk niet voorzien. De Koning werd in die tijd als uitvoerende macht beschouwd, en kon weliswar regels stellen, maar die werden beschouwd als uitvoering van de wet. Dat die regels "het karakter van uitvoering gemakkelijk uiterst ver zouden kunnen uitbreiden", was men zich wel bewust. ${ }^{168}$

De Grondwet gaf aan de wetgever uitdrukkelijk opdrachten om onderwerpen te regelen, waarin een waarborg werd gezien tegen regeling door de Koning (en "vorstelijke willekeur"). Dat die wetgever daarbij bevoegdheden aan de Koning zou delegeren kwam niet als gedachte op. "En toen het probleem zich in de praktijk aandiende, waren de koning en de wetgever beide instellingen met een geheel andere functie dan in 1815 voorzien was. "169

Feitelijk ontwikkelde de delegatie door de wetgever zich doordat hij zich door maatschappelijke en politieke veranderingen gedwongen zag: hij was niet meer in staat alles zelf te regelen, en zag zich genoodzaakt anderen in het regelgevingsproces te betrekken.

De vraag die Van der Hoeven dan behandelt is "hoe werd deze ontwikkeling beoordeeld vanuit de geldende grondwet"? ${ }^{170} \mathrm{Hij}$ constateert dat met name bij het delegatievraagstuk de Grondwet een remmende ("en naar gelijkmatigheid van de ontwikkeling tenderende") werking heeft gehad. Hij onderbouwt dit met enkele voorbeelden.

In het eerste voorbeeld (betreffende artikel 3 van de Spoorwegwet van 1875 waarin aan de Kroon een regelingsbevoegdheid werd gedelegeerd voor een privaatrechtelijk onderwerp) komen de opvattingen van Buys naar voren. Buys zag het delegatievraagstuk in de verhouding wet-algemene maatregel van bestuur.

167. Van der Hoeven 1988, p.124.

168. Van der Hoeven 1988, p.124, en de daar aangehaalde noot 5.

169. Van der Hoeven 1988, p.124-125.

170. Van der Hoeven 1988, p. 125. 
Voor hem deed de bepaling in de Grondwet die een opdracht aan de wetgever gaf niet ter zake. Volgens hem had de Koning al wetgevende macht, tezamen met de Staten-Generaal, die alleen beperkt kon worden in bijzondere grondwetteijke bepalingen. ${ }^{171}$ Een gedelegeerde grondwettelijke bevoegdheid had de Koning echter niet, daarvoor was een grondwetswijziging nodig die in 1887 tot stand kwam. ${ }^{172}$

Van der Hoeven ziet in het latere werk van Buys een werschuiving van standpunt: dan wil ook Buys "toetsing van de delegatie aan de bijzondere opdracht door de grondwetgever aan de wetgever verstrekt". ${ }^{173}$

Verder bespreekt Van der Hoeven de opvattingen van Oppenheim die als tegenstander van delegatie gezien kan worden, "al wil ook hij "nadere uitwerking" van de regels door de wetgever gesteld, binnen duidelijke grenzen aanvaarden. "174

"In later jaren heeft de formalisering van het wetsbegrip in de grondwet ertoe bijgedragen, dat het delegatievraagstuk werd beperkt tot de gevallen, waarin de grondwet aan de wetgever uitdrukkelijk opdraagt een bepaalde materie te regelen. Daarbuiten was het delegatie-probleem geen probleem meer: de algemene maatregel van bestuur, mits aan de daaraan door de grondwet gestelde eisen beantwoordend, kon zijn belangrijke rol gaan vervullen." 175 Delegatie werd meer en meer erkend hetgeen gepaard ging met het stellen van eisen aan de grenzen ervan, die in de Grondwet werden gezocht.

Het feit dat de Grondwet de bevoegdheid van de wetgever hier beperkt, brengt volgens Van der Hoeven mee dat gezocht wordt naar de inhoud en strekking van een bepaling, om daarmee de vraag te kunnen beantwoorden of delegatie geoorloofd is. Het overwicht van de uitvoerende macht en haar vermogen om 'praktische politieke problemen' aan te pakken is nog niet zo groot dat de wetgever zich moet beperken tot de hoofdzaken van een regeling. Hier kan de Grondwet nog geacht worden normatieve werking te hebben. ${ }^{176}$

171. Van der Hoeven 1988, p.125, verwijzend naar Buys, De Grondwet I, Arnhem 1883, p.583 e.w.

172. Van der Hoeven 1988, p. 125.

173. Van der Hoeven 1988, p.126, verwijzend naar Buys, De Grondwet III, Arnlyem 1888, p.94 e.r.

174. Van der Hoeven 1988, p.126.

175. Van der Hoeven 1988, p.126, verwijzend naar Kramenburg, Nederlands Staatsrecht 1 , Haarlem 1938 5e druk, p.114 e.v.; Van der Pot 1916, en Stellinga, Preadvies NJV 1951, p.ll 23 e.v.

176. Yan der Hoeven 1988, p. 126-127. 


\section{Hoofdstuk 3}

Maar de Grondwet kan feitelijke ontwikkelingen niet tegen houden. En dat kan met zich mee brengen dat, wanneer de feiten niet meer inhoudelijk aansluiten bij een grondwetsbepaling, die bepaling formeel geïnterpreteerd gaat worden. Van der Hoeven ziet die ontwikkeling terug in de opvattingen van Oud die het delegatievraagstuk gaat hanteren met de formeel opgevatte begrippen 'wetgeving' en 'uitvoering", waarbij die begrippen gekoppeld zijn aan bepaalde organen. Het overlaten door de wetgever van regelling aan een lager orgaan, is dan geen delegatie maar uitwoering, en mag telkens wanneer het hogere orgaan de inschakeling van het lagere wenselijk acht. Alleen wanneer een hoger orgaan uit bijvoorbeeld gemakzucht of onverschilligheid nadere regeling aan een lager orgaan overlaat is sprake van plichtsverzuim. ${ }^{177}$

Van der Hoeven: als deze opvatting van Oud klopt, dan is toetsing van delegatiebevoegdheden aan de bedoeling van de (grond) wetgever in strijd met het constitutionele recht. Hij geeft overigens geen oordeel over de juistheid van de "vèrgaande opvatting' van Oud. "Voor ons doel is vooral van belang om naast elkaar te plaatsen de principieel verschillende interpretatie-methoden, hierboven weergegeven, en aan te tonen, dat deze verschillende methoden en de verschillende resultaten waartoe deze komen, nauw samenhangen met een klaarblijkelijk verschillende visie op de rechtswerkelijkheid der delegatie: naarmate men deze verder van het oorspronkelijke grondwettelijke patroon verwijderd acht, wordt de interpretatieve band met de grondwet van formeler aard. "178

Voor Van der Hoeven geeft de Grondwet wel degelijk de grenzen aan die de wetgever in acht dient te nemen, en kan deze niet vrijelijk over zijn bevoegdheid beschikken. De manier waarop Oud het delegatievraagstuk aanpakt, ziet hij als een kwestie van het 'vaststellen en waarderen' van de rechtswerkelijkheid en niet zozeer als het 'opsporen van de geest van de Grondwet'. ${ }^{179}$ Dit ziet Van der Hoeven als voorbeeld "van het feit, dat grondwetsvoorschriften de relatie tussen constitutionele instellingen niet normatief vermogen vast te leggen" ${ }^{180}$ een hoofdconclusie van zijn werk.

Ouds opvatting moge dan in strijd zijn met de 'geest van de Grondwet', hij is wel in overeenstemming met het geldende constitutionele recht.

De band met de Grondwet is echter dan wel een heel dunne geworden: de Grondwet noemt een wetgevende en uitvoerende macht, waarbij het eerstgenoemde als hoger orgaan en het tweede als lager orgaan wordt gezien. Elk orgaan is vrij om

177. Van der Hoeven 1988, p. 127-128, verwijzend naar Oud, Het Constitutioneel recht wan het Koninkrijk der Nederlanden $I_{n}$ Z wolle 1953, p.219-220.

178. Van der Hoeven 1988, p. 128.

179. Van der Hoeven 1988, p.129.

180. Van der Hoeven 1988, p. 130. 
te beslissen of het zijn bevoegdheid overdraagt. De grondwettelijke bepalingen worden hierdoor formeel gewaardeerd. ${ }^{181}$

In de herdruk van Van der Hoevens dissertatie in 1988 is een hoofdstuk VIII toegevoegd getiteld 'De grondwetsherziening van 1983'. Hier komt ook kort het delegatievraagstuk aan de orde. Van der Hoeven constateert dat de delegatiediscussie, al voor de herziening van 1983, vooral een kwestie van grondwettelijke terminologie is geworden. Uit de tekst van een grondwetsbepaling en de bedoeling van de grondwetgever werd afgeleid of, en in hoeverre, delegatie was toegestaan. "Daarbij was de politieke behoefte van het moment meestal doorslaggevend voor de interpretatie pro of contra. "182

Maar de tekst van de bepaling en de bedoeling van de grondwetgever waren niet steeds duidelijk, reden waarom in de Grondwet van 1983 een grondwettelijke delegatieterminologie werd ingevoerd. Van der Hoeven woorziet weinig problemen voor de wetgever bij de uitvoering van de terminologie, nu delegatie volgens hem ruim wordt toegestaan. Wel signaleert hij door die ruime delegatiemogelijkheden een ander probleem, namelijk in hoeverre deze (bestuurs)regelingen getoetst zouden kunnen worden aan de beginselen van behoorlijke wetgeving. Ook parlementaire controle op de regelingen schiet tekort. Wanneer hier aan de rechter een (grotere) taak wordt toebedeeld beoordeelt deze, naast de grenzen van de bevoegdheid, ook de kwaliteit van de uitvoering ervan. En dat zou kunnen inhouden dat ook het begrip 'uitvoering' weer een rol in de discussie over het delegatievraagstuk gaat spelen. ${ }^{183}$

\subsubsection{Bespreking}

De waarde van de weergave van Van der Hoevens bespreking van het delegatievraagstuk voor dit hoofdstuk ligt hierin dat het Van der Hoeven niet zozeer te doen is om de lezer te overtuigen van een eigen visie op dat delegatievraagstuk, als wel dat hij laat zien hoe de verschillende opvattingen van anderen nauw verbonden zijn met de interpretatie van de Grondwet. Helemaal nieuw is die visie niet, ook in andere paragrafen van dit hoofdstuk is dit geconstateerd. Wel laat Van der Hoeven scherper de (soms slechts nog broze) band tussen een opvatting over delegatiemogelijkheden en de (tekst van de) Grondwet zien.

181. Van der Hoeven 1988, p.130.

182. Van der Hoeven 1988, p.299.

183. Van der Hoeven 1988, p.299-300. 


\section{Hoofdstuk 3}

Van belang is zijn conclusie dat de Grondwet niet (of slechts ten dele, hij relativeert deze stellige uitspraak elders in zijn werk) ${ }^{184}$ in staat is de feiten normatief te beinvloeden.

Het is interessant om deze algemene conclusie uit zijn werk, die geldt voor het hele grondwettelijke recht, en niet alleen voor het delegatievraagstuk ${ }^{185}$, te doordenken voor de grondwetsherziening van 1983.

In deze Grondwet is beoogd onduidelijkheid over de vraag of delegatie al dan niet is toegestaan wit te sluiten. ${ }^{186}$ Volgens de toelichting op de delegatieterminologie is niet alleen de precieze tekst van de bepaling, maar ook de aard, inhoud en strekking van een onderwerp van belang om de mate waarin delegatie is toegestaan te bepalen. Het betreft dan đus duidelijk een materiële benadering van het delegatievraagstuk. Het is voor een goede uitvoering van de delegatieterminologie te hopen dat deze materiële benadering gevolgd wordt.

Maar ook kan gevreesd worden voor een ontwikkeling in de richting van formallsering, waarin alleen de tekst van de bepaling een rol speelt, bijvoorbeeld: delegatie is toegestaan, en dat betekent dat veel/alles mag, zonder te nuanceren. Of zelfs: delegatie is verboden maar gelet op maatschappelijke ontwikkelingen is delegatie noodzakelijk in de ogen van de wetgever...

In zijn terugblik op de grondwetsherziening laat Van der Hoeven zien dat de opvatting van Oud niet de geldende leer is geworden. Niet de opvatting van de wetgever over de wenselijkheid van delegatie werd doorslaggevend geacht, maar de tekst van een bepaling en de bedoeling van de grondwetgever. In het feit dat deze opvatting is neergelegd in de grondwettelijke delegatieterminologie ziet hij het neerleggen van constitutionele ontwikkelingen in de Grondwet.

\subsubsection{Recensies}

Feiten spelen volgens Van der Hoeven een belangrijke rol bij de vaststelling welke inhoud een rechtsregel heeft.

Deze nadruk op het belang van de feiten, die in de ogen van Van der Hoeven de normatieve werking van grondwettelijke bepalingen ondermijnt, is niet onweersproken gebleven. In deze paragraf komen de recensies van Logemann en Duynstee aan de orde. Ik geef niet uitgebreid hun kritiek weer. Slechts over de

184. Zie bijvoorbeeid Van der Hoeven 1988, p. 162-169.

185. En die zeker ook niet onbekritiseerd is gebleven, zie paragraaf 3.6.3.

186. Zie hoofdstuk 4 voor een uitgebreide bespreking van de delegatieterminologie en haar betekenis. 
hierboven genoemde hoofdconclusie en Van der Hoevens weergave van het delegatievraagstuk geef ik het commentaar van de auteurs. ${ }^{187}$

Op de laatste bladzijde van zijn recensie vat Logemann het werk van Van der Hoeven in een notedop samen. "De grondwet als element van het constitutionele recht komt er in dit boek niet te best af. Haar normatieve kracht wordt in al haar onderdelen wel heel laag geschat. Betekenis voor de bevoegdheidsverdeling bijna nihil. De grondrechten geëerbiedigd, maar niet omdat ze in de grondwet staan. Alleen formaliteiten strikt nageleefd. " 188

Hij is het hier niet mee eens: "Aldus aan de grondwetgevende macht alle ordenende kracht te ontzeggen, gaat veel te ver. De schrijver miskent, dat de grondwetgever aanvaard gezag uitoefent; dat gezag impliceert de aanwezigheid van mensen, die bereid zijn het gezagswoord te onderhouden; (...). Gezag duurt niet eeuwig, maar het duurt." "189

Zijn kritiek komt er op neer dat hij de grondgedachte van Van der Hoeven (een relativering van het normatieve vermogen van de Grondwety onderschrijft, maar de uitwerking van die gedachte en stellingnames te overdreven vindt. Zo zegt hij bijvoorbeeld over het standpunt dat Van der Hoeven in hoofdstuk $\mathrm{V}$ inneemt: "Hier wordt de rechtsvormende kracht van het gezagswoord des grondwetgevers eenvoudig op nul gesteld. De schrijver makkt het zich al bijzonder gemakkelijk door te poneren - zover ik zien kan, zonder bewijs - dat zelfs indien al de tekst van de grondwet ergens overeenstemt met het werkelijk geldende constitutionele recht dit aan alles toe te schrijven is behalve aan de grondwet. De heerschappij der 'realia', der feiten, is absoluut gemaakt." 190

Maar verderop nuanceert Logemann zijn betoog: "Dit alles is niet helemaal zonder waarheid. Ik verwijs naar hetgeen ik heb opgemerkt over het ontbreken van een hiërarchie der rechtsbronnen, over gezag, over ongeschreven recht. Maar hier is eenzijdige overdrijving tot een systeem gesmeed, waarvan het zo vage en aanvechtbare recht der feiten de kern vormt en dat zelf helaas de kern is van dit door omvangrijke kennis, stofbeheersing en scherpzinnigheid toch wel imponerende boek. "191

Het onderscheid dat Van der Hoeven bij grondwetsinterpretatie maakt tussen rechtsverfijning (het zoeken naar de materiële betekenis van een bepaling) en

187. Logemann 1958 en Duynstee 1959.

188. Logemann 1958, p.430.

189. Logemann 1958, p. 422 .

190. Logemann 1958, p.424.

191. Logemann 1958, p. 424-425. 


\section{Hoofidstuk 3}

formalisering (de betekenis van een bepaling zoeken in de formele ordening en niet in de materiele strekking) noemt Logemann 'interessant". Door formalisering bestaat volgens hem gevaar voor 'uitholling' van cen bepaling. Van der Hoeven gebruikte het delegatievraagstuk als voorbeeld om het verschijnsel formalisering te Hllustreren.

Logemann vraagt zich af of dit wel een juist voorbeeld is. Want Van der Hoeven "gaat er immers van uit, dat wetgeving en uitvoering oorspronkelijk als materiële begrippen in de grondwet zijn geintroduceerd. Toenemende behoefte aan delegathe constateert men in ons land vooral na 1887. Men zou kunnen zeggen, dan moet dus toen het formaliseringsproces begonnen zijn. ${ }^{\text {192 }}$

Volgens Logemann echter is er een ongekeerde ontwikkeling waar te nemen. Zo is er bij de totstandkoming van de Grondwet niet zozeer aan een materiele invulling van het wetsbegrip gedacht, maar is later getracht, bijvoorbeeld door Buys, om die invalling te geven. En hij herinnert aan de woorden van Hogendorp, dat nu het wetsbegrip niet duidelijk omschreven is, men "daarvan dan maken kan wat men wil." 193

Een soortgelijke kritiek op Van der Hoevens weergave van het delegatievraagstuk heeft Duynstee, die het betoog van Van der Hoeven op dit punt 'weinig overnigend' acht. Ook Duynstee vraagt zich af of inderdaad bedoeld is een bepaald materieel wetsbegrip in de eerste grondwetten op te nemen, zoals Van der Hoeven kennelijk veronderstelt. Van der Hoeven "ziet een voortdurende inperking van het delegatieverbod langs de weg eerst van een redenatie van rechtsverfijning (delegatie alleen verboden in de gevallen waar de Grondwet een formele wet eist) en dat momenteel - naar hij blijkbaar vermoedt - langs de weg van verdergaande 'formalisering' van de grondwettelijke bepalingen, d.i. weginterpreteren van politiek ongewenste materiële beletselen van een grondwetsartikel. Een dergelijke gang van zaken kunnen wij in onze constitutionele ontwikkeling niet lezen, al erkennen wij dat in bepaalde tijden bepaalde onderdelen van het delegatievraagstuk tot verschuivingen in opvattingen hebben geleid. "194

Naast belangrijke verdiensten van het werk dicht hij het ook de kwalificatie "nogal provocerend" toe. ${ }^{195}$ Hij heeft vooral bezwaren tegen de zijns inziens. "ondeugdelijke methodologische vooropstellingen", zoals bijvoorbeeld de opvattingen van Van der Hoeven over wat 'staat', 'recht' en 'soevereiniteitdragende

192. Logemann 1958, p.425-426.

193. Logemann 1958, p.426.

194. Duynstee 1959, p.315.

195. Duynstee 1959, p.305. 
instelling' is. ${ }^{196}$ Hij heeft echter ook waardering voor het werk van Van der Hoeven. Over diens: Ve hoofdstuk zegt hij: "Maar Van der Hoeven weet in elk geval op scherpzinnige manier in te prenten, dat bij de toepassing van een niet onbelangrijk aantal grondwetsbepalingen een redeneerwijze wordt gevolgd, welke bepaald lijkt door hetgeen zich in de constitutionele verhoudingen en praktijken als gedragslijn vormde. ${ }^{\mathrm{F} 197}$

\subsection{Lijnen in de geschiedenis}

De ontwikkelingen rond het delegatievraagstuk hangen nauw samen met ontwikkelingen in de verhoudingen tussen de staatsmachten. Waar in het midden van de vorige eeuw de parlementaire macht ten opzichte van de Koning nog bevochten moest worden was het begrijpelijk dat die macht niet zomaar weer aan diezelfde Koning afgestaan mocht worden. De bekende zegswijze 'publiek recht is publieke plicht' is dan ook uit deze tijd afkomstig.

De maatschappij veranderde echter in snel tempo, en de wetgever kon die veranderingen nauwelijks met "passend" recht volgen. Delegatie werd steeds meer noodzaak. Het bestuur kreeg meer en meer (regelgevende) bevoegdheden. In een staatsrechtelijke theorie die uitgaat van een scheiding der machten, en van waarborgen tegen machtsmisbruik door 'de Koning' voor de burgers is delegatie echter maar moeilijk te plaatsen. De theorie slaagde er nauwelijks in afdoende antwoord op de onontkoombare aanwending van delegatie te vinden.

In het kader van de 'strijd' om de macht tussen Koning en parlement op delegatiegebied is het Meerenbergarrest van 1879 een mijlpaal. Dat arrest had tot gevolg dat bij de grondwetsherziening in 1887 de (zelfstandige) rechtsvaststelling door de Koning werd beperkt, door het invoeren van artikel $56 \mathrm{Gw}$ :' 1 . Door den Koning worden algemeene maatregelen van bestuur vastgesteld. 2. Bepalingen door straffen te handhaven, worden in die maatregelen niet gemaakt, dan krachtens de wet. 3. De wet regelt de op te leggen straffen.' Bij Van der Pot hebben we kunnen lezen dat door velen stilzwijgend uit dit artikel werd afgeleid dat delegatie aan de Koning nu geen enkel probleem meer was. Toch waren hiermee niet alle problemen opgelost. ${ }^{198}$

196. Duynstee 1959, p.316. Zie ook p.311 e.v.

197. Duynstee 1959, p.314.

198. In dit verband nog een citaat van Donner, Handelingen NIV 1951, p.143: "(..) men heeft in 1887 ook geprobeerd in art. 56 niet een bepaald concreet punt vast te leggen en in de ijskast te zetten, maar men heeft geprobeerd een hele theoric in de ijskast te zetten. Namelijk die hele theorie van het materieel wetsbegrip. Dat is niet gelukt. Men kan dan 
Minder omstreden was dat de Koning uitvoerende macht toekwam. De vraag of delegatie (van regelgevende bevoegdheid) geoorloofd was kon dan ook uit de weg gegaan worden door niet de term delegatie te gebruiken, maar het begrip uitvoering. Dit gebeurde bijwoorbeeld door Addens, die delegatie ongeoorloofd achtte, maar het begrip uitwoering zover oprekte dat daar zo ongeveer alles onder viel.

Toen bleek dat delegatie van wetgevende macht onontkoombaar was werden andere oplossingen van het hierboven geschetste dilemma aangedragen. De theorie ging aansluiting zoeken bij de praktijk. Zo wilde Van der Pot de ministeriële verantwoordelijkheid een grotere rol laten spelen en zocht Stellinga meer naar de grenzen van delegatie: delegatie van hoofdzaken was niet toegestaan, die dienden in de formele wet zelf te liggen. Hiermee wordt beoogd om waarborgen te zocken tegen te vergaande delegatie.

Zien we enerzijds aanpassing van de theorie aan de praktijk, anderzijds paste ook de wetgeving zich aan de praktijk (en uitkomsten van rechterlijke uitspraken) aan. De bestaande (soms ongeoorloofd geachte) praktijk werd gedekt doordat aan wet of Grondwet een bepaling werd toegevoegd.

Enkele (bekende) voorbeelden zijn de volgende. Artikel 169 Gemeentewet (oud) ${ }^{199}$ is toegevoegd in 1931, na alle jurisprudentie over de reikwijdte van de bevoegdheid van $\mathrm{B}$ en $\mathrm{W}$ tot het uitvoeren van de raadsverordeningen; (alleen) uitvoeren mocht wel, nadere regels stellen was alleen toegestaan voorzover het

nog wel zeggen dat art. 56 toch een grote waarborg yormt en ik zal de waarde van het artikel mist ontkennen, maar de concrete misbruiken, waar indertijd de opneming van art. 56 tegen bedoelde te waken, zijn tenslotte langs de achterdeur van de delegatie allemaal weer in huis gekomen. "

199. Dit artikel luidde: 'Hij (de gemeenteraad) kan in die verordeningen burgemeester en we thouders of door hem ingestelde commissies bevoegd verklaren nadere regels te stellen nopens bepaalde, in die verordening aangewezen, onderwerpen.' Zie over deze toevoeging ook Böhtlungk 1958, p.11-12: "Dit artikel geeft echter helemaal geen antwoord op de vraag, waar het in all die oude arresten om ging, of aan $B$. en W. her geven van bevelen en vergunningen e.d. mag worden vrijgelaten. Mag men nu, zoals gedaan wordr, betogea, dat het artikel, reppend wan nadere regels, ook deze meer concrete beslissingen woldoende dekt, ondat het mindere in het meerdere begrepen ligt? Dit adagium, dat men op allerlei plaatsen in rechtspradak en literatuur ontmoet, is onbetwistbaar juist, maar bewijst niets zolang niet vaststaat wat het meerdere is en wat het mindere. Naar mijn overtuiging is het geven van concrete beslissingen het meerdere van het stellen van nadere regels en heeft de herziening van 1931 geen verandering gebracht op het stuk van de toekenning van vrije beslissingsbevoegdheden aan $B$. en $W$. ${ }^{\text {m }}$ 
onder uitvoeren viel te brengen. Artikel $194 \mathrm{Gw} 1922^{200}$ is toegevoegd na felle discussies over verordeningsrecht voor publiekrechtelijke bedrijfsorganisaties (bijvoorbeeld voor raden van arbeid) ${ }^{201}$ Artikel 10 Arbeidswet werd aangepast aan de uitkomsten van het Jaminantest ${ }^{202}$ : de Hoge Raad oordeelde dat volgens artikel 10 Arbeidswet alleen bij algemene maatregel van bestuur voorwaarden gesteld mochten worden, dus niet door een districtshoofd. De wetswijziging hield in dat niet alleen bij, maar voortaan ook krachtens algemene maatregel van bestuur voorwaarden vastgesteld konden worden. ${ }^{203}$

Een derde manier om (vergaande) delegatie te rechtvaardigen hanteerde de regering in 1951 bij de Noodwet Indonesie, door een beroep te doen op noodrecht.

In veel (andere) gevallen leverde de tekst van de Grondwet onduidelijkheden op bij de vraag of delegatie was toegestaan. Die onduidelijkheid heeft de grondwetsherziening van 1983 beoogd weg te nemen. De geschiedenis van die grondwetsherziening (waarvan de wortels al in de jaren ' 50 liggen) wordt, voor zover het de delegatieterminologie betreft, beschreven in het volgende hoofdstuk. Ter afronding van dit hoofdstuk en ter voorbereiding op het volgende, volgt hier een citaat van Minister de Wilde, uit de Memorie van Antwoord naar aanleiding van het wetsontwerp tot Grondwetsherziening, 1936-1937..$^{204}$

"Het opnemen van een bepaling in de Grondwet betreffende delegatie van wetgevende bevoegdheid is overbodig en gevaarlijk te achten. Lang reeds behoort de tijd tot het verleden, dat men bij de oude triasleer met haar materiële omlijning van de werkingssfeer der machten zwoer als ware zij een politiek credo. Na 1887 heeft de wetgever in steeds toenemende mate aan de uitvoerende macht nader detailleerende regelingen overgedragen; vooral in de wereldoorlog en onder de huidige crisis nam dit systeem afmetingen aan, waaraan tevoren niet was gedacht en die de staatsrechtkenner uit het midden der vorige eeuw een bedenkelijk symptoom van staatsrechtelijke ketterij zou hebben geschenen. Werden in den beginne nog ernstige toonen gehoord, dat de overdracht van regelende bevoegdheid niet strookte met de Grondwet, onder den indruk van de noodzakelijkheid van zoodanige overdracht nam de kracht van het waarschuwend woord af.

Een nieuwe staatsrechtelijke opvatting brak zich baan, niet alleen in ons land, maar ook daarbuiten. Volgens deze opvatting beperkt de taak van de wetgevende macht zich tot het stellen van algemeene regelen van principieelen aard, terwijl de nadere witwerking wordt

200. Dit artikel luidt: 'De wet kan aan andere dan in de Grondwet genoemde lichamen verordenende bevoegdheid geven.'

201. Voorbeeld aangehaald bij Donner 1951, p.154.

202. HR 25 januari 1926, NJ 1926, blz.246.

203. Wet van 14 juni 1930, Stb. 261.

204. Uit Van Driel 1956, p. 83. 


\section{Hoofdstuk 3}

owergelaten aan het uitwoerend gezag. Met de Grondwet is deze statsrechtelijke ontwilkkeling niet in strijd, daar een materieel wetsbegrip in de Grondwet nergens is vastgelegd. Het ware gewaarlijk door opneming van een beperkende regeling in de Grondwet aan de gezonde ontwikkeling der wetgevingsidee een keursliff aan te leggen." 205

205. Noot bij Vam Driell 1956, p.83: Cf. Bijlagen van het Verslag der Handelingen van de Tweede Kamer $1936 / 37$ no. 105, 2, pag. 32-33. 


\section{Hoofdstuk 4}

\section{De invoering van de delegatieterminologie in de Grondwet van 1983; het delegatievraagstuk na 1983}

\subsection{Inleiding}

Een ijkpunt in de ontwikkeling van het delegatievraagstuk in het Nederlandse recht is de invoering van de delegatieterminologie in de Grondwet van 1983. De terminologie zelf (vervoegingen van het werkwoord regelen; de woorden regeling of regels; de term bij of krachtens) ondervond weinig bestrijding. De uitleg en precieze betekenis ervan leverden echter meer problemen op.

Uit de volgende passage uit de Memorie van Antwoord van het wetsontwerp op de provincies en gemeenten blijkt dat de delegatieterminologie de regering de nodige hoofdbrekens heeft gekost: "In de terziene Grondwet zal door systematisering van de terminologie vaststaan, wanneer de wetgever, waar deze in enige grondwettelijke bepaling met een taak belast of een bevoegdhejd toegerust wordt, de uitoefening van deze taak of bevoegdheid in wezen zelf zall moeten verrichten, en wanneer de Grondwet hem in beginsel vrijlaat daarbij andere organen in te schakelen.

Hiermee is volledig aangegeven wat de herziene Grondwet op dit punt, ook in relatie tot de lagere openbare lichamen, zal inhouden. Voorts dient benadrukt te worden dat het inzicht in deze materie alleen maar verduisterd wordt, wanneer men zich overgeeft aan beschouwingen over de eigenlijke inhoud van het begrip 'delegatie' en daaraan conclusies voor de probiematiek tracht te verbinden. (Cursivering JD) Het lijkt daarbij van belang dat dit begrip zijn bestaan dankt aan de publiekrechtelijke literatuur en in de wetgeving zelf niet wordt gebezigd. ${ }^{1}$ Wanneer wij spreken over het al of niet bestaan van delegatiemogelijkheid, dan betekent dat niet meer en niet minder dan dat wij in navolging van de staatscommissie met een gemakkelijk te hanteren en begripsmatig ook niet ongeoorloofde benaming het hierboven aangeduide onderscheid in grondwettelijke bevoegdheid voor de wetgever willen aangeven. "2

De parlementaire behandeling van de delegatieterminologie bespreek ik in paragraaf 4.2. Aan het einde van die paragraaf is een voorlopige conclusie gewijd aan de betekenis van de delegatieterminologie. Een voorlopige conclusie, omdat een meer onderbouwde conclusie pas te trekken is wanneer ook de literatuur, wetge-

1. Dit verandert wanneer in de Algemene wet bestuursrecht Hoofdstuk 10 Bepalingen over bestuursorganen in werking treedt. Daarin is een titel Mandaat en delegatie voorzien. In paragraaf 2.3 is uiteengezet dat deze delegatiebepalingen ook betrekking kunnen hebben op algemeen verbindende voorschriften die afkomstig zijn van lagere regelgevers op centraal en decentraal niveau. (noot JD)

2. Kamerstukken II 1976-1977, 13990, nr 6 MvA. p.8. 
ving en rechtspraak samenhangend met de delegatieterminologie en het delegatievraagstuk onderzocht zijn.

In paragraaf $4.3 \mathrm{komt}$ de uitleg van de delegatieterminologie in regeringsrapporten en -nota's aan de orde. Daarnaast wordt in die paragraaf aandacht besteed aan het rapport Orde in de regelgeving (1985) van de Commissie Wetgevingsvraagstukken.

De opvattingen over de delegatieterminologie in de wetenschappelijke literatuur worden besproken in paragraaf 4.4 . Ook visies op de ontwikkeling van het delegatievraagstuk na 1983 komen daar aan de orde.

De invloed van de delegatieterminologie op het delegatievraagstuk én omgekeerd, staat centraal in paragraaf 4.5. In die paragraaf wordt ook bekeken of de definities van attributie, delegatie en mandaat zoals gegeven in paragraaf 2.2 passen in de delegatieterminologie.

In paragraaf 4.6 worden de grenzen van delegatie onderzocht. En in paragraaf 4.7 blijkt dat het zoeken naar waarborgen tegen te vergaande delegatie steeds doorgalat. Enkele relativeringen van de delegatieterminologie komen aan bod in hoofdstuk 5.

En de praktische uitwerking van de delegatieterminologie in wetgeving en jurisprudentie staat centraal in hoofdstuk 6 . 4.2 De delegatieterminologie in de parlementaire geschiedenis van
de Grondwet 1983

\subsubsection{Inleiding}

De Grondwet zelf vermeldt niets over de (betekenis van de) delegatieterminologie. Wie niet beter weet merkt misschien niet eens op dat er verschillende redacties van grondwetsartikelen zijn die ieder hun eigen betekenis hebben. Die betekenis dient gezocht te worden in de toelichtende stukken. Dat de beschrijving van die betekenis meerdere subparagrafen in beslag neemt is te wijten aan de niet steeds heldere behandeling van de delegatieterminologie in de parlementaire stukken.

De bespreking van de delegatieterminologie is in de paragrafen 4.2.3 en 4.2.4 voor de verschillende facetten van die terminologie uit elkaar gehaald orn een duidelijker beeld te kunnen geven. Bronnen zijn de wetsontwerpen op de grondrechten en het wetsontwerp op de provincies en gemeenten. Als facetten zijn te onderscheiden: de terminologie in het algemeen $(4.2 .3 .1$ en 4.2 .4 .1$)$, de gevolgen van de terminologie voor de bevoegdheden van de lagere overheden (4.2.3.2 
en 4.2.4.2), het onderscheid regelgeving-uitvoering (4.2.3.3 en 4.2 .4 .3$)$ en de uitdrukking 'behoudens ieders verantwoordelijkheid volgens de wet" (4.2.3.4).

\subsubsection{De terminologie in de voorbereidende rapporten op de grondwetsherziening}

De Staatscommissie Van Schaik, ingesteld in 1950 om de regering te adviseren over de grondwetsherziening, kiest in haar Eindrapport uit 1954 voor het eerst voor een vaste delegatieterminologie. Volgens de Commissie blijkt uit de redactie van de dan geldende Grondwet niet duidelijk wanneer delegatie is toegestaan en wanneer niet. In een aantal bepalingen waarin de Grondwet aan de wetgever taken opdraagt, is delegatie niet toegestaan, hetzij wegens de aard van die taken, hetzij wegens de uitdrukkelijke bedoeling van de Grondwetgever. Bij bepalingen waarbij wél delegatie is toegestaan, is niet duidelijk hoever die delegatie mag gaan. De Commissie wil geen terminologie ontwikkelen, waarin duidelijk wordt in welke mate delegatie is toegestaan. Het betreft volgens haar "een materie van levend recht", waarvan de ontwikkeling aan de praktijk kan worden overgelaten. $^{3}$

De Commissie kiest voor de volgende terminologie. Delegatie is toegestaan bij het gebruik van de uitdrukking 'bij of krachtens', het werkwoord 'regelen' of het zelfstandig naamwoord 'regels'. Als toelichting op het woord 'regels' vermeldt de Commissie dat bij gebruik hiervan geen uitputtende regeling beoogd is; volstaan kan in dat geval ook worden met het stellen van algemene normen die door anderen uitgewerkt worden. ${ }^{4}$

$\mathrm{Na}$ dit Eindrapport volgt in 1966 de Proeve van een nieuwe Grondwet. ${ }^{5}$ Daarin worden de voorstellen voor de delegatieterminologie van de Commissie Van Schaik overgenomen. De samenstellers van de Proeve overwegen nog of het niet eenvoudiger is aan te geven wanneer delegatie verboden is, in plaats van wanneer delegatie is toegestaan, maar volgen toch de terminologie van de Commissie Van Schaik. Er vindt geen verdere differentiatie plaats in de terminologie naar de mate waarin delegatie is toegestaan. ${ }^{6}$

Ook in de Rapporten van de Staatscommissie Cals-Donner wordt de delegatieterminologie zoals voorgesteld door de Commissie Van Schaik overgenomen. ${ }^{7}$

3. Eindrapport Commissie Van Schaik, p.24.

4. Eindrapport Commissie Wan Schaik, p.25.

5. De Proeve is een werkstuk van de afdeling grondwetszaken van het Ministerie wan Binnenlandse Zaken.

6. Proeve 1966, p.43-44.

7. Zie het Tweede Rapport van de Commissie Cals/Donner, p.47 en het Eindrapport, p.28. 


\section{Hoofdstuk 4}

In haar Eindrapport stuit de Commissie op problemen waar het gaat om bepalingen van openbare lichamen (provincies en gemeenten). De Commissie wil in de delegatieterminologie tot uitdrukking kunnen brengen dat de wetgever verordenende bevoegdheid geeft aan andere provinciale of gemeentelijke organen dan provinciale staten of de gemeenteraad, of dat op hun beurt provinciale staten of de gemeenteraad hun verordenende bevoegdheid in bepaalde gevallen aan andleren kunnen overdragen. Zij kiest hiervoor de formule "behoudens bij de wet te voorziene uitzonderingen'."

\subsubsection{De terminologie in de wetsontwerpen op de grondrechten ${ }^{9}$}

\subsubsection{De terminologie in het algemeen}

Veel nieuws ten opzichte van de voorbereidende rapporten is er niet. De voorgestelde terminologie wordt overgenomen. Belangrijk is de opmerking dat de voorgestelde delegatieterminologie alléén voor de Grondwet geldt en niet voor andere wettelijke regelingen.

Delegatie is toegestaan wanneer een vorm van het werkwoord 'regelen' is gebruikt, éen van de zelfstandige naamwoorden 'regels' of 'regeling', of de term 'bij of krachtens'. Komt éen van deze termen niet voor dan is delegatie verboden. De regering omschrijft delegatie als "de bevoegdheid van de wetgever om de hem grondwettelijk verleende taak of bevoegdheid aan andere organen over te dragen". ${ }^{10}$

In de terminologie wordt niet onderscheiden naar de mate waarin delegatie is toegestaan. De wetgever mag zelf beslissen óf hij delegeert, aan wie en hoeveel. "Hij zal hierbij rekening moeten houden met de hele bepaling en met de aard van het onderwerp. Een aanduiding voor de omvang van de delegatie kan liggen in de gebruikte terminologie: een uitdrukking als 'de wet regelt' "kan soms op een meer omvattende opdracht luiden dan een term als 'de wet stelt regëls omirent". "12

Het delegatieverbod houdt in dat geen regelgevende bevoegdheid mag worden overgedragen. Ook mag niet door het gebruik van vage normen of discretionaire

8. Eindrapport Commissie Calls-Donmer, p.28-29. Zie artikel 127 Gw 1983.

9. Verklaring dat er grond bestat een voorstel in overweging te nemen tot verandering in de Grondwet van bepalingen inzake grondrechten (13872) en Verklaring dat er grond bestaat een voorstel in overweging te nemen tot verandering in de Grondwet strekkende tot opneming van bepalingen inzake sociale grondrechten (13873).

10. Kumerstukken II 1975-1976, 13872, nr 3 MvT, p.22.

11. Kamerstukken II 1975-1976, 13872, ar $3 \mathrm{MvT}$, p. 22 .

12. Kamerstukken II 1975-1976, 13872, nr 3 MvT, p.23. 
bevoegdheden in feite toch regelgevende bevoegdheid worden overgedragen. Zo zal, wanneer er een vergunningenstelsel in de wet wordt gecreeerd, de wet zélf moeten aangeven in welke gevallen een vergunning wordt verleend of geweigerd. ${ }^{13}$

De Raad van State stemt in met de gehanteerde terminologie, maar vraagt zich af welke materiële criteria er door de regering zijn gehanteerd bij het bepalen of delegatie ten aanzien van een bepaald onderwerp al dan niet is toegestaan. ${ }^{14} \mathrm{Als}$ materiële criteria noemt de regering in het Nader rapport: "bestaande wetgevings- en bestuurspraktijken, een te verwachten toekomstige behoefte aan delegatie, de historie van de bepaling, de aard van het onderwerp en de wens in bepaalde gevallen gelet op de aard en inhoud van het betreffende onderwerp delegatie grondwettelijk uit te sluiten $(\ldots){ }^{n 15}$

Nadere uitleg over de terminologie volgt in de Memorie van Antwoord, met name over de uitdrukking 'krachtens de wet'. ${ }^{16}$ Deze woorden houden volgens de regering een bevoegdheid tot delegeren in. Worden de woorden 'volgens de wet' of 'ingevolge de wet' gebruikt, dan is bedoeld "die daad van wetgeving of bestuur die verricht is ter uitvoering of uitoefening van een in de wet neergelegde taak of bevoegdheid. ${ }^{n 7}$ Voorts wordt nogmaals uitgelegd dat de delegatieterminologie alleen iets zegt over het feit of delegatie is toegestaan dan wel verbodlen en niet over de mate waarin of de organen aan wie gedelegeerd mag worden. ${ }^{18}$ Dit laatste punt blijft onderwerp van discussie. Bij de mondelinge behandeling spreekt Veerman de vrees uit dat de wetgever eerder dan tot dan toe tot delegatie zal overgaan. ${ }^{19}$ Hiervoor hoeft volgens de minister geen angst te bestaan. Deze ontwikkeling zou zich ook al onder de toenmalige grondwet hebben kunnen

13. Kamerstukken II 1975-1976, 13872, nr 3 MvT, p.23.

14. Kamerstukken II 1975-1976, 13872, nr 4 Bijlagen bij de MwT, Bijlage I Advies van de $\mathrm{RvS}, \mathrm{p} .61$.

15. Kamerstukken II 1975-1976, 13872, nr 4 Bijlagen bij de MvT, Bijlage II, Nader rapport, p.84.

16. Zue de artikelen 36 en 100 (krachtens een wet) en 89 lid 2 en 127 (krachtens de wet) Gw 1983. Zie ook hoofustuk 5.

17. Kamerstukken II 1976-1977, 13872, nr 7 MvA, p.13.

18. Kamerstukken II 1976-1977, 13872, nr 7 MvA, p.13. Bij de behandeling van een later ingediend ontwerp wordt wel ingegaan op de mate warrin gedelegeerd mag worden: dat hangt af wan het onderwerp, de historie en de strekking van de grondwettelijke bepaling in kwestie. Kamerstukken II 1980-1981, 16162, nr 11, p.2. De regering noemt als voorbeeld artikel 116 lid 2 : hoewel delegatie mogelijk is, is geen decentralisatie toegestan. ('De wet regelt de inrïchting, samenstelling en bevoegdheid wan de rechterlijke macht'). Zie ook Kortmann 1987a, p.27.

19. Handelingen II 1976-1977, p.1989 (Veerman, ARP). 


\section{Hoofdstuk 4}

voondoen. Hij benadrukt dat de wetgever zich bij het delegeren zal laten leiden door rechtsoverwegingen, de historie van de bepaling, de aard van het onderwerp en door beleidsoverwegingen. En hij voegt eraan toe: "Als er gedelegeerd moet worden, is de Kamer er altijd zelf bij. "

Bij de schriftelijke behandeling in de Eerste Kamer vraggt het $\mathrm{CDA}$ zich af waarom de regering geen onderscheid maakt tussen overdracht van regelgevende bevoegctheid binnen hetzelfde overheidslichaam en overdracht van regelgevende bevoegdheid van het rijk naar lagere overheden. ${ }^{21}$ De regering antwoordt: "Wij wijzen er hierbij op, dat het niet belangrijk is of hier de term 'delegatie' al dan niet wordt gebruikt. Dit is geen grondwettelijke of wettelijke term, maar een term uit de staatsrechtelijke literatuur evenals de termen attributie en medebewind." De wetgever mag kortom zelf beoordelen wat en aan wie hij delegeert. ${ }^{22}$

\subsubsection{De terminologie en de bevoegdheden van lagere overheden}

De Memorie van Toelichting geeft in dat verband twee voorbeelden: de formele wetgever krijgt in artikel 9 de bevoegdheid om het recht op betoging te beperken, waarbij hij gebruik mag maken van delegatie. Dit betekent dat de gemeente een eventuele regelgevende bevoegdheid op dit punt moet ontlenen aan een specifieke wettelijke bepaling. De gemeente mag terzake geen regeling treffen op grond van artikel 149 Gemeentewet, haar algemene verordenende bevoegdheid. In artikel 10 lid 2 en 18 lid 2 krijgt de wetgever de bevoegdheid om over de bescherming van de persoonlijke levenssfeer in verband met het vastleggen en verstrekken van persoonsgegevens en over het verlenen van rechtsbijstand aan minder draagkrachtigen regels te stellen. Hier mogen lagere organen wel gebruik maken van hun verordenende bevoegdheid en regelend optreden, mits zij niet met een hogere regeling in strijd komen. ${ }^{23}$

Duidelijke regels voor de gevallen waarin nog regelgevende ruimte overblijft voor lagere organen geeft de regering hier niet. "Wij geven er de voorkeur aan te dien aanzien de mogelijkheid open te houden om door middel van interpretatie van de betreffende bepalingen zich wijzigende inzichten tot hun recht te laten komen. "24 Hier is én uitzondering op: wanneer in een bepaling een subjectief recht aan de burgers wordt toegekend dan zijn er twee mogelijkheden. Ofwel er is geen enkele beperkingsmogelijkheid voor een lager orgaan (namelijk wanneer

20. Handelingen II 1976-1977, p.2116 (Minister De Gaay Fortman).

21. Kamerstukken I 1976-1977, 13872-13873, nr 55a VV, p.12.

22. Kamerstukken 1 1976-1977, 13872-13873, nr 55b MvA, p.22-23.

23. Kamerstukken II 1975-1976, 13872, nr 3 MvT, p.23.

24. Kamerstukken II 1975-1976, 13872, nr 3 MvT, p.24. 
elke beperkingsmogelijkheid ontbreekt, zie de artikelen 1, 3 en $5 \mathrm{Gw}$, en wanneer alleen de formele wetgever de beperkingsbevoegdheid heeft, zie de artikelen 6 lid 1, 7 lid l en 3,8 en 9 lid $1 \mathrm{Gw}$ ); ofwel kan de formele wetgever gebruik maken van zijn delegatiebevoegdheid (zie de artikelen 6 lid 2, 7 lid 3, 9 lid 2 en $10 \mathrm{lid} 1 \mathrm{Gw}$ ), en dan dient er een specifieke wettelijke grondslag voor de beperking van dat recht door een lager orgaan te zijn. ${ }^{25}$

In het Voorlopig Verslag stellen de fracties van KVP, ARP en CHU aan de orde dat wanneer de grondwet (van 1972, JD) aan de wet de regeling van een bepaald onderwerp opdraagt, er geen ruimte meer is voor regeling door lagere organen. Ook mag de wetgever niet, door gebruik te maken van medebewind, de lagere organen hun verordenende bevoegdheid laten uitoefenen. Delegatie van regelgevende bevoegdheid houdt zo in dat bevoegdheden worden overgedragen aan organen van het centraal overheidsverband zoals de Kroon of de minister. ${ }^{26}$

De regeringsvoorstellen wijken in twee opzichten daarvan af: met betrekking tot de klassieke grondrechten kan, wanneer delegatie is toegestaan, ook gedelegeerd worden aan gedecentraliseerde (zoals gemeentelijke) organen. En bij de regeling van de sociale grondrechten kunnen gedecentraliseerde regelgevers zelfstandig regels treffen, waarbij die regels echter niet in strijd mogen komen met een hogere regeling. Wordt het waarborgkarakter van een aan de wet opgedragen regeling hierdoor niet verminderd? ${ }^{27}$

De regering herhaalt haar eerdere standpunt. Uit de terminologie kan niet afgeleid worden of er bij een opdracht tot wettelijke regeling nog regelingsbevoegdheid voor lagere organen overblijft, behalve wanneer het om een subjectief recht gaat. Dan is alleen de formele wetgever tot beperking bevoegd (al of niet met de mogelijkheid van delegatie). Het beperken van grondrechten mag niet buiten de formele wet om en delegatie moet alleen toegestaan worden wanneer er dringende redenen voor zijn. ${ }^{28} \mathrm{Bij}$ de regeling van sociale grondrechten mogen naast de formele wetgever ook de lagere overheden optreden. $\mathrm{Zij}$ mogen daarbij niet in strijd komen met een lhogere regeling. ${ }^{29}$

Bij de mondelinge behandeling vraagt Kamerlid Waltmans om verduidelijking van het delegatiebegrip: delegatie betekent traditioneel overdracht van bevoegdheden binnen dezelfde bestuurslaag. Delegatie naar een andere bestuurslaag wordt medebewind genoemd. Wat is de uitleg van de regering? $?^{30}$

25. Kamerstukken II 1975-1976, 13872, nr 3 MvT p.24.

26. Kamerstukken II 1975-1976, 13872, nr $6 \mathrm{VV}, \mathrm{p} .20$.

27. Kamerstukken II 1975-1976, 13872, nr 6 VV, p.21.

28. Kamerstukken II 1976-1977, 13872, nr 7 MvA, p.15.

29. Kamerstukken II 1975-1976, 13873, nr 3 MvT, p.6.

30. Handelingen II 1976-1977, p.1981 (Waltmans, PPR). 


\section{Hoofdstuk 4}

Op deze vraag antwoordt regeringscommissaris Simons. Hij beschrijft daarbij medebewind als de verhouding tussen rijk en lagere overheden waarbij op de laatsten de plicht rust aan een door het rijk gegeven opdracht te voldoen. Vanuit het rijk bezien is het geven van zo'n opdracht delegatie te noemen. ${ }^{31}$

Ook bij de schriftelijke behandeling in de Eerste Kamer blijkt bezorgdheid over de autonome bevoegdheden van de lagere overheden. Dit levert echter geen nieuwe gezichtspunten op.

\subsubsection{Het onderscheid regelgeving-uitvoering}

Bij de schriftelijke behandeling in de Eerste Kamer stelt het CDA de vraag of de regering bij de door haar gehanteerde uitleg van delegatie in de Memorie van Toelichting niet onnodig het onderscheid tussen delegatie en uitvoering vervaagt. Het verschil lijkt zich te beperken tot de vraag hoe discretionair de bevoegdheid tot het geven van bepaalde beschikkingen is. Omdat het onderscheid delegatie-uitvoering niet duidelijk is, kan delegatie zo gekwalificeerd worden als uitvoering. ${ }^{32}$ De regering legt uit dat ze in de Memorie van Toelichting het onderscheid tussen delegatie en uitvoering juist had willen verduidelijken: wanneer door het gebruik van vage formuleringen de wetgever een taak feitelijk toch aan een ander orgaan overdraagt, dan kan dat betekenen dat een delegatieverbod ontdoken wordt. ${ }^{33}$

\subsubsection{Behoudens ieders verantwoordelijkheid volgens de wet}

De uitdrukking 'behoudens ieders verantwoordelijkheid volgens de wet', houdt nauw verband met de delegatieproblematiek. Hierbij heeft het woord 'wet' de betekenis van 'wet in formele zin". Bij gebruik van deze uitdrukking (in de artikelen 6,7 en $9 \mathrm{Gw}$ ) is delegatie verboden. ${ }^{34}$

Gebruikt de wetgever de beperkingsmogelijkheid dan moet hij er voor zorgen dat er in het concrete geval waarbij het grondrecht beperkt wordt, een rechtsgang naar een rechterlijk orgaan openstaat. Dit kan élk onafhankelijk rechtsprekend orgaan zijn. ${ }^{35}$

31. Handelingen II 1976-1977, p.2126 (regeringscommissaris Simons).

32. Kamerstukken I 1976-1977, 13872-13873, nr 55a VV, p. 12-13.

33. Kamerstukken I 1976-1977, 13872-13873, nr 55b MvA, p.23.

34. Kamerstukken II 1975-1976, 13872, nr 3 MvT, p.18 en 23.

35. Kamerstukken II $1975-1976,13872$, nr 3 MvT, p.18. 
De Raad van State heeft met name tegen deze laatste eis bezwaren en acht een dergelijke extensieve interpretatie van de clausule ongewenst nu daarvoor geen aanknopingspunten in de clausule zelf te vinden zijn. ${ }^{36}$

4.2.4 De terminologie in het wetsontwerp op de provincies en gemeenten ${ }^{37}$

\subsubsection{De terminologie in het algemeen}

De regering legt in de Memorie van Antwoord nog eens uit wat volgens haar een delegatiemogelijkheid inhoudt: de wetgever mag organen van hetzelfde of een ander bestuursniveau inschakelen bij het uitvoeren van een grondwettelijke opdracht. ${ }^{38}$ Die organen kunnen de bevoegdheid krijgen regels te stellen of concrete maatregelen te nemen (besluiten met directe werking). ${ }^{39}$ "Tussen regelgeving en het treffen van concrete maatregelen bestaat, wat dit betreft, geen wezenlijk verschil. Waar het om gaat is of de door het ingeschakelde orgaan te verrichten regelgeving of te treffen concrete maatregelen een wezenlijk onderdeel vormen van de in het grondwetsartikel omschreven taak. ${ }^{140}$ Krijgt het lagere orgaan hierbij de vrijheid om zelf de inhoud van de concrete maatregelen of regels te bepalen dan is er sprake van een gedelegeerde bevoegdheid. In andere gevallen spreekt de regering van 'min of meer gebonden uitvoering'. "Alleen wanneer men op deze wijze een onderscheid maakt, komt het terminologisch verschil tussen grondwetsbepalingen die wel en die geen delegatie mogelijk maken tot zijn recht. "41

Het woord 'delegatie' is door de regering gebruikt om aan te geven dat het gaat om de overdracht van een grondwettelijke opdracht. Past die opdracht in de beleidssfeer van het lagere orgaan zozeer dat het als een eigen taak van dat orgaan beschouwd kan worden, dan zou zo'n opdracht ook attributie genoemd kunnen worden. ${ }^{42}$

In antwoord op kamervragen zet regeringscommissaris Simons nog eens uiteen dat een delegatieverbod betekent dat de uitvoeringswet een "concrete en duide-

36. Kamerstukken II 1975-1976, 13872, wr 4 Bijlagen bij de MvT, Bijlage I Advies van de RvS, p 58 .

37. Verklaring dat er grond bestaat een voorstel in overweging te nemen tot verandering in de grondwet van bepalingen inzake provincies en gemeenten (13990).

38. Kamerstukken II 1976-1977, 13990, nr 6 MwA, p.8.

39. De kwalificatie, besluiten met directe werking, ontleende de regering aan het Voorlopig Verslag. Kamerstukken II 1976-1977, 13990, nr 6 MwA, p.8.

40. Kamerstukken II 1976-1977, 13990, nr 6 MvA, p.8.

41. Kamerstukken II 1976-1977, 13990, nr $6 \mathrm{MvA}_{n}$ p.8.

42. Kamerstukken II 1978-1979, 13990, nr 9 Herdruk, Nota nala aanleiding van het EV, p.10-11. 


\section{Hoofdstuk 4}

lijke normstelling" dient te bevatten. Ook mogen er geen "al te ruime en onbepaalde bevoegdheden aan uitvoerende organen" gegeven worden. ${ }^{43}$

Voorts gaat hij nog.in op het onderscheid delegatie-attributie. Welke term op een concreet geval van toekenning van een bevoegdheid van toepassing is hangt vaak af van wiens kant men de toekenning bekijkt. De overdrager zal de toekenning van de bevoegdheid als delegatie kunnen beschouwen, terwijl de ontvanger er meer attributie in kan zien. ${ }^{44}$

\subsubsection{De terminologie en de bevoegdheden van lagere overheden}

Opnieuw wordt in het Voorlopig Verslag de vraag gesteld naar de (regelgevende) ruimte die er voor lagere overheden overblijft wanneer de Grond wet de term 'de wet regelt' gebruikt. ${ }^{45}$ Het antwoord van de regering houdt in dat dit een kwestie van interpretatie van de Grondwet zal zijn. Hierbij zullen het onderwerp en de aard van de regelingsopdracht op de eerste plaats een belangrijke rol spelen en op de tweede plaats pas de gehanteerde terminologie. ${ }^{46} \mathrm{Zo}$ is er voor regeling door lagere wetgevers op het terrein van artikel 123 lid $2 \mathrm{Gw}$ (de wijziging van gemeentelijke grenzen) en artikel 132 lid $2 \mathrm{Gw}$ (het toezicht op de gemeentebesturen) volgens de regering dan ook geen plaats. ${ }^{47}$ Als voorbeeld van bepalingen die wel ruimte bieden voor regeling door (ook) lagere regelgevers noemt de regering artikel 10 lid 2 en $3 \mathrm{Gw}$. De bemoeienis van de lagere regelgevers mag niet zover gaan dat $z \mathrm{ij}$ het grondrecht op bescherming van de persoonlijke levenssfeer beperken. Zij mogen echter wel extra waarborgen bieden. ${ }^{48}$

\subsubsection{Het onderscheid regelgeving-uitvoering}

In de Nota naar aanleiding van het Eindverslag besteedt de regering maar liefst 4,5 pagina's aan de beantwoording van kamervragen over delegatie en het onderscheid regelgeving -uitvoering. Een algemeen aanvaarde omschrijving van het begrip wetgeving is volgens de regering "de regeling van alle wezenlijke onderdelen en aspecten van een (ter wetgeving opgedragen) onderwerp. ${ }^{49} \mathrm{Bij}$ het

43. Handelingen II 1978-1979, p.4042 (regeringscommissaris Simons). Dit geeft hij ook als antwoord op de cerste door Stoffelen gestelde vraag. Zie Handelingen II 1978-1979, p. $4042-4043$ (Simons).

44. Tlandelingen II 1978-1979, p.4042 (regeringscommissaris Simons).

45. Kamerstukken II 1976-1977, 13990, nr 5 VV, p.46.

46. Kamerstukken II 1976-1977, 13990, nr 6 MvA, p.9.

47. Kamerstukken II 1976-1977, 13990, nr 6 MvA. p.9.

48. Kamersiukken II 1978-1979.13990, nr 9 Herdruk, Nota naar aanleiding van het EV. p. 10 .

49. Kamersukken II 1978-1979, 13990, nr 9 Herdruk, Nota maar aanleiding van het EV, p.8. 
uitvoeren van een wet gaat het dan om voorschriften over detailkwesties en ondergeschikte punten die het praktisch funktioneren van de regeling mogelijk maken. Hierop heeft het delegatievraagstuk geen betrekking. Delegatie van wetgeving vindt plaats wanneer wezenlijke aspecten van een regelling aan een ander orgaan worden overgedragen en bovendien wanneer ruime, discretionaire bevoegdheden worden opgedragen aan een uitvoerend orgaan. Het stellen van de norm gebeurt dan niet door de wetgever, maar door het uitvoerend orgaan. Hieruit blijkt dat niet "de vorm van de overdracht (het stellen van algemene regels dan wel de bevoegdheid besluiten voor concrete gevallen te nemen) bepalend is", maar dat ook gekeken moet worden naar de "werkelijke betekenis en omvang. " 50

\subsubsection{De betekenis van de terminologie, voorlopige conclusie}

Het is tijd om een eerste balans op te maken. Bij de mondelinge behandeling van het wetsontwerp op de provincies en gemeenten merkte Stoffelen over de uiteenzetting van het delegatievraagstuk door de regering in de Memorie van Antwoord op: "Ik zal (...) mede spreken over de betekenis van autonomie en medebewind en vervolgens over het begrip delegatie. Op zich zelf is het al de moeite waard, dit te doen, maar zeker als wij zien hoe de Regering deze begrippen volledig de mist in helpt in haar uitleg die, als men het goed leest, erop neerkomt dat wetgeving eigenlijk precies hetzelfde is als uitvoering. ${ }^{" 51}$

Dit citaat geeft aardig weer hoe groot de verwarring bij de lezer kan zijn wanneer hij de diverse stukken heeft doorgewerkt op zoek naar de betekenis van de delegatieterminologie. Die verwarring ontstaat vooral doordat in de hierboven besproken wetsontwerpen de reikwijdte van het delegatieverbod verschillend wordt uitgelegd. In de Memorie van Toelichting in het wetsontwerp op de klassieke grondrechten, en in de daarop volgende stukken wordt een strakke uitleg van de delegatieterminologie gegeven. Nauwkeurig wordt onschreven wat het delegatieverbod inhoudt: geen overdracht van regelgevende bevoegdheden, geen gebruik van vage normen en geen attributie van discretionaire bevoegdheden.

In de stukken van het wetsontwerp op de provincies en gemeenten gebruikt de regering andere begrippen bij de uitleg van de delegatieterminologie. Het delegatieverbod wordt minder strak geformuleerd. De formele wetgever dient zelf de 'wezenlijke bepalingen' van een onderwerp te regelen. De regeling van 'detailpunten' kan aan lagere regelgevers worden overgelaten, in dat geval is sprake

50. Kamerstukken II 1978-1979, 13990, nr 9 Herdruk, Nota naar aanleiding van het EV, p.8. 51. Handelingen II 1978-1979, p.3678 (Stoffelen, PvdA). 


\section{Hoofdstuk 4}

van 'min of meer gebonden uitvoering'. ${ }^{52}$ Zo lijkt er in een dergelijk geval ook een regellgevende bevoegdheid te kunnen worden gedelegeerd, ondanks een 'delegatieverbod'.

Welke redenen zouden er kunnen zijn voor dit verschil in uitleg van de terminologie? Een verklaring zou kunnen liggen in de omstandigheid dat er misschien een flink verloop van tijd was tussen de behandeling van het ene en het andere wetsontwerp. Zo zou er dan door verkiezingen een ander kabinet aangetreden kunnen zijn, met een andere visie op het onderwerp. Dat was echter niet het geval. ${ }^{53}$

Een andere 'inhoudelijke' verklaring is gebaseerd op de eigen (andere) aard van de verschillende wetsontwerpen. Is het bijvoorbeeld zinvol om de delegatieterminologie in het kader van de bescherming van grondrechten strakker uit te leggen dan in het kader van de vrijheden van provincies en gemeenten? Bij het lezen van de parlementaire stukken van wetsontwerp 13990 springt in het oog dat er telkens weer wordt gevraagd naar de regelgevende ruimte die voor de lagere overheden overblijft wanneer de wetgever een grondwettelijke opdracht tot regeling krijgt. En het antwoord daarop is misschien dan wel eenvoudig ('het hangt af van de interpretatie van het desbetreffende grondwetsartikel'), maar daardoor zeker niet gemakkelijk in de praktijk toepasbaar.

Of wordt hier een 'belangenstrijd' gevoerd? Zien gemeenten hun eigen werkterrein verkleind door regelingen (formele wetten) van de centrale overheid en willen ze dat alsnog voorkomen?

Een verklaring met een historische achtergrond wordt geput uit de staatsrechtelijke literatuur. In het kader van het delegatievraagstuk is vaker gesteld dat de wetgever zelf de wezenlijke bepalingen dient vast te leggen en detailpunten kan overlaten aan uitvoerende instanties. ${ }^{54}$

Ook Heida zoekt naar een mogelijke reden voor het verschil in uitleg van de delegatieterminologie. ${ }^{55} \mathrm{Hij}$ vindt een verklaring in de positie van betrokken

52. Deze begrippen roepen echter weer nieuwe vragen op. Daarop wordt in de volgende hoofidstukken nog uitgebreid ingegaan.

53. De Mv' in het wetsontwerp op de klassieke grondrechten is uitgebracht op 2 april 1976 , de MvT in het wetsontwerp op de provincies en gemeenten op 11 augustus 1976 en de Mw A hierin op 7 januari 1977 .

54. Zie paragraaf 3.4. Stellinga, aanhanger van een materieel wetsbegrip, kijkt naar de taak van de wetgever (het regelen van een onderwerp) en leidt daaruit af dat de wetgever zelf steeds de hoofdzaken moet regelen. Zie ook de uitslag van de stemming aan het eind van de vergadering van de NJV. De wetgever mag, zij het niet onbeperkt, delegeren; hij moet er naar streven om hoofdlijnen in de wet zelf vast te leggen. Handelingen NJV 1951, p. $150-152$.

55. Heida 1984, p. $45-47$. 
partijen. Bij het neerleggen van de delegatieterminologie in de Grondwet zijn er vanuit het wetgevingsproces gezien twee belanghebbenden: de grondwetgever en de formele wetgever. De grondwetgever wilde vooral duidelijkheid in de Grondwet voor de gevallen waarin de formele wetgever een onderwerp zelf moet regelen. Daarbij lag de nadruk dus op het delegatieverbod. ${ }^{56}$ Daaronder valt ook het toedelen van discretionaire beschikkingsbevoegdheden, die de normstelling in feite overlaten aan een bestuursorgaan. Dat is weliswaar geen overdracht van regelgevende bevoegdheden, maar toch in strijd met het delegatieverbod dat inhoudt dat de wetgever zellf de norm moet stellen. ${ }^{57}$

De beide kamers zagen mogelijk hun taak als (mede) formele wetgever al op zich afkomen, en vroegen zich vooral af wat de omvang van een delegatiebevoegdheid zou zijn: "(..) hoever mag deze dan strekken?; moet daarbij onderscheid worden gemaakt tussen overdracht van regelgevende bevoegdheid en opdracht van bestuursbevoegdheden?; moet onderscheid worden gemaakt tussen overdracht in de eigen bestuurlijke kolom (wet-algemene maatregel van bestuur) en overdracht aan lagere publiekrechtelijke lichamen?; is het gebruik van de term delegatie hier niet verwarrend in verband met het onderscheid dat in de literatuur wordt gemaakt tussen delegatie en attributie? Op al deze vragen kan de in de Grondwet gebezigde terminologie eenvoudigweg geen antwoord geven en zij heeft zulks ook nooit beoogd. " 58

Resumerend: de uitleg van delegatieterminologie ziet er in deze tussenbalans als volgt uit. Delegatie is toegestaan wanneer de term 'bij of krachtens', een vorm van het werkwoord 'regelen' of een van de woorden 'regels' of 'regeling' wordt gebruikt. De mate waarin de wetgever van delegatie gebruikt maakt is hierdoor niet bepaald. Wanneer delegatie is toegestaan mag een grondrecht alleen beperkt worden wanneer daarvoor een specifieke wettelijke basis is aan te wijzen. Voor provinciale en gemeentelijke besturen biedt de algemene verordenende bevoegdheid onvoldoende basis.

Een delegatieverbod houdt in dat de formele wetgever wezenlijke bepalingen in de wet zelf dient vast te leggen. De regeling van detailpunten mag overgelaten worden aan lagere regelgevers ${ }^{59}$ De wetgever mag niet door het attribueren van

56. Vooral de regering hield het standpunt van de grondwetgever in hell oog.

57. Heida 1984, p. 46 .

58. Heida 1984, p. $46-47$.

59. Een meer bevredigende oplossing voor de tegenstrijdigheid die bestaat tussen de verschillende Memories (een 'absoluut' verbod om regelgevende bevoegdheid over te dragen tegenower een genuanceerder versie, namelijk 'in beginsel' geen regelgevende bevoegdheid overdragen) zie ik niet. Zie ook Waaldijk 1994, p. 168. 
discretionaire bestuursbevoegdheden of het gebruik van vage normen in feite de normstelling aan lagere organen overlaten. ${ }^{60}$ Zo kan inderdaad het nemen van concrete maatregelen zoals een beschikking (krachtens een discretionaire bestuursbevoegdheid) vallen onder het delegatieverbod. En hoeft delegatie van een regelgevende bevoegdheid, die alleen op detailpunten betrekking heeft, niet het delegatieverbod te ontduiken.

Daarmee zijn we er nog niet. Immers steeds zal bij de interpretatie van de delegatieterminologie gekeken moeten worden naar het onderwerp, de strekking en de historie van de bepaling. ${ }^{61}$ Dat maakt de zaak er niet eenvoudiger en duidelijker op.

De hierboven weergegeven uitleg van het delegatieverbod, waarbij een beperkte overdracht van regelgevende bevoegdheid mogelijk is, heeft overigens niet mijn voorkeur. Liever zou ik een absoluut delegatieverbod zien, in die zin, dat bij een grondwettelijk delegatieverbod elke overdracht van regelgevende bevoegdheid is verboden. Ook het opnemen van vage normen en discretionaire bevoegdheden dient zoveel mogelijk vermeden te worden. Dat is niet alleen systematisch gezien mooier, maar biedt ook meer duidelijkheid in de praktijk. Voor zover er bestuursbevoegdheden nodig zijn om de grondwettelijke opdracht (mede) uit te voeren, kunnen de regels, die het bestuursorgaan daarbij nodig acht, betiteld worden als beleidsregels. Op deze materie ga ik nog uitgebreid in in hoofdstuk 8 .

De gedachte van een absoluut verbod om regelgevende bevoegdheid over te dragen bij een grondwettelijk delegatieverbod vinden we overigens wel terug in de MvA van het herzieningsvoorstel voor het onderwijs. Dit standpunt van de regering is hierboven niet vermeld omdat het de vraag is welke waarde hieraan moet worden gehecht, nu het herzieningsvoorstel is verworpen. ${ }^{62}$

60. Uit deze weergave kan geconcludeerd worden dat de grondwettelijke delegatieterminologie zowel betrekking heeft op delegatie van regelgevende bevoegcheid als attributie van bestuursbevoegdheid. Niet op attributie van regelgevende bevoegdheid omdat het steeds gat om een bevoegdheid die de wetgever zelf heeft. Wanneer hij die uit handen geeft is er sprake van delegatie.

61. Er is overigens niet bij elk artikel uitwoerig gediscussieerd hoe de delegatieterminologie eruit zou moeten zien en in welke mate delegatie toegestaan zou zijn.

62. Zie verder nog kort hoofdstuk 5. 


\subsection{De delegatieterminologie in regeringsrapporten na 1983}

In deze paragraaf staat de uitleg van de grondwettelijke delegatieterminologie in regeringsstukken na 1983 centraal. Hierbij denkt de vlag 'regeringsrapporten' niet geheel de lading. Naast ook nota's van regeringszijde worden er enkele rapporten besproken die uitgebracht zijn door adviescommissies (zoals de Commissie Wetgevingsvraagstukken).

Aparte subparagrafen zijn gewijd aan de 'heersende leer" (zoals uiteengezet in een rede van Minister van Justitie Hirsch Ballin in 1992) en de Aanwijzingen voor de regelgeving, in werking getreden op 1 januari 1993.

\subsubsection{De uitleg voor 1992}

Een eerste interpretatie van de delegatieterminologie van regeringszijde is opgenomen in de Aanwijzingen voor de wetgevingstechniek 1984. ${ }^{63}$ Aanwijzing 51 luidt: "De Grondwet kent een vaste delegatieterminologie om aan te geven in welke gevallen de formele wetgever een hem opgedragen taak zelf moet verrichten en in welke gevallen hij bevoegd is te delegeren aan lagere regelgevers (zoals Kroon, minister, provinciebestuur, gemeentebestuur). De bevoegdheid tot delegatie wordt tot uitdrukking gebracht door het gebruik van enigerlei vorm van het werkwoord 'regelen', de zelfstandige naamwoorden 'regels', en 'regeling' of de term 'bij of krachtens'. Komt geen van deze formuleringen in een grondwetsbepaling voor, dan is delegatie niet geoorloofd. Dit betekent dat de wetgever dan zelf alle wezenlijke bepalingen met betrekking tot een onderwerp in de wet moet vastleggen. Het is derhalve niet in strijd met een delegatieverbod te achten, dat de wetgever het geven van voorschriften over detailpunten die ertoe strekken de praktische toepassing van een wettelijke regeling mogelijk te maken, aan lagere regelgevers overlaat."

De regering (minister-president) kiest hier voor de uitleg van het delegatieverbod zoals neergelegd in de parlementaire stukken van het wetsontwerp op de provincies en gemeenten (zie paragraaf 4.2). Er geldt dus geen 'absoluut' verbod op het overdragen van regelgevende bevoegdheid.

In Aanwijzing 52 krijgt de mate waarin mag worden gedelegeerd de aandacht. Nu daar in het algemeen geen aanknopingspunten voor zijn te vinden in de terminologie dient de wetgever dat per bepaling te bekijken. Tekst en strekking van de grondwetsbepaling en daarnaast de totstandkomingsgeschiedenis en de aard

63. Besluit van de Minister-President van 14 februari 1984, Stcrt 52. Deze aanwijzingen zijn inmiddels vervangen door de Aanwijzingen voor de regelgeving. Besluit van de MinisterPresident van 18 november 1992 , Stcrt 230 . 


\section{Hoofdstuk 4}

van de bepaling spelen hierbij een rol. In het bijzonder wordt in deze Aanwijzing gewezen op artikel $104 \mathrm{Gw}$ (belastingen), omdat dit het enige artikel betreft waarin de terminologie niet strikt gevolgd is. Aanwijzing 53 constateert tenslotte dat de specifieke betekenis van de termen 'regelen', 'regels" en 'regeling", beperkt blijft tot de grondwettelijke delegatieterminologie.

Volgens het rapport Orde in de regelgeving, het Eindrapport van de Commissie Wetgevingsvraagstukken (1985), is het de bedoeling van de grondwetgever dat bij een delegatieverbod wel regelgevende bevoegdheid aan lagere wetgevers mag worden overgedragen, mits de wetgever zelf de wezenlijke bepalingen van een onderwerp vaststelt. Lagere wetgevers mogen voorschriften over detailpunten vastleggen die de praktische toepassing van de wet betreffen. ${ }^{64}$ Ook deze opvatting sluit aan bij de opvattingen in de Memorie van Antwoord in wetsontwerp 13990.

In het rapport wordt gekozen voor het primaat van de formele wet: in de parlementaire behandeling ligt de democratische grondslag voor regelgeving. Bovendien verbetert door een openbare behandeling in het algemeen de kwaliteit van de regeling. Maar delegatie is noodzaak: om overbelasting van parlement en regering tegen te gaan en uit behoefte aan flexibiliteit en slagvaardigheid. De wet dient de hoofdlijnen en belangrijkste normen van een regeling te bevatten, de verdere uitwerking en detaillering kan aan de lagere regelgever overgelaten worden. ${ }^{55}$ Voorkeur verdient delegatie aan de regering in plaats van de minister, omdat de totstandkoming van een algemene maatregel van bestuur met meer waarborgen is omkleed. Zo dient het ontwerp in de ministerraad behandeld te worden, en brengt de Raad van State advies uit. ${ }^{65}$

(Sub)delegeren aan de minister komt pas aan de orde "indien het òf om de invulling van allerlei op zich minder belangrijke, maar wel noodzakelijke administratieve voorschriften gaat, of het uitvoeringswoorschriften betreft die frequent moeten worden aangepast. "67

Het kabinet onderschrijft in zijn standpunt op het rapport de conclusie uit Orde in de regelgeving dat het primaat bij de formele wet dient te liggen. Maar delegatie vindt niet alleen noodgedwongen plaats. Zo is het niet de taak van de wet-

64. Orde in de regelgeving 1985, p.45. De Commissie noemt geen (parlementaire) bron voor haar vitleg van het delegatieverbod. Het standpunt van de Commissie wordt niet gedeeld door Heringa/ 2 wart 1991, p.8. Volgens hen "knabbelt (de Commissie) aan de consequenties van het verbod van delegatie, ten onrechte (...) nogal wat af."

65. Orde in de regelgeving $1985, \mathrm{p} .42-43$.

66 . Orde in de regelgeving 1985, p.52-53.

67 . Orde in de regelgeving 1985, p. 53 . 
gever om bij elk onderwerp alle details in een formele wet te regelen. ${ }^{8 B}$ Wel dient de regeling helderheid te bieden over haar bereik en over de normen die de wetgever wenselijk acht, hoe die normen toegepast en gehandhaafd worden en welke voorzieningen de wetgever nodig acht. ${ }^{69}$

Overigens is het niet bij elk beleidsterrein steeds duidelijk wat de 'voornaamste duurzame normen' zijn. "De taak van de wetgever is dan beperkt tot het entameren van beleid, het attribueren van bevoegdheden en het bieden van een kader waarbinnen de lagere regelgever zich moet bewegen. "70

Evenals in het rapport Orde in de regelgeving krijgt in het kabinetsstandpunt delegatie aan de algemene maatregel van bestuur de voorkeur. Een uitzondering wil het kabinet maken voor regelingen die spoed eisen, en regelingen die dienen ter implementatie van internationaal recht en waarvan de inhoud grotendeels vaststaat. ${ }^{71}$ Het grondwettelijk delegatieverbod houdt volgens de regering in dat geen regelgevende bevoegdheid overgedragen mag worden, een 'absoluut' delegatieverbod dus. ${ }^{72}$ Voor de praktische toepassing van de wet mag wel, woor zover het detailpunten betreft; het 'treffen van voorzieningen' worden overgelaten aan lagere organen. ${ }^{73}$

In de kabinetsnota Zicht op wetgeving uit 1991 wordt voor wat betreft het delegatievraagstuk aangesloten bij de uitgangspunten neergelegd in Orde in de regelgeving en het kabinetsstandpunt daarop. De uitleg van de delegatieterminologie krijgt geen aparte vermelding. ${ }^{74}$

68. Regelgeving centrale overheid, Kamerstukken II 1986-1987, 20038, nr 2, p.6.

69. Regelgeving centrale overheid, Kamerstukken II 1986-1987, 20038, nr 2, p.6.

70. Regelgeving centrale overheid, Kamerstukken II 1986-1987, 20038, nr 2, p.6.

71. Regelgewing centrale overheid, Kamerstukken II 1986-1987, 20038, nr 2, p.12.

72. Deze uitleg is merkwaardig gezien het eerdere door de regering ingenomen standpunt in de Aanwijzingen voor de wetgevingstechiek 1984, en de uitleg in het rapport Orde in de regelgeving. Vergelijk het volgende citaat van Van der Burg 1993, p.141: "Het kabinetsstandpunt inzake het rapport "Orde in de regelgeving" werd aan de Tweede Kamer toege zonden in 1987, slechts enkele jaren na de algehele grondwetsherziening van 1983, en dat is bijzonder opmerkelijk. Bij de algehele grondwetsherziening heefi men wat de delegatie van wetgeving betreft, nagenoeg uitsluitend aandacht geschonken aan de delegatieterminologie. Daardoor werd de indruk gewekt dat delegatie zonder meer aanvaardbaar is, voor zover het niet gat om een onderwerp dat wolgens de Grondwet bij de wet geregeld moet worden. Het kabinetsstandpunt van 1987 is veel en veel strenger. Overigens heeft dit standpunt geen enkele rechtskracht. Bestaande wetten met te ruime delegatiebepalingen blijven zonder meer van kracht en het lijkt mij niet waarschijnlijk dat de Tweede Kamer krachtig zal optreden tegen een minister wiens delegatiemoral niet beantwoord aan de hoge maatstaven van het kabinetsstandpunt."

73. Regelgeving centrale overheid, Kamerstukken II 1986-1987, 20038, nr 2, p.7.

74. Zicht op wetgeving, Kamerstukken II 1990-1991, 22008, nrs 1-2, p.24. 


\section{Hoofdstuk 4}

In haar eerste jaarverslag sluit de Commissie voor de toetsing van wetgevingsprojecten zich aan bij de hierboven weergegeven opvattingen "dat de formele wetgever zelf de hoofdlijnen van het beleid dat hem voor ogen staat dient te bepalen. De formele wetgever moet zuinig en precies zijn in het verlenen van bevoegdheden aan de centrale overheid en bij zelfregulering of decentralisatie de verantwoordelijkheden van rijk, medeoverheden of anderen duidelijk afbakenen. "75 De rol van de overheid dient een terughoudende te zijn: de overheid dient zich "zoveel mogelijk te beperken tot het scheppen van de noodzakelijke randvoorwaarden, het stellen van minimum-eisen, het ondersteunen van maatschappelijke processen door het verzekeren van institutionele en materiële voorwaarden en het waken (bij voorbeeld wia gespecialiseerde inspecties) tegen ongewenste of ontoereikende resultaten." 76

In een reactie op het advies van de Commissie voor de Toetsing van wetgevingsprojecten over de wetsprocedure toont het kabinet zich geen voorstander van verruiming van delegatiemogelijkheden. ${ }^{77}$ Ook de discussie in de Tweede Kamer duidt eerder op een aanscherping dan verruiming van de voorschriften met betrekking tot delegatie.

\subsubsection{De 'heersende leer' in 1992}

In maart 1992 houdt Minister van Justitie Hirsch Ballin tijdens een symposium van de Vereniging voor Wetgeving en Wetgevingsbeleid een rede getiteld 'Dellegatie in wetgeving is juiste toedeling verantwoordelijkheden". Hierin zet hij, zoals hij het noemt, de 'heersende leer' met betrekking tot het delegatievraagstuk uiteen. ${ }^{78}$

In de eerste plaats geldt de grondwettelijke delegatieterminologie. In de tweede plaats zijn er delegatievoorschriften opgenomen in de 'Aanwijzingen inzake terughoudendheid met regelgeving ${ }^{79}$ zoals aanwijzing 7: "Het aantal delegatiebepalingen in een regeling moet zoveel mogelijk worden beperkt. Indien delegatie ten behoeve van een meer flexibele wijze van normstelling noodzakelijk is, moeten de grenzen van delegatie zoveel mogelijk in de wet worden vastgelegd."

75. Kamerstukken II 1988-1989, 20800, hfdst. VI, nr 13, p.8-9.

76. Kamerstukken II 1988-1989, 20800, hfdst. VI, nr 13, p.7.

77. Kamerstukken II 1993-1994, 23462, n I (Voortvarend wetgeven), p.20-21.

78. Hirsch Ballin 1992, p.102. De toespraak is tevens gepubliceerd in Staatscourant 1992, nr 58, p.6-7. Zie ook Sewandono 1992 b.

79. Besluit vastgestald door de minister-president dd 5 november 1984 . Hirsch Ballin verwijst ook naar de nieuwe, in voorbereiding zijnde Aanwijzingen voor de regelgeving, die inmiddels op 1 januari 1993 in werking zijn getreden. Daarbij zijn de hier genoemde Aanwijzingen inzake terughoudendheid met regelgeving verwallen. 
In de derde plaats citeert Hirsch Ballin het rapport Orde in de regelgeving:. "Het primaat van de wetgever brengt mee dat de wet zelf ten minste de reikwijdte, de structurele elementen en de voornaamste duurzame normen van een regeling dient te bevatten. ${ }^{~}{ }^{80} \mathrm{Bij}$ het kabinetsstandpunt hierop uit $\mathbb{1 9 8 7}$ (de vierde bron) werd dit primaat van de wetgever onderschreven, maar ook genuanceerd: "Delegatie moet niet worden gezien als noodzakelijk kwaad. Delegatie betreft het op juiste wijze toedelen van bevoegdheden aan bestuursorganen ten aanzien van taken die niet des wetgevers ziji. "81 In de nota 'Zicht op wetgeving' is deze visie door het kabinet Lubbers-Kok overgenomen. In parlementaire discussies is gebleken dat ook de Tweede Kamer zich achter deze visie stelde. ${ }^{82}$ Als laatste bron noemt Hirsch Ballin de adviezen van de Commissie voor de toetsing van wetgevingsprojecten. ${ }^{83}$

Zijn conclusie is dat aan het primaat van de wetgever veel belang wordt gehecht, maar dat er ook ruimte voor delegatie dient te zijn. In deze conclusie ligt volgens Hirsch Ballin het hedendaagse dilemma van het delegatievraagstuk beslloten. "Aan de ene kant wordt delegatie soms haast beschouwd als geformaliseerde plichtsverzaking door de wetgevende macht, die onverenigbaar is met het veelgeprezen 'primaat van de politiek'; aan de andere kant worden wetten die tot in details de regeling aan zichzelf houden, beschouwd als blijken van falend dereguleringsbeleid. " ${ }^{84}$ Hirsch Ballin ziet in het dilemma geen "onoverbrugbare tegenstelling".

Details bijvoorbeeld hoeven niet altijd (in een formele wet) geregeld te worden. Ze kunnen worden vermeden door regels in algemene wetten vast te leggen. Hij noemt als voorbeeld de procedureregels in de Algemene Wet Bestuursrecht en de Algemene wet op het binnentreden. Ook noemt hij het kiezen van minder, en eenvoudiger regels (voorbeeld: de nieuwe verkeerswetgeving). En ook is (wette-

80. Orde in de regelgeving $1985, p .44$. In artikel 80 van het Duitse Grundgesetz zijn soortgelijke criteria gecodificeerd: '(1) Durch Gesetz können die Bundesregierung, ein Bundes. minister oder die Landesregierungen ermächtigt werden , Rechtsverordnungen zu erlassen. Dabei müssen Inhalt, Zweck und Ausmaf (cursivering JD) der erteilten Ermächtigung im Gesetze bestimmt werden. Die Rechtsgrundlage ist in der Verordnung anzugeben. (...) Een dergelijke grondwettelijke bepaling lijkt woor het Nederlandse stelsel minder zinwol wegens het toetsingsverbod wan artikel $120 \mathrm{Gw}$.

81. Regelgeving centrale overheid, Kamerstukken II 1986-1987, 20038, nr 2, p.6.

82. Hirsch Ballin noemt de discussie over het kabinetsstandpunt inzake "Orde in de regelgeving " en over het rapport wan de parlementaire enquêtecommissie bouwsubsidies (Kamerstukken II 1987-1988, 19623), en de beschouwingen van de Bijzondere Commissie Vraagpunten, de commissie Deetman (Kamerstukken II 1989-1990, 21427).

83. Hirsch Ballim 1992, p.102.

84. Hirsch Ballin 1992, p.99. 


\section{Hoofdstuk 4}

lijke structurering van) zelfregulering een mogelijkheid (zie de gedragscode voor persfusies). "Het gaat er dus om dat een afweging van belangen steeds plaatsvindt door diegenen die daartoe het meest geschikt zijn. Daarbij gelden natuurlijk wel de (spel)regels van een democratische rechtsstaat. Steeds moet met het oog op handhaafbaarheid en uitvoerbaarheid de meest geschikte wijze van toedeling van verantwoordelijkheden worden gevonden." 85

Hirsch Ballin plaatst het delegatievraagstuk hiermee in een breder perspectief. Niet de wetgever dient alle belangen af te wegen, maar ook 'anderen" dienen hierin verantwoordelijkheden te krijgen. Die 'anderen' zijn, naast (vanouds) bestuursorganen, ook burgers en maatschappelijke instituties. ${ }^{86}$

Deze omschrijving roept enkele vragen op. Wat bedoelt Hirsch Ballin precies met het woord 'verantwoordelijkheden'? Op het eerste gezicht is de juridische betekenis hiervan niet duidelijk: verantwoordelijkheid is immers niet hetzelfde als bevoegdheid. ${ }^{87}$ Een verantwoordelijkheid kan vertaling vinden in een taak, waaraan een (regelgevende of bestuurs)bevoegdheid gekoppeld kan zijn. In de meeste gevallen zullen bevoegdheden echter noodzakelijk zijn om een bepaalde verantwoordelijkheid te kumnen uitoefenen, of een bepaalde taak te kunnen uitvoeren.

Een tweede kwestie is hoe Hirsch Ballin die toedeling van verantwoordelijkheden ziet: kan die toedeling omschreven worden in de bekende termen attributie-delegatie-mandaat? Met een toedeling van verantwoordelijkheden (bevoegdheden) aan bestuursorganen zijn we vertrouwd, maar in welke vorm kunnen de verantwoordelijkheden gegoten worden voor maatschappelijke instanties en burgers? Door welk soort bevoegdheden kan een verantwoordelijkheid vorm krijgen? Zo lijkt

85. Hirsch Ballin 1992, p. 105.

86. Zie in deze zin ook Hirsch Ballin 1989, p.60: "De keuze van het niveau en het type van normstelling dient derhalve gerelateerd te worden aan een beoordeling door welk orgaan binnen een democratische rechtstat een adequate belang enafweging kan geschieden . ${ }^{*} \mathrm{Zie}$ in de nota Zicht op wetgeving (Kamerstukken II 1990-1991, 22008, nrs 1-2, p.26) de omschrijving van het subsidiariteitsbeginsel (op nationaal niveau): waar mogelijk worden verantwoordelijkheden bij decentrale overheden en maatschappelijke organisaries gelegd.

87. Een koppeling assen verantwoordelijkheid, bevoegdheid en controle wordt gelegd in Belinfante/de Reede in het bekende 'Beginselen'. Er worden twee grondregels voor een staatsorganisatie geformuleerd. De eerste luidt: "Geen bewoegdheid zonder grondslag in wet of Grondwet" en de tweede: "Niemand kan een bevoegdheid uitoefenen zonder verantwoording schuldig te zijn of zonder dat op die oefening controle bestaat". Belinfante/de Reede 1991 , p.20 en p.22. Oorspronkelijk formuleerde Belinfante nog een derde grondregel: "Niemand is verantwoording verschuldigd dan over de uitoefening van hem toegekende bevoegdheden". Zie hierover Elzinga 1992, p.339. Belinfante/de Reede leggen geen verband met het delegatievraagstuk. 
het op voorhand niet aannemelijk om burgers en maatschappelijke instanties regelgevende bevoegdheden toe te kennen. ${ }^{88}$

De omschrijving van Hirsch Ballin is kortom niet duidelijk. Een preciezere juridische invulling is mijns inziens nodig om er een 'werkbare' formule van te maken. In het verloop van deze studie blijft deze bredere omschrijwing dan ook buiten beschouwing.

\subsubsection{De Aanwijzingen voor de regelgeving 1993}

De hier te noemen laatste bron waarin de delegatieterminologie van regeringswege behandeld wordt, zijn de Aanwijzingen voor de regelgeving die op 1 januari 1993 in werking zijn getreden. ${ }^{89}$

Specifiek over het grondwettelijke delegatieverbod gaat aanwijzing 23: ' 1 . In ieder geval worden in de wet opgenomen voorschriften ten aanzien van onderwerpen waarvoor de Grondwet een regeling bij wet eist en geen delegatie toelaat.

2. Een in de Grondwet neergelegd verbod tot delegatie houdt in dat a. alle wezenlijke bepalingen ten aanzien van het betrokken onderwerp in de wet moeten worden vastgelegd en b. in de wet niet mag worden volstaan met het ter zake van het betrokken onderwerp toekennen van vage bestuursbevoegdheden in de wet, waarbij de invulling van de regeling in feite geheel aan lagere organen wordt overgelaten.'

In de toelichting is opgenomen dat bij een delegatieverbod "het stellen van als uitvoering te beschouwen regels over details toch aan een lagere regelgever mag worden overgelaten. " 90

88. Wel 'kunnen zij 'in eigen kring' gedragscodes opstellen.

89. Besluit wan de minister-president van 18 november 1992. Gepubliceerd in de Staatscourant van 26 november 1992, nr 230. Zie voor een bespreking ervan T.C. Borman, Aanwijzüngen voor de regelgeving, in AA 1993, p.183-193; RegelMaat 1993, nr 1, diverse bijdratgen; Eijlander/Voermans 1993; Polak 1993.

90. Verder wordt verwezen nat Kamerstukken II 1975-1976, 13872, ar 3, p.22 e.w. Onnauwkeurig in de toelichting zijn de voorbeelden van artikelen die volgens de toelichting een grondwettelijk delegatieverbod behelzen, want:

- in artikel 6 is in lid 2 delegatie toegestaan ('regels").

- in artikel 7 lid 3 tweede volzin wordt delegatie toegestaan ("regelen').

- in artikel 9 lid 2 is delegatie toegestaan ("regels").

- het voorbeeld van artikel 23 lid 2 is gecompliceerd. De grondwettelijke delegatieterminologie geldt niet voor artikelen uit de 'oude' Grondwet waarvan herzieningsvoorstellen het niet gehaald hebben. Zie hoofdstuk 5 .

- in artikel 112 lid 2, tweede volzin, is delegatie toegestaan ("regelt"). 


\section{Hoofdstuk 4}

Wat opvalt in deze aanwijzing is, dat de uitleg van de grondwettelijke delegatieterminologie eruit is gehaald (vergelijk Aanwijzing 51 van de vroegere Aanwijzingen voor de wetgevingstechniek, hierboven weergegeven). Slechts in de toelichting wordt de terminologie uiteengezet. Ook wordt geen aandacht meer besteed aan de mate waarin gedelegeerd mag worden (vergelijk de vroegere Aanwijzing 52). Daarvoor is van belang dat gekeken wordt naar het onderwerp, de strekking en de geschiedenis van de betreffende bepaling. Deze 'aanwijzing' wordt de regelgever nu onthouden. De term 'vage besturursbevoegdheden' is geen juridiscli algemeen gehanteerde term. In de parlementaire stukken is steeds gesproken van 'vage normen' en 'discretionaire bevoegdheden', termen die meer duidelijkheid bieden.

Meer in het algemeen hebben de aanwijzingen $22,24,25$ en 26 betrekking op delegatie. ${ }^{91}$ Aanwijzing 22 luidt: 'Bij verdeling van de elementen van een regeling over de wet en algemeen verbindende voorschriften van lager niveau bevat de wet ten minste de hoofdelementen van de regeling. Bij de keuze welke elementen in de wet zelf regeling moeten vinden en ter zake van welke elementen delegatie is toegestaan, dient het primaat van de wetgever als richtsnoer., 92

Met Van der Flier kan geconstateerd worden dat de aanwijzingen 22 en 23 geen duidelijke richtlijnen geven voor de afbakening van "wat wel en niet als 'delegatie" kan worden aangemerkt en wanneer delegatie wel en niet wenselijk is. "93 Aanwijzing 24 schrijft voor welke onderwerpen in de wet zelf geregeld dienen te worden. Ze komen aan bod in hoofdstuk 9.

Aanwijzing 25 tracht delegatie af te bakenen: 'Elke delegatie van regelgevende bevoegdheid dient in de delegerende regeling zo concreet en nauwkeurig mogelijk te worden begrensd.' In de toelichting wordt aangegeven dat hierbij kan worden gedacht "aan het concretiseren van de omstandigheden waarin van de gedelegeerde bevoegdheid gebruik mag worden gemaakt, van de te regelen onderwerpen en van de doeleinden waartoe zij mag worden gebruikt."

91. Bepalingen over delegatie zijn te vinden in de parag rafen 2.2 en 2.3 van de Aanwijzingen vorr de regelgeving. De belangrijkste worden hier besproken. Aanwijzingen die betrekking hebben op de terminologie komen aan bod in hoofdstuk 7 .

92. Verduidelijking vindt plaats in de toelichting: "Hoofdelementen zijn in ieder geval de reikwijdte en de structurele elementen van de regeling. Veelal zullen daartoe ook de voornasmste duurzame normen behoren. Het kan echter uit een oogpunt van toegankelijke regelgeving beter zijn om in de wet over een bepaald onderwerp geen materiële normen op te nemen, matar aan de lagere wetgever over te laten een integrale materiële regeling tot stand te brengen."

93. RegelMaat 1993, nr 2, p.86-92 (verslag van studieochtend: wel of niet wettelijke basis voor Aanwijzingen?), p.89. 
Aanwijzing 26 handelt over delegatie aan de minister ${ }^{34}$ : '1. Delegatie aan een minister van de bevoegdheid tot het stellen van algemeen verbindende voorschriften wordt beperkt tot voorschriften van administratieve aard, uitwerking van de details van een regeling, voorschriften die dikwijls wijziging behoeven en voorschriften waarvan te voorzien is dat zij mogelijk met grote spoed moeten worden vastgesteld.

2. Delegatie aan een minister van de bevoegdheid tot het vaststellen van algemeen verbindende voorschriften is ook toegestaan indien het gaat om het verwerken in de Nederlandse wetgeving van internationale regelingen die de Nederlandse wetgever, behoudens op ondergeschikte punten, geen ruimte laten voor het maken van keuzen van beleidsinhoudelijke aard.'

Met deze aanwijzingen is een poging gedaan om het delegatievraagstuk vorm te geven en te begrenzen. Het is de verdienste van de Aanwijzingen voor de regelgeving dat ze een meer omvattende blik bieden op het delegatievraagstuk, in vergelijking met vroegere aanwijzingen. Of ze in de praktijk werkbaar zijn voor de wetgever is een andere vraag. ${ }^{95}$ Daarvoor lijken de aanwijzingen veelal (te) vaag te zijn..$^{96}$

\subsubsection{Samenvatting}

De reikwijdte van het delegatieverbod staat centraal in de uitleg van de grondwettelijke delegatieterminologie. De regering kiest (in de Aanwijzingen voor de wetgevingstechniek) voor de opvatting zoals neergelegd in de parlementaire stukken van het wetsontwerp op de provincies en gemeenten: bij zen delegatieverbod dient de wetgever zelf de wezenlijke bepalingen te regelen. Overdracht van regelgevende bevoegdheid is toegestaan voor zover het detailpunten betreft. De mate van delegatie is in de terminologie niet vastgelegd. De wetgever zal bij uitvoeringswetgeving rekening moeten houden met de tekst, strekking en historie van de bepaling.

94. Deze delegatie vindt krachtens aanwijzing 27 zoweel mogelijk rechtstreeks in de wet plaats.

95. Voorbeelden van adviezen van de Raad van State warin deze delegatiebepalingen toetst (en soms te ruim acht) geeft De Jong 1993, p.71-76.

96. De vraag is of de Aanwijzingen veel concreter hadden kunnen zijn nu ze onder meer de uitleg van de grondwettelijke delegatieterminologie hebben en die volgen. Overigens lijkt niet alleen vaagheid debet aan niet-naleving van de Aanwijzingen. Ook efficiency speelt hierbij soms een rol. Zie voor een voorbeeld Hijmans 1993, p.213-214 over het amendement Van der Vaart/Koetje (Kamerstukken II 1993-1994, n 22690, nr 10). Zie ook paragraaf 5.4.1. 


\section{Hoofdstuk 4}

In het rapport Orde in de regelgeving wordt aangesloten bij deze regeringsuitleg van het delegatieverbod. De commissie Wetgevingsvraagstukken gaat vervolgens uitgebreid in op de mate waarin gedelegeerd mag worden. Haar opmerkingen betreffen het delegatievraagstuk in het algemeen. De mate waarin delegatie geoorloofd is, wordt aan banden gellegd. De wet dient de hoofdlijnen van een regeling vast te leggen en de voornaamste durzame normen. Hiermee wordt een lijn in denken over delegatie uitgezet die in de jaren daarna navolging heeft gekregen en die samen te vatten is als 'terughoudendheid met delegatie'. In de woorden van de Toetsingscommissie: "de formele wetgever moet 'zuinig en precies" zijn bij de toedeling van bevoegdheden (...)."

Het betreft een ontwikkeling die na 1983 is begonnen. Het is aannemelijk én wenselijk dat deze algemene opvattingen over het delegatievraagstuk ook gelden voor de delegatie die op grond van de grondwettelijke delegatieterminologie is toegestaan. Aannemelijk omdat met geen woord wordt gerept over een uitzonderingspositie voor het grondwettelijke delegatiebegrip; wenselijk omdat het de duidelijkheid ten goede komt wanneer één opvatting over de reikwijdte van delegatie wordt gehanteerd, waarbij het primaat van de wetgever als uitgangspunt geldt.

Naast de juridische benadering valt op dat het delegatievraagstuk vooral ook beleidsmatig benaderd wordt. Voorbeelden van het laatste vinden we in het kabinetsstandpunt op Orde in de regelgeving, het eerste jaarverslag van de commissie voor toetsing van wetgevingsprojecten en de rede van Hirsch Ballin. Gepleit wordt voor een terughoudender rol van de overheid en inschakeling van anderen dan de wetgever bij de afweging van belangen. Het gaat gepaard met gebruik van woorden als 'verantwoordelijkheden', zelfregulering, decentralisering. Of en hoe deze verbreding van het delegatievraagstuk ook juridische vertaling vindt dient afgewacht te worden. Dat zou een interessant onderwerp kunnen zijn voor een volgende studie. 


\subsection{De delegatieterminologie in de literatuur}

\subsubsection{Enkele opvattingen}

In de (wetenschappelijke) literatuur komen, naast de uitleg van de delegatieterminologie, vaak ook de consequenties ervan voor het delegatievraagstuk, aan de orde. ${ }^{97}$ In deze paragraaf worden enkele opvattingen weergegeven en becommentarieerd.

Kortmann ziet drie ontwikkelingen in het delegatievraagstuk als gevolg van de in 1983 ingevoerde delegatieterminologie. Een eerste karakteristiek van het nieuwe stelsel past in de traditie: de terminologie geeft niet aan in welke mate gedelegeerd mag worden. Met de traditie breekt de tweede karakteristiek, dat overdracht van bevoegdheden onder de nieuwe Grondwet geoorloofd is van rijksorgaan naar gedecentraliseerd lager orgaan (bijvoorbeeld bevoegdheden overdragen bij algemene maatregel van bestuur aan provinciale of gemeentelijke organen). ${ }^{98}$ Ook de derde karakteristiek biedt iets nieuws: onder delegatie valt niet alleen de verhouding hogere regeling-lagere regeling, maar ook de verhouding regeling-concreet besluit "indien dit besluit op grond van een discretionaire bevoegdheid is genomen." "99

Zijn conclusie over het stelsel is dat er "een grove en rigide tweedeling" is ontstaan waarin delegatie wel of niet mogelijk is. "Zo delegatie wel mogelijk is valt er in beginsel nagenoeg alles onder: al dan niet vèrgaande overdracht of opdracht

97. Zie bijwoorbeeld Van der Pot/Donner/Prakke 1989 p.527-528; Heringa/Zwart 1991, p.68; Van der Vlies 1991, p.99-100; Akkermans/Koekkoek 1992, p.4-6; Van der Burg 1993, p.138-141; Kortmann 1994, p.319-321.

98. Kortmann 1987a, p.25-27. Commentaar op deze uitbreiding geeft ook Jeukens 1978 , p.78. Hij wil de delegatie beperkt zien tot delegatie aan Kroon of minister, "beide onder directe ministeriële verantwoordelijkheid. In deze zin zou de grond wettelijke opdracht aan de wetgever om regelen te stellen in volle omvang een waarborg blijven voor de burgers zowel naar procedure als naar het beginsel van de rechtsgelijkheid."

99. Kortmann 1987a, p.28. Kortmann 1980, p.203-204 confronteert deze opvatting van de grondwetgever (van delegatie kan gesproken worden wanneer een discretionaire bevoegdheid wordt gecreëerd) met jurisprudentie van de Hoge Raad op artikel 169 gemeentewet. Hij concludeert dat de Hoge Raad deze opvatting niet deelt. Op p.205 bespreekt hij het bromfietsvalhelmarrest van de Hoge Raad waarin de Raad oordeelde over een ministeriële bevoegdheid en tot de conclusie kwam dat er sprake was van uitvoering. De AdvocaatGeneraal kwam tot verboden delegatie (want in zijn ogen had de minister een discretionaire bevoegdheid; dit standpunt zou aansluiten bij dat van de grond wetgever.) Opgemerkt dient echter te worden dat dit jurisprudentie betreft van wó́r de inwerkingtreding van de gewijzigde grondwet. Hoe is het daarna gegaan? Is er een kentering in de opvattingen van de Hoge Raad waar te nemen? Zie hoofdstuk 7 . 


\section{Hoofdstuk 4}

van regelgevende of beschikkingsbevoegdheid aan welk centraal of gedecentraliseerd orgaan dan ook. Is delegatie niet mogelijk, dan moet de wetgever zelf nagenoeg àlles regelen, met het risico dat, indien hij het een en ander ter uitvoering aan een ander orgaan opdraagt dit als ongeoorloofde delegatie wordt gekwalificeerd. Het is al met al een weinig aantrekkelijk stelsel, dat echter in de praktijk zijn scherpe kanten wel zal verliezen. "100

Over de uitleg van de delegatieterminologie merken De Haan/Drupsteen/Fernhout op dat de ruime delegatie-opvatting van de grondwetgever niet strookt met het in de literatuur gebruikte onderscheid tussen attributie en delegatie. ${ }^{101} \mathrm{Zij}$ verbinden hier echter geen consequenties aan.

Volgens Van der Hoeven blijkt uit de delegatieterminologie in de nieuwe Grondwet dat deze delegatie van wetgeving 'in het allgemeen toelaatbaar oordeelt, "102 Hij signaleert, nu delegatie in hoge mate mogelijk is, een nieuw probleem. Dienen alle krachtens delegatie tot stand gekomen regelingen getoetst te worden aan de beginselen van behoorlijke wetgeving? Als een rechter gaat toetsen dan beoordeelt deze niet alleen meer de bevoegdheid van de lagere regelgever, maar ook "de kwaliteit van diens produkt binnen de grenzen van die opdracht." ${ }^{103}$ Van der Hoeven richt hierbij ge aandacht op de constitutionele consequenties. Voor ons onderwerp is echter de gedlachte interessant van toetsing van gedelegeerde regelgeving door de rechter aan de algemene beginselen van behoorlijke wetgeving. Dit punt, het zoeken van waarborgen rond gedelegeerde regelgeving, komt in paragraaf 4.6 aan de orde.

$\mathrm{Na}$ geconstateerd te hebben dat delegatie al geruime tijd volop wordt toegepast, merken Van der Pot/Donner/Prakke op dat het bedenkelijk is dat het bestuur wordt ingeschakeld om normen te stellen: het wordt wetgever in eigen zaak. "Immers, terwijl van de volksvertegenwoordiging verwacht mag worden dat zij de behoeften aan een vitvoerige regeling afweegt tegen de belangen van het publiek, heeft het bestuur de neiging om vooral op eigen gerief en op de ernst van de eigen taak en verantwoordelijkheid te letten en dus liever te veel dan te weinig te regelen. Het was niet voor niets dat de doctrine eiste dat de burgers bindende regels in overleg met hun vertegenwoordiging werden vastgesteld!"104 Het grondwettelijke delegatieverbod houdt volgens hen in dat de wetgever "de

100. Kortmann 1987a, p.29-30; zie ook Kortmann 1994, p.35-37 en p.319-326.

101. De Haan/Drupsteen/Fernhout 1986, I, p.207-208.

102. Van der Hoeven 1988, p.299.

103. Van der Hoeven 1988, p.299-300. Hij acht het ook mogelijk dat het begrip 'uitvoering' weer in de discussie wordt betrokken.

104. Van der Pot/Donner/Prakke 1989, p.527. Zie voor een historisch overzicht van het delcgatievraagstuk p.520 e.v. 
materie aan zichzelf te houden heeft en slechts op onderdelen kan delegeren." 105

Volgens Belinfante/de Reede wordt delegatie algemeen geoorloofd geacht. Delegatie vindt plaats wanneer de wetgever hoofdlijnen van een te regelen onderwerp in de wet vastlegt, maar de uitwerking ervan aan anderen opdraagt. Het delegatiebegrip is sinds de grondwetsherziening van 1983 uitgebreid doordat ook het toedelen van bevoegdheden van de wetgever aan gedecentraliseerde organen eronder kan vallen. ${ }^{106}$

Heringa/Zwart beschrijven de delegatieterminologie aan de hand van de parlementaire stukken van het wetsontwerp op de klassieke grondrechten. Bij een delegatieverbod mag de wetgever zijn bevoegdheid niet overdragen. In hun ogen "knabbelt de Commissie Wetgevingsvraagstukken aan de consequenties van het verbod van delegatie, ten onrechte gelet op de geciteerde overwegingen, nogal wat af. " ${ }^{107}$ Heringa/Zwart kan tegengeworpen worden dat zij geen acht slaan op de parlementaire stukken van het wetsontwerp op provincies en gemeenten waarin het delegatieverbod immers een andere invulling krijgt. ${ }^{108}$

Van der Vlies concludeert dat de grondwetsherziening geen belangrijke verduidelijkingen heeft opgeleverd op het terrein van de delegatie (welke bevoegdheden komen de wetgever en regering toe, wat zijn de grenzen van delegatie). ${ }^{109} \mathrm{Vol}-$ gens haar geldt de delegatieterminologie niet voor (vergaande) attributie van beschikkingsbevoegdheid. ${ }^{110}$ Hierover kan opgemerkt worden dat, wanneer er een grondwettelijk delegatieverbod geldt, attributie van beschikkingsbevoegdheid wel de grenzen van het delegatieverbod kan overschrijden wanneer het bestuursorgaan de bevoegdheid krijgt wezenlijke bepalingen te stellen.

Akkermans/Koekkoek achten het streven van de grondwetgever naar een uniforme en duidelijke delegatieterminologie niet geslaagd. In de eerste plaats doordat de delegatieterminologie niet geldt voor enkele oude grondwetsartikelen, en op de

105. Van der Pot/Donner/Prakke 1989, p.527-528. Zij noemengeen bron voor deze bewering en geven niet aan welke onderdelen gedelegeerd mogen worden.

106. Belinfante/de: Reede 1991, p.119.

107. Heringa/Zwart 1991 , p.6-7. Citaat op p.8.

108. Zie ook Heringa 1987, p.79 die concludeert dat de grond wettelijke delegatieterminologie "in feite een lege huls" blijkt: "als delegatie is toegestaan hangt het weer van de desbetreffende bepaling af hoever die mag gaan en is het bovendien ook mogelijk dat andere (autonome) regelgevers zelfstandig regels stellen; en als delegatie niet is toegestaan mag. het volgens de commissie Wetgevingswraagstukken toch, een opvatting waar de regering zich nu kennelijk van harte achter schaart."

109. Van der Vlies 1991, p.97.

110. Van der Vlies 1991, p.99. 


\section{Hoofdstuk 4}

tweede plaats omdat de uitleg van de terminologie niet duidelijk is. ${ }^{111} \mathrm{Zij}$ bespreken de delegatieterminologie aan de hand van de Aanwijzingen voor de wergevingstechniek (zie hierboven). ${ }^{112}$ Kern hiervan is volgens hen de vraag wat preeies de inhoud van het begrip wezenlijke bepalingen is. Een delegatieverbod kan omzeild worden wanneer de wetgever onder het mom van niet-wezenlijke bepalingen bevoegdheden tot regeling aan andere organen toebedeelt. Dat dit niet de bedoeling van de grondwetgever is geweest leiden de auteurs af uit de memorie van toelichting in het wetsontwerp op de klassieke grondrechten: bij een delegatieverbod mag geen regelgevende bevoegdheid worden overgedragen.

De uitleg in Aanwijzing 51 wordt dan ook als 'fout' betiteld, een fout die in de ogen van de auteurs begrijpelijk is nu het voor de (formele) wetgever bijna ondoenlijk is on een onderwerp tot in alle details te regelen. Door deze 'verzwakking van het delegatieverbod' kan ook het onderscheid regelgeving-uitvoering weer een rol gaan spelen.

Zij concluderen dat de grondwetgever een "ingewikkeld en tot verwarring aanleiding gevend systeem met betrekking tot de delegatieterminologie in de Grondwet" heeft gehanteerd. ${ }^{13}$

Over de ontstane verwarring merkt Eijlander op dat het aanbeveling verdient niet te spreken over grondwettelijke delegatieterminologie, "maar van de in de Grondwet tot uitdrukking gebrachte normering ten aanzien van de overdracht of toekenning van bevoegdheden door de wetgever aan andere organen. ${ }^{114}$ Eenzelfde woordgebruik hanteert Konijnenbelt. Ook hij acht het beter om, in het kader van de grondwettelijke delegatieterminologie, niet te spreken van delegatie van regelgevende bevoegdheid, maar van nadere normstelling door "andere autoriteiten'. Niet van belang is welke vorm die normstelling heeft: dit kunnen zowel algemeen verbindende voorschriften, als administratieve maatregelen of beschikkingen zijn. ${ }^{1 / 5}$

111. Reden voor onduidelijkheid zijn verder in hun ogen: de pasitie van lagere overheden (hoeveel regelgevende ruimte blijft voor hen over bij een grondwettelijke opdracht aan de formele wetgever?) en het feit dat bij de interpretatie van de delegatieterminologie steeds gekeken moet worden naar het onderwerp, de historie en de strekking van de bepaling in kwestie. Akkermans/Koekkoek 1992, p.6.

112. Akkermans/Koekkoek 1992, p.4-5.

113. Akkermans/Koekkoek 1992, p.6.

114. Eijlander 1993, p.60.

115. Konijnenbelt 1993, p.120. 


\subsubsection{Samenvatting}

De handboeken besteden vooral in juridisch-technische zin aandacht aan delegatieterminologie en -vraagstuk. Geen enkele auteur bestrijdt delegatie nog principieel. $^{116}$

Ook de grondwettelijke delegatieterminologie vindt geen bestrijding. Verschillende auteurs betwijfelen echter de beoogde duidelijkheid wan de grondwettelijke delegatieterminologie.

Zij constateren verschuivingen in het delegatievraagstuk als gevolg yan de invoering van de terminologie; het begrip 'delegatie van regelgevende bevoegdheid' is ruimer geworden. Er valt nu ook onder de overdracht van bevoegdheden van rijks- naar gedecentraliseerd orgaan en de overdracht van algemene regeling naar concreet besluit.

Of hiermee sprake is van een uitbreiding die ook geldt voor delegatie buiten de Grondwet om, is in de volgende paragraaf aan de orde.

\subsection{De invloed van de delegatieterminologie op het delegatievraag-} stuk en omgekeerd

\subsubsection{De invloed van de delegatieterminologie op het delegatievraagstuk}

In de vorige paragraaf bleek uit de bespreking van de literatuur dat het begrip 'delegatie van regelgevende bevoegdheid' is uitgebreid onder invloed van de uitleg van de grondwettelijke delegatieterminologie. Het is de vraag of deze uitbreiding ook geldt voor niet op de Grondwet gebaseerde wetten. In de لiteratuur komt deze vraag niet expliciet aan de orde. Uit de wijze waarop het delegatievraagstuk en de delegatieterminologie besproken worden kan geconcludeerd worden dat dat niet vanzelfsprekend is, maar er lijken ook geen signalen voor het tegendeel te zijn.

De meeste auteurs beginnen bij de beschrijving van het delegatievraagstuk met een definitie van delegatie zoals die in paragraaf 2.2 is gegeven: delegatie is de overdracht van een eigen bevoegdheid aan een ander om die op eigen naam en onder eigen verantwoordelijkheid uit te oefenen (of soortgelijke woorden). ${ }^{17}$

116. Well hebben Van der Pot/Donner/Prakke bedenkingen over het feit dat 'het bestuur wetgever in eigen zaak' wordt.

117. Zie Van der Pot/Donner/Prakke 1989, p.527-528; De Meij 1990, p. 124; Belinfante/de Reede 1991, p. 119; Van der Vlies 1991, p.90; Stroink/Steenbeek 1993, p.44; Kortmann 1994 , p.36 en p.320; Koopmans 1994, p.24. 


\section{Hoofdstuk 4}

Een uitleg van de grondwettelijke delegatieterminologie wordt apart gegeven; waarbij aandacht is voor de verruiming die het delegatievraagstuk ondergaat voor wat betreft op de Grond wet gebaseerde wetten. Door de afzonderlijke behandeling wordt de indruk gewekt dat het grondwettelijke delegatiebegrip een apart delegatiebegrip is. ${ }^{118}$

De conclusie lijkt dan ook gerechtvaardigd dat de verruiming van het begrip 'delegatie van regelgevende bevoegdheid' alleen geldt in het kader van de grondwettelijke delegatieterminologie. Het toedelen van bevoegdheden aan organen van decentrale overheden in niet op de Grondwet gebaseerde wetten zal, als vanouds, attributie genoemd worden, terwijl die toedeling in wel op de Grondwet gebaseerde wetten als delegatie betiteld kan worden. Een verschillend 'etiket' heeft echter geen verstrekkende consequenties nu aan het onderscheid attributiedelegatie constitutioneelrechtelijk geen rechtsgevolgen verbonden zijn.

Dat kan echter veranderen wanneer de delegatiebepalingen in de Algemene wet bestuursrecht, zoals neergelegd in het wetsvoorstel Derde tranche, in werking treden. Delegatie wordt dan wettelijk geregeld en genormeerd, er vindt een verdere verfijning van het delegatievraagstuk plaats. Delegatie aan ondergeschikten wordt verboden (dit zal vooral van belang zijn voor delegatie van bestuursbevoegdheden). Ook het vereiste van een wettelijke grondslag wordt gecodificeerd. De in het voorontwerp nog gecodificeerde gewoonte (overigens alleen geldend voor de formele wetgever) dat de delegans een regelgevende bevoegdheid na de overdracht ook nog zelf kan uitoefenen, vervalt echter in het wetsontwerp. Attributie wordt niet geregeld in het wetsvoorstel Derde tranche Awb. Een verschillend etiket op een toegedeelde bevoegdheid kan mogelijk wel rechtsgevolgen hebben (zoals bij de toedeling van bevoegdheid aan een ondergeschikte).

De Awb geldt niet voor de formele wetgever, wel voor lagere regelgevers zoals de regering en minister. De invloed op het grondwettelijke delegatievraagstuk zal daarom gering zijn, nu die in hoofdzaak ziet op delegatie door de formele wetgever.

Ook de Aanwijzingen voor de regelgeving 1993 zijn van belang. De delegatiebepalingen daarin gelden wel voor de formele wetgever, hoewel ze de formele wetgever niet binden, in de zin dat ze afdwingbaar zijn. ${ }^{199}$ Delegatie wordt ech-

118. Konjjuenbelt 1993, p.119, constateert naar aanleiding van de voorstellen in het voorontwelp derde tranche Awb dat we in het publiekrecht werken met 'twee, zo al niet drie delegatiebegrippen', warvan de grondwettelijke delegatie er éen is.

119. Volgens Polak (1993, p.1397) hebben de Aanwijzingen een 'onduidelijke status', ze hebben in ieder geval niet een 'zelfstandig bindende kracht'. De formele wetgever kan niet gedwongen worden de Aanwijzingen na te komen. Op blz. 1397-1398 geeft Polak als voorbeeld het advies van de Rad van State over de Interimwet ammoniak en vee- 
ter niet gedefinieerd. De nadruk ligt vooral op datgene wat er in de formele wet behoort te worden opgenomen, niet wat er gedelegeerd (of geattribueerd?) mag worden.

In paragraaf 4.4 bleek dat in de uitleg van de grondwettelijke delegatieterminologie, het begrip 'delegatie van regelgevende bevoegdheid' is verruimd. Daaronder valt nu ook de overdracht van bevoegdheid van rijksorgaan naar decentraal orgaan. Een tweede verruiming is daarin gelegen dat ook over delegatie van regelgevende bevoegdheid gesproken kan worden wanneer de bevoegdheid tot het nemen van concrete besluiten toegedeeld wordt.

Zijn deze verruimingen in de in paragraaf 2.2 gegeven ("traditionele") delegatiedefinitie onder te brengen? Daarvoor dienen we deze definitie nog eens goed te bekijken. Delegatie is de overdracht van een eigen bevoegdheid aan een ander om die op eigen naam en onder eigen verantwoordelijkheid uit te oefenen. In deze definitie zit niet: het vereiste van een wettelijke grondslag; de bepaling aan welk orgaan gedelegeerd mag worden (bijvoorbeeld alleen binnen de eigen bestuurskolom); ${ }^{120}$ en in welke mate gedelegeerd mag worden.

De verruiming in de delegatiedefinitie die is aangebracht door de delegatieterminologie, in die zin dat bijvoorbeeld ook door rijksorganen aan organen van decentrale lichamen 'gedelegeerd' kan worden, levert geen problemen op. De omschrijving hoeft niet aangepast te worden: 'orgaan is orgaan'. Wel is een andere uitleg van 'orgaan' nodig.

Moeilijker in te passen is het feit dat volgens de nieuwe uitleg ook de verhouding algemene regeling-concreet besluit onder delegatie van 'regelgevende bevoegdheid' valt. Zolang de definitie spreekt van een 'eigen' bevoegdheid die wordt overgedragen, komt de formele wetgever in problemen. Diens belangrijkste bevoegdheid is immers een regelgevende, en niet een bestuurlijke. Delegeert hij die (regelgevende) bevoegdheid, dan krijgt het ontvangende orgaan niet een bevoegdheid om concrete besluiten te nemen. Aanpassing van de definitie lijkt dan ook noodzakelijk.

houderij (Kamerstukken II 23221). De Raad beriep zich in dat advies op Aanwijzing 25. Deze aanwijzing schrijft woor dat de delegatie zo concreet en mauwkeurig mogelijk dient te worden begrensd. De door de Raad op dit punt geleverde kritiek is niet overgenomen door de regering. In een Bijlage op p.1399 geeft Polak een overzicht van overige adviezen waarin de Raad van State verwees naar de Aanwijzingen voor de regelgeving.

120. Het inschakelen van organen uit een andere bestuurskolom kwam vooral voor wanneer een wetgever op rijksniveau opdrachten gaf aan een orgaan van een decentraal lichaam. Dit viel niet onder de delegatiedefinitie, maar werd medebewind genoemd. 


\section{Hoofdstuk 4}

Het feit dat het begrip 'delegatie van regelgevende bevoegdheid' is uitgebreid bij de uitleg van de grondwettelijke delegatieterminologie is misschien de belangrijkste oorzaak van bredere omschrijvingen van delegatie. Zo kwamen we in paragraaf 4.3 omschrijwingen tegen als "Delegatie kan men dan omschrijven als het overdragen van taken die de delegans niet zelf wil verrichten. " 121 Of (in het kabinetsstandpunt op Orde in de regelgeving): "Dellegeren is mede het op juiste wijze toedelen van bevoegdheden aan een bestuursorgaan ten aanzien van taken die nier des wetgevers zijn. " ${ }^{122}$ Of Hirsch Ballin in zijn rede van 1992: 'Delegatie in wetgeving is een juiste toedeling van verantwoordelijkheden".

\subsubsection{De invloed van het delegatievraagstuk op de delegatieterminologie}

De invloed van het denken over het delegatievraagstuk op de uitvoering van de grondwettelijke delegatieterminologie is in paragraaf 4.3 reeds aan het licht gekomen. De grondwettelijke delegatieterminologie bepaalt niets over de omvang van de delegatie. Wel moet daarbij rekening gehouden worden met het onderwerp, de strekking en historie van de bepaling. Maar meer richtlijnen over de toegestane omvang van de delegatie zijn bij de grondwetsherziening niet gegeven. ${ }^{123}$

Sinds 1983 is terughoudendheid met delegatie het motto in regeringsstukken. Het meest recent is deze opvatting neergelegd in de Aanwijzingen voor de regelgeving 1993. In de formele wet dienen in ieder geval de hoofdelementen van de regeling te worden opgenomen en dient elke delegatie zo concreet en nauwkeurig mogelijk te worden begrensd. Daarbij wordt in het algemeen aan delegatie aan de regering de voorkeur gegeven boven delegatie aan de minister. Ook is voor een aantal onderwerpen bepaald dat ze zoveel mogelijk in de formele wet geregeld moeten worden. ${ }^{124}$

Zoals betoogd in paragraaf 4.3 is het aannemelijk (en wenselijk) dat deze opvatting ook geldt voor delegatie in wetten die op de Grondwet zijn gebaseerd, nu in de stukken geen uitzondering hiervoor wordt gemaakt. Zet de tendens van terughoudendheid met delegatie door, dan zien we dat het grondwettelijke delegatieverbod en de geoorloofdheid van delegatie in het algemeen naar elkaar toe

121. De Meij 1990, p.125.

122. Regelgeving centrale overheid, Kamerstukken III 1986-1987, 20038, nr 2, p.6.

123. Behalve soms de opmerking dat de wetgever terughoudend moet zijn met delegeren, zoals bij de behandeling van artikel $104 \mathrm{Gw}$ (belastingen). Zie Kamerstukken II 1978 1979,15575 , nr 3, MyT, p.5. Eveneens bij de bespreking van artikel $132 \mathrm{Gw}$ : terughoudendheid ten aanzien van de instelling van preventief toezicht op provincies en gemeenten. Kamerstukken II 1976-1977, 13990, nr 6 MvA, p.26.

124. Zie ook De Jong 1993, p.73. 
groeien. Want bij een delegatieverbod behoren 'wezenlijke bepalingen' in de formele wet thuis, bij delegatie 'in het algemeen' de hoofdelementen.

Daarmee zijn tegelijkertijd de mogelijkheden voor de formele wetgever om te delegeren wanneer de Grondwet delegatie toestaat, verkleind.

\subsection{Grenzen aan delegatie}

\subsubsection{Grenzen aan delegatie in de 'heersende leer'}

$\mathrm{Nu}$ het delegeren van regelgevende bevoegdheden door de wetgever op zichzelf (behoudens grondwettelijke delegatieverboden) algemeen aanvaard lijkt, is de vraag of er grenzen aan die delegatiebevoegdheid zijn. Het delegatievraagstuk doet zich immers niet alleen met betrekking tot de Grondwet en haar uitvoeringswetten voor, maar nog aanzienlijk frequenter bij andere wetgeving. Zijn er constitutionele grenzen aan delegatie vast te stellen? Biedt de 'heersende leer" hiervoor wellicht aanknopingspunten? ${ }^{125}$

De eerst genoemde bron uit de rede van Hirsch Ballin, de grondwettelijke delegatieterminologie, bepaalt niet in welke mate gedelegeerd mag worden als delegatie wordt toegestaan. Er worden - formeel - geen grenzen aan de delegatie gesteld, behoudens het delegatieverbod. ${ }^{126}$ Materieel gezien hangt de mate waarin delegatie is toegestaan af van de aard, strekking en historie van de betreffende bepaling. ${ }^{127}$ Een 'harde' grens levert dit niet op.

De tweede bron, aanwijzing 7 van de 'Aanwijzingen inzake terughoudendheid met regelgeving', biedt evenmin veel houvast: delegatie moet zoveel mogelijk worden beperkt, en de grenzen van de delegatie dienen in de wet te worden vastgelegd. Welke die grenzen zijn blijkt hier niet uit.

In het rapport Orde in de regelgeving wordt als grens aangegeven dat in de wet ten minste 'de reikwijdte, de structurele elementen en de voornaamste duurzame normen' dienen te worden opgenomen. ${ }^{128}$

125. Op de standpunten in regeringstukken en rapporten van door de regering ingestelde commissie wordt in deze paragraff niet eerst afzonderlijk ingegaan. Zij komen bij een bespreking van de bronnen uit de 'heersende leer" aan bod.

126. Orde in de regelgeving 1985, p.45. Zie ook Van der Vlies 1991, p.94: de problematiek inzake de grenzen van de bevoegdheid tot delegatie is door de Grondwet van 1983 niet opgelost.

127. Orde in de regelgeving 1985, p.46; Heringa 1987, p.77.

128. Orde in de regelgewing 1985, p.45. 


\section{Hoofdstuk 4}

Het kabinetsstandpunt uit 1987 op Orde in de regelgeving, stelt de grenzen aan de bevoegdheid tot delegeren als volgt. De hoofdlijnen van de regeling dienen in de wet zelf te liggen; blanco-delegatie is onwenselijk; de grondwettelijke delegatieverboden moeten worden nageleefd, en ook al is delegatie toegestaan, dan dient soms grote terughoudendheid in acht te worden genomen. ${ }^{129}$

\subsubsection{Grenzen aan delegatie in de Aanwijzingen voor de regelgeving 1993}

Een eerste grens is het grondwettelijke delegatieverbod (aanwijzing 23). Een tweede grens is neergelegd in aanwijzing 22: tenminste de hoofdelementen horen in de formele wet zelf thuis. De toelichting vermeldt dat in ieder geval de reikwijdte van de regeling en de structurele elementen zijn (en in veel gevallen ook de voornaamste duurzame normen). Verder geeft aanwijzing 24 informatie over soorten voorschriften die zoveel mogelijk in de wet opgenomen moeten worden. Aanwijzing 25 bepaalt dat elke delegatie van regelgevende bevoegdheid in de delegerende regeling zo concreet en nauwkeurig mogelijk wordt begrensd.

\subsubsection{Grenzen aan delegatie in de literatuur}

Belinfante/de Reede zien 'in beginsel' geen grenzen aan de delegatiebevoegdheid, behoudens die welke voortvloeien uit de grondwettelijke delegatieterminologie. Ook 'zeer belangrijke' regelingen kunnen door de wetgever aan de Kroon opgedragen worden. Daarbij dient één algemene beperking in acht genomen te worden die is neergelegd in artikel 89 lid 2 Gw: door straffen te handhaven bepalingen dienen een wettelijke grondslag te hebben. ${ }^{130}$

In Koopmans' Compendium wordt, buiten het grondwettelijke delegatieverbod, een tweetal grenzen getrokken. "Een eerste grens hangt samen met het bevoegdheidsterrein van de delegataris zelf. Wanneer de Grondwet bijvoorbeeld aan de wetgever de taak attribueert op bepaalde terreinen de bevoegdheid van de regering te regelen (zie bijw. art. 89 leden 2 en 3 en art. 91 lid 2 Gr.w) dan zou het in strijd met de strekking van de Grondwet zijn indien de wetgever deze taak. overlaat of overdraagt aan de regering zèlf. (...) Een tweede grens is naar heersende opvatting de ongeoorloofdheid van 'blancodelegatie', d.w.z. de wetgever stelt dan zelf in het geheel geen regels, maar delegeert de materie in toto aan de regering $(\ldots)^{2}$, 13i

129. Regelgeving centrale overheid, Kamerstukken II $1986-1987,20038$, nr 2, p.6-7.

130. Belinfante/de Reede 1991 , p. 121

131. Koopmans 1994, p.132-133. 
Met de voorbeelden die genoemd worden bij de eerste grens heb ik moeite. De artikelen 89 lid 2 en 91 lid 2 Gw behelzen een delegatieverbod: het is de wetgever niet toegestaan (nadere) regeling over te laten aan de regering; in artikel 89 lid $3 \mathrm{Gw}$ is delegatie toegestaan, en lijkt mij delegatie aan de regering heel goed mogelijk.

Overigens ben ik het inhoudelijk eens met deze grens. De volgende voorbeelden bieden steun voor deze opvatting. In artikel $106 \mathrm{Gw}$ (De wet regelt het geldstel$s e l$ ) is delegatie toegestaan. Delegatie aan provinciale of gemeentelijke organen lijkt bij dit onderwerp echter niet voor de hand te liggen. Dat geldt ook voor artikel 132 lid $6 \mathrm{Gw}$, met name voor de bepaling dat de wet de financiële verhouding regelt van gemeenten en provincies tot het Rijk. ${ }^{132}$

Volgens Van den Berg stelt de doctrine geen grenzen aan de omvang van de delegatie. De 'pogingen' volgens hem gedaan in Orde in de regelgeving en het kabinetsstandpunt daarop vertonen weinig samenhang. ${ }^{133}$ Desondanks lukt het de wetgever niet steeds om hieraan de hand te houden. Van den Berg geeft voorbeelden op het terrein van het milieuhygiënerecht waarin zeer ruime delegatiebepalingen voorkomen terwijl de materie zwaar ingrijpt in de levenssfeer van de burger. Om de positie van de burger recht te doen is beroep op de administratieve rechter nodig. Van den Berg bepleit openstelling van beroep tegen algemeen verbindende voorschriften om de kwaliteit van deze voorschriften te bewaken. ${ }^{134} 135$

\subsubsection{Conclusie}

In het rapport Orde in de regelgeving en het kabinetsstandpunt daarop kan een pleidooi gelezen worden voor terughoudendheid met delegatie. Die terughoudendheid is ook neergelegd in de nieuwe Aanwijzingen voor de regelgeving. Hoe

132. Voorbeeld ontleend aan Simons, Handelingen II 1978-1979, p.4042, bij de behandeling van thet herzieningsontwerp op provincies en gemeenten. Zie ook paragraaf 4.2.3.1.

133. Van den Berg 1992, p.1235.

134. Van den Berg 1992, p.1233-1234.

135. Ook aan de uitoefening van een gedelegeerde bevoegdheid zijn grenzen gesteld. Zo mag de delegataris de omvang van een gedelegeerde bevoegdheid niet te buiten gaan. Ook mag de inhoud wan gedelegeerde regelgeving niet in strijd zijn met hogere regelingen. Zie Van der Burg 1993 , p.136-137. Voorbeelden uit de jurisprudentie: HR 8 februari 1955, NJ 1955, 254; Rb Arnhem 24 november 1978, NJ 1979, 203; HR 1 juli 1983, NJ 1984,360 (prijzenbeschikking medische hulp aan particulieren); HR 10 april 1984, NJ 1984, 612 (jodiumhoudend broodzout); HR 26 februari 1985, NJ 1985, 595 (art. 7 bloedproefbesluit); VZ ARRS 30 augustus 1990, AB 1991, 567 (visserijwet); ARRS 29 juli $1993, \mathrm{AB} 1994,3$. 


\section{Hoofdstuk 4}

'ruim' er gedelegeerd mag worden is overigens niet eenvoudig op te maken uit de stukken. Eensgezindheid is er over een tweetal 'harde grenzen': het grondwettelijke delegatieverbod en het verbod op blanco-delegatie. De criteria die verder genoemd worden om de delegatie te begrenzen (voornaamste duurzame normen, reikwijdte van een regeling, hoofdelementen etcetera) bieden weinig houvast. Bij deze wat negatieve conclusie dient echter opgemerkt te worden dat het waarschijnlijk ook niet mogelijk is om scherpere criteria te vinden die in het algemeen toepasbaar zijn.

Nu de (omvang van de) delegatie zich op voorhand moeilijk laat voorschrijven (en beheersen) is het niet verwonderlijk dat wetenschappers en politici blijven zoeken naar waarborgen tegen al te vergaande delegatie.

\subsection{En nog steeds: zoeken naar waarborgen}

\subsubsection{Inleiding}

De principiële strijd over het delegatievraagstuk lijkt gestreden. Delegatie is in het algemeen toegestaan, behoudens de grondwettelijke delegatieverboden en blanco-delegatie. Delegatie is noodzakelijk omdat de praktijk niet meer zonder kan. ${ }^{136}$ Als voordelen van delegatie worden vaak genoemd: delegatie dient de doelmatigheid, de flexibiliteit, ontlast het parlement, deskundigheid kan beter ingezet worden en specifiekere groepen van belanghebbenden kunnen gehoord worden. ${ }^{137}$

Maar delegatie heeft ook nadelen. Zo is de zeggenschap van het (democratisch gekozen) parlement over, en de controle op de tot stand te brengen regeling minder; en de rechtszekerheid van de burger kan in het geding komen doordat er geen openbaar debat over de regeling plaatsvindt. ${ }^{138}$

136. Af en toe is er parlementaire ophef over te veel delegatie, die dan soms wordt teruggedraaid. Een voorbeeld is de commotie rond de Machtigingswet 1974 (Stb. 1974, 1). Zie hierover Oostenbrink 1978, p.11. Een recenter voorbeeld betreft de Wet stelselwijziging ziektenkostenverzekering tweede fase (Stb.1991, 587). Besproken door Mazel 1992, p. 30-31.

137. Bok 1984, p.162; Mazel 1992, p.14-24; Koopmans 1994, p.131. Visscher 1994, p.30 noemt als voornaamste reden voor het veelvuldig vóórkomen van delegatie van regelgevende bevoegdheden thet feit dat de wetsvoorstellen vrijwel altijd afkomstig zijn van de regaring.

138. Mazel 1992, p.24; Koopmans 1994, p.131. Op p.25 noemt Mazel nog een praktisch argument tegen delegatie: "tegen normen in de wet zelf kan geen arob-beroep worden ingesteld." Dit zall echter veranderen per 1 januari 1999: dan is beroep mogelijk tegen 
In hoofdstuk 3 hebben we gezien dat in de historie verschillende maatregelen zijn voorgesteld die als waarborgen moeten dienen om de bescherming van de positie van de burger te vergroten. Zo wilde Van der Pot een groter gebruik door het parlement van zijn bevoegdheid om de minister ter verantwoording te roepen. ${ }^{139}$ En in de jaren ' 50 werd door Van der Goes van Naters (aangehaald door Donner) voorgesteld om gedelegeerde regelingen ter inzage te leggen. ${ }^{140}$ De literatuur in de jaren ' 80 en ' 90 geeft een verdere verfijning van die voorstellen te zien. Daarbij zijn met name voorstellen gedaan die de controle van het parlement op gedelegeerde wetgeving beogen te versterken: delegatie onder voorbehoud. ${ }^{141}$

\subsubsection{Delegatie onder voorbehoud}

Er zijn drie hoofdvormen te onderscheiden (vooral bij ontwerpen van algemene maatregelen van bestuur, maar ook voor ontwerpen van ministeriële regelingen): gecontroleerde, tijdelijke en voorwaardelijke delegatie. Als bijzondere vorm wordt in de Aanwijzingen voor de regelgeving 1993, genoemd de delegatie onder het vereiste van goedkeuring bij wet.

Gecontroleerde delegatie houdt in dat de gedelegeerde regeling voor de inwerkingtreding aan het parlement wordt voorgelegd (de 'voorhangprocedure'). Het parlement krijgt een aantal maanden de tijd om op de regeling te reageren en er een discussie over aan te gaan met regering of verantwoordelijke minister. Aanwijzing 36 luidt: ${ }^{142}$ "Gecontroleerde delegatie wordt slechts toegepast ingeval een materie regeling bij wet rechtvaardigt maar zich daarvoor toch niet goed

algemeen verbindende voorschriften en beleidsregels.

139. Zie paragraaf 3.3.1.

140. Zie paragraaf 3.4 .2 .

141. Zie over gecontroleerde delegatie onder meer: Van Angeren 1978, p.350; Bok 1984, p.163-166; Orde in de regelgeving 1985, p. 55 e.v.; De Beaufort 1989, p.78-79; Van der Pot/Donner/Prakke 1989 p.528; Van der Vlies 1991 p.43; Van der Burg 1993. p.142-146; Koopmans 1994, p.139; Kortmann 1994, p.323. Overigens betreft het hier een al tientallen jaren bestaand werschijnsel. Zo geven Van der Pot/Donner, Handboek van het Nederlandse staatsrecht, in de $8 \mathrm{e}$ druk (1968), p.357 voorbeelden uit de "thams vervallen Plantenziektenwetten van 2 april $1898,5.79$, en 17 juli $1911, \$ .212,(\ldots)$ de Nuttige Dierenwet 1914 en (...) de Veewet van 1920." Voorbeelden geven ook Van Angeren 1978, p.349 en Oostenbrink 1978, p.13.

142. Geciteerd wordt uit de Aanwijzingen voor de regelgeving, in werking getreden per 1 januari 1993. De Aanwijzingen bevatten ook modelbepalingen voof wormen van delegatie onder voorbehoud. 


\section{Hoofdstuk 4}

leent vanwege haar sterk technische karakter, de noodzaak wan snelle wijzigingen of de grote omvang van de te stellen regels.'

Bij tijdelijke delegatie dient binnen een korte tijd na de inwerkingtreding van de gedelegeerde regeling een wetsvoorstel te worden ingediend die de regeling gaat vervangen. Aanwijzing 38 bepaalt: 'Tijdelijke delegatie blijf beperkt tot gevallen waarin te stellen voorschriften gelet op hun betekenis bij wet moeten worden vastgesteld maar de totstandkoming van een wet niet kan worden afgewacht."

De derde vorm, woorwaardelijke delegatie; houdt in dat de gedelegeerde regeling aan de Kamers wordt voorgelegd. Binnen een bepaalde termijn (bijvoorbeeld 30 dagen) kan (een vijfde deel van) een der Kamers aangeven dat de geregelde materie alsnog in een wet in formele zin neergelegd dient te worden.

Hierover bepaalt Aanwijzing 42: 'Met toepassing van voorwaardelijke delegatie wordt grote terughoudendheid betracht. Zij wordt slechts toegepast indien in het algemeen voor de regeling van een materie kan worden volstaan met een lagere regeling, maar het wenselijk is de mogelijkheid open te houden dat in bepaalde gevallen woor de totstandkoming de wetsprocedure wordt gevolgd."

Bij delegatie onder het vereiste van goedkeuring bij wet treedt de gedelegeerde regeling in werking, maar dient de goedkeuring voor die regeling bij wet in formele zin te geschieden. Aanwijzing 40 noemt de gevallen waarin deze vorm gebruikt kan worden: 'Delegatie onder het vereiste van goedkeuring bij wet blifft beperkt tot gevallen waarin tijdelijke delegatie aanvaardbaar is en het gaat om regelingen die de Tweede Kamer in beginsel slechts kan goedkeuren of weigeren goed te keuren.' De ratio hiervan is dat er problemen kunnen ontstaan wanneer de Tweede Kamer door middel van de goedkeuringswet wijzigingen brengt in de al geldende regeling.

\subsubsection{Bezwaren tegen delegatie onder voorbehoud}

Delegatie onder voorbehoud is niet onomstreden. ${ }^{143}$ Bok noemt haar een 'ambivalente figuur": in feite gaat het om onderwerpen die zo belangrijk zijn dat ze in

143. Kortmann 1989 wergelijkt de delegatie onder voorbehoud met het legislatieve veto in de Verenigde Staten. "Een legislatief veto wordt gekenmerkt door drie elementen: er is sprake van delegatie door een wet aan de administratie; de administratie maakt gebruik van har $\mathrm{r}$ gedelegeerde bevoegdheid; een of beide hwizen van het Congres zijn bevoegd het door de delegataris genomen besluit ongedaan te maken." (p.98) In de Chadhazaak (Immigration and Naturalization Service v. Chadha, 462 US 919 (1983)) werd deze constructie ongrond wetrig geoordeeld. Zie hierover Flinterman 1983 en De Ridder 1993. Een woorstander toont 2 ich overigens Visscher 1994, p. 795: "Vanuit de norm van democratie ligt het voor de hand delegatie van regelgevende bevoegdheid als regel via een woorhangprocedure van parlementaire goedkeuring afhankelijk te maken." 
een later stadium toch door de formele wetgever zelf geregeld (dienen te) worden. Een ander bezwaar is dat de formele wetgever geneigd kan zijn sneller naar het middel van delegatie te grijpen, als daar een vorm van controle aan gekoppeld wordt. Ook de invloed die achteraf door het parlement op de tot stand gekomen regeling kan worden uitgeoefend is kleiner dan de vooraf uit te oefenen invloed. ${ }^{144}$ En bij veel voorkomend gebruik van gecontroleerde delegatie kan er een zekere verslapping van de aandacht van het parlement plaatsvinden. ${ }^{145}$

Bezwaren tegen gecontroleerde delegatie zijn dat het parlement slechts de normale parlementaire middelen heeft om de regering ter verantwoording te roepen; ook komt gecontroleerde delegatie te vaak voor en verliest ze daardoor haar signalerende functie. ${ }^{146}$ Tijdelijke delegatie komt in feite neer op dubbel regelgeven. ${ }^{147}$ En het bezwaar van voorwaardelijke delegatie is dat de procedure halfslachtig is. Delegatie wordt toegestaan, maar een relatief klein aantal kamerleden kan de delegatie weer terugdraaien. Het middel is te zwaar ten opzichte van het doel (parlementaire betrokkenheid). ${ }^{148}$

Belinfante/de Reede doen het voorstel om het parlement gedelegeerde regelgeving te laten amenderen of vernietigen. De procedure die daarvoor gevolgd zou kunnen worden is die van de goedkeuring van verdragen. ${ }^{149}$ Het parlement dient binnen een bepaalde termijn te reageren op de ter inzage gelegde regeling. Gebeurt dat niet dan wordt de regeling geacht te zijn goedgekeurd. Nadeel van deze werkwijze is volgens Belinfante/de Reede echter dat de extra werkzaamheden het parlement nog meer zullen belasten. ${ }^{150}$

\subsubsection{Samenvatting}

Delegatie onder voorbehoud wil waarborgen scheppen bij het delegatieproces zelf, om parlementaire betrokkenheid te garanderen en daarmee het democratisch

144. Zo is bij tijdelijke delegatie de regeling all in werking en kan het parlement er feitelijk soms moeilijk wat an veranderen.

145. Bok 1984, p.172-173; Rapport bijzondere commissie Vraagpunten, Kamerstukken II $1989-1990,21427$, p.40. De commissie acht de 'zuiverheid en duidelijkheid" van het wetgeving sproces in het geding. Een voorhangprocedure voor algemene maatregelen van bestuur acht de commissie niet wenselijk.

146. Bok 1984, p.175; Orde in de regelgeving 1985, p.56; Mazel 1992, p.28.

147. Bok 1984, p.174; Orde in de regelgeving 1985, p.57; Mazel 1992, p.28.

148. Orde in de regelgeving 1985, p.56-57; Mazel 1992, p.28.

149. Zie additioneel artikel XXI Gw en met name artikel $61 \mathrm{G} w$ oud.

150. Belinfante/de Reede 1991, p.123-124. 


\section{Hoofdstuk 4}

gehalte van de tot stand te brengen regeling. Het verschijnsel lijkt echter haar grootste bloeiperiode te hebben gehad, getuige het afnemend enthousiasme ervoor en de genoemde bezwaren.

Een ander aspect van het zoeken naar waarborgen tegen te vergaande delegatie is in de vorige paragrafen aan de orde geweest: het ontwikkelen van criteria om de omvang van delegatie te begrenzen.

Ook buiten de delegatie om worden waarborgen gezocht om de burger te beschermen tegen de enorme hoeveelheid regels waar hij dagelijks mee te maken heeft. Hierbij kan gedacht worden aan het vergroten van de kwaliteit van de regelgeving, bijvoorbeeld door het ontwikkelen van algemene beginselen van behoorlijke regelgeving. Daarnaast gaan stemmen op om de rechtsbescherming voor de burger te vergroten, bijvoorbeeld door het instellen van een rechtstreeks beroep tegen algemeen verbindende voorschriften en beleidsregels.

\subsection{Samenvatting}

Waar past de Grondwetsherziening 1983 in de delegatiediscussie? Over de geoorloofdheid van delegatie in het algemeen is nauwelijks nog discussie. Het is cornmunis opinio dat delegatie noodzakelijk en in sommige gevallen wenselijk is. Wel kan in bijzondere gevallen de te regelen materie zo belangrijk zijn dat delegatic niet is toegestaan, bijvoorbeeld bij sommige klassieke grondrechten. Die waarborggedachte is verwerkt in de grondwettelijke delegatieterminologie, waarin een onderscheid wordt gemaakt tussen gevallen waarin delegatie is toegestaan en gevallen waarin delegatie is verboden.

Een sterk punt van de grondwettelijke delegatieterminologie is dat de terminologie op zich zelf duidelijk is (delegatie is toegestaan bij het gebruik van een vervoeging van het werkwoord 'regelen'; de woorden 'regels' of 'regeling'; de term 'bij of krachtens').

Zwakke punten zijn er echter ook: de uitleg van het delegatieverbod is in de parlementaire stukken niet eenduidig en wanneer delegatie is toegestaan is de omvang ervan niet begrensd.

Wellicht is het onder invloed van dit laatste dat de discussie over het delegatievraagstuk zich na 1983 toespitst op de grenzen van delegatie. Geprobeerd wordt om de omvang van de delegatie te reguleren. De jongste resultaten daarvan zijn te vinden in de Aanwijzingen voor de regelgeving 1993.

Ook is er na 1983 veel aandacht voor de delegatie onder voorbehoud.

Tot nu toe zijn slechts regeringsstukken en opvattingen van wetenschappers over de delegatieterminologie, de uitleg ervan en de verhouding tot het delegatievraagstuk besproken. Hoe met de grondwettelijk delegatieterminologie wordt om- 
Inwoering delegatieterminologie; delegatievraagstuk na 1983

gegaan in wetgeving en jurisprudentie komt in hoofdstuk 6 aan bod. In hoofdstuk 5 volgen echter eerst enkele relativeringen van de grondwettelijke delegatieterminologie. 
$\therefore$ 


\section{Hoofdstuk 5}

\section{Enkele relativeringen van de delegatieterminologie}

\subsection{Inleiding}

In het vorige hoofdstuk is de grondwettelijke delegatieterminologie aan de orde geweest zoals die betekenis heeft gekregen in verschillende parlementaire stukken op de grondwetsherziening. Daarbij kwam aan de orde hoe de delegatieterminologie na 1983 gehanteerd is in regeringsstukken en literatuur. Ook het delegatievraagstuk in algemene zin en de relatie tot de grondwettelijke delegatieterminologie werd besproken.

Dit en het volgende hoofdstuk kennen een meer praktische aanpak. In paragraaf 5.2 keren we terug naar de Grondwet en de parlementaire behandeling van de herziening van 1983. In die paragraaf zal blijken dat de grondwettelijke delegatieterminologie niet voor alle artikelen in de Grondwet geldt. In paragraaf 5.3 worden enkele grondwetsartikelen besproken waaruit blijkt dat de delegatieterminologie niet consequent is toegepast. En in paragraaf $5.4 \mathrm{zal}$ ingegaan worden op de vraag of in het kader van de implementatie van EG-regelgeving de grondwettelijke delegatieterminologie gevolgd moet worden. Een samenvatting in paragraaf 5.5 besluit dit hoofdstuk.

\subsection{De terminologie geldt niet voor enkele 'oude' artikelen}

De grondwettelijke delegatieterminologie geldt niet voor artikelen uit de Grondwet naar de tekst van 1972 waarvan herzieningsvoorstellen het niet gehaald hebben. Die artikelen zijn: artikel 23; artikel 68', de artikelen 97-102.

\subsubsection{Artikel 23 Grondwet}

In het bijzonder bij de parlementaire behandeling tijdens de grondwetsherziening van artikel 23 (het onderwijsartikel) speelde het delegatievraagstuk een belangrijke rol. In het herzieningsvoorstel was delegatie (onder meer) toegestaan op het punt van bekostigingsvoorwaarden en te stellen deugdelijkheidseisen. Volgens de delegarieterminologie zou daarbij ook aan lagere overheden gedelegeerd

1. Artikel 68 is herzien bij de grondwetsherziening wan 1987 . Het artikel bewat geen delega tieterminologie en wordt hier niet besproken. 


\section{Hoofdstuk 5}

mogen worden. Voor de confessionele partijen was deze consequentie van de delegatieterminologie onaanvaardbaar. Mede hierom werd het herzieningsvoorstel verworpen. ${ }^{2}$ Daarop bleef de tekst van artikel 208 Grondwet 1972 gehandhaafd. ${ }^{3}$ In hoeverre delegatie op grond van de tekst van dat artikel mogelijk is is niet geheel duidelijk. ${ }^{4}$ De grondwettelijke delegatieterminologie geldt in elk geval niet zonder meer voor het huidige artikel 23 Grondwet, voor zover het de mogelijkheid betreft om aan lagere overheden te delegeren. ${ }^{5}$ Een nieuw herzieningsvoorstel uit 1985, dat beoogde delegatie van regelgevende bevoegdheid aan lagere overheden uit te sluiten, werd ingetrokken. ${ }^{6}$

\subsubsection{Artikelen 97-102 Grondwet}

Ook het herzieningsvoorstel voor de defensiebepalingen sneuvelde. De artikelen 97-102 Gw 1983 zijn hierdoor nagenoeg ongewijzigd uit de Grondwet van 1972 overgenomen. ${ }^{7}$ Bij de bezwaren die de verschillende fracties tegen het herzieningsvoorstel hadden speelde het delegatievraagstuk echter geen rol. ${ }^{g}$

2. Kamerstukken II 1975-1976, 13874; Kortmann 1987a, p.129-133; Mentink 1989, p.153159; Heringa/Zwart 1991 , p.91-93; Visscher 1994, p.550-552.

3. Delegatietermen komen voor in lid 2 : bij de wet aangewezen, (...) bij de wet te regelen; lid 3: bij de wet geregeld; lid 4: bij de wet te stellen regels; lid 5: bij de wet geregeld; lid 7: bij de wet te stellen voorwaarden $(. .$.$) , de wet stelt de voorwaarden vast.$

4. Heringa/Zwart $1991, p .91-92$.

5. Kortmann 1987a, p. 145; angehald door Hennekens 1994 , p. 176 .

6. Kamerstukken II 1985 1986, 19032, ingetrokken in april 1990. Het grond wettelijke onderwijsartikel blift de genoederen bezig houden. Zo wraagt Hennekens 1994 , p.173-179 en p.201-207 zich af welke bevoegdheden op het terrein wan het onderwijs gedelegeerd kunnen worden aan provincies en gemeenten, daarbij een onderscheid makend tussen openbaar en bijzonder onderwijs. Zijn conclusie is negatief: vooral uit een oogpunt van rechtseenheid acht hij delegatie niet wenselijk.

7. Delegatietermen die in deze artikelen voorkomen zijin de volgende. Artikel 98 lid 3: de wet regelt; Zij regelt ook (...) ; artikel 99 : bij de wet worden genoemd; artikell 102 lid 2 : volgens algemene regels bij de wet te stellen en lid $3:$ bij de wet vastgesteld. Artikel 100 bevat de woorden 'krachtens een wet', een uitdrukking die strikt genomen niet in de grondwettelijke delegatieterninologie voorkomt.

8. Kamerstukken If 1978-1979, 15467 (R1114); Kortmann 1987a, p.281-283; Heringa/Zwart 1991, p.211-212; Visscher 1994, p.571-572. Belangrijkste reden voor verwerping was het niet meer expliciet vermelden van de krijgsmacht in de Grondwet. 
Een nieuw woorstel (waarbij veel bepalingen uit het eerdere herzieningsvoorstel waren overgenomen) werd in tweede lezing verworpen bij de grondwetsherziening van $1987 .{ }^{\circ}$

De grondwettelijke delegatieterminologie geldt dus ook niet voor de artikelen 97 $102 \mathrm{Gw}$. Discussie of en in welke mate delegatie is toegestaan op grond van de tekst van deze artikelen speelt hier, anders dan bij het politiek gevoelige artikel $23 \mathrm{Gw}$, geen belangrijke rol.

\subsection{De terminologie is niet consequent toegepast}

Hieronder worden enkele artikelen besproken waarbij hetzij de redactie van het artikel, hetzij de uitleg in de parlementaire geschiedenis vragen oproept.

\subsubsection{Artikel 36 Grondwet}

De Koning kan de uitoefening van het koninklijk gezag tijdelijk neerleggen en die uitoefening hervatten krachtens een wet, waarvan het voorstel door of vanwege hem wordt ingediend. De Staten-Generaal beraadslagen en besluiten ter zake in verenigde vergadering.

In de eerste volzin zijn de woorden 'krachtens een wet' gebruikt. ${ }^{10}$ De term 'krachtens' zelfstandig gebruikt komt in de voorgestelde delegatieterminologie niet voor. Tijdens de behandeling van het wetsontwerp op de klassieke grondrechten, gaf de regering te kennen dat de uitdrukking 'krachtens de wet' een bevoegdheid tot delegeren inhoudt."

9. Kamerstukken II 1984-1985, 19017 (R1285) en Kamerstukken II 1985-1986, 19554 (R1308) (tweede lezing); Kortmann 1987a, p.283-288; Heringa/Zwart 1991, p.212. In september 1993 is er wederom een herzieningsvoorstel tot wijziging van de grondwettelijke defensiebepalingen ingediend (In eerste lezing aanvaard. Kamerstukken II 1993 1994, 23327, Stb.1994, 172). Hiermee wordt beoogd de bepalingen omtrent de dienstplicht te wijzigen.

10. Zie ook artikel 89 lid 2 Gw: "krachtens de wet". Gelezen echter in samenhang met het eerste lid van dat artikel is de betekenis duidelijk: de formele wet dient ta bepalen of in een bepaalde algemene maatregel van bestuur straffen mogen worden opgelegd. Zie verder artikel $100 \mathrm{Gw}$ : "krachtens een wet". Dit artikel stamt uit de oude Grondwet; hierop is de delegatieterminologie niet van toepassing. En tenslotte artikel $127 \mathrm{Gw}$ : 'krachtens de wet': de wet bepaalt in welke gevallen provinciale staten en de gemeenteraad aan andere ambten verordeningsbevoegdheid kunnen overlaten.

11. Kamerstukken II 1976-1977, 13872, nr 7 MvA, p.13. Zie paragraaf 4.2.3. 


\section{Hoofdstuk 5}

Deze interpretatie geldt volgens de regering ook voor artikel 36: delegatie is toegestaan, evenals onder de oude Grondwet het geval was. De Staten-Generaal kan bij het opstellen van de delegerende wet grenzen aan de uitoefening van de bevoegdheid stellen, of achteraf; de minister ter verantwoording roepen. ${ }^{12}$ Gelet op deze opvatting van de regering en de tekst van het artikel betekent dat dat er een formele wet nodig is die de neerlegging en hervatting van het koninklijk gezag regelt. Delegatie is mogelijk: genoemd wordt de delegatie naar het koninklijk besluit. Er wordt geen aandacht besteed aan eventuele delegatie naar lagere organen hetgeen in dit verband ook niet voor de hand ligt. Theoretisch gezien zou dat wel kunnen, gelet op de uitleg van de delegatieterminologie. Delegatie naar de regering lijkt evenwel hier de enig toegestane delegatie te zijn. ${ }^{13}$ Nu beoogd is delegatie mogelijk te maken zou het consequenter zijn geweest om de woorden 'bij of krachtens' in het artikel op te nemen. ${ }^{14}$

\subsubsection{Artikel 104 Grondwet}

Belastingen van het Rijk worden geheven wit kracht van een wet. Andere heffingen van het Rijk worden bij de wet geregeld.

De eerste volzin bevat de woorden 'uit kracht van een wet'. De grondwettelijke delegatieterminologie is hier niet toegepast (well weer in de tweede volzin: 'bij de wet geregeld'; hierdoor is delegatie toegestaan). ${ }^{15}$ De regering had als tekst voorgesteld: "Belastingen en andere heffingen van het Rijk worden bij de wet

12. Kamerstukken II 1980-1981, 16034 (R1138), nr 9 MvA, p.23. Zie ook Vermeulen 1990, p.78.

13. In de uitvoeringswet op (onder andere) dit artikel, de Regentschapswet (Wet van 10 juni 1981, Sib.382), is het neerleggen van de functie door het staatshoofd en het weer opnemen darvan an de regering gedelegeerd.

14. Dat dit niet gebeurd is is wellicht te werklaren uit het feit dat dit artikel steunt op artikel 43 oud: "Het Koninklijk gezag wordt mede waargenomen door een Regent, ingeval de Koning krachtens een wet, waarvan het owtwerp door hem is voorgedragen, tijdelijk de witoefening van het Koninklijk gezag heeft neergelegd. Over het ontwerp dier wet, welke tevens in de benoeming van de Regent voorziet, beraadslagen en besiuten de StatenGeneraal in verenigde vergadering.' Zie verder over dit artikel Kortmann 1987, p.164. 165; Dolle 1988, p.270; Heringa/Zwatt 1991, p. 109-111; Akkermans/Koekkoek 1987, p. $447-448 ; 1992$, p. 6 en p. $451-455$.

15. Volgens adnwijzing 52 van de Aanwijzingen voor de wetgevingstechniek 1984 is artikel $104 \mathrm{Gw}$ het enige grondwetsartikel waarin is afgeweken van de grondwettelijke delegatieterminologie. In gelijke zin Kortmann 1987a, p.292. De terminologie in artikel 36 Gw (krachtens een wet) zou ik echter ook als een afwijking van de delegatieterminologie willen beschouwen. 
geregeld." Door het aannemen van een amendement Van Rooijen ${ }^{16}$ werden de woorden 'uit kracht wan een wet' overgenomen uit het oude grondwetsartikel (artikel $188 \mathrm{GW} 1972)^{17}$ en in artikel $104 \mathrm{Gw} 1983$ opgenomen. Hiermee werd beoogd de wetgever te manen terughoudend om te gaan met delegatie op het punt van de belastingen. Onderdelen als de kring van belastingplichtigen, de basis van het tarief, en de belastinggrondslag, dienen in de wet zelf vermeld te worden. ${ }^{18}$ In dit artikel wordt van de grondwettelijke delegatieterminologie afgeweken om de formele wetgever duidelijk te maken dat met delegatie op het terrein van de belastingen terughoudend moet worden omgesprongen. Om meerdere redenen is het de vraag of deze uitzondering hiermee voldoende gerechtvaardigd kan worden. Op de eerste plaats omdat ook de woorden 'uit kracht van een wet' delegatie toestaan en ze strikt genomen geen waarborg bieden tegen (te) vergaande delegatie. ${ }^{19}$ Dat werd door de regering in de MvA nog eens onderstreept. Indachtig de verdere uitleg van de delegatieterminologie benadrukte zij dat ook de aard en strekking van de grondwettelijke bepaling alsmede de traditie rond delegatie van belasting wetgeving een belangrijke rol spelen. ${ }^{20}$

16. Kamerstukken II 1979-1980, 15575, nr 10, Amendement van het lid Van Rooijen c.s.

17. Artikel $188 \mathrm{Gw}$ 1972: 'Geen belastingen kunnen ten behoeve van 's Rijks kas worden geheven, dan uit kracht van een wet. (...) ${ }^{+} \mathrm{Zie}$ voor delegatieperikelen rond het oude belastingartikel: Stellinga 1951, p.140-141.

18. Kamerstukken II 1978-1979, 15575, nr $3 \mathrm{MvT}$, p.5. Zie verder over dit artikel Orde in de regelgeving 1985, p.48-49; Kortmann 1987a, p.292-293; Heringa/Zwart 1991, p.214215; Akkermans/Koekkoek 1992, p.935-940. Zij verwijzen op p.938 naar een rapport uit 1990 van de Commissie ter bestudering van het begrip 'belastingen' van de Vereniging voor Belastingwetenschap (no 184). De Commissie stelt voor artikel $104 \mathrm{Gw}$ te schrappen en in hoofdstuk $1 \mathrm{Gw}$ een nieuw artikel 14a op te nemen: '1. Belastingen kunnen alleen worden opgelegd wit kracht van een wet dan wel uit kracht van een door het wetgevende orgaan van een andere overheid dan het Rijk rechtmatig genomen besluit. 2. Belastingen zijn betalingen die de overheid op grond van een publiekrechtelijke regeling, uitsluitend of mede ter verwerving van inkomsten door de in die regeling aangewezen lichamen, en anders dan op grond vant een privaatrechtelijke overeenkomst, dwangmatig en overeenkomstig algemene regelen wordert."

19. Overigens is dit natuurlijk een probleem dat voor de hele grondwettelijke delegatieterminologie geldt. De interpretatie en uitwoering ervan zal in alle gevallen een kwestie van 'goede wil' zijn. De controle op de naleving is in handen van het parlement zelf, nu de rechter, wegens het toetsingsverbod van artikel $120 \mathrm{Gw}$, hierin vrijwel geen rol kan spelen. Wat betreft de delegatiebeperking in artikel $104 \mathrm{Gw}$ is P.J. Wattel sceptisch: die 'stelt in de praktijk bijzonder weinig voor'. Hij geeft hiervoor twee redenen: het rechterlijk toetsingsverbod en het vage onderscheid tussen belastingen en heffingen (bij heffingen is wel delegatie mogelijk). Zie Wattèl 1993, p.117-1.18.

20. Kamerstukken II 1979-1980, 15575, nr 7 MvA, p.3 en p.5. 


\section{Hoofdstuk 5}

Op de tweede plaats zijn er meerdere grondwetsartikelen op grond waarvan delegatie is toegestaan, maar waarbij terughoudendheid met delegatie geboden is, zie bijvoorbeeld de discussie rond artikel 107, eerste lid Gw. ${ }^{21}$ Hierop wordt nader ingegaan in het volgende hoofdstuk.

\subsection{Invloed van EG-regelgeving: bij implementatie grondwettelijke delegatieterminologie toepassen?}

De vraag die in deze paragraaf aan de orde wordt gesteld is of, bij het uitvoeren van EG-regelgeving, ${ }^{22}$ de grondwettelijke delegatieterminologie in acht genomen dient te worden. Deze vraag is bij de parlementaire behandeling van de grondwetsherziening niet aan de orde gesteld. ${ }^{23}$ Gezien de toenemende invloed van EG-regelgeving op de Nederlandse wetgeving is het interessant deze vraag - kort - aan de orde te stellen. ${ }^{24}$ In de Aanwijzingen voor de regelgeving 1993 zijn hiervoor richtlijnen opgesteld (5.4.1). In paragraaf 5.4.2 worden meningen van enkele auteurs besproken.

\subsubsection{De Aanwijzingen voor de regelgeving 1993}

Hoofdstuk 8 van de Aanwijzingen bevat richtlijnen voor de voorbereiding en implementatie van communautaire regelgeving. ${ }^{25}$ Aanwijzing 339 luidt: 'Bij de afweging op welk niveau van regeling de implementatie dient plaats te vinden,

21. Kamerstukken II 1979-1980, 15046, nr 7 MvA, p.5-6.

22. Bij implementatie zal vooral aan EG-richtlijnen gedacht worden. Maar ook EG-verordeningen vereisen soms implementatie. Zie E.H. Pijnacker Hordijk, Emmott, en hoe verder? in NJB 1994, p.499-504, p.501: "Het kan evenwel niet worden ontkend, dat ook bij verordeningen zich regelmatig de situatie voordoet, dat nadere implementatiemaatregelen van de zijde van de nationale overheden noodzakelijk zijn om het regime van de verordening tot leven te brengen."

23. De vraag naar de precieze verhouding tussen EG-recht en de Nederlandse Grond wet is bij de grondwetsherziening die resulteerde in de Grondwet van 1983 niet aan de orde geweest. Heringa (1992b, p.866) betitelt de Grondwet op dit punt als 'hopelloos verouderd".

24. Enkele kwantitatieve gegevens ower de toenemende invloed van EG-regelgeving: zie een onderzoek van J.H. van den Heuvel, Wetgeving belicht, 1982, die vermeldt (p.24) dat van de door hem onderzochte 468 parlementaire wetten en wetsontwerpen $4.7 \%$ diende ter uitvoering van een EEG-richtijn.

25. Waarbij implementatie is gedefinieerd als 'de uitvoering van een bindend besluit van de Raad of de Commissie van de Europese Gemeenschappen in het nationale recht door middel van het vastsiellen van algemeen verbindende voorschriften" (Aanwijzing 328). 
komt, onverminderd de aanwijzingen 23 en $24,{ }^{26}$ delegatie van regelgevende bewoegdheid eerder in aanmerking naarmate;

a. het te implementeren besluit de Nederlandse wetgever bij de uitvoering minder ruimte laat voor het maken van keuzen van beleidsinhoudelijke aard;

b. het te implementeren besluit gedetailleerder van aard is;

c. de termijn waarbinnen de implementatie moet geschieden korter is:

d. vaker verwacht mag worden dat in de toekomst het te implementeren besluit wijzigingen zal ondergaan,

$e$. in het bestaande systeem van regelgeving waarin de implementatieregeling een plaats zal krijgen, vaker is gekozen woor delegatie van regelgevende bevoegdheid. ${ }^{27}$

26. Deze aanwijzingen zijn besproken in paragraaf 4.3 .

27. Een in het licht van deze aanwijzing opmerkelijk amendement is het amendement Van der Vaart/Koetje ter wijziging van de Wet Milieubeheer en de Wet verontreiniging oppervlaktewater. Dit amendement houdt onder meer in dat, waar beide wetten regeling bij algemene maatregel van bestuur verlangen, eem ministeriële regeling voldoende (zelfs verplicht) is wanneer het om implementatie van EG-regelgeving gaat. De betreffende ministeriële regeling wordt een maand voor inwerkingtreding voorgehangen bij beide Kamers wan de Staten-Generaal. Zie bijwoorbeeld artikel 21.6 lid 7 Wet milieubeheer: 'Hetgeen ingevolge deze wet bij algemene maatregel van bestuur kan worden geregeld, wordt in afwijking daarvan bij ministeriële regeling geregeld, indien de regels uitsluitend strekken ter uitvoering van een voor Nederland verbindend verdrag of een voor Nederland verbindend besluit van een volkenrechtelijke organisatie, tenzij voor een juiste uitvoering wijziging van een algemene maatreget van bestuur of de wet noodzakelijk is. Indien de wijziging van een algemene maatregel van bestuur noodzakelijk is, wordt daarvan, gelijktijdig met de voordracht aan Ons gemotiveerd kennisgegeven aan de Staten-Generaal, onder vermelding van de korte inhoud van de voorgenomen algemene maatregel van bestuur. Het ontwerp van een ministerielle regeling als bedoeld in de eerste volzin wordt ten minste een maand voordat de regeling wordt vastgesteld, toegezonden aan de Staten-Generaal. (...)' Kamerstukken 1993-1994, 22690, nr 10. Zie hierover H. Hijmans, Het amendement Van der Vaart/Koetje: over het primaat van de ministeriële regeling, in RegelMaat 1993, p.213214. Hijmans wijst erop dat deze keuze van de Tweede Kamer in strijd is met Aanwijzing 26 ('1. Delegatie aan een minister van de bevoegdheid tor het stellen van algemeen verbin dende voorschriften wordt beperkt tot voorschriften van administratieve aard, witwerking van de details van een regeling, voorschriften die dikwijls wijziging behoeven en voorschriften waarvan te voorzien is dat zij mogelijk met grote spoed moeten worden vastgesteld.

2. Delegatie aan een minister van de bevoegdheid tot het vaststellen van algemeen verbindende voorschriften is ook toegestaan indien het gaat on het verwerken in de Nederlandse wetgeving van internationate regelingen die de Nederlandse wetgever, behoudens op ondergeschikte punten, geen ruimte laten voor het maken van keuzen van beteidsinhoudelijke aard.") 


\section{Hoofdstuk 5}

Uit deze aanwijzing vallt niet af te leiden of de grondwettelijke delegatieterminologie toegepast moet worden, wanneer de uitvoeringswetgeving (mede) een grondwettelijk geregeld onderwerp betreft. Fen indicatie hiervoor vinden we echter wel in de Toelichting op deze aanwijzing: 'Aan de in deze aanwijzing bedoelde afweging moet steeds de vraag vooraf gaan of de Grondwet dan well het primaat van de wetgever vereist dat voorschriften in de wet zelf moeten worden opgenomen: zie de aanwijzingen 23 en 24. (...)' Deze toelichting suggereert dat, waar nodig, inderdaad de delegatieterminologie toegepast dient te worden. Daarmee lijkt de hierboven gestelde vraag (bij uitvoering van EG-regelgeving de grond wettelijke delegatieterminologie respecteren?) in positieve zin beantwoord.

\subsubsection{Meningen van enkele schrijvers}

In haar dissertatie 'Uitvoering van EG-verordeningen in Nederland", stelt Bonnes voor om, voor de implementatie van EG-verordeningen, eenvormige delegatiebepalingen in een algemene machtigingswet (of eventueel in de Aanwijzingen voor de regelgeving 1993) op te nemen. ${ }^{28}$ De door haar voorgestelde bepaling luidt (voor zover hier relevant): 'Algemeen verbindende voorschriften die uitsluitend strekken tot uitvoering van een verordening of een algemene beschikking, vastgesteld door de Raad of de Commissie van de Europese Gemeenschappen. kunnen bij of krachtens algemene maatregel van bestuur worden vastgesteld, voor zover de Grondwet zich daartegen niet verzet.' In de toelichting hierop betoogt Bonnes dat de clausule "voor zover de Grondwet zich daartegen niet verzet" betekent dat het grondwettelijk delegatieverbod gerespecteerd moet worden. ${ }^{29}$ Bonnes gaat hierbij echter niet in op de gevallen waarin krachtens de grondwettelijke delegatieterminologie delegatie is toegestaan, maar er wel een formele wet aan de regeling van een onderwerp ten grondslag moet liggen. Het is de vraag of ook dan de delegatieterminologie gevolgd dient te worden en er een specifieke wettelijke grondslag dient te zijn bij implementatievoorschriften.

Twijfel of ann het grondwettelijk delegatieverbod steeds voorrang moet worden gegeven toont Kortmann: "Daar waar de Grondwet regeling bij formele wet voorschrijft valt naar huidige inzichten aan implementatie bij formele wet niet te ontkomen. Het is echter de vraag of de Grondwet dan wel de interpretatie ervan op dit punt nog geheel bij de tijd zijn. Naar analogie van artikel 91 , derde lid, GW, zou het standpunt kunnen worden ingenomen dat het EEG-recht tot afwijken van de Grondwet kan noodzaken ook al is het EEG-werdrag indertijd niet met een twee derden meerderheid goedgekeurd. Nu het EEG-recht een eigen rechts-

28. Bonnes 1994, p.300-301.

29. Bonnes 1994, p.302-303. 
orde vormt en de soevereiniteit - zij het op een beperkt terrein - aan de lidstaten is ontvallen, kan de stelling worden verdedigd dat bij door het EEG-recht veroorzaakte noodzaak tot implementatie, deze implementatie kan geschieden onder afwijking van de Grondwet. "30

Kortmanns redenering is zoals hierboven geschetst, niet overgenomen in de Aanwijzingen voor de regelgeving 1993. Op grond van deze Aanwijzingen is er een formeel-wettelijke grondslag nodig wanneer de Grondwet regeling bij (of krachtens) de wet eist.

Het is denkbaar dat zich gevallen voordoen waarin de grondwettelijke delegatieterminologie een te star kader is. Dat kan bijvoorbeeld het geval zijn bij implementatie van een EG-verordening, die slechts op details nog uitvoering in de Nederlandse rechtsorde behoeft. Mij lijkt dat de EG-verordening als een specifieke wettelijke grondslag kan worden aangemerkt, terwijl de Nederlandse uitvoering geschiedt bij algemene maatregel van bestuur of ministeriële regeling.

Het grondwettelijk delegatieverbod verdient echter (voorlopig) strikte navolging. Dit verbod speelt met name bij grondrechten een belangrijke rol, in die zin dat het verbod waarborgen voor de burger inhoudt. Bepaalde regelingen mogen alleen door de formele wetgever zelf getroffen worden. Nu de legitimatie van EG-regelgeving in veel gevallen nog een gebrekkige is, kan deze regelgeving niet als basis dienen voor de onderwerpen waarbij de Nederlandse grondwet een regeling bij formele wet eist.

30. Kortmann 1991, p.47. Vergelijk ook de discussie rond de grondwettigheid van het Verdrag van Maastricht. Zie Heringa, De verdragen van Maastricht in strijd met de Grondwet. Goedkeuring met twee derde meerderheid? in NJB 1992, p.750-75 (Heringa $1992 \mathrm{a}$ ). Ook L.F.M. Besselink, Het Verdrag van Mastricht wijkt ook op andere punten af van de Grondwet en eveneers van het Statuut, in NJB 1992, p.864-865 pleitte voor goedkeuring met twee derde meerderheid. Daarentegen werd geen strujd met de Grond wet aanwezig geacht door bijwoorbeeld J.G. Brouwer, Wijkt het Unie-Verdrag van Maastricht af van de Grondwet of van het Statuut?, in NJB 1992, p.1045-1049; M.C. Burkens en B.P. Vermeulen, Maastricht in strijd met de Grondwet?, in NJB 1992, p.861-862; C.A.J.M. Kortmann, De werdragen van Maastricht niet in strijd met de Grondwet, in NJB 1992. p. $862 ;$ I. Sewandono, Grondwettelijke bezwaren tegen Maastricht zijn ver gezocht, in NJB 1992, p.863. Zie ook Heringa's reactie, Naschrift in NJB 1992, p.865-866. 


\section{Hoofdstuk 5}

\subsection{Samenvatting}

De grondwettelijke delegatieterminologie geldt niet voor alle grondwetsartikelen. De herzieningswoorstellen voor onderwijs en defensie werden tijdens de parlementaire behandeling verworpen en de bepalingen over deze onderwerpen uit de oude Grondwet overgenomen (de artikelen 23 en $97-102 \mathrm{Gw} 1983$ ). Het delegatievraagstuk speelde bij de behandeling van het onderwijsvoorstel een belangrijke rol; bij de bepalingen over defensie echter nauwelijks.

Een gevolg van de verwerping van de herzieningsvoorstellen, en het overnemen van de 'oude" teksten is, dat op het eerste oog de onduidelijkheid over toepassing van de delegatieterminologie toeneemt. Kennisneming van de parlementaire stukken op de grondwetsherziening blijkt eens te meer van groot belang om de delegatieterminologie correct (al dan niet) uit te voeren.

Dat geldt ook voor de artikelen die een afwijkende terminologie hanteren: hierboven zijn de artikelen 36 en $104 \mathrm{Gw}$ besproken. In beide gevallen was die afwijking mijns inziens niet noodzakelijk geweest. Bij artikel $36 \mathrm{Gw}$ is dit nogal geruisloos gebeurd, bij artikel $104 \mathrm{Gw}$ bewust. Dit laatste is, evenals de verwerping van de herzieningsvoorstellen, aan de krachten in het politieke spel te wijten. Kan de regering nog wél toegerekend worden dat de uitleg van de betekenis van de delegatieterminologie niet in alle opzichten duidelijk is ${ }^{31}$, haar past (in deze gevallen) geen blaam voor de verwerping of de amendering van de herzieningsvoorstellen.

Bij implementatie van EG-regelgeving dient volgens de Aanwijzingen voor de regelgeving 1993 de grondwettelijke delegatieterminologie gerespecteerd te worden. Dat geldt in het bijzonder voor het grondwettelijke delegatieverbod. Gelet op de waarborgen die het delegatieverbod beoogt te bieden is er ook geen reden om daar van af te wijken.

31. Zie de paragrafen 4.2 .5 en 7.3.5. 


\section{Hoofdstuk 6}

\section{Uitwerking van de delegatieterminologie in wetgeving en jurisprudentie}

\subsection{Inleiding}

In deze paragraaf komen enkele voorbeelden van de uitvoering van de grondwettelijke delegatieterminologie in wetgeving aan de orde (6.1). In hoeverre organieke wetgeving op andere punten in strijd is, of op gespannen voet staat, met grondwettelijke bepalingen komt hier niet aan de orde. ${ }^{1}$

Veel van het onderstaande is gebaseerd op materiaal van andere auteurs. Het totaal aan (op de Grondwet gebaseerde) uitvoeringswetgeving is aanzienlijk ${ }^{2}$. Daarom was het binnen het kader van deze studie niet mogelijk alle uitvoeringswetgeving zelf te onderzoeken.

De meeste aandacht gaat uit naar het grondwettelijke delegatieverbod, maar ook daar waar delegatie mogelijk is gemaakt is het interessant om te bekijken in hoeverre de formele wetgever van die mogelijkheid gebruik heeft gemaakt (waarbij 'veel' of 'weinig' delegatie natuurlijk niet op voorhand iets zegt over de kwaliteit van de regelgeving). Een conclusie volgt in paragraaf 6.2.9.

Jurisprudentie waarin de grondwettelijke delegatieterminologie een rol speelt komt aan bod in paragraaf 6.3. Ook hier gaat het om typerende voorbeelden, en is niet beoogd volledig te zijn.

Een conclusie in paragraaf 6.4 besluit dit hoofdstuk.

\subsection{Delegatieterminologie en uitvoeringswetgeving}

\subsubsection{Artikel 2 Grondwet}

Artikel 2 lid 2 luidt: 'De wet regelt de toelating en de uitzetting van vreemdelingen'.

1. Zie bijvoorbeeld de discussie over de toelatbaarheid om de opkomstplicht bij de dienstplicht af te schaffen zonder grondwetswijziging. (Inmiddels wordt een grondwetswijziging voorbereid. In eerste lezing is een voorstel aanwaard: Stb.1994, 172.) Zie ook de discussie over de vraag of de Kaderwet Bestuur in verandering (Wet van 21 april 1994, Stb.396) in strijd is met de grondwettelijke bepalingen.

2. Voor de grondrechten (de artikelen 1-23 Grondwet) is - per artikel - een overzicht van uitwoeringswetgeving te vinden bij Gerbranda/Kroes 1991. 


\section{Hoofdstuk 6}

Op grond van de woorden 'de wet regelt" is delegatie toegestaan. De positie van vreemdelingen is geregeld in de Vreemdelingenwet ${ }^{3}$, "een gecompliceerde regeling die gedurende haar toepassing is overgroeid met een woud van uitvoeringsregelingen en circulaires. "4 Welke waarborg biedt deze bepaling? Inhoudelijk voor de positie van vreemdelingen (en vluchtelingen) geen enkele, nu de Grondwet alleen voorschrijft dat er een dergelijke wet moet komen. Van de mogelijkheid om te delegeren wordt bovendien ruim gebruik gemaakt en daarnaast wordt veel beleid vastgelegd in beleidsregels. De veelheid van lagere regels (gedelegeerde regelingen of beleidsregels) hoeft op het eerste gezicht niets te zeggen over de kwaliteit van de wetgeving, maar een indicatie is wel de klacht over de ontoegankelijkheid en onoverzichtelijkheid van de vreemdelingenwetgeving. ${ }^{5}$

Artikel 2 lid 4 luidt: 'leder heeft het recht het land te verlaten, behoudens in de gevallen, bij de wet bepaald.

Delegatie is verboden, gelet op de woorden 'bij de wet bepaald'. In de literatuur is de aandacht uitgegaan naar artikel 21 lid 1 sub b van de Wet op de inlichtingen- en veiligheidsdiensten ${ }^{6}$, walarin de regering de bevoegdheid kreeg om bij $\mathrm{KB}$ landen aan te wijzen waarnaar bepaalde ambtenaren niet mogen reizen. ${ }^{7} \mathrm{De}$ vraag is of deze bestuursbevoegdheid miet in strijd komt met het grondwettelijke

3. Wet van 13 januari 1965, Stb.40, ingrijpend gewijzigd bij wetten van 23 december 1993 , Stb. 707 en Stb. 690 en wet van 9 december 1993, Stb. 725. Zie ook het Vreemdelingenbesluit, besluit van 19 september 1966, Stb.387, gewijzigd bij besiviten van 30 december 1993, Stb. 1994, 8; 23 februari 1994, Stb. 146 en 7 april 1994, Stb.265.

4. Kortmann 1994, p. 381. Zie ook NJB 1995, aflevering 2, Urgente kwesties in het Vreemdelingenrecht.

5. Een ander punt is dat in de beleidsregelgewing eisen aan vreemdelingen worden gesteld die in strijd komen met andere grondrechten. Zo wordt in de Vreemdelingencirculaire als voorwaarde voor de afgifte van een verblijfsvergunning geëist dat de vreemdeling zich onderwerpt aan een tuberculose-onderzoek. Een specifieke wettelijke grondslag is daarvoor in de Vreemdelingenwet niet te winden. Dit zou wel moeten gelet op de artikelen 10 en 11 Gw. Zie hierover J.C.J. Dute, De wetgeving ter bestrijding van infectieziekten, Ars Aequi Libri Nijmegen 1994, p.86. Kritisch over het vreemdelingenrecht is ook Th. Holterman,
in NJB 1995, p.596.

6. Wet van 3 december 1987 , Stb.635.

7. Het meest recente $\mathbb{K B}$ is van 22 april 1993, Stb. 249 . 
delegatieverbod. De regering achtte geen strijd aanwezig ${ }^{8}$, diwerse auteurs verschillen van mening. ${ }^{9}$

In paragraaf 4.2 .5 is, op basis van de parlementaire stukken, het delegatieverbod uitgelegd als een opdracht aan de wetgever om in de formele wet de wezenlijke bepalingen vast te leggen. Regeling van detailpunten mag aan lagere regelgevers overgelaten worden. Het toedelen van discretionaire bestuursbevoegdheden is niet toegestaan, de formele wetgever dient zelf de norm te stellen. Artikel 21 lid 1 aanhef en sub $b$ Wet op de inlichtingen-en veiligheidsdiensten luidt: 'Het is de ambtenaar van een dienst verboden, anders dan in de uitoefening van zijn functie, te reizen naar dan wel te verblijven in (...) b. bij koninklijk besluit aangewezen landen, waarin het verblijf door de ambtenaar van een dienst een bijzonder risico voor de veiligheid of andere gewichtige belangen van de Staat kan opleveren.' In hoeverre men hier strijd met het delegatieverbod aanwezig acht is een kwestie van interpretatie. Olde Kalter verdedigt de bepaling omdat de wet de voornaamste normen stelt: de wet wijst de kring van betrokken ambtenaren aan; de inhoud van de verplichting wordt vastgelegd (een reisverbod) en de categorieën landen waarvoor het reisverbod geldt worden in de wet omschreven ${ }^{10}$

Anderzijds kan; gelet op de formulering van deze bevoegdheid, (bijzonder risico voor de veiligheid of andere gewichtige belangen van de Staat) geconstateerd worden dat de regering veel beoordelingsruimte wordt gelaten, hetgeen op gespannen voet staat met de uitleg van het delegatieverbod.

\subsubsection{Artikel 6 en artikel 9 Grondwet}

Artikel 6: 1. 'Ieder heeft het recht zijn godsdienst of levensovertuiging, individueel of in gemeenschap met anderen, vrij te belijden, behoudens ieders verantwoordelijkheid volgens de wet. "2. 'De wet kan ter zake van de uitoefening van dit recht buiten gebouwen en besloten plaatsen regels stellen ter bescherming van de gezondheid, in het belang wan het verkeer en ter bestrijding of voorkoming van wanordelijkheden."

8. Bijwoorbeeld Handelingen I 1987-1988, p.221.

9. Zie hierover Olde Kalter 1988, p. 54 , die geen strijd aanwezig acht: de bevoegdheid vam de regering beschouwt hij als een uitvoeringsbewoegdheid; Kortmann, Constitutioneel recht, 1990, p.321, die hiermee het delegatieverbod wel erg opgerekt acht; Vermeulen 1990 , p.79 en 81 , die constateert dat in theorie misschien wel niet voldaan is aan het systeem van de grondwettelijke delegatieterminologie, maar die de gang van zaken uit praktisch oogpunt te verdedigen acht; Kortmann 1994, p.388.

10. Olde Kalter 1988, p.54. 


\section{Hoofdstuk 6}

Artikel 9: I. 'Het recht tot wergadering en betoging wordt erkend, behoudens ieders verantwoordelijkheid volgens de wet.'2. 'De wet kan regels stellen ter bescherming van de gezondheid, in het belang van het verkeer en ter bestrijding of voorkoming wan wanordelijkheden.

In beide artikelen is in het eerste lid delegatie verboden, en in het tweede lid delegatie toegestaan. Uitwerking van beide artikelen vindt onder meer plaats in de Wet Openbare Manifestaties (WOM) ${ }^{11}$ Artikel 9 WOM (een uitwerking van lid 1 van de artikelen 6 en 9 , nu een verwijzing naar de beperkingsgronden van lid 2 van die artikelen ontbreekt) geeft de burgemeester de bevoegdheid om aanwijzingen te geven aan degenen die in de nabijheid van een gebouw van het Internationaal Gerechtshof, een diplomatieke vertegenwoordiging of een volkenrechtelijke organisatie een bijeenkomst houden tot het belijden van godsdienst of levensovertuiging, of deelnemen aan een vergadering of betoging, en die zich gedragen op een manier die het functioneren van die instellingen aantast. Handelt men in strijd met die aanwijzingen dan kan de burgemeester de deelnemers aan de bijeenkomst opdracht geven de bijeenkomst te beëindigen en uiteen te gaan. Ook hier heeft de burgemeester een discretionaire bestuursbevoegdheid, want wanneer tast een gedraging het functioneren van een instelling aan, en welk soort aanwijzingen mogen dan gegeven worden $?^{12}$ Weliswaar stelt de WOM in artikel 9 de norm dat deelnemers aan bijeenkomsten zich moeten onthouden van gedragingen die het functioneren van een bepaalde instelling aantasten ${ }^{13}$, maar die norm is toch betrekkelijk vaag en biedt de burgemeester een (te) ruime interpretatievrijheid. De bevoegdheid lijkt dan ook op zijn minst op gespannen voet te staan met het grondwettelijke delegatieverbod.

Een soortgelijk probleem doet zich voor met betrekking tot de twee artikelen in de Gemeentewet ${ }^{14}$ die de noodbevoegdheden van de burgemeester betreffen. ${ }^{15}$

11. Wet van 20 april 1988, Stb.157. Ook de Zondagswet en de Wet op de veiligheids- en inlichtingendiensten bevatten bepalingen die beide grondrechten betreffen.

12. Zie onder meer Heringa 1985, die een te rume bevoegdheid aanwezig acht; Vermeulen 1990 , p.81; Kortmann 1994, p.409, die de bevoegdheid van de burgemeester "slechts te verdedigen (acht), indien men de alanwijzingsbevoegdheidziet als een uitvoeringsbevoegdheid betreffende artikel 9 , eerste lid, van de wet."

13. Aldus ook het standpunt van de regering. Zie Kamerstukken IT 1985-1986, 19427, nг 3 MvT, p.24; Kamerstukken II 1986-1987, 19427, nr 5 MvA, p.19; Handelingen II 1987 1988 p.2240; Kamerstukken I 1987-1988, 19427, nr 135b MvA, p.6-7: de uitvoeringsbevoegdheid van het bestuur, is gericht op de concretisering en individualisering wan de verantwoordelijkheid volgens de wet.

14. Wet van 14 februari 1992, Stb. 96 ; zie ook de tekstplaatsing van 26 november 1993 , Stb.611. 
De burgemeester krijgt vrij ver gaande bevels- en noodverordeningsbevoegdheden geattribueerd, en mag daarbij afwijken van andere dan bij de Grondwet vastgestelde voorschriften. Verdraagt dit systeem zich met het grondwettelijke delegatiestelsel? In artikel 176 , lid 1 Gemeentewet krijgt de burgemeester de bevoegdheid gedelegeerd om algemeen verbindende voorschriften te stellen ter handhaving van de openbare orde of beperking van gevaar (wanneer een situatie als bedoeld in artikel 175 lid 1 Gemeentewet zich voordoet).

Deze bevoegdheid botst met het in lid 1 van de artikelen 6 en $9 \mathrm{Gw}$ neergelegde delegatieverbod ${ }^{16}$ : de bevoegdheid gaat immers verder dan het stellen van detailpunten.

Lid 2 van de artikelen 6 en 9 Gw staat wel delegatie van regelgevende bevoegdheid toe, echter voor zover het de daar weergegeven doelcriteria betreft. Deze doelcriteria sporen niet met de doelcriteria uit de artikelen 175 en 176 Gemeentewet. ${ }^{17}$ Zou dit probleem al op te lossen zijn, door de doelcriteria uit de grondwetsartikelen (welwillend) in te lezen in de artikelen 175 en 176 Gemeentewet, dan rijst als volgende probleem dat de grondwettelijke delegatieterminologie voor de inbreuk op een grondrecht vereist dat hiervoor een specifieke wettelijke basis aan te wijzen is. Een algemene verordenende bevoegdheid is niet voldoende. ${ }^{18}$ Voor wat betreft de bevoegdheid van de burgemeester op grond van artikel 175 lid 1 Gemeentewet om 'alle bevelen' te geven die hij nodig acht, gaat dezelfde redenering op. Er is strijd met het delegatieverbod uit lid 1 van de artikelen 6 en

15. Artikel 175 Gemeentewet: ' 1 . In geval van oproerige beweging, van andere ernstige wanordelijkheden of van rampen, dan wel van ernstige vrees voor het ontstaan daarvan, is de burgemeester bevoegd alle bevelen te geven die hij ter handhaving van de openbare orde of ter beperking van gevaar nodig acht. Daarbij kan van andere dan bij de Grondwet gestelde voorschriften worden afgeweken. 2. (...)' Artikel 176 Gemeentewet: ' 1 . Wanneer een omstandigheid als bedoeld in artikel 175 , eerste lid, zich voordoet, kan de burgemeester algemeen verbindende voorschriften geven die ter handhaving vain de openbare orde of ter beperking van gevaar nodig zijn. Daarbij kan van andere dan bij de Grondwet gestelde voorschriften worden afgeweken. (...)'

16. Zie paragraaf 4.2.5. Delegatie van regelgevende bevoegdheid is niet toegestaan, tenzij het om het regelen van detailpunten gaat. Ook is attributie van discretionaire bestuursbevoegdheden bij een delegatieverbod niet geoorloofd.

17. Kortmann 1994, p. 476 .

18. In gelijke zin A. Meijer, De burgemeester in (nood)toestand, NJB 1987, p.237 e.v. Anders: J. Bokma/H.P. Vonhögen, Artikel 6 en artikel 9 Grondwet: Zwakke waarborgen, gebrekkige uitwerking, in De wetgeving ter uitvoering van Hoofdstuk 1 van de Grondwet, W.E.J. Tjeenk Willink, Zwolle 1988, p.97-125, p.114: "De formele wetgever geeft zelf de norm aan; (...) Daar het hier in zekere zin toch wel gaat om een noodbevoegdheid kan de formele wetgever uiteraard de norm niet nader specificeren. (...) De bevoegdheid van de burgemeester is slechts in schijn discretionair." 


\section{Hoofdstuk 6}

$9 \mathrm{Gw}$ nu het een discretionaire bestuursbevoegdheid betreft. En, (zo de doelcriteria wit lid 2 van de artikelen 6 en $9 \mathrm{Gw}$ al te verenigen zijn met de doelcriteria uit de artikelen 175 en 176 Gemeentewet) vindt dan de inbreuk van de beschermde rechten plaats zonder specifieke wettelijke basis.

De conclusie kan zijn dat deze noodbevoegdheden van de burgemeester problematisch zijn en in strijd komen met de grondwettelijke delegatieterminologie. ${ }^{19}$

\subsubsection{Artikel 10 lid 2 en 3 Grondwet}

Lid 2: 'De wet stelt regels ter bescherming van de persoonlijke levenssfeer in verband met het vastleggen en verstrekken van persoonsgegevens."

Lid 3: 'De wet stelt regets inzake de aanspraken van personen op kennisneming van over hen vastgelegde gegevens en van het gebruik dat daarvan wordt gemaakt, alsmede op verbetering van zodanige gegevens."

Delegatie is op grond van beide leden toegestaan (de wet stelt regels). Uitwerking geschiedt in de Wet Persoonsregistraties (WPR) ${ }^{20}$ en de Wet Politieregisters ${ }^{21}$. De WPR kent 55 artikelen. Van de mogelijkheid om te delegeren wordt in 16 (leden van) artikelen gebruik gemaakt. ${ }^{22}$ In de Wet Politieregisters (33 artikelen) vindt in 11 (leden van) artikelen delegatie plaats. ${ }^{23}$ Het NJCM-Commentaar op dit wetsvoorstel stelt aan de orde in hoeverre dit voorstel ${ }^{24}$ overeenstemt met de Grondwet, nu zo ruim van delegatiemogelijkheden gebruik wordt gemaakt. ${ }^{25}$

19. Op vergelijkbare wijze doet dit probleem zich voor bij artikel 7 lid $1 \mathrm{Gw}$. Zie Meijer 1987 , p.237-238 en Kortmann 1994, p.476.

20. Wet van 28 december 1988, Stb.665. Zie hierover J.M.A. Berkvens/J.E.J. Prins, redac. tie, Priwacyregulering in theorie en praktijk, Kluwer Deventer 1994. Zie ook L. Verhej 1992, p. $351-366$.

21. Wet van 21 juni 1990, Stb.414.

22. Gerbranda/Kroes 1991, deell 3, p. 10 1.49 spreken over een kaderwet: "Concrete uitwerking van de bescherming van de persoonllijke levenssfeer bij persoonsregistraties zal moeten geschieden door middel van amvb's, reglementen en actief gedrag van de betrokken burgers. "Zie ook Gerbranda/Kroes 1993, p.42-44.

23. Zowel de Raad wan State als de Tweede Kamer en Eerste Kamer hadden bezwaar tegen de mate van delegatie in het wetsvoorstel. Het argument wan de regering om van nadere uitwerking in de wet af te zien was tijdgebrek: zij wilde de wet tot stand brengen voor de beoogde inwerkingtreding van artikel ID Gw: Z̈ie Gerbranda/Kroes 1993, p.45-47.

24. Het wetswoorstel en de wettekst stemmen op het punt wan delegatie voor een belangrijk deel overeen. De tweede volzin van artikel 21 lid 1 van het wetsvoorstel komt in de wet niet meer voor. Deze zin luidde: "Omtrent het bepaalde in de eerste volzin kunnen bij algemene matregel wan bestuur nadere regels worden gesteld. 'In lid 3 zijn de woorden 'of krachtens" vervallen. 
In zijn algemeenheid zeggen eijfers over aantallen delegaties natuurlijk maar weinig. Belangrijker zijn vragen als aan wie gedelegeerd wordt, en welke onderwerpen gedelegeerd worden. Eerst na beantwoording van deze vragen kan een oordeel worden gegeven over de 'kwaliteit' van de formele wet en de daarop gebaseerde regelgeving in het kader van het delegatievraagstuk.

Uitwerking vindt eveneens plaats in de wet Gemeentelijke basisadministratie persoonsgegevens (GBA) ${ }^{26}$ Ook in deze wet wordt gebruik gemaakt van delegatie. Uit de MvA: "Het beleid in dezen is dat in de wet zelf ten minste de hoofdelementen van de regeling dienen te worden opgenomen. (...) Vanuit een oogpunt van toegankelijke regelgeving verdient het echter soms de voorkeur in de wet zelf geen materiële normen op te nemen maar het aan de lagere regelgever over te laten een integrale materiële regeling tot stand te brengen. (...) Een en ander heeft in het wetsvoorstel op diverse plaatsen tot delegatie en subdelegatie geleid. Voor zover de behoefte aan regelgeving geen betrekking heeft op het stelsel als geheel en in de behoefte kan worden voorzien door de gemeentebesturen is aan hen regelgevende bevoegdheid verleend (bijvoorbeeld de artikelen 8 , 76 en 79)." ${ }^{27}$ Gerbranda/Kroes vragen zich af of bij de regeling van deze materie niet de rechtszekerheid en de rechtseenheid voorop zouden moeten staan, waardoor de formele wetgever meer zelf had moeten regelen. ${ }^{28}$

Een voorlopige conclusie kan zijn dat de formele wetgever bij de uitwerking van de leden 2 en 3 van artikel $10 \mathrm{Gw}$ ruim gebruik heeft gemaakt van de delegatiemogelijkheden.

\subsubsection{Artikel 18 lid 2 Grondwet}

'De wet stelt regels omtrent het verlenen van rechtsbijstand aan minder draagkrachtigen.'

De uitvoeringswet op dit artikel, de Wet op de rechtsbijstand, ${ }^{29}$ bevat onder meer de voorwaarden (vaak in vage bewoordingen gesteld) waaronder rechtsbij-

25. NJCM-Bulletin 1987,p.251 e.v. (L.Verhey). Aangehaaldbij Gerbranda-Kroes 1991, deel 3, p.10-140-141. Van der Meer 1990, p.200 spreekt over een 'uitzonderlijk groot aantal' algemene maatregelen van bestuur in de WPR, de Sofiwet en de Wet politieregisters.

26. Wet van 9 juni 1994 , Stb.494.

27. Kamerstukken II 1990-1991,21123, nr 6 MwA, p.127. Aangehaald bij Gerbranda/Kroes 1993. P.69.

28. Gerbranda/Kroes 1993, p.69-70.

29. Wet van 23 december 1993, Stb. 775 . 


\section{Hoofdstuk 6}

stand aan minder vermogenden wordt verleend. Uitwerking van deze voorwaarden vindt plaats in een drietal algemene maatregelen van bestuur. ${ }^{30}$

De regering koos voor deze delegaties op grond van de doelmatigheid: een specifieke en gedetalleerde uitwerking van de voorwaarden en criteria. "leent zich minder goed voor vastlegging bij formele wet" ${ }^{\text {"31 }}$

De regering was van oordeel dat 'van regeling van onderwerpen bij algemene maatregel van bestuur een zo terughoudend mogelijk gebruik gemaakt (is). $3 z$ Dit oordeel kon de Raad van State niet onderschrijven, maar de regering bleef bij haar standpunt..$^{33}$

\subsubsection{Artikel 79 Grondwet}

'Vaste colleges van advies in zaken van wetgeving en bestuur van het Rijk worden ingesteld bij of krachtens de wet.'

Op grond van deze bepaling is een formele wet nodig voor het instellen van vaste adviescolleges. $\mathrm{De}$ instemming van het parlement met het instellen van deze colleges is vereist om uitholling van de positie van het parlement tegen te gaan. Dat zou kunnen gebeuren wanneer door de regering ingestelde adviescolleges als een soort 'voorparlement' zouden functioneren. ${ }^{34}$

Bij de voorlopige adviesraden ontbreekt een wettelijke basis voor de instelling. Die is ook, grondwettelijk gezien, niet nodig. Zo is ingesteld een Voorlopige Adviesraad voor de vrede en veiligheid. ${ }^{35}$ Deze Voorlopige Adviesraad werd

30. Zoals het Besluit draagkrachtcriteria rechtsbijstand, KB van 11 januari 1994, Stb.33 (bevat 19 artikelen); het Besluit rechtsbijstand-en toevoegcriteria, KB van 11 januari 1994 , Stb. 32 ( 10 artikelen) en het Besluit vergoedingen rechtsbijstand $1994, \mathrm{~KB}$ van 11 januari 1994, Stb. 31 (75 artikelen).

31. Kamerstukken II 1991-1992,22609, B, Nader rapport, p.2, na kritiek van de Raad van State die niet overtuigd was van de delegatie op grond van artikel 13 lid 2 wetsvoorstel (criteria voor weigering van rechtsbijstand, thans artikel 12 lid 2 ) en artikel 36 lid 3 (criteria voor draagkracht en inkomen, thans artikel 34 lid 4). Zie ook De Jong 1993 , p.74.

32. Kamerstukken II 1991-1992, 22609, nr 3 MvT, p.7.

33. Kamerstukken If 1991-1992, 22609, B, Nader rapport, p.12-13. Kritisch over de wet, vooral inhoudelijk (de wet bewerkstelligt een sterk verminderde anspraak op rechtsbijstand) zijn I. Muller, Afscheid van de Rechtshulp, in NJB 1994, p.1101-1104 en H.D.L.M. Schruer/H.E. Eelkman, Nieuwe wetten, nieuwe heren, in NJB 1994, p. 1104. 1105

34. Kamerstukken II 1979-1980, 16040 (R1141), nr 3 MvT, p.3.

35. De Voorlopige Adviesraad is ingesteld bij Besluit van 2 augustus 1985, Stb.484. 
opgevolgd door de Adviesraad voor de vrede en veiligheid. ${ }^{36} \mathrm{Er}$ is geen wettelijke basis voor de instelling van deze Adviesraad. ${ }^{37}$ Die wordt voorbereid in het voorstel voor een Raamwet Adviesraden buitenlands, ontwikkelingssamenwerkings- en defensiebeleid. ${ }^{38}$

De instelling van een Adviesraad die een voorlopige adviesraad op hetzelfde terrein opvolgt, zonder dat er een basis in een formele wet is, staat op gespannen voet met het bepaalde in artikel $79 \mathrm{Gw} .{ }^{39}$ In feite functioneert de raad als een vast college, en is ook beoogd dat in de toekomst te doen.

Inmiddels heeft er een discussie plaatsgevonden over de omvang van en aantallen (vaste) adviesraden. De bijzondere commissie Vraagpunten Adviesorganen (Commissie-De Jong) bracht hierover in februari 1993 het rapport Raad op maat uit. ${ }^{40}$ Beoogd wordt een sterke reducering van het aantal vaste adviescolleges, tot eén per departement. In voorbereiding is een Kaderwet adviescolleges.

\subsubsection{Artikel 80 lid 2 Grondwet}

'Adviezen, uitgebracht ter zake van voorstellen van wet die door of vanwege de Koning worden ingediend, worden, behoudens bij de wet te bepalen uitzonderingen, aan de Staten-Generaal overgelegd.'

Delegatie is niet toegestaan gelet op de woorden 'bij de wet te bepalen'. In artikel 25a Wet op de Raad van State wordt de Minister opgedragen de adviezen openbaar te maken. Openbaarmaking blijft achterwege wanneer éen van de uitzonderingsgronden van artikel 10 Wet openbaarheid van bestuur (WOB) ${ }^{41}$ van toepassing is. Volgens Kortmann komen hier aan de Minister, ondanks het delegatieverbod, 'wezenlijke beslissingsbevoegdheden toe', met name bij de gronden vermeld in artikel 10 lid 2 WOB. ${ }^{42}$ Gelet op de grondwettelijke delegatietermi-

36. De Adviesraad is ingesteld bij KB van 11 oktober 1990,5 tb.566 (naar de vorm is dit een voorbeeld van een $\mathrm{KB}$ warin algemeen verbindende voorschriften voorkomen, mar waarover niet de Raad van State is gehoord).

37. Dit blijkt onder meer uit artikel 14 van het Besluit waarin wordt bepald dat het besiluit terugwerkt tot 1 juli 1990 en dat het Besluit verwalt zodra de Adviesraad bij of krachtens de wet wordt ingesteld, doch uiterlijk vier jaar ma de datum van inwerkingtreding.

38. Kamerstukken II $1987-1988_{2} 20585$, latste stuk is $\mathrm{nr} 9$, Nota naar aanleiding van het $\mathrm{EV}$ dd 26 julli 1990.

39. In deze zin ook Van der Burg 1993, p:62-63.

40. Kamerstukken II 1992-1993, 21427, nr 30.

41. Wet van 31 oktober 1991, Stb. 703 .

42. Kortmann 1987a, p.251. De weigeringsgronden voor het verstrekken van informatie op grond van artikel 10 lid 2 WOB zijn onder meer: de betrekkingen van Nederland mer andere staten; de economische of financiële belangen van de Staat; de opsporing of verwoll- 


\section{Hoofdstuk 6}

nologie zouden deze discretionaire beslissingsbevoegdheden niet aan de minister toegedeeld mogen worden. Deze beslissingsbevoegdheid is vrij ruim nu de weigeringsgronden niet concreet omschreven zijn.

\subsubsection{Artikel 91 lid 1 en 2 en artikel 95 Grondwet}

Artikel 91 lid 1: 'Het Koninkrijk wordt niet aan verdragen gebonden en deze worden niet opgezegd zonder voorafgaande goedkeuring van de Staten-Generaal. De wet bepaalt de gevallen waarin geen goedkeuring is vereist."

Lid 2: 'De wet bepaalt de wijze waarop de goedkeuring wordt verleend en kan voorzien in stilzwijgende goedkeuring.'

Artikel 95: 'De wet geeft regels omtrent de bekendmaking van verdragen en besluiten van volkenrechtelijke organisaties. '

In artikel 91 is delegatie verboden (de wet bepaalt) terwijl artikel 95 delegatie toestaat (de wet geeft regels). Uitvoering vindt plaats in de Rijkswet omtrent de goedkeuring en bekendmaking van verdragen. ${ }^{43}$ Deze 23 artikelen tellende wet bevat volgens de Memorie van Toelichting ${ }^{44}$ geen delegatie van regellgevende bevoegdheid. Ook worden er geen nieuwe bestuursinstrurnenten in het leven geroepen. Lezing van de wet laat zien dat in vier artikelen aan de minister van Buitenlandse Zaken een bevoegdheid wordt gegeven. ${ }^{45}$ De bevoegdheden lijken goed afgebakend. Bovendien hebben de bevoegdheden betrekking op de bekendmaking van verdragen; waarbij delegatie is toegestaan.

In een artikel 'De parlementaire goedkeuring van verdragen in Nederland"46 constateert Besselink strijd met de grondwettelijke delegatieterminologie waar het

ging wan strafbare feiten; inspectie, controle en toezicht door of vanwege bestuursorganerw en de eerbuediging van de persoonlijke levenssfeer.

43. Rijkswet van 7 juli 1994, Stb, 542 .

44. Kamerstukken II 1988-1989, 21214 (R.1375), nr 3 MvT * p.4.

45. Namelijk in artikel 1 'Onze Minister van Buitenlandse Zaken verstrekt periadiek aan de Staten-Generaal en aan de Siaten wan de Nederlandse Antillen en de Staten van Aruba een lijst van ontwerp-verdragen over de totstandkoming waarvan voor het Koninkrijk onderhandeld wordt; artikel 16 lid 2 'De zorg voor de uitgifte van het Tractatenblad berust bij Onze Mintster vam Buitenlandse Zaken'; artikel 19 lid 2 'Onze Minister van Buitenlandse Zaken kan woor een bepaald geval deze termijn (...) wijzigen door een mededeling in het Tractatenblad' (namelijk de termijn waarna een verdrag als bekend gemaakt geldt); en artikel 20 lid 3 'In bijzondere gevallen kan Onze Minister van Buitentandse Zaken bepalen dat bijlagen bij een verdrag of beshiten wan wolkenrechtelijke organisaties niet door plaatsing in het Tractatenblad, doch door terinzagelegging worden bekendgemaakt. Van zodanige bekendmaking wordt mededeling gedaan in het Tractatenblad."

46. Gepubliceerd in het Tijdschrift voor Bestuurswetenschappenen Publiekrecht 1994, p.106112 , in het bijzonder p.110. 
betreft de voorlopige toepassing van verdragen die geen goedkeuring behoeven (artikel 15 Rijkswet goedkeuring en bekendmaking verdragen). Ik kan hem daarin niet volgen. De Grondwet eist in artikel 91 lid 1 dat de formele wet bepaalt in welke gevallen verdragen geen goedkeuring behoeven. Daaraan voldoet de Rijkswet (zie artikel 7). Over voorlopige roepassing van verdragen rept de Grondwet niet. Regeringsbevoegdheden op dit terrein vallen buiten de delegatieterminologie. ${ }^{47}$

\subsubsection{Artikel 107 Grondwet}

Lid 1: 'De wet regelt het burgerlijk recht, het strafrecht en het burgerlijk en strafprocesrecht in algemene wetboeken, behoudens de bevoegdheid tot regeling van bepaalde onderwerpen in afzonderlijke wetten."

Lid 2: 'De wet stelt algemene regels van bestuursrecht vast.'

Op grond van de delegatieterminologie is delegatie in beide leden toegestaan. Bij de parlementaire behandeling bleek echter dat, gezien de aard van de codificatieopdracht, delegatie op grond van het eerste lid slechts beperkt toelaatbaar zou zijn. ${ }^{48}$ Voor het bestuursrecht zou aan lagere regelgevers ruimte gelaten kunnen worden om bepaalde punten nader te regelen. ${ }^{49}$

In de literatuur is de terughoudende opvatting ten aanzien van de delegatiemogelijkheid in lid 1 wel opgevat als een delegatieverbod ${ }^{50}$ Commotie ontstond er over het amendement Lansink ingediend bij de ontwerp-Wet bodembescherming ${ }^{51}$. Lansink wilde het beginsel van risico-aansprakelijkheid ten aanzien van handelingen in de wet vastleggen. De minister was van opvatting dat een regeling in een milieuwet, waarbij bovendien vergaand werd gedelegeerd, in strijd zou zijn met artikel 107 lid $1 \mathrm{Gw} .{ }^{52} \mathrm{Het}$ amendement werd echter aangenomen: zie thans artikel 14 Wet bodembescherming..$^{53}$ De Eerste Kamer dreigde

47. Zie ook de hierover gevoerde parlementaire discussie: Kamerstukken I 1993-1994, 21214 (R1375), nr 44a VV, p.2; Kamerstukken I 1993-1994, 21214 (R1375), nr 44b p. 1-2 en Handelingen 15 juli 1994, p.39/1935-1939. Kortmann 1994, p.160-161.

48. Kamerstukken II 1979-1980, 15046, nr 7 MvA, p.6.

49. Kamerstukken II 1978-1979, 15046, nr 6 VV, p.6; Kamerstukken III 1979-1980, 15046, nr 7 MvA, p. 11.

50. J. de Boer, De elektronische schriftelijke vorm, in NJB 1992, p.670-672 en J. De Boer "Een constitutioneel lesje à $f 310$ miljoen", in NJB 1993, p.50-51.

51. Kamerstukken II 1984-1985, 16529, nr 66.

52. Kamerstukken II 1984-1985, 16529, nr 67, p.2.

53. Het artikel luidt als volgt: 1. De krachtens de art. 8-13a bij algemene maatregel van bestuur vast te stellen regels kunnen inhouden dat degene die daarbif aangewezen hande lingen op of in de bodem verricht of doet verrichten, anders dan als ondergeschikte. 


\section{Hoofdstuk 6}

het wetsvoorstel te verwerpen en vroeg advies aan de Raad van State. De Raad achtte geen strijd met artikel $107 \mathrm{Gw}$ aanwezig, nu de minister had toegezegd terughoudend te zijn bij de uitleg van de bepaling. ${ }^{54}$

Strikt genomen behelst artikel $107 \mathrm{lid} 1 \mathrm{Gw}$ geen delegatieverbod: slechts terughoudendheid met delegatie is geboden. In die zin is de vraag of in strijd is gehandeld met de grondwettelijke delegatieterminologie weer een kwestie van interpretatie. Daarbij lijken vooral praktische en politieke wensen een belangrijke rol te spelen.

\subsubsection{Conclusie}

Hierboven zijn enkele voorbeelden aangestipt van uitvoeringswetgeving waarin de grondwettelijke delegatieterminologie een rol speelt.

Wanneer delegatie is toegestaan blijkt daar in een aantal gevallen ruim gebruik gemaakt van te worden. Die conclusie trekken ook Gerbranda/Kroes die veel uitvoeringswetgeving op de grondrechten onderzochten. Soms is dat in hun ogen ook niet te vermijden. In het wetgevingsproces stelt vooral de Raad van State zich op als bewaker van de grondwettelijke aspecten. ${ }^{55}$ Gerbranda/Kroes noemen onder meer als voorbeeld de kritiek van de Raad van State bij het wetsvoorstel Paspoortwet over de voorgestelde delegatie in de artikelen 15 en 17. Het wetsvoorstel is daarna aangepast. ${ }^{36}$ "De conclusie moet welhaast zijn, dat de wetgever zonder expliciete afweging van de noodzakelijkheid van delegatie alvast overgaat tot delegatie. Door een heroverweging naar aanleiding van het advies van de Raad van State blijkt er veel meer in formele wetgeving vastgelegd te

aansprakelijk is voor de daardoor aangerichte schade, voor zover die schade het gevolg is van de door die handelingen veroorzaakte verontreiniging of aantasting van de bodem.

2. Bij de maatregel wordt het bedrag vastgesteld tot hetwelk de in het eerste lid bedoelde aansprakelijkheid ten hoogste geldt. Tevens wordt daarbij bepaald op welke van de in de eerste lid bedoelde personen de aansprakelijkheid rust. 3. De rechter kan de verplichting tot schadevergoeding matigen. 4. Dit artikel vervalt op het tijdstip waarop door het in werking treden van een wijziging van het Burgerlijk Wetboek wordt voorzien in het onderwerp van het eerste lid.

54. Zie hierover H.J.M. Desain, Amendement Lansink aan de Grondwet getoetst, NJB 1985 , p.932 e.v.; De Boer 1987, p.475-476; Van der Vlies 1991, p.84 ("Betwijfeld kan worden of de Raad van State hier wijs heeft geadviseerd. Het is merkwaardig dat mogelijke strijd van de letterlijke tekst van een wettelijke bepaling wordt opgeheven door de toezegging van een minister bij de verdediging van het voorstel dat de bepaling niet zo zal worden uitgelegd als zij luidt."); De Boer 1993, p.50-51; E. Bauw, Publiek-en privaatrechtelijke aansprakelijkheid in de gewijzigde Wet bodembescherming, AA 1994, p.810-820.

55. Gerbranda/Kroes 1993 , p. 99 .

56. Gerbranda/Kroes 1.993 , p.99-100. 
kunnen worden dan men aanvankelijk dacht. Het uitgangspunt van de grondwetgever, dat de wetgever dient te beslissen over de mate waarin gebruik wordt gemaakt van delegatiebevoegdheden, lijkt in de praktijk nauwelijks te worden nageleefd. Wanneer deze bevoegdheid bestaat, wordt daarvan vrijwel automatisch gebruik gemaakt." ${ }^{\text {s7 }}$

Vooral het grondwettelijk delegatieverbod lijkt de wetgever echter moeilijkheden op te leveren. Daarbij gaat het niet zozeer om de niet toegestane overdracht van regelgevende bevoegdheden, maar om de reikwijdte van (in de praktijk noodzakelijke, dan wel zeer wenselijke) bestuursbevoegdheden.

Een van de leerstukken die hierbij een rol speelt is het onderscheid tussen regelgeving en uitvoering (zie hoofdstuk 7). In de parlementaire stukken en literatuur komen we veelvuldig de opvatting tegen, dat een (discretionaire) bestuursbevoegdheid geen strijd met het grondwettelijke delegatieverbod oplevert, wanneer die bevoegdheid als uitvoering wordt aangemerkt. Daarbij wordt het begrip uitvoering soms wel erg ruim uitgelegd. ${ }^{58}$ In hoofdstuk 7 zal blijken dat het onderscheid regelgeving-uitvoering in onbruik raakt. Daarvoor in de plaats komt het denken in bevoegdheden: regelgevende en bestuursbevoegdheden. Door niet meer de verhullende term 'uitvoering' te hanteren in het kader van een grondwettelijk delegatieverbod zal duidelijker worden in welke mate een bestuursbevoegdheid discretionair is en of die discretionairheid zich verdraagt met het grondwettelijk delegatieverbod.

\subsection{Delegatieterminologie en jurisprudentie}

\subsubsection{Inleiding}

Uitspraken waarin een letterlijk beroep wordt gedaan op de grondwettelijke delegatieterminologie zijn schaars. Met een letterlijk beroep bedoel ik het noemen

57. Gerbranda/Kroes 1993, p.100. Ook over de motieven om tot delegatie over te gaan hebben zij hun twijfels: "Delegatie is zowell met betrekking tot artikel 10 als met betrekking tot artikel $11 \mathrm{Gw}$ toegestaan. Het is echter de vraag of de motieven die worden aangevoerd om tot delegatie over te gaan, zoals de wens tot vereenvoudiging en tot een sober en terughoudend wetgevingsbeleid, zijn te verenigen met de waarborgen die de grondwetgever in de betrokken grondrechten neer heeft willen leggen. Wanneer het beleid leidt tot een veelheid van lagere regelgeving waarbij het initiatief tot bescherming van het recht op persoonlijke levenssfeer bij de burger zelf wordt gelegd, kan wel sprake zijn van sobere wetgeving, maar rijst wel de vraag waar de prioriteit wordt gelegd."

58. Zie ook Kortmann 1994, p.321. 


\section{Hoofdstuk 6}

van de term delegatieterminologie of het doen van een beroep op het delegatieverbod. Wel willen annotatoren er nog wel eens naar verwijzen. ${ }^{59}$

Uit het geringe aantal uitspraken zou afgeleid kunnen worden dat de uitvoering van de grondwettelijke delegatieterminologie weinig problematisch is.

Bij deze conclusie kan echter de kanttekening geplaatst worden dat, wanneer een regeling in een formele wet bestreden wordt, toetsing aan de grondwettelijke bepaling (en grondwettelijke delegatieterminologie) niet is toegestaan op grond van artikel $120 \mathrm{Gw}{ }^{60}$ Hiermee is constitutioneel een controlemiddel op een juiste uitvoering van de grondwettelijke delegatieterminologie geblokkeerd. ${ }^{61}$

Een tweede opmerking is dat in een aantal uitspraken de grondwettelijke delegatieterminologie weliswaar niet letterlijk wordt genoemd, maar dat wel een beroep wordt gedaan op het vereiste van een wettelijke grondslag. Voor zover daarbij een grondwetsartikel in het geding is (bijvoorbeeld éen van de grondrechten) waarin delegatieterminologie is opgenomen, is dat mijns inziens ook een beroep op de delegatieterminologie. ${ }^{62}$

De jurisprudentie waarin de grondwettelijke delegatieterminologie een rol speelt bespreek ik (niet uitputtend) als volgt: Is er strijd met het delegatieverbod? (6.3.2). Een specifieke wettelijke basis voor thet bestreden besluit ontbreekt (6.3.3) en de grondwettelijke delegatieterminologie in horizontale verhoudingen (6.3.4). Een, met het grondwettelijke toetsingsverbod verwant probleem is, hoever de rechter mag gaan bij toetsing van lagere (gedelegeerde) regelingen aan de Grondwet (6.3.5). Een korte conclusie volgt in paragraaf 6.3.6.

59. Met behulp van de CD Rom kan op deze termen gezocht worden in belangrijke bronnen van gepubliceerde jurisprudentie, zoals de $\mathrm{AB}$ en NJ. Uitspraken waarin grondrechten een rol spelen zijn talrijk. Zie voor een overzicht Gerbranda/Kroes 1991 , documentatierapporten $1-6$.

60. Artikel $120 \mathrm{Gw}$ : 'De rechter treedt niet in de beoordeling van de grondwettigheid' van wetren en verdragen."

61. In een zaak die speelde voor het Hof Leeuwarden stelde belanghebbende dat de delegatie aan de Minister in artikel 13 Meststoffenwet in strijd was met artikel 104, eerste volzin Gw, nu in artikel 13 de regeling van de essentialia aan de minister wordt overgedragen. Het Hof komt niet azn toetsing toe wegens artikel $120 \mathrm{Gw}$. (Hof Leeuwarden 5 oktober 1990, FED, afl. 2325, ar.8.) Op de discussie over de (on)wenselijkheid van constitutionele toetsing ga ik hier niet in.

62. Overige uitspraken, waarin het ontbreken wan een wettelijke grondslag aan de orde is, komen aan bod in hoofdstuk 9 , wat het gaat om de invulling van een materieel wetsbegrip. 


\subsubsection{Strijd met het delegatieverbod?}

Bij een grondwettelijk delegatieverbod dient de formele wet zelf de belangrijkste normen te bevatten. Regelgevende bevoegdheden mogen worden gedelegeerd voor zover ze de regeling van detailpunten betreffen. Slechts gebonden bestuursbevoegdheden mogen worden geattribueerd ${ }^{63}$ Het is de rechter niet toegestaan de regeling in de formele wet te toetsen aan de Grondwet. De rechter mag echter wel toetsen of de (uitoefening) van een op een formele wet gebaseerde bestuursbevoegdheid in overeenstemming is met het grondwettelijke delegatieverbod. Vooral op het terrein van de grondrechten komen dergelijke zaken nog wel eens voor de rechter. In paragraaf 6.2 is gebleken dat sommige bestuursbevoegdheden nogal ruim zijn, waardoor ze strijd met het grondwettelijke delegatieverbod kunnen opleveren.

Een directe verwijzing naar het delegatieverbod vinden we in de annotatie van Boon bij de uitspraak van de Afdeling rechtspraak Raad van State over de Paspoortinstructie $\mathrm{e}^{64}$, waarin artikel 2 lid $4 \mathrm{Gw}$ een rol speelt. ${ }^{65}$ De nieuwe Grondwet is overigens op het moment van de uitspraak nog niet in werking getreden. Boon constateert dat de Paspoortinstructie (die een wettelijke basis ontbeert) na inwerkingtreding van artikel 2 lid $4 \mathrm{Gw}^{66}$ in strijd is met het delegatieverbod uit die bepaling,

De rechter waagt zich niet snel aan (een letterlijke) interpretatie van het delegatieverbod. Hij heeft andere wegen gezocht en gevonden om te beoordelen of de in het geding zijnde bevoegdheid correct is uitgeoefend. Daarbij accepteert hij in sommige gevallen dat grondrechten beperkt worden, hoewel strikt genomen niet aan de vereisten van de grondwettelijke delegatieterminologie is voldaan. Of de rechter daarmee de leer van de algemene beperkingen heeft aanvaard wordt verschillend beoordeeld. Kort omschreven houdt deze leer in dat grondrechten mogen worden beperkt als neveneffect van een maatregel of regeling die zich niet rechtstreeks op dat grondrecht richt. Bekend voorbeeld is het vereiste van een hinderwetvergunning voor een drukkerij: door die eis wordt niet de vrijheid van meningsuiting beperkt. ${ }^{67}$ Bij de grondwetsherziening van 1983 is deze leer in

\section{Zie paragraaf 4.2 .}

64. ARRS 10 januari 1983, AB 1983, 306, m.nt. P.J. Boon.

65. 'Leder heeft het recht het land' te verlaten, behoudens in de gevallen, bij de wet bepaald.'

66. Krachtens additioneel artikel I zou het artikel uiterlijk op 17 februari 1988 in werking treden.

67. HR 11 februari 1986, NJ 1986,673, m.nt. ThWvV, kritisch over deze uitspraak Den Dekker-van Bijsterveld 1991, p.384; AGRS 20 november 1992, AB 1993, 241, m.nt. 1. Sewandono. 


\section{Hoofdstuk 6}

eerste instantie door de regering van de hand gewezen, uit angst voor uitholling van de grondrechten ${ }^{68}$ Later verzachtte zij haar standpunt: in uitzonderingsgevallen zou een grondrecht ook buiten een bijzondere beperkingsgrond beperkt mogen worden ${ }^{69}$ Gerbranda/Kroes concluderen dat het afwijzen van de leer van de algemene beperkingen "in de praktijk tot weinig moeilijkheden (heeft) geleid" ". 70

Den Dekker-van Bijsterveld en Kistenkas zijn van mening dat niet te snel geconcludeerd moet worden dat de rechter de leer van de algemene beperkingen aanvaardt. ${ }^{71}$ Daarentegen concluderen Vermeulen ${ }^{72}$ en Boon dat de rechter de leer van de algemene beperkingen wel heeft aanvaard. Boon trekt deze conclusie in zijn noot bij de volgende uitspraak. ${ }^{73}$ De Evangeliegemeente De Deur houdt manifestaties in de open lucht om haar geloofsboodschap uit te dragen. Het gebruik van versterkte muziek beschouwt zij daarbij als een essentieel onderdeel. Op grond van de Zwolse APV is zij vergunningplichtig. Wanneer de vergunning geweigerd wordt beroept zij zich op de Wet openbare manifestaties. De voorzitter honoreert dit beroep niet. Het feit dat er een grondrecht in het geding is laat toepassing van de bepalingen uit de Zwolse APV onverlet, zolang de uitoefening van dat grondrecht niet volledig onmogelijk wordt gemaakt; wel is extra zorgvuldigheid door de gemeente vereist bij toepassing van de bepalingen ${ }^{74} \mathrm{De}$ Voorzitter toetst de bepaling uit de Zwolse APV niet aan artikel 6 Grondwet. Hij

68. Kamerstukken II $1975-1976,13872$, nr 3 MvT, p.21.

69. Kamerstukken II 1975-1976, 13872, nr 3 MvT, p.21-22; Kamerstukken II 1976-1977, 13872, nr 7 MvA, p.12. Kortmann 1987, p.52-57.

70. Gerbranda/Kroes 1993, p.105, onder verwijzing nalar M.C.B. Burkens, Algemene leerstukken van grondrechten naar Nederlands constitutioneel recht, Zwolle 1989, p.137 en P.W.C. Akkermans, Redelijke grondwetsinterpretatie?, in AA 1990, p.398-402. In gelijke zin Kortmann 1994, p. 361.

71. Kistenkas 1991, p.380; Den Dekker-van Bijsterveld 1991, p.383-384. Een uitspraak warin volgens haar de leer van de algemene beperkingen wel is aanvaard is Pres. Rb Den Bosch 25 juni 1985, KG 1985, 217, waarin de president het gebruik van een gebouw als moskee in strijd oordeelt met de gebruiksbepalingen van het bestemmingsplan.

72. Vermeulen 1990, p. 78.

73. Vz ARRS 17 augustus 1990, AB 1991, 44, m.nt. P.J. Boon.

74. Vergelijk ABRS 27 oktober 1994, NJB-katern 1994, p.572-573, nr 45: "Ook het feit dat het hier de uitvoering van het in art. 6 lid $1 \mathrm{Gw}$ gewaarborgde grondrecht betreft, dwingt er niet toe dat hetgeen bij of krachtens de Hinderwet is geregeld, zijn betekenis ter zake vertiest. Wel brengt dit met zich dat de aan een hinderwetvergunning verbonden voorschriften niet zo ver mogen gaan dat daardoor het gebruik van de klok illusoir wordt gemaakt of onnodig wordt beperkt." 
toetst de toepassing van die bepaling aan de algemene beginselen van behoorllijk bestuur, in het bijzonder het zorgvuldigheidsbeginsel, welk hij geschonden acht. Annotator Boon constateert dat de Voorzitter de leer van de 'algemene beperkingen" van grondrechten aanvaardt. ${ }^{75}$ In de ogen van Boon is de aanvaarding van deze leer in de jurisprudentie begrijpelijk gezien de vrij 'strenge' uitleg van de grondwettelijke delegatieterminologie. In casu zou de Voorzitter op problemen zijn gestuit bij de toepassing van de artikelen 6 en $7 \mathrm{Gw}$. Verzoekster beriep zich op de vrijheid van godsdienst en levensovertuiging. Het beoefenen van die vrijheid buiten gebouwen en besloten plaatsen mag op grond van artikel 6 lid $2 \mathrm{Gw}$ beperkt worden bij of krachtens de wet. Er dient voor die beperking een specifieke wettelijke grondslag te zijn, een grondslag in een autonome gemeentelijke verordening is niet voldoende ${ }^{76}$ Het gebruik van geluidsapparatuur is niet in die wet geregeld en had dus niet op basis van de WOM verboden kunnen worden. Verzoekster had ook een beroep kunnen doen op artikel 7 lid $3 \mathrm{Gw}$ (vrijheid van meningsuiting anders dan door de drukpers, radio of televisie). Beperking bij autonome gemeentelijke verordening is toegestaan, mits daarbij de inhoud van de meningsuiting geen rol speelt. Plaats en tijd van de meningsuiting kunnen wel aan beperkingen onderworpen worden, mits de uitoefening van het grondrecht niet onmogelijk wordt gemaakt. De Voorzitter kiest in casu impliciet voor de benadering dat niet artikel $6 \mathrm{Gw}$ in het geding is, maar artikel 7 lid $3 \mathrm{Gw}$. Boon bekritiseert deze opstelling: voor De Deur is het gebruik maken van geluidsversterkende apparatuur essentieel onderdeel van haar geloofsuitdraging. De grens tussen inhoud en niet-inhoud acht hij hier aanvechtbaar. Zo is er naast strijd met artikel $6 \mathrm{Gw}$, mogelijk ook strijd met artikel 7 lid $3 \mathrm{Gw}$. Boon constateert dat de Voorzitter 'al deze niet geringe ingewikkeldheden' uit de weg gaat, en de zaak oplost door de toetsing aan de algemene beginselen van behoorlijk bestuur, 'zonder zijn handen te binden voor toekomstige procedures waarin de verschillende belangen zich weer heel anders ten opzichte van elkaar kunnen verhouden".

\subsubsection{Een specifieke wettelijke basis ontbreekt}

Bij de parlementaire behandeling van de delegatieterminologie in hoofdstuk 4 bleek dat de beperking van een grondrecht (wanneer delegatie is toegestaan) steeds op een specifieke wettelijke basis moet berusten. Uit de jurisprudentie wordt duidelijk dat die wettelijke grondslag nog wel eens ontbreekt. Zo oordeel-

75. Dat doet hij ook in zijn noot bij Vz ARRS 16 februari 1989, AB 1990, 9; AA 1990 , p.398-402, m.nt. P.W.C. Akkermans.

76. Verwijzend naar A.E. Schilder, Het recht tot vergadering en betoging 1989, p. 109-110. 


\section{Hoofdstuk 6}

de de Hoge Raad in het Wangslijmarrest ${ }^{77}$ dat het tegen de wil van de verdachte afnemen wan wangslijm ten behoeve van een DNA-proef in strijd is met artikel $11 \mathrm{Gw}$, nu een specifieke wettelijke grondslag daarvoor ontbreekt.

Strijd met artikel $11 \mathrm{GW}$ werd eveneens geconstateerd door het Hof Arnhem, ${ }^{78}$ waar het onder meer gedwongen separatie van een psychiatrische patiënt betrof, zonder dat een specifieke wettelijke grondslag was aan te wijzen. De wettelijke basis voor deze en andere (dwang)behandelingen is thans gelegd in de Wet BOPZ (Bijzondere Opnemingen in Psychiatrische Ziekenhuizen). ${ }^{79}$ Daarentegen was dwangmedicatie bij een psychiatrische patiënt wel toegestaan, nu de weigering van de patiènt om toestemming te geven rechtstreeks voortkwam uit de geestelijke stoornis, die de patiënt belette de behandelnoodzaak te doorzien. Bovendien was de beslissing tot dwangmedicatie genomen in samenspraak tussen behandelend arts, vakgenoten en een extern geneeskundige. ${ }^{80}$

Het op grond van artikel 24 eerste lid Erkenningsregeling vrijwillige plaatsingen jeugdhulpverlening ${ }^{B 1}$ inzage geven aan ambtenaren van WVC van dossiers van individuele cliënten is een inbreuk op de persoonlijke levenssfeer van die cliënten. ${ }^{82}$ De Erkenningsregeling heeft geen wettelijke grondslag. De Voorzitter van de Afdeling rechtspraak achtte de bepaling in strijd met artikel 10 lid $1 \mathrm{Gw}$ : voor beperkingen van het grondrecht op eerbiediging van de persoonlijke levenssfeer is een wettelijke grondslag nodig.

De Roermondse rechtbank bepaalde dat het geslotenverklaren van een woning wegens drugsoverlast op basis van artikel $35 \mathrm{~b}$ APV Venio in strijd is met artikel 10 lid $1 \mathrm{Gw}$, nu voor deze matregel een formeel-wettelijke grondslag ontbreekt. ${ }^{83}$

Het gedwongen verblijf van een asielzoeker in een gesloten opvangcentrum in afwachting van de beslissing over een verblijfsvergunning, is aangemerkt als

77. HR 2 juli 1990 , NJ 1990,751 , m.nt. Sch.

78. Hof Arnhem 12 juli 1988, AB 1989, 122, m.nt. M.J. Sluys, NJ 1989, 761.

79. Wet van 29 oktober 1992, Stb.663, nadien meerdere keren gewijzigd.

80. Rb Roermond 27 juli 1989, NJ 1990, 759.

81. Stcrt. 1987,140 .

82. Vz ARRS 30 juni 1988, AB 1989, 438, m.nt. ICvdV.

83. Rb Roermond 3 januari 1995, NJCM-Bulletin 1995, p.431-438, m.nt. J.M.E. Derks; Gemeentestem 1995, nr 7006, nr 6, m.nt. HH. Een voorbeeld van een uitspraak waarin evencens een bepaling uit een gemeentelijke verordening onverbindend werd verklaard wegens strijd met de Grond wet is HR 10 november 1992, NJ 1993, 197, m.nt. "it H, over artikel 7 lid $3 \mathrm{Gw}$ en artikel 64 APV Den Bosch. Op het recht van vrije meningsuiting conform artikel 7 lid 3 Gw mogen alleen bij formele wet beperkingen worden aangebracht. Artikel 64 APV is onverbindend. 
vrijheidsontneming in de zin van artikel 15 lid $1 \mathrm{Gw} .{ }^{84}$ Nu hiervoor geen wettelijke grondslag bestond was deze vrijheidsbeneming ongeoorloofd. ${ }^{85}$. Dit gold. ook voor het gedwongen verblijf van een asielzoeker in de transitruimte van het vliegveld Schiphol, ook al kon de asielzoeker de transithal verlaten door uit Nederland te vertrekken. ${ }^{86}$

Artikel 18 lid $1 \mathrm{Gw}$ werd ingeroepen voor de Haagse president die oordeelde dat "Het beginsel van vrije advocatenkeuze (...) zozeer in onze rechtsorde verankerd (is) dat daarop slechts inbreuk kan worden gemaakt bij of krachtens een wettelijke bepaling. De Modelregeling rechtshulp aan asielzoekers ontbeert een dergelijke wettelijke grondslag. "87

Meerdere keren is in de jurisprudentie artikel 19 lid $3 \mathrm{Gw}$ ingeroepen. ${ }^{88}$ Zoals in een uitspraak van de Centrale Raad van Beroep waarin de vraag was of het weigeren van ontslag aan een beroepsmilitair in strijd was met het grondrecht op vrije keuze van arbeid, een vraag die door de Centrale Raad bevestigend werd beantwoord. ${ }^{89}$ De weigering om te ontslaan leidde tot een verplichting tot arbeid. Deze inbreuk op de vrijheid van arbeidskeuze had geen grondslag in een specifieke wettelijke bepaling.

In een andere zaak ${ }^{90}$ klaagde een politie-agent over het weigeren van ontheffing van het verbod om nevenwerkzaamheden uit te oefenen. Hij achtte dit in strijd met het recht op vrije arbeidskeuze. De rechtbank oordeelde de wettelijke basis voor het weigeren van de ontheffing (artikel 125, eerste lid, onder $h$, thans $j$, Ambtenarenwet 1929) te weinig specifiek. Daarentegen achtte de rechtbank artikel 125, eerste lid, onder a Ambtenarenwet wel een voldoende specifieke grondslag. In die bepaling wordt de bevoegdheid tot het stellen van voorschriften over de aanstelling (inclusief nevenwerkzaamheden) gedelegeerd. Uitwerking geschiedt in het ARAR. Nu het een politie-agent betreft is artikel 22 Politiewet (oud, JD) in het geding, welk artikel volgens de rechtbank eveneens een voldoende specifieke wettelijke basis voor het weigeren van de ontheffing biedt. Aardig

84. Artikel 15 lid $1 \mathrm{Gw:} \mathrm{"Buiten} \mathrm{de} \mathrm{gevallen} \mathrm{bij} \mathrm{of} \mathrm{krachtens} \mathrm{de} \mathrm{wet} \mathrm{bepaald} \mathrm{mag} \mathrm{niemand} \mathrm{zijm:}$ vrijheid worden ontnomen."

85. HR 9 december 1988, AB 1989, 121, m.nt. FHvdB.

86. HR 8 februari 1991, RvdW 1991, 54.

87. Pres. Rb Den Haag 12 september 1991, NJCM-Bulletin 1992, p.37-41, m.nt. A. Derks; Rechtspraak V reemdelingenrecht 1991, 62 m.nt. TS.

88. Artikel 19 lid $3 \mathrm{Gw}$ : 'Het recht wan ledere Nederlander op vrije keuze wan arbeid wordt erkend, behoudens de beperkingen bij of krachtens de wet gesteld."

89. CRvB 10 december 1992, TAR 1993, 34.

90. Rb Zwolle 11 maart 1993, TAR 1993, 133. 


\section{Hoofdstuk 6}

in deze uitspraak is dat de rechtbank vrij uitgebreid ingaat op de grondwetsherziening van 1983 en ook naar de betreffende kamerstukken verwijst.

De constatering dat een specifieke wettelijke grondslag ontbreekt noopt sommige rechters tot creatieve oplossingen om gerezen problemen op te lossen. Zo ging de Centrale Raad van Beroep een eigen interpretatienorm hanteren." In geding was de vraag of het een politie-ambtenaar toegestaan kon worden om de nevenfunctie van rij-instructeur uit te oefenen. De Centrale Raad stelde vast dat het geven van auto-rijles de bescherming van artikel $23 \mathrm{Gw}$ genoot. De beperkingsclausules in het tweede en derde lid van dit artikel zijn echter niet zodanig in een wettelijke regeling uitgewerkt dat het onderhavige geval daaraan te toetsen is. De daaruitvolgende conclusie dat het geven van onderwijs niet beperkt kan worden wanneer is voldaan aan de normen uit artikel 23 lid 2 en 3 Gw was voor de Centrale Raad onacceptabel. De Raad hanteerde daarom een zelfstandige beperkingsnorm, die inhoudt ' dat de ambtenaar in de uitoefening van grondrechten niet zover mag gaan dat de goede vervulling van zijn functie of de goede functionering van de openbare dienst in volstrekt ontoelaatbare mate wordt aangetast."

In zijn noot bij deze uitspraak merkt Hennekens op dat de Centrale Raad niet rept over de grondwetsherziening van 1983 en de gevolgen daarvan voor artikel 23 . De delegatieterminologie is, doordat het herzieningswoorstel is verworpen, en de tekst van het oude artikel $208 \mathrm{Gw} 1972$ is overgenomen, niet van toepassing ${ }^{32}$ Ook de leer van de algemene en bijzondere beperkingen geldt niet voor dit grondwetsartikel. ${ }^{93}$ Toch lijkt het alsof de Centrale Raad aspecten van de delegatieterminologie in gedachten heeft. Met name onderzoekt de Raad of in casu een specifieke wettelijke grondslag aanwezig is om de vrijheid van onderwijs te beperken. De Raad vindt zo'n grondslag niet en hanteert dan een (overigens al in eerdere jurisprudentie geïntroduceerde) eigen beperkingsnorm. ${ }^{94}$

91. CRvB 16 november 1989, AB 1991, 24, m.nt. HH. Zie ook de annotatie van C.J.G. Olde Kalter in TAR 1990, p,380-384.

92. Hennekens verwijst naar Kortmann $1987 a$, p.145. Zie ook paragraaf 5.2 .

93. Zie Hennekens 1994, p.174, verwijzend naar L.F.M. Verhey en B.P. Vermeulen in NTYOR 1990, p.97-103.

94. Volgens Hennekens doet de Centrale Raad geen beroep op de leer van de algemene beperkingen. Zie over deze uitspraak ook Den Dekker-van Bijsterveld 1991, p.385. 
Een tweede opvallende uitspraak doet de Afdeling bestuursrechtspraak RvS. ${ }^{55}$ De Afdeling oordeelt de Regeling Geldelijke Steun Huisvesting Gehandicapten 1989 wegens het ontbreken van een grondslag in een wet in formele zin in strijd met artikel 132, zesde lid, $\mathrm{Gw}^{96}$. De Regeling ('een samenstel van beleidsregels') regelt de financiële verhouding gemeente-Rijk. De Afdeling laat de Regeling niet buiten toepassing (daarbij overwegend dat de gemeente daar geen belang bij heeft, nu de enige manier waarop de gemeente een aanspraak op de bijdrage kan maken gelegen is in de Regeling), maar geeft de gemeente aanspraak op een bijdrage op basis van het vertrouwensbeginsel. Hier derogeert dus in feite een algemeen beginsel van behoorlijk bestuur aan de grondwettelijke delegatieterminologie!

\subsubsection{De delegatieterminologie in horizontale verhoudingen}

De grondwettelijke delegatieterminologie wordt in de jurisprudentie geïnterpreteerd als een systeem dat burgers waarborgen beoogt te verschaffen tegen optreden van de overheid. In horizontale verhoudingen speelt de terminologie geen rol in zoverre dat een specifieke wettelijke basis vereist zou zijn om een grondrecht te beperken. Een inbreuk kan een basis vinden in een algemene wettelijke grondslag, zoals het onrechtmatige daadsartikel (artikel 6:162 BW). Een voorbeeld is de uitspraak van de Hoge Raad inzake de verkrachter en de Aidstest. ${ }^{97}$ Eiseres eiste dat haar verkrachter zich onderwierp aan een HIV-test. Zij hoopte daardoor uitsluitsel te krijgen over een mogelijke besmetting. De Hoge Raad oordeelde dat de dader (die door eiseres te verkrachten een onrechtmatige daad jegens haar had gepleegd) de test moest ondergaan. Hij kon zich niet met succes op artikel $11 \mathrm{Gw}$ beroepen 'nu dit recht zijn grenzen vindt in de bij of krachtens de wet de stellen beperkingen. In elk geval (curs. JD) ${ }^{98}$ tussen burgers onderling kan een zodanige beperking in beginsel worden gegrond op artikel $1401^{99}$, zulks mede aan de hand van de in dat artikel besloten liggende normen die het in het maatschappe-

95. ABRS 21 juni 1994, in NJB-katern 1994, p.419, nr 29 B en W Rotterdam tegen de Staatssecretaris vari VROM.

96. Artikel 132 lid $6 \mathrm{Gw}$ : 'De wet bepaalt welke bellastingen door de besturen van provincies en gemeenten kunnen worden geheven en regelt hun financięle verhouding tot het Rijk."

97. HR 18 juni 1993, NJ 1994, 347, m.mt. EAA en CJHB.

98. Anders dan Alkema (in zijn noot bij deze uitspraak) bespeur ik hier dat de Hoge Raad een mogelijkheid open houdt dat ook voor de overheid een algemene wettelijke grondslag voldoende zou zijn om het grondrecht wan artikel $11 \mathrm{Gw}$ te beperken. Alkema daarentegen leest hierin de suggestie dat "de eisen die aan de overheid zelf gesteld moeten worden volgens de Hoge Raad anders - waarschijnlijk hoger- moeten zijn;"; (..).

99. Oud BW, thans artikel 6:162 BW. 


\section{Hoofdstuk 6}

lijk verkeer betaamt jegens elkaar in acht te nemen'. ${ }^{100}$ De dader wordt verplicht de test te ondergaan om de door hem toegebrachte schade zoveel mogelijk te beperken. ${ }^{101}$

In zijn noot merkt Alkema op dat; wanneer de verplichting on de Aidstest te ondergaan in een strafprocedure zou zijn opgelegd (als bijkomende straf), artikel $11 \mathrm{Gw}$ wel verticale werking zou hebben gehad. Dan had de overheid zich volledig moeten houden aan de eisen van het artikel, namelijk dat de inbreuk op het grondrecht van verdachte een wettelijke grondslag moet hebben.

\subsubsection{Toetsing van lagere regelingen}

Toetsing van de formele wet aan de Grondwet is de rechter niet toegestaan. In hoeverre toetst de rechter of een lagere regelgever binnen de gedelegeerde bevoegdheid is gebleven?

Heersende leer is dat door de formele wet gedelegeerde, strikt gebonden regelgeving, niet getoetst mag worden aan de Grondwet. ${ }^{102}$

Een mooi voorbeeld biedt $\mathrm{Rb}$ Den Haag 18 januari $1995 .^{103}$ Het ging in deze zaak om kerndoelen, vastgelegd in de Wet op het basisonderwijs (WBO) en in het Besluit kerndoelen basisonderwijs. De rechter overweegt: "De wetgever in formele zin heeft (immers) aan de Kroon opgedragen bij algemene maatregel van bestuur kerndoelen vast te stellen, en dus niet gekozen voor een wijze van delegatie waarbij eventueel ook van het vaststellen van kerndoelen zou kunnen worden afgezien. Bovendien zou, hoewel het toetsingsverbod van artikel 120 Grondwet als zodanig zich niet uitstrekt tot het besluit, door toetsing aan de Grondwet van (onderdelen van) het besluit, gelet op de door eisers geuite bezwaren, welke zich vooral richten op het cognitieve element van de kerndoelen, ook de wet worden getoetst, hetgeen aan de rechter niet vrijstaat."

100. In zijn conclusie verwijst AG Koopmans naar eerdere jurisprudentie waaronder HR 24 meil 1985, NJ 1987, 1, m.nt. Brunner en Alkema (straatverbod), en HR 2 februari 1990. NJ 1991, 289, m.nt. Alkema (Goeree).

101. Zie hierover uitgebreid de noot wan Brunner bij deze uitspraak.

102. Zne hierover de discussie tijdens grondwetsherziening: Kamerstukken II 1975-1976, 13872, nr 6 VV, p.12-13 en Kamerstukken II 1976-1977, 13872, nr 7 MvA, p.9. Zie voonts Böhtlingk/Logemann 1966, p.150; Van der Vlies 1984, p.71; Kortmann 1994, p.363.

103. Besproken door G. Leenknegt, Hoe lang is de arm van artikel $120 \mathrm{Gr}$. w.? , in RegelMaat $1995, \mathrm{p} .65-67$, die iw ijfelt of artikel $120 \mathrm{Gw}$ zo ruim dient te worden uitgelegd en bepleit dat artikel $120 \mathrm{Gw}$ alleen vooi formele wetten geldt. Zie ook de reactie hierop van E.C.M. Jurgens, in RegelMaat 1995, p.68-69, die de rechterlijke uitspraak verdedigt. 


\subsubsection{Conclusie}

Twee aspecten van de grondwettelijke delegatieterminologie komen vooral aan de orde in de jurisprudentie: een (impliciet) beroep op het delegatieverbod en het ontbreken van een specifieke wettelijke grondslag die een inbreuk op een grondrecht rechtvaardigt. Mij zijn geen uitspraken bekend waarin wordt geconstateerd dat een geboden delegatiemogelijkheid te ruim is uitgewerkt.

Wat betreft het eerste aspect, de toepassing van het delegatieverbod, bleek in de vorige paragraaf dat een nauwkeurige uitvoering in sommige gevallen moeilijk waar te maken is. De uitvoeringswetgever zag zich in een aantal gevallen genoodzaakt om discretionaire bestuursbevoegdheden toe te kennen. Ook in de jurisprudentie is handhaving van het delegatieverbod, wanneer er ruime bestuursbevoegdheden in het geding zijn, een problematische zaak.

De rechter waagt zich niet aan een interpretatie van deze bestuursbevoegdheden tegen de achtergrond van een delegatieverbod. Ook het reguleren van de uitoefening van grondrechten door middel van een autonome gemeentelijke verordening wordt toegelaten.

Het tweede aspect, het ontbreken van een specifieke wettelijke grondslag, wanneer op een grondrecht inbreuk wordt gemaakt, levert in veel gevallen minder problemen op: hier spreekt de rechter in de meeste gevallen duidelijk uit dat de bestreden beslissing in strijd is met het grondwettelijke regime. ${ }^{104}$

Niet in alle gevallen echter oordeelt de rechter dat een specifieke wettelijke grondslag ontbreekt, en dat derhalve de inbreuk in strijd is met de grondwettelijke bepaling. Soms zoekt hij naar wegen om een andere oplossing te bereiken. De twee, in paragraaf 5.4 .4 beschreven zaken betreffen verschillende gevallen. In de uitspraak van de Centrale Raad van Beroep acht deze het onacceptabel dat, nu een specifieke wettelijke grondslag ontbreekt, de uitoefening van het grondrecht in casu helemaal niet beperkt zou kunnen worden. Dat noopt de Centrale Raad tot het hanteren van een eigen beperkingsgrond. Voor appellant zou het ontbreken van een beperkingsgrond gunstig zijn: hij zou het in liet geding zijnde grondrecht onbelemmerd kunnen uitoefenen. De toetsingsmatstaf die de Centrale Raad in casu echter aanlegt is dermate strikt, dat deze acceptabel is te achten en voor appellant in casu ook gunstig uitpakt: de ambtenaar mag bij de uitoefening van grondrechten niet zover gaan dat de goede vervulling van zijn functie

104. Wellicht dat het aantal zaken hierover vermindert wanneer meer inbreukmakende maatregelen een wettelijke basis hebben gekregen. Of dat in alle gevallen de waarborgen voor de burger doet toenemen hangt van de betreffende wettelijke regeling af, met name of de inbreukmakende maatregel duidelijk genormeerd is. 


\section{Hoofdstuk 6}

of de goede functionering van de openbare dienst in volstrekt ontoelaatbare mate (curs. JD) wordt aangetast.

In de uitspraak van de Afdeling bestuursrechtspraak constateert de rechter weliswaar dat een wettelijke grondslag voor de Regeling ontbreekt, maar dat het hanteren van de Regeling door het Rijk bij de gemeente het vertrouwen heeft gewekt dat aanspraak op een bijdrage krachtens de Regeling gemaakt zou kunnen worden. De gemeente als appellant heeft voordeel bij deze benadering: wanneer de Afdeling de Regeling buiten toepassing zou laten zou er helemaal geen grondslag voor de aanspraak op een bijdrage zijn. Toch geeft het te denken dat een algemeen beginsel van behoorlijk bestuur (in samenhang met gehanteerde beleidsregels) de grondwettelijke delegatieterminologie opzij kan zetten.

Het zou wat zwaar zijn om uit bovenstaande uitspraken af te leiden dat het systeem van de grondwettelijke delegatieterminologie faalt. Wel blijkt het stelsel in de praktijk voor zodanige problemen te zorgen dat de rechter in sommige gevallen strikte toetsing aan de delegatieterminologie achterwege laat en andere toetsingsmaatstaven kiest. ${ }^{105}$ De praktijk is weerbarstiger dan de theorie achter de grondwettelijke delegatieterminologie doet vermoeden.

\subsection{Conclusie}

In dit hoofdstuk is aan de hand van enkele voorbeelden onderzocht hoe formele wetgever en rechter in de praktijk met de grondwettelijke delegatieterminologie omgaan. Beiden blijken de terminologie niet in alle gevallen naar de letter uit te voeren.

De formele wetgever heeft de meeste moeite met het grondwettelijke delegatieverbod, gezien de geringe ruimte die er is om lagere organen bij de uitvoering van de wet te betrekken omdat er geen discretionaire bestuursbevoegdheden mogen worden toegekend. In een aantal gevallen is toch gebruik gemaakt van (meer of minder) discretionaire bevoegdheden. In sommige gevallen staan die bevoegdheden op gespannen voet met de uitleg van het delegatieverbod.

105. Zie ook de conclusie die Vermeulen trekt: "(...) dat het beperkingssysteem zoals het de grondwetgever voor ogen gestaan heeft niet onverkort in acht genomen kan worden. Soms zal aan onaanvaardbare consequenties ontkomen kunnen worden door 'creatief gebruik van de door de grond wetgever zelf geboden ontsnappingsclausules, dan wel door middel van ruim geformuleerde delegatiebepalingen (...)." Vermeulen 1990, p.83. 
Wanneer delegatie is toegestaan maakt de formele wetgever daar in een aantal gevallen veelvuldig gebruik van (bijvoorbeeld in de Vreemdelingenwet en de Wet op de persoonsregistraties).

Nu verder niet is onderzocht welke onderwerpen, an wie, gedelegeerd mogen worden past terughoudendheid met conclusies over de kwaliteit van de wetgeving en de uitvoering van de delegatieterminologie. Die kwaliteit is echter in het geding wanneer door de hoeveelheid lagere regelingen (inclusief beleidsregelingen) de overzichtelijkheid van de regeling van het onderwerp te lijden heeft.

De rechter vermijdt een strikte toetsing van de uitoefening van bestuursbevoegdheden aan het delegatieverbod en aanvaardt beperkingen van grondwettelijk geregelde grondrechten die strikt genomen niet tot een grondwettelijke beperkingsgrond herleidbaar zijn. Uit dogmatisch oogpunt vormt het systeem van de grondwettelijke delegatieterminologie hierdoor geen gesloten stelsel. De rechter ontwikkelt eigen toetsingsnormen waarbij hij in toenemende mate overgaat tot een belangenafweging. In commentaren is er echter op gewezen dat de oplossingen van de wetgever en rechter rond het delegatieverbod misschien wel geen schoonheidsprijs verdienen, maar praktisch gezien wel hanteerbaar zijn.

Uitspraken waarin een oordeel wordt gegeven over te ruime delegatie zijn mij niet bekend.

Het toetsingsverbod van artikel $120 \mathrm{Gw}$ staat overigens toetsing door de rechter van formele wetgeving aan de delegatieterminologie in de weg. Ook (strikt) gebonden gedelegeerde regelgeving wordt door de rechter niet getoetst aan de Grondwet.

Bij de uitleg van het delegatieverbod in de parlementaire stukken is een uitdrukkelijk onderscheid gemaakt tussen regelgevende en uitvoerende bevoegdheden. Ook de formele wetgever heeft hier meermalen een beroep op gedaan, door een bestuursbevoegdheid als "uitvoering' te betitelen. Wat opvalt in de hier gepresenteerde jurisprudentie is dat de rechter deze terminologie niet overneemt. Hij stelt niet vast dat er een uitvoeringsbevoegdheid in het geding is die is toegestaan ondanks het delegatieverbod.

Hoofdstuk 7 is gewijd aan het onderscheid tussen regelgeving en uitvoering. Bezien wordt of en hoe het onderscheid in (vooral de hedendaagse) jurisprudentie nog een rol speelt. 


\section{Hoofdstuk 7}

\section{Het onderscheid regelgeving-uitvoering}

\subsection{Inlleiding}

Eén van de conclusies uit hoofdstuk 3 (Schets van het delegatievraagstuk tot 1983 ) is dat het onderscheid wetgeving (regelgeving)-uitwoering in het delegatievraagstuk een belangrijke rol speelt. Daarbij hebben zich in de loop van de tijd verschuivingen voorgedaan in het begrip uitvoering.

Een ruime opvatting daarvan werd in de vorige eeuw veelal aangehangen door tegenstanders van delegatie. Overdracht van de bevoegdheid van de wetgever aan anderen (met name de Koning) was voor hen niet aanvaardbaar. Tegelijkertijd was echter duidelijk dat de praktijk niet zonder delegatie kon en was de formele wetgever genoodzaakt om delen van haar wetgevende taak aan anderen over te laten.

Om deze spanning tussen theorie en praktijk te ondervangen, werkten tegenstanders van delegatie met een ruim begrip uitvoering: een regeling was of formele wet, of uitvoering. 'Wanneer de formele wet regelgevende bevoegdheid aan een algemene maatregel van (inwendig) bestuur overliet, werd dat betiteld als uitvoering ${ }^{2}$. De bevoegdheid kwam immers in handen van de uitvoerende macht (de Koning). ${ }^{3}$

1. Zie ook de bekende woorden van Thorbecke, geciteerd door Van der Pot 1916, p. 319: "Eene wet kan meer of minder zijn uitgewerkt; bij algemeene trekken blijven, of in de deelen van het onderwerp treden; in het eerste geval zal aan het Biestuur eene aariwullende, regelende magt zijn gelaten, en uitvoering dus meer, in het ander gewal minder omvatten. Soms is de uitwoering eener wet zeer eenvoudig, soms vorderi zij een geheel stelsel van

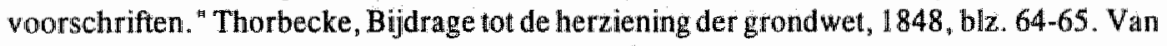
der Pot wijst op de formele betekenis die Thorbecke hier aan het woord uitvoering toekent.

2. Nu de Grondwet van 1815 wel het begrip "algemeene maatregel van inwendig bestuur" hanteerde, maar daarbij geen uitleg gaf, was men vrij om het naar eigen goeddunken te interpreteren. Zo kon daar ook onder vallen de bevoegdheid om naar buiten werkende algemeen verbindende voorschriften te stellen.

3. Vergelijk over de situatie rond de eerste grondwetten van 1814-1815 Van der Hoeven 1988, p.124: "Uit de in de ('oude' JD) grondwet gebruikte formuleringen en uit het ontbreken wan uitlatingen over delegatie, moet worden afgeleid, dat het vraagstuk als zodanig tijdens de totstandkoming der grondwet niet werd gezien. Dit is verkllaarbaar. Hoewel de bevoegdheid van de Koning am bindende voorschriften te stellẹ zich in het constitutionele recht reeds zeer spoedig wist te doen erkennen, werd, met betrekking tot de wetgever (in 


\section{Hoofdstuk 7}

Wanneer delegatile van wetgevende macht meer geaccepteerd wordt, leidt dat tot de erkenning dat ook via een algemene maatregel van bestuur wetgevende macht kan worden uitgeoefend. Dan komt de vraag aan de orde of, en zo ja, in hoeverre delegatie van wetgevende bevoegdheid (in een bepaald geval) is toegestaan. Dit was bijvoorbeeld de probleemstelling van Addens' dissertatie in 1884 (zie paragraaf 3.2). Addens hinkt nog op twee gedachten. Hij acht delegatie van wetgevende macht aan een algemene maatregel van bestuur ongrondwettig, maar een opdracht aan de koning om de wet uit te voeren was wel toegestaan (mits uit de grondwettelijke bepaling was af te leiden dat de formele wetgever niet het hele onderwerp zelf moest regelen). De vraag was dan wat allemaal 'ter uitvoering' overgelaten kon worden aan de koning. ${ }^{4}$

Deze vraag is de discussie rond regelgeving-uitvoering blijven beheersen. Daarbij verschoof de aandacht naar de bevoegdheden van lagere regelgevers. De problemen deden zich voor wanneer een wet of algemene maatregel van bestuur een bevoegdheid aan een minister toedeelde. ${ }^{5}$

Veelal zag de rechter zich voor de vraag geplaatst of de uitvoeringsregels die de minister in het kader van de uitoefening van zijn bevoegdheid stelde, nog als geoorloofde uitvoering dan wel ongeoorloofde delegatie te beschouwen waren. Het begrip uitvoeringsregels kan verschillende betekenissen hebben. In een publikatie van de VNG uit 1993 worden als soorten uitvoeringsregels onderscheiden: algemene regels (bedoeld zijn algemeen verbindende voorschriften door de gemeenteraad bij verordening vastgesteld); nadere regels (gegeven door het orgaan dat door de verordening met de uitvoering van de verordening is belast; deze nadere regels kunnen ook de status hebben van algemeen verbindend voorschrift) en beleidsregels. ${ }^{6}$

In dit hoofdstuk zal ik zelf onder uitvoeringsregels verstaan: regels die een bestuursorgaan stelt bij de uitvoering van wettelijke voorschriften, niet zijnde

formele zin) de Koning als witvoerder gezien. Het feit der delegatie - dat natuurlijk ook toen bestond - werd geheel in dit uitvoeringsverband verklaard en aanvaard, al was men nilet blind woor het geval dat reglementen ter uitwoering van de wet dat karakter van uitvoering gemakkelijk uiterst ver zouden kunnen uitbreiden. "

4. Zoals in paragraaf 3.2 is omschreven zoekt Addens steun bij Laband die als uitvoering ziet: voorschriften ter verdere verfijning van een regeling en voorschriften die de wet in het concrete geval beogen uit te voeren. Verdere richtijnen ontleent Addens aan Vivien. Zie ook paragraaf 7.4 .

5. Een ander strijdtoneel was jarenlang het inschakelen van burgemeester en wethouders bij de uitvoering van gemeenteraadsbesluiten. Meer hierover in paragraaf 7.3.

6. Gemeente en regelgeving 1993, p.84-85. 
algemeen verbindende voorschriften. In veel gevallen zullen dit beleidsregels of, een andere categorie, richtlijnen zijn (zie hoofdstuk 8) ${ }^{7}$

Daarmee hanteer ik in dit hoofdstuk een beperkte definitie van het begrip uitvoering (zie paragraaf 2.1.5).

In het vervolg van dit hoofdstuk zal echter blijken dat in parlementaire stukken, jurisprudentie of literatuur soms een ruimere invulling van het begrip 'uitvoering(sregel)' gehanteerd wordt. $\mathrm{Na}$ onderzoek van deze bronnen hoop ik aan te kunnen geven welke de 'heersende leer' op dit punt is.

Een rechtvaardiging om in deze studie over de delegatieterminologie een hoofdstuk te wijden aan het (oude) onderscheid regelgeving-uitvoering ligt hierin dat het onderscheid meermalen aangehaald is bij de bespreking van de betekenis van de grondwettelijke delegatieterminologie tijdens de parlementaire behandeling. Al kort is dit in paragraaf 4.2 naar voren gekomen. Er valt echter meer over te zeggen dan daar is gebeurd. Een uitgebreidere weergave van de opmerkingen van de regering over het onderscheid regelgeving-uitvoering vindt plaats in paragraaf 7.2 , gevolgd door een nadere beschouwing.

In paragraaf 7.3 staat de jurisprudentie over regelgeving-uitvoering centraal. De bespreking ervan is uitgesplitst in uitspraken die gemeentelijke bevoegdheden betreffen en overige zaken. De behandeling van een 'mini-leerstuk' (over de bevoegdheid van de burgemeester om ontheffing te verlenen van in de APV neergelegde sluitingstijden voor horeca-inrichtingen) in deze paragraaf geeft een aardige verschuiving in de jurisprudentie over regelgeving-uitvoering te zien. Het lijkt erop alsof we afkoersen op een jurisprudentie waarin het begrip 'uitvoering' geen rol meer speelt. Die plaats wordt overgenomen door het begrip 'beleidsregel'.

Zo bezien lijkt het alsof het niet meer nodig is een criterium te ontwikkelen om het onderscheid regelgeving - uityoering te kunnen aangeven. Veel auteurs hebben zich daar al decennia lang de nodige moeite voor getroost. De bevindingen in paragraaf 6.2 , over grondwettelijke uitvoeringswetgeving, toonden echter aan dat de formele wetgever nog wel degelijk worstelt met het begrip 'uitvoering'. ${ }^{8}$

7. Vergelijk Van der Vlies 1991, p. 120: "Regels die niet krachtens een wettelijke regelgevende bevoegdheid zijn gesteld en hun rechtsgrond in een andere bevoegdheid vinden, worden wel unitvoeringsregels of beleidsregels genoemd. "

8. Met name een delegatieverbod in een grond wettelijke bepaling blijkt de formele wetgever woor problemen te plaatsen. Verschillende (ruime) bestuursbevoegdheden worden 'gered" met een beroep op de uitvoeringsconstructie. Zie paragraaf 6.2. Zie over de noodbevoegdheden van de burgemeester en het begrip uitvoering, Kortmann 1994, p.476. 


\section{Hoofdstuk 7}

Daarom komen in paragraaf 7.4 de verschillende manieren om het onderscheid regelgeving-uitvoering te duiden aan bod.

In paragraaf 7.5 worden de belangrijkste zaken uit dit hoofdstuk nog eens op een rijtje gezet.

\subsection{Het onderscheid regelgeving-uitvoering in parlementaire stukken op de grondwetsherziening}

Bij de bespreking van de delegatieterminologie tijdens de grondwetsherziening werd ook aandacht besteed aan het onderscheid regelgeving-uitvoering. Daarvan is al kort verslag gedaan in de paragrafen 4.2.3.3 en 4.2.4.3. Een uitgebreidere weergave van de behandeling alsmede een nadere analyse ervan staan centraal in deze paragraaf."

\subsubsection{Het onderscheid regelgeving-uitvoering in parlementaire stukken}

Tijdens de behandeling van de wetsontwerpen op de grondrechten sprak de regering over het onderscheid tussen delegatie en uitvoering. Volgens de regering zou een delegatieverbod ontdoken kunnen worden wanneer de formele wet een discretionaire bestuursbevoegdheid toekent, onder het mom dat het gaat om een uitvoeringsbevoegdheid. Hetzelfde geldt wanneer de formele wet door het gebruik van vage normen een bestuursorgaan in feite de bevoegdheid geeft inhoudelijk een onderwerp te regelen. ${ }^{10}$

Deze uitleg bleef vragen oproepen. Tijdens de behandeling van het wetsontwerp op de provincies en gemeenten volgde een uitvoerige uiteenzetting door de regering in de Nota naar aanleiding van het Eindverslag.

Allereerst hield de regering een beschouwing over de inhoud van de begrippen wetgeving en uitvoering. Wetgeving "betreft de regeling van alle wezenlijke onderdelen en aspecten van een (ter wetgeving opgedragen) onderwerp. " Uitvoe-

9. Bromnen hierbij zijn de parlementaire stukken van de wetsontwerpen op de klassieke en sociale grondrechten (Kamerstukiken 13872-13873) en het wetsontwerp op de provincies en gemeenten (Kamerstukken 13990). Ook bij de behandeling van het wetsontwerp betreffende het onderwijs (Kamerstukken 13874) stond het onderscheid regelgeving - uitwoering veelvuldig in de belangstelling. Omdat dit voorstel verworpen is, is afgezien van bespreking van de opwattingen ower het onderscheid regelgeving - uitvoering in deze paragraaf, nu de status van deze opvattingen niet duidelijk is. Zie uitgebreid over het onderscheid Mentink 1989, p.153-197.

10. Kamerstukken II 1975-1976, 13872, nr 3 MvT, p.23 en Kamerstukken I 1976-1977, $13872-13873$, nr 55b MvA, p. 23 . 
ring is dan "het geven van voorschriften over detailkwesties, over ondergeschikte punten, die het wezen van de zaak niet raakten, maar uitsluitend ertoe dienden wettelijke bepalingen voor de praktische toepassing geschikt te maken." De regering voegde eraan toe dat het delegatievraagstuk hierop geen betrekking hoeft te hebben. "Verder heeft men zeer wel oog gehad voor het feit, dat een wettelijke regeling die op essentiële punten aan uitvoerende organen ruime en onbepaalde of zeer vaag omschreven bevoegdheden geeft in concrete gevallen beslissingen te nemen, in wezen aan deze organen het bepalen van de betekenis van een wet overlaat, met andere woorden weliswaar niet formeel maar wel praktisch gesproken 'wetgeving' overlaat. "1!

Delegatie van wetgeving vindt volgens de regering "formeel en feitelijk plaats, indien een orgaan, waaraan wetgeving is opgedragen, de regeling van wezenlijke aspecten of onderdelen van het ter wetgeving opgedragen onderwerp aan andere organen opdraagt, en weliswaar niet formeel, maar well feitelijk indien de wet aan uitvoerende organen ten aanzien van wezenlijke aspecten of onderdelen vañ dat onderwerp ruime, onbepaalde bevoegdheden geeft in concrete gevallen beslissingen te nemen. Niet de wetgever bepaalt in dat geval de norm, maar het uitvoerend orgaan." 12

Ook de inhoud van het delegatieverbod komt nog aan bod. Bij een delegatieverbod wordt "grondwettelijk aan de wetgever het gebod (...) gesteld alle wezenlijke bepalingen met betrekking tot het onderwerp in de wet vast te leggen. Voor zover de aard van het onderwerp er zich niet tegen verzet kunnen daarbij voorschriften over detailpunten die ertoe strekken de praktische toepassing van een wettelijke regeling mogelijk te maken aan andere organen worden overgelaten. Verder moet in de desbetreffende grondwetsbepaling het verbod worden gelezen aan uitvoerende organen ruime, onbepaalde bevoegdheden ter uitvoering van een wet te geven." 13

11. Kamerstukken II 1978-1979, 13990, nr 9 Herdruk, Nota naar aanleiding van het EV, p.8. In een noot werwijst de regering naar HR 5 maart 1883, W. 4893; HR 17 februari 1896 , W. 6769 en HR 25 juni 1900, W. 7478 alsmede Van der Pot in Oppenheim, Gemeenterecht, wijfde druk deel III blz. 64 en 65 .

12. Kamerstukken II 1978-1979, 13990, nr 9 Herdruk, Nota naar aanleiding van het EV, p.8.

13. Kamerstukken $\mathbb{I 1} 1978-1979,13990$, nr 9 Herdruk, Nota naar aanleiding van het EV, p.8. De hier beschreven 'uitvoeringsconstructie' wan de regering ziet Vermeulen alls een "verzachting van de al te strenge delegatieterminologie." Vermeulen 1990, p.79-80. Minder mild zijn Akkermans/Koekkoek: zij wijzen er op dat de regering bij de herziening van het grondwettelijke onderwijsartikel in eerste instantie het onderscheid regelgewing - uitwoering a fwijst (dle regering houdt vast aan een 'absoluut' delegatieverbod conform de memorie van toelichting op de grondrechten (zie paragraaf 4.2.3.1)). Via de nota naar aanleiding van het eindverslag bij datzelfde artikel en met name bij de behandeling van het 


\section{Hoofdstuk 7}

\subsubsection{Nadere beschouwing}

In het hierboven - vrijwel letterlijk - weergegeven standpunt wijkt de regering af van traditionele opvattingen. ${ }^{14}$ Dat bleek ook reeds bij de bespreking van de delegatieterminologie in hoofdstuk 4. Het loont de moeite om nog eens wat preciezer naar dat standpunt te kijken.

De regering duidt het onderscheid regelgeving-uityoering aan als het verschil tussen wetgeving en uitvoering. Met de omschrijvingen die zij geeft van deze begrippen (wetgeving: de regeling van alle wezenlijke onderdelen van een onderwerp; en uitvoering: het geven van voorschriften over detailkwesties die de praktische toepassing van de wet mogelijk dienen te maken) kan in grote lijnen ingestemd worden..$^{13}$ Daarmee zegt de regering echter niets over de status van de regels die bij wetgeving (regelgeving) of uitvoering tot stand komen. Dat houdl de mogelijkheid open dat er zowel bij wetgeving alls bij uitvoering algemeen verbindende voorschriften gegeven kunnen worden.

Deze conclusie trekt de regering dan ook. ${ }^{16}$ Met name bij de uitleg van de reikwijdte van het delegatieverbod gebruikt de regering de term uitvoering. In die uitleg dient de formele wetgever zelf de wezenlijke bepalingen in de wet vast te leggen. De regeling van detailpunten is volgens de regering uitvoering van de wet en kan aan andere organen overgelaten worden. Die regeling kan plaatsvinden door regelgeving: het stellen van algemeen verbindende voorschriften. Omgekeerd kan echter door een discretionaire bestuursbevoegdheid ('uitvoerings'bevoegdheid) het delegatieverbod ontdoken worden wanneer daardoor een be-

wetswoorstel op de prowincies en gemeenten sluipt de 'uitwoeringsconstructie" de uitleg van de delegatieterminologie binnen: "Zo keert het eerder afgekeurde onderscheid tussen wetgeving en uitwoering terug!" Akkermans/Koekkoek 1992, p.5-6, verwijzend naar Kamerstukken II 1976-1977, 13874, nr 6, p.15; Kamerstukken II 1976-1977, 13874, nr 10, p.6-7 en Kamerstukken II 1978-1979, 13990 , nr 9, p.8.

14. Hoewel ze dat niet beoogt: "De voorgestelde (delegatie)terminologie beoogt deze onzekerheid (of delegatie grond wettelijk is toegestaan of niet, JD) op te heffen en aldus verduidelijk ing te brengen. $Z \mathrm{Zj}$ heeft echter niet het doel de traditionele betekenis van de begrippen "wetgeving' en 'delegatie van wetgeving" te veranderen." Kamerstukken II 1978-1979, 13990 , nr 9 Herdruk, Nota naar aanleiding van het EV, p.8.

15. Zij het dat ik eraan toe zou willen voegen: wetgeving gebeurt door het stellen van allgemeen verbindende voorschriften; uitvoering is meer dan 'het geven van voorschriften' (namelijk de toepassing in het concrete geval, door middel wan beschikkingen of besluiten var algemene strekking, niet zijnde algemeen verbindende voorschriften). Bij uitwoering kunnen ook regels gesteld worden, maar die hebben dan (in mijn opwatting) niet de status van algemeen verbindend voorschrift.

16. Zie ook paragraaf 4.2 waar de betekenis van de delegatieterminologie is besproken. 
stuursorgaan wezenlijke onderdelen van een wet kan vaststellen. De regering spreekt in zo'n geval ook van delegatie (van regelgevende bevoegdheid).

Het is de vraag of het standpunt van de regering, dat onder witvoering oók kan vallen het stellen van algemeen verbindende voorschriften, overeen komt met opvattingen in jurisprudentie en literatuur. Deze opvattingen worden in de volgende paragrafen besproken. Ik kom daar op dit standpunt van de regering terug.

Een opmerkelijke uitspraak van de regering is die waarin zij stelt dat, bij discretionaire bevoegdheden, het nemen van concrete beslissingen "praktisch gesproken 'wetgeving" " is. De regering verwijst in een noot naar drie arresten van de Hoge Raad en de opvatting van Van der Pot in Oppenheims Gemeenterecht. ${ }^{17}$ De arresten zijn HR 5 maart 1883, W. 4893, HR 17 februari 1896, W. 6769 en HR 25 juni 1900 , W. 7478 .

Vooral in de eerste twee uitspraken speelt de kwestie of er sprake is van geoorloofde uitvoering dan wel ongeoorloofde delegatie. De P-G concludeert in beide gevallen tot uitvoering, de Hoge Raad echter ziet er (verboden) delegatie in.

In HR 5 maart 1883, W. 4893 gaat het om een bevoegdheid van burgemeester en wethouders. In de APV is een bepaling opgenomen met de volgende inhoud: het is verboden te bouwen, zonder inachtneming van de door $B$ en W in het belang der openbare orde, zedelijkheid en gezondheid te geven voorschriften ten aanzien van de plaats waar het gebouw wordt opgericht. Deze ('reglementeerende') bevoegdheid heeft de wet opgedragen aan de gemeenteraad. De raad heeft hier volgens de Hoge Raad wel niet formeel reglementerende bevoegdheid overgedragen, maar wel feitelijk, door de regeling van het onderwerp aan B en W over te laten.

In HR 17 februari 1896, W. 6769 is een bevoegdheid van de burgemeester in het geding. De Hoge Raad spreekt van ongeoorloofde delegatie van wetgevende macht. In de APV heeft de burgemeester de bevoegdheid gekregen om af te wijken van sluitingstijden in de APV (voor de 'horeca"), "hetzij in het algemeen, hetzij voor enkele der localiteiten en, zowel voor bepaalde als onbepaalde tijd een andere sluitingstijd vast (te) stellen en daaraan alle zodanige voorwaarden te verbinden die hij dienstig acht'. Ook dit is een bevoegdheid die de wet heeft opgedragen aan de gemeenteraad, en die de raad ten onrechte heeft gedelegeerd aan de burgemeester.

17. Kamerstukken II 1978-1979, 13990, nr 9 Herdruk, Nota naar aanleid ing van het EV, p:8, noot 3. 


\section{Hoofdstuk 7}

Deze uitspraken bieden ruimte aan twee interpretaties. De eerste is die van de regering: bij een discretionaire bevoegdheid kan het nemen van beslissingen in concrete gevallen als wetgeving beschouwd worden. Deze opvatting dient dan zo uitgelegd te worden dat het nemen van een reeks beslissingen in concrete gevallen in het kader van een niime bevoegdheid neerkomt op wetgeving. ${ }^{18}$

In beide hier besproken gevallen kan de in het geding zijnde bevoegdheid mijns inziens echter ook zo uitgelegd worden, dat het betreffende orgaan (burgemeester, burgemeester en wethouders) algemene regels kan stellen, naast het nemen van concrete beslissingen. Het is die ruimte, tot regeling, die door de Hoge Raad wordt afgekeurd, en waardoor hij spreekt van verboden delegatie van wetgevende bevoegdheid.

De derde door de regering genoemde uitspraak is HR 25 juni 1900, W. 7478. De daar in het geding zijnde bevoegdheid is gebaseerd op art. 2 APV: 'Een ieder is verplicht zich te gedragen naar de aanwijzingen, door de ambtenaren en beambten der politie in het belang van orde of veiligheid op de straat gegeven.' Deze bevoegdheid kan volgens de Hoge Raad niet gebaseerd worden op de verordenende bevoegdheid van de gemeenteraad. De bevoegdheid die hier aan politieambtenaren toekomt is volgens de Hoge Raad te ruim en komt in strijd met artikel $1 \mathrm{Sr}$ ('Geen feit is strafbaar dan uit kracht van een daaraan voorafgegane wettelijke strafbepaling'.) Niet in een wettelijke bepaling is immers een duidelijke norm opgenomen waarvan op overtreding straf is gesteld, maar de politieambtenaar kan naar eigen inzicht bepalen wanneer volgens hem de 'orde of veiligheid op straat' in het geding is.

De regering verwees verder naar Van der Pot in Oppenheim, Het Nederlandsch gemeenterecht, 1932, p.64. Van der Pot signaleert een ontwikkeling in de jurisprudentie waarbij de Hoge Raad een 'strenge' periode heeft gekend en al snel concludeerde tot 'verboden delegatie van macht'. "Het is waar, dat in de strenge periode bepalingen, waarin deze figuren voorkwamen, bij herhaling door den Hoogen Raad te licht zijn bevonden, maar gaandeweg is deze toch wel gaan inzien, dat hier van delegatie van wetgevend gezag geen sprake is, tenzij natuurlijk de bepaling uit de raadsverordening zelf geen enkel voorschrift inhoudt, doch alles overlaat aan de autoriteit, die de aanwijzing, enz. heeft te geven. Ook dan is, wat deze te doen heeft, slechts regelen van geval tot geval en dus in streng

18. Vergelijk de gang van zaken rond het ontstaan van beleidsregels: geaccepteerd is dat het nemen van een reeks concrete besluiten kan leiden tot het volgen van een vaste beleidslijn terzake, die uit kan monden in een beleidsregeling. 
theoretischen zin geen wetgeven, maar praktisch komt het daar dan toch geheel op neer." 19

Wanneer de gemeenteraad niet het kader aangeeft waarbinnen de beslissingen in het concrete geval door het uitvoerende orgaan moeten worden genomen, en dit orgaan steeds naar eigen inzicht kan beslissen, kan het als het ware op deze manier een onderwerp regelen. Dat kan als een vorm van wetgeving aangeduid worden. (De regeling ontstaat niet vooraf, maar 'al doende'). In modernere termen kan de beslissing in het concrete geval echter als een beschikking, of soms ook als besluit van algemene strekking (niet zijnde algemeen verbindend voorschrift) aangeduid worden.

De regering heeft het onderscheid tussen 'formele en feitelijke delegatie' nodig omdat zij het delegatieverbod tot kern van de delegatieterminologie maakt. Wanneer delegatie volgens de grondwettelijke delegatieterminologie is toegestaan dan biedt de uitleg van de terminologie nauwelijks nog aanknopingspunten voor de grenzen waarbinnen die delegatie zich moet afspelen. ${ }^{20}$

Het delegatieverbod daarentegen is door de regering uitgebreider omschreven: de wetgever dient alle wezenlijke bepalingen met betrekking tot het onderwerp in de wet vast te leggen. De regeling van detailpunten daarentegen mag overgelaten worden aan andere organen. Het delegatieverbod mag miet ontdoken worden door aan uitvoerende organen discretionaire bevoegdheden ter uitvoering van een wet toe te kennen, waardoor in feite niet meer de formele wetgever de norm stelt, maar de uitvoerende instantie.

Deze benadering van de regering is toe te juichen: zij kijkt niet alleen formeel naar bevoegdheidstoekenning (overdracht van regelgevende bevoegdheid is verboden bij een delegatieverbod ${ }^{21}$ ), maar zij heeft ook oog voor de situatie dat door toedeling van discretionaire bevoegdheden aan bestuursorganen de normstelling in feite kan verschuiven en het delegatieverbod daardoor ontdoken kan worden.

Bij de door de regering aangehaalde vroege jurisprudentie speelt de soort bevoegdheid (regelgevend dan wel bestuurlijk) een minder belangrijke rol. Er

19. J. Oppenheim, Het Nederlandsch gemeenterecht, vijfde geheel herziene druk, derde deel (supplement, bewerkt door C.W. van der Pot bz.) Haarlem, De erven F.Bohn N.V. 1932 , p.64-65.

20. Zie paragraaf 4.2 .5 : bij de interpretatie van een delegatiebepaling zall steeds rekening gehouden moeten worden met het onderwerp, de strekking en de historie van de bepaling.

21. Hoewel dit miet absolluut gebeurt: de regeling van detailpunten mag immers wel in algemeen verbindende voorschriften plaats vinden. 


\section{Hoofdstuk 7}

wordt gesproken over (verboden) delegatie van macht of, (verboden) delegatie van reglementerende dan wel wetgevende macht. Ook de status van de regel die tot stand komt is nauwelijks voorwerp van onderzoek. ${ }^{22}$ In die zin zijn er verschuivingen van opvattingen waar te nemen in de jurisprudentie van de afgelopen decennia. Zie paragraaf 7.3 .

In onze tijd wordt preciezer onderscheiden tussen de soort bevoegdheid (regelgevend dan wel bestuurlijk) en speelt ook de aard van de tot stand gekomen regel een belangrijke rol. Het is mede daarom niet duidelijk waarom de regering zich beperkt tot een verwijzing naar drie arresten van de Hoge Raad die voor en in 1900 zijn gewezen. Daarna is er immers ook nog veel jurisprudentie waarin het onderscheid regelgeving-uitvoering een rol speelt. ${ }^{23}$

In mijn optiek maakt de regering het zich bij de omschrijving van het delegatieverbod (onnodig) moeilijk door niet te onderscheiden tussen delegatie van regelgevende bevoegdheid en attributie van bestuursbevoegdheid. Dit komt doordat de regering als het ware het delegatieverbod invult in de omschrijving van delegatie van regelgevende bevoegdheid. Het delegatieverbod had mijns inziens duidelijker omschreven kunnen worden als: het verbod om regelgevende bevoegdheid over te dragen en het verbod om discretionaire bestuursbevoegdheden te attribueren of vage normen in de wet op te nemen (waardoor rechter of bestuursorgaan in feite een onderwerp inhoudelijk invullen).

Delegatie van wetgeving kan dan gedefinieerd worden als de overdracht van een regelgevende bevoegdheid: een bevoegdheid die de wetgever zelf heeft en overdraagt aan een ander orgaan dat die bevoegdheid op eigen naam en onder eigen verantwoordelijkheid gaat uitoefenen ${ }^{24}$ Een regelgevende bevoegdheid houdt

22. Zie ook Stroink 1978, p.113.

23. De hier geciteerde Nota naar aanleiding van het Eindverslag dateert van 22 december 1978. Een bekend arrest over regelgeving - uirvoering, het bromfietsvalhelinarrest, is HR 11 januari 1977, NJ 1977, 467 en had dus in de beschouwingen meegenomen kunnen. worden. Zie paragraaf 7.3 .

24. Zie paragraaf 2.2.3.2. In deze studie hanteer ik de termen wetgevende bevoegdheid en regelgevende bevoegdheid als synoniemen. Dit kan omdat ik een materieel wetsbegrip hanteer. Een precieze invulling daarvan is moeilijk te geven. Zo voldoet bijvoorbeeld de notie dat het tot de taak van de formele wetgever behoort om algemene regels te stellen niet meer helemaal. Dat komt niet alleen omdat er op deze hoofdregel uitzonderingen zijn (de Grondwet wijst de formele wetgever in sommige bepalingen aan om een 'beschikking" te nemen), maar ook omdat een 'algemene regel' steeds vaker specifieke doelgroepen betreft, dus minder algemeen is. Dat neemt niet weg dat ik van mening ben, dat er consti- 
in de bevoegdheid om algemeen verbindende voorschriften te stellen. Onder delegatie van regelgevende bevoegdheid valt niet attributie van een bestuursbevoegdheid. Maar wanneer de formele wetgever tot delegatie bevoegd is (hij mag dus andere organen inschakelen om de grondwettelijke opdraclit uit te voeren) ligt attributie van bestuursbevoegdheden mede voor de hand.

\subsubsection{Conclusie}

Inhoudelijk gezien deel ik het standpunt van de regering: het delegatieverbod kan ontdoken worden door te ruime bestuursbevoegdheden in een formele wet op te nemen. Ik zou echter de 'traditionele' terminologie aan willen houden bij het omschrijven van het delegatieverbod en delegatie van regelgevende bevoegdheid.

Zoals eerder genoemd in paragraaf 4.2 zou mijn invulling van het delegatieverbod de volgende zijn. Bij een delegatieverbod is elke overdracht van regelgevende bevoegdheid verboden. Wanneer het nodig is om andere organen bij de uitvoering van de formele wet te betrekken dan dient de toegekende bevoegdheid een goed afgebakende, niet discretionaire te zijn. Die bestuursorganen kunnen dan beleidsregels stellen om duidelijk te maken hoe hun bevoegdheid uitgevoerd zal worden.

Ik zou die toedeling van bevoegdheden attributie noemen, en niet vangen onder het delegatiebegrip, om verwarring te voorkomen. Het is heel goed mogelijk om een (te vergaande) attributie van bestuursbevoegdheden in strijd te achten met het delegatieverbod.

Ik realiseer me dat de problemen op het terrein van de regelgeving-uitvoering voor de uitvoeringswetgever (zoals in het vorige hoofdstuk aan bod gekomen) met een andere 'definitie' niet zijn opgelost. De formele wetgever zal immers, wanneer de grondwetsbepaling een delegatieverbod inhoudt, nog steeds moeten bepalen of een toe te kennen bestuursbevoegdheid, past binnen dat delegatieverbod. Wel wordt hiermee meer duidelijkheid geboden over de aard van de door het bestuursorgaan gestelde regels: wanneer het bestuursorgaan binnen het kader van de toegekende bestuursbevoegdheid regels stelt, dan zijn dit beleidsregels en geen algemeen verbindende voorschriften.

tutioneel gezien een materieel wetsbegrip is aan te wijzen, in die zin dat 'belangrijke" of 'ingrijpende' besluiten een formeel-wettelijke basis dienen te hebben. Zie verder paragraaf 9.4. 


\subsection{Het onderscheid regelgeving-uitvoering in de jurisprudentie}

\subsubsection{Inleiding}

De in de vorige paragraaf besproken arresten van de Hoge Raad hadden alle drie betrekking op gemeentelijke bevoegdheden. Zoals bekend is hier veel jurisprudentie over geweest. ${ }^{25}$ De gemeentewet bepaalde dat aan de gemeenteraad de bevoegdheid toekwam tot het maken van verordeningen. Aan burgemeester en wethouders was vervolgens het uitvoeren van die verordeningen opgedragen. Kregen B en W een ruime bevoegdheid (en soms stelden zij daarbij regels op), dan rees al gauw de vraag of de gemeenteraad geen regelgevende bevoegdheid had overgedragen, zodat er sprake was van verboden delegatie.

In 1931 werd dit probleem grotendeels opgelost toen in de gemeentewet een bepaling werd opgenomen die aan de gemeenteraad de bevoegdheid gaf om aan $B$ en $W$ het stellen van nadere regels bij het uitvoeren van de verordening over te dragen. ${ }^{26}$

Welke koers volgt de Hoge Raad na 1900 met betrekking tot het onderscheid regelgeving-uitvoering? Het is interessant om dit te onderzoeken nu de regering geen beroep heeft gedaan op de latere jurisprudentie van de Hoge Raad. Is in deze (latere) jurisprudentie steun te vinden voor de opvattingen van de regering? Met name interesseren mij twee vragen: volgt de Hoge Raad (of andere rechters)

25. Daarbij lijkt zij er niet in geslaagd om duidelijke criteria voor het onderscheid te ontwikkelen. (De problemen ontstaan overigens voor een groot deel door onduidelijke wetgeving.) Het motto van dit hoofdstuk zou kumnen zijn: "hier is geen sleutel te vinden die op clk slot past." (Ontleend aan Böhtlingk/Logemann 1966, p.124: "Waar de wettelijke competentieonschrijving zich tegen delegatie geacht wordt te verzetten, placht men het probleem te stellen in de vorm: geoorloofde uitvoering of ongeoorloofde delegatie. Leverde deze formule de gelegenheid om tot zekere hoogte het wetmatigheidsbeginsel van de rechtsstat te handhaven, ieder wist tweeertlei. Vooreerst, dat men zich hier bevindt in een grensgebied van onzekere contouren, wat in onvaste jurisprudentie tot uiting komt. (...) Het staat van te voren wast, dat hier geen sleutel te vinden is die op elk slot past. ")

26. De betreffende artikelen in de Gemeentewet (oud) zijn: artikel 168 (Aan hem (de gemeenteraad, JD) behoort het maken van de verordeningen, die in het belang der openbare orde, zedelijkheld en gezondheid worden vereischt en van andere, betreffende de huishouding der gemeente.) en artikel 169 (Hij kan in die verordeningen burgemeester en wethouders of door hem ingestelde commissies bevoegd verklaren nadere regels te stellen nopens bepaalde, in die verordeningaangewezen onderwerpen). Artikel 169 is in 1931 ingevoegd. In de op 1 januari 1994 in werking getreden Gemeentewet is deze materie geregeld in de artikelen 108 juncto 147 , voor zover het medebewindsverordeningen betreft, en artikel 108 juncto 149 en 156 wat autonome verordeningen betreft. 
de koers: 'het nemen van (een reeks) concrete besluiten op grond van een discretionaire bevoegdheid is in feite wetgeving'? En hanteert de Hoge Raad (of andere rechters) de opvatting dat het stellen van algemeen verbindende voorschriften tot uitvoering gerekend kan worden, mits het gaat om detailpunten?

In de volgende subparagrafen probeer ik een antwoord op deze vragen te kriggen. Ik besteed apart aandacht aan de jurisprudentie van de Hoge Raad over het onderscheid regelgeving-uitvoering bij gemeentelijke (7.3.2) en overige (vooral ministeriële) bevoegdheden (7.3.4). Daarbij bespreek ik de jurisprudentie niet uitputtend, maar beperk ik me tot enkele hoofdlijnen. Waar dat dienstig is maak ik gebruik van de literatuur. In paragraaf 7.3.5 volgt een evaluatie van het standpunt van de regering.

Bij deze speurtocht blijkt zich een interessante ontwikkeling voor te doen in de jurisprudentie over regelgeving-uitvoering. Ook andere rechters (met name de Afdeling rechtspraak van de Raad van State na 1976) gaan zich uitspreken over het onderscheid regelgeving-uitvoering. Het begrip uitvoering verdwijnt langzamerhand als onderscheidend begrip ten opzichte van regelgeving uit de rechtspraak. De beleidsregel doet zijn intrede. Aan de hand van een 'mini-leerstuk' over de bevoegdheid van de burgemeester om ontheffing te verlenen van in de APV neergelegde sluitingstijden voor horeca-inrichtingen wordt dit in paragraaf 7.3.3 uit de doeken gedaan.

In paragraaf 7.3.6 komen mogelijke verklaringen voor de verminderde jurisprudentie over regelgeving-uitvoering aan de orde.

\subsubsection{Jurisprudentie betreffende gemeentelijke bevoegdheden}

Van belang is op de eerste plaats de constatering dat de Hoge Raad blijkens de hierboven besproken uitspraken steeds zocht naar een materiële afbakening van regelgeving (wetgeving) en uitvoering. ${ }^{27}$ De Hoge Raad had natuurlijk ook een formeel criterium kunnen kiezen: verordeningen door de gemeenteraad tot stand gebracht zijn wetgeving; de nadere regels en andere besluiten gesteld door burgemeester en wethouders uitvoering. Die kant is de Hoge Raad echter niet opgegaan.

In vroege uitspraken volgt de Hoge Raad een strenge koers en sneuvelen veel APV-bepalingen omdat ze verboden delegatie bevatten. Daarna volgt de omslag

27. Huart 1928, p.569: gezocht moest worden naar de "objectieve kenmerken van wetgeving eener-, uitwoering anderzijds"'. Zie ook Stroink 1978, p.112. 


\section{Hoofdstuk 7}

naar een soepeler regime. Wanneer de gemeenteraad de uitvoering van de verordening overlaat aan burgemeester en wethouders en daarbij de kaders aangeeft waarbinnen $B$ en $W$ moeten blijven dan zal dit als uitvoering beschouwd kunnen worden. Krijgen B en W echter een ruime bevoegdheid, waarbij de gemeenteraad geen richtlijnen heeft gegeven hoe de bevoegdheid in te vullen dan is sprake van verboden delegatie. ${ }^{28}$

Enkele voorbeelden van bevoegdheden van burgemeester of burgemeester en wethouders die de Hoge Raad als uitvoering bestempelde:

B en W mogen 'bij openbare kennisgeving aanwijzen welke straten in het belang van de vrijheid en de veiligheid van het verkeer in de door de Raad zelf gestelde verbodsbepaling zijn begrepen. ${ }^{29}$

En de burgemeester mag in bijzondere gevallen het in de verordening vastgestelde sluitingsuur voor tapperijen later stellen. Ook mag hij 'van de tijden gedurende welke de vergunningslokaliteiten op Zondag gesloten moeten zijn, afwijking toestaan, d.w.z. deze bekorten. ${ }^{30}$

Met het volgen van een soepeler koers is de Hoge Raad een ruimer begrip uitvoering gaan hanteren: wanneer minder vaak tot verboden delegatie wordt geconcludeerd betekent dat oprekking van het begrip uitvoering.

28. Huart 1928, p.571: "In het algemeen mag men verwachten, dat hij (de Hoge Raad, JD) al is de oudere jurisprudentie op dit punt strenger dan de tatere - in die gevallen 'verboden delegatie" zal aannemen, waarin het de 'uitvoering" geldt van een zoo algemeen geformuleerd voorschrift, dat die uitvoering neerkomt op een beslissing van Burgemeester en Wethouders of anderen 'naar goedvinden', 'naar willekeur"." Bij een begrensde opdracht wan de Raad aan $B$ en $W$ is er een goede kans dat de Hoge Raad uitwoering aanneemt. Zie ook A-G Besier in zijn conclusie onder HR 20 december 1928, W. 11935. De lijn word voortgezet in HR 22 april 1932, W. 12441. Zie verder de in de paragraaf 7.2 aangehaalde uitspraak van Van der Pot in Oppenheims Het Nederlandsch gemeenterecht, 1932, p.64 en Vos in zijn bewerking van 'Rechtspraak en literatuur op de gemeentewet.' Volgens Vos heeft die omslag reeds in 1900 plaatsgevonden; in HR 2 januari 1900, W. 7386. Vos 1934, p.318-319. Brederveld/Schroot/Wijma (E. Brederveld, J.C. Schroot en N. Wijma, Begrip van de Nederlandse gemeente, deel 1, Samsom H.D. Tjeenk Willink Alphen aan den Rijn 1990, tweede geheel herziene druk) noemen enkele andere arresten van de Hoge Raad, waarin de omslag te zien is: HR 30 april 1900, Gst. 2536 en HR 24 december 1900, Gst. 2579 (p.165).

29. HR 30 oktober 1911, W. 9335.

30. HR 26 juni 1916, AB 1916, p.352. In dezelfde zin HR 6 januari 1919, NJ 1919, p.233. De bevoegdheid van de burgemeester is discretionair: hij mag immers in bijzondere gevallen andere sluitingstijden vaststellen. Toch komt de Hoge Raad hier niet tot verboden delegatie, maar vindt hij dit een uitvoerende bevoegdheid. 
Dat betekent ook dat de opvatting van de regering 'bij een discretionaire bevoegdheid kan het nemen van concrete besluiten gelijk gesteld worden aan wetgeving' (afgeleid uit drie vroege arresten van de Hoge Raad) minder navolging krijgt.

Kortmann heeft in een artikel in 1980 de opvatting van de regering 'getest' aan de hand van een aantal uitspraken van de Hoge Raad over gemeentelijke bevoegdheden. ${ }^{31}$ Hij bespreekt onder andere HR 9 januari 1962, AB 1963, p. 143. $B$ en $W$ mochten plaatsen aanwijzen waar het houden van varkens verboden was (binnen een afstand van 100 meter uit de as van de Gestelsestraat binnen de bebouwde kom van Waalre), in verband met hinder voor de omwonenden, of nadeel voor de gezondheid of zindelijkheid. De Hoge Raad oordeelt dat het besluit van $B$ en W uitvoering is. In gelijke zin de A-G, die naar 'vaste juris-

31. Kortmann 1980, p.203-205. Overigens doet zich bij gemeentelijke verordeningen het probleem voor dat er twee 'categorieèn' verordeningen zijn: de autonome en de medebewindsverordeningen. De autonome steunen op de artikelen 168 en 169 Gemeentewet (oud), de medebewindsverordeningen hebben een grondslag in artikel 209 aanhef en onder a Gemeentewet (oud), en andere wetten of algemene maatregelen van bestuur. Artikel 209 aanhef en onder a luidt: 'Tot het dagelijksch bestuur der gemeente, aan burgemeester en wethouders opgedragen, behoort a. het uitvoeren der beshiten van den raad,' er is geen delegatiebepaling bij opgenomen.

Het is niet duidelijk of bij medebewindsverordeningen het stellen van nadere regels door de gemeenteraad gedelegeerd mag worden aan B en W. Zie bijwoorbeeld de conclusie van de A-G bij HR 1 november 1955, NJ 1956, 40. In deze uitspraak gaat het om artikel 4 Slagersverordening. Volgens dit artikel is het verboden om een (slagers)winkel geopend te hebben in een door $B$ en $W$ aangewezen tijdvak (waarbij B en W artikel 5 tweede lid Winkelsluitingswet 1951 in acht hebben te nemen). HR: (...) dat in art. 4 van de verordening geen delegatie van verordenende bevoegdheid, (...) heeft plaats gehad, dóch aan B en W overeenkomstig het bepaalde in art. 209 aanhef en onder a van de Gemeentewet het uitvoeren der verordening is opgedragen; (...). " AG 's Jacob nam hier aan dat het ging om (toegestane) delegatie van regelgevende bevoegdheid aan $B$ en $W$ op grond van artikel 169 Gemeentewet (verwijst naar Bool, Gemeentewet supp. 1932, p.49: in art. 169 staat 'die' verordeningen, verwijzend naar art. 1.68 gemeentewet; dat zou volgens hem (en de AG) moeten zijn "verordeningen") (Zie ook HR 27 juni 1972, NJ 1972, 496; anders: HR 19 november 1968, NJ 1969, 103.)

Er zijn twee redenen waarom de Hoge Raad hier tot uitvoering kon concluderen. In de eerste plaats omdat de Hoge Raad de bevoegdheid van B en W inderdaad nauwkeurig genoeg begrensd acht. In de tweede plaats omdat de Hoge Raad delegatie bij medebewindsverordeningen afwijst, maar hiermee niet de hele bepaling op het spel wilde zetten en om het punt te omzeilen, uitwoering aanneemt.

In het vervolg zal ik hier geen aandacht meer aan besteden. 


\section{Hoofdstuk 7}

prudentie" verwijst (HR 2 januari 1902, W. 7386). B en W mogen niet de norm wijzigen, maar wel in concreto de plaatsen bepalen. ${ }^{32}$

Volgens Kortmann hebben $B$ en $W$ hier een discretionaire bevoegdheid en mogen zij zelf de norm invullen (wanneer is sprake van hinder of nadeel). In de opvatting van de regering zou dit als delegatie en ('praktisch gesproken') als wetgeving te beschouwen $z i j$. $^{33}$

In een ander geval ${ }^{34}$ geeft de gemeenteraad van Bergen in de APV het verbod om ontsierende reclame op of aan de openbare weg te tonen. B en W mogen bepalen in welke gevallen reclame ontsierend is. Volgens de Hoge Raad mocht de gemeenteraad hier B en W bij de uitvoering van de APV betrekken. Deze uitvoering van een discretionaire bevoegdheid is volgens de Hoge Raad geen delegatie (wetgeving).

Kortmanns conclusie is dan ook dat de Hoge Raad het standpunt van de regering niet deelt. ${ }^{35}$ Het standpunt van de Hoge Raad is begrijpelijk: weliswaar is steeds een discretionaire bevoegdheid in het geding, maar daaraan wordt wel richting gegeven door criteria als 'nadeel voor de gezondheid, hinder voor omwonenden', 'zindelijkheid' of 'ontsierende reclame'.

We moeten echter in het oog houden dat Kortmann arresten van de Hoge Raad heeft besproken uit de periode vóór de invoering van de grondwettelijke delegatieterminologie. Hij kon nog niet onderzoeken of de Hoge Raad de opvatting van de regering na de invoering van die terminologie in 1983 heeft overgenomen.

Uit de periode na 1983 is echter nauwelijks nog jurisprudentie van de Hoge Raad over regelgeving-uitvoering op gemeentelijk niveau. Daar zijn de invoering van de Afdeling rechtspraak Raad van State in 1976, en het beschikkingenbegrip in de Wet Administratieve Rechtspraak Overheidsbeschikkingen (Wet AROB) ${ }^{36}$

32. Vergelijkbaar is de bepaling in de APV van de gemeente Best waarin B en W was opgedragen plaatsen aan te wijzen waar zij het houden van de daarin genoemde dieren hinderlijk of voor de gezondheid of zindelijkheid nadelig achtten. Voor die plaatsen verbood de APV het houden van dieren. De Hoge Raad (HR 18 oktober 1960, NJ 1961, 38) achtte dit uitvoering. Zo ook A-G Van Oosten, verwijzend naar HR 26 juni 1916, AB 1916, p.352; HR 6 januari 1919, NJ 1919, p.233 en HR 10 november 1902, W. 9834.

33. Kortmann 1980, p.204.

34. HR 14 januari 1969, AB 1969, blz. 539.

35. Kortmann 1980, p. 204.

36. Wet van $\mathbb{1}$ mei 1975, Stb.284, houdende regels betreffende beroep op de Raad van State tegen overheidsbeschikkingen. 
debet aan. Het overgrote deel van de zaken rond de gemeentelijke verordeningen kwam, via het beschikkingenbegrip, bij de nieuwe administratieve rechter terecht. Bij de Hoge Raad kwamen nog slechts de strafzaken van overtreders van de gemeentelijke APV terecht.

Het wordt dus moeilijk om te zien of de Hoge Raad de opvattingen van de regering na 1983 heeft gevolgd.

Wel kunnen we onderzoeken of de Afdeling rechtspraak het standpunt van de regering volgt en hoe de Afdeling met het begrip 'uitvoering' omgaat. Voordat we daar echter aan toekomen bespreek ik eerst een andere ontwikkeling, die als gevolg heeft gehad dat er de laatste jaren nog maar weinig jurisprudentie over regelgeving-uitvoering is: het verdwijnen van het begrip uitvoering uit de jurisprudentie en de opkomst van de beleidsregel.

\subsubsection{Intermezzo: van uitvoering naar beleidsregels}

Zoals ook nog zal blijken is er nauwelijks nog recente jurisprudentie over het onderscheid regelgeving-uitvoering te vinden. Dat komt mijns inziens omdat de rechter een andere 'formule" is gaan hanteren. Met behulp van een 'mini-leerstuk' will ik deze verschuiving laten zien.

In geding in dit 'mini-leerstuk' is steeds de bevoegdheid van de burgemeester om ontheffing te verlenen van in de APV neergelegde sluitingstijden voor horecainrichtingen. In veel APV's is daar een bepaling over opgenomen. ${ }^{37}$

Voor de rechter spelen de redactie en de reikwijdte van die bepaling een belangrijke rol bij de beoordeling of de bevoegdheid van de burgemeester door de beugel kan.

Als aanloop naar de hierboven aangekondigde verschuiving een tweetal 'oude' uitspraken van de Hoge Raad.

37. Vergelijk de Model-algemene plaatselijke verordening van de VNG 1986 (nog gebaseerd op de oude Gemeentewet). Artikel 2.3.1.2, Sluitingsuur, luidt (voor zover relevant): '1.

Het is de houder van een inrichting. (...) verboden zonder vergunning van de burgemeester deze voor bezoekers geopend te hebben of aldaar bezoekers toe te laten of te laten verblijven: op maandag tot en met vrijdag tussen ... uur en ... uur, en op zaterdag en zondag tussen ... uur en ... uur."

Artikell 2.3.1.4, Afwijking sluitingswar, algehele sluiting, luidt: 'De burgemeester kan in het belang van de openbare orde, veiligheid, zedelijkheid of gezondheid of in geval wan bijzondere omstandigheden, te zijner beoordeling, bij openbaar bekend te maken besluit tijdelijk andere dan in de artikel 2.3 .1 .2 genoemde sluitingsuren vaststellen of tijdelijk algehele sluiting van een of meer inrichtingen bevelen. Hij brengt het besluit ter stond ter kennis van de houder van de inrichting die het betreft." 
De eerste uitspraak betreft HR 17 februari $1896, W .6769 . .^{38}$ De bevoegdheid wan de burgemeester om af te wijken van de in de APV vermelde sluitingstijden "hetzij in het algemeen, hetzij voor enkele der localiteiten en, zowel voor bepaalde als onbepaalde tijd een andere sluitingstijd vast (te) stellen en daaraan alle zodanige voorwaarden te verbinden die hij dienstig acht" was ongeoorloofde delegatie van wetgevende maclut. De wet draagt volgens de Hoge Raad die bewoegdheid op aan de Raad, zonder delegatiemogelijkheid..$^{39}$

In casu heeft de burgemeester ook wel een heel ruime bevoegdheid gekregen, zodat de uitkomst van de rechtszaak past in de lijn van de jurisprudentie toen.

In een uitspraak van de Hoge Raad twintig jaar later ${ }^{40}$ concludeert de Hoge Raad tot uitvoering. In de APV was de burgemeester aangewezen om "in bijzondere gevallen het in die verordening vastgestelde sluitingsuur voor tapperijen later te stellen en van de tijden gedurende welke de vergunningslokaliteiten op Zondag gesloten moeten zijn, afwijking toe te staan, d.w.z. deze te bekorten". Volgens de Hoge Raad mag de burgemeester hier dispensatie verlenen van het door de gemeenteraad gestelde verbod en doet hij daarmee niets anders dan de APV uitvoeren.

Ook deze uitspraak past mijns inziens goed in de opvattingen van de Hoge Raad tot dan toe over delegatie en uitvoering op gemeentelijk niveau.

We maken een sprong in de tijd en belanden in de tweede helft van de jaren ' 70 . Met de invoering van de Afdeling rechtspraak Raad van State als administratieve rechter in 1976, en het daaraan gekoppelde beschikkingenbegrip, komen de meeste beroepszaken over dit onderwerp bij deze rechter. ${ }^{41}$

In 1983 doet de Afdeling uitspraak over de bevoegdheid van de burgemeester van Oploo om ontheffing te verlenen van het sluitingsuur van horeca-gelegenheden. ${ }^{42}$ De burgemeester had zich op het standpunt gesteld dat hij niet kon ingaan op het verzoek van appellanten om een permanente ontheffing van het sluitingsuur voor de nacht van zaterdag op zondag te geven, omdat hij daarmee

38. Zie ook paragraaf 7.2 .

39. Over de bevoegdheid om de sluitingstijd voor 'horeca'-inrichtingen (toen nog tapperijen, herbergen, localiteiten genoemd) vast te stellen, of daarvan ontheffing te verlenen is veel jurisprudentie. Bij deze uitspraak van de Hoge Raad plaatste de redactie van het Weekblad van het recht als 'noot' dat de burgemeester in bijzondere gevallen wel dispensatie mag verlenen; dan is er sprake van uitvoering.

40. HR 26 juni 1916, AB 1916, p.352; NJ 1916, 715.

41. Zie over een strafzaak (overtreding van het verbod in de APV) betreffende dit onderwerp HR 3 mei 1977, NJ 1977, 536, m.nt. ThWvV.

42. ARRS 2 september 1983, AB 1984, 245. 
inbreuk zou maken op de regelgevende bevoegdheid van de gemeenteraad. De Afdeling verwerpt dat standpunt: "Immers, de gemeenteraad heeft in art. 56 derde lid $\mathrm{APV}^{43}$ in het geheel geen grenzen gesteld aan de ontheffingsbevoegdheid van de burgemeester. De visie van de burgemeester dat hij zich op het terrein van de gemeentelijke wetgever zou bewegen, zou slechts opgaan indien hij aan alle inrichtingen in de gemeente onbeperkt ontheffing van het in art. 56 eerste lid vervatte verbod zou verlenen. In dat geval zou de burgemeester immers de door de gemeenteraad vastgestelde sluitingsuren als vermeld in art. 56 eerste lid APV in feite ter zijdle stellen."

Deze uitspraak is opmerkelijk in het licht van eerdere jurisprudentie van de Hoge Raad: de gemeenteraad heeft immers geen enkele grens gesteld aan de ontheffingsbevoegdheid van de burgemeester. Vroeger zou deze bevoegdheid wellicht te ruim zijn bevonden en zou de rechter tot verboden delegatie hebben geconcludeerd.

Een uitspraak van de Voorzitter van de Afdeling rechtspraak, gedaan zo'n twee maanden na de hierboven genoemde over de bevoegdheid van de Oploose burgemeester (ditmaal betreft het een bevoegdheid van de burgemeester van Alphen aan den Rijn) laat heel mooi zien hoe zich een andere oplossing van het probleem regelgeving-uitvoering aandient. ${ }^{44}$ In deze uitspraak buigt de voorzitter zich niet meer over (verboden) delegatie dan wel uitvoering, maar interpreteert hij de gestelde regels in het licht van het gevoerde beleid.

Art. 70 lid 1 APV Alphen aan den Rijn 1948 bepaalde, dat het de houdler van een inrichting is verboden deze voor het publiek geopend te hebben of daarin bezoekers te ontvangen, toe te laten of te hebben in de nacht van zaterdag op zondag van 23.30 uur tot 06.00 uur en in de overige nachten van 00.00 uur tot 06.00 uur. Op grond van het derde lid van dit artikel kan de burgemeester van het in het eerste lid gestelde verbod ontheffing verlenen. De voorzitter overweegt dat de burgemeester het beleid voert (cursivering JD) dat als regel aan horeca-inrichtingen voor een jaar ontheffing wordt verleend tot 02.00 uur voor de zondagavond tot en met de donderdagavond en voor een kwartaal ontheffing wordt verleend tot 03.00 uur voor de vrijdag- en zaterdagavond.

Hier krijgen de gestelde regels niet meer het etiket uitvoering (of verboden delegatie), maar zijn het beleidsregels geworden. ${ }^{45}$ En beleidsregels zijn een be-

43. 'De burgemeester kan ontheffing verlenen van de in het eerste lid vervatte verboden.'

44. Vz ARRS 1 november 1983, AB 1984, 489.

45. De hier aangehaalde uitspraak is natuurlijk niet de eerste waarim beleidsregels een rol spelen. Zie daarover uitgebreider het volgende hoofdstuk. 


\section{Hoofdstuk 7}

noembaar juridisch fenomeen, met een eigen status en rechtsgevolgen. ${ }^{46}$ En dat feit brengt met zich mee dat rechters mijns inziens meer geneigd zijn een ruime bestuursbevoegdheid, die 'gestructureerd' is door beleidsregels, te accepteren, dan in vroegere uitspraken onder uitwoering toegestaan zou zijn.

In de jurisprudentie van de Hoge Raad over regelgeving-uitvoering zou van dit beleid van de Alphense burgemeester gezegd kunnen zijn dat hij een deel van de regelgevende bevoegdheid van de raad (ten onrechte) heeft overgenomen. Bovendien stelt de raad geen grenzen aan de ontheffingsbevoegdheid van de burgemeester.

De hijn wordt doorgezet in een uitspraak over de APV Amsterdam, ${ }^{47}$ waarvan artikel 76 eerste lid bepaalt dat het verboden is een inrichting zonder vergunning van de burgemeester voor bezoekers geopend te hebben of hen daarin te laten verblijven tussen 24.00 uur en 06.00 uur. (...) De burgemeester heeft hierop een beleid ontwikkeld, waarbij aan nachtclubs en discotheken, indien aan enkele voorwaarden wordt voldaan, een zogenaamde '22-4 vergunning' wordt verleend. Een dergelijke vergunning geeft tevens het recht om op vrijdag- en zaterdagavonden een uur langer-derhalve tot 05.00 uur open te zijn. Aan besloten clubs kan wolgens de APV tot 06.00 uur vergunning worden verleend.

Deze bevoegdheid, hoewel ruim, is in de ogen van de Afdeling kennelijk niet te ruim. Ook in deze uitspraak blijkt dat de Afdeling zich niet (meer) verdiept in de vraag of al dan niet sprake is van verboden delegatie. Er wordt gekeken naar de bevoegdheid: is dat een bestuursbevoegdheid en geen regelgevende bevoegdheid, dan hoeven de gestelde regels niet als 'verboden delegatie' te worden opgevat, maar kunnen ze beschouwd wörden als beleidsregels. ${ }^{48}$

46. Het begrip beleidsregel is meer en meer gejuridificeerd. In de beoogde wettelijke regeling (Derde tranche Algemene Wet Bestuursrecht) bliff de beleidsregel gehandhaafd met een aparte status ten opzichte van algemeen verbindende voorschriften. De wetgever makt nitet de keuze om beleidsregels gelijk te stellen aan algemeen verbindende voorschriften. Zie daraver hoofdstuk 8.

47. ARRS 22 maant 1985, AB 1985, 471.

48. Overigens is er ook jurisprudentie waruil blijkt dat de rechter de vraag ontwijkt of er sprake is van verboden delegatie van regelgevende bevoegdheid, zie ARRS 18 juni 1985 , AB 1985, 541, m.nt. JHvdV. De kantine van de tennisclub in Krimpen aan den LIssel kreeg geen uitbreiding van de sluitingstijd. Art. 76 lid 1 APV bepaalde dat het de houder van een inrichting als bedoeld in de Drank-en Horecawet werbodlen is deze inrichting van maandag $1 / \mathrm{m}$ vrijdag van 01.00 uur tot 06.00 uur en op zaterdag en zondag van 02.00 uur tot 06.00 uur voor het publiek geopend te hebben of daarin een of meer bezoekers toe te laten of te thebben. De burgemeester kan wolgens het tweede lid op grond van bijzondere omstandighedendie tijdstippen hetzij voor alle, hetzij voor bepaalde inrichtingen wijzigen. 
Het mag echter niet al te gortig worden: de rechter kan nog steeds het oordeel 'verboden delegatie' uitspreken. Dat overkwam de Bussumse burgemeester. ${ }^{49}$ Art. 46 eerste lid APV Bussum verschaft aan de burgemeester de bevoegdheid om voor alle 'inrichtingen' te bepalen op welke tijd deze voor het publiek geopend mogen zijn. Volgens de Afdeling is hiermee aan de burgemeester een bevoegdheid toegekend, die alleen aan de raad toekomt, "nu het hier gaat om het vaststellen van algemeen werkende voorschriften, gericht tot alle exploitanten van de in de gemeente aanwezige inrichtingen. ${ }^{\text {"50 }}$

Annotator Van der Veen acht hier, en daar sluit ik me bij aan, wel heel duidelijk de grens tussen uitvoering en geoorloofde delegatie overschreden. ${ }^{51}$

De Afdeling overweegt: "Nu het ten dezen betreft een verzoek tot wijziging van het sluitingsuur voor een bepalde inrichting kan de Afd. voorbij gaan aan de vraag of woormeld art. 76, tweede lid in zoverre de raad van de gem. Krimpen aan den IJssel verweer: der daarbij de bevoegdheid heeft toegekend eerderbedoelde tijdstippen ook voor alle inrichtingen te wijzigen, zich verdraagt met het bepaalde in de art. 167,168169 en 220 gem.w." In eerdere uitspraken zou mijns inziens deze bevoegdheidsoverdracht tot verboden delegatie hebben geleid. In zijn noot beschrijft Van der Veen de constructie die de Afdeling rechtspraak hanteert: de Afdeling kan volgens hem aan de bevoegdheidsvraag voorbij gaan omdat het hier een andere sluitingstijd betreft, namelijk tot 23.00 uur of tot 24.00 uur. In zoverre acht de Afdeling de bepaling verbindend.

Het 'vervolg' op deze uitspraak vindt plaats in ARRS 21 maart 1988, AB 1989, 14, m.nt. JHydV. in deze uitspraak wordt verder geen uitdrukkelijke aandacht meer besteed aan de bevoegdheid.

49. ARRS 7 juni 1985, AB $1985,539, m . n t$. JHvdV.

50. VNG Model-algemene plaatselijke verordening 1986; de toelichting op artikel 2.3 .1 .2 vermeldt als conclusie uit de rechtspraak: "De burgemeester is (..) bij zijn ontheffingenbeleid derhalve gebonden aan de volgende grenzen: a. de ontheffing mag geen permanent karakter hebben; $b$. de ontheffing mag daarbij niet alle in de gemeente aanwezige inrichtingen betreffen." (p.I1-3-8)

51. Hij schrijft verder nog over de verschillende redacties die in APV's voorkomen. Zo mag de burgemeester in sommige verordeningen bijvoorbeeld in bepaalde omstandigheden ontheffing verlenen en in andere verordeningen in bijzondere omstandigheden. "Bij dit laatste criterium lijkt de door de raad aan de burgemeester toegedachte ruinte, zowel wat het gaat om het geven van beschikkingen als war (miet-geoorloofde) regelgeving in het beeld kan komen, aanmerkelijk beperkter dan bij het nogal onbepaalde criterium "op grond van bepaalde omstandigheden. "(..) Krijgt de burgemeester beleidsruimte dan verdient het aanbeveling dat hij voor het gebruik van de bevoegdheid richtlijnen opstelt. "Ook dan is er de vraag welke regels de raad ten minste zelf dient te geven om zich van zijn wetgevende taak gekweten te kunnen achten met zicht op aan de burgemeester toevallende pseudo-wetgevende bevoegdheid." 


\section{Hoofdstuk 7}

Zien we tot nu toe dus een ontwikkeling in de rechtspraak waarin een (niet tê) ruime bevoegdheid wordt toegestaan wanneer die bevoegdheid is 'opgevuld' met beleidsregels: ook die beleidsregels moeten aan bepaalde juridische normen voldoen, de algemene beginselen van behoorlijk bestuur.

Zie daarover een uitspraak van de Voorzitter over een bevoegdheid van de Haarlemse burgemeester. ${ }^{52}$

Artikel 22 Drank- en Horecaverordening van de gemeente Haarlem luidt als volgt: ' 1 . Het is verboden een inrichting voor het publiek geopend te hebben; $a$. op andere dagen dan de onder b en $c$ bedoelde van 0.30 tot 7.00 uur; $b$. in de nachten van vrijdag op zaterdag en van zaterdag op zondag van 1.00 tot $7.00 \mathrm{u}$; c. in de nacht van 31 dec. op 1 jan. van 21.00 tot $7.00 \mathrm{u}$. 2. De burgemeester kan ontheffing verlenen van het in lid 1 van dit artikel gestelde verbod. ' De burgemeester krijgt hier dus een ruime, niet geclausuleerde bevoegdheid. De voorzitter overweegt dat "De ruime mate van beleidsvrijheid waarover verweerder (de burgemeester, JD) ter zake beschikt echter begrensd (wordt) door het verbod van willekeur en door het in het algemeen rechtsbewustzijn levend beginsel van behoorlijk bestuur dat een beslissing met de vereiste zorgvuldigheid moet worden voorbereid en genomen. "53

Kort samengevat zien we de volgende ontwikkeling: de twee 'oude' uitspraken van de Hoge Raad passen in de lijn zoals die in paragraaf 7.3.2 is beschreven. De Afdeling rechtspraak hanteert een (nog) ruimer begrip uitvoering. Voldoende is dat de gemeenteraad de sluitingstijden in de APV heeft vastgelegd, de burgemeester mag (ongeclausuleerd) ontheffing verlenen. De regels die de burgemeester daarbij hanteert worden beschouwd als beleidsregels, en de uitoefening van de bevoegdheid moet voldoen aan de algemene beginselen van behoorlijk bestuur.

52. VZ ARRS 18 oktober 1990, AB 1991, 193, m.nt. JHvdV.

53. In casu was een al te plotselinge omslag van beleid het probleem. De algemene beginselen wan behoorlijk bestuur vormen het algemene kader waarbinnen beleidsregells gehanteerd worden. Zie Scheltema 1988, p.455: "Terwijl het bindend karakter wan algemeen verbindende voorschriften uit de ard van de wetgevende functie voortvloeit is de binding die van beleidsregels uitgaat eerst de laatste decennia erkend. Dat hangt samen met de ontwikkeling van de beginselen van behoorlijk bestuur in de rechtspraak. Twee van die beginselen, het gelijkheidsbeginsel en het rechtszekerheidsbeginsel, wijzen sterk in de richting van de binding van het bestuur aan beleidsregels. Heeft het bestuur een beleid in regels vastgelegd, dan zou het immers in strijd met de gelijkheid zijn om in een incidenteel geval van die regel af te wijken. Een dergelijke afwijking zou ook in strijd met de rechtszekerheid zijn ondat een burger erop mag rekenen dat er in overeenstemming met de beleidsregels wordt beslist." Zie verder hoofdstuk 8 . 
Het overlaten door de gemeenteraad aan de burgemeester van het bepalen van de sluitingstijden van alle inrichtingen is niet toegestaan.

\subsubsection{Jurisprudentie betreffende ministeriële bevoegdheden}

We stappen af van de gemeentelijke bevoegdhedenperikelen en gaan terug naar de jurisprudentie over regelgeving-uitvoering, maar nu op 'rijks'niveau. Welke opvattingen hanteert de Hoge Raad (en eventueel andere rechters) daarin? De verwachting is overigens hierbij dat de in de vorige paragrafen uitgezette lijnen ook hier van toepassing zijn.

In uitspraken die in deze paragraaf besproken worden speelt veelal een bevoegdheid van een minister een rol. Bij een bevoegdheid van een minister is vaak het probleem dat niet duidelijk wordt hoe ver zijn bevoegdheid strekt. Is sprake van een regelgevende bevoegdheid, of "slechts" van een uitvoerende bevoegdheid? Die onduidelijkheid hangt samen met de redactie van het wets- (of amvb)artikel waarop de bevoegdheid berust.

Worden daarin de woorden 'regels stellen' of een soortgelijke formulering gebruikt, dan is vaak een regelgevende bevoegdheid aanwezig. ${ }^{54}$ Ook zijn er niet zoveel problemen wanneer het gaat om de bevoegdheid om concrete besluiten te nemen (en die bevoegdheid nauwkeurig omschreven is).

De meeste moeilijkheden doen zich echter voor wanneer de minister bijwoorbeeld eisen mag stellen of (nadere) voorschriften mag geven.

De minister doet dat in veel gevallen door middel van een regeling. Voor de betrokkenen (burgers, minister en rechter) is dan van belang welke status die regeling (regels) heeft (hebben). ${ }^{55}$

Enkele hoofdlijnen uit de jurisprudentie zijn de volgende.

Een minister mag een regelgevende bevoegdheid uitoefenen (in de zin van algemeen verbindende voorschriften stellen) wanneer de formele wet hetzij recht-

54. Vooruitlopend op de hier te bespreken jurisprudentie dient hier echter en kanttekening bij te worden geplaatst: er dient daamaast een wettelijke grondslag voor delegatie wan regelgevende bevoegdheid te zijn. Zie hierna.

55. In de Aanwijzingen voor de regelgeving $1993 \mathrm{zijn}$ bierover de volgende bepalingen opgenomen. Aanwijzing 28: '1. Voor delegatie van de bevoegdheid tot het vaststellen wan algemeen verbindende voorschriften aan de regering wordt de formule bij algemene maatregel van bestuur' gebruikt. 2. Is het de bedoeting subdelegatie van deze bevoegdheid door de regering mogelijk te maken, dan wordt de formule bij of krachtens algemene maatregel van bestuur' gebruikt.' en aanwijzing 30: '1. Voor delegatie van regelgevende bevoegdheid aan een minister wordt de formule 'bij ministeriéle regeling' of de formule 'bij regeling van Onze Minister van ...' gebruikt. 2. (...)' 


\section{Hoofdstuk 7}

streeks regelgevende bevoegdheid aan de minister toekent ${ }^{56}$, hetzij de formule 'bij of krachtens algemene maatregel van bestuur' hanteert. ${ }^{57}$

In deze gevallen is er wat de bevoegdheidsgrondslag betreft dus geen probleem. Er kan wel een probleem ontstaan wanneer de rechter onderzoekt of de minister binnen de grenzen van zijn bevoegdheid handelt (regels stelt). Overschrijding van een gedelegeerde bevoegdheid is niet toegestaan. ${ }^{58}$

56. Zie bijvoorbeeld HR 24 mei 1985, NJ 1986, 543. De Hoge Raad overweegt: "(i) Art. 69 lid 1 Veewet luidt: "Voor zover Onze minister van $\mathrm{L} \& \mathrm{~V}$ niet anders bepaalt $(. .$.$) , ten$ bewijze dat voldaan is aan de met het oog op de uitvoer door hem gestelde eisen met betrekking tot: (...) (ii) de Beschikking Vleesproducten 1965 (BV 1965): hierin geeft de minister regels ontrent de keuring. Art. 69 lid 1 behelst tweeërlei delegatie; de minister kan 'anders bepalen' t.a.v. het verbod vleesprodukten uit te voeren; en de minister kan keuringseisen stellen. De BV 1965 moet worden aangemerkt als een uitwerking van deze laatste delegatie (...)." De Hoge Raad merkt de gestelde eisen aan als algemeen verbindende voorschriften. Zie ook HR 9 maart 1990, NJ 1990, 406 over artikel 29 Wet Studiefinanciering, dat luidt: 'De studerende dient een schriffelijk verzoek om toekenning van studiefinanciering in met inachineming wan de door Onze minister te stellen regelen.' En voorts HR 18 januari 1991. NJ 1992, 638 (Leffers) waar de status van de Regeling verbod voedsel- en slachtafvallen (Stcrt.1986, 66), gebaseerd op artikel 36 Veewet ('De minister van Landboww en Visserij kan regelen stellen ...') in het geding is.

57. Zie bijwoorbeeld HR 23 november 1976, NJ 1977, 290; art, 2 WVW verleent de bevoegdheid tot het bij of krachtens algemene maatregel van bestuur stellen van nadere regelen betreffende het verkeer op de wegen, en de besluitgever is de darmede verleende bevoegdheid niet te buiten gegaan door bij het RVV evenwermelde gedragsregels te stellen en tegen overtreding daarvan straf te bedreigen. In gelijke zin HR 9 mei 1978, NJ 1979 , 25; HR 29 november 1977, NJ 1978, 565: De Beschikking contingenteringsregeling tong en schol Noondzee 1976 kan teruggevoend worden op artikel 4 Visserijwet (bij of krachtens algemene maatregel van besturr). Minister overschrijdt bevoegdheid niet; HR 5 oktober 1984, NJ 1985, 74: subdelegatie aan minister om voorwaarden te stellen geoorloofd (kan gebaseerd worden op art. 8 lid 2 Ziekenfondswet, bij of krachtens algemene maatregel van bestuur, en artikel 10 lid 1 sub b Verstrekkingenbesluit).

58. Dit deed zich voor in de volgende uitspraken: HR 8 februari 1955 , NJ 1955, 254; Rb Arnhem 24 november 1978, NJ 1979, 203; HR 1 juli 1983, NJ 1984, 360 (Prijzenbeschikking medische hulp aan particuliere patiènten 1980) Hoge Raad:" "Het Hof heeft terecht aangenomen dat de onderhavige prijzenbeschikkingen, die in eerste instantie beogen het inkomen van de medische specialisten aan te passen aan de bovenbedoelde door de regering wenselijk geachte inkomensvorming - en waarbij derhalve overwegingen die niet van conjunctuur-politieke aard zijn op de voorgrond staan -, buiten het raam van de Prijzenwet vallen. Daaraan doet niet af dat bij het nemen van een prijsmaatregel doelstellingen van conjunctuurbeleid en van inkomensbeleid dooreen zullen kunnen lopen."'; HR 10 april 1984, NJ 1984, 612 (Jodiumhoudend broodzout) Hoge Raad: "De strekking van art. 16 lid 1 Warenwet, beschouwd in het licht van de geschiedenis van zijn totstandkoming brengt mede, dat krachtens die bepaling uitsluitend voorschriften kunnen worden 
De jurisprudentie is echter niet consistent. Moeilijkheden zijn er vooral rond (ministeriële) bevoegdheden die niet rechtstreeks steunen op de formele wet, maar op een algemene maatregel van bestuur. De formele wet geeft een delegatiemogelijkheid 'bij algemene maatregel van bestuur'. De algemene maatregel van bestuur kent vervolgens een (regelgevende) bevoegdheid toe aan de minister. Kunnen de regels die de minister in een dergelijk geval stelt, erkend worden als algemeen verbindende voorschriften? Een criterium dat hierbij nog wel eens een rol speelt is de mate waarin een bevoegdheid discretionair is ${ }^{59}$ Er kunnen in zo'n geval drie uitkomsten zijn: er is sprake van witvoering, ongeoorloofde delegatie, of de Hoge Raad neemt de verbindendheid van de bevoegdheid aan, en accepteert dat de gestelde regels algemeen verbindende voorschriften zijn (dat wil zeggen, er is sprake van geoorloofde subdelegatie)..$^{60}$

Bij de laatste opvatting wijkt de Hoge Raad af van de hierboven geschetste lijn dat voor subdelegatie een grondslag in de formele wet aanwezig dient te zijn. ${ }^{61}$

gegeven, welke verband houden met de kwaliteit van de bij de desbetreffende amvb aangewezen, waren en met de eisen welke in het belang van de volksgezondheid aan die waren als zodanig zijn te stellen (...) De voorschriften (voor het verplicht toevoegen van jodium aan brood, JD) vinden geen wettelijke grondslag (...) in art. 16 lid 1 Warenwet. Uit de omstandigheid dat de jodering van het broodzout uitsluitend ter voorkoming wan struma is voorgeschreven volgt immers, dat dit voorschrift geen verband houdt met aan de samenstelling, bereiding of verdere behandeling van het brood als zodanig te stellen eisen."; HR 26 februari 1985, NJ 1985, 595; Vz ARRS 30 augustus 1990, AB 1991, 567 (visserijwet).

Wel binnen de grenzen van de gedelegeerde bevoegdheid was bijvoorbeeid HR 1 juli 1981, NJ 1981, 618 (artikel 15 Bloedproefbeschik king is niet onverbindend wegens strijd met de artikelen 12 en 13 Bloedproefbesluit; geen ongeoorloofde delegatie. Uit conclusie AG Remmelink: "Het komt mij voor dat (...) de regeling van art. 15 wel beschouwd kan worden als een legitieme uitwerking van art. 13 van het Besluit, dat aan de minister van Justitie opdraagt nadere aanwijzing met betrekking tot $(0 . \mathrm{m}$.) de bewaring van bloedmonsters te geven. Weliswaar stelt de Nota van Toelichting dat deze regeling is getroffen (o.m.) met het doel om bederf daarvan te voorkomen, doch het is duidelijk, dat de besiuitgever niet zal hebben bedoeld, dat een beperking aan de duur van de bewaring niet als een uitwerking van het artikel zou kunnen worden beschouwd. Een dergelijke bepaling zal immers, naar mij voorkomt, ook in de lijn liggen van het streven aan het te gebruiken monster hoge eisen te stellen."

59. Echt heldere criteria zijn in dit verband niet ontwikkeld. Zie paragraaf 7.4. Volgens Kortmann, Constitutioneel recht, 1990, p.323 spelen ook de "(veronderstelde) wil van de wetgever en de aard van de geregelde materie" een rol.

60. Zie hierover ook Kortmann 1994, p.324-325.

61. Van der Pot/Donner/Prakke 1989, p.530. 


\section{Hoofdstuk 7}

Van (geoorloofde) witwoering was sprake in het bekende Bromfietsvalhelmarrest. ${ }^{62}$ Het betrof hier de bevoegdheid van de minister om een lijst van goedgekeurde valhelmen op te stellen. De Hoge Raad hanteert hier een ruim begrip uitvoering: ook de opgestelde regeling valt hieronder. De gestelde regels hebben niet de status van algemeen verbindende voorschriften.

Dit arrest uit 1977 is (voor zover mij bekend) de laatste uitspraak van de Hoge Raad waarin het onderscheid regelgeving-uitvoering een belangrijke rol speelde. ${ }^{63}$

Dat betekent ook dat de conclusie van Akkermans/Koekkoek, dat, in theorie althans, bij de 'uitvoering' van de delegatieterminologie de problematiek van regelgeving of uitvoering een rol kan spelen, in de rechtspraak niet hard wordt gemaakt. ${ }^{64}$

Het bekendste voorbeeld van ongeoorloofde delegatie is het Jaminarrest. ${ }^{65}$ De door het districtshoofd gestelde verwarmingseisen vonden volgens de Hoge Raad geen grondslag in de Arbeidswet, nu artikel 10 van die wet bepaalde dat voorwaarden voor arbeid van jeugdigen en vrouwen 'bij algemene maatregel van bestuur' voorgeschreven moesten worden. Het feit dat de bevoegdheid van het districtshoofd in de ogen van de Hoge Raad te ruim was was doorslaggevend. Zie ook de noot van L.B. onder het arrest: "De Hooge Raad is daarbij trouw gebleven aan zijne ook bij vroeger gelegenheden gehuldigde opvatting, dat een wet-

62. HR 11 januari 1977 , NJ 1977, 467. Van der Burg 1993, p.162-163 betwijfelt de uitkomst van het arrest. "In de tekst van art.94a, tweede lid, RVR was inderdaad geen sprake wan regelgevende bevoegdheid, maar in de toelichting op deze bepaling had de minister van Verkeer en Waterstaat duidelijk geschreven dat het in zijn woormemen lag 'keuringseisen voor een betrekkelijk lichte en goedkope en bovendien doelmatige bromfietshelm vast te stellen..." en deze woorden wijzen mijns inziens wel op gesubdelegeerde regelgeving. Het lijkt mij dan ook dat aan dit arrest slechts een zeer beperkte betekenis kan worden toegekend. "In een noot verwijst hij naar het Distributiewetarrest, waarin de Hoge Raad wel en regelgevende bevoegdheid van de minister aannam. (Zie hierna.) Kortmann 1980, p.205 trekt een parallel met de gemeentelijke jurisprudentie: "(...) het verbod zelf is vervat in het rechtsgeldige besluit (amvb of verordening), het besluit noodzakelijk voor de werking van het verbod is dan als uitvoering te beschouwen, ook al bezit de instantie die dat besluit neemt een ruime appreciatie-marge. "Hieraan kan echter toegewoegd worden dat er geen voorschriften worden gegeven waarbinnen de minister zijn bevoegdheid moet vitoefenen.

63. Ook in recente handboeken staats-en bestuursrecht wordt geen arrest op dit terrein van na die datum genoemd. Zie Van der Pot/Donner/Prakke 1989, p.529-530; Van der Vlies 1991 , p.121; Van der Burg 1993, p.162-163; Kortmann 1994, p.324;

64. Akkermans/Koekkoek 1992, p.5-6. (Aangehaald in paragraaf 7.2.1.)

65. HR 25 januari 1926, NJ 1926, blz.246, m.nt. Besier. 
gever de uitvoering zijner voorschriften aan anderen kan opdragen, maar dat alleen dan van uitvoering sprake kan zijn, indien die wetgever zelf de voorschriften geeft, binnen welker grenzen de witvoerende autoriteit zich zal hebben te bewegen. "66

Bekend is verder het Vuurwerkarrest. ${ }^{67}$ Volgens de Hoge Raad was het de bedoeling van de Kroon om de minister algemeen verbindende voorschriften te laten stellen (een lijst van vuurwerken), maar de Kroon mocht de wetgevende bevoegdheid niet overdragen, nu artikel 1 Wet vervoer Buskruit vermeldde dat bij algemene maatregel van bestuur de voorschriften gegeven moesten worden. De bevoegdheid van de minister was te ruim: hij mocht zelf beslissen voor welke soorten vuurwerk het (vervoers)verbod gold en welke samenstelling het moest hebben. ${ }^{68}$

De verbindendheid van de bevoegdheid, waarbij de gestelde regels werden erkend als algemeen verbindende voorschriften, werd aangenomen in bijvoorbeeld het Distributiewetarrest. ${ }^{69}$ Een circulaire steunde op een Beschikking van de Minister van Economische Zaken die op zijn beurt weer een grondslag vond in het Tegemoetkomingsbesluit 1939. Dit Besluit (een AMvB) vloeide voort uit

66. Van der Pot/Donner/Prakke 1989, p.530, over dit arrest: "Sedertdien wordt als uitgangspunt aanvaard dat subdelegatie van wetgevende bevoegdheid slechts is toegestaan indien de wet daartoe heeft gemachtigd." Anders Stroink 1978, p.110, die een beschikkingsbevoegdheid van het districtshoofd in het geding achtte. Zie ook zijn noot bij dit arrest in AB Klassiek 1994, p.42-49.

67. HR 26 november 1957 , NJ 1958,53 .

68. De wetgeving is naderhand aangepast, waardoor subdelegatie is mogelijk gemaakt. Zie hierover W.F. Prins in zijn noot onder HR 22 december 1976, NJ 1977, 114: "Men notere, dat de "bovenvermelde wet', daterende van 1884 , sindsdien werd vervangen door de huidige Wet gevaarlijke stoffen, die kwistig de formule "bij of krachtens" bezigt:" Andere voorbeelden van verboden delegatie: HR 19 januari 1931, NJ 1932, p.439. Volgens artikel 19 van de Visscherijwet moesten de woorschriften gesteld worden 'bij algemene maatregel van bestuur". Het geven van zulke voorschriften ("hetwelk een daad van wetgeving en niet slechts uitvoering is") mocht niet gedelegeerd worden aan de minister. En KB 19 januari 1979, AB 1979, 241. "Het gestelde in een desbetreffende circulaire van de staatssecretaris van CRM behoort niet tot de nadere regelen; bedoeld in art. 11, lid 1 ABW en ontbeert derhalve verbindende kracht." Artikel 11 lid 1 ABW bepaalt dat de nadere regelen 'bij amvb' moeten worden gesteld.

69. HR 8 mei 1953, NJ 1953, 614. Voorstander van deze benadering toonde zich Stellinga 1951, p.135: "Wanneer een orgaan, dat zelf krachtens delegatie wetgevende bewoegdheid heeft gekregen, het voor de juiste uitoefening daarvan aangewezen acht, dat een lager orgaan mede zijn diensten daarbij verleent, dan moet het hem vrijstaan dit in de hand te werken." 


\section{Hoofdstuk 7}

artikel 10 lid 2 Distributiewet 1939 dat de zinsnede bevatte: 'bij AMvB te stellen regelen". De Hoge Raad acht een regelgevende bevoegdheid voor de minister aanwezig: "dat (...) voormeld artikel 10 lid 2 , mede gelet op den aard van de voorziening, niet kan worden geacht de Kroon te verplichten zelve alle de bedoelde regelen te stellen en niet de nadere uitwerking op bepaalde punten van de gegeven regelen over te laten aan den Minister. "70

Een tweede voorbeeld is Hof Den Haag 18 mei 1989, AB 1989, 411, m.nt. FHvdB. "Ten overvloede meent echter het hof, (...) dat, hoewel art. $48 \mathrm{~Sv}$ niet spreekt over regels die bij 'of krachtens' amvb kunnen worden gegeven, van een verboden subdelegatie in het Strafmoduulbesluit (art. 3) geen sprake is aangezien de wetsgeschiedenis doet vermoeden dat de wetgever die het probleem vermoedelijk niet heeft onderkend, tegen subdelegatie geen bezwaar had, terwijl voorts de "aanwijzingen voor de wetgevingstechniek" (Stcrt. 1984, 52), waarop in dit verband een beroep werd gedaan, pas rondom de jongste grondwetswijziging zijn ontstaan en de wetgever van de twintiger jaren - uit welke periode het artikel

70. Zie verder HR 6 juni 1980, NJ 1981, 563 m.nt. MS, en HR 20 maart 1981, NJ 1982 , 183 , m.nt. WHH. (Beschikking geldelijke steun eigen woningen 1968) Uitgebreid hierover Scheltema 1988, p.456 e.v. Zie ook verschillende onderwijsuitspraken. Pres. Rb Den Haag 22 juni 1982, NJ 1983, 175, over het Rechtspositiebesluit gebaseerd op de Wet op het Voortgezet Onderwijs (WVO). De materie van de overuren in het voortgezet onderwijs behoort tot de onderwerpen die de wetgever heeft gedelegeerd aan de Kroon (Bij amvb, JD). De Kroon mocht in het Rechtspositiebesluit WVO de regeling van het maximum aantal leseenheden aan de minister delegeren. "De regeling van het maximum aantal leseenheden is in art. I-P2 lid 9 Rechtspositiebesluit WVO gedelegeerd aan de minister. De tweede stelling van de eiseressen luidt dat hier sprake is wan een verboden subdelegatie. Volgens eiseressen staat art. 39 lid 2 van de wet (Bij Amw worden voorschriften gegeven omtrent geneeskundig onderzoek bij benoeming, ontrent vakantie, verlof, aanspraken op salaris ingeval wan militaire dienst, ziekte of ongeval, wachtgeld, alsmede orntrent andere rechten van de rector, de directeur, de leraren en het overig personeel, bedoeld in art. 38 ) die subdelegatie niet toe. Voor deze stelling is evenwel noch in de tekst van de wet noch in de wetsgeschiedenis - in het bijzonder niet in de geschiedenis van het met art. 39 lid 2 vergelijkbare art 29 lid 5 van de wet - weinig steun te vinden, zodat ook deze grondslag falt." Overigens lijkt mij dat de Rechtbank hier wel een grondslag in het geldende recht had kunnen winden. Vergelijkbare overwegingen als de President hanteert ook de Conmissie van beroep protestants christelijk voorgezet onderwijs 23 juni 1982 , AB 1983, 95. Tegen toegestane subdelegatie, wanneer de wet (in casu de WVO) enkel 'bij amvb' voorschrijft is de Raad van State in zijn advies bij KB 27 januari 1987, Stb.56. De opvatting wordt bestreden door de minister. Zie uitgebreider hierover Scheltema 1988 , p.459. Afwijkende uitspraak: CRvB 28 april 1978, Jurisprudentie onderwijswetten 1978/153. De Raad oordeelde de subdelegatie strijdig mett art. 38 WVO, ondat dit artikel bepaalde dat salarissen "bij" algemene maatregel van bestuur moeten worden vastgesteld. 
stamt - zich minder scherp placht uit te drukken. Overigens kan hier nauwelijks van subdelegatie worden gesproken. In het Strafmoduulbesluit (art.3) werd immers bepaald dat de minister het basisbedrag 'met een bedrag van ten hoogste $f 105^{\prime}$ kon verlagen zodat de omstreden bezuinigingsmaatregel in wezen door de Kroon zelf werd getroffen. Het beroep op verboden subdelegatie behoort dus ook daarom te worden verworpen. "71

Ook in de jurisprudentie over regelgeving-uitvoering op rijksniveau zien we de ontwikkeling dat langzamerhand steeds minder de kwalificatie uitvoering wordt gehanteerd en dat discretionaire bestuursbevoegdheden worden geaccepteerd wanneer er beleidsregels gesteld worden. ${ }^{72}$ Voor de Hoge Raad vormde daarbij

71. Hierover zegt Van der Burg in zijn noot: "Mocht de Kroon in Haar besluit van 25 mei 1988 , tot wijziging van het Besluit vergoeding rechtsbijstand in strafzaken aan de Minister de bevoegdheid toekennen het bezuinigingsbedrag wast te stellen? Het hof zegt dat men van de wetgever van de jaren twintig niet kan verlangen dat hij zich zo scherp uitdrukte als nu volgens de Aanwijzingen voor de wetgevingstechniek wordt verlangd. Het lijkt mij dat dit argument niet opgaat. Regellgevende bevoegdheid moet op een duidelijke wettelijke grondslag berusten. Vgl. ook het Vuurwerkarrest HR 26 nov. 1957, AB 1958, p.305. Sterker lijkt mij het tweede argument dat hier nauwelijks van subdelegatie gesproken kan worden.".

72. Een uitspraak waarin dat niet gebeurt is ARRS 3 februari 1984, AB 1984, 404, m.nt. JHvdV. (Regeling Modelvliegtuigen gemeente Velsen). Deze Regeling mist verbindende kracht: noch in de Luchtvaartwet (artikel 174: 'bij algemene maatregel van bestuur", noch de Wet Geluidhinder, (waarnaar in de aanhef van de Regeling Modelvliegtuigen is verwezen), noch in enige andere wettelijke regeling, is een wettelijke grondslag voor de bevoegdheid tot het stellen van algemene regelgeving alangaande de modelvliegsport voor de minister van Verkeer en Waterstaat aanwezig. "Uit noot Van de Veen: "In vorenstaande uitspraak heeft de Afd, na de conclusie dat de Regeling Modelvliegtuigen verbindende kracht mist, niet aangegeven of zij wellicht anderszins een rechtens relevante plaats zou kunnen hebben. Niet zelden wordt aan regels die een niet tot algemene regelgeving be. woegd administratief orgaan in het kader van een discretionaire bestuursbevoegdheid vaststelt, de plaats gewezen van (een verzameling) beleidsregels (cursief JD) (zie ARRS 24 februari 1984, AB 1984, 284, m.nt. JHvdV, Woonruimtereglement Soest, vastgesteld door $B$ en $W$ ). Aan te nemen valt dat de Afd. via een duiding van de Regeling Modelwliegtuigen als beleidsregels (of pseudowetgeving) geen bevoegdheid van $B$ en $W$ naar voren zag komen. In dit verband werdient de aandacht dat de Afd. met name whiar in de Regeling Modelvliegtuigen de medewerking aan har uitvoering door andere organen is voorzien, grond ziet voor de conclusie dat het hier gat om algemene regelgeving. Aldus komt dan weer in het beeld de vanouds bekende regel dat voor delegatie wan bevoegdheden een wettelijke grondslag wordt vereist. (Zie bv Eindrapport wan de Werkgroep Herziening gemeentewet den haag 1980, mvt p.48.)" Zie ook vergelijkbare overwegingen in Vz ARRS 16 oktober 1984, AB 1986, 224, m.nt. F.A. van Bakelen. 
artikel 99 Wet RO een 'obstakel': beleidsregels werden niet erkend als recht in de zin van dit artikel, konden niet in cassatie geïnterpreteerd worden. In 1990 ging de Hoge Raad om en erkende hij beleidsregels, onder bepaalde voorwaarden, wel als recht in de zin van artikel 99 Wet RO. ${ }^{73}$ In het volgende hoofdstuk kom ik hier uitgebreider op terug.

We zijn toe aan een korte samenvatting van het bovenstaande. Het begrip uitvoering wordt in de jurisprudentie van de Hoge Raad en Afdeling Rechtspraak steeds ruimer geînterpreteerd. Ook regelingen (niet zijnde algemeen verbindende voorschriften) kunnen er onder vallen. ${ }^{74}$ De vraag of er van uitvoering sprake is, is aan de orde wanneer een duidelijke wettelijke grondslag voor een regelgevende bevoegdheid ontbreekt. Die wettelijke grondslag is aanwezig wanneer de wet een bestuursorgaan rechtstreeks regelgevende bevoegdheid toekent, dan wel bepaalt dat 'bij of krachtens amvb' (nadere) regels kunnen worden gesteld. Wanneer die wettelijke grondslag er niet is, kan het mede van de mate waarin een bevoegdheid discretionair is afhangen of de Hoge Raad uitvoering, of verboden delegatie aanneemt, dan wel de gestelde regels toch erkent als algemeen verbindende voorschriften. Mede, omdat ook de wetsgeschiedenis of de bedoeling van de wetgever een rol kunnen spelen.

Is een bevoegdheid gebonden dan lijkt eerder sprake te zijn van uitvoering, maar consistent is de jurisprudentie op dit punt niet. Zo was het stellen van verwarmingseisen (Jaminarrest, 1926), en het aanleggen van een lijst van verboden vuurwerken (Vuurwerkarrest, 1957) verboden delegatie, maar werd het opmaken van een lijst van goedgekeurde bromfietsvalhelmen (Bromfietsvalhelmarrest, 1977) als uitvoering beschouwd.

Is dit verschil van opvatting te wijten aan het tijdsverschil tussen de verschillende uitspraken? Hierboven hebben we immers gezien dat, naarmate de jaren vorderen, rechters (Hoge Raad en Afdeling rechtspraak) het begrip uitvoering ruimer gaan interpreteren, ongetwijfeld onder invloed van de toegenomen regeldichtheid. De beleidsregel is daarbij een welkom 'hulpmiddel': het geeft de rechter de mogelijkheid discretionaire bevoegdheden, mits gestructureerd door beleidsregels, te accepteren.

73. HR 28 maart 1990, NJ 1991, 118 (Leidraad administratieve boeten 1984); HR 19 juni 1990. NJ 1991, 119 (Richtlijn Openbaar Ministerie Belastingdienst) en HR 29 juni 1990 , NJ 1991, 120 (Vreemdelingencirculaire).

74. Kortmann 1980, p.207; Scheltema 1988, p.459; Van der Pot/Donner/Prakke 1989, p.529. 


\subsubsection{Toetsing van het standpunt van de regering}

In de inleiding van deze paragraaf is gesteld dat de jurisprudentie op het onderscheid regelgeving-uitvoering ook is onderzocht om het standpunt van de regering (zoals dat in de vorige paragraaf naar voren kwam) te kunnen toetsen. Naar aanleiding van dat standpunt zijn twee vragen geformuleerd: gaat de rechtspraak (vooral ook na 1983) uit van de visie dat bij een discretionaire bevoegdheid het nemen van (een reeks) concrete besluiten gelijk te stellen is aan wetgeving; en kan het stellen van algemeen verbindende voorschriften tot uitvoering gerekend worden, mits het gaat om detailpunten?

De eerste vraag is, voor wat betreft de jurisprudentie vóór 1983, onderzocht door Kortmann. Zijn conclusies zijn hierboven weergegeven: de Hoge Raad deelt niet het standpunt van de regering. Ook in de hierboven gepresenteerde jurisprudentie blijkt geen (veranderde) opvatting van de Hoge Raad.

Een van de redenen daarvoor zou kunnen zijn dat het regeringsstandpunt niet past in het systeem van het staats-en bestuursrecht zoals dat bijvoorbeeld in de Wet AROB en, sinds 1 januari 1994, in de Wet Algemene wet bestuursrecht is vastgelegd. Het nemen van een concreet besluit op grond van een discretionaire bevoegdheid wordt immers als een beschikking aangemerkt (Wet AROB) mits voldaan is aan de eisen van het beschikkingbegrip (afkomstig van administratief orgaan, gericht op enig rechtsgevolg, niet zijnde besluit van algemene strekking of rechtshandeling naar burgerlijk recht).

De Awb hanteert het besluitbegrip: een schriftelijke beslissing van een bestuursorgaan, inhoudende een publiekrechtelijke rechtshandeling. Ook de Awb kent het begrip beschikking: een besluit dat niet van algemene strekking is.

Voor het tweede standpunt van de regering: uitvoering kan het stellen van algemeen verbindende voorschriften inhouden, mits het gaat om details, zijn ook nauwelijks aanknopingspunten te vinden in de jurisprudentie. In een bekende uitspraak waarin het om uitvoering ging (Bromfietsvalhelmarrest), kreeg de nadere regeling niet de status van algemeen verbindend voorschrift. ${ }^{75}$

Van het feit dat beleidsregels hun grondslag vinden in een bestuursbevoegdheid (niet zijnde een bevoegdheid om algemeen verbindende voorschriften te stellen) maakt de rechter gebruik door voor algemeen verbindende voorschriften een

75. Hetgeen af te leiden is uit de volgende overweging van de Hoge Raad: "dat dan ook in het tweede lid van art. $94 \mathrm{a}$ aan de minister slechts uitvoering wordt opgedrăgen nodig on aan het door de besluitgever gegeven werbod de vereiste werking te verzekeren en niet het geven van nadere regelen als bedoeld in art. 2 WVW wordt gedelegeerd." 


\section{Hoofdstuk 7}

wettelijke grondslag (in de zin van een regelgevende bevoegdheid) te eisen. Die wettelijke grondslag is het meest belangrijk onderscheidend criterium voor beleidsregels en algemeen verbindende voorschriften. Hierin komt de bindingskracht van de verschillende regels tot uiting. Kort gezegd: door middel van algemeen verbindende voorschriften mogen wel verplichtingen aan burgers worden opgelegd, door middel van beleidsregels niet. In het volgende hoofdstuk kom ik hier op terug.

Op grond van jurisprudentie en literatuur, waarin het vereiste van een formeelwettelijke grondslag wordt gesteld voor (sub)delegatie en de status van algemeen verbindend voorschrift, en waarin bovendien niet wordt gerefereerd aan het afwijkende standpunt van de regering bij de grondwetsherziening, kunnen we dan ook stellen dat dit standpunt van de regering (dat uitvoering ook kan inhouden het stellen van algemeen verbindende voorschriften, mits het om detailpunten gaat), niet gevolgd wordt. ${ }^{76}$ Ondanks de niet-constante jurisprudentie is de heersende leer in de literatuur dat voor subdelegatie van regelgevende bevoegdheid en daarmee de status van algemeen verbindend voorschrift van een regel een wettelijke basis nodig is. ${ }^{77}$

76. Zie ook Orde in de regelgeving 1985, p.18: "Ook de Afdeling rechtspraak van de Raad wan State houdt nauwkeurig in het $00 \mathrm{~g}$ of een ministeriële regeling een wettelijke grondslag heeft of niet. Ontbreekt een wettelijke grondslag, dan beschouwt de Afdeling de regeling niet alleen slechts als een bekendmaking van het voorgenomen beleid, waaraan de minister niet strikt gebonden is, maar bovendien wordt in een dergelijk geval nimmer vernietigd op de grond genoemd in artikel 8 , eerste lid, sub a van de wet Arob (strijd met een algemeen verbindend voorschrifi). Doch uitsluitend op grond van een van de overige in dit artikel genoemde gronden."

77. Orde in de regelgeving 1985, p.49; zie ook het Kabinetsstandpunt hierop: "de alanmerking als algemeen verbindend woorschrift is in het algemeen gereserveerd voor regels die krachtens een wettelijke bevoegdheid tot regelgeving zijn gesteld. "Regelgeving centrale overheid, Kamerstukken II 1986-1987, 20038, nr 2, p.2. Met de opwatting van de Comw missie Wetgevingsvraagstukken, dat alleen de formele wetgever de bevoegdheid tot subdelegatie kan creeren is de regering het 'in beginsel' eens. Regelgeving Centrale Owerheid, Kamerstukken II 1986-1987, 20038, nr 2, p.11. Aangehaald bij Scheltema 1988 , p.460, zie ook p.458. Recent vinden we deze opvatting van de regering bevestigd in de MvT bij de Derde tranche Awb, op het vereiste van een grondslag in een wettelijk voorschrift voor delegatie. "Indien subdelegatie niet is toegestaan, zall delegatie van wetgevende bevoegdheid echter wel de mogelijkheid kunnen omvatten uitvoerende taken aan bestuursorganen toe te delen. Daaraan wordt de algemene grens gesteld dat die taken niet mogen bestaan uit het nemen van besluiten die algemeen verbindende voorschriften inhouden. Gaat het echter niet om een dergelijk voorschrift, maar om een besluit van algemene strekking, dan verzet artikel 1A.1.2.3 zich daartegen niet. Met deze benadering 


\subsubsection{Mogelijke verklaringen voor de afgenomen jurisprudentie}

Terwijl we in het vorige hoofdstuk gezien hebben dat de formele wetgever bij het uitvoeren van de grondwettelijke delegatieterminologie problemen heeft met het begrip uitvoering, lijkt deze term langzamerhand te verdwijnen uit de jurisprudentie. Opvallend is dat er geen rechterlijke uitspraken zijn waarin het onderscheid regelgeving-uitvoering in het kader van de grondwettelijke delegatieterminologie cen rol speelt.

Het afnemen van de jurisprudertie over het onderscheid regelgeving-uitvoering is mijns inziens vooral toe te schrijven aan de opkomst en erkenning als rechtsregel, van de beleidsregel. Er zijn echter meer redenen aan te yoeren die aan de verminderde jurisprudentie over uitvoering hebben kunnen bijgedragen.

Zo is delegatie van regelgevende bevoegdheid steeds meer geaccepteerd. Dat betekent dat de bereidwilligheid groter is om een bevoegdheid van een minister (bijvoorbeeld om voorschriften te geven, eisen te stellen, een regeling te maken), uit te leggen als (toegestane) delegatie, dan wel om een ruim begrip uitvoering te hanteren; in ieder geval wordt minder snel geconcludeerd dat er verboden delegatie is.

Bovendien wordt in veel wetgeving gedelegeerd, waarbij gebruik gemaakt wordt van de woorden 'bij of krachtens algemene maatregel van bestuur'; hiermee is subdelegatie van regelgevende bevoegdheid mogelijk gemaakt. ${ }^{78}$

wordt een in beginsel duidelijke grens getrokken tussen hetgeen wel en niet is toegestaan. Zij sluit in uitkomst aan bij de lijn die de Hoge Raad in deze materie heeft getrokken (men zie HR 8 mei 1953, NJ 1953, 614 en HR 11 januari 1977 , NJ 1977, 467), al werd in die jurisprudentie het onderscheid ussen algemeen werbindend voorschrift en besluit van algemene strekking niet als zodanig gemaakt." Kamerstukken II 1993-1994, 23700, nr 3 MvT, p.179. In dezelfde zin de toelichting op Aanwijzing 28 van de Aanwijzingen voor de regelgeving 1993. Ook de Hoge Raad stelt de eis van wettelijke grondslag voor een algemeen verbindend voorschrift. Zie HR 28 maart 1990, NJ 1991, 118 (zie hoofdstuk 8).

78. Zie hierover bijvoorbeeld Kortmann 1994, p.324-325: "Inmiddels ondervangt de wetgever dit vraagstuk (van geoorloofde uitvoering dan wel ongeoorloofde delegatie, JD) veelal, en m.i. te vaak, door in geval van delegatie te spreken van regeling bij of krachtens AMvB." Hij verwijst hierbij naar Scheltema 1988, p.457 e.v. In gelijke zin Van der Vlies 1991, p.123: "Om interpretatiemoeilijkheden te vermijden verleent de wetgever overigens steeds meer de bevoegdheid tot regelstelling als volgt: "bij of krachtens algemene maatregel van bestuur" 


\section{Hoofdstuk 7}

Meer duidelijkheid over de aard van een (ministeriële) bevoegdheid wordt ook bereikt door een duidelijker terminologie in een wetsartikel. Richtlijnen hiervoor staan in de Aanwijzingen voor de regelgeving $1993 .{ }^{79}$

Verder wordt vaak in een hoofdstuk van een wet een bepaling opgenomen waaruit blijkt dat het de bedoeling is dat de minister een regelgevende bevoegdheid toekomt. ${ }^{80}$

Er is echter ook een tendens om delegatie van regelgevende bevoegdheid terug te dringen. Dat kwam naar voren in paragraaf 4.6 . Een 'vertaling' van de gedachten daarover van regeringszijde is te vinden in de Aanwijzingen voor de regelgeving 1993. De normstelling dient zoveel mogelijk in de wet plaats te vinden, evenals de grenzen van de delegatie.

De vraag is of hiermee niet weer meer een beroep moet worden gedaan op het begrip uitwoering? Bestaat er, bij strak afgebakende gedelegeerde bevoegdheden een behoefte aan een ruim begrip uitwoering? Een 'herwaardering' van het begrip uitvoering lijkt echter niet voor de hand te liggen. Voor de wetgever zal het niet meevallen om dit beleid (het terugdringen van delegatie van regelgeving) te vertalen in concrete wetgeving. Delegatiebepalingen mogen voorkomen, mits duidelijk geformuleerd en nauw geclausuleerd. De formele wet zal tenminste de 'hoofdelementen' zoals de reikwijdte en de structurele elementen van een regeling moeten bevatten. Bestuursbevoegdheden zullen nodig blijven, maar voor de structurering daarvan kunnen beleidsregels gehanteerd worden. ${ }^{81}$ Zo is er een vrij overzichtelijk plaatje te construeren én hanteren van de verschillende bevoegdheden en de daarbij behorende regels. Het is niet te verwachten dat de rechter zijn toevlucht weer zal nemen tot het onduidelijke onderscheid regelgeving-uitvoering.

79. Zie de Aanwijzingen 26-30.

80. Zie Van der Vlies 1991, p.118-119: "Overigens heeft de wetgever in veel gevallen een poging ondernomen om twijfel over het karakter van een regeling weg te nemen. In die gevallen wordt aan het einde van een hoofdstuk of van de wet een bepaling als de volgende opgenomen: "Onze Minister kan ter uitvoering van zijn bevoegdheden (die hem in deze wet zijn verleend of die hem in dit hoofdstuk zijn verleend) nadere regelen stellen"."

81. Zie echter Aanwijzing 17' 1. Bij de toekenning van bestuursbevoegdheden wordt de uitoefening daarvan zoveel mogelijk genormeerd. 2 . Met het oog hierop worden discretionaire bevoegdheden en bevoegdheden met vage toepassingscriteria niet toegekend, tenzij daarvoor goede gronden zijn." 


\subsection{Formele en materiële benaderingen van het onderscheid}

Een telkens in de literatuur terugkerende verzuchting over het onderscheid regelgeving-uitvoering is dat dit onderscheid niet duidelijk te maken valt. Toch zijn er in de loop van de tijd verschillende pogingen gedaan een bruikbaar onderscheidend criterium te ontwikkelen. Enerzijds zijn er auteurs die het onderscheid formeel maken en daarbij in hoofdzaak kijken naar het orgaan dat een bevoegdheid heeft. Anderzijds wordt het onderscheidend criterium gezocht in het onderwerp waarop de regels betrekking hebben en de soort regels die daarbij tot stand komen.

\subsubsection{Formele benaderingen}

Op het eerste gezicht oogt een formele benadering aantrekkelijk wegens de eenvoud ervan: afhankelijk van het orgaan dat een besluit heeft genomen, of de regels heeft gesteld, is er sprake van uitvoering dan wel regelgeving.

Uit het historisch hoofdstuk bleek dat deze benadering in de vorige eeuw populair was: wetgeving werd tot stand gebracht door de formele wetgever; het uitvoeren van die wetgeving gebeurde door (toen veelal) de Kroon.

Een duidelijk voorstander van de formele benadering in deze eeuw is Oud. Hij wil de organen wetgevende en uitvoerende macht uitsluitend in formele zin opvatten waarbij de wetgevende macht het hogere en de uitvoerende macht het lagere orgaan is ${ }^{82}$

Als gevolg van de parlementaire behandeling van de grondwetsherziening en het in paragraaf 7.2 weergegeven regeringstandpunt over regelgeving-uitvoering komt Kortmann met een voorstel waaraan een formele benadering ten grondslag ligt. Inspiratie hiervoor ontleent hij (in navolging van Donner) aan het Franse recht. Het Franse recht kent een heel ruim begrip uitvoering: daaronder vallen ook reglementen van bestuursorganen (inhoudende algemeen verbindende voorschriften) ${ }^{83}$ In tegenstelling tot in het Nederlandse recht wordt delegatie van wetgevende macht in het Franse recht niet erkend. ${ }^{84}$

82. Oud 1970, p.224. Besproken bij Van der Hoeven 1988, p. 127.

83. Donner 1977, p.229.

84. Donner 1977, p.232-233. 


\section{Hoofdstuk 7}

Zowel Donner als Kortmann pleiten voor de erkenning van een categorie 'uitvoeringsregels": regel's die het bestuur stelt ter uitvoering van wetten. ${ }^{85}$

Beide auteurs hebben gelijk gekregen. Alleen hebben theorie en praktijk de uitwoeringsregels een andere naam gegeven beleidsregels. ${ }^{86}$. Waar Kortmann nog uitgaat van de tweedeling wetgeving-beschikking, en pleit voor de tweedeling wetgeving-bestuur kunnen we nu constateren dat er veel eerder sprake is van een onderscheid algemeen verbindend voorschrift-beleidsregel. Daarbij is de vorm van het besluit waarin een algemeen verbindend voorschrift dan wel beleidsregel is neergelegd van minder belang.

Betekent dat nu dat de rechtspraktijk tegenwoordig uitgaat van een formele benadering van het onderscheid regelgeving-uitvoering? Mijns inziens is er een zekere formalisering kenbaar: er wordt strikter onderscheiden naar bevoegdheid en soort regel die daarmee tot stand kan worden gebracht. Een regelgevende bevoegdheid geeft de bevoegdheid tot het stellen van algemeen verbindende voorschriften; op basis van een bestuursbevoegdheid kunnen beleidsregels gesteld worden. Hiermee is echter nog niets gezegd, over de mogelijke onderwerpen waar deze regels betrekking op kunnen hebben: de materiële benadering. In de volgende subparagraaf zal blijken dat ook die benadering (in regeringsstukken) nog een rol speelt.

\subsubsection{Materiële benaderingen}

Bij een materiële benadering staat niet het orgaan voorop dat de regels stelt, maar het onderwerp of de aard van de regel.

Een vertegenwoordiger van de materiële benadering uit de vorige eeuw is Addens (zie ook paragraaf 4.2). Richtlijnen voor het onderscheid wetgeving-uitvoering

85. Donner 1977, p. 237; Kortmann 1980, p.207. In het stelsel wan Kortmann is beslissend voor de vrag of wan en uitwoeringsbesluit sprake is, welk orgaan het besluit nam (een formeel criterim). Hij vraagt zich vervolgens af welke categorie regels niet als uitvoeringsregels moeten gelden. Hij zondert daarvoor uit (op decentraal niveau): besluiten van gekozen wetgevende organen en besluiten warrvoor bijzondere procedurewaarborgen gelden. Algemene maatregelen wan bestuur en ministeriële regelingen zouden als uitwoeringsregels aangemerkt kumnen worden wanneer ze gesteld werden ter uitwoering van een wet. Kormann 1980, p.210-211.

86. Ook bestaat tegen deze regels rechtsbescherming (bepleit door Donner 1977, p.237 en Kortmann 1980, p.208): ze zijn door de Hoge Raad erkend als recht in de zin van artikel 99 Wet $\mathrm{RO}$; ze kunnen getoetst worden via de algemene beginselen van behoorlijk bestuur en op 1 januari 1999 kan er rechtstreeks, beroep tegen worden ingesteld. 
ontleent Addens aan Vivien ${ }^{87}$. Deze acht het doelmatig de regeling over te laten aan een Koninklijk Besluit (hetgeen werd gezien als uitvoering), wanneer:

- er veel technische kennis nodig is

- er voortdurend behoefte is aan herziening

- het iets locaals betreft

- het iets tijdelijks en voorbijgaands is.

Dezelfde criteria vinden we terug bij Oppenheim" ${ }^{88}:$ "(..) onder het gebied der uitvoering die nadere regeling te omvatten, welke tijdelijke of voorbijgaande, of van locale omstandigheden afhankelijke punten rakende, of technische details betreffende, door ieder talrijke wetgevende vergadering moet worden overgelaten, omdat zij practisch niet kan worden neergelegd in de, van de wetgevende macht uitgaande, algemeen karakter dragende, regeling, dan zullen de opgenoemde gevallen onder delegatie niet gerangschikt kunnen worden, maar moeten zij vallen onder $(. .$.$) uitvoering."$

In de vorige paragraaf is gesignaleerd dat ook in de jurisprudentie een materiële benadering is gehanteerd. Daarbij speelde mede als criterium de onbepaaldheid van de bevoegdheid een rol, maar echt helder was die jurisprudentie niet. Wanneer we enkele uitspraken nog eens bekijken dan levert dat het volgende op.

Het stellen van verwarmingseisen door het districtshoofd was geen uitvoering, maar verboden delegatie (Jaminarrest 1926) ${ }^{89}$

De minister mocht niet regelen dat het 'ter bescherming van de snoek verboden was van 1 juni tot en met 31 oktober 1929 te visschen met een hengel geaasd met visch in alle binnenwateren, behalve in de uitdrukkelijk uitgezonderde' (1931). Het opstellen van een lijst van verboden vuurwerken was ook verboden delegatie (Vuurwerkarrest 1957), evenals het bepalen in een circulaire van een kennismakingsperiode van drie maanden voor bijstandsgerechtigden die een nieuwe relatie aangaan (KB 1979).

Het aanwijzen door B en W van straten waar een verbod door de gemeenteraad gesteld zou gelden was uitvoering. Zo ook het afwijken van een sluitingsuur van een horeca-inrichting door de burgemeester in bijzondere gevallen, het bepalen

87. Addens 1884 , p. 35. M. Vivien, Etudes administratives I, p. 5 e.v. Parijs 1845.

88. Oppenheim, Het Nederlandsch gemeenterecht, Groningen 1895 , p.205-206, aangehaald bij Stroink 1978, p.114.

89. Hier kan verdedigd worden dat het 'slechts' om invulling gaat van de norm dat de verwarming deugdelijk en voldoende moet zijn (zie ook de conclusie van de AG bij dit arrest), maar de Hoge Raad vindt de bevoegdheid te ruim. 


\section{Hoofdstuk 7}

in welke gevallen reclame ontsierend is, en het maken van een lijst van goedgekeurde bromfietsvalhelmen (Bromfietsvalhelmarrest 1977).

Naast het feit dat uit de hier weergegeven casuistiek nog niet zo eenvoudig materiële criteria gedistilleerd kunnen worden, is misschien nog wel belangrijker dat de Hoge Raad zélf niet (bij mijn weten) het onderscheid regelgeving-uitwoering op deze manier presenteert. De Hoge Raad redeneert niet (stelselmatig): we hebben te doen met (bijvoorbeeld) een technische regeling, dus is het uitvoering.

Toch blift een materieel onderscheid tussen regelgeving-uitvoering kennelijk aantrekkelijk. De regering koos in de parlementaire stukken op de grondwetsherziening van 1983 eveneens een materiële benadering. Zij omschreef wetgeving als "de regeling van alle wezenlijke onderdelen en aspecten van een (ter wetgeving opgedragen) onderwerp", en uitvoering als "het geven van voorschriften over detailkwesties, over ondergeschikte punten", om wettelijke bepalingen in de praktijk te kunnen toepassen. ${ }^{\circ}$

De criteria voor uitvoering van Addens en Oppenheim blijken ook in deze tijd nog te gelden. De Boer geeft als omschrijving van wat hij 'uitvoeringsregels' (of detailregels> noemt: "typische uitvoeringsvoorschriften met een gedetailleerd, ten dele organisatorisch karakter, die zonodig snel moeten kunnen worden bijgesteld en die zich daardoor voor regeling in een formele wet niet lenen. ${ }^{91}$

Hoe weinig we echter verder komen met deze (materiële) criteria voor uitvoering blijkt wanneer we ze plaatsen naast de criteria die door verschillende auteurs zijn aangevoerd voor delegatie.

Zo acht bijvoorbeeld Van der Pot delegatie toelaatbaar wanneer het gaat om een materie die niet meer binnen het bereik van de volksvertegenwoordiging ligt; wanneer wijziging op korte termijn noodzakelijk is; of wanneer een regeling veel details bevat waardoor de wetsvorm minder bruikbaar is. ${ }^{92}$

90. Kamerstukken II 1978-1979, 13990, nr 9 Herdruk, Nota naar aanleiding van het EV, p.8.

91. De Boer 1987, p.474.

92. Van der Pot 1916, p.359-360. Hij voegt er aan toe: (Spelen deze gevallen niet, JD) "dan zal wel veelal de doelmatigheid er voor pleiten om de regeling te doen geschieden bij de wet, wardoor de veorbereiding grondiger, de aanraking met het rechtsbewustzijn des volks nauwer, ten slotte het gezag der regeling grooter wordt. Stof voor meeningsverschil over de vraag, of delegatie in een bepaald geval gewenscht is, blijft er dus te over. Veelal zal men uit een doelmatigheidsoogpunt zoowel vór als tegen delegatie in een bepaald geval kunnen pleiten." 
Van der Pots richtsnoeren blijken ook in 1993 actueel. Zo bevatten de Aanwijzingen voor de regelgeving 1993 de volgende criteria voor delegatie (aan de minister). Aanwijzing 26 schrijft voor (voor zover hier relevant): '1. Delegatie aan een minister van de bevoegdheid tot het vaststellen van algemeen verbindende voorschriften wordt beperkt tot voorschriften wan administratieve aard, witwerking van de details van een regeling, voorschriften die dikwijls wijziging behoeven en voorschriften waarvan te voorzien is dat zij mogelijk met grote spoed moeten worden vastgesteld. ${ }^{.93}$

Daarmee verliezen zowel de criteria voor uitvoering als voor regelgeving hun onderscheidend vermogen en lijkt een eeuw discussie hierover weinig te hebben opgeleverd. ${ }^{94}$ Toch hoeft een afrondende conclusie niet somber te zijn. Allereerst $k$ an de vraag gesteld worden of het nog noodzakelijk is om criteria te zoeken voor het onderscheid regelgeving-uitvoering. Het lijkt erop alsof dit een gepasseerd station is. Tegenwoordig is immers meer van belang of er een regelgevende dan wel een bestuursbevoegdheid in het geding is, of een gestelde regel algemeen verbindend voorschrift dan wel beleidsregel is.

De wetgever dient in het toekennen van bevoegdheden (en dat is niet veranderd) de keuzes te maken. Maar door het ontwikkelen van duidelijke terminologie $e n$ het gebruik daarvan zijn veel problemen te voorkomen.

De noodzaak om naar criteria te zoeken voor het onderscheid regelgeving-uitvoering wordt ook minder nu een praktisch argument (de geboden rechtsbescherming $)^{95}$ over enkele jaren achterhaald is. De rechtsbescherming wordt, onder invloed van de Algemene wet bestuursrecht uitgebreid. Naast beroep tegen beschikkingen is per 1 januari 1999 ook beroep tegen algemeen verbindende voorschriften en beleidsregels mogelijk.

93. Lid 2: 'Delegatie aan een minister van de bevoegdheid tot het waststellen wan algemeen verbindende voorschriften is ook toegestaan indien het gaat om het verwe rken in de Nederlandse wetgeving van internationale regelingen die de Nederlandse wetgever, behoudens op ondergeschikte punten, geen ruimte laten voor het maken van keuzen wan beleidsinhoudelijke aard."

94. Om dit nog met een voorbeeld te illustreren: hoe moet een bevoegdheid van een minister om technische gegevens vast te stellen beoordeeld worden? Is het een regelgevende dan wel uitwoerende bevoegdheid? Veel zal afhangen van de woorden waarin de bepaling is gesteld.

95. Van Maarseveen in Bevoegdheden, p. 72-73: "Men heeft aan het onderscheid wetgevingbestuur theoretisch hoe langer hoe minder houvast, maar in de praktijk is het wan belang gebleven en heeft het gevolgen"', zo is er bijvoorbeeld bij de administratieve rechter geen beroep mogelijk tegen de vaststelling van wetgeving; in Algemene begrippen van staatsrecht, Th. Holterman (red.), W.E.J. Tjeenk Willink, Zwolle, 1991, derde druk. 


\subsection{Conclusie}

Het onderscheid regelgeving-uitvoering kan (in theorie) ook onder de Grondwet van 1983 cen probleem zijn. Het begrip uitvoering dook in het kader van de grondwettelijke delegatieterminologie vooral op bij de uitleg van het delegatieverbod bij de behandeling van het wetsontwerp op de provincies en gemeenten. Uit hoofdstuk 6 bleek dat de formele wetgever in sommige gevallen ook heeft geworsteld met het onderscheid.

Daarentegen zijn er na 1983 geen rechterlijke uitspraken bekend waarin het onderscheid regelgeving-uitvoering in het licht van de grondwettelijke delegatieterminologie een rol speelt.

De door de regering tijdens de grondwetsherziening gegeven uitleg van de begrippen uitvoering en delegatie van wetgeving bleek af te wijken van traditionele opvattingen. De opvattingen van de regering bleken bovendien niet dwingend te volgen uit de door haar geciteerde bronnen. Sterker nog: wanneer de regering recentere jurisprudentie en literatuur in haar beschouwingen had betrokken was zij wellicht tot andere opvattingen gekomen. (Zie paragraaf 7.2)

De (ontwikkelingen in de) jurisprudentie over regelgeving-uitvoering stonden centraal in paragraaf 7.3. Meest opvallende ontwikkeling is de erkenning van de beleidsregel die in feite het begrip uitvoering gaat vervangen. ${ }^{97}$

Het standpunt van de regering over uitvoering en delegatie van wetgeving vond geen weerklank in zowel jurisprudentie vóór als na 1983.

Om de beeldvorming rond regelgeving-uitvoering te completeren kwamen in paragraaf 7.4 opvattingen in de literatuur aan bod. Om het onderscheid te kunnen maken zijn zowel formele als materiële benaderingen gevolgd. Het meest recent van regeringswege is de materiële benadering gevolgd in de Aanwijzingen voor de regelgeving 1993 .

Vergelijking van de criteria die in de literatuur (en regeringsstukken) zijn genoemd voor uitvoering dan wel delegatie leverde op dat ze beide nagenoeg dezelfde zijn: er is nauwelijks onderscheidend vermogen.

96. Kamerstukken II 1978-1979,13990, nr 9 Herdruk, Nota naar aanleiding van het EV, p.8.

97. Mentink 1989 , p.187-191 komt tot een soortgelijke conclusie: het onderscheid regelgeving-uitvoering is achterhaald. Het begrip uitvoering is meer en meer vervangen door het begrip bestuur, dat bij de uitoefening van een bevoegdheid beleidsregels kan stellen. 
De noodzaak voor het maken van een onderscheid tussen regelgeving en uitwoering is echter afgenomen. De huidige rechtspraktijk werkt met algemeen verbindende voorschriften en beleidsregels en lijkt daarmee goed uit te voeten te kunnen.

Voor een regellgevende bevoegdheid (het stellen van algemeen verbindende voorschriften) is een formeel-wettelijke basis nodig, en mag er geen grondwettelijk delegatieverbod zijn. Voor het overige kunnen bevoegdheden worden opgevat als bestuursbevoegdheden en zijn de bij de uitoefening gestelde regels beleidsregels. Het volgende hoofdstuk is aan het onderscheid tussen beide soorten regels gewijd. 


\section{Hoofdstuk 8}

\section{Het onderscheid beleidsregels-algemeen verbindende voorschriften}

\subsection{Inleiding}

In dit hoofdstuk wordt nader ingegaan op de begrippen algemeen verbindend voorschrift en beleidsregel. De laatste soort regel is de laatste decennia sterk in de belangstelling komen te staan en krijgt een steeds zelfstandiger functie binnen het rechtssysteem. Dat blijkt onder meer uit de erkenning van de beleidsregel als rechtsregel. In het vorige hoofdstuk bleek dat het begrip uitvoering tegenwoordig in feite wordt ingevuld door beleidsregels. Een gevolg daarvan lijkt dat bestuursorganen meer ruimte krijgen bij het uitoefenen van hun bevoegdheden, in vergelijking tot de vroegere situatie waarin de uitoefening van die bevoegdheden als uitvoering werd afgezet tegen gedelegeerde bevoegdheden. Een bestuursbevoegdheid viel dan nog wel eens de kwalificatie 'verboden delegatie' ten deel.

De belangrijkste reden om in deze studie een hoofdstuk te wijden aan algemeen verbindende voorschriften en beleidsregels, en de overeenkomsten en verschillen daartussen, is de vraag welke consequenties (vooral) gelijkstelling zou kunnen hebben voor de grondwettelijke delegatieterminologie. Overigens is bij de bespreking van die terminologie nauwelijks of geen aandacht besteed aan het verschijnsel pseudo-wetgeving/beleidsregel hoewel dat, gezien ook de gangbare benaming in die tijd: pseudo-wetgeving, wel voor de hand had gelegen (meer nog dan bij de tegenwoordig gebruikte term beleidsregel). In de literatur bepleiten sommige auteurs al geruime tijd een gelijke status van beide soorten regels.

De rechter (bij de erkenning van beleidsregels als recht in de zin van artikel 99 Wet RO) en de regering (in het wetsvoorstel Derde tranche Awb) hebben die stap (nog) niet gezet en blijven een apart rechtsregime hanteren voor beide categorieën regels.

Onderzocht wordt in dit hoofdstuk welke gevolgen deze jurisprudentie, alsmede de beoogde wettelijke regeling in de Derde tranche $A w b$, maar ook en vooral eventuele gelijkstelling van algemeen verbindende voorschriften en beleidsregels, kan hebben voor de grondwettelijke delegatieterminologie.

Voordat we aan een analyse van dit vraagstuk toekomen is een aanloop in de vorm van een beknopte schets van de ontwikkeling van het verschijnsel pseudowetgeving/beleidsregel wenselijk (paragraaf 8.2 ). In paragraaf 8.3 komen dan aspecten van overeenkomsten en verschillen tussen algemeen verbindende voorschriften en beleidsregels aan bod. De relatie tussen algemeen verbindend voor- 
schrift, beleidsregel, delegatievraagstuk en grondwettelijke delegatieterminologie staat centraal in paragraaf 8.4. Paragraaf 8.5, Conclusie, besluit dit hoofdstuk.

\subsection{Beleidsregels: schets van de ontwikkeling}

\subsubsection{Beleidsregels in de literatuur voor 1983}

Het jaar 1983 is in een tweetal opzichten geschikt om als cesuur te dienen voor een beknopte beschrijving van de ontwikkelingen rond pseudo-wetgeving/beleidsregels. In de eerste plaats omdat in dat jaar de herziene Grondwet in werking trad en in de tweede plaats omdat in 1983 de dissertatie van Van Kreveld 'Beleidsregels in het recht' verschijnt. Diens analyse van het verschijnsel pseudo-wetgeving/beleidsregels en de conclusies die hij daaraan verbindt hebben veel invloed uitgeoefend (zie paragraaf 8.2.3). De onderstaande schets van beleidsregels in de literatuur voor 1983 is grotendeels aan hem ontleend.

Het gebruik van beleidsregels komt op na de Tweede Wereldoorlog. Onduidelijkheid is er echter over de status van deze regels: wel of niet juridisch? Een wat negatieve kijk op het verschijnsel toont Mannoury in 1960 in zijn artikel "Spiegelrecht" ${ }^{\prime \prime}$, waarbij hij de nadruk legt op het bedrieglijke van beleidsregels: "spiegelrecht is géén recht, maar spiegeling van recht." ${ }^{2}$

Enkele jaren later verschijnt de diesrede van Van der Hoeven waarin deze de term pseudo-wetgeving introduceert ${ }^{3}$, "(...) de eerste behoorlijke, algemene studie over het verschijnsel beleidsregels (pseudo-wetgeving)". "Belangrijk is volgens Van der Hoeven dat pseudo-wetgeving een vorm van zelfbinding van het bestuur is, waarmee het bestuurshandelen voorspelbaar wordt en-waardoor de reclatszekerheid en de rechtsgelijkheid worden bevorderd. Via de algemene beginselen van behoorlijk bestuur ziet hij binding van het bestuur aan pseudowetgeving. ${ }^{5}$ Pseudo-wetgeving of de algemene beginselen van behoorlijk bestuur creëren echter niet een bevoegdheid om algemene regels te stellen, daarvoor blijft een wettelijke grondslag nodig. ${ }^{6}$ Volgens Van der Hoeven is er een duidelijke behoefte aan pseudo-wetgeving en voldoet delegatie van wetgeving als alter-

1. J. Mannoury, Spiegelrecht, in Opstellen angeboden aan G, van den Bergh, Alphen aan den Rijn 1960 , p.139 e.v.

2. Van Kreveld 1983 , p. 20 .

3. I. van der Hoeven, Pseudo-wetgeving, Zwolle 1965.

4. Van Kreveld 1983, p. 22.

5. Van der Hoeven 1965, p.12-14.

6. Van der Hoeven $1965,12$. 
natief ook niet steeds. Daaraan zijn debet de steeds nieuwe taken yan het bestuur en de voortdurend veranderende maatschappelijke omstandigheden, waarbij optreden door middel van regelstelling noodzakelijk is. ${ }^{7}$ Wordt een beleid bestendig dan dient de woorkeur gegeven te worden aan een regeling met wettelijke grondslag. ${ }^{8}$

De rede van Van der Hoeven blijkt veel invloed te hebben. Van Kreveld constateert dat de invloed van Van der Hoeven zo groot kon zijn "(...) mede omdat de juridische wereld er rijp voor was". Hij verwijst daarbij met name naar signalen over spanning tussen 'praktijkrecht en rechtersrecht' op het terrein van de belastingen. ${ }^{9}$ Daar werd veel gewerkt met ministeriële resoluties, die - theoretisch gezien - qua bevoegdheidsgrondslag maar moeilijk geplaatst konden worden. ${ }^{10}$ Naast aandacht voor het verschijnsel pseudo-wetgeving in de fiscale literatuur werd er ook in de handboeken over het algemene bestuursrecht aandacht besteed aan het verschijnsel beleidsregels, nog voor de grondwetsherziening van 1983 (waarvan de parlementaire behandeling in 1976 aanving). ${ }^{1}$ De stand van zaken

7. Van der Hoeven 1965, p: 13 , noot 17.

8. Van der Hoeven 1965, p. 15.

9. Van Kreveld 1983, p.23.

10. Zie de door Van Kreveld aangehaalde literatuur, p.23-24. Dat met name op het gebied van de belastingen beleidsregels zo talrijk en invloedrijk waren (en zijn) is opmerkelijk. Naar de letter van het (toenmalige) grondwetsartikel betreffende de belastingen (artikel $188 \mathrm{Gw}$ 1953) moest terughoudend met delegatie van regelgevende bevoegdheid worden omgegaan. Deze terughoudendheid met delegatie leverde in de praktijk kennelijk problemen op. Er was veel behoefte aan (aanvullende) regelgeving, die (onder meer) gestalte kreeg in de vorm van ministeriële resoluties. Praktijk en theorie lijken hier niet helemaal met elkaar te sporen. Bij de grondwetsherziening van 1983 stond de Tweede Kamer er op om ook in het nieuwe artikel 104 Gw wast te leggen dat op het terrein van de belastingen met delegatie van regelgevende bevoegdheid terughoudend moet worden omgegaan. Daarvoor werd afgeweken van de grondwettelijke delegatieterminologie en werd in het nieuwe artikel de redactie van het oude grondwetsartikel overgenomen (zie paragraaf 5.3). Na 1983 vindt er echter nog steeds veel delegatie van regelgevende bevoegdheid plaats, en wordt er veel aanwullend geregeld door beleidsregels. Zie Akkermans/Koekkoek 1992, p.935 e.w. en de daar aangehaalde literaturur. Zie ook Wattel 1993.

11. Van Kreveld 1983, p.25-26, noemt onder meer Belinfante, Kort begrip wan het administratief recht, 1968; Donner, Nederlands Bestuursrecht, Algemeen deel, 1974; De Goede, Beeld van het Nederlands bestuursrecht, 1975; Van Wijk/Konijmenbelt 1976 , Hoofdstukken van administratief recht, derde druk. Daa rentegen komt in diverse handboeken op het terrein van het staatsrecht het woord pseudo-wetgeving niet voor in de registers. Hier werkt men nog met het begrip uitvoering. Zie bijwoorbeeld Van Haersolte, Inleiding tot het Nederlandse staatsrecht, 1972, p.83; Belinfante, Beginselen van het Nederlandse staatsrecht, 1976, p.102-103; Koopmans, Compendium van het staatsrecht, 1976, p.141-142. Een uitzondering is Van der Pot/Donner, Handboek van het Neder- 


\section{Hoofdstuk 8}

met betrekking tot pseudo-wetgeving kan voor die tijd als volgt omschreven worden. Pseudo-wetgeving behelst vaak algemene regels door een bestuursorgaan gesteld ter invulling van een ruime bestursbevoegdheid. Ze worden vaak gepubliceerd, sommige zelfs op dezelfde manier als wettelijke voorschriften. Toch zijn het geen wetten in materiêle zin, nu een wettelijke grondslag tot regelgeving ontbreekt. Het rechtsgevolg van pseudo-wetgeving is indirect: binding van het bestuursorgaan door middel van de algemene beginselen van behoorlijk bestuur, met name het vertrouwens- en gelijkheidsbeginsel. ${ }^{12}$ De Hoge Raad beschouwt beleidsregels niet als recht in de zin van artikel 99 Wet RO. ${ }^{13}$

De ontwikkelingen gaan echter in rap tempo door. Van Kreveld beschrijft hoe sinds 1979 de discussie op gang komt over de verhouding tussen beleidsregels en algemeen verbindende voorschriften. Hij onderscheidt twee benaderingen: de eerste bepleit een gelijkstelling van beleidsregels en algemeen verbindende voorschriften; de tweede zoekt naar een afbakening van verschillende terreinen waarop beide soorten regels ingezet kunnen worden. ${ }^{14}$

Aanhangers van de eerste benadering toonden zich Scheltema, Van der Vlies en Kortmann. Scheltema wil dat wettelijke voorschriften meer gaan lijken op beleidsregels; Van der Vlies en Kortmann bepleiten een opwaardering van de status van beleidsregels in die van wettelijke voorschriften. Van der Vlies beperkt zich daarbij tot ministeriële regels; Kortmann wil een bevoegdheid tot het stellen van algemeen verbindende voorschriften, als uitvoeringsbevoegdheid. ${ }^{15}$

Voorstanders van de tweede benadering zoeken naar criteria voor de afbakening van terreinen van regelgeving waarop beleidsregels dan wel algemeen verbindende voorschriften de voorkeur verdienen. ${ }^{16}$ De Haan-Drupsteen-Fernhout zien weinig ruimte voor beleidsregels die niet gebaseerd kunnen worden op een wette-

landse staatsrecht, 1972, p.451, die een onderscheid maken tussen aanschrijvingen en circulaires (die "een zuiver intern karakter" hebben) en wettelijke voorschriften. Waarna ze constateren dat dat onderscheidl in de "praktijk van de uitvoering vervluchtigt'. "Daaron is hier wel gesproken van 'Spiegelrecht" of van 'Pseudo-wetgeving' en is betoogd, dat wij hier met een juridisch en maatschappelijk verschijnsel te doen hebben, dat de traditionele schema's omtrent bevoegdheidsverdeling doorbreekt. Intussen vormen die schema"s over de scheiding van regelende en besturende bevoegdheden nog de grondslag van het stellig recht (...)."

12. Zie Belinfante 1968, p.61-63; Donner 1974, p.94 en 114; De Goede 1975, p.98-99 en 115; Van Wijk/Konijnenbelt 1976, p.102-105.

13. HR 25 april 1969, NJ 1969, 303 (Pluvier), met noot Veegens.

14. Van Kreveld 1983 , p.27 e.v.

15. Scheltema 1979, p. 90 e.v.; Van der Vlies 1979 , p.487 e.v.; Kortmann 1980, p.208 e.v.

16. Van Kreveld 1983, p.28-29. 
lijke bestuursbevoegdheid en stellen yoor om alle bestuurshandelen een wettelijke grondslag te geven; ${ }^{17}$ daarentegen waarschuwen Ter Spill-Tak voor te veel wettelijke regelingen en zien zij ruimte voor buitenwettelijk bestuur, en dus ook buitenwettelijke beleidsregels. In hun ogen moet dan wel voldaan zijn aan democratische en rechtseisen. ${ }^{1.8}$

Hiermee is echter de vraag op welke terreinen beleidsregels gehanteerd kunnen worden, en welke gebieden uitdrukkelijk voorbehouden zijn aan de wetgever volgens Van Kreveld (nog) niet afdoende beantwoord: "Het is duidelijk dat gepoogd zou moeten worden criteria te ontwikkelen voor de keuze tussen beleidsregelgeving en de verschillende vormen van wetgeving, gelet op de voor- en nadelen van deze verschillende instrumenten. ${ }^{119}$

De vraag op welke terreinen beleidsregels ingezet kunnen worden of welke onderwerpen voorbehouden zijn aan de (formele) wetgever hangt samen met de vraag naar de inhoud van het legaliteitsbeginsel en het materieel wetsbegrip. Hieraan is hoofdstuk 9 gewijd.

\subsubsection{Beleidsregels en de grondwetsherziening van 1983}

Tijdens de parlementaire behandeling van de grondwetsherziening die heeft geleid tot de Grondwet van 1983 is er nauwelijks of geen aandacht besteed aan het verschijnsel pseudo-wetgeving of beleidsregels. Uit het hierboven gegeven overzicht van beleidsregels in de literaturur voor 1983 bleek dat pseudo-wetgeving al geruime tijd voor kwam. De vraag rijst waarom er dan niet tijdens de parlementaire behandeling van bijvoorbeeld de delegatieterminologie (de wetsontwerpen op de grondrechten en de provincies en gemeenten) aandacht is besteed aan de functie en plaats van beleidsregels. ${ }^{20}$ Het woord pseudo-wetgeving alleen al zou daartoe toch alle aanleiding hebben kunnen geven. Een deel van de verklaring zou kunnen zijn dat pseudo-wetgeving/beleidsregels vooral als bestuursrechtelijk fenomeen werd en wordt gezien, en delegatie (van regelgevende bevoegdheid) als staatsrechtelijk vraagstuk. ${ }^{21}$

17. Van Kreveld 1983, p.29, verwijzend naar De Haan-Drupsteen-Fernhout 1978, p.149 e.v. In paragraaf 9.3 , over de inhoud van het legaliteitsbeginsel, zal blijken dat wiet iedereen onverdeeld gelukkig is met het voorstel van De Haan-Drupsteen-Fernhout.

18. Van Kreveld 1983, p.29; verwijzend naar Ter Spill-Tak 1981, p.48 e.v.

19. Van Kreveld 1983, p.29.

20. Zie voor een bespreking van de terminologie hoofdstuk 4 .

21. Dat bleek ook uit de aandacht die de handboeken bestuursrectit in die lijd besteedden aan pseudo-wetgeving/beleidsregels ten opzicht van de aandacht die er aan het verschijnsel werd gewijd in de handboeken staatsrecht. Zie ook de opmerking in de MvT op de Derde tranche van de Awb: "Beleidsregels zijn de laatste twee decennia in het bestuarsrecht 


\section{Hoofdstuk 8}

Uit de voorgaande hoofdstukken is echter gebleken dat dit cen versluierend onderscheid is: de grondwettelijke delegatieterminologie heeft ook betrekking op bestuursbevoegdheden en het delegeren van regelgevende bevoegdheid kan ook gebeuren aan en door bestuursorganen.

Een tweede reden zou kunnen zijn dat de materie tamelijk complex is. Pseudowetgeving bleek ook 'goede kanten' te hebben (erkenning vindt met name plaats na het verschijnen van de diesrede van Van der Hoeven in 1965, zie de vorige subparagraaf). Pasklare oplossingen om het fenomeen een eigen plaats te geven ontbraken echter. ${ }^{22}$ In hoofdstuk 4 bleek dat met name de aanduiding van de omvang van het delegatieverbod de wetgever heel wat hoofdbrekens heeft gekost. De inpassing van een 'nieuwe' categorie regels zou dat zeker niet eenvoudiger gemaakt hebben.

Ook bij de behandeling van het wetsontwerp betreffende de wetgevende macht, de algemene maatregelen van bestuur en andere voorschriften, zijn beleidsregels niet ter sprake gekomen. ${ }^{23}$ Een van de discussiepunten betrof beleidsvoornemens (nota's, plannen) van de regering en de rol van het parlement daarbij, ${ }^{24}$ maar het ging hier dus niet om beleidsregels.

Een tweede discussiepunt was of de formele wetsvorm niet gebruikt zou kunnen worden voor beleidsbesluiten die geen regelgeving zijn, in het kader van een verruiming van het wetsbegrip. ${ }^{25}$ De regering was hier niet tegen, maar vertoonde wel aarzelingen op dit punt. "Er zal nog veel studie verricht moeten worden voordat duidelijk is voor welke soorten nota's en beleidsbeslissingen de wetsvorm geschikt is. "26

De tendens die hier te bespeuren valt is om niet zozeer een ander soort regels (beleidsregels) als rechtsregels te erkennen (die komen niet eens in het verhaal voor), maar omgekeerd, om de formele wetsvorm te gebruiken voor andere beleidsinstrumenten, die niet per se uit regelgeving hoeven te bestaan.

(curs. JD) van enorme betekenis geworden." Kamerstukken II 1993-1994, 23700, nr 3 MvT, p. 4 .

22. Van Kreveld 1983, p.27.

23. Het wetswoorstel is ingediend in mei 1978, de stemming in de Eerste Kamer (eerste lezing) vond plaats in december 1980.

24. Kamerstukken II 1979-1980, 15047 (R1099), nr 8 MvA, p.11-12.

25. Bijvoorbeeld Kamerstukken I 1979-1980, 15047 (R1099), nr 126 VV, p.1-2; Kamerstukken I 1980-1981, p. 223-224.

26. Kamerstukken I 1980-1981, p.235 (minister Wiegel). 


\subsubsection{Beleidsregels in de literatuur na 1983}

In 1983 verschijnt de hierboven meermalen aangehaalde dissertatie van Van Kreveld. De parlementaire behandeling van de grondwetsherziening van 1983 is dan al afgerond, zodat het werk daarop geen invloed meer kan uitoefenen. ${ }^{27}$ Maar Van Krevelds analyse van het verschijnsel pseudo-wetgeving/beleidsregel en zijn daaraan verbonden conclusies hebben grote invloed gehad. Zo heeft de introductie van het woord 'beleidsregel' brede navolging gekregen.

Van Kreveld onderscheidt vier 'soorten' beleidsregels: binnen-wettelijke (beleidsregels gesteld in het kader van de beoordelingsvrijheid die de wetgever het bestuur heeft gelaten bij het uitoefenen van een concreet omschreven bevoegdheid; het gaat bijvoorbeeld om vrijheid ten aanzien van de te hanteren beoordelings criteria; de inhoud van het te nemen besluit, of de te volgen procedure ${ }^{28} ;$ buiten-wettelijke (beleidsregels gesteld in het kader van een niet op een specifieke wettelijke grondslag berustende bestuursbevoegdheid) (29; $^{29}$ tegen-wettelijke (beleidsregels die het bestuur stelt in het kader van een gebonden bevoegdheid, maar die afwijken van de wet) ${ }^{30}$; en wetsinterpreterende regels (Van Kreveld noemt ze geen beleidsregels; het gaat om regels gesteld in het kader van een gebonden bestuursbevoegdheid waarbij de wetgever vage objectieve criteria hanteert). ${ }^{31}$

De eerste drie soorten regels kunnen door de rechter marginaal getoetst worden, de wetsinterpreterende regels kan de rechter 'vol' toetsen. ${ }^{32} \mathrm{Na}$ een onderzoek naar de bevoegdheidsgrondslag; rechtmatigheidseisen te stellen aan beleidsregelgeving, en de gebondenheid eraan komt hij tot de volgende omschrijving van 'het rechtsbegrip beleidsregel ${ }^{33}$ : het gaat om algemene regels, die worden gesteld in het kader van een discretionaire bestuursbevoegdheid; de grondslag ligt niet uitdrukkelijk in de wet doch impliciet in de bestuursbevoegdheid besloten; de regels binden het bestuur ingevolge de beginselen van behoorlijk bestuur. In voor de burger gunstige gevallen mag het bestuur afwijken van de beleidsregel, dit noemt Van Kreveld de inherente afwijkingsbevoegdheid ${ }^{34}$

Na de dissertatie van Van Kreveld heeft de discussie zich meer en meer toegespitst op de vraag waar nog het onderscheid ligt tussen een algemeen verbindend

27. Overigens besteedt Van Kreveld in zijn dissertatie ook geen aandacht aan de grondwetsherziening of de grondwettelijke delegatieterminologie.

28. Van Kreveld 1983 , p. 40 .

29. Van Kreveld 1983, p.58.

30. Van Kreveld 1983, p.67.

31. Van Kreveld 1983, p.91-92.

32. Van Kreveld 1983, p.273.

33. Van Kreveld 1983, p. 242 en p. 275.

34. Van Kreveld 1983, p.195-196. 


\section{Hoofdstuk 8}

voorschrift en een beleidsregel, en of het wenselijk is dit onderscheid te handhaven. Een pleidooi om (ministeriële) beleidsregels betreffende een beschikkingsbevoegdheid de status van algemeen verbindend voorschrift te geven houdt Van der Vlies in haar dissertatie "Het wetsbegrip en beginselen van behoorlijke regelgeving' in $1984 .{ }^{35}$ In het feit dat volgens haar de verbindende kracht van beide soorten regels net veel verschilt, het karakter van de regelingen vaak hetzelfde is, en de regelingen op vrijwel dezelfde wijze tot standkomen, ziet zij redenen om het onderscheid op te heffen. Een ministerièle regeling zou dan aan de algenene beginselen van behoorlijk bestuur getoetst moeten worden ${ }^{36}$ en in bijzondere gevallen zou de minister mogen afwijken. ${ }^{37}$ Voor de regelingen zou cen publikatieplicht moeten komen, en ze zouden in cassatie voorwerp van toetsing moeten kunnen zijn. ${ }^{38}$ In het rijtje voorstanders schaart zich Verheij, die een zelfstandige ministeriële regelgevende bevoegdheid wil erkennen, voor zover de minister al over een discretionaire bestuursbevoegdheid beschikt. ${ }^{39}$

Tegenstanders zijn er echter ook. Zoals de Commissie Wetgevingsvraagstukken in haar rapport Orde in de regelgeving, die principieel verschillen in rechtsgevolgen ziet tussen algemeen verbindende voorschriften en beleidsregels, "hoezeer ook de verschillen in de praktijk van alledag naar de achtergrond kunnen verdwijnen. ${ }^{1140}$ De verbindendheid van een algemeen verbindend voorschrift komt voort uit de wettelijke grondslag; beleidsregels verbinden uit kracht van de algemene beginselen van behoorlijk bestuur. De Commissie wil onderscheid tussen beide soorten regels handhaven. ${ }^{41}$

De overeenkomsten en verschillen tussen algemeen verbindende voorschriften en beleidsregels blijven in daaropvolgende publikaties een rol spelen. ${ }^{42}$ Daarbij

35. Van der Vlies 1984, p.150 e.v.

36. Voor zover de rechter die toetsing (nog) niet uitvoert dienen er algemene beginselen van behoorlijke regelgeving ontwikkeld te worden. Van der Vlies 1984, p.150.

37. Van der Vlies 1984, p. 151 .

38. Van der Vlies 1984, p. 151.

39. Verheij 1985, p.1146. Zie ook Verheij 1984, p.3: "Waar de wettelijke grondslag geen begrenzing of normering van de toegekende bevoegdheid meer inhoudt, is zij geen wezenlijke warborg meer."

40. Orde in de regelgeving 1985, p. 20 .

41. Orde in de regelgeving 1985, p.20-21. Zie voor commentaar op het standpunt van de Commissie Wetgevingsvraagstukken: Konijnenbelt 1986; zie ook Ruiter 1986a en 1986b en Van der Burg 1986a.

42. Zie Van Kreveld 1985, Het verkleinen wan de juridische verschillen tussen beleidsregels en daarmee verwante wettelijke voorschriften; Van Kreveld 1988, Verdere inbouw van beleidsregels in het recht, NTB 1988, p.189-196; Van der Vlies 1991, p.129-134; Van 
wordt vrijwel steeds geconcludeerd dat beleidsregels en algemeen verbindende voorschriften naar elkaar toegroeien. ${ }^{43}$ Tot een gelijkstelling van beide soorten regels is het echter (nog) niet gekomen.

In paragraaf $8.3 \mathrm{ga}$ ik nader in op overeenkomsten en verschillen tussen beleidsregels en algemeen verbindende voorschriften, en op de verschillende vormen van gelijkstelling.

\subsubsection{Beleidsregels recht in de zin van artikel 99 Wet RO}

Een belangrijke stap in de ontwikkeling rond beleidsregels is de erkenning door de Hoge Raad van beleidsregels als recht in de zin van artikel 99 Wet RO. ${ }^{44}$ In de jaren ' 80 waren daar enkele uitspraken aan voorafgegaan die hierover geen duidelijkheid verschaften. ${ }^{45}$ Zo werd het Uniform Aanbestedingsreglement niet erkend als recht in de zin van artikel 99 Wet RO, maar de Sloopregeling Binnenvaart 1976 wel "nu deze regeling, die blijkens haar inhoud ertoe strekt om aan de betrokken eigenaren van binnenschepen onder bepaalde voorwaarden een recht jegens de Staat op een sloopuitkering toe te kennen en die is openbaar gemaakt in de Nederlandse Staatscourant 1976, $\mathrm{nr} 80$, moet worden beschouwd als een naar buiten werkende, de Staat jegens de betrokkenen bindende regeling".

Male in Akkermans/Koekkoek 1992, p.797 e.v.

43. Zie bijwoorbeeld ook Aanwijzing 2 van de Aanwijzingen voor de regelgeving 1993 :

'Onder regelingen worden in deze aarwijzingen verstaaw." a. algemeen verbindende voorschriften; $b$. interne regelingen; $c$. beleidsregels. ' en Aanwijzing 3: 'Op beleidsregels zijn deze aanwijzingen van toepassing, woor zover de aard van de beleidsregels zich daartegen niet verzet:' De Toelichting vermeldt als bijkomend 'vormvoorschrift' dat beleidsregels zoveel mogelijk worden ingedeeld in artikelen.

44. HR 28 maant 1990, NJ 1991,118 (Leidraad administratieve boeten 1984); HR 19 juni 1990, NJ 1991, 119 (Boadu-arrest, over de Vreemdelingencirculaire 1982) en HR 29 juni 1990. NJ 1991, 120. Zie hierover onder andere Kortmann 1990; Van der Vlies 1990, Meer recht in de zin van art, 99 Wet RO, in NJB 1990, p. 1147-1151; Van der Meulen e.a. 1991, Bestuursbevoegdheid als bron van recht? in NTB 1991, p.133- 141 .

45. HR 31 mei 1985 , NJ 1985, 648, AB 1985, 480, m.nt. FHvdB (Uniform Aanbestedingsreglement); HR 11 oktober 1985, AB 1986, 84, m.nt. FHvdB; NJ 1986, 322, m.nt. MS (Avanti). Deze jurisprudentie is onder andere besproken door Hirsch Ballin 1986, Recht op beleidsregels en beleidsregels als recht, in AA 1986, p.493-501 (hij noemt op p.498 nog andere voorbeelden uit de jurisprudentie); Kortmann $1987 \mathrm{~b}$. Avanti rijp voor sloop? Wet en recht in artikel 99 RO, RM Themis 1987 , p. 369-382; Kortmann 1990, Van eendagsvlieg nar insectenplaag?, in RegelMaat 1990, p.70-71. Discussie was er vooral over de vraag of het oordeel wan de Hoge Raad in het Avanti (Sloopregeling Binnenvaart 1976) arrest dat de regeling recht was in de zin van artikel 99 Wet RO nu ook betekende dat die regeling als een algemeen verbindend woorschrift werd aangemerkt. 


\section{Hoofdstuk 8}

De Hoge Raad sluit in zijn arrest wan 28 maart 1990 hierop aan met de volgende overweging. Onder recht in de zin van art. 99 Wet RO valt "mede te begrijpen door een bestuursorgaan binnen zijn bestuursbevoegdheid vastgestelde en behoorlijk bekend gemaakte regels omtrent de uitoefening van zijn beleid, die weliswaar niet kunnen gelden als algemeen verbindende voorschriften omdat zij niet krachtens enige wetgevende bevoegdheid zijn gegeven, maar die het bestuursorgaan wel op grond van enig algemeen beginsel van behoorlijk bestuur binden, en die zich naar hun inhoud en strekking ertoe lenen jegens de bij de desbetreffende regeling betrokkenen als rechtsregels te worden toegepast. Daaraan doet niet af dat de aard van de gebondenheid aan een zodanige regel kan meebrengen dat het bestuursorgaan daarvan onder bepaalde omstandigheden kan afwijken. Als behoorlijke bekendmaking in de hier bedoelde zin kan gelden de plaatsing in de Staatscourant of in een ander vanwege de overheid algemeen verkrijgbaar gesteld publikatieblad, dan wel een andere door of met goedvinden dan wel medeweten van de overheid gedane bekendmaking op zodanige wijze dat verzekerd is dat de regels voor de betrokkenen kenbaar en toegankelijk zijn. ${ }^{146}$

Met deze uitspraak handhaaft de Hoge Raad het onderscheid tussen algemeen verbindende voorschriften en beleidsregels.

8.2.5 Beleidsregels in het wetsvoorstel van de Derde tranche van de Algemene wet bestuursrecht

\subsubsection{Beschrijuing van de regeling}

In vijf artikelen wordt in de Algemene wet bestuursrecht een aparte regeling voor beleidsregels neergelegd. ${ }^{47}$ Allereerst wordt aan artikel $1: 3$ een vierde lid toegevoegd, waarin een definitie van beleidsregel gegeven wordt: 4. 'Onder beleidsregel wordt verstaan: een bestuit, niet inhoudende een algemeen verbindend

46. Kritisch becommentarieerd door Kortmann 1990, p.68-71. Zie ook HR 13 september 1994, NJB-Katern 1994, p.531, nr 211, over de 'Richtlijn voor het doen van angifte of het opmaken van proces-verbal ter zake van fraude met sociale vitkeringen' van 15 februari 1993 (Stcrt. 1993, 31): "De regels die zijn vervat an de genoemde richtlijn moeten worden beschouwd als 'recht in de zin van artikel 99 Wet RO (vergelijk HR 19 juni 1990 , NJ 1991, 1 19). Gelet op de aard van die richtlijn, warvan kenmerkend is dat zij niet kan gelden als een algemeen verbindend voorschrift omdat $z$ ij niet krachtens enige wetgevende bevoegdheid is gegeven, en met name ook gelet op de grondslag waarop zij het openbaar ministerie bindt - te weten het vertrouwen dat een verdachte daaraan onder omstandigheden kan ontlenen - is de rechter evenwel niet tot ambtshalve toepassing ervan gehouden (vergelijk HR 28 maant 1990, NJ 1991, 118)."

47. Kamerstukken II 1993-1994, 23700, nr 2, Voorstel van wet. 
voorschrift, dat een algemene regel geeft omtrent de afweging van belangen, de vaststelling van feiten of de uitleg van wettelijke voorschriften bij het gebruik van een bevoegdheid van een bestuursorgaan."

Vervolgens wordt in titel 4.4 een viertal artikelen toegevoegd. Artikel 4.4.1: 1. 'Een bestuursorgaan kan beleidsregels vaststellen met betrekking tot een hem toekomende of onder zijn verantwoordelijkheid uitgeoefende, dan wel door hem gedelegeerde bevoegdheid.' 2 . 'In andere gevallen kan een bestuursorgaan slechts beleidsregels vaststellen, voor zover dit bij wettelijk voorschrift is bepaald."

Artikel 4.4.3:48 "Ter motivering van een besluit kan slechts worden volstaan met een verwijzing naar een vaste gedragslijn voor zover deze is neergelegd in een beleidsregel."

Artikel 4.4.4: 'Bij de bekendmaking van de beleidsregel wordt zo mogelijk het wettelijk voorschrift vermeld waaruit de bevoegdheid waarop de beleidsregel betrekking heeft voortvloeit.'

Artikel 4.4.5: 'Het bestuursorgaan handelt overeenkomstig de beleidsregel, tenzij dat voor een of meer belanghebbenden gevolgen zou hebben die wegens bijzondere omstandigheden onevenredig zijn in verhouding tot de met de beleidsregel te dienen doelen."

\subsubsection{Enkele opmerkingen}

Op het (voor)ontwerp zijn veel commentaren verschenen. ${ }^{49}$ In het kader van deze studie ga ik niet op alle aspecten van de voorgestelde regeling in, maar beperk ik mij tot twee punten: de wettelijke grondslag voor beleidsregels en algemeen verbindende voorschriften, en de aard van de bevoegdheid die met beleidsregels dan wel algemeen verbindende voorschriften kan worden uitgeoefend. Omdat deze aspecten het onderscheid tussen algemeen verbindende voorschriften en beleidsregels betreffen bespreek ik ze in de volgende paragraaf. Ik

48. Vervallen is artikel 4.4 .2 uit het voorontwerp dat luidde: 'Indien een bestuursargaan bij het gebruik van een bevoegdheid tot het nemen van besluiten of het verrichten vam privaatrechtelijke rechtshandelingen een waste gedragslijn volgt ter zake van het afwegen van belangen, het vaststellen van feiten of het uitleggen van wettelijke voorschriften, wordt deze in een beleidsregel neergelegd, tenzij redelijkerwijs kan worden aangenomen dat daaraan geen behoefte bestaat.'

49. Zie onder anderen Bakker 1992, Kleijn 1992, Langbroek e.a. 1992 -Nicolaï 1992, Verheijb 1992, Bakker e.a. 1993, Michiells 1993, De Groot/Van der Meulen/Van Rossum 1994, Heldeweg 1995. 


\section{Hoofdstuk 8}

ga er hier aan voorbij of de voorgestelde regeling voor beleidsregels wel de meest wenselijke is. ${ }^{50}$

Een vergelijking tussen de omschrijving van beleidsregels door de Hoge Raad en de voorgestelde wettelijke regeling in de Awb laat zien dat beide voor een belangrijk deel dezelfde elementen bevatten. Beide zijn duidelijk in de bepaling dat een beleidsregel geen algemeen verbindend voorschrift is. Ook de eisen van behoorlijke bekendmaking komen overeen ${ }^{51}$, zij het dat de Awb verlangt dat (zo mogelijk) bij bekendmaking het wettelijk voorschrift wordt vermeld waarop de bestuursbevoegdheid steunt. Enkele verschilpunten zijn er echter ook: de Awb bepaalt specifiek dat beleidsregels betrekking hebben op de afweging van belangen, de vaststelling van feiten of de uitleg van wettelijke voorschriften, daar waar de Hoge Raad spreekt van 'regels omtrent uitoefening van beleid'. Ook is de regeling in de Awb strikter in het bepalen wanneer van de beleidsregel kan worden afgeweken. Volgens de Hoge Raad kan 'onder bepaalde omstandigheden' worden afgeweken, op grond van de Awb kan daarvan pas sprake zijn wanneer de gevolgen van het handelen overeenkomstig de beleidsregel jegens een belanghebbende 'wegens bijzondere omstandigheden onevenredig zijn in verhouding tot de met de beleidsregel te dienen doelen'. Een uitbreiding geeft de Awb daar waar ze stelt dat beleidsregels ook gegeven kunnen worden met betrekking tot een gemandateerde of gedelegeerde bevoegdheid.

De binding van een bestuursorgaan aan beleidsregels geschiedt volgens de Hoge Raad op grond van de algemene beginselen van behoorlijk bestuur; de binding op grond van de Awb is gebaseerd op artikel 4.4.5, vloeit rechtstreeks uit de wer voort.

Zullen deze verschillen gevolgen gaan hebben voor de toetsing van beleidsregels door de Hoge Raad? Het valt te verwachten dat beleidsregels die voldoen aan de eisen van de Algemene wet bestuursrecht door de Hoge Raad worden erkend als recht in de zin van artikel 99 Wet RO. Op één punt liggen de opvattingen van de Hoge Raad en Awb-wetgever tot nu toe uiteen. Op grond van de Awb kunnen ook beleidsregels gesteld worden voor privaatrechtelijk handelen van de overheid. Tot nu toe heeft de Hoge Raad de door bestuursorganen in dat kader gehan-

50. Zie Bakker e.a. 1993 , p.57 e.v.; Michiels 1993, p.311. Met name tegen de kwalificatie als beshilt zijn zwaarwegende bedenkingen aan te voeren. Ook het feit dat voor alle 'soorten" beleidsregels dezelfde wettelijke regeling geldt is betwistbaar.

51. De bekendmaking van beleidsregels gebeurt op basis van artikel $3: 42 \mathrm{Awb}$ : 'De bekendmaking wan beshiten die rilet tot een of meer belanghebbenden zijn gericht, geschiedt door kennisgeving wan het besluit of van de zakelijke inhoud ervan in een van overheidswege witgegeven blad of een dag-, nieuws- of huis-aan-hwis-blad, dan wel op een andere ge-
schikte wijze: 
teerde algemene voorwaarden echter niet erkend als recht in de zin van artikel 99 Wet RO. ${ }^{52}$ De vraag is of de Hoge Raad zijn jurisprudentie op dit punt zal gaan aampassen. ${ }^{53}$

$\mathrm{Nu}$ beleidsregels door een wettelijke regeling verder geformaliseerd worden is het de vraag of er geen "gevaar' bestaat voor verdere regelverdichting. Zo zouden bestuursorganen behoefte kunnen hebben aan een categorie regels die niet hoeft te voldoen aan de eisen gesteld in de Awb (en dus bijvoorbeeld minder tijd en geld kosten). ${ }^{54}$ Het volgen van een vaste gedragslijn of mondelinge beleidsregels is niet voldoende om ter motivering (uitsluitend) naar te verwijzen. Zo zullen er dus beleidsregels 'in de zin van de Awb' en beleidsregels die dat niet zijn, gehanteerd worden. ${ }^{55}$ Daarbij zal de kwalificatie van een richtlijn/gedragslijn/circulaire in de toekomst rechtsgevolgen gaan hebben. De aanduiding als 'beleidsregel in de zin van de Awb' betekent immers dat het regime van de Awb van toepassing wordt. ${ }^{56}$

52. HR 20 januari 1992, AB 1992, 282, m.nt. Van der Burg.

53. Zie ook Michiels 1993, p.313. Van Wijk/Konijnenbelt/Van Male 1994, p.286 noemen de opvatting neergelegd in de MvT dat ook algemene regels voor de uitoefening van privaatrechtelijke bevoegdheden beleidsregels zijn een 'misvatting': dat zijn algemene voorwaarden, geregeld in afdeling 3 van boek $6 \mathrm{BW}$. De vaststelling ervan is een privaatrechtelijke rechtshandeling. Wel kunnen de bepalingen van de Awb inżake beleidsregels er op van toepassing verklaard worden.

54. Zie ook G.R.J. de Groot, B.M.J. van der Meulen en A.A. van Rossum, Subsidies, beleidsregels, bestuursorganen, in NJB 1994, p.1193-1200, p.1197: "Beleidsregels moeten worden voorbereid, gemotiveerd en bekendgemaakt als besluiten in de zin van de Awb. En als daaraan niet de hand wordt gehouden? Dan is er geen sprake van een beleidsregel in de zin van de Awb. Handelen overeenkomstig de 'beleidsregel' is daarmee niet onrechtmatig. Het bestuursorgaan moet beslissen overeenkomstig het bekend gemakte beleid of de gewolgde vaste gedragslijn. Dat vloeit voort uit het gelijkheidsbeginsel en het vertrouwensbeginsel. Een wezenlijk verschil met de gebondenheid aan "echte" beleidsregels is er niet. Alleen kan voor de motivering niet worden volstaan met verwijzing naar die beleidsregel."

55. Vergelijk de opmerking in de Memorie wan Toelichting: "Niet iedere uitspraak over toekomstig beleid is een beleidsregel. Naar de inhoud moet het gaan om een algemene, voor herhaalde toepassing vatbare, regel voor het gebruik van een bevoegdheid van een bestuursorgaan. " Kamerstukken II 1993-1994, 23700, nr 3 MvT, p.113.

56. Zie ook de noot van F. Vlemminx onder CRvB 7 april 1995, JB 1995/124. In deze uitspraak ging het om de uitleg van een 'circulaire' van de Sociale Verzekeringsraad, door de Centrale Raad betiteld als werkafspraken en gedragslijin. De Raad waagt zich niet aan de kwalificatie 'beleidsregel'. 


\section{Hoofdstuk 8}

Een voorbeeld van aanduiding van verschillende soorten regels vinden we in een uitspraak van de CRvB. ${ }^{57}$ De Raad hanteert de woorden "beleids- en uitvoeringsregels', zonder daar verdere overwegingen aan te wijden of op mogelijk verschil in te gaan. Wel erkent de Raad hierbij een 'inherente afwijkingsbevoegdheid'58 en een publikatieplicht voor beleids- en uitvoeringsregels op grond van de algemene beginselen van behoorlijk bestuur; in het bijzonder het zorgvuldigheidsbeginsel. In zijn noot veronderstelt Stroink dat de CRvB geen aparte categorie regels heeft willen onderscheiden ten opzichte van algemeen verbindende voorschriften en beleidsregels, maar de term uitvoeringsregels als synoniem gebruikt voor beleidsregels.

Ook in de literatuur worden nieuwe categorieën regels 'ontdekt' en in kaart gebracht. Zo is van Bröring een onderzoek naar richtlijnen verschenen. ${ }^{59}$ Richtlijnen zijn bestemd voor een andere instantie dan de regelgever zelf, of diens hierarchisch ondergeschikten (bij richtlijnen ontbreekt dus de van beleidsregels bekende zelfbinding). Overigens kunnen deze richtlijnen volgens de Awb ook aangemerkt worden als beleidsregels. Op richtlijnen zoals Bröring ze definieert ga ik verder niet in.

\subsection{Beleidsregel en algemeen verbindend voorschrift}

\subsubsection{Inleiding}

In het wetsvoorstel Derde tranche Awb en in de jurisprudentie van de Hoge Raad wordt het onderscheid tussen algemeen verbindende voorschriften en beleidsre-

57. CRVB 11 mei 1994, JB 1994/152 m.nt. FAMS.

58. "De Raad onderkent evenwel de mogelijkheid dat, (...) onder zeer bijzondere omstandigheden er zich fitten van een zo zwaarwegende aard kumnen voordoen dat de beleids- en uitvoeringsregels met toepassing van de algemene beginselen van behoorlijk bestuur moeten wijken voor een concrete weging van omstandigheden in een indiwidueel geval, berustende op een aan dit soort gevallen inherente afwijkingsbevoegdheid. "Opvallend is dat de Centrale Raad op dit punt strenger lijkt dan de voorgestelde regeling in artikel 4.4.5 Awb: de wet spreekt van 'bijzondere gevallen', de Raad van 'zeer bijzondere gevallen'.

59. H.E. Bröring, Richtlijnen, Kluwer Deventer 1993. Hij omschrijft richtlijnen als buitenwettelijke regels, die zich van beleidsregels onderscheiden omdat zij niet zijn vastgesteld door het ter zake bevoegde bestuursorgaan, bijwoorbeeld ministerielle circulaires bestemd voor gemeentebesturen, Bröring 1993b, p.27. Besproken door I.C. van der Vlies in NJB
1995, p.672-673. 
gels gehandhaafd. ${ }^{60}$ Desondanks groeien beide soorten regels naar elkaar toe, juist ook door een wettelijke regeling van beleidsregels. ${ }^{61}$ Achtereenvolgens wordt in deze (hoofdzakelijk beschrijvende) paragraaf aandacht besteed aan de term algemeen verbindend voorschrift (8.3.2); overeenkomsten (8.3.3) en verschillen (8.3.4) tussen beleidsregels en algemeen verbindende voorschriften; implementatie van EG-recht (8.3.5); conversie (8.3.6) en voorstellen die gedaan zijn om beleidsregels en algemeen verbindende voorschriften eenzelfde status te geven (8.3.7). In de volgende paragraaf zullen hieruit in het licht van het delegatievraagstuk en de grondwettelijke delegatieterminologie conclusies getrokken worden.

\subsubsection{De term algemeen verbindend voorschrift}

\subsubsection{Omschrijvingen}

De term algemeen verbindend voorschrift wordt in (bijvoorbeeld) de Grondwet of de Awb niet gedefinieerd. Wel wordt de term genoemd in artikel 89 lid 4 $\mathrm{GW}^{62}$, artikel $8: 2 \mathrm{Awb}^{63}$ en in het (toekomstige) artikel $1: 3$ lid $4 \mathrm{Awb}^{64}$. In de parlementaire stukken op de grondwetsherziening is geen omschrijving gegeven van het begrip algemeen verbindend voorschrift. ${ }^{65}$

60. Eerder werd het onderscheid gehandhaafd in de Bekendmakingswet (Wet van 4 februari 1988, Stb.1988, 18).

61. Zie ook de Aanwijzingen voor de regelgeving 1993, Aanwijzing 3: "Op beleidsregels zinn deze aanwijzingen van toepassing, voor zover de aard van die regels zich daartegen nief verzet.'

62. "Het tweede en derde lid zijn van overeenkomstige toepassing op andere vanwege het Rijk vastgestelde algemeen verbindende voorschriften."

63. "Geen beroep kan worden ingesteld tegen." $a$. een besluit, inhoudende een algemeen verbindend woorschrift of een beleidsregel, $b$. een besiwit, inhoudende de intrekking of de vaststelling van de inwerkingtreding van een algemeen werbindend voorschrift of een beleidsregel, en c. een besluit, inhoudende de goedkeuring van een bestuit, inhoudende een algemeen verbindend woorschrift of een beleidsregel of de intrekking of de vaststelling van de inwerkingtreding van een algemeen werbindend voorschrift of een beleidsregel."

64. 'Onder beleidsregel wordt verstatan: een besituit, niet inhoudende cen algemeen verbindend voorschrift, dat een algemene regel geef ontrent de afweging van belangen, de vaststelling van feiten of de uitleg van wettelijke woorschriften bij het gebruik vam een bevoegdheid' van een bestuursorgaan."

65 . Orde in de regelgewing 1985, p. 13. 


\section{Hoofdstuk 8}

Met een grove schets kan de ontwikkeling van het begrip algemeen verbindend voorschrift als volgt worden weergegeven. ${ }^{66}$ Buys omschreef een 'wet' als: "Elke daad van het staatsgezag waardoor het gebiedend of verbiedend tegenover de onderdanen optreedt, hun plichten oplegt, welke zonder dat gebod niet zouden gelden, hunne door de wet gewaarborgde vrije beschikking over persoon en goed wijzigt en beperkt, elk zoodanig voorschrift is eene wet. "67

De Hoge Raad gaf in 1919 een iets andere omschrijving. ${ }^{68}$ Onder 'wet' in artikel 99 Wet RO vallen (naast wetten in formele zin) ook 'naar buiten werkende, dus tot een ieder gerichte algemeene regelingen, welke zijn uitgegaan van een openbaar gezag, dat de bevoegdheid daartoe aan de wet, in de zin van eene regeling door de wetgevende macht, ontleent'.

Een verruiming vond plaats in 19696\%: 'voldoende is dat het voorschrift betrekking heeft op herhaalbare gevallen en is gericht tot niet geïndividualiseerde personen, ongeacht of zij voor de steller al dan niet kenbaar waren.' (...) Het moet gaan om 'naar buiten werkende en voor hen die bij deze regeling waren betrokken, bindende woorschriften.'

En de Memorie van Toelichting op de Derde tranche Awb hanteert (in 1994) als omschrijving van de term algemeen verbindend voorschrift: 'naar buiten werkende, voor de daarbij betrokkenen bindende regels, uitgegaan van het openbaar

66. Zie voor een overzicht ook Hirseh Ballin 1985, p.636-640; Van der Vlies 1991, p.115116. Over de gehanteerde terminologie nog het volgende. De eerste interpretaties van wat nu 'algemeen verbindend voorschrift' genoemd wordt vonden plaats in het licht van artikel 99 Wet RO (oud) en betroffen de uitleg van de term 'wet'. Daaronder werd niet alleen een wet in formele zin begrepen, maar ook een wet in materiële $z$ in. De term algemeen verbindend voorschrift of wettelijk voorschrift werd later gehanteerd. De laatste twee termen hanteer ik als synoniemen. De term "wet in materiële zin' is een wat ongelukkige geworden nu de Hoge Raad ook beleidsregels erkent als recht in de zin van artikel 99 Wet RO, zijndle regels die niet op grond van een uitdrukkelijke wettelijke grondslag zijn gegeven. Ik zal de term wet in materiêle zin dan ook niet gebruiken. Anders: Van Male in Akkermans/Koekkoek 1992, p.796, die de termen algemeen verbindend voorschrift, wettelijk voorschrift en wet in materièle zin als synoniemen beschouwt. Kortmann 1994, p.52-53 maakt een onderscheid tussen de termen algemeen verbindend voorschrift en wet in materiele zin. Het belangrijkste verschil ziet hij in het feit dat een algemeen verbindend voorschrift ook enkel interne werking kan hebben, in tegenstelling tot een wet in materiële zin, die steeds extern werkt.

67. Buys 1883, I, p.336. Aangehaald bij Böhtlingk/Logemann 1966, p.50.

68. HR 10 juni 1919, NJ 1919, p.647 (Rogge).

69. HR 25 april 1969, NJ 1969, 303, m.nt. DJV. Zie ook HR 28 juni 1979, AB 1979,488 , m.nt. Stellinga. 
gezag dat de bevoegdheid daartoe aan de wet ontleent: ${ }^{70}$ De in deze beschrijving genoemde elementen 'naar buiten werken', 'voor betrokkenen bindende regels', "uiltgegaan van het openbaar gezag" en het vereiste van een wettelijke bevoegdheidsgrondslag worden ook in de literatuur genoemd. ${ }^{71}$

\subsubsection{Algemeenheid}

Uit deze bijzonder beknopte schets blijkt dat het vereiste van algemeenheid in de loop van de jaren aan reikwijdte inboet. Met de toenemende rechtsverfijning is aanvaard dat steeds meer (wettelijke) regels een kleinere doelgroep hebben. Het vereiste van 'naar buiten werkende, dus tot een ieder gerichte algemene regeling' (Hoge Raad 1919) is vervangen door 'naar buiten werkende en voor de daarbij betrokkenen bindende regels' (Hoge Raad 1969 en Awb 1994). ${ }^{72}$ 'Algemeenheid" vindt in het arrest van de Hoge Raad uit 1969 uitdrukking in de elementen 'herhaalbaarheid ${ }^{73}$ en 'gericht op niet geïndividualliseerde personen'.

70. Kamerstukken II 1993-1994, 23700, nr 3 MvT, p. 105. Verwijzend naar HR 1.0 juni 1919 , NJ 1919, p.647 en Orde in de regellgeving 1985, p. 14. In de Memorie van Toelichting op de 'Tweede tranche was gesteld dat het begrip 'algemeen verbindend voorschrift nauwkeurig is afgebakend', zonder dat overigens die afbakening werd gegeven: Kamerstukken II 1991-1992, 22495, nr 3 MvT, p.9. De omschrijving in de MvT vindt navolging in de jurisprudentie. Zie Rb Utrecht 21 februari 1994, JB 1994/38 "Gelet op het samenstel van de onder 2.2 genoemde bepalingen moet worden aangenomen dat richtlijnen als bedoeld in artikel 11 van de Wet tarieven Gezondheidszorg het karakter hebben van een algemeen verbindend voorschrift. Het betreft immers naar buiten werkende, voor de daarbij betrokkenen bindende regels, uitgaande van het openbaar gezag dat de bevoegdheid daartoe uitdrukkelijk aan de wet ontleent (MvT, voorontwerp derde tranche Awb). " Zie over het aanmerken van de hier bedoelde richtilijnen als wettelijke voorschriften ook CBB 1 maart 1994, JB 1994/50 m.nt: MAH.

71. Donner 1987, p. 76-77; Orde in de regelgeving 1985, p. 19; Hirsch Ballin 1989, p. 23; Van der Vlies 1991, p.115-125; Van Male in Akkermans/Koekkoek 1992, p.801; Van Wijk/Konijnenbelt/ $/ a n$ Male 1994, 253. Zie ook de Aanwijzingen voor de regelgewing 1993, Aanwijzing 19: 'Als algemeen verbindend voorschrift, vastgesteld vanwege het Rijk, wordt beschouwd een naar buiten werkende algemene regel, vastgesteld bij of krachtens wet dan wel, in bijzondere gevallen, bij of krachtens zelfstandige algemene maatregel van bestuur.'

72. Zie ook de noot van BvM/MAH bij CRvB 28 april 1994, JB 1994/263.

73. Zie ook de uitspraak van de President van de rechtbank Assen die oordeelde dat een besluit van Gedeputeerde Staten van Drenthe, inhoudende onder meer dat Borger niet langer standplaats is voor ambulancevervoer, wel een besluit van algemene strekking is, maar niet een algemeen verbindend voorschrift. Het besluit richt zich niet tot één of meer bepaalde personen, en heeft ook niet betrekking op een bepaald goed of een bepaalde zaak en is in zoverre algemeen, maar het besluit leent zich niet voor herhaalde toepassing. Pres. Rb Assen 9 februari 1995, NA 1995, 130. 


\section{Hoofdstuk 8}

Het vereiste van algemeenheid kan betrekking hebben op meerdere aspecten zoals algemeenheid naar personen (rechtssubjecten), tijd en plaats. ${ }^{74}$ Van der Burg vertaalt algemeenheid ${ }^{75}$ bij elk aspect in "meer dan één": zo is een norm die slechts geldt voor één bepaalde plaats, of éen bepaald tijdstip of één bepaalde persoon in beginsel geen algemeen verbindend voorschrift. ${ }^{76}$ Een norm die zich richt tot één ambtsdrager voldoet aan het vereiste van algemeenheid wanneer de norm betrekking heeft op ieder persoon die het ambt uitoefent. ${ }^{77}$ Een norm hoeft echter niet steeds aan alle algemeenheidsaspecten te voldoen om als algemeen verbindend voorschrift te kunnen gelden. ${ }^{78}$ Een norm die slechts geldt voor één bepaald tijdstip (zoals enkele uren) kan algemeen zijn wanneer hij zich in principe tot een onbepaald aantal personen richt. ${ }^{79} \mathrm{Het}$ algemeenheidsvereiste naar persoon heeft in beginsel het zwaarste gewicht. ${ }^{\text {a }}$

Een algemeen verbindend voorschrift hoeft zich niet per se te richten tot natuurlijke personen, maar kan ook (enkel) betrekking hebben op rechtspersonen. Zo voldoet een regelifg die zich enkel richt tot gemeenten volgens de Hoge Raad aan het algemeenheidsvereiste. ${ }^{81}$ Van belang is dat het gaat om een regel die geldt voor herhaalbare gevallen. ${ }^{82}$

De inhoud van de norm (in de zin dat het om een bepaling gaat die de burger iets verbiedt of gebiedt) staat niet meer op de voorgrond. Al langer is immers geaccepteerd dat ook bepalingen waaraan burgers aanspraken kunnen ontlenen kunnen gelden als algemeen verbindend voorschrift. Voor aanmerking als algemeen verbindend voorschrift lijken daarom twee aspecten bepalend: het vereiste

74. Orde in de regelgeving 1985 , p.15-16, verwijzend naar Böhtlingk/Logemann 1966, p.1920. Zie ook de noot van J.A. Borman bij ARRS 11 maart 1980 , AB 1980, 463 die verschillende criteria voor algemeentheid opsomt. Van Male 1992, Besluiten van algemene strekking in het nieuwe bestuursprocesrech, gaat in op factoren die de algemeenheid van een beshuit van algemene strekk ing beinvloeden, p. $28-32$.

75. Zoals omschreven in Orde in de regelgeving 1985, p.15-17.

76. Van der Burg 1993, p.148.

77. Van Male 1992, p.29.

78. Orde in de regelgeving 1985, p. 16 .

79. Van Male 1992, p.30.

80. Van Male in Akkermans/Koekkoek 1992, p.813. Hij woegt eraan toe: "Concretiserende/individualiserende factoren, zoals ruimte, tijd en herhaalbaarheid, kunnen niettemin zo zwatr wegen dat het (qua personenkring) algemene karakter van een bepald besluit
wordt ontkend."

81. HR 20 maart 1981, NJ 1982,183 m.nt. FHJM en WHH (Beschikking geldelijke steun eigen woningen 1968); zie ook Van der Vlies 1991, p.115; Van Male in Akkermans/ Koekkoek 1992, p.812.

82. Van der Vlies 1991, p. 1 16. Van Male 1992, p.30. 
van algemeenheid en het vereiste van een wettelijke grondslag (op basis van een regelgevende bevoegdheid). ${ }^{83}$

Doordat 'algemeen' steeds minder 'algemeen' hoeft te zijn, is het onderscheid tussen algemeen verbindend voorschrift (of ander besluit van algemene strekking) en met name een beschikking soms nog moeilijk te maken. ${ }^{84}$ Enkele voorbeelden uit de jurisprudentie bieden de volgende uitspraken.

In een uitspraak van de Afdeling rechtspraak ${ }^{85}$ werd bij het bestreden besluit een weekmarkt naar een ander perceel verplaatst. Het besluit hield tevens een wijziging van de gemeenteverordening in. De Afdeling oordeelt dat het besluit als een beschikking moet worden aangemerkt nu het gaat om een bepaalbare groep rechtssubjecten. "Dat naar opposante heeft aangevoerd deze groep geen besloten groep is maakt dit niet anders. Bepalend is dat het gaat om de betrokken marktkooplieden." Nu de kring van rechtssubjecten (de betrokken marktkooplieden) voor uitbreiding vatbaar is had mijns inziens echter een aanmerking als besluit van algemene strekking (tevens algemeen verbindend voorschrift) meer voor de hand gelegen. Ook het feit dat de uitvoering van het bestreden besluit voor herhaling vatbaar is (zolang het besluit niet wordt gewijzigd) ligt meer in de lijn van een besluit van algemene strekking dan een beschikking. Vóór de kwalificatie als beschikking pleit dat sprake is van één concreet perceel.

Ook de uiteenlopende jurisprudentie over de bevoegdheid van de Staatssecretaris van Onderwijs en Wetenschappen om een numerus fixus af te kondigen (het Besluit beperking inschrijving geneeskunde) laat zien hoe geworsteld wordt met de kwalificatie algemeen verbindend voorschrift. De bevoegdheid van de Staatssecretaris is neergelegd in artikel $7.56 \mathrm{WHW}$, dat luidt voor zover relevant: 1 . 'Indien het aanbod van afgestudeerden van een bepaalde opleiding de behoefte daaraan op de arbeidsmarkt in aanmerkelijke mate overtreft en dit naar verwachting gedurende een reeks van jaren her geval zal zijn, kan Onze minister een besluit nemen waarin worden vastgesteld: a. het aantal personen dat over de twee daaropvolgende studiejaren ten hoogste voor de eerste maal kan worden ingeschreven voor de propedeutische fase van de desbetreffende opleiding aan de universiteiten of hogeschalen waaraan deze is verbonden, en $b$. de verdeling van dat aantal over elk van de onder a bedoelde instellingen.'

83. Van Male in Akkermans/Koekkoek 1992, p.811, verwijzend naar Hirsch Baltin 1989, p.24.

84. Zie ook R.M. van Male, Een eenarmige bandiet, in NTB 1993, p. 127.

85. ARRS 11 juni 1992, AA 1993, p.732-737, m.nt. L.J.A. Damen, De beschikte weekmarkt van Maassluis. 


\section{Hoofdstuk 8}

De President van de Utrechtse rechtbank ${ }^{86}$ oordeelde dat het Besluit "geen algemene, abstracte regels bevat die zich voor herhaalde concrete toepassing lenen en derhalve het karakter van materiële wetgeving ontbeert. Dat het Besluit ook rechtsgevolgen heeft voor een onbepaald aantal personen die door de uitvoering daarvan worden geraakt, is niet beslissend voor het rechtskarakter. Datzelfde kan immers het geval zijn bij beschikkingen." De president acht wel een besluit van allgemene strekking aanwezig nu het Besluit zich in beginsel richt tot een onbeperkt aantal universiteiten. Gelet op het bepaalde in artikel 7:56 lid 1 onder b betwijfel ik echter of hier een 'onbepaald aantal universiteiten" in het geding is. Het besluit zal immers een opsomming bevatten over de toedeling van aantallen studenten per met name genoemde universiteit. Met annotator Stroink ben ik dan ook van mening dat het Besluit als een bundel beschikkingen te kwalificeren is. Het oordeel van de Utrechtse president dat er geen sprake is van algemeen verbindende voorschriften wordt gedeeld door zijn Maastrichtse collega: ${ }^{87}$ "Dat verweerders besluit is genomen op grond van een hem door de wet (artikel 7.56 WHW) gegeven bevoegdheid, is onmiskenbaar. Deze wettelijke bepaling geeft echter geen uitsluitsel omtrent de vraag of deze bevoegdheid moet worden gezien als een (algemene) regelgevende bevoegdheid of als een beschikkingsbevoegdheid. Gelet vervolgens op de aard, de inhoud en de strekking van het besluit is de president, onder verwijzing naar met name de uitspraak van de Afdeling rechtspraak van de RvS van 11 juni 1992 (Gem.stem 6950, $\mathrm{nr}$ 5) van oordeel dat hier niet gesproken kan worden van een algemeen verbindend voorschrift. Daarvoor is het besluit te concreet geticht tot een beperkte en gesloten groep van met name aangeduide rechtspersonen. Voorts geeft de uitwerking in artikel 2 van het besluit precies aan hoeveel personen voor de eerste maal kunnen worden ingeschreven voor de propaedeuse geneeskunde bij verzoekers instelling, met exacte vermelding van de twee studiejaren waarvoor zulks heeft te gelden. Derhalve kan toch bezwaarlijk worden gezegd dat het hier algemene, abstracte regels betreft die voor nadere concretisering en/of herhaalbare toepassing in aanmerking komen. "Impliciet is uit de uitspraak op te maken dat de President een (bundel) beschikking(en) aanneemt, waar hij constateert dat de rechtsgevolgen uit de wet zelf voortvloeien en niet door het besluit worden geregeld: "Immers deze omstandigheid doet zich zeer frequent voor bij beschikkingen ter uitvoering van een wettelijke regeling."

86. Pres, Rb Utrecht 31 augustus 1994, JB 1994/255, m. nt. FAMS.

87. Pres. Rb Maastricht 12 oktober 1994, JB 1994/299, m.nt. R. Schlössels. 
Tot het oordeel dat het Besluit wel algemeen verbindende voorschriften inhoudt komt de Bossche president. ${ }^{88}$ "Naar mijn voorlopig oordeel dient een besluit genomen op voet van artikel 7.56 WHW te worden aangemerkt als een algemeen verbindend voorschrift, dat wil zeggen als een naar buiten werkende, voor de daarbij betrokkenen bindende regel, uitgaande van het openbaar gezag dat de bevoegdheid daartoe uitdrukkelijk aan de wet ontleent. ${ }^{n 9}$

De problematiek over de aanduiding van een besluit als een algemeen verbindend voorschrift speelt eveneens in recente jurisprudentie over gemeentelijke grenscorrecties. De President van de Rotterdamse rechtbank oordeelde dat uit artikel 283 Gemeentewet ${ }^{90}$ blijkt dat grenscorrecties bij algemeen verbindend voorschrift worden vastgesteld. ${ }^{91}$ Als motivering voert hij aan: "De onderhavige grenscorrectie is krachtens bij artikel 283, lid 3, sub a van de Gemeentewet aan de raden van de gemeenten Rotterdam en Zevenhuizen-Moerkappelle geattribueerde bevoegdheid vastgesteld. Die vaststelling is derhalve een algemeen verbindend voorschrift."

In een vergelijkbaar geval oordeelde de Bossche president echter dat besluiten als bedoeld in artikel 283 , derde lid, sub a en vierde lid van de Gemeentewet geen algemeen verbindende voorschriften zijn, ${ }^{22}$ nu de bevoegdheid de betrokken gemeenteraden niet op een krachtens wettelijke bepaling verordenende bevoegdheid berust. Voor de Bossche president is niet doorslaggevend het feit dat het raadsbesluit tot grenscorrecties in artikel 1, aanhef, en onder e, van de Wet algemene regels herindeling (Wet arhi) wordt vermeld in een opsomming van algemeen verbindende voorschriften. "Immers, of een besluit al dan niet een algemeen verbindend voorschrift is, is niet afhankelijk van het behoren tot een in de wet opgenomen opsomming van algemeen verbindende voorschriften, nog daargelaten dat gemeenteraden aan bedoeld artikelonderdeel niet de bevoegdheid

88. Pres. Rb Den Bosch 23 september 1994, JB 1994/298, m.nt. FAMS. Zie ook L.J.A Damen, Wordt de spoeling voor dokters echt te dun of kan het geen kwalad om er wat meer op te leiden?, in AA 1995 , p.43-49.

89. Inmiddels wordt een wetswijziging voorbereid: Kamerstukken II 1994-1995, 24075.

90. Artikel 283 Gemeentewet luidt (voor zover relevant): (...) 3. 'De overige grenscorrecties geschieden: $a$. bij gelijkluidend besluit van de raden van de betrokken genteenten; $b$. bij beshit van provinciale staten; c. bij algemene maatregel van bestuur in het geval bedoeld in artikel 28.8 , tweede lid; of d. bij de wet. 4. Besluiten als bedoeld in het derde lid onder a behoeven de goedkeuring van gedeputeerde staten. Gedeputeerde staten doen van hun besluit tot goedkeuring dan wel onthouding van goedkeuring mededeling aan Onze Minister.'

91. Pres. Rb Rotterdam 12 december 1994, NA 1995, 83.

92. Pres. Rb Den Bosch 30 december 1994, NA 1995, 84; Gst. 1995, 7004, 4, ni.nt. HH. 


\section{Hoofdstuk 8}

ontlenen grenscorrecties vast te stellen." Hoewel de conclusie van de president bevredigt, is er op de motivering wel wat af te dingen. Doorslaggevend zou het rechtskarakter van het betreffende besluit ${ }^{93}$ moeten zijn. Met Hennekens ben ik van mening dat de besluiten van de gemeenteraden geen algemeen verbindende voorschriften zijn. De besluiten zijn weliswaar op rechtsgevolg gericht, maar bakenen slechts de grenzen van een bepaald gebied af, en richten zich niet tot een ieder maar tot de betreffende gemeentebesturen. Voor de betrokken inwoners geldt dat zij rechtens niet in een andere positie worden gebracht. ${ }^{94}$

Deze jurisprudentie toont dat het begrip algemeen verbindend voorschrift vervaagt. Soms is dat mede te wijten aan het feit dat de in het geding zijnde bevoegdheid niet duidelijk een regelgevende dan wel bestuursbevoegdheid is. Meer nog dan tot nu toe het geval is zou de wetgever daar duidelijkheid in moeten verschaffen. Maar dat mag niet leiden tot 'toestanden' dat de wetgever een duidelijke bestuursbevoegdheid aanmerkt als een bevoegdheid om algemeen verbindende voorschriften te stellen, zonder daarbij rekening te houden met de aard van het te nemen besluit. Iets dergelijks lijkt te gebeuren met de voorgestelde wijziging van artikel 7.56 WHW: de staatssecretaris wordt geacht zijn bevoegdheid om een numerus fixus vast te stellen uit te oefenen door middel van een ministeriële regeling. De Raad van State merkt hierover op dat niet de benaming van een besluit, maar de materiële kenmerken van een besluit bepalend zijn voor het karakter ervan. ${ }^{95}$ De minister erkent dit maar houdt vast, mijns inziens ten onrechte, aan de kwalificatie algemeen verbindend voorschrift voor het fixusbe-

93. Voor de kwatificatie als algemeen verbindend woorschrift is op de eerste plats vereist dat er een wettelijke geregelde regelgevende bevoegdheid is. Wanneer de ard van de bewoegdheid echter niet duidelijk is komt het rechiskarakter van het besluit in beeld.

94. Hennekens in zijn noot in de Gemeentestem 1995, 7004, 4. Hij wil hier liever spreken van een publiekrechtelijke overeenkomst, die naar zijn aard geen algemeen verbindend voorschrift kan zijn.

95. Kamerstukken II 1994-1995, 24075, B, p.2. Tegen een ministeriêlle regeling (algemeen verbindend voorschrift) is op grond van de Awb tot 1 januari 1999 geen beroep mogelijk. Artikel 7:56 WHW wordt als volgt gewijzigd. 1. De aanhef van het eerste lid komt te luiden: 1.'Indien het aanbod van afgestudeerden van een bepaalde opleiding de behoefte daaraan op de arbeidsmarkt in aanmerkelijke mate dreigt te overtreffen of daadwerkelijk overtreft en dit naar verwaching gedurende en reeks van jaren het geval zal aijn, kan bij ministeriéle regeling worden vastgesteld'. 2. Het derde lid komt te luiden: 3 . 'Een ministeriele regeling als bedoeld in het eerste lid, wordt vastgesteld uiterlijk drie maanden na vaststelling van het hoger onderwijs-en onderzoekplan waarin die regeling is aangekondigd." 
sluit. ${ }^{96}$ Het gaat immers niet om herhaalbare gevallen en ook de rechtssubjecten zijn met naam en toenaam omschreven en zijn niet vatbaar voor uitbreiding. ${ }^{97}$

\subsubsection{Vereiste van een wettelijke grondslag}

In de omschrijving van het begrip algemeen verbindend voorschrift in de Awb is het vereiste van een wettelijke grondslag opgenomen ${ }^{98}$ In paragraaf 7.3 kwam deze eis aan de orde vanuit de bevoegdheidskant: een regelgevende bevoegdheid (de bevoegdheid om algemeen verbindende voorschriften te stellen) behoeft een grondslag in de (formele) wet. Naast de daar besproken jurisprudentie komen hier nog slechts enkele voorbeelden aan de orde. ${ }^{99}$ In een uitspraak van de Afdeling rechtspraak betreffende het Besluit landbouwbedrijven met ontwikkelingsmogelijkheden van het Ontwikkelings- en Saneringsfonds voor de Landbouw oordeelt de Afdeling dat de regels vervat in het Besluit 'niet een algemeen verbindend voorschrift (vormen), daar zij niet - hetzij rechtstreeks, hetzij indirect - steunen op een wet in formele zin', maar slechts 'een bekendmaking van het beleid" zijn dat het fonds voert, dat wil zeggen beleidsregels. ${ }^{100}$ Zie eveneens een uitspraak van de Afdeling over de Regeling geldelijke steun huisvesting gehandicapten 1989: "(..) nu elke grondslag van de regeling in een wet in formele zin ontbreekt, dient deze regeling te worden geduid als een sa-

96. Kamerstukken II 1994-1995, 24075, B, p.2-3.

97. Om de gerezen problemen rond de verschillende rechterlijke uitspraken het hoofd te bieden is gekozen om de numerus fixus geneeskunde voor de jaren 1994-1996 wettelijk vast te leggen. De (voorgestelde) bepaling luidt als volgt: '1. Het aantal personen dat voor de studiejaren 1994-1995 en 1995-1996 voor de eerste maal kan worden ingeschreven voor de propedeutische fase van de opleiding geneeskunde aan al de universiteiten waaraan deze is verbonden, wordt vastgesteld op 1686.2. Het aantal personen bedoeld in het eerste lid wordt als volgt over de universiteiten verdeeld: Rijksuniversiteit te Groningen 229; Erasmusuniversiteit te Rotterdam 229; Universiteit van Amsterdam 229; Vrije Universiteit te Amsterdam 229; Rijksuniversiteit te Leiden 180; Katholieke Universiteit te Nijmegen 180; Universiteit te Utrecht 210; Rijksuniversiteit Limburg te Maastricht 200. 3. De verdeling van personen over de in het tweede lid bedoelde universiteiten geschiedt met toepassing van artikel 7.56 , tweede lid, van de Wet op het hoger onderwijs en wetenschappelijk onderzoek. 4. Het Besluit beperking inschrijving geneeskunde 19941995 en 1995-1996 (besluit van de Staatssecretaris van Onderwijs en Wetenschappen van 17 april 1994, Uitleg OenW-Regelingen nr.12, 27 april 1994) wordt ingetrokken.'

98. Omgekeerd hoeft niet iedere bepaling in een wet in formele zin of lagere regelgeving de status van algemeen verbindend voorschrift te hebben. Van der Vlies 1991, p.116-117.

99. Zie ook Van Male in Akkermans/Koekkoek 1992, p. 799 voor verwijzingen naar jurisprudentie.

100. ARRS 2 november 1977, AB 1978, 55, m.nt. In 't Veld. 


\section{Hoofdstuk 8}

menstel van beleidsregels die verweerders in bijzondere gevallen terzijde kunnen stellen." ior

Het vereiste van een wettelijke grondslag voor de aanmerking als algemeen verbindend voorschrift werd ook genoemid door de Hoge Raad in het Leidraadarrest " daar ging het om regels die "niet kunnen gelden als algemeen verbindende voorschriften omdat zij niet krachtens enige wetgevende bevoegdheid zijn gegeven. "103

Een bekende uitzondering is de uitspraak van de Afdeling rechtspraak inzake Koninklijk tehuis voor oud-militairen 'Bronbeek'. ${ }^{104}$ De Afdeling merkte het Reglement voor het Koninklijk tehuis voor oud-militairen 'Bronbeek', een 'klein $\mathrm{KB}$ ', aan als algemeen verbindende voorschriften, terwijl er geen wettelijke basis voor aan te wijzen was.

Nu echter beleidsregels een duidelijker plaats in het rechtssysteem krijgen wordt het vereiste van een (specifieke) wettelijke grondslag voor de status van algemeen verbindend voorschrift in de jurisprudentie strikter gehandhaafd.

\subsubsection{Beleidsregel-algemeen verbindend voorschrift; overeenkomsten}

Wanneer de wettelijke regeling van beleidsregels in werking treedt, gelden voor de totstandkoming van beleidsregels en algemeen verbindende voorschriften nagenoeg dezelfde bepalingen. Voor beleidsregels zijn alle bepalingen uit hoofdstuk 3 Awb van toepassing (zorgvuldigheid, belangenafweging, advisering, voorbereidingsprocedure, bekendmaking en mededeling, motivering). Voor algemeen verbindende voorschriften gelden (op grond van artikel 3:1 lid $1 \mathrm{Awb}$ ) de in de Awb neergelegde eisen van zorgvuldigheid, belangenafweging, advisering en voorbereidingsprocedure. Bekendmaking en mededeling zijn geregeld in de Bekendmakingswet.

101. ARRS 10 november 1992, AB 1993, 153 m.nt. NV. Zie ook ARRS 8 april 1978, AB 1979, 222: "De in het Beëindigingsvergoedingsbesluit neergelegde algemeen geldende regelen vormen niet een algemeen verbindend voorschrift, daar zij niet - hetzij rechtstreeks, hetzij indirect - steunen op een wet in formele zin."

102. HR 28 maart 1990, NJ 1991, 118.

103. Vergelijk de overwegingen in HR 31 mei 1985, NJ 1985, 648, AB 1985, 480 (UARarrest). Het Uniform Aanbestedingsreglement is aan te merken als 'een naar buiten werkende, voor de Rijksoverheid en de bij haar aanbestedingen betrokkenen bindende, regeling, uitgegaan van het openbaar gezag, dat de bevoegdheid dlaartoe ontleent aan de
wet."

104. ARRS 26 januari 1984, AB 1984, 384; AA 1985, p.633-641 m.nt. Hirsch Ballin. 
Ook zijn in de Awb de beroepsmogelijkheden tegen beide soorten regels hetzelfde geregeld: (rechtstreeks) beroep is op grond van artikel 8:2 niet mogelijk. ${ }^{105}$

Een andere overeenkomst is dat ook voor beleidsregels (in de zin van de Awb) het vereiste van algemeenheid geldt. De Raad van State meende in zijn advies dat in het voorgestelde artikel 1:3 lid 4 Awb het woord 'algemene' geschrapt kon worden. De regering deelde deze opvatting niet. Volgens haar "heeft een algemeen verbindend voorschrift dezelfde mate van algemeenheid als een beleidsregel. "106 In de definitie "geeft het begrip 'regel' aan dat het gaat om een besluit dat naar haar aard voor herhaalde toepassing vatbaar is. Daarnaast volgt uit het woord 'algemene' dat het een besluit is dat op een open groep van gevallen betrekking heeft. "107

Maar ook ten aanzien van beleidsregels is het 'een ieder' vereiste vervangen door 'betrokkenen'. Zo omschreef de Hoge Raad beleidsregels in het Leidraadarrest $^{108}$ als regels die zich lenen 'jegens betrokkenen als rechtsregels te worden toegepast'. Zelfs slechts een viertal betrokkenen kan daarbij voldoende zijn. De Hoge Raad oordeelde de Financieringsregeling van de minister van Welzijn, Volksgezondheid en Cultuur recht in de zin van artikel 99 Wet RO. ${ }^{109}$ "De Financieringsregeling bevat immers, (..) door de minister van WVC vastgestelde en gelet op de aard van de regeling en degenen tot wie zij zich richt (de vier grote gemeenten) behoorlijk - immers via een brochure - bekendgemaakte regels, omtrent de uitoefening van het beleid, die weliswaar niet kunnen gelden als algemeen verbindende voorschriften omdat zij niet krachtens enige wetgevende bevoegdheid zijn gegeven, maar die de minister wel op grond van in zijn verhouding tot de vier grote gemeenten geldende beginselen van behoorlijk bestuur binden en die zich naar inhoud en strekking ertoe lenen jegens de betrokkenen als rechtsregels te worden toegepast." Van der Burg vraagt zich in zijn noot af of de Hoge Raad hier breekt met het algemeenheidsvereiste voor de aanmerking

105. Artikel 8:2 verwalt per 1 januari 1999 , door aanneming van een amendement Jurgens/Biesheuvel. Kamerstukken II 1992-1993, 22495, nr 19. Zie over de nadelen van beroep tegen algemeen verbindende voorschriften : A van Veen, Het algemeen verbindend voorschrift in de Algemene wet bestuursrecht; een zorgenkind, in AA 1994, p. 637-645.

106. Kamerstukken II 1993-1994, 23700, A, p.48.

107. Kamerstukken II 1993-1994, 23700, A, p.48-49, nr 3 MvT, p. 108: een beleidsregel richt zich tot een open in abstracto omschreven groep van personen. ${ }^{~} \mathrm{O}$ p deze punten werschilt de bevoegdheid niet van een algemeen verbindend woorschrift inzake de uitoefening van een bestuursbevoegdheid."

108. Zie HR 28 maart 1990, NJ 1991, 118, AB 1990, 306; paragraaf 8.2.4.

109. HR 5 februari 1993, AB 1993, $239 \mathrm{~m}$ nt. FHudB. Zie over deze uitspraak ook S. Prontvan Bommel, Recht van beroep wan decentrale overheden na repressief toezicht, Gst. 6974 (1993), p.505-510. 


\section{Hoofdsiuk 8}

als recht in de zin van artikel 99 Wet RO. Als andere mogelijkheid ziet hij dat de Hoge Raad een regeling gericht tot vier rechtssubjecten kennelijk nog een algemene regeling vindt. Hij vraagt zich - terecht - af waar de grens ligt. Volgens de criteria aangelegd door de Commissie Wetgevingsvraagstukken zou hier niet voldaan zijn aan het algemeenheidsvereiste nu het voorschrift zich richt tot met name genoemde rechtssubjecten. ${ }^{110}$

Een laatste hier te noemen overeenkomst is de toetsing van beide soorten regels aan algemene beginselen van behoorlijk bestuur of behoorlijke regelgeving. "II

\subsubsection{Beleidsregel-algemeen verbindend voorschrift; verschillen}

Naast overeenkomsten bestaan er tussen beleidsregels en algemeen verbindende voorschriften nog steeds belangrijke verschillen. Dat wil niet zeggen dat deze verschillen in de literatuur steeds in het oog worden gehouden. Enkele 'gevaarlijke" citaten zijn in dit verband: "Beleidsregels en algemeen verbindende voorschriften vertonen in de rechtspraktijk grote gelijkenis: het gaat om regels die zijn geschreven om te worden opgevolgd." ${ }^{112}$ "De basisovereenkomst, op grond waarvan de vergelijking principieel kan plaatsvinden, is dat beide te handhaven regels zijn. ${ }^{113}$ Handhaving van algemeen verbindende voorschriften kan echter op een heel andere basis plaatsvinden dan de handhaving van beleidsregels. En: "De Hoge Raad heeft bepaald dat beleidsregels kunnen vallen onder het begrip 'recht' in de zin van artikel $99 \mathrm{RO}$, mits die regels de grenzen van de bestuursbevoegdheid niet overschrijden, ze behoorlijk zijn bekendgemaakt en ze zich naar inhoud en strekking ertoe lenen om als algemene rechtsregel te worden toegepast. Hiermee heeft de Hoge Raad mijns inziens het begrip 'beleidsregel' een beperkte inhoud willen geven: het moet gaan om binnenwettelijke regels, die

110. Orde in de regelgeving 1985, p. 15 .

111. Zie voor algemeen verbindende voorschriften de noot van FHvdB bij HR 25 september 1985. AB 1986, 64 met verwijzing naar andere uitspraken. Zie ook A.F.M. Brenninkmejer en I.C. van der Vlies, Het algemene deel van het bestuursrecht, in De staat van het recht, Bijlage bij NJB 23 september 1994, p.52-53 over toetsing van algemeen verbindende voorschriften aan de algemene beginselèn wan behoorlijk bestuur en de dar angehaalde jurisprudentie. Zie voor uitspraken warin een beleidsregel word getoetst aan een rechtsbeginsel CR 6 B 6 februari 1992, TAR 1992,80 (de beleidsregels zijn niet onredelijk) en Vz ARRS 23 augustus 1993, AB 1994, 165 (gemeentelijk beleid is niet onredelijk), aungehaald bij Brenninkmeijer/Van der Vlies 1994, p.52. Zie ook Bröring $1993 \mathrm{a}$, p.394 die constateert dat steeds vaker direct aan de beleidsregel wordt getoetst en niet meer via de omweg van de algemene beginselen van behoorlijk bestuur.

112. Regelgeving centrale overheid, Kamerstukken II 1986-1987, 20038, nr 2, p.2.

113. Van der Vllies 1991, p.133. 
behoorlijk zijn bekend gemaakt en in feite op een met algemeen verbindende voorschriften vergelijkbare wijze rechten en verplichtingen van burgers vastleggen."' (curs. JD) ${ }^{114}$ Zoals hieronder zal blijken kunnen beleidsregels echter niet in dezelfde mate verplichtingen aan de burgers opleggen zoals algemeen verbindende voorschriften.

\subsubsection{Een specifieke wettelijke grondslag}

Eén belangrijk (formeel) verschil tussen algemeen verbindende voorschriften en beleidsregels tot nu toe was het ontbreken van een wettelijke grondslag voor het stellen van beleidsregels. Voor algemeen verbindende voorschriften is die (specifieke) wettelijke grondslag een vereiste. Verdedigd kan worden dat de voorgestelde regeling in de Awb die wettelijke grondslag wel biedt. Dat geldt a fortiori voor artikel 4.4.1 lid 2 (het vereiste van een specifieke wettelijke grondslag, in andere dan de in lid 1 genoemde gevallen).

In zijn advies merkt de Raad van State op dat hierdoor een verdere relativering van het onderscheid tussen algemeen verbindende voorschriften en beleidsregels plaatsvindt. ${ }^{115} \mathrm{De}$ regering erkent dit en concludeert 'dat het ontbreken van een wettelijke grondslag niet meer als een beslissend verschil tussen beleidsregels en algemeen verbindende voorschriften kan worden beschouwd." 116 Volgens de regering zijn de belangrijkste kenmerken van beleidsregels dat het regels zijn voor de uitoefening van een bestaande bestuursbevoegdheid waaraan de rechtsgevolgen zijn verbonden die in titel 4.4 zijn omschreven. En beleidsregels hebben een minder sterke bindende werking dan algemeen verbindende voorschriften. ${ }^{117}$ Een bestuursorgaan kan alleen algemeen verbindende voorschriften stellen wanneer daarvoor een specifieke grondslag in de wet bestaat. ${ }^{118}$

Ik deel deze laatste opvatting van de regering. Maar ik vraag me af of zij niet te ongenuanceerd concludeert dat het ontbreken van een wettelijke grondslag geen beslissend verschil meer is voor de kwalificatie als algemeen verbindend voorschrift of beleidsregel. De wettelijke grondslag voor beleidsregels is (afgezien van de uitzonderingssituatie van artikel 4.4.1 lid 2) een heel algemene. Voor de status van algemeen verbindend voorschrift is noodzakelijk dat er een specifieke

114. Bolt 1993, p.147.

115. Kamerstukken II 1993-1994, 23700, A, Nader rapport, p.46-47.

116. Kamerstukken II 1993-1994, 23700, A, Nader rapport, p.48; nir 3 MvT, p.108.

117. Kamerstukken II 1993-1994, 23700, A, Nader rapport, p.48.

118. Kamerstukken II 1993-1994, 23700, nr 3 MvT, p.101. 


\section{Hoofdstuk 8}

wettelijke basis is aan te wijzen. ${ }^{119}$ Dat betekent dat Nicolai's standpunt dat beleidsregels aan te merken zijn als algemeen verbindende voorschriften in de zin van de $A w b$, nu ze in artikel 4.4 .1 een wettelijke grondslag krijgen, ${ }^{120}$ niet wordt gedeeld.

Van belang is wel de vraag hoe specifiek een wettelijke grondslag moet zijn. Een enkele basis in een begrotingswet of de Comptabiliteitswet ${ }^{12 t}$ is voor de kwalificatie als algemeen verbindend voorschrift onvoldoende. Het uitgangspunt zou moeten zijn dat, hoe groter de inbreuk op de persoonlijke levenssfeer van de burger is, hoe specifieker de wettelijke grondslag moet zijn. In het volgende hoofdstuk zullen daarvan voorbeelden besproken worden. Daar zal blijken dat rechters een duidelijke wettelijke basis eisen voor een algemeen verbindend voorschrift dat inbreuk maakt op de persoonlijke levenssfeer van de burger.

\subsubsection{Inherente afwijkingsbevoegdheid}

Een tweede verschil tussen beleidsregels en algemeen verbindende voorschriften is de voor beleidsregels geldende 'inherente afwijkingsbevoegdheid' ${ }^{122}$ Een beleidsregel bindt de overheid voor zover in het betreffende geval geen bijzondere omstandigheden zijn aan te wijzen die nopen om van de vastgestelde beleidsregel (ten voordele van de burger) af te wijken. ${ }^{123}$ In de Awb is dit vereiste in artikel 4.4.5 neergelegd en aangescherpt: een bestuursorgaan dient van een vastgestelde beleidsregel af te wijken wanneer het handelen overeenkomstig de beleidsregel "voor een of meer belanghebbenden gevolgen zou hebben die wegens bijzondere omstandigheden onevenredig zijn in verhouding tot de met de beleidsregel te dienen doelen.' Ik zou mij kunnen voorstellen dat deze formulering ook als hardheidsclausule wordt gebruikt bij een regeling die algemeen verbindende voorschriften bevat. Voor algemeen verbindende voorschriften geldt weliswaar

119. Schreuder-Vlasblom 1992, p.25. Zie ook Bakker e.a. 1993, p.55: "het vereiste van een wettelijke grondslag is niet het kenmerkende onderscheid ten opzichte van beleidsregels, mar is darvoor de voorwaarde." Zij verwijzen naar ARRS 2 november 1977 , AB 1978, 55, m.nt. In "t Veld, en ARRS 25 mei 1992, SEW 1993, p.257, m.nt. J.M. Bon. nes.

120. Nicolai 1992, p. 84 .

121. Voorbeelden ontleend aan Van der Vlies 1986, p.74; Van der Vlies 1991, p.131.

122. Van Kreveld 1985, p.293-294. De afwijkingsbevoegdheid van beleidsregels is angemerkt als een principieel verschil, zie bijwoorbeeld Michiels 1993, p.311. Van de term 'inherente afwijkingsbevoegdheid' is betoogd dat zij eigenlijk niet juist is: vallen gevallen wegens bijzondere omstandigheden niet onder de beleidsregel dan is de beleidsregel daarvoor ook niet geschreven. Bröring 1993a, p.399. Zie ook Heldeweg 1995, p.92.

123. Van Kreveld 1983 , p. 195. 
(behoudens in sommige gevallen een hardheidsclausule) geen afwijkingsbevoegdheid maar in de jurisprudentie wordt steeds vaker aangenomen dat afwijking in een bijzonder geval geoorloofd of zelfs noodzakelijk is. ${ }^{124}$

Ook in dit opzicht raken beleidsregels en algemeen verbindende voorschriften dus meer verwant.

\subsubsection{Burgers bindende bepalingen}

Een derde belangrijk (materieel) verschil tussen algemeen verbindende voorschriften en beleidsregels is de aard van de bevoegdheden die met beide soorten regels kunnen worden uitgeoefend. Wat wel en niet door middel van beleidsregels geregeld mag worden, hangt af van de opvatting over het legaliteitsbeginsel: voor welke inbreuken op het doen en laten van de burger is een wettelijke grondslag noodzakelijk? Volgens de klassieke invulling van het legaliteitsbeginsel is er voor inbreuken op de vrijheid en eigendom van burgers (het opleggen van ge- en verboden) een wettelijke grondslag nodig. ${ }^{125}$ Dat betekent dat op basis van beleidsregels deze inbreuken niet gepleegd mogen worden. Alleen bij algemeen verbindende voorschriften kan benadelend gehandeld worden ten opzichte van burgers. ${ }^{126}$ Deze voorschriften kunnen door straffen gehandhaafd worden (mits voldaan is aan artikel 89 lid 2 en lid $4 \mathrm{Gw}$ ). ${ }^{127}$ De MvT bij het wetsvoorstel Derde tranche Awb hanteert op dit punt verhullend taalgebruik waar ze stelt dat algemeen verbindende voorschriften en beleidsregels op dezelfde onderwerpen betrekking kunnen hebben, maar algemeen verbindende voorschriften "behoeven zich daartoe niet te beperken: zij kunnen zich ook rechtstreeks tot de burger richten of bepalen over welke bevoegdheden een bestuursorgaan beschikt." 128

Ook in de jurisprudentie zijn voorbeelden te vinden van bevoegdheden die niet door middel van beleidsregels mogen worden uitgeoefend. In een zaak die speel-

124. Zie Sectie staats- en bestursrecht KUB 1992, p.256 die als voorbeeld geven Vz ARRS 24 februari 1987, tB/S 1987, $31 \mathrm{~m}$.nt. BdW. Zij verwijzen ook naar M. Schreuder-Vlasblom, De harde wet en haar zachte kant; enige opmerkingen over hardheidsclausules, in Bestuurswetenschappen 1987, p.100-117. Zij concluderen dat hierdoor het verschil in binding tussen algemeen verbindende voorschriften en beleidsregels meer een gradueel dan een principieel werschil is geworden.

125. Zie paragraaf 9.2 .

126. Bröring 1993a, p.393. Van Wijk/Konijnenbelt/Van Male 1994, p.284.

127. Van der Vlies 1991, p. 133; Van der Meulen e.a. 1991, p. 137; Bakker e.a. 1993, p.5455.

128. Kamerstukken II 1993-1994, 23700, nr 3 MvT, p.102-103. 


\section{Hoofdstuk 8}

de voor de Afdeling rechtspraak ${ }^{129}$ was in geschil de intrekking van de toekenning van rentesubsidie, én terugvordering van de reeds betaalde subsidie, vermeerderd met een boete van $10 \%$. De boete was geregeld in artikel 29 Besluit Landbouwbedrijven met ontwikkelingsmogelijkheden, een verzameling beleidsregels. De Afdeling kwalificeerde de boete als 'louter een sanctie wegens het niet naleven van de aan de rentesubsidie verbonden voorwaarden' en vernietigde de beslissing van de Minister van Landbouw, Natuurbeheer en Visserij betreffende het opleggen van die boete.

In deze uitspraak verwijst de Afdeling naar een eerdere uitspraak ${ }^{130}$ waarin zij overwoog "dat een verzameling beleidsregels die niet is vastgesteld krachtens enige in de wet neergelegde bevoegdheid, geen voldoende grondslag biedt voor het aan de betrokkene in rekening brengen van rente en kosten over een ten onrechte genoten subsidie. Dit geldt a fortiori voor het opleggen van een financièle sanctie. Nu het besluit (Besluit Investeringspremie Zeescheepvaart 1983, JD) eveneens een verzameling beleidsregels is die niet is vastgesteld krachtens enige wettelijk vastgelegde bevoegdheid, en gesteld noch gebleken is dat de stichting uit enigerlei andere hoofde bevoegd is tot het opleggen van sancties, ontbreekt een voldoende grondslag voor de onderhavige boete."

\subsubsection{Het beperken van grondrechten}

Een tweede bevoegdheid waarin algemeen verbindende voorschriften en beleidsregels wezenlijk van elkaar verschillen is thet beperken van grondrechten. Grondrechten kunnen alleen beperkt worden door middel van algemeen verbindende voorschriften. ${ }^{\mid 31}$ Voor de grondwettelijke grondrechten is daar geen discussie over. In sommige gevallen lijken verdragsrechtelijke grondrechten echter wel door middel van beleidsregels beperkt te mogen worden. ${ }^{132}$ Hèt bekende voor-

129. ARRS 4 november 1993, AB 1994, 182, m.nt. NV; AA 1994, p.231-237 m.nt. L.J.A. Damen, De agrariër die te snel verkocht.

130. ARRS 30 juni 1992, AB 1993, 447, m.nt. AFMB.

131. Bakker e.th 1993, p.55.

132. Van Kreveld 1985, p.48; Van der Vlies 1991, p.134; Van der Meulen e.a. 1991, p.137; Van Male in Akkermans/Koekkoek 1992, p.808. Anders: Bakker e.a. 1993, p.55 die stellen "dat beperkingen terug te voeren moeten zijn tot een, voldoende specifieke en met waarborgen omklede, wettelijke bevoegdheidsgrondslag. Een beleidsregel sec wolstaat daartoe niet. Bele idsregels kunnen slechts een rol spelen ter invulling van zo'n wettelijke bevoegdheidsgrondslag. " 
beeld is de uitspraak van de Afdeling rechtspraak over de Paspoortinstructie. ${ }^{133}$ Een ander voorbeeld uit de Nederlandse jurisprudentie vinden we in een uitspraak van de Centrale Raad van Beroep. ${ }^{134}$ In geding was een woonverplichting op basis van het Ambtenarenreglement woor de gemeentepolitie 1958. De gevraagde ontheffing was afgewezen omdat de aanvrager niet voldeed aan bepaalde voorwaarden van het in juli 1988 vastgestelde beleid. De Centrale Raad oordeelde dat de ontheffing kon worden geweigerd zonder in strijd te komen met artikel 2 lid 1 van het vierde protocol bij het EVRM, en artikel 12 IVBPR.

Van belang is dat de grondrechtbeporkingen voldoen aan (overige) eisen die de jurisprudentie stelt. Voor het EVRM geldt (onder meer) dat de grondrechtbeperkende regels moeten voldoen aan eisen van voorzienbaarheid en kenbaarheid. ${ }^{135}$

\subsubsection{Het toedelen van bevoegdheden}

Een derde bevoegdheid die alleen bij algemeen verbindend voorschrift kan worden uitgeoefend is het toedelen (attribueren of delegeren) van regelgevende en bestuursbevoegdheden. ${ }^{135}$ Dit werd reeds vastgesteld in een uitspraak van de Afdeling rechtspraak uit 1978 waarin de Afdeling bepaalde dat het bestuur van de Stichting Fonds voor de Letteren geen administratief orgaan in de zin van artikel 1 lid 1 Wet Arob is. "Ingevolge art. 1, eerste lid, van voornoemde wet moet onder administratief orgaan worden verstaan iedere persoon en ieder college met enig openbaar gezag binnen Nederland bekleed. Naar het oordeel van de Afd. kan verweerder niet worden aangemerkt als een administratief orgaan in evenbedoelde zin, aangezien geen algemeen verbindend voorschrift is aan te wijzen, waaraan hij hetzij rechtstreeks hetzij indirect enig openbaar gezag kan ontlenen. ${ }^{1137}$ Mandaat kan wel bij beleidsregelgeving verleend worden.

133. ARRS 10 juni 1983, AB 1983 , 306, m.nt. P.J. Boon (Paspoortinstructie) De Paspoortinstructie Nederland 1952, die niet gebaseerd was op een formele wet, bood voldoende grondslag om artikel 12 lid 3 IVBPR te beperken.

134. CRvB 25 juli 1991, AB 1991, $656 \mathrm{~m}$.nt. HH. De Raad verwijst in zijn uitspraak naar CRvB 26 april 1990, AB 1990, 448, m.nt. $\mathrm{HH}$.

135. Zie het Sunday Times arrest, EHRM 26 april 1979. NJ 1980, 146, Vol. 30 paragrafen 47 en 49 . Zie ook paragraaf 9.2 .1 .

136. Bakker e.a. 1993, p.55. Kamerstukken II 1993-1994, 23700, nr 3 MvT, p. 102-104.

137. ARRS 7 aprill 1978, AB 1978,474, m.nt. J.A. Borman. Zie ook Van Male in diens noot bij ARRS 26 augustus 1993, AB 1994, 199: "Attributie en delegatie van bestuursbevoegdheid kunnen slechts plaatswinden door middel van een wettelijk voorschrift, niet door middel van beleidsregels." (Verwijzend naar ARRS 17 mei 1978, AB 1978, 429.) 


\section{Hoofdstuk 8}

\subsubsection{Implementatie van EG-recht}

Zowel algemeen verbindende voorschriften als, onder omstandigheden, beleidsregels kunnen gebruikt worden bij de implementatie wan EG-recht. Er kan een onderscheid gemaakt worden tussen implementatie van EG-verordeningen en EGrichtlijnen. Voor verordeningen betoogt Bonnes dat het van de tekst, het doel en de strekking van de verordening afhangt of een nationale uitvoeringsregeling algemeen verbindend moet zijn. Als eis stelt zij, dat de implementatie-regels bekend gemaakt moeten zijn en een zekere bestendigheid moeten hebben. Dat geldt te meer waar verordeningen meer ruimte laten en invulling voor particulieren belangrijker is. Implementatie door middel van allgemeen verbindende voorschriften zal dan eerder de aangewezen weg zijn. ${ }^{138}$

In een kwestie rond de implementatie van een EG-verordening oordeelde de Afdeling rechtspraak ${ }^{139}$ dat implementatie bij wege van beleidsregels in casu in strijd was met de rechtszekerheid. De Afdeling stelde dat "de Bestuursrichtlijn een verzameling beleidsregels is die op ieder ogenblik door het bestuur van de Stichting naar eigen inzicht kan worden gewijzigd, zonder dat daartoe enige met waarborgen omklede procedure behoeft te worden gevolgd. Evenmin is enig het bestuur bindend voorschrift gegeven over de wijze waarop publikatie van een Bestuursrichtlijn moet plaatsvinden. " Hoewel in deze zaak volgens Bonnes inderdaad niet aan de eisen van rechtszekerheid is voldaan wil dat niet zeggen dat beleidsregels in geen enkel geval als instrument kunnen worden gebruikt. Ze kunnen bijvoorbeeld wel ingezet worden wanneer een verordening uitputtend is bedoeld. Dan mogen er geen algemeen verbindende voorschriften gebruikt worden bij de implementatie. ${ }^{140}$

Worden bij implementatie van EG-richtlijnen strengere eisen gesteld? Het Hof van Justitie EG heeft uitgemaakt dat de lidstaten bij implementatie steeds 'de meest passende worm en middelen (dienen) te kiezen teneinde het nuttig effect der richtlijnen te verzekeren'. ${ }^{14}$ Bovendien moeten ook hier de implementatieregels voldoen aan vereisten van kenbaarheid en rechtszekerheid.

Om de rechtszekerheid voor het gehele grondgebied te waarborgen zal vaak implementatie door algemeen verbindende voorschriften dienen te geschie-

138. Bonnes 1994, p.99-100.

139. ARRS 25 mei 1992, SEW 1993, p.257, m.nt. J.M. Bonnes; AB 1992, 610, m.nt. AFMB.

140. Bionnes 1994, p. 104-105.

141. HvJ EG 8 april 1976, 48/75, Royer, Jur. 1976, 497, r.o.75. Aangehaald bij De Moorvan Vugt e.a. 1992, p.602. Zie ook K.J.M. Mortelmans en T.P.J.N. van Rijn, Europese regelgeving en Nederlandse implementatie, in NTB 1992, p.74-94. 
den. ${ }^{142}$ Wanneer bestaande algemeen verbindende voorschriften in strijd zijn met de richtlijn is implementatie door beleidsregels niet toegestaan. ${ }^{143}$ In sommige gevallen kunnen beleidsregels echter, in het kader van een wettelijke regeling, wel voldoen ter implementatie. ${ }^{144}$ of de rechtszekerheid bij implementatie van richtlijnen met beleidsregels voldoende wordt gediend wordt betwijfeld door Van der Burg: de inherente afwijkingsbevoegdheid bij beleidsregels kan een derde-belanghebbende in onzekerheid brengen over zijn positie. ${ }^{145}$

De conclusie kan zijn dat zowel voor algemeen verbindende voorschriften als beleidsregels bij implementatie geldt dat ze moeten voldoen aan eisen van kenbaarheid en rechtszekerheid. ${ }^{146}$ Wanneer de wettelijke regeling van beleidsregels in werking treedt lijken die beleidsregels (in de zin van de Awb) meer aan die eisen te gaan voldoen. $\mathrm{Zij}$ moeten immers op grond van de $\mathrm{Awb}$ behoorlijk bekend gemaakt worden en ook de procedure van totstandkoming is genormeerd. Dat neemt niet weg dat beleidsregels vrij gemakkelijk gewijzigd kunnen worden en zodoende op gespannen voet met het rechtszekerheidsbeginsel kunnen komen te staan. Hetzelfde geldt echter ook voor (sommige categorieën) algemeen verbindende voorschriften (bijvoorbeeld ministeriële regelingen). ${ }^{147}$ Op grond van de jurisprudentie is aannemelijk dat ook voor beleidsregels geldt dat beleidswijziging geen (aperte) strijd met het rechtszekerheidsbeginsel mag opleveren. Zo nodig moeten in de regeling bepalingen van overgangsrecht opgenomen worden.

\subsubsection{Conversie}

Bij conversie wordt een onverbindend algemeen verbindend voorschrift omgezet in een verbindende beleidsregel. De vraag rijst of dat in alle gevallen de meest wenselijke oplossing is. Per geval zal bekeken moeten worden wat de reden is om een algemeen verbindend voorschrift onverbindend te verklaren. Verheij maakt een onderscheid tussen onverbindendheid op materiële en formele gronden. ${ }^{148}$ Conversie is in zijn ogen slechts mogelijk "voor zover het door onverbindendheid getroffen voorschrift iets beoogde dat op zichzelf ook met een be-

142. De Moor-van Vugt e.a. 1992 , p.602.

143. HvJ EG 6 mei 1980, 102/79, Commissie v. België, Jur. 1980, 1473. Aangehaald bij De Moor-van Vugt e.a. 1992 , p.602.

144. Bonnes in haar noot in SEW 1993, p.262. Zie ook ARRS 2 december 1991, AB 1992, 475, m.nt. I. Sewandono.

145. Noot bij HVJ EG 30 mei 1991, AB 1992, 453.

146. De Moor-yan Vugt e.a. 1992, p.602.

147. Aangehaald bij Brenninkmeijer/Van der Vlies 1994, p.53: ARRS 9 juli 1992, AB 1994, 61 , overgangsrecht en verbod wan willekeur.

148. Verheij 1989, p.41. 


\section{Hoofdstuk 8}

leidsregel bereikt had kamnen worden." ${ }^{49}$ Dat betekent dat wanneer een algemeen verbindend voorschrift onverbindend is wegens strijd met een hogere regel conversie niet zal kunnen plaatsvinden omdat dan ook de beleidsregel in strijd zal zijn met de hogere regel. Twijfelachtig is ook of een regeling die niet behoorlijk bekend is gemaakt als algemeen verbindend voorschrift geconverteerd kan worden in een beleidsregel. ${ }^{150}$ Eveneens is niet steeds duidelijk of conversie mogelijk is wanneer aan een algemeen verbindend voorschrift een bevoegdheidsgebrek kleeft. Verheij betoogt dat in een dergelijk geval niet te snel de mogelijkheid van conversie aangenomen moet worden. Wanneer de formele wet regeling bij algemene maatregel van bestuur eist, terwijl de algemene maatregel van bestuur de hele regeling van het onderwerp aan de minister overdraagt is sprake van onverbindende algemeen verbindende voorschriften. Door deze voorschriften vervolgens te accepteren als beleidsregels worden de waarborgen rond de totstandkoming van de algemene maatregel van bestuur omzeild. ${ }^{151}$ Milder toont zich Scheltema die uiteen zet dat de minister op grond van zijn bestuursbevoegdheid beleidsregels zou mogen stellen. Het is in zijn ogen niet acceptabel dat de minister aan geen enkele regeling gebonden zou zijn wanneer de (beoogde) algemeen verbindende voorschriften onverbindend zouden worden verklaard. ${ }^{152}$ Wanneer een specifieke regelgevende bevoegdheid ontbreekt dan is het mogelijk dat, onder voorwaarden, de regeling wordt aangemerkt als beleidsregeling. Daarvan zijn verschillende voorbeelden uit de jurisprudentie te geven. Voorwaarde daarbij is dat de inhoud van de regeling voldoet aan (de klassieke invulling van) het legaliteitsbeginsel: wordt door middel van de gestelde regeling inbreuk gemaakt op de vrijheid en rechten van burgers dan kan de conversie niet plaatsvinden. ${ }^{153}$ Een voorbeeld uit de jurisprudentie waarin door B en W gegeven voorschriften wel tot beleidsregels werden geconverteerd biedt de Afdeling rechtspraak. ${ }^{154}$ De Afdeling overweegt dat op grond van artikel 4 Woonruimtewet 1947 slechts de gemeenteraad tot regelgeving bevoegd is en dat delegatie aan $\mathrm{B}$ en $\mathrm{W}$ niet

149. Verheij 1989, p.41.

150. Verlueij 1989, p.42. Zie VZ CBB 16 november 1990, AB 1991, 300, m.nt. Goorden (Taxiverordening Zeeland). Wegens een gebrek in de afkondiging van een provinciale verordening zijn de algemeen verbindende voorschriften onverbindend. Er vindt conversie platats in rechtsgeldige beleidsregels. De vecordening had gepubliceerd moeten worden in een provinciaal blad, is echter alleen bekendgemaakt in twee provinciale dagbladen. Nu dit laatste is gebeurd, lijken de beleidsregels behoorlijk bekend gemaakt en kan ingestemd worden met de aanmerking als beleidsregels.

151. Verheij 1989, p.41 e.v.

152. Scheltema 1988, p.465.

153. Verhei $1989, p .41$.

154. ARRS 24 februari 1984, AB 1984, 284. 
mogelijk is. De Afdeling merkt de door B en W krachtens de raadsverordening vastgestelde regels aan als richtlijnen/beleidsregels. ${ }^{155}$

Eveneens vond conversie plaats in een uitspraak van de Centrale Raad van Beroep over 'Richtlijnen bezoldigingsbeleid'. ${ }^{156}$ De Raad merkt deze Richtlijnen aan als beleidsregels en niet als algemeen verbindende voorschriften nu een regelgevende bevoegdheid ontbreekt. Vervolgens sneuvelt het bestreden besluit echter nu verweerder niet heeft getoetst of sprake was van bijzondere omstandigheden waardoor afwijking van de Richtlijnen geboden was. De annotatoren merken op dat in hun ogen terecht onverbindendverklaring van de Richtlijnen achterwege blijft. ${ }^{157}$

Een voorbeeld waarbij, volgens annotator Hennekens onterecht, conversie werd toegepast is een uitspraak van de Afdeling rechtspraak over de Regeling geldelijke steun huisvesting gehandicapten $1989 .{ }^{158}$ De Regeling (die werkt tussen Rijk en gemeente) heeft geen grondslag in een formele wet terwijl deze volgens de Grondwet vereist zou zijn (artikel 132 lid 6 ('De wet bepaalt welke belastingen door de besturen van provincies en gemeente kunnen worden geheven en regelt hun financiele verhouding tot het Rijk.')). Hier was onverbindendheid van de regeling op zijn plaats geweest. ${ }^{159}$ Dit lijkt mij een terecht standpunt. Zeker daar waar de Grondwet een wettelijke basis eist dient daaraan te worden voldaan. Het grondwettelijke delegatiesysteem wordt omzeild indien regeling niet plaats vindt door middel van (krachtens delegatie tot stand gekomen) algemeen verbindende voorschriften. Dat wil niet zeggen dat ik geen enkele ruimte zie voor beleidsregels in het kader van de grondwettelijke delegatieterminologie. Maar daarvoor zall slechts incidenteel plaats zijn: in het kader van een wettelijk geattribueerde bestuursbevoegdheid binnen een wettelijk genormeerde regeling.

155. In gelijke zin ARRS 4 juli 1991, AB 1991, 688, m.nt. JHvdV. De Woonruimtewet biedt geen ruimte voor de gemeenteraad om het stellen van distributienormen aan $B$ en $W$ te delegeren. Artikel 7 van de door B en W vastgestelde verordening merkt de Afdeling aan als een beleidsregel, namelijk een andere uitleg van een voorschrift, waartoe $B$ en W ook zonder nadere voorschriften geroepen zouden zijn.

156. CRvB 28 april 1994, JB 1994/263, m.nt. BwM/MAH.

157. En er dus terecht conversie heeft plaats gevonden.

158. ARRS 7 augustus 1992, Gst. 6952, 4, m.nt. HH.

159. Hemnekens in zijn noot onder de hierboven aangehaalde uitspraak Zie ook Hennekens 1992, p. 615 . 


\section{Hoofdstuk 8}

8.3.7 Beleidsregels en algemeen verbindende voorschriften dezelfde status geven?

Uit paragraaf 8.2 bleek dat in de literatuur stemmen zijn opgegaan om beleidsregels en algemeen verbindende voorschriften dezelfde status te geven. Hierbij kunnen drie situaties onderscheiden worden. De eerste is dat beleidsregels de status van algemeen verbindend voorschrift krijgen (paragraaf 8.3.7.1). De tweede is dat algemeen verbindlende voorschriften de status van beleidsregel krijgen (8.3.7.2) en een derde optie is een gedeeltelijke gelijkstelling (8.3.7.3).

\subsubsection{Beleidsregels kriggen de status van algemeen verbindend voorschrift}

Voorstanders van de opwaardering van beleidsregels tot algemeen verbindende voorschriften toonden zich, zoals in paragraaf 8.2 vermeld, Van der Vlies ${ }^{160}$ en Verheij ${ }^{161}$.

Zij zien (midden jaren ' 80 ) met name voor ministeriële regels in het kader van een beschikkingsbevoegdheid geen goede reden meer om onderscheid te blijven maken, nu ministeriële algemeen verbindende voorschriften en ministeriële beleidsregels op nagenoeg dezelfde wijze totstandkomen, en qua vormgeving niet of nauwelijks verschillen. In het bijzonder speelt hierbij een rol dat beide soorten regels een gebrekkige democratische legitimatie hebben. Bij de bevoegdheidstoedeling vindt doorgaans weinig inhoudelijke normering plaats. Voor aanmerking als algemeen verbindend voorschrift wordt gekozen omdat de regels in de praktijk als zodanig al functioneren en ze toetsbaar zijn in cassatie. Ook dienen de regels (als algemeen verbindend voorschrift) behoorlijk bekend gemaakt te worden. ${ }^{162}$

Inmiddels is de rechtsontwikkeling zo ver gevorderd dat de laatste twee argumenten aan kracht hebben ingeboet. Beleidsregels zijn door de Hoge Raad onder bepaalde voorwaarden immers erkend als recht in de zin van artikel 99 Wet RO en zij dienen krachtens de Algemene wet bestuursrecht behoorlijk bekend gemaakt te worden. Het argument dat deze beleidsregels in de praktijk als algemeen verbindend voorschrift werken is niet zo sterk. Er is toch nog altijd een verschil tussen in de praktijk als zodanig werken, of ook echt (juridisch) algemeen verbindend voorschrift, en dus afdwingbaar, zijn.

De aanmerking van beleidsregels als algemeen verbindend voorschrift, voor zover die beleidsregels geen burgers benadelende regels inhouden, geen inbreuk maken op grondrechten en geen bevoegdheden attribueren of delegeren ontmoet

161. Verheij 1985, p.1144-1147. Zie aok Ruiter $1986 \mathrm{a}$.

162. Van der Vlies 1984, p. 150-152; Verheij 1985, p.1146. 
weinig bedenkingen. De rechtsgevolgen voor de burger zullen beperkt blijven tot het feit dat deze algemeen verbindende voorschriften afgedwongen kunnen worden. Nu deze regels geen inbreuk mogen maken op het hier omschreven legaliteitsbeginsel zal deze afdwingbaarheid een gering effect hebben. Wanneer de regels niet meer de status van beleidsregel hebben, maar van algemeen verbindend voorschrift, gaat de toepassing van de inherente afwijkingsbevoegdheid verloren. Gelet echter op de stringente omschrijving van deze bevoegdheid in artikel 4.4.5 Derde tranche Awb is de verwachting dat deze afwijkingsbevoegdheid slechts op beperkte schaal zal worden toegepast.

Een nadeel van het aanmerken van beleidsregels als algemeen verbindende voorschriften in de situatie dat het gaat om regels gesteld in het kader van een wettelijke genormeerde ministeriële beschikkingsbevoegdheid is dat deze bestuursbevoegdheid tot algemeen verbindende voorschriften kan leiden, maar andere bestuursbevoegdheden dat niet doen, hetgeen onduidelijkheid in de hand werkt.

\subsubsection{Algemeen verbindende voorschriften krijgen de status van beleidsregel}

Een tweede mogelijkheid van gelijkschakeling van beleidsregels en algemeen verbindende voorschriften is dat (met name door bestuursorganen vastgestelde) algemeen verbindende voorschriften de status van beleidsregel krijgen. Een decennium geleden toonde Scheltema zich hiervan voorstander. ${ }^{163}$ Belangrijkste argument voor hem was dat het bestuur regels opstelt voor gevallen waar het zelf als partij bij betrokken is. Zulke regels zijn volgens hem geen recht, maar binden via de algemene beginselen van behoorlijk bestuur en zouden daaraan getoetst moeten worden. ${ }^{154}$

In de jaren ' 90 krijgt hij bijval van bijvoorbeeld Lubberdink. ${ }^{165}$ Die baseert zijn standpunt op de zijns inziens veranderde relatie tussen bestuur en burger. Die relatie wordt verwoord in de Memorie van Toelichting op de Tweede tranche Awb: "Naar huidig inzicht is het bestuur niet meer te typeren als de overheid die over de burger beslist zonder met diens zienswijze rekening te houden. Weliswaar is het bestuur in de eerste plaats gebonden aan de regels van de wetgever en aan de resultaten van de politieke besluitvorming, maar binnen die grenzen moet het ook rekening houden met de belangen van de bij de besluitvorming betrokken burger, zoals die burger deze zelf ziet. Dit vergt een andere benadering van de burger, waarbij sprake is van een betere communicatie dan vroeger

163. Scheltema 1984, p.14.

164. Scheltema 1984, p.13-15.

165. Lubberdink 1993, p.131-139. Zie ook (voorzichtig) Bröring 1993a, p.400. 


\section{Hoofdstuk 8}

nodig werd geoordeeld. "Ito Lubberdink stelt vanuit deze visie voor om een voortdurende discussie over de toepassing van de regel in het concrete geval tussen belanghebbende en overheid mogelijk te maken. ${ }^{167}$ Is sprake van een bijzonder geval dan dient de wettelijke regel opzij gezet te worden. "Algemeen verbindende voorschriften zouden hiermede dezelfde bindende kracht krijgen als naar geldend recht aan beleidsregels toekomt. "it68

Dit voorstel van Lubberdink, om vanuit een (verondersteld) veranderde positie bestuur-burger de laatste de mogelijkheid te geven om elk gesteld algemeen verbindend voorschrift ter discussie te stellen trekt mij niet aan. Een praktisch argument is dat ik vrees voor een ernstige overbelasting van het bestuursapparaat. Belangrijker is echter de principiële kant. Onder algemeen verbindende voorschriften worden veel situaties vastgelegd die voor een ieder (althans betrokkenen) gelden. Daarbij geldt: lex dura sed lex. Zou van dit principe afgeweken worden in die zin dat bestuur en burger in onderling overleg de toepasselijkheid van de regel kunnen bepalen dan lijkt mij dat de poort naar willekeur wijd wordt open gezet. Aan belangrijke principes van recht, zoals kenbaarheid, rechtszekerheid en rechtsgelijkheid wordt afbreuk gedaan. Een burger die beter gebekt is kan een gunstiger besluit afdwingen. Ik moet er overigens ook niet als burger aan denken om voortdurend mijn rechtspositie ten opzichte van het bestuur middels discussie te moeten bevechten. Lubberdinks voorstel verdient dan ook geen steun.

Wanneer wordt voorgesteld om algemeen verbindende voorschriften de status van beleidsregel te geven gebeurt dat voornamelijk vanuit de onvrede met de gebrekkige democratische legitimatie van krachtens delegatie tot stand gekomen algemeen verbindende voorschriften. De keuze om die regels de status van beleidsregel te geven houdt mijns inziens in dat bepaalde bevoegdheden daarmee niet (meer) uitgeoefend mogen worden: er mogen geen verplichtingen in die regels worden opgenomen, bevoegdheden geattribueerd of gedelegeerd, of grondrechten beperkt.

Wanneer dit geldt voor alle algemeen verbindende voorschriften waaraan geen democratisch gekozen orgaan heeft meegewerkt zouden deze regels in (bijvoor-

166. Kamerstukken II 1992-1993, 22495, nr $3 \mathrm{MvT}$, p. $11-12$. Zie over dit concept wan de "wederkerige rechtsbetrekking' E.C.H.J. van der Linden en A.Q.C. Tak (red.), Eenzijdig en wederkerig?, Kluwer Deventer 1995, waarin dit concept aan kritische beschouwingen is onderworpen.

167. Lubberdink 1993, p.136.

168. Lubberdink 1993, p. 136. 
beeld) de formele wet ${ }^{169}$, provinciale of gemeentelijke verordening neergelegd moeten worden. Dat lijkt me een behoorlijke (en nauwelijks realiseerbare) taakverzwaring voor de formele wetgever (alsmede provinciale staten en de gemeenteraad). Het voorstel lijkt dan ook praktisch niet goed realiseerbaar. Dat neemt niet weg dat de gebrekkige legitimatie van (sommige) gedelegeerde regelgeving een punt van zorg is. Er zijn verschillende ontwikkelingen te noemen die beogen de kwaliteit van de tot stand te brengen regels te verhogen. Inhoudelijk spelen de Aanwijzingen voor de regelgeving 1993 een belangrijke rol, terwijl voor de totstandkoming van gedelegeerde regelgeving verwezen kan worden naar de bepalingen in hoofdstuk $3 \mathrm{Awb}$, die van toepassing zijn voor zover de aard van het te nemen besluit zich er niet tegen verzet. Ook de rechter draagt een steentje bij door de burger meer rechtsbescherming te bieden door steeds verder gaande toetsing van algemeen verbindende voorschriften.

\subsubsection{Gedeeltelijke gelijkstelling}

De gedachte om beleidsregels gedeeltelijk gelijk te stellen aan algemeen verbindende voorschriften, namelijk voor zover ze geen inbreuk maken op het legaliteitsbeginsel, verwoordde Scheltema in zijn noot onder het Avanti-arrest. Wanneer die regels verplichtingen opleggen aan burgers, grondrechten beperken of bevoegdheden delegeren is een specifieke wettelijke grondslag noodzakelijk. ${ }^{170}$ Dit voorstel van Scheltema wijkt af van de door Van der Vlies en Verheij bepleitte gelijkschakeling. Zij beperken zich tot ministeriële regels die gegeven worden binnen het kader van een wettelijk toegekende beschikkingsbevoegdheid. Scheltema's voorstel betreft, als ik het goed zie, beleidsregels in het algemeen, maar hij zondert beleidsregels die zien op bepaalde bevoegdheden uit. Het nadeel van zijn voorstel is dat er in eén (beleids)regeling bepalingen met een verschillende status kunnen voorkomen. Sommige bepalingen zullen de status van algemeen verbindend voorschrift hebben, andere bepalingen zullen niet zo gekwalificeerd kunnen worden omdat ze een ge- of verbod inhouden, bevoegdheden toedelen, of grondrechten beperken. Ze kunnen dan echter ook niet als beleidsregel gelden ondat er voor deze regels een specifieke wettelijke grondslag benodigd is. De regels moeten onverbindend worden geacht. Dit brengt ongewenste onduidelijkheid met zich mee.

169. Of algemene maatregel van bestuur nu daarvoor geldt dat deze in de ministerraad wordt besproken en de Raad van State advies uitbrengt.

170. HR $1 \mathbb{1}$ oktober 1985 , AB 1986, 84 . 


\subsubsection{Conclusie}

Aan de gedane voorstellen om algemeen verbindende voorschriften en beleidsregels op de een of andere wijze een gelijke status te geven kleven uiteenlopende bezwaren. Wanneer wordt vastgehouden aan de principiële verschillen tussen beleidsregels en algemeen verbindende voorschriften is er reden on het onderscheid tussen deze regels te handhaven. Die reden is vooral gelegen in de duidelikkeid rond het uitoefenen van een bevoegdheid. Die duidelijkheid wordt bevorderd wanneer vastgehouden wordt aan een bevoegdheid tot het stellen van beleidsregels als een bestuursbevoegdheid aanwezig is, en een bevoegdheid tot het stellen van algemeen verbindende voorschriften in geval er een specifieke wettelijke basis is voor het uitoefenen van een regelgevende bevoegdheid.

\subsection{Relatie algemeen verbindend voorschrift-beleidsregel- delegatievraagstuk-delegatieterminologie}

\subsubsection{Inleiding}

Nadat in de vorige paragrafen de begrippen beleidsregel en algemeen verbindend voorschrift nader bekeken zijn, alsmede de overeenkomsten en verschillen daartussen, komt in deze paragraaf aan de orde welke de relatie is tussen algemeen verbindende voorschriften, beleidsregels, het delegatievraagstuk en de grondwettelijke delegatieterminologie. Achtereenvolgens zullen de volgende vragen aan bod komen: welke gevolgen heeft de opkomst van de beleidsregel voor het delegatievraagstuk, en meer in het bijzonder, voor de grondwettelijke delegatieterminologie (paragraaf 8.4.2)? En welke gevolgen heeft een eventuele gelijke status van beleidsregels en algemeen verbindende voorschriften voor de grondwettelijke delegatieterminologie (paragraaf 8.4.3)?

8.4.2 Gevolgen van de opkomst van de beleidsregel voor het delegatievraagstuk en de delegatieterminologie

\subsubsection{Beleidsregel en delegatievraagstuk}

De vraag naar de betekenis van de opkomst van de beleidsregel voor het delegatievraagstuk kwam ook aan de orde in hoofdstuk 7 (Het onderscheid regelgevinguitvoering). Uit dit hoofdstuk bleek dat het traditionele onderscheid regelgevinguitwoering (dat afkomstig is uit het denken over functies) bij het delegatievraagstuk in de jurisprudentie als zodanig niet meer gehanteerd lijkt te worden. Daarvoor is in de plaats gekomen het denken in bevoegaheden. Een regelgevende bevoegdheid (een bevoegdheid om algemeen verbindende voorschriften te stellen) 
wordt mu afgezet tegen een bestuursbevoegdheid waarbinnen een bestuursorgaan beleidsregels mag stellen. Eén van de conclusies uit hoofdstuk 7 was dat, in vergelijking met vroegere jurisprudentie over de reikwijdte van een (gedelegeerde dan wel geattribueerde) bevoegdheid, een bestuursorgaan meer mag regelen met beleidsregels dan met een 'uitvoerende' bevoegdheid. Omdat door het stellen van beleidsregels de uitoefening van de bestuursbevoegdheid wordt begrensd, mag in ruimere mate gedelegeerd worden. Overigens is het natuurlijk niet zo dat (enkel) door de opkomst van de beleidsregel er meer gedelegeerd mag worden. Veeleer past de beleidsregel in een ontwikkeling waarin de overbelaste formele wetgever al meer tot delegatie overgaat (zie hoofdstuk 4). De belleidsregel maakt die delegatie (van bestuursbevoegdheden) meer acceptabel doordat zij de uitoefening van die bestuursbevoegdheden structureert en normeert.

\subsubsection{Beleidsregel en delegatieterminologie}

Voor de grondwettelijke delegatieterminologie betekent de opkomst van de beleidsregel dat er een soort regel bij is gekomen, die bij de parlementaire behandeling van de terminologie niet is erkend en er ook geen plaats in heeft gekregen. Wanneer volgens de terminologie delegatie is toegestaan zijn de gevolgen hetzelfde als voor het delegatievraagstuk in het algemeen. Ruimere delegatie is toegestaan mits het bestuursorgaan zijn bevoegdheden structureert door middel van beleidsregels. De delegatieterminologie op zichzelf bepaalt niets over de mate waarin gedelegeerd mag worden. Daarvoor gelden de normen die ook buiten het grondwettelijke delegatievraagstuk gelden (zie hoofdstuk 4).

Ook wanneer delegatie is verboden zullen beleidsregels zijn toegestaan in het kader van een geattribueerde (of gedelegeerde) bestuursbevoegdheid. Een vereiste is wel dat het bestuursorgaan niet zelf de norm van de regeling bepaalt, maar dat die normering in de formele wet ligt besloten.

Het bovenstaande geldt zolang beleidsregels en algemeen verbindende voorschriften verschillende soorten regels zijn met verschillende rechtsgevolgen. In de volgende paragraaf wordt uiteengezet wat de gevolgen zijn van een gelijke status van beide soorten regels. Daarbij ga ik eerst in op een gelijkstelling van beleidsregels aan algemeen verbindende voorschriften en vervolgens op het toekennen van de status van beleidsregel aan algemeen verbindende voorschriften.

\subsubsection{Gevolgen van een gelijke status voor het delegatievraagstuk en de delegatieterminologie}

\subsubsection{Gelijkstelling van beleidsregels aan algemeen verbindende voorschriften}

Door verschillende schrijvers is opgemerkt dat gelijkstelling van beleidsregels aan algemeen verbindende voorschriften vergaande consequenties heeft voor het 


\section{Hoofdstuk 8}

delegatievraagstuk en de grondwettelijke delegatieterminologie. Zo bijvoorbeeld Ackermans-Wijn, in hä bijdrage aan de Staatsrechtconferentie 1984: "Indien pseudowetgeving tot recht in de zin van art. 99 RO zou worden verheven leidt dat tot afschaffing, althans ondergrawing, van de delegatiefiguur. Gezien de ruime aandacht die bij de jongste grondwetsherziening aan delegatie is besteed, een ridicule gedachte. Daarmee zouden de uitgangspunten van democratie en rechtsstaat, die in een sociale verzorgingsstaat toch al steeds moeilijker te herkennen zijn, echt om zeep zijn geholpen. ${ }^{n 175}$

Wanneer (alle) beleidsregels de status van algemeen verbindend voorschrift krijgen is een bestuursbevoegdheid een voldoende basis om 'burgers bindende regels' te stellen. Het onderscheid tussen een regelgevende bevoegdheid en een bestuursbevoegdheid valt weg. Het vraagstuk van delegatie van regelgevende bevoegdheden verliest relevantie: een regelgevende bevoegdheid ligt dan immers besloten in een bestuursbevoegdheid. Van belang zal zijn dat er een wettelijke basis geëist zal blijven worden voor de overdracht van bestuursbevoegdheid. Als op ruime schaal ook ongeschreven (bestuurs)bevoegdheden geaccepteerd gaan worden dan wordt de democratische basis voor 'ingrijpend', optreden van bestuursorganen wel erg wankel. Blijft men echter vasthouden aan een wettelijke basis voor bestuursoptreden dan zal het gevolg van het gelijkstellen van beleidsregels aan algemeen verbindende voorschriften 'beperkt' blijven tot het feit dat burgers geconfronteerd worden met waarschijnlijk ongeveer dezelfde hoeveelheid regels, die echter ingrijpender voor hun rechtspositie kunnen zijn, wanneer ze ook afgedwongen kunnen worden.

Gelijkstelling van alle beleidsregels aan algemeen verbindende voorschriften is echter niet bepleit. Zowel Van der Vlies en Verheij als Scheltema hebben het oog op bepaalde beleidsregels waarvoor zij de status van algemeen verbindend voorschrift aantrekkelijk vinden. Daardoor zullen de gevolgen van gelijke waardering ook geringer zijn.

Wat zijn de gevolgen van gelijkstelling voor de grondwettelijke delegatieterminologie? Wanneer delegatie is toegestaan zijn mijns inziens de gevolgen zoals

171. Ackermans-Wijn 1984, p.6. In dezelfde zin Van der Burg in zijn noot onder HR 31 mei 1985. AB 1985, 480 (Uniform Aanbestedingsreglement): "Naar mijn mening moet het onderscheid (tussen beleidsregels en algemeen verbindende voorschriften, JD) gehandhatafd worden. Zou men het onderscheid opgeven, dan zou het beginsel dat regelgevende bevoegdheid direkt of indirekt op de Grondwet moet steunen om de hals gebracht worden." Ook een verwijzing naar de grondwettelijke delegatieterminologie geeft Kortmann $1987 b$, p. 382. 
hierboven beschreven bij de gevolgen voor het delegatievraagstuk in het algemeen.

Wat zijn echter de consequenties voor het delegatieverbod? Wanneer de betekenis van het delegatieverbod is dat in de formele wet de belangrijkste bepalingen en normen dienen te worden opgenomen, volgt daaruit dat de ruimte die nog rest voor bestuursorganen om zaken te regelen gering is (zo mogen ook geattribueerde bestuursbevoegdheden niet discretionair zijn). Het moet dan in elk geval om detailpunten gaan. Daaronder vallen niet bepalingen die verplichtingen aan burgers opleggen, grondrechten beperken of bevoegdheden verlenen, of anderszins inbreuk maken op de vrijheid of rechten van burgers. In deze situatie is het toekennen van de status van algemeen verbindend voorschrift aan de regels die nog wel gesteld kunnen worden minder bezwaarlijk. De grootste waarborg ligt immers in het delegatieverbod zelf, dat voorschrijft dat alle essentiële aspecten van een onderwerp in de formele wet zelf geregeld moeten worden. Uit een oogpunt van een consistent systeem van bevoegdheden en de daarbij te stellen regels verdient het echter geen aanbeveling om in deze situatie gestelde beleidsregels aan te merken als algemeen verbindende voorschriften. Dat zou immers de onduidelijkheid vergroten ten opzichte van andere bestuursbevoegdheden waarbij alleen beleidsregels gesteld mogen worden.

Daar waar de grondwettelijke delegatieterminologie voor de regeling van een onderwerp een formele wet eist, kan niet met beleidsregels volstaan worden. Dat wil echter niet zeggen dat er geen ruimte voor beleidsregels is. Zowel bij toegestane als verboden delegatie kunnen in het kader van geattribueerde of gedelegeerde bestuursbevoegdheden beleidsregels gesteld worden. De enige harde norm verder die de omzetting van beleidsregels in algemeen verbindende voorschriften tegenhoudt is artikel 89 lid 2 en lid $4 \mathrm{Gw}$ ('Voorschriften door straffen te handhaven dienen een basis in een formele wet te hebben'). ${ }^{172}$

\subsubsection{Gelijkstelling van algemeen verbindende voorschriften aan beleidsregels}

Wanneer alle krachtens attributie of delegatie door bestuursorganen vastgestelde algemeen verbindende voorschriften de status van beleidsregel krijgen is het vraagstuk van delegatie van regelgevende bevoegdheid voor een groot deel niet meer van toepassing. Wél van toepassing zou het delegatievraagstuk kunnen zijn in de relatie formele wet-algemene maatregel van bestuur, nu de Raad van State hierover advies uitbrengt. Een extra waarborg is er bovendien bij algemene maatregelen van bestuur waarbij een voorhangprocedure wordt toegepast: de

172. Zie F.H. van der Burg in Bestuurswetenschappen 1986, p. 334. 


\section{Hoofdstuk 8}

Kamers zijn dan in elk geval in de gelegenheid om invloed op de inhoud van de regeling uit te oefenen.

Er kunnen in een formele wet of algemene maatregel van bestuur wel regelgevende bevoegdheden worden gedelegeerd, maar de uitoefening daarvan zal 'slechts" beleidsregels opleveren. Bovendien zullen dat geen voorschriften mogen zijn die ge- of verboden inhouden of grondrechten beperken. Deze regels zullen in de formele wet (of algemene maatregel van bestuur) zelf moeten worden opgenomen, hetgeen een taakverzwaring voor de formele wetgever inhoudt.

Dat heeft dan wel tot gevolg dat meer wordt voldaan aan het streven om delegatie van regelgevende beveegdheid terug te dringen en meer in de formele wet zelf op te nemen (zie onder meer de Aanwijzingen voor de regelgeving 1993).

Voor de grondwettelijke delegatieterminologie betekent deze gelijkstelling dat daar waar delegatie van regelgevende bevoegdheid wordt toegestaan, dat een beperking van de bevoegdheden van de formele wetgever inhoudt. Alleen delegatie aan de regering, of democratisch gekozen lagere organen lijkt mogelijk, tenminste voorzover wordt beoogd regelingen vast te stellen die de burgers kunnen binden.

Voor de onderwerpen waarvoor een grondwettelijk delegatieverbod geldt zijn de gevolgen beperkt. Hierbij was de formele wetgever immers al verplicht om de belangrijkste elementen zelf te regelen. Slechts voor zover het detailpunten betreft mag hij lagere organen inschakelen. Dat de te stellen regels de status van beleidsregel krijgen is geheel in de geest van het delegatieverbod.

\subsection{Conclusie}

In enkele decennia tijd heeft de beleidsregel een enorme opkomst doorgemaakt. Naast kwantitatieve groei is ook sprake van kwalitatieve groei: erkenning door de Hoge Raad als rechtsregel in de zin van artikel 99 Wet RO en een (toekomstige) wettelijke regeling in de Algemene wet bestuursrecht. Beleidsregels en algemeen verbindende voorschriften zijn als soorten regels dan ook veel op elkaar gaan lijken. Dat geldt in het bijzonder waar het gaat om algemeen verbindende voorschriften die in het kader van een gedelegeerde regelgevende bevoegdheid tot standkomen.

Overeenkomsten tussen de regels zijn dat (na inwerkingtreding van de Derde tranche Algemene wet bestuursrecht) voor beide nagenoeg dezelfde regels rond de totstandkoming gelden (zie Afdeling $3.2 \mathrm{Awb}$ ); daarnaast zijn de beroepsmogelijkheden in de Awb voor beide soorten regels op dezelfde manier geregeld 
in die zin dat rechtstreeks beroep (bij de administratieve rechter) (nog) niet mogelijk is. Ook toetst de rechter bij een besluit de onderliggende regeling (beleidsregel of algemeen verbindend voorschrift) aan de algemene beginselen van behoorlijk bestuur.

Er zijn echter ook belangrijke verschillen tussen algemeen verbindende voorschriften en beleidsregels. Voor algemeen verbindende voorschriften geldt dat een specifieke wettelijke grondslag is vereist. Die wettelijke grondslag dient ter legitimatie van de soort regel die met uitoefening van een regelgevende bevoegdheid kan worden gesteld. Het betreft het opleggen van ge- of verboden aan burgers, of het stellen van (andere) benadelende regels; het maken van inbreuken op (grondwettelijk geregelde) grondrechten en het attribueren of delegeren van bevoegdheden. Doordat beleidsregels deze specifieke wettelijke grondslag ontberen kunnen zij niet ingezet worden ter regeling van deze onderwerpen.

Een ander verschil tenslotte is de inherente afwijkingsbevoegdheid die beleidsregels kenmerkt. Het verschil is echter nog slechts gradueel doordat óók van algemeen verbindende voorschriften afgeweken wordt in situaties waarin, hetzij de wetgever een hardheidsclausule heeft voorzien, hetzij de rechter corrigerend optreedt door toetsing aan de algemene beginselen van behoorlijk bestuur. De voorgestelde wettelijke regeling van de afwijkingsbevoegdheid voor beleidsregels zoals neergelegd in artikel 4.4.5 Awb Derde tranche doet vermoeden dat afwijking van de gestelde beleidsregel in mindere mate zal worden toegepast dan tot nu toe het geval was.

Gelet op de hierboven besproken principiële verschillen tussen beide soorten regels is een gelijkstelling van algemeen verbindende voorschriften en beleidsregels niet wenselijk. Doorslaggevend hierbij zijn het vereiste van een specifieke wettelijke grondslag voor de aanmerking als algemeen verbindend voorschrift en de aard van de bevoegdheden die met de verschillende soorten regels kunnen worden uitgeoefend. Die bevoegdheden zijn: het maken van inbreuken op de vrijheid en eigendom van burgers, het attribueren en delegeren van bevoegdheden en het beperken van (grondwettelijke) grondrechten. Aan deze keuze ligt een bepaalde invulling van het legaliteitsbeginsel en materieel wetsbegrip ten grondslag. Aan beide begrippen kan een verschillende inhoud worden gegeven. Een bespreking ervan vindt plaats in het volgende hoofdstuk. Daarop vooruitlopend is hier de voorkeur gegeven aan een 'klassieke' invulling van het legaliteitsbeginsel.

In het licht van deze keuze zijn ook de verschillende vormen van gelijkstelling van algemeen verbindende voorschriften en beleidsregels besproken. Daarvan is de conclusie dat het wenselijk is om het onderscheid tussen beide soorten regels te handhaven, met name om een consistent systeem van bevoegdheidsuitoefening te waarborgen. 


\section{Hoofdstuk 8}

Wanneer een bestuursbevoegdheid in sommige gevallen tot algemeen verbindende voorschriften leidt, maar in andere gevallen tot beleidsregels, werkt dat ongewenste onduidelijkheid in de hand.

Ook vanuit het oogpunt van het delegatievraagstuk en de grondwettelijke delegatieterminologie heeft de opkomst van de beleidsregel gevolgen. Voor het delegatievraagstuk in het algemeen geldt dat door het stellen van beleidsregels in het kader van een bestuursbevoegdheid, die bevoegdheid ruimer mag zijn dan wanneer sprake zou zijn van een 'uitvoerende' bevoegdheid (zie ook hoofdstuk 7). In dit opzicht is delegatie van bestuursbevoegdheid meer aanvaardbaar geacht. Beide manieren van gelijkstelling: beleidsregels de status van algemeen verbindend voorschrift geven, en algemeen verbindende voorschriften de positie van beleidsregel, hebben grote gevolgen voor zowel het delegatievraagstuk als de grondwettelijke delegatieterminologie. Wanneer beleidsregels de status van algemeen verbindend voorschrift krijgen is een bestuursbevoegdheid voldoende basis om de burgers bindende regels te stellen. Er is minder noodzaak om tot delegatie van regelgevende bevoegdheid over te gaan: attributie van een bestuursbevoegdheid voldoet immers. Van belang is om voor overdracht van een bestuursbevoegdheid steeds een wettelijk genormeerde grondslag te eisen ter legitimatie van het bestuursoptreden. Naast attributie van bestuursbevoegdheid kan delegatie van regelgevende bevoegdheid blijven plaatsvinden aan andere organen. Het vraagstuk van delegatie van regelgevende bevoegdheid verliest echter betekenis wanneer krachtens delegatie tot stand gekomen algemeen verbindende voorschriften gaan gelden als beleidsregels. Bepaalde bevoegdhedlen zoals het stellen van regels die de burger treffen in hun vrijheid of eigendom, en het beperken van grondrechten kunnen dan niet meer door middel van gedelegeerde regelgeving tot stand worden gebracht. Gezien de 'zwaarte' van deze regels is regeling in een formele wet, algemene maatregel van bestuur; provinciale of gemeentelijke verordening (of andere regeling tot stand gebracht door een democratisch gekozen orgaan) een voorwaarde. Dat betekent een niet gewenste taakverzwaring voor de organen die deze regelingen tot stand brengen.

De conclusie is dat het niet gewenst is om algemeen verbindende voorschriften en beleidsregels op de een of andere manier gelijk te stellen. 


\section{Hoofdstuk 9}

\section{Legaliteitsbeginsel, materieel wetsbegrip en delegatieterminologie}

\section{$9.1 \quad$ Inleiding}

\subsubsection{Onderzoeksvragen}

Uitgangspunt voor dit hoofdstuk is de vraag of de invoering van de grondwettelijke delegatieterminologie gebaseerd is op een bepaalde visie van de grondwetgever op het legaliteitsbeginsel en de inhoud van een materieel wetsbegrip. De gedachte achter deze vraag is dat "de grondwetgever", bij de invoering van de grondwettelijke delegatieterminologie in de verschillende bepalingen, steeds een afweging heeft moeten maken of delegatie zou worden toegestaan dan wel verboden. Is die afweging aan de hand van bepaalde criteria gemaakt? Heeft de grondwetgever zich laten leiden door heersende opvattingen over de invulling van het legaliteitsbeginsel of een materieel wetsbegrip? Heeft het Fluorideringsarrest uit 1973 bijvoorbeeld invloed uitgeoefend? In paragraaf $9.2 \mathrm{ga} \mathrm{ik}$ op deze vragen in. In paragraaf 9.3 worden enkele opvattingen over de inhoud van het legaliteitsbeginsel na 1983 besproken. Ook komen in die paragraaf voorstellen aan de orde voor een nieuwe inhoud van het materieel wetsbegrip. Op de vraag of de grondwettelijke delegatieterminologie op haar beurt invloed heeft gehad op de inhoud van het legaliteitsbeginsel en een materieel wetsbegrip wordt ingegaan in paragraaf 9.4. Met een samenvatting in paragraaf 9.5 eindigt dit hoofdstuk.

\subsubsection{Legaliteitsbeginsel en materieel wetsbegrip: twee kanten van dezelfde medaille}

In de 'klassieke' opvatting richt het legaliteitsbeginsel zich tot het bestuur: voor bevoegdheden waarmee een inbreuk wordt gemaakt op de vrijheid of eigendom van burgers dient een wettelijke grondslag te zijn (zie paragraaf 9.3.1). Wanneer echter het legaliteitsbeginsel zo wordt opgevat dat het ook voor de formele wetgever geldt (in die zin dat het legaliteitsbeginsel eist dat de formele wetgever het nemen van belangrijke (rechtspolitieke) keuzes niet mag overlaten aan bestuur of rechter; zie paragraaf 9.3.2.4) vallen het legaliteitsbeginsel en het materieel 


\section{Hoofdstuk 9}

wetsbegrip samen. 'Immers, dan is het zowel vanuit het legaliteitsbeginsel als vanuit het materieel wetsbegrip de vraag welke regels zo belangrijk zijn dat ze in de formele wet zelf opgenomen moeten worden, of welke regels tenminste een basis in de formele wet dienen te hebben. Dat samenvallen eindigt daar waar het legaliteitsbeginsel zo wijd wordt opgerekt dat de betekenis wordt dat alle overheidshandelen steun moet vinden in algemene regels (waaronder ook vallen de algemene beginselen van behoorlijk bestuur of beleidsregels). Dan klopt de gelijkschakeling van legaliteitsbeginsel aan materieel wetsbegrip niet meer. Het materieel wetsbegrip is immers nadrukkelijk gekoppeld aan de formele wet (of gedelegeerde algemeen verbindende voorschriften). Beide begrippen komen daarom in dit hoofdstuk aan de orde, waarbij ze soms ieder een eigen betekenis hebben, en soms daarentegen ook dezelfde invulling krijgen.

\subsection{Opvattingen over het legaliteitsbeginsel en materieel wetsbegrip in de parlementaire stukken op de grondwetsherziening}

\subsubsection{Inleiding}

In deze paragraaf komt aan de orde of de grondwetgever bij de grondwetsherziening van $1983^{2}$ blijk heeft gegeven van een bepaalde visie op het legaliteitsbeginsel/materieel wetsbegrip. ${ }^{3}$ Deze visie zou zich kunnen uiten in een stelsel van

1. Een enkele auteur behandelt ze als synoniemen. Zie Van der Vlies 1991, p.79. Zie ook voor de verhouding tussen deze twee begrippen Schreuder-Vlasblom 1985, p.493 en 497498 naar aanleiding van de dissertatie van Van der Vlies. Stout 1994, p.85, bespreekt de verhouding tussen deze begrippen als de samenhang tussen het materieel legaliteitsbeginsel en het materieel wetsbegrip.

2. Een enkel voorbeeld is ontleend aan de grondwetsherziening van 1987 .

3. Het herzien wan de Grondwet is een proces waarin meerdere actoren gedurende langere tijd een rol spelen. De wisseleride samenstelling van die actoren kan leiden tot verschillende inzichten. Dat zal de hantering van een samenhangende visie bemoeilijken. De parlementaire behandeling van de wetsontwerpen die heeft geleid tot de Grondwet van 1983 heeft plaatsgevonden tussen 2 april 1976 (indiening bij de Tweede Kamer van de eerste wetsontwerpen) en 11 mei 1982 (de stermming in de Eerste Kamer in tweede lezing). Tenminste vier van de vijf betrokken organen (te weten Koning, kabinet, Eerste en Tweede Kamer en Raad van State) wisselden sterk van samenstelling in deze (ruim) zes jaren. Zo ging het koningschap op 30 april 1980 over van Juliana op Beatrix. Er regeerden drie kabinetten van verschillende kleur: 1. het kabinet Den Uyl (van 11 mei 1973 - 19 december 1977), werd op 22 maart 1977 demissionair; in dit kabinet was Den Uyl (PvdA) minister-president; W.F. de Gaay Fortman (AR) minister van Binnenlandse Zaken en Van Agt (KVP) minister van Justitie; 2, her kabinet Van Agt I (van 19 december 1977 - 11 september 1981). Van Agt (CDA) was minister-president, Wiegel (VVD) minister van Binnenlandse 
gehanteerde criteria bij de vraag of delegatie wordt toegestaan dan wel verboden. Vanuit de invalshoek van een materieel wetsbegrip zijn de vragen: welk onderwerp is zo belangrijk dat het door de formele wetgever zelf (helemaal) geregeld moet worden (delegatieverbod) en: welk onderwerp dient in elk geval een formeel-wettelijke grondslag te hebben, maar kan door lagere regelgevers worden uitgewerkt.

Voordat ik op deze vragen inga, schets ik heel kort opvattingen over het legaliteitsbeginsel en materieel wetsbegrip voor 1983 (paragraaf 9.2.2.). Vervolgens komt aan de orde of er in de Grondwet zelf misschien een materieel wetsbegrip is neergelegd. Aanknoping bij de parlementaire geschiedenis van artikel $81 \mathrm{Gw}$ leent zich daar het best voor (paragraaf 9.2.3).

In paragraaf 9.3.4 wordt verslag gedaan van de speurtocht naar criteria in de parlementaire stukken. Een korte conclusie volgt in paragraaf 9.3.5.

\subsubsection{Korte schets van opvattingen over het legaliteitsbeginsel en materieel wetsbegrip voor 1983}

In haar dissertatie, Het wetsbegrip en beginselen van behoorlijke regelgeving, besteedt Van der Vlies ruim aandacht aan opvattingen over het legaliteitsbeginsel en materieel wetsbegrip in de $19 \mathrm{e}$ en $20 \mathrm{e}$ eeuw. Aan haar onderzoek ontleen ik het volgende. Aan het eind van de $19 \mathrm{e}$ eeuw is de opvatting over het legaliteitsbeginsel dat het bestuur niet zelfstandig de burgers bindende bepalingen mag vaststellen. Die voorschriften behoeven een wettelijke grondslag. Ook mag het bestuur niet de regeling aan zich trekken van onderwerpen die de Grondwet aan de wetgever heeft toebedeeld. ${ }^{4}$

In de twintigste eeuw dringt langzaam aan het besef door dat met deze opvatting van het legaliteitsbeginsel onvoldoende recht wordt gedaan aan optreden van de overheid die ook op andere manieren dan door 'burgers bindende regels" rechten

Zaken en De Ruiter (CDA) minister van Justitie; 3. het kabinet Van Agt II (van 11 september 1981 - 29 mei 1982). Van Agt (CDA) was opnieuw minister-president, Van Thijn (PvdA) minister van Binnenlandse Zaken en De Ruiter (CDA) minister van Justitie. Door deze politieke wisselingen is de positie van münister van Binnenlandse Zaken (onder wiens leiding de Stafafdeling Constitutionele Zaken en Wetgeving verantwoordelijk is woor de ambtelijke voorbereiding van regeringsstukken bij de grondwetsherziening) in handen geweest van drie verschillende politieke partijen (AR (nu CDA)), VVD en PVdA). De samenstelling wan de Staten-Generaal in de periode 1976 - 1982 wisselde eveneens vrij sterk. Van de leden van de Eerste Kamer waren er in 1982 nog $17(=22,7 \%)$ die ook al in 1976 zitting hadden. En van de leden wan de Tweede Kamer waren dat er in 1982 nog 43 $(=28,7 \%)$. Hoe de samenstelling van de Raad van State veranderde is niet nagegaan.

4. Van der Vlies 1984, p.92. 


\section{Hoofdstuk 9}

en plichten van burgers bepaait. Onontkoombaar is dat de formele wetgever keuzes gaat maken in zaken die wel en niet geregeld kunnen worden. ${ }^{5}$ De discussie krijgt nieuwe impulsen door het Fluorideringsarrest dat in 1973 wordt gewezen door de Hoge Raad. ${ }^{6}$ De Raad oordeelde dat voor 'ingrijpende besluiten', zoals in casu het toevoegen van fluoride aan drinkwater, een wettelijke gronidslag

nodig is. In de literatuur trok dit arrest de nodige aandacht. ${ }^{7}$ Van der Vlies concludeert dat met het eriterium 'ingrijpende besluiten behoeven een wettelijke grondslag", een nieuwe invulling aan het legaliteitsbeginsel is gegeven. ${ }^{8}$

Met het zoeken naar criteria voor de invulling van het legaliteitsbeginsel en materieel wetsbegrip verdwijnt de discussie over de vraag of in de Grondwet een formeel dan wel materieel wetsbegrip is neergelegd naar de achtergrond.

Toch doet zich naar aanleiding van de grondwetsherziening de vraag voor of er in de (nieuwe) Grondwet, en dan in het bijzonder in artikel 81, een formeel of materieel wetsbegrip is neergelegd. Aan deze vraag is de volgendle subparagraaf gewijd.

\subsubsection{Een formeel of materieel wetsbegrip in artikel $81 \mathrm{Gw}$ ?}

De vraag of er een formeel dan wel materieel wetsbegrip in artikel $81 \mathrm{Gw}^{9}$ is neergelegd, is niet met zoveel woorden aan de orde gesteld bij de behandeling van wetsontwerp 15047 (bepalingen betreffende de wetgevende macht en de algemene maatregelen van bestuur, alsmede tot opneming van bepalingen betreffende andere voorschriften).

Een duidelijke keuze voor hetzij een formeel, hetzij een materieel wetsbegrip ontbreekt in de parlementaire stukken mijns inziens dan ook. Wel zijn sporen van beide opvattingen aan te treffen, bijwoorbeeld in het volgende citaat: "Het lijkt dan ook niet geraden te zeggen, dat het vaststellen van de wetten slechts een vorm van overheidsoptreden is, naast andere even legitieme vormen en dat de wet zich alleen formeel onderscheidt van andere voorschriften, die materieel evenzeer als wetgeving moeten worden beschouwd. "10

5. Van der Vlies 1984, p. 99.

6. HR 22 juni 1973, N 1973,386 , m.nt. Bloembergen; AB 1973, 187, m.nt. Van der Hoeven.

7. Zie voor een bespreking Van der Vhies 1984, p.94-95.

8. Van der Vlies 1984, p.95.

9. 'De vaststelling wan wetten geschiedt door de regering en de Staten-Generaal gezamenlijk."

10. Kamerstukken lit 1977-1978, 15047 (R1099), nr 3 MvT. p.10. 
De opvatting dat er in artikel $81 \mathrm{Gw}$ (in ieder geval) een formeel wetsbegrip is vastgelegd zal weinig bestrijding ondervinden. Interessanter is of er daarnaast nog aanknopingspunten liggen voor een materiële opvatting van wat een wet moet/kan inhouden. Impliciet lijkt de opvatting aangehangen dat het bij wetgeving gaat om regelgeving: in de MvA stelt de regering dat de algemene maatregel van bestuur zich qua vorm onderscheidt van de wet, maar dat het "in beide gevallen gaat om regelgeving. "11 Als soort regelgeving vinden we de omschrijving van Buys, 'de burgers bindende regels' in de parlementaire stukken. ${ }^{12}$ Veel meer dan deze summiere aanwijzingen is er niet te vinden. De regering erkent dat de vraag wat een wet (dan wel een algemene maatregel van bestuur) nu eigenlijk is niet wordt beantwoord in ons grondwettelijk stelsel. ${ }^{13}$

Ook de discussie over een 'verruimd en vernieuwd wetsbegrip' in de Eerste Kamer levert niet veel op. ${ }^{14} D^{\prime} 66$ voert aan dat de Nederlandse constitutie nooit een expliciet wetsbegrip heeft gehad. "Nooit heeft de Grondwet aan de wetgever duidelijk gemaakt wàt hij moest doen, altijd alleen maar hóe hij het moest doen. Op de vraag wat hij moest doen werd van het begin af aan eigenlijk alleen maar als antwoord gegeven: alles wat hij belangrijk genoeg vindt om het volgens de wetgevende procedure te doen, alles wat hij belangrijk genoeg vindt om verpakt te worden in de vorm van de formele wet. (...) Als de wetgever er zelf niet op kwam dan gaf de rechter wel eens een kleine hint, zoals in het bekende fluorideringsarrest." (...) Onze Grondwet kent geen materieel wetsbegrip en constitutioneel kunnen wij alle kanten uit (...) Belangrijke beleidsbesluiten verpakt in de formule van de formele wet zijn heel goed mogelijk, maar deze wijze van werken zal de wetgeving als proces er niet eenvoudiger op maken. ${ }^{15}$

De VVD-fractie stelt dat de wetsvorm ook gehanteerd kan worden voor niet strikt regelgevende besluiten. ${ }^{16}$ Het antwoord van de regering over het volgen van de wetsprocedure is weinig zeggend: "Acht men voor enig voorstel het volgen van die procedure van belang, dan is daarvoor de vorm van de wet beschikbaar. "17

11. Kamerstukken II 1979-1980, 15047 (R1099), nr 8 MvA, p.3.

12. Handelingen II 1979-1980, p.5307 (minister Wiegel): "Ik ben het eens met de geachte afgevaa rdigde mevrouw Korte-van Hemel dat burgers bindende regels bij of krachtens de wet moeten worden vastgesteld. "(Hoewel uit het Nader rapport ook valt aff te leiden dat een wet in formele zin zowel regelgeving als beschikkingen (als voorbeeld wordt naturalisatie genoemd) kan bevatten. Kamerstukken II 1977-1978, 15047 (R1099), nr 4 Bijlagen bij de MvT, Bijlage II Nader rapport, p.23.)

13. Kamerstukken II 1979-1980,15047 (R 1099), nr 11 Nota naar aanleiding van het EV, p.6.

14. Kamerstukken I 1979-1980, 15047 (R1099), nr 126a VV, p.1.

15. Handelingen I 1980-1981, p.228 (Vis).

16. Kamerstukken I 1979-1980, 15047 (R\099), nr 126a VV, p.2.

1.7. Kamerstukken I 1980-1981, 15047 (RI099), nr 16 MvA, p.2. 


\section{Hoofdstuk 9}

Een formele benadering derhalve die niets toevoegt aan de vraag in welke gevallen die wetsprocedure gevolgd moet worden.

Volgens sommige schrijvers ${ }^{19}$ heeft de Grondwet niet beoogd een materieel wetsbegrip te introduceren. $\mathrm{Zij}$ gaan uit van een formeel wetsbegrip in artikel 81 Gw. Dat is natuurlijk ook zo. Daarnaast meen ik echter dat er, zo niet grondwettelijk, dan in elk geval constitutioneel wel aanknopingspunten zijn voor de opvatting, dat artikel $81 \mathrm{Gw}$ ook een materieel wetsbegrip behelst. Wanneer we het over een formele wet hebben, zullen we daar toch in de meeste gevallen de voorstelling bij hebben dat die wet algemene regels inhoudt (een voorstelling die ook aan slijtage onderhevig is, nu 'algemeen' naar personen, tijd en plaats steeds minder algemeen wordt.) Maar een formele wet bevat in het overgrote deel van de gevallen algemeen verbindende voorschriften en slechts zelden beschikkingen. ${ }^{19}$ Daarnaast leeft de idee bij de grondwetgever dat in elk geval ook belangrijke zaken door de formele wetgever geregeld worden, hetzij in een formele wet zelf, hetzij met behulp van delegatie. ${ }^{20}$ Dat ook dit slechts een zwak criterium voor de inhoud van een materieel wetsbegrip is, besef ik. Maar het maakt voor mij aannemelijk dat er niet alleen maar een formeel wetsbegrip in artikel $81 \mathrm{Gw}$ is neergelegd.

\subsubsection{Op zoek naar criteria in de parlementaire stukken}

Sommige grondwetten, zoals de Amerikaanse, kennen een preambule waarin enkele belangrijke normen worden vastgelegd, die aan de grondwet ten grondslag liggen. Zo is de Amerikaanse constitutie vastgesteld 'in order to perform a more perfect Union, establish justice, insure domestic tranquillity, provide for the common defence, promote the general welfare and secure the blessings of liberty to ourselves and our posterity'. Een dergelijke preambule kan zelfs wetskracht krijgen, zo oordeelde de Conseil d'Etat over de preambule in de Franse grondwet van 1946.21

In haar Eindrapport legt de staatscommissie Cals/Donner uit dat zij overwogen heeft om in de 'nieuwe' grondwet eveneens een preambule op te nemen. $\mathrm{Zij}$ heeft hiervan afgezien: "hoewel bij de opneming zal worden betoogd, dat zij niemand in geweten bindt en de geestelijke vrijheid onverlet laat, zal zij toch, eenmaal

18. Van der Vlies 1984, p.169 e.v.; Kortmann 1987a, p.257-258; Akkermans/Koekkoek 1992, p.741.

19. In dezelfde zin Van der Vlies 1991, p.97.98.

20. Zie ook paragrafif 9.3.4.

21. Koopmans, Vergelijkend publiekrecht 1986 , p.75. 
opgenomen, gaan fungeren als een maatstaf voor het overheidsbeleid, waaraan de gedane handelingen en gegeven voorsehriften zoal niet door de rechter dan toch door de publieke opinie worden getoetst. "22 Het lid Verbrugh van de Commissie pleitte echter wel voor opneming van een preambule met een duidelijk doel. "Een voorbeeld zou kunnen zijn de vermelding, dat wetgeving en bestuur, onder gebruikmaking van de door God gegeven mogelijkheden, de vrije ontplooiing van mens en samenleving bevorderen en daarbij rekening houden met de ontwikkeling van de Nederlandse staat vanuit het verleden en met de eigen plaats die deze staat in de wereld inneemt." ${ }^{23}$

Tot het opnemen van een preambule is het niet gekomen in de Grondwet van 1983. Ook is er, voorafgaand aan de grondwetsherziening geen debat gehouden over de invulling van een materieel wetsbegrip, en samenhangend daarmee, over de op te nemen delegatieterminologie. Bij het laatste zou de vraag geweest kunnen zijn welke de criteria zijn om delegatie toe te staan dan wel te verbieden. De vraag is echter of zo'n debat veel op zou leveren. Worden de criteria gedetailleerd opgesteld, dan zal er niet snel overeenstemming bereikt worden. Wordt wel consensus bereikt dan is de inhoud ervan waarschijnlijk zo algemeen dat die weinig richting geeft.

Hierboven is geconstateerd dat er in artikel $81 \mathrm{Gw}$ in elk geval geen duidelijk materieel wetsbegrip is neergelegd. Ook de andere herzieningswoorstellen alsmede de parlementaire behandeling ervan zijn onderzocht op het vóórkomen van een materieel wetsbegrip en criteria voor het hanteren van de grondwettelijke delegatieterminologie. Enkele resultaten zijn hieronder samengebracht.

De gemaakte opmerkingen kunnen betrekking hebben op het niveau waarop een onderwerp geregeld dient te worden: aan wie wordt een bevoegdheid geattribueerd? Maar ook kunnen ze gaan over welke aspecten van een onderwerp alan bod dienen te komen. En soms worden er concrete aanzetten voor de uitwerking van een onderwerp gegeven. Hieronder volgen, ter illustratie, enkele voorbeelden.

Op grond van artikel 2 lid $2 \mathrm{Gw}$ ('De wet regelt de toelating en uitzetting van vreemdelingen') kan de wetgever een toelatingsregeling voor vreemdelingen treffen die volgens de MvT moet voldoen aan de volgende eisen: de situatie dient een toelatingsregeling te rechtvaardigen; de te bereiken doeleinden kunnen niet langs andere, betere weg bereikt worden; de regeling mag niet discriminatoir zijn

22. Eindrapport Commissie Cals/Donner, p.22.

23. Eindrapport Commissie Cals/Donner, p.22. 


\section{Hoofdstuk 9}

en ook niet anderszins grondrechten ongeoorloofd beperken. ${ }^{24}$ De criteria zijn vaag en het lijkt me dat er veel verschillendle uitwerkingen mogelijk zijn, met name van de eerste twee genoemde punten. Heel wat concreter is het 'verlanglijstje' ten aanzien van artikel 2 lid $4 \mathrm{Gw}$ ('Teder heeft het recht het land te vertaten, behoudens in de gevallen, bij de wet bepaald'): omstandigheden waaronder iemand het land niet uit mag of de voorwaarden waaronder dat wel mag. In de MvT worden als omstandigheden genoemd: veroordeling in Nederland tot gevangenisstraf en die nog moeten ondergaan; bij schorsing van iemands voorlopige hechtenis; het zich onttrekken aan een op jemand rustende onderhoudsplicht door vestiging in het buitenland; bij belastingschuld of staat van faillissement. ${ }^{25}$ Concreet zijn ook de woorbeelden van de beperkingen van het recht op onaantastbaarheid van het menselijk lichaam (artikel $11 \mathrm{Gw}$ 'Ieder heeft, behoudens bij of krachtens de wet te stellen beperkingen, recht op onaantastbaarheid van zijn lichaam'): medisch onderzoek in verband met de aanstelling van overheidspersoneel; medisch onderzoek van dienstplichtigen; inentingsregelingen voor millitairen; medisch onderzoek in verband met bepaalde regelingen over sociale uitkeringen; gedwongen verpleging van geesteszieken; bloedproef; fouillering van het lichaam. ${ }^{26}$ Ook zou elke toevoeging van stoffen aan dranken en voedsel onder de werking van het artikel kunnen vallen (de Warenwet, Vleeskeuringswet en Waterleidingwet bieden een wettelijke grondslag). Daarentegen is de verplichting tot het gebruik van de autogordel of bromfietsvalhelm geen inbreuk op het recht op onaantastbaarheid van het menselijk lichaam. ${ }^{27}$

24. Kamerstukken II 1976-1977, 14200 (R1048), nr 3 MvT, p.4-5. Nu de Grondwet voor vreemdelingen de eis stelt dat de regeling bij of krachtens formele wet geschiedt geldt dat ook voor Nederlanders. "Daar komt nog bij, dat het in ons staatsbestel niet denkbaar is, dat een dergelijke regeling, die zo diep zou ingrijpen in de positie van Nederlanders, zou worden vastgesteld bij een zelfstandige algemene maatregel van bestuur of een zelfstandige ministeriêle verordening. In het geheel van ons constitutionele recht kan dat niet anders dan bij formele wet geschieden. "Handelingen II 1977-1978, p.2767 (Minister van Binnenlandse Zaken)

25. Kamerstukken II $1976-1977,14200$ (R1048), nr 3 MvT, p.9.

26. Kamerstukken II 1978-1979, 15463, nr 4 Lijst van antwoorden, p.2. "Wij merken hierbij verder op dat zich terreinen van het recht op onaantastbaarheid van het lichaam laten denken waarbij de wet de beperkingen op dit recht zelf geheel vast dient te leggen en geen regelgeving aan lagere organen zal behoren toe te staan. Te wijzen valt op de regeling van de fouillering van het lichaam, zoals onder meer neergelegd in artikel 56 Wetboek van Strafvordering en artikel 19 Vreemdelingenwet. "Kamerstukken II 1979-1980, 16086, nr 3 MvT, p.6.

27. Handelingen II 1979-1980, p.5324 (Minister Wiegel). 
Bij de grondwetsherziening van 1987 stelde de regering bij artikel 12 lid $2 \mathrm{GW}$ ('Voor het binnentreden overeenkomstig het voorgaande lid zijn voorafgaande legitimatie en mededeling van het doel van het binnentreden vereist, behoudens bij de wet gestelde uitzonderingen. Aan de bewoner wordt een schriftelijk verslag van het binnentreden verstrekt') dat de wetgever de uitzonderingsbevoegdheid slechts met betrekking tot drie categorieën van gevallen mag toepassen: in verband met ernstig en onmiddellijk gevaar voor de veiligheid van personen (noodsituaties); in verband met de opsporing of beëindiging van misdrijven die de rechtsorde ernstig schokken en in die gevallen waarin legitimatie en mededeling van het doel van het binnentreden feitelijk onmogelijk zijn (bijvoorbeeld bij afwezigheid van de bewoner of geen reactie op bellen/kloppen). ${ }^{28}$

Ten aanzien van artikel 53 lid $1 \mathrm{Gw}$ ('De leden van beide kamers worden gekozen op de grondslag van evenredige vertegenwoordiging binnen door de wet te stellen grenzen") stelt de regering dat het evenredigheidsbeginsel ook in afzonderlijke kiesgebieden kan worden toegepast. De omvang van een kiesgebied bepaalt de grondwettigheid. Beslissend hiervoor acht de regering de mate waarin de uitkomsten van dat stelsel uit een oogpunt van evenredigheid afwijken van de zetelverdeling bij een stelsel zonder kiesgebieden zoals we dat thans kennen. De afwijkingen mogen slechts zeer gering zijn. Vier kiesgebieden mag, 18 kiesgebieden zou ongrondwettig zijn. Per kiesgebied zouden dan slechts 3-4 zetels te verdelen zijn. ${ }^{29}$

Bij de behandeling van artikel $111 \mathrm{Gw}$ ('Ridderorden worden bij de wet ingesteld") schetst de CDA-fractie de voor haar wenselijke hoofdlijnen van een wettelijke regeling als volg ${ }^{30}$ : erkenning in de Nederlandse adel blijft mogelijk voor leden van geslachten waarvan takken van Nederlandse adel zijn; verheffing is voorbehouden aan (toekomstige) leden van het Koninklijk Huis; inlijving is slechts mogelijk voor Nederlanders afkomstig uit landen, die op het moment van indiening van een verzoek tot inlijving nog adeldom kennen; ontadeling moet geregeld worden. ${ }^{31}$ Dit laatste acht de minister niet wenselijk. ${ }^{32} \mathrm{Nu}$ het grondwettelijk verbod op het aannemen van buitenlandse ordetekenen vervalt is het de bedoeling dat verbod in de gewone wet op te nemen, bijvoorbeeld door wijziging

28. Kamerstukken II 1984-1985, 19013, nr 3 MvT, p.6.

29. Kamerstukken II 1978-1979, 14223, nr 6 M*A, p.3.

30. Additioneel artikel XXV eist een wettelijke regeling wan de adeldom. De wetgever kan bepalen of adeldom bij wet of bij KB wordt verleend. De regering zegt dit nog niet te weten. De kwestie zal in de toekomst door de wetgever worden beslist. Handelingen I $1980-1981$, p.613 en p.645 (minister Wiegel).

31. Handelingen II 1979-1980, p.5935-5936 (Van der Burg, CDA).

32. Handelingen II 1979-1980, p.6020 (minister Wiegel). 


\section{Hoofdstuk 9}

van artikel 435 ten tweede Wetboek van Strafrecht. ${ }^{33}$ De herziening van het decoratiestelsel beoogt een vermindering van het aantal vormen van onderscheidingstekens. Een dapperheidsonderscheiding zou er weer een meer zijn. ${ }^{34}$

Bij artikel 116 lid $2 \mathrm{GW}$ ('De wet regelt de inrichting, samenstelling en bevoegdheid van de rechterilike macht') kan toepassing bijvoorbeeld geschieden om onderlinge taakwerdeling mogelijk te maken; om het aantal rechters te bepalen anders dan bij formele wet; om ook andere taken op te dragen zoals het benoemen van een voogd of curator of het uitoefenen van toezicht op het beheer van voogden en dergelijke. ${ }^{35}$ Als criterium voor het behoren tot de rechterlijke macht kan gelden: instanties die een duurzame rechterlijke taak vervullen. ${ }^{36}$

Vaak onthoudt de grondwetgever zich opzettelijk van specifieke aanwijzingen omdat de wetgever in de toekomst ruimte nodig heeft om naar bevind van zaken te handelen. Dat gebeurt bij de behandeling van artikel $122 \mathrm{Gw}$ ('Gratie wordt verleend bij koninklijk besluit na advies van een bij de wet aangewezen gerecht en met inachtneming van bij of krachtens de wet te stellen voorschriften. Amnestie wordt bij of krachtens de wet verleend'). Aan de wetgever wordt overgelaten welk gerecht advies moet verlenen. De formele wet hoeft niet de criteria aan te geven voor de gevallen waarin gratie dient te worden verleend. De uitoefening van het gratierecht zall een zaak blijven van de regering. De Staten-Generaal kan de minister ter verantwoording roepen. ${ }^{37}$

Zelfs wanneer duidelijke keuzes mogelijk zijn wordt dat uit de weg gegaan. Een voorbeeld biedt de behandeling van artikel $135 \mathrm{Gw}$ ('De wet geeft regels ter voorziening in zaken waarbij twee of meer openbare lichamen zijn betrokken. Daarbij kan in de instelling van een nieuw openbaar lichaam worden voorzien, in welk geval artikel 134, tweede en derde lid, van toepassing is'). In het Voorlopig Verslag werd door leden van de VVD gevraagd of de regering ter zake van de uitwerking van dit artikel dacht aan: een wet die algemene regels over modellen van samenwerking geeft, dan wel incidentele wetten, toegesneden op de concrete samenwerking van bepaalde, met name aangeduide openbare lichamen. ${ }^{38}$ De regering antwoordde dat de wetgever de ruimte heeft te beslissen op grond van de behoeften van de bestuurspraktijk. ${ }^{39}$

33. Handelingen II $1979-1980$, p.6019 (minister Wiegel).

34. Kamerstukken $11980-1981,15883$ (R1129), nr $7 \mathrm{~b}$ MvA, p.2.

35. Kamerstukken II 1979-1980, 16162, nr 3 MvT, p.17.

36. Kamerstukken II 1980-1981, 16162, nr 8 MvA, p.18.

37. Kamerstukken II 1979-1980, 16162, nr 3 MvT, p.24.

38. Kamerstukken II 1976-1977, 13995, nir 5 VV, p.3.

39. Kamerstukken II 1976-1977, 13995, nr 6 MvA, p.1-2. 
Op andere momenten echter is de grondwetgever bang voor 'de waan van de dag" en wil ze de bevoegdheid van de wetgever zo veell mogelijk concretiseren en aan banden leggen. Het zijn vooral Kamerleden die hierover opmerkingen maken. Zo merken leden van de VVD-fractie over artikel $1 \mathrm{GW}$ op ('Allen die zich in Nederland bevinden, worden in gelijke gevallen gelijk behandeld. Discriminatie wegens godsdienst, levensovertuiging, politieke gezindheid, ras, geslacht of op welke grond dan ook, is niet toegestaan') "Brengt de 'vrij grote beleidsvrijheid. die volgens de toelichting aan de wetgever wordt open gelaten niet tevens mee dat hij in een eventueel verschuivend oordeel over de vraag welke aspecten in een gegeven situatie relevant zijn, het gelijkheidsgebod zozeer naar eigen maat snijdt dat het voor hem meer een subjectieve dan een objectieve norm is? ${ }^{140}$ En leden van de GPV-fractie: "Wat is de betekenis van dit grondwetsartikel voor de wetgever? Moet ook hier niet verwacht worden dat deze bepaling in de praktijk weinig zal inhouden, omdat de wetgever zelf, als enige uitlegger van de wet, bepaalt wat gelijke gevallen zijn? En zal de uitlegging daarvan niet sterk afhangen van de politieke overtuigingen?"${ }^{14 !}$

De PvdA-fractie uit haar bezorgdheid bij de behandeling van artikel 7 lid $1 \mathrm{Gw}$ ('Niemand heeft voorafgaand verlof nodig om door de drukpers gedachten of gevoelens te openbaren, behoudens ieders verantwoordelijkheid volgens de wet') en wil een instructienorm voor de wetgever die voorschrijft dat de wetgever regels moet stellen om pluriformiteit van informatieverstrekking te waarborgen een en ander ter voorkoming van monopolievorming. ${ }^{42}$

En bij de behandeling van artikel 57 lid $4 \mathrm{Gw}$ ('De wet kan ten aanzien van andere openbare betrekkingen bepalen dat zij niet gelijktijdig met het lidmaatschap van de Staten-Generaal of van een der kamers kunnen worden uitgeoefend') merkt de Raad van State op dat de wetgever teveel vrijheid heeft. "Het constitutioneel recht van iedere burger om niet slechts als volksvertegenwoordiger te worden gekozen, maar ook als zodanig te functioneren wordt aldus aan de grondwettelijke bescherming onttrokken."4,3 De regering antwoordt dat zij het liefst een uitputtende regeling in de Grondwet zou willen maar dat dat gezien de aard van het onderwerp niet kan, nu niet duidelijk is wat er in de toekomst nodig is. ${ }^{44}$ Ook het CDA vindt de voorgestelde bepaling te ruim: 'andere be-

40. Kamerstukken II 1975-1976, 13872, nr 6 VV p.24.

41. Kamerstukken II 1975-1976, 13872, nr 6 VV p.26.

42. Kamerstukken II 1975-1976, 13872, nr 6 VV, p.33.

43. Kamerstukken II 1976-1977, 14223, nr 4 Bijlagen bij de MvT, Bijlage I Adwies van dle RvS, p. 28.

44. Kamerstukken II 1976-1977, 14223, nr 4 Bijlagen bij de MvT, Bijlage II Nader rapport, p.35. 


\section{Hoofdstuk 9}

trekkingen" wordt 'andere openbare betrekkingen" na aanvaarding van een amendement De Kwaadsteniet. ${ }^{45}$

\subsubsection{Conclusie}

Na lezing van de parlementaire stukken valt op dat een samenhangende visie op een grondwettelijk te regelen onderwerp ontbreekt, althans niet uit het verhandelde is op te maken. Slechts incidenteel worden (inhoudelijke) aanwijzingen voor de formele wetgever gegeven. Er is geen stelsel van criteria te ontdekken dat daarbij gehanteerd wordt. Dat maakt de opgave voor deze paragrataf (cen onderzoek naar mogelijk gehanteerde criteria) een moeilijke, want wat er niet is kan (in dit geval) ook niet aangetoond worden.

In veel gevallen is er in het kader van de delegatieterminologie wel iets gezegd over wat er wel of wat er niet in een formele wet thuishoort (zie Bijlage), maar enige samenhang, of systematisch gehanteerde criteria, heb ik niet kunnen ontdekken.

Ook het criterium 'ingrijpende besluiten' uit het Fluorideringsarrest komt nauwelijks als zodanig terig. Van der Burg heeft het Fluorideringsarrest qua belang wel vergeleken met het Meerenbergarrest; ${ }^{46}$ het Fluorideringsarrest staat volgens hem gelijk met een grondwetswijziging. Dat dit criterium bij de afgelopen grondwetsherziening niet gecodificeerd is betekent volgens hem niet dat de grondwetgever het criterium terzijde heeft gesteld, maar dat er gewoonweg niet aan gedacht is. Men wilde het oude artikel 57 overnemen. ${ }^{47}$ Volgens Van der Burg geldt het Fluorideringsarrest ook naast de herziene Grondwet. ${ }^{48}$ Hoewel ik het met Van der Burg eens ben dat (het criterium uit) het Fluorideringsarrest geen grote rol heeft gespeeld bij de grondwetsherziening van $1983 \mathrm{en} \mathrm{ik} \mathrm{dit,} \mathrm{evenals}$ hij, toeschrijf aan een praktisch feit, namelijk dat er simpelweg nauwelijks aan gedacht is, is dit wel een zwak argument. De vraag is of het arrest wel zoveel waarde toekomt als (sommige) wetenschappers veronderstellen, nu er bij de grondwetsherziening nauwelijks aandacht aan is besteed en het criterium uit dit arrest in ieder geval niet door de grondwetgever is geconstitutionaliseerd.

45. Kamersitukken 11 1979-1980, 14223, nr 15.

46. HR 13 januari 1879, W. 4330.

47. 'Door de Koning worden algemene maatregelen van bestuur vastgesteld. Bepalingen, door straffen te handhaven, worden in die maatregelen niet gemaakt, dan krachtens de wet. De wet regelt de op te leggen straffen."

48. Van der Burg $1986 \mathrm{~b}$, p.62-63. 
De enkele opmerking dat een besluit of maatregel een ingrijpend karakter heeft is in de parlementaire stukken niet vaak terug te vinden. Het enige criterium lijkt te zijn dat een bepaald onderwerp (politiek) zo belangrijk is dat regeling bij (of krachtens) formele wet wenselijk is. Soms wordt dit criterium expliciet genoemd, vaak ook wordt het niet uitgesproken. ${ }^{49}$

In de wetenschappelijke literatuur en regeringsstukken is er het laatste decennium veel oog voor de verhouding tussen de formele wet en lagere regelgeving, het legaliteitsbeginsel en het materieel wetsbegrip. Die aandacht is onder meer uitgemond in de Aanwijzingen voor de regelgeving 1993. De daarin opgenomen bepalingen over in de formele wet op te nemen onderwerpen (zie paragraaf 9.4.3) zullen bij een eventuele volgende grondwetsherziening een rol kunnen spelen.

\subsection{Opvattingen over de inhoud van het legaliteitsbeginsel na 1983}

\subsubsection{Opvattingen in handboeken}

De grondwettelijke delegatieterminologie, en ruimer het delegatievraagstuk, zijn ingebed in een bredere staats- en bestuursrechtelijke context: de 'democratische en sociale rechtsstaat' ${ }^{50}$ Veel auteurs onderscheiden nagenoeg dezelfde kenmerken van een 'rechtsstaat ${ }^{51}$ zoals een scheiding der machten: wetgeving (mede)

49. Zie echter Van der Vlies 1984, p. 184: "Gezien de ontwikkelingen in de jurisprudentie en de dogmatiek, en gezien de praktijk van de totstandkoming van wetten en de problemen van wetgeving. werd in hoofdstuk 5 gesteld dat de wetgever zijn competentie zou moeten beperken tot het vaststellen van de ingrijpende besluiten. De kamerdiscussies over de aard van de competentie van de wetgever in de nieuwe Grondwet geven aanleiding om aan te nemen dat dit wetsbegrip een adequate interpretatie van art. 81 Gw 1983 zou zijn. De kamers hebben immers de wens te kennen gegeven om (mede) beleidsbepalende beslissingen wast te stellen, 20 mogelijk via de wetgevingsprocedure."

50. Stroink/Steenbeek 1993, p.49-50, platsen 'het ontstaan' van de democratische rechtsstaat in 1887: het jaar warrin in de Grondwet is neergelegd dat de Kroon geen bepalingen door straffen te handhawen kan uitvaardigen zonder formeel-wettelijke grondslag. "In deze constellatie kan men zien dat het rechtsstaatsbeginsel aangewuld is met het democratisch postulaat, dat het volk, middels zijn vertegenwoordiging, meebeslist over de regelen die de samenleving beheersen."

51. Zie bijwoorbeeld Van der Pot/Donner/Prakke 1989, p. 159; Van der Vlies 1991, p.78; Van Wijk/Konijnenbelt/Van Male 1994, p.41; Kortmann 1994, p.46-50; Koopmans 1994. p.13. Zie echter Scheltema 1989, p.14 die constateert dat in de recente Nederlandse literatuur "opsommingen van elementen van de rechtsstaat (worden) gegeven, die onderling verschillen en bovendien vaak ongelijksoortige elementen bevatten." In mijn optiek 


\section{Hoofdstuk 9}

in handen van een (gekozen) parlement; bestuursoptreden op basis van de wet; een onafhankelijke rechter; en waarborging van grondrechten. Het democratisch element is bij sommigen ${ }^{52}$ (soms impliciet) aanwezig waar zij er vanuit gaan dat de wetgeving tot stand komt met medewerking van een door burgers gekozen parlement, en bij anderen niet. ${ }^{53}$

Het legaliteitsbeginsel ${ }^{54}$ is omschreven als 'bestuursoptreden op basis van een wet' ${ }^{55}$ In de klassieke opvatting houdt het beginsel in dat voor ingrepen door het bestuur in de vrijheid en eigendom van de burger een wettelijke basis dient te zijn: ${ }^{56}$ De begrippen 'bestuur' en "wet' nemen een centrale plaats in. Daarover schrijft Van Male: "In de klassieke rechtsstaatconceptie kwam aan de wet een centrale positie toe. De wet vormde de primaire rechtsbron en werd vastgesteld door de primaire wetgever. Zij vormde het instrument waarmee de met uitvoering en rechtspraak belaste organen ter wille van de vrijheid en de eigendom van de individuele burger werden gebonden. ${ }^{157}$ En: "De centrale positie van de wet als warborg voor de burger komt tot uitdrukking in het legaliteitsbeginsel. Dit beginsel houdt enerzijds in dat het bestuur zijn zelfstandig benadelende bevoegdheden slechts aan de wet kan ontlenen, anderzijds dat het bij de uitoefening van zijn bevoegdheden de wet in acht behoort te nemen. De binding van het bestuur aan de wet vindt zijn complement in het rechterlijk toezicht: de burger heeft

zijn echter de overeenkomsten in de verschillende omschrijvingen groter dan de verschillen. Scheltema behandelt de grondslagen van de rechtsstaat vanuit vier beginselen: het rechtzekerheidsbeginsel, het gelijkheidsbeginsel, het democratiebeginsel en het beginsel van de dienende overheid. Scheitema 1989, p.15.

52. Zoals bij Van der Pot/Donner/Prakke 1989; Wan Wijk/Konijnenbelt/Van Male 1994 en Kortmann 1994.

53. Zoals bij Koopmans 1994, p.13.

54. Een term die vooral in de literatuur is uitgewerkt. In zijn noot bij HR 8 oktober 1993, AB 1994, 299 merkt Van der Burg op dat het bij zijn weten de eerste keer is dat de Hoge Raad de term legaliteitsbeginsel gebruikt. De Hoge Raad noent het legaliteitsbeginsel in relatie tot de artikelen 104 en $132 \mathrm{Gw}$. De Centrale Raad van Beroep gebruikt de term legaliteitsbeginsel in CRvB 11 mei 1994, JB 1994/152 m.nt. FAMS.

55. Voor het bestuursrecht nader gespecificeerd als het specialiteitsbeginsel. Zie Van Wijk/Konijinenbelt/Van Male 1994, p.425, noot 193: "een bepaalde wettelijke regeling is gericht op, en het bereik ervan beperkt tot, speciale doelen of belangen".

56. Vergelijk Böhtlingk in Böhtlingk/Logemann 1966, p.15: "Volgens de in de Franse Revolutie aanvaarde beginselen mogen de burgers slechts "geboden en verboden (...) worden gesteld bij de wet, dus bij een van de wetgever uitgaande algemene rechtsregel." Aangehaald bij Hirsch Ballin 1989, p.9-10. Zie ook Van Wijk/Konijnenbelt/Van Male 1994, p.41.

57. Van Male 1988, p. 262. 
terzake van bestuursgeschillen in principe recht op toegang tot de onafhankelijke rechter, zulks als waarborg voor de naleving van het legaliteitsbeginsel. ${ }^{n 58}$ De maatschappelijke veranderingen die hebben geleid tot de verschuiving van 'klassieke' rechtsstaat naar 'sociale' rechtsstaat (de opkomst van de verzorgingsstaat) hebben ook consequenties voor de inhoud van het legaliteitsbeginsel. Die veranderingen vinden we terug in de verschillende omschrijvingen van het legaliteitsbeginsel in de literatuur.

Bij Van der Pot/Donner/Prakke houdt het legaliteitsbeginsel in dat bestuursoptreden op de wet berust (zonder de toevoeging dat die eis slechts geldt wanneer het bestuursoptreden benadelend voor de burger is) ${ }^{5 \%}$ Scheltema omschrijft de legaliteitseis ${ }^{60}$ als "de eis dat het optreden van de overheid op een wettelijke grondslag moet berusten. Deze eis is in het positieve recht uitgewerkt door grondwetsbepalingen die een wettelijke grondslag vereisen voor bestuursoptreden waaruit voor de burger verplichtingen voortvloeien. ${ }^{n 6 l}$ Van Wijk/Konijnenbelt/Van Male omschrijven het legaliteitsbeginsel als "wetmatigheid van bestuur: de uitvoerende macht bezit uitsluitend die bevoegdheden welke haar uitdrukkelijk door de Grondwet of door een andere wet zijn toegekend. " ${ }^{62}$ In de woorden van Kortmann houdt het legaliteitsbeginsel in dat "Elk overheidsoptreden dient te berusten op een algemene, d.w.z. voor herhaalde toepassing vatbare, regel, hetzij krachtens attributie, hetzij krachtens delegatie vastgesteld. Tevens moet dat optreden conform de algemene regel zijn, qua inhoud en procedure. " ${ }^{63}$ En bij Koopmans wordt het legaliteitsbeginsel beschreven als het beginsel "dat de staat niet naar willekeur optreedt, maar (in principe) louter op grond van algemene regels. ${ }^{164}$ Een ruime omschrijving vinden we eveneens bij Van der Vlies: "Het legaliteitsbeginsel houdt in dat de inrichting en het handelen van het bestuur onderworpen

58. Van Male $1988, p .263$.

59. Van der Pot/Donner/Prakke 1989, p.159.

60. Hij ziet de legaliteitseis als onderdeel vars het rechtzekerheidsbeginsel. Scheltema 1989. p. 16.

61. Scheltema 1989, p. 16.

62. Van Wijk/Konijnenbelt/Van Male 1994; p.31. In een noot voegen zij eraan toe: "Daarbij wordt ervan uitgegaan, dat de 'wet' een algemene regeling is, afkomstig (...) van de parlementaire wetgever."

63. Kortmann 1994, p.48. Zie ook Kortmann, Constitutioneel recht, 1990, p.33 en p.304. Van Male merkt hierover op: (Kortmann) "gebruikt een weel ruimere omschrijving: het legaliteitsbeginsel houdt z.i. globaal genomen in dat alle overheidsoptreden moet berusten op en overeenstemmen met algemene regels. Een dergelijke norm windt evenwel onvoldoende grondslag in de jurisprudentie." Van Male in Akkermans/Koekkoek 1992, p.784.

64. Koopmans 1994, p. 13. Een vroege aanhanger van zo'n ruime opvatting van het legaliteitsbeginsel is Böhtlingk 1958, p.17. Aangehaald bij Hirsch Ballin 1989, p.10-11. 


\section{Hoofdstuk 9}

moeten zijn aan het recht. De inhoud van het legaliteitsbeginsel is dus niet afdoende omsehreven met de eis dat het handelen van het bestuur onderworpen moet zijn aan de wet. Het heeft mede betrekking op het systeem waarmee wordt bereikt dat het bestuur zich daadwerkelijk aan de wet houdt. Het legaliteitsbeginsel houdt in de meest ruime zin in dat het bestuur bij al zijn handelen voldoet aan ongeschreven rechtsbeginselen, dat de grondrechten in de staat worden gerespecteerd en dat er een adequaat systeem van rechtsbescherming is. Het element dat het handelen van het bestuur aan de wet onderworpen is, is dus slechts een van de elementen. Het samenstel van deze elementen wordt ook wel als rechtsstaat aangeduid. " 5 Sirsch Ballin tenslotte 'thematiseert' het legaliteitsbeginsel als een grondrecht op vrijheid behoudens beperkingen bij wettelijk voorschrift, ${ }^{66}$ waarbij opvalt dat het legaliteitsbeginsel niet zozeer wordt geformuleerd als richtsnoer voor handelen van de overheid, en gericht tot die overheid, maar als 'afweerrecht' voor de burger ten opzichte van die overheid.

In verschillende van de hierboven weergegeven omschrijvingen van het legaliteitsbeginsel wordt dit beginsel geacht niet alleen meer van toepassing te zijn op het 'bestuur', maar op 'de staat' of 'de overheid". De eis van een grondslag in de formele wet vindt vertaling in de eis dat het handelen genormeerd moet worden volgens algemene regels. ${ }^{67} \mathrm{Bij}$ de meeste auteurs dienen die algemene regels een wettelijke grondslag te hebben, ${ }^{68}$ maar bij Koopmans is het wettelijk vereiste losgelaten. Tot de algemene regels die een voldoende basis kunnen bieden kunnen kennelijk ook behoren de algemene beginselen van behoorlijk bestuur en beleidsregels. ${ }^{69} 70$

65. Van der Vlies 1991, p.78. De kritiek, dat het legaliteitsbeginsel geen enkele imhoudelijke eis stelt aan bestuursoptreden (wanneer het berust op een wettelijke grondslag) is onder meer geuit door N. Verheij, Ministerielle regelingen en ministerièle besluiten, Staatsrechtconferentie 1984 (stencil) " p.2. Hij verwijst daarbij naar Ter Spill en Tak 1981, p.32, "die betogen dat de eis van inhoudelijke normering uit de wetmatigheidseis zou moeten worden afgeleid, maar tevens constateren dat zulks in de jurisprudentie niet gebeurt". $Z$ o bepleit Eijlander 1993, p.47 (is Eijlander, De regelgeving geordend?, in NJB 1986, p.13901393): "Een aangepast legaliteitsbeginsel, in die zin dat de wetgever zelf de structurele ellementen en belangrijkste voorschriften moet geven (ook als het gaat om positief, presterend overheidsoptreden) gecombineerd met de eis dat delegatiebepalingen nauwkeurig moeten worden omschreven en geclausuleerd, (...)."

66. Hirsch Ballin 1989, p.5.

67. Zie hoofdstuk 8 voor de onduidelijkheid die rond het vereiste van algemeenheid heerst.

68. Zoals bij Scheltema 1989, p. 16 en bij Kortmann 1994, p.48.

69. Koopmans 1994, p.13-14. Zie paragraaf 2.1 .7 en verder hoofdstuk 8 woor een omschrijving van het begrip 'beleidsregel'. 
Aan de ene kant lijkt het legaliteitsbeginsel dus 'soepeler' van betekenis te zijn geworden: de strikte eis van wettelijke grondslag wordt (in sommige gevallen) losgelaten, eer basis in een 'algemene (rechts)regel' lijkt dan voldoende ${ }^{7 !}$; aan de andere kant wordt meer overheidshandelen onder de werking van het legaliteitsbeginsel gebracht en wordt de reikwijdte van het legaliteitsbeginsel op die manier uitgebreid. ${ }^{72}$

Er rijzen vragen als: geldt het legaliteitsbeginsel ook voor (wat wordt genoemd) de presterende functie van de overheid (paragraaf 9.3.2.1); en geldt het legaliteitsbeginsel voor privaatrechtelijk handelen van de overheid (9.3.2.2)? Kunnen bestuursbevoegdheden worden ontleend aan het ongeschreven recht $(9.3 .2 .3)$ ? En is de wetgever gebonden aan het legaliteitsbeginsel (9.3.2.4)?

\subsubsection{Een veranderende inhoud?}

\subsubsection{Een wettelijke grondslag voor de presterende functie van de overheid?}

Wanneer het gaat om de presterende functie van de overheid is de vraag aan de orde of daarop het legaliteitsbeginsel van toepassing is, in die zin dat er een wettelijke grondslag vereist is. Deze vraag beantwoordde Hirsch Ballin in zijn rede voor de Vereniging voor Wetgeving en Wetgevingsbeleid bevestigend. Met de inwerkingtreding van de herziene Grondwet van 1983 werd volgens hem niet alleen voor vrijheidsbeperkingen door de overheid, maar ook voor andersoortig overheidsoptreden een wettelijke grondslag vereist. Hij noemde met name de

70. Zie over de werruiming van het legaliteitsbeginsel ook Hirsch Ballin 1989, p.11, verwijw zend naar Oostenbrink 1978; Ter Spill/Tak 1981 en Donner 1981a. Zie ook Bröring 1993a, p.398-399: "beleidsregels blijken verregaand recht te doen aan de aan het legaliteitsbeginsel ten gronde liggende rechtsstatelijke warden van rechtszekerheid en gelijkheid in behandeling. Daarbij is de tegenwerping dat deze regels doorgaans een democratische legitimatie missen weinig overtuigend. Want dit geldt evenzeer voor perifere be stuurswetgeving (een woorbehoud past bij de algemene matregelen van bestuur)."

71. Deze benadering is ook terug te vinden in de jurisprudentie van het Europese Hof voor de Rechten wan de Mens over de uilleg van het begrip 'wet' en daarmee samenhangende legaliteitsvereisten. In deze jurisprudentie wordt de eis gesteld dat het recht/de wet voldoende 'accessible and foreseeable' is: het recht moet voldoende toegankelijk zijn voor de burger, en voorzienbaar (de burger moet kunnen zien op welke normen hij zijn gedrag dient af te stemmen). Zie het Sunday Times arrest, EHRM 26 april 1979 , NJ 1980, 146 , Vol. 30 paragrafen 47 en 49 . In sommige gevallen voldoen ook beleidsregels aan deze eisen. Zie over de legaliteitscontrole door het Europese Hof voorts de noot van E.A. Alkema onder EHRM 22 juni 1989, NJ 1992, 705.

72. Zie voor de wenselijkheid van die verruiming ook Damen 1987, p. 270-271, die de verruiming ontleent aan de eisen van een democratšsche legitimatie, de rechtszekerheid en rechtsgelijkheid. 


\section{Hoofdstuk 9}

presterende functie van de overheid: "(..) het ereëren van voorzieningen die de vrijheid van de burger beogen te bewerkstelligen c.q. te versterken." ${ }^{\text {"73 }}$

Ook buiten de Grondwet wordt op sommige gebieden een wettelijke grondslag geëist voor presterend overheidsoptreden. Hirsch Ballin noemde het voorbeeld van subsidieverlening door de overheid. Zo wordt in het voorontwerp van de Derde tranche van de Awb voorgesteld om subsidieverlening een wettelijke grondslag te geven. ${ }^{74}$

Al eerder stelde Konijnenbelt voor om een wettelijke grondslag te eisen voor wat hij noemt de 'Leistungsverwaltung ' die tevens 'Eingriffsverwaltung' is, presterend handelen door de overheid waaraan ook nadelen voor de burger verbonden zijn, bijvoorbeeld subsidiebeschikkingen, waarbij voorschriften worden gesteld, die bezwarend zijn voor de burger. ${ }^{75}$

Nog verder ging het voorstel van De Haan/Drupsteen/Fernhout om te streven "het overheidsbeleid en daarmee het bestuur over de gehele linie een wettelijke grondslag te geven." ${ }^{176}$ Dit voorstel is niet onverdeeld met gejuich ontvangen. Hirsch Ballin zag hierbij problemen "om tot een zinvolle normering te komen." ${ }^{77}$ Wanneer de wetgever daarbij zijn toevlucht zou nemen tot blanketwetgeving en veel zou delegeren biedt dat 'uit een oogpunt van vertrouwen op het recht weinig voordelen' in de zin van waarborgen voor de burger. ${ }^{78}$

In die zin achtte Hirsch Ballin de ontwikkeling, neergelegd in de herziene Grondwet, waarbij voor veell onderwerpen expliciet een wettelijke grondslag wordt gevraagd, gelukkiger: "De herziene Grondwet heeft, zonder het klassieke legaliteitsbeginsel overboord te zetten, het aldus inderdaad mogelijk gemaakt, voor de bepaling in welke gevallen het bestuurshandelen een wettelijke grondslag behoeft, consequenties te verbinden aan de aard en het gewicht van de in een sociale rechtsstaat te behartigen belangen. Dit betekent intussen niet dat de grondwettelij-

73. Hirsch Ballin 1992, p. 100.

74. (Thans wetsvoorstel.) Hirsch Ballin 1992, p.100. Tegen de eis van een wettelijke grondslag voor alle subsidiering is Van der Vlies 1989, p.70: "Tegenwoordig wordt veel raamwetgeving in verband met subsidiering gemaakt. Het is niet te verwachten dat de praktijk van de subsidiëring daardoor wezenlijk zal veranderen, omdat de normen volgens welke zall worden gesubsidieerd niet in de wet zelf worden opgenomen. Men kan stellen dat het bij dit soort wetgeving meer gaat om wettelijke windowdressing, dan om een effectieve naleving van het legaliteitsbeginsel. Wetgeving zonder inhoudelijke normering heeft weinig te betekenen voor het verhogen van de bestuursk waliteit."

75. Konijnenbelt 1982, p.654; Van Wijk/Konijnenbelt/Van Male 1994, p.41-43.

76. De Haan/Drupsteen/Fernhout I 1986, p.229.

77. Hirsch Ballin 1989, p.45.

78. Hirsch Ballin 1989, p.45. In dezelfde zin Kobussen 1991, p.117; Van Male in Akkermans/Koekkoek 1992, p. 793 en Van Wijk/Konijnenbelt 1993, p.41-42. 
ke vereisten inzake wettelijke regelingen als eindpunt van de rechtsontwikkeling moeten worden beschouwd. "79

Er lijkt kortom een uitbreiding van de werking van het legaliteitsbeginsel plaats te vinden: enerzijds doordat de Grondwet een wettelijke basis eist ook bij onderwerpen waarbij het handelen van de overheid niet benadelend voor de burger hoeft uit te pakken ${ }^{80}$ en anderzijds doordat ook buiten de Grondwet om voor (bepaald) begunstigend handelen van de overheid een wettelijke basis wordt geeist. $^{81}$

\subsubsection{Geldt het legaliteitsbeginsel voor privaatrechtelijk handelen van de overheid?}

Voor de vraag $^{82}$ of het legaliteitsbeginsel geldt voor privaatrechtelijk handelen van de overheid is van belang om eerst vast te stellen dat het legaliteitsbeginsel hier in de 'klassieke' betekenis gehanteerd wordt: de eis van een wettelijke grondslag voor benadelend ingrijpen van de overheid in de vrijheid en eigendom van de burger.

Deze opvatting loslaten op privatrechtelijk handelen van de overheid doet op het eerste moment wat vreemd aan. Kan in dat verband wel gesproken worden van 'benadelend' handelen van de overheid? Het privaatrecht gaat immers uit van partijautonomie. Voor een van de meest voorkomende vormen van privaatrechtelijk handelen, de overeenkomst, is wilsovereenstemming een vereiste om de overeenkomst tot stand te laten komen. Beide betrokken partijen dienen hun toestemming te geven. Die toestemming dekt de legitimiteit van de overeenkomst. $^{83}$

79. Hirsch Ballin 1989, p.55.

80. Zie bijwoorbeeld de artikelen 18 lid 2, 19 lid 2, 20 leden 2 en 3 en $109 \mathrm{Gw}$.

81. Zie echter Van der Burg 1993, p. 108 over de gelding van het legaliteitsbeginsel voor presterend overheidsoptreden: "Ik beschouw deze ruime opvatting van het legaliteitsbeginsel echter niet als geldend recht, maar als een rechtspolitiek desideratum."

82. De vraag is pas de laatste jaren aktueel en wordt onder andere besproken door Kobussen 1991, p. 107-118; Van Male 1992, p.790-791 en Simon 1993, passim. Hirsch Ballin 1989, p. 17 erkent dat hier een mogelijke uitbreiding van de werking van het legaliteitsbeginsel in het geding is, maar merkt op dat er 'significante verschillen' zijn tussen bestuursrechtelijk en privaatrechtelijk optreden van de overheid. Hij gaat verder niet in op de vraag of voor dit laatste optreden een wettelijke grondslag vereist is.

83. De legitimiteit van de handelling ten opzichte van derde-belanghebbendenis hiermee echter niet gedekt. In het publieke recht wordt de legitimiteit wan het (benadelend) handelen van de overheid gedekt door (een grondslag in) een formele wet, die tot stand gekomen is met medewerking van het gekozen parlement: op deze wijze worden regels wastgesteld die de burger 'zelf heeft gewild'. 


\section{Hoofdstuk 9}

Dit is niet anders wanneer overheid en burger de partijen zijn. Ondat het niet aannemelijk is dat de burger toestemming geeft voor een handeling die (louter) nadelig voor hem is, zal de overheid niet verweten kunnen worden eenzijdig 'benadelend' te handelen.

Het uitgangspunt van de partijautonomie in het privaatrecht is echter in verschillende situaties niet meer geldig. ${ }^{84} \mathrm{De}$ veronderstelde privaatrechtelijke gelijkwaardigheid van partijen is sterk onder druk komen staan in verhoudingen als werkgever-werknemer, verhuurder-huurder, handelaar-consument. Ook wanneer de overheid partij is kan die ongelijkwaardigheid zich doen gelden. Bijvoorbeeld wanneer zij een monopoliepositie heeft, algemene voorwaarden (zoals erfpachtvoorwaarden) hanteert, weigert een contract aan te gaan, een onrechtmatige daadsactie instelt. ${ }^{85}$

De ongelijkwaardigheid van partijen is op sommige gebieden gecompenseerd door de zwakkere partij een sterkere positie te bieden in de vorm van dwingendrechtelijke bepalingen, ${ }^{86}$ maar op andere terreinen is die compensatie er niet.

Een (heel) algemene wettelijke grondslag voor privaatrechtelijk handelen van de overheid is te vinden in de bepalingen van het $\mathrm{BW}^{87}$, maar dat is niet steeds voldoende: "Vooral bij het uitoefenen van aan eigendom of beperkte zakelijke rechten verbonden bevoegdheden, alsmede wanneer de overheid contractueel optreedt als monopolist wordt het feitelijke verschil met publiekrechtelijke bevoegdheidsoefening vaak zo dun dat het redelijk kan zijn ook hier een wettelijke grondslag te verlangen. " 88

84. Kobussen 1991, p. 109-110.

85. Hier komt ook de problematiek van de 'twee-wegenleer' in zicht: in hoeverre mag de overheid bij de uitoefening van publiekrechtelijke bevoegdheden gebruik maken van het privaatrecht? Zie Simon 1993, p.350-409. In het kader van dit onderzoek ga ik hier niet verder op in.

86. Daarnaast springt de rechter in de bres. Hij toetst via open nomen en kan op deze wijze rekening houden met persoonlijke omstandigheden van partijen. Privaatrechtelijk handelen van de overheid wordt ook aan de algemene beginselen van behoorlijk bestuur getoetst.

87. Kobussen 1991, p.97. De grondslag ligt in de artikelen $2: 1$ en $2: 5 \mathrm{BW}$.

88. Van Male in Akkenmans/Koekkoek 1992, p.791. Simon 1993, p.233, schetst nog een ander nadeel van privaatrechtelijk handelen door de overheid: "Van essentieel belang. zeker bok voor de praktijk, is dat gebruik van het privaatrecht kan leiden tot, in de woorden van Konijnenbelt, détournement de procedure. Het gebruik van een privaatrechtelijke bevoegdheid welke ertoe leidt dat de wederpartij of een derde rechtswaarborgen worden onthouden die de publiekrechtelijke weg wel te bieden heeft, meer specifiek, die de bestuurde afhouden van de rechtsbescherming door de administratieve rechter, is, in zoverre, nietig." 


\section{Legaliteitsbeginsel, materieel wetsbegrip en delegatieterminologie}

In de literatuur zijn nog maar weinig voorbeelden te vinden waarvoor dat zou moeten gelden.

De heersende leer lijkt er vooralsnog vanuit te gaan dat een dergelijke, meer specifieke wettelijke grondslag niet nodig is ${ }^{89}$

In het verlengde van de uitbreiding van het legaliteitsbeginsel voor publiekrechtelijk handelen van de overheid: is er ook een wettelijke grondslag nodig voor begunstigend handelen, of is er zelfs een wettelijke grondslag nodig voor alle bestuurlijk handelen, komt de aandacht ook voor het privaatrechtelijk handelen al snel te liggen bij de vraag of voor alle privaatrechtelijk handelen van de overheid een wettellijke grondslag nodig is.

Kobussen toont zich geen voorstander, om dezelfde redenen als genoemd in de vorige paragraaf waar het ging om voor al het (bestuursrechtelijk) handelen van de overheid een wettelijke grondslag te eisen: gevaar voor blanketwetgeving en gevaar voor een weinig zinvolle normering. Zij zoekt daarentegen de oplossing in rechterlijke toetsing van privaatrechtelijk handelen. De rechter kan immers ook privaatrechtelijk handelen van de overheid aan de algemene beginselen van behoorlijk bestuur toetsen en zo de beoogde rechtsbescherming bieden. ${ }^{90}$ Van Male acht dit geen doorslaggevend argument tegen uitbreiding van het legaliteitsbeginsel: ook publiekrechtelijk handelen van de overheid wordt getoetst aan de algemene beginselen van behoorlijk bestuur en toch blijft daar het legaliteitsbeginsel onverkort overeind ${ }^{91}$

Een andere opvatting lijkt Simon ${ }^{92}$ er op na te houden: "Over de betekenis van het legaliteitsbeginsel voor het privaatrechtelijk handelen van de overheid ver-

89. Van Male in Akkermans/Koekkoek 1992, p.790, verwijzend naar Oostenbrink 1978, p.22 23; Kobussen 1991, p.108.

90. Kobussen 1991, p.117.

91. Van Male in Akkermans/Koekkoek 1992, p.791.

92. Simon, Publiekrecht of privaatrecht $\mathbb{1 9 9 3}$, benadert de vraag of voor privaatrechtelijk handelen van de overheid een wettelijke basis nodig is, zeer genuanceerd. De ondertitel van zijn studie. "Een geschiktheidsonderzoekaan de hand van het nutsmax imalisatiebeginsel toegespitst op het gebruik wan het privaatrecht door het bestuur" geeft aan dat de schrijver een in lhet bestuursrecht ongewone 'economische' invalshoek heeft gekozen. De auteur gaat op diverse plaatsen in zijn boek in op de vraag of een wettelijke grondslag. voor privaatrechtelijk handelen van de overheid is vereist. Hij besteed daarbij aandachit aan verschillend privaatrechtelijk handelen zoals eenzijdig handelen (de weigering te contracteren, de eenzijdige uitoefening van prívaatrechtelijke bevoegdheden birnen een overeenkomst, de actie uit onrechtmatige daad of de actie bij onverschuldigde betaling). Maar ook tweezijdig handelen komt aan de orde, waarbij met name overeenkomsten een belangrijke rol spelen. 


\section{Hoofdstuk 9}

schillen de meningen. ${ }^{93}$ In een stelsel waaraan het nutsmaximalisatiebeginsel ten grondslag ligt is de toepasselijkheid van het legaliteitsbeginsel op het privaatrechtelijk handelen van de overheid vanzelfsprekend. Daarin sta ik overigens niet alleen. In de literatuur gaan meerdere stemmen op om het legaliteitsbeginsel van toepassing te achten op elk overheidshandelen, ook het feitelijk en privaatrechte1ijk handelen van de overheid, "94.

De conclusie kan zijn dat de eis van een wettelijke grondslag voor privaatrechtelijk handelen van de overheid niet wordt gesteld, ook niet wanneer dat handelen benadelend is. ${ }^{95}$ Het privaatrechtelijk handelen moet wel voldoen aan de algemene beginselen van behoorlijk bestuur. ${ }^{96}$

\subsubsection{Kunnen bestuursbevoegdheden ontleend worden aan het ongeschreven recht?}

De relatie tussen deze vraag en het legaliteitsbeginsel 'in klassieke zin' is duidelijk: een bevoegdheid ontleend aan het ongeschreven recht heeft geen wettelijke grondslag. Er zou daarentegen wel een relatie met een ruimere opvatting van het legaliteitsbeginsel kunnen bestaan wanneer de bevoegdheid ontleend wordt aan een algemene regel van ongeschreven recht, bijvoorbeeld een algemeen beginsel van behoorlijk bestuur. Hierbij is ook de aard van de bevoegdheid (benadelend of begunstigend) van belang.

Volgens Van Wijk/Konijnenbelt/Van Male komt het in de praktijk niet veel voor dat een bestuursbevoegdheid zijn grondslag vindt in een ongeschreven rechtsregel. ${ }^{97}$ Als klassiek voorbeeld, de burgers benadelend handelen betreffend, bespreken zij een arrest van de Hoge Raad, Schielands Hooge Zeedijk, ${ }^{98}$ "waarin werd aangenomen dat de bevoegdheid van een waterschapsbestuur om aan een particulier de plicht op te leggen dijkverzwaring op zijn terrein te dulden, kan voortvloeien uit de 'inrichting' van het waterschap, die naast het waterschaps-

93. Simon 1993, p.273, verwijzend naar Kobussen 1991 , p.93 e.v.

94. Simon 1993, p.273, verwijzend naar De Haan/Drupsteen/Fernhout 1986 deel I, p.229. Dit standpumt is in de literatuur echter omstreden zoals hierboven al besproken is.

95. Behalve wanneer dat handelen inbreuk maakt op een grondrecht (maar dan is steeds een wettelijke grondslag vereist, ongeacht of de overheid privaatrechtelijk dan wel publiekrechtelijk handelt). Zie Kobussen 1991, p.117.

96. Stout 1994, p.164. Van Wijk/Konijnenbelt/Van Male 1994, p.459.

97. Van Wijk/Konijnenbelt/Van Male 1994, p.134.

98. HR 12 januari 1923, NJ 1923, blz. 307. 
reglement ook ongeschreven, traditionele elementen kan bevatten. ${ }^{199}$ Een bevoegdheid voor het bestuur om te handelen wordt soms ook wel aangenomen met een beroep op het 'publieke taak'-criterium. 100

Van Male merkt op dat de eis van een wettelijke grondslag slechts lijkt op te gaan voor zelfstandige ingrepen in de vrijheid en eigendom van de burgers: "Onzelfstandige verplichtende voorwaarden verbonden aan een begunstigende beschikking behoeven in het algemeen geen grondslag in een algemeen verbindend voorschrift. "101

Verder kan het bestuur in gevallen van noodrecht zonder wettelijke grondslag optreden en daarbij ingrijpen in rechten van vrijheid en eigendom van de burger. ${ }^{102}$

De burger bevoordelende bevoegdheden, waar bijvoorbeeld in de meeste gevallen het subsidiebeleid onder gebracht kan worden, komen (nog) veel zonder wettelijke basis voor. ${ }^{103}$

99. Zie ook Hennekens in zijn naschrift onder Vz ARRS 12 mei 1992, Gst. 6960, nr 2: "De Afdeling rechtspraak heeft wel eens overwogen dat aan beheer van een openbare zaak (weg, water) bevoegdheden door het bestuur tot optreden tegen burgers ontleend kunnen worden zonder dat daaryoor een specifieke wettelijke grondslag in het leven is geroepen. Zie ARRS 28 februari 1980 , Gst. $1980,6625,8$, m.nt. JMK inzake weigering tot uitweg door b en w van Laren. Waar geen geschreven regel woorhanden is zou toch jegens de burger door het bestuur met ge- en verboden kunnen worden opgetreden. Anders oordeelde ARRS 13 december 1990, Gst. 1991, 6920, nr 4 m.nt. HH (Soest). In Vz ARRS 17 april 1989, Gst. 1990,6895,5 m.nt. B. overwoog de Voorzitter: "Artikel 209, aanhef en onder $h(.$.$) kan naar Ons aanvankelijk oordeel geen rechtsgrondslag bieden voor$ enige aanlegverplichting als hier gesteld (..). Op grond hiervan zijn Wij van oordeel dat het besluit van verweerder niet (...) is aan te merken als een beschikking. (...)" In mijn naschrift onder Vz ARRS 17 augustus 1990, Gst. 1991, 69 17,6 (Hoeven) heb ik een woorbeeld gegeven waarbij naar mijn oordeel zich een uitzondering aandient ten aanzien van een expliciete wettelijke bevoegdheidsgrondslag om een beschikking an te nemen. Het betrof hier besluiten van gemeente, provincie, waterschap en Rijk waarbij op zowel privaatrechtelijke als niet uitdrukkelijk omschreven publiek rechtelijke grondslag een weg tot openbare weg bestemd wordt. Art. 5 Wegenwet biedt naar mijn mening een indirecte grondslag voor het aanvaarden van deze bestuursrechtelijke bevoegdheid tot het verrichten van publiekrechtelijke rechtshandelingen. Naar mijn oordeel strekt art. 209 aanhef en sub h gemeentewet niet zover."

100. Zie bijvoorbeeld Rb Roermond 18 april 1995, JB 1995/135 en Pres. Rb Breda 26 april 1995, JB 1995/168, beide met noot R. Schlössels.

101. Van Male in Akkermans/Koekkoek 1992, p.789. Zie echter de voorstellen van de Algemene wet bestuursrecht op dit punt.

102. Nicolai e.a. 1994, p.79-80; Van Wijk/Konijnenbelt/Van Male 1994,p. 135.

103. Nicolaï e.a. 1994, p.80. Ook dit zal veranderen wanneer de woorstellen van de Derde tranche Awb kracht van wet krijgen. 


\section{Hoofdstuk 9}

Concluderend kunnen we stellen dat benadelend handelen van de overheid zonder wettelijke grondslag zeer uitzonderlijk is. In de sporadisch voorkomende gevallen lijkt ook geen verruiming van het legaliteitsbeginsel aan bod te zijn: de bevoegdheid wordt in zo'n geval niet ontleend aan een 'algemene regel', in de zin van een algemeen beginsel van behoorlijk bestuur, maar aan een regel van gewoonterecht of noodrecht. Bewoordelend handelen zonder wettelijke grondslag komt daarentegen herhaaldelijk voor.

\subsubsection{Geldt het legaliteitsbeginsel ook voor de wetgever?}

Gezien de omschrijvingen van het legaliteitsbeginsel in paragraaf 9.3.1, waarbij meer overheidshandelen onder de werking van het legaliteitsbeginsel wordt gebracht, wekt het geen verwondering dat de vraag aan de orde komt of dit beginsel ook geldt voor de formele wetgever. ${ }^{104}$ We vinden een bevestigend antwoord bij Van Male ${ }^{105}$ : "Het legaliteitsbeginsel heeft verschillende functies. Het houdt in de eerste plaats een norm in voor de wetgever. In die hoedanigheid schrijft het voor dat bepaalde belangrijke beslissingen in de rechtsorde zijn voorbehouden aan de wetgever (in formele zin). "106 Hij licht dit als volgt toe: "Voor de wetgever betekent het legaliteitsbeginsel dat hij zelf de belangrijkste (rechts)politieke keuzen behoort te maken en dat hij het maken van deze keuzen niet behoort over te laten aan het bestuur of de rechter. Daarbij is - binnen de grenzen van het constitutionele recht - discussie mogelijk over de vraag welke keuzen als belangrijk moeten worden aangemerkt. De duidelijkheid is het grootste daar waar de Grondwet zich uitspreekt." "107

De Grondwet geeft, zeker na de deconstitutionalisering bij de afgelopen herziening, veel opdrachten aan de wetgever, waarbij de delegatieterminologie een belangrijk richtsnoer is of de wetgever bij de regeling van een onderwerp ook lagere regelgevers en bestuursorganen mag inschakelen. ${ }^{108}$ Van Male betoogt dat daarbij de (rechts)politieke keuzen door de wetgever zelf gemaakt dienen te worden. In een enkel geval lijkt het echter voor de wetgever kennelijk onvermijdelijk te zijn om het bestuur of de rechter in te schakelen, die dan zelf "rechtspolitieke" keuzen dienen te maken.

104. Zie ook de dissertatie van Van der Vlies, Het wetsbegrip en beginselen van behoorlijke regelgeving, met als ondertitel, De verandering van het legaliteitsbeginsel in de twintigste eeuw, 1984 .

105. Zive ook Bohtlingk/Logemann 1966, p.51: Het legaliteitsbeginsel beperkt ook de bevoegdheid van de wetgever. Eijlander 1993, p.122-123 gaat te rade bij het Duitse recht.

106. Van Male in Akkermans/Koekkoek 1992, p.784.

107. Van Male in Akkermans/Koekkoek 1992, p.785.

108. Vergelijk ook Van der Vies 1991, p.101. 
Een mooi voorbeeld biedt artikel 8 Grondwet: 'Het recht tot vereniging wordt erkend. Bij de wet kan dit recht worden beperkt in het belang van de openbare orde." Aan de formele wetgever wordt opgedragen het recht op vereniging te beperken (in het belang van de openbare orde). Delegatie van regelgevende bevoegdheid is niet toegestaan. Ook mogen er bij zo'n delegatieverbod geen ruime (discretionaire) bevoegdheden aan bestuur (of rechter?!) worden opgedragen (zie paragraaf 2. 1.2).

Belangrijkste artikel waarin het recht op vereniging wordt beperkt is artikel $2: 20$ BW109: "1. Een rechtspersoon waarvan de werkzaamheid in strijd is met de openbare orde, wordt door de rechtbank op vordering van het openbaar ministenie verboden verklaard en ontbonden. 2 . Een rechtspersoon waarvan het doel in strijd is met de openbare orde, wordt door de rechtbank op vordering van het openbaar ministerie ontbonden. Alvorens de ontbinding uit te spreken kan de rechtbank de rechtspersoon in de gelegenheid stellen binnen een door haar te bepalen termijn zijn doel zodanig te wijzigen dat het niet meer in strijd is met de openbare orde.'

Op een aantal manieren heeft de wetgever hier het recht op vereniging beperkt. Op de eerste plaats kan het recht alleen worden beperkt wanneer het om het doel of de werkzaamheid van de vereniging gaat; op de tweede plaats is de beperkingsgrond 'in het belang van de openbare orde' verengd tot 'strijd met de openbare orde'. Maar is hiermee voldaan aan de delegatieterminologie, die eist dat in geval van een delegatieverbod de formele wet zelf de norm stelt? Het is de rechter die in voorkomende gevallen bepaalt wat de inhoud van het openbare orde begrip is. De conclusie van de onderzoeksters Gerbranda en Kroes "dat de wetgever bij deze wettelijke regeling een zorgvuldige afweging heeft gemaakt tussen enerzijds het grondrecht en anderzijds de noodzakelijke beperkingen, en dat het vereiste van formele wetgeving hier als versterking van de grondwettelijke waarborg heeft kunnen functioneren" kan dan ook maar gedeeltelijk onderschreven worden. ${ }^{110}$

Tijdens de parlementaire behandeling van dit wetsontwerp op de verboden reclitspersoon zijn voorstellen gedaan om het 'openbare orde' begrip inhoud te geven: "Slechts handelingen die inbreuk maken op de algemeen aanvaarde grondvesten van ons rechtsstelsel, kunnen het verbod van een vereniging of andere rechtspersoon rechtvaardigen: ongerechtvaardigde aantasting van de vrijheid van anderen

109. Wet van 17 maart 1988 , Stb. 104 .

110. Gerbranda/Kroes 1993, p.61. Hier duikt het bijzondere probleem van het begrip 'openbare orde" op. Zie hierover J.G.C. Schokkenbroek, De openbare orde als beperkingsgrond voor de vrijheid van meningsuiting, in NJCM-Bulletin 1986, p.3-22. 


\section{Hoofdstuk 9}

of van de menselijke waardigheid. Gebruik van geweld of bedreiging daarmee tegen het openbare gezag of tegen degene met wier opvattingen men het, al dan niet op goede gronden, oneens is, valt eronder, evenals rassendiscriminatie en andere verboden discriminatie. Evenzo het heulen met een mogendheid waarvan valt te verwachten dat zij een geboden kans om ons volk te onderdrukken zou grijpen, het weerstreven van onherroepelijke rechterlijke uitspraken of onrechtmatige benadeling van anderen als middel om het bestaan van de rechtspersoon te rekken. Het stelselmatig niet afdragen van premies en frauderen valt daaronder. Ten slotte behoren als strijdig met de openbare orde en de goede zeden te worden aangemerkt uitlatingen zoals het aanzetten tot haat en uitingen die verboden discriminatie inhouden of een mensonterend streven zoals het in de literatuur gegeven voorbeeld van een pleidooi om het doden van bepaalde volksgroepen straffeloos te maken. Al deze voorbeelden hebben gemeen dat zij een aantasting inhouden van de als wezenlijk ervaren beginselen van ons rechtsstelsel die, indien op grote schaal toegepast, ontwrichtend zou blijken voor de samenleving. " "\|1

Wanneer de wetgever ervoor had gekozen om deze criteria in de wet vast te leggen (zoals een vergelijkbaar amendement Wiebenga voorstelde) ${ }^{112}$ had de rechter meer houvast gehad en was diens discretionaire bevoegdheid meer inhoudelijk ingevuld ${ }^{113}$

Het is verdedigbaar dat discretionaire bevoegdheden bij een delegatieverbod niet alleen niet aan het bestuur, maar ook niet aan de rechter mogen worden opgelegd. In beide gevallen stelt immers een ander orgaan dan de formele wetgever de norm. ${ }^{114}$

111. Handelingen II 1984-1985, 17476, n.r 5, p.3. Aangehaald bij J.A.O. Eskes, Repressie van politieke bewegingen in Nederland, W.E.J. Tjeenk Willink Zwolle 1988, p.507-508.

12. Amendement Wiebenga: "Op cen politieke groepering wordt lid 1 af lid 2 slechts troegepast, indien de groepering bedrijft of voorstaat, a. gebruik van geweld" b. aantasting van de wrijheid wan anderen of van de menselijke waardigheid; of $c$. verboden discriminatie." Handelingen II 1986-1987, 17476, ar 13, angehaald bij Eskes 1988, p.525.

113. Artikel $8 \mathrm{GW}$ is overigens het enige grondwetsartikel waarin de term openbare orde voorkomt.

114. Rond het wetsontwerp verboden rechtspersonen is nog een discussie gevoerd over de aard van de door de rechter te verrichten handeling (het verbieden en ontbinden): heeft die een bestuursrechtelijk of privaatrechtelijk karakter? De minister hield vast aan een burgerrechtelijk karakter van het verbodsregime. Zie echter Van der Grinten: "Inderdaad heeft een bepaling, die een vereniging tot een verboden vereniging verklaart; een publiekrechtelijk karakter. Er zijn echter in het BW tal wan voorschriften van publiekrechtelijke aard an te treffen." (Van der Grinten, aangehaald bij Eskes, p.551. Ook Eskes mengt zich in de discussie.) Over dit (toch wel opmerkelijke) standpunt van de minister, 
Het zoeken van Van Male naar aanknopingspunten voor de wetgever in de Grondwet, om aan het legaliteitsbeginsel te voldoen, lijkt optimistisch. De Grondwet geeft richtlijnen, en meer of minder duidelijk omschreven opdrachten. Maar daarmee kan de wetgever niet in alle gevallen voldoende uit de voeten. Het blijft zoeken naar (overige) criteria voor het vormgeven van het legaliteitsbeginsel voor de wetgever, of, anders geformuleerd, voor het invullen van een (nieuw) materieel wetsbegrip. Daar kom ik in paragraaf 9.3.4 op terug.

\subsubsection{Conclusie}

De inhoud van het legaliteitsbeginsel is aan verandering onderhevig, maar wellicht minder dan recente omschrijvingen van het legaliteitsbeginsel suggereren (zie paragraaf 9.3.1). Overeind blijft dat voor bestuursrechtelijk handelen van de overheid waardoor wordt ingegrepen in de vrijheid of eigendom van de burger, een (formeel)wettelijke basis vereist is. Ook voor inbreuken op grondrechten is dit onomstreden.

Van Male spreekt in dit verband over een geschreven (grondwettelijke) norm, neergelegd in artikel $89 \mathrm{Gw}$ : door straffen te handhaven bepalingen hebben een formeelwettelijke basis nodig; en een ongeschreven constitutioneelrechtelijke norm: "(..) ingrepen van het bestuur in de vrijheid en eigendom van de burger (behoeven) een wettelijke grondslag."

De sterkste tendens die waargenomen kan worden is om ook voor presterend overheidshandelen een (formeel)wettelijke grondslag te eisen. Daarvan worden in de literatuur als voorbeelden genoemd (sommige) sociale grondrechten, ${ }^{116}$ en de subsidiëring (voorontwerp, thans wetsvoorstel Derde tranche Awb).

dat ook in de parlementaire stukken bestreden werd, zou ik het volgende theorietje willen poneren, Het kostte de wetgever (lees: regering) veel moeite om het onderwerp 'verboden rechtspersoon' netjes te regelen, niet in de laatste plats omdat het begrip 'openbare orde" een belangrijke rol speelde. Delegatie is bovendien door de grondwer verboden. Toch moet er iemand beslissen ower het eventueel verbieden van rechtspersonen (en waar het hier om gat: verenigingen, in het bijzonder politieke partijen). Dat wordt de rechter, die daartoe in het door de regering voorgestelde ontwerp, een discretionaire bevoegdheid krijgt. (Stel dat de burgemeester deze bewoegdheid zou hebben gekregen "dan zou strijd met de delegatieterminologie waarschijnlijk weel eerder zijn opgemerkt.) Zou de minister de (rechterlijke) bevoegdheid als bestuurlijk van aard betitelen, dan zouden (nog niet wakkere) kamerleden wel eens op het idee kunnen komen, dat hier sprake was wan strijd met de grondwettelijke delegatieterminolog ie. Door consequent vol te houden dat sprake was van een privaatrechtelijke bewoegdheid is in het parlement (en voor zover ik weet ook daarbuiten) niet de discussie over (strijd met) het delegatieverbod gevoerd.

115. Van Male in Akkermans/Koekkoek 1992, p.787.

116. Zoals de artikelen 18 lid 2 en 19 lid 2 Gw. Hirsch Ballin 1992, p. 100. 


\section{Hoofdstuk 9}

Voor privaatrechtelijk handelen van de overheid wordt in het algemeen geen specifieke wettelijke grondslag geëist.

Voor de wetgever geldt dat de herziene Grondwet voor meer onderwerpen, dan in de Grondwet van 1972 geregeld, een wettelijke regeling verlangt.

Verschillende auteurs gaan in op de gedachte om al het overheidshandelen een wettelijke grondslag te geven, maar daarbij zijn er vooralsnog meer tegenstanders dan voorstanders. Ik sluit mij aan bij de tegenstanders. Een scenario dat wel steeds een wettelijke grondslag wil zal leiden tot het volgende. Om elk (publiekrechtelijk dan wel privaatrechtelijk) handelen van de overheid een wettelijke basis te geven zullen veel wettelijke bepalingen nodig zijn wil de wetgever enigzins precies werken en zinvolle normen voor de verschillende gevallen onderscheiden. Die werkdruk zall het parlement niet aankunnen en het zal zijn toevlucht nemen tot veel delegatiebepalingen. Veel (en mogelijk blanco) delegatie is echter in strijd met de Aanwijzingen voor de regelgeving (zie paragraaf 4.4). ${ }^{117}$

De conclusie kan zijn dat vooral voor het presterend handelen ook een wettelijke grondslag wordt geëist, en in die zin wordt het legaliteitsbeginsel dus verruimd. Aan de wettelijke basis voor benadelend handelen lijkt niet getornd te worden: een basis in een algemene rechtsregel, bijvoorbeeld een beleidsregel of algemeen beginsel van behoorlijk bestuur is niet goed denkbaar. Wel is denkbaar dat begunstigend handelen plaats vindt op basis van beleidsregels, of de algemene beginselen van behoorlijk bestuur.

\subsubsection{Het legaliteitsbeginsel in de jurisprudentie}

De discussie rond het legaliteitsbeginsel leert dat het niet eenvoudig is om in het algemeen criteria te ontwikkelen die aangeven welke onderwerpen wettelijke regeling behoeven of voor welke maatregelen een wettelijke basis noodzakelijk is. In enkele bijzondere gevallen is gebleken dat wel een formeel-wettelijke grondslag nodig is. In hoofdstuk 6 kwamen voorbeelden aan de orde van uitspra-

117. Al het overheidshandelen een wettelijike grondslagg geven is geen oplossing voor het aan de orde zijnde probleem: het bieden van voldoende waarborgen aan de burger tegen optreden door de overheid.

Ook de oplossing die Kobussen biedt: ingrijpen door de rechter die toetst aan de algemene beginselen van behoorlijk bestunr acht ik maar half gelukkig. Ingrijpen door de rechter is altijd achteraf, de burger moet maar zien dat hij zijn gelijk haalt. Aan de ene kant zien we verder hierbij dat de rechtsbescherming voor de burger wordt uitgebreid: de rechter toetst meer, en uitgebreider, handelen van de overheid, aan de andere kant dreigt de rechtsbescherming te worden verminderd door een drastische verhoging van de griffierechten en vermindering van de rechtsbijstand. 
ken waarin de rechter een bepaalde regeling of maatregel afkeurde omdat er, op grond van de grondwettelijke delegatieterminologie, een basis in een formele wet vereist was. Daarbij werd niet zozeer naar de inhoud van de betrokken regeling of maatregel gekeken, maar naar het ontbreken van de wettelijke grondslag. Dit lijkt een wat formele benadering van het legaliteitsbeginsel. Maar de uitspraken werden veelal gedaan in het kader van een inbreuk op een grondrecht waardoor de formeel ogende beslissing moeilijk losgemaakt kan worden van de inhoud:

Hieronder komen uitspraken over de inhoud van het legaliteitsbeginsel aan de orde die gewezen zijn buiten de grondwettelijke delegatieterminologie om.

Eén van de bekendste arresten over het legaliteitsbeginsel, gewezen voór de grondwetsherziening van 1983, is het hierboven al genoemde Fluorideringsarrest. ${ }^{118}$ De Hoge Raad oordeelde in dit arrest dat voor ingrijpende besluiten (in casu de toevoeging van fluoride aan drinkwater) een wettelijke basis dient te zijn. De Hoge Raad hanteerde als elementen om tot dat oordeel te komen, dat drinkwater een van de eerste levensbehoeften is; dat de eigenaar van het waterleidingbedrijf een monopoliepositie inneemt; en dat de aanleg van een tweede waterleidingnet praktisch niet is te verwezenlijken zodat feitelijke dwang ontstaat voor gebruikers met overwegende bezwaren om gefluorideerd drinkwater te gebruiken.

Een tweede bekend arrest in de lijn van het Fluorideringsarrest, is de uitspraak over het jodiumhoudend broodzout. ${ }^{119}$ Een bakker weigerde gebruik van jodiumhoudend broodzout. Het voorhanden hebben van ander broodzout was strafbaar gesteld in artikel 7 lid 1 sub m en 8 sub e Broodbesluit. De Hoge Raad oordeelde dat deze bepalingen geen wettelijke grondslag in artikel 16 lid 1 Warenwet vinden. ${ }^{120}$ Niet alleen onderzoekt de Hoge Raad in dit arreśt of er een wettelijke grondslag voor de in geding zijnde bevoegdheid is, maar ook of die grondslag zich uitstrekt tot het omstreden voorschrift. ${ }^{121}$

118. HR 22 juni 1973, NJ 1973, 386 m.nt. Bloembergen; AB 1973, 187 m.nt. Van der Hoeven.

119. HR 10 april 1984, NJ 1984, 612, m.nt. "t Hart. Zie pver deze arresten ook Dute 1994 , p.113: "Opmerkelijk is dat juist in de arresten warin de volksgezondheid in het geding was, de Hoge Raad de eisen welke woortvloeien uit het legaliteitsbeginsel, heeft bevestigd en aangescherpt."

120. Zowel de advocaat van werdachte als $\mathrm{AG}$ Leijten verwijzen naar het Fluorideringsarrest en toetsen de bestreden bepaling aan de criteria die de Hoge Rad in dat arrest ontwikkelt. Op de verschillen tussen beide zaken wijst annotator " $t$ Hart. Hij laat tevens zien dat in deze zaak niet aan alle elementen uit het Fluorideringsarrest is voldaan.

121. De Meij 1990, p.127. Zie paragraaf 7.3.4 voor andere voorbeedden van uitspraken waarin de rechter een gedelegeerde bevoegdheid overschreden achtte. 


\section{Hoofdstuk 9}

Een vergelijking met het Fluorideringsarrest trekt Scheltema in zijn noot onder een uitspraak van de Hoge Raad over de uitzending van dienstplichtigen wegens de daarin gebruikte formuleringen van de Hoge Raad. ${ }^{122}$ De Hoge Raad oordeelde dat de uitzending niet gebaseerd kon worden op artikel 33 lid 1 onder d Dienstplichtwet: een uitzending als de onderhavige is voor de betrokken dienstplichtigen zo ingrijpend, dat niet kan worden aangenomen dat deze zonder machtiging mogelijk is.

In de paragrafen 9.3.1 en 9.32 is aan de orde geweest dat de inhoud van het legaliteitsbeginsel aan het veranderen is, in die zin dat voor meer overheidshandelen een wettelijke basis vereist is. Deze verandering vinden we ook in een enkel geval terug in de jurisprudentie. In het Methadonbriefarrest ${ }^{123}$ oordeelde de Hoge Raad dat er geen wettelijke bepaling was aan te wijzen waaraan de Hoofdinspecteurs van het Staatstoezicht op de Volksgezondheid de bevoegdheid ontlenen om zelfstandig werkzame artsen bindende voorschriften te geven over de wijze waarop die hun praktijk hebben uit te oefenen. Annotator Scheltema wijst er op dat hier de norm wordt gehandhaafd dat ingrijpend overheidsoptreden op een wettelijke grondslag dient te berusten. In geding was hier niet de klassieke opvating van het legaliteitsbeginsel: het opleggen van een ge- of verbod, door straf te handhaven. ${ }^{124}$

Voor een gedwongen verblijf van asielzoekers in een 'opvangcentrum' was geen wettelijke grondslag aan te wijzen. De Hoge Raad eiste die grondslag wel. ${ }^{125}$ Volgens Van der Burg kan ook dit arrest uitgelegd worden aan de hand van het criterium uit het Fluorideringsarrest dat ingrijpend overheidsoptreden een wettelijke grondslag dient te hebben.

Het besluit van de minister om zelf de opgave van een varkenshouder aan te passen en een nieuwe referentiehoeveelheid fosfaat vast te stellen heeft volgens het College van Beroep voor het Bedrijfsleven geen basis in de Meststoffenwet. ${ }^{126}$

122. HR 8 februari 1980 , NJ 1981,334 , m.nt. MS.

123. HR 27 juini 1986, NJ 1987, 898, m.nt. MS; AB 1987, 241, m.nt. FHvdB.

124. Zie ook Van Male in zijn noot onder CBB 21 september 1990, AB 1991, 97.

125. HR 9 december 1988, AB 1989, $121 \mathrm{~m}$.nt. FHudB; NJ 1990, 265, m.nt. EAA. De wettelijke grondslag is daarop snel gecreëerd door toevoeging van art. 7a Vreemdelingenwet (Stb. 1989, 6). De procedure van wetgeving oogstte niet ieders bewondering. Damen en Hoogenboom (NIB 1989, p.145-153) signaleren een aantal statsrechtelijke onregelmatigheden a:s gevolg van de overhaaste behandeling.

126. Zie ook CBB 21 september 1990, AB 1991,98. Hierop is de Meststoffenwet gewijzigd. Kamerstukken 22836, Stb. 1993, 388. 
De verplichting om zich te onderwerpen aan een loopbaanonderzoek werd door de Centrale Raad van Beroep aangemerkt als (zeer) ingrijpend in de persoonlijke levenssfeer waarvoor geen wettelijke basis aangewezen kon worden. ${ }^{127}$

En de rechtbank Roermond oordeelde dat er geen wettelijke basis is om op het uit te betalen pensioen de premie AOW/AWW in te houden, welke bij naheffingsaanslag van de inhoudsplichtige wordt geheven over reeds uitbetaald pensioen. ${ }^{128}$

De hierboven genoemde uitspraken laten zien dat de rechter (bij verschiflende rechterlijke instanties) oog heeft voor maatregelen die genomen worden zonder (voldoende) wettelijke grondslag. Daarbij wordt soms de formulering gebruikt dat het handelen dermate ingrijpend is dat een wettelijke grondslag nodig is; in andere gevallen wordt daar geen overweging aan gewijd. Vaste formuleringen treffen we niet aan. De jurisprudentie lijkt op dit punt nog niet uitgekristalliseerd. Dat lijkt ook moeilijk zolang de opvattingen over de betekenis van het legaliteitsbeginsel in beweging zijn, en zolang er ook geen brede consensus bestaat over de inhoud van een materieel wetsbegrip. Ook op dit punt staan de ontwikkelingen echter niet stil. In literatuur en regeringsstukken zijn de laatste jaren voorstellen op dit punt gedaan waarvan er enkele in de volgende paragraaf bekeken worden.

\subsection{Opvattingen over de inhoud van het materieel wetsbegrip na 1983}

Vanuit de gedachte dat het klassieke legaliteitsbeginsel niet meer voldoet, omdat burgers op veel meer manieren dan door ge- en verboden door en aan de overheid gebonden worden, ${ }^{129}$ ên vanuit de constatering dat de kwaliteit van de formele wet en de daarop gebaseerde uitvoeringswetgeving onder druk is komen te staan (mede ook door de sterk toegenomen omvang ervan) ${ }^{130}$, is gezocht naar een andere invulling van het legaliteitsbeginsel en materieel wetsbegrip.

Van die voorstellen ${ }^{131}$ komen achtereenvolgens (beknopt) aan bod de dissertatie

127. CRvB 30 januari 1992, TAR 1992, 68 .

128. Rb Roermond 28 oktober 1992; TAR 1993 „17.

129. Hirsch Ballin 1989, p. 21

130. Zie uitgebreid de dissertatie wan Van der Vlies, en woor de periode daama onder andere de rapportage van de Commissie Staatkundige, bestuurlijke en statsrechtelijke vernieuwingen (Commissie Deetman) Kamerstukken II 1989-1990, 21427. Reacties erop kwamen van M.C. Burkens, S.W. Couwenberg, H. Franken en L.d. Brinkhorst: Staatsrechtelijke vernieuwingen, Tjeenk Willink $Z$ wolle, 1991 . Over het (falende) dereguleringsbe- 
van Van der Vlies (paragraaf 9.4.1), de suggesties van de Commissie Wetgevingsvraagstukken en het kabinetsstandpunt daarop (9.4.2), enkele Aanwijzingen voor de regelgeving (9.4.3) en de dissertatie van Stout (9.4.4). In paragraaf 9.4.5 volgt een korte conclusie.

\subsubsection{Van der Vlies 1984}

Van der Vlies heeft (onder meer) het Fluorideringsarrest als uitgangspunt genomen voor de ontwikkeling van criteria die volgens haar aangelegd moeten worden bij de beslissing of iets in de formele wet geregeld moet worden. De bevoegdheid van de wetgever is volgens haar beperkt tot ingrijpende besluiten. ${ }^{\mathrm{I} 2}$ Die ingrijpendheid is vast te stellen aan de hand van de volgende kenmerken: het

leid schreef de Raad van State in zijn Jaarverslag over 1991: "Geconstateerd moet wor" den dat de omvang wan de totale wetgeving in Nederland nog steeds belangrijk toeneemt. Het is thet college uit eigen wetenschap bekend dat, bezien over de periode 1980-1990, het wettenbestand zoals het wordt uitgegeven in de editie Schuurman en Jordens met $40 \%$ is toegenomen. Een duidelijk signaal. Ook in zijn adviezen heeft het college bij herhaling moeten vaststellen dat de noodzaak van wetgeving niet of onvoldoende was aangetoond." Aangehaald in NJB 1992, p.532.

131. Over dit onderwerp publiceerden onder anderen ook Donner $1981 \mathrm{a}$, die voorstelt om (naar aanleiding van het in één hoofdstuk in de Grondwet opnemen van klassieke en sociale grondrechten) het materieel wetsbegrip van Buys 'de burgers bindende rechtsregelen' zoals uitgewerkt in 'door straffen te handhaven woorschriften' aan te wullen met 'de burgers helpende rechtsregels'; als de regels waardoor woorzieningen ten behoeve van de burger worden opgericht en waarbij de voorwaarden worden gesteld waaronder de burger een individuele of collectieve (...) aanspraak op die voorzieningen krijgt" (p.15); Konijnenbelt 1982, p.654 acht dit te ruim en wil het legaliteitsbeginsel oprekken tot presterend handelen van de overheid voor zover daarbij plichten aan burgers worden opgelegd die niet rechtstreeks voortwloeien uit het doel dat gediend wordt met het presterend handelen; Bok 1984, p.170-175; Van der Burg 1986b, p.66 die voorstelt om het criterium 'door straffen te handhaven' te veranderen in 'naar buiten werkende"; Eijlander 1993, p.125: "De wetgever in formele zin moet de wezenlijke beslissingen op een bepaald terrein van overheidsbemoelenis derhalve zelf nemen via duidelijke, nauwkeurige regelling in de wet zelf. Het gaat niet aan dergelijke beslissingen door delegatie van regelgevende bevoegdheid of door attributie van discretionaire bestuursbevoegdheden over te laten aan andere organen." Interessant is ook zijn verwijzing (op p.127) naar een artikel van $\mathrm{E}$. Baader in Juristenzeitung 1992, p.394-401, die van mening is "dat de vraag wat 'wesentlich' is moet worden beantwoord in het licht van de doel-middel verhouding van een rechtsregel. De middelen die moeten bijdragen aan de verwezenlijking van het doel vain de regel moeten in zijn visie door de wetgever zelf worden bepaald."

132. Die vaststelling hoeft niet te gebeuren door middel van algemene regels, Van der Vlies 1984, p. 123. 
zijn besluiten die betrekking hebben op eerste levensbehoeften of fundamentele rechtsbeginselen (daaronder valt ook het verlenen van bevoegdheden); als gevolg hiervan zal er "(nagenoeg) onontkoombare dwang (...) ontstaan om conform het besluit te handelen"; over het besluit bestaan "diepgaande meningsverschillen in de samenleving" of het besluit raakt "fundamentele zaken (...) die de staatsorganisatie betreffen en waarbij het bestuur een eigen belang heeft dan wel de schijn daarvan bestaat."1133

Dit 'ingrijpendheidscriterium' van Van der Vlies is door verschillende auteurs bekritiseerd omdat het te vaag zou zijn. ${ }^{134}$ Ook de (formele) wetgever lijkt het criterium niet (consequent) toe te passen, gezien de regelingen die in het Staatsblad verschijnen.

Uit het hanteren van het criterium 'ingrijpende besluiten' volgt dat de formele wetgever het nemen van ingrijpende besluiten niet mag delegeren aan lagere organen. Daarentegen moet de uitwerking van die besluiten wel aan andere organen overgelaten worden. ${ }^{135}$ Witteveen toont met enkele voorbeelden aan dat hiermee echter geen eenduidig antwoord wordt gegeven op de vraag of er gedelegeerd zou mogen worden. Hij wijt dat met name aan het feit dat de door Van der Vlies gebruikte termen (fundamentele rechtsbeginselen; eerste levensbehoeften) uit de grondrechtensfeer afkomstig zijn. Door de zich sterk uitbreidende invloed van grondrechten kunnen zeer veel besluiten onder het 'ingrijpendheidscriterium' geschaard worden. ${ }^{136}$

\subsubsection{Orde in de regelgeving 1985 en Regelgeving centrale overheid 1987}

In haar rapport uit 1985 gaat de Commissie Wetgevingsvraagstukken uitgebreid in op de verdeling van voorschriften over de wet en lagere vormen van regelgeving. ${ }^{137}$ De Commissie constateert dat het "onmogelijk (is) gebleken om zoda-

133. Van der Vlies 1984, p. $105-106$.

134. Witteveen 1992, p.86-89. Van Wijk/Konijnenbelt/Van Male 1994, p.45, concluderendat het criterium niet in plaats van het klassieke legaliteitsbeginsel als uitgangspunt moet worden genomen, maar aanvullend daarop. In zijn recensie van Van der Vlies' dissertatie merkt Van der Hoeven over het criterium 'ingrijpende besluiten' op dat het meer een 'politicologisch desideratum' betreft dan een 'juridisch criterium'. Van der Hoeven 1985 , p.55. Zie echter ook Van der Burg 1986b, p.66: "Hoewel ik de voorkeur geef aan de wijziging van de formule 'door straffen te handhaven' in 'naar buiten werken", acht ik het door mevr. Van der Vlies voorgestelde materiële wetsbegrip van goede betekenis. Het vormt $\mathrm{m} . \mathrm{i}$. een belangrijke bijdrage in de strijd tegen het verval van de wetsvorm."

135. Van der Vlies 1984, p.133.

136. Witteveen 1992, p.86-89.

137. Orde in de regelgeving 1985, p.46-52. 


\section{Hoofdstuk 9}

nige criteria te formuleren dat voor ieder geval daaruit steeds zou kunnen worden afgeleid welk voorschrift in de wet en wat bij algemene maatregel van bestuur of door een minister mag worden geregeld." Volgens de Commissie dienen in elk geval de structurele elementen wan een regeling in een formele wet te worden opgenomen en verder andere (belangrijke) voorschriften die niet regelmatig gewijzigd hoeven te worden. ${ }^{138}$ Als concrete voorbeelden noemt zij: bepalingen die grondrechten beperken of nader bepalen; bepalingen die een vergunningenstelsel in het leven roepen; bepalingen die een belasting of een heffing in het leven roepen; bepalingen die lagere overheden in medebewind roepen; bepalingen tot het oprichten van nieuwe bestuursorganen; bepalingen betreffende de inrichting van de rechtsbescherming; bepalingen betreffende sancties, ongeacht de strafrechtelijke, civielrechtelijke of administratiefrechtelijke aard ervan; bepalingen die controle- of opsporingsbevoegdheden toekennen. ${ }^{139}$

De Commissie geeft verder aan welke voorschriften gedelegeerd kunnen worden. Onder de voorwaarde dat de delegatieverlening nauwkeurig wordt begrensd kan het "nader uitwerken van regels die in meer algemene bewoordingen in de wet worden gesteld, en het stellen van voorschriften van administratieve aard, wanneer die van belang zijn voor een goede uitvoering van de wet" aan lagere organen overgedragen worden. ${ }^{140}$

In het kabinetsstandpunt op het rapport Orde in de regelgeving wordt de visie van de Comissie Wetgevingsvraagstukken grotendeels bevestigd. Op onderdelen nuanceert het kabinet de voorbeelden van de Commissie. ${ }^{141}$

\subsubsection{De Aanwijzingen voor de regelgeving $1993^{142}$}

Een neerslag van de aanbevelingen van de Commissie Wetgevingsvraagstukken over in de wet op te nemen onderwerpen en het kabinetsstandpunt daarop is te vinden in de aanwijzingen 22 en 24 . Aanwijzing 22 geeft in het algemeen aan welke elementen van een regeling in de formele wet opgenomen moeten worden en welke elementen in een lagere regeling thuishoren. 'Bij verdeling van de elementen wan een regeling over de wet en algemeen verbindende voorschriften

138. Orde in de regelgeving $1985, \mathrm{p} .64$.

139. Orde in de regelgeving $1985, p .64$.

140. Orde in de regelgeving 1985, p.64. Op de pagina's 46-52 gaat de Commissie op de afzonderlijke bepalingen in. Besproken door Witteveen 1992, p.54-56 die concludeert dat "de criteria (.im.) meer globale aandachtspunten (zijn) waarover in het voorliggende geval discussie mogelijk is dan duidelijke regels die men al dan niet kan toepassen."

141. Regelgeving centrale overheid, Kamerstukken II 1986 1987, 20038, nr 2 p.7-12.

142. Besluit van de minister-president van 18 november 1992 , in werking getreden op 1 januari 1993. Zie ook paragraaf 4.3.3. 
van lager niveau bevat de wet ten minste de hoofdelemerten van de regeling. Bij de keuze welke elementen in de wet zelf regeling moeten vinden en ter zake van welke elementen delegatie is toegestaan, dient het primaat wan de wetgever als richtsnoer'. ${ }^{143}$

Aanwijzing 24 noemt concrete onderwerpen: '1. Zoveel mogelijk worden in de wet opgenomen:

a. voorschriften die de grondslag vormen van een stelsel van vergunningen of een stelsel waarbij anderszins de toelaatbaarheid van handelen afhankelijk wordt gesteld van verlof van de overheid;

b. voorschriften die andere overheden in medebewind roepen;

c. voorschriften waarbij nieuwe bestuursorganen in het leven worden geroepen;

d. voorschriften betreffende rechtsbescherming;

e. voorschriften inzake sancties van administratiefrechtelijke of civielrechtelijke aard;

f. voorschriften waarbijtoezichts-of opsporingsbevoegdheden worden toegekend;

g. voorschriften omtrent rechten en verplichtingen van burgers jegens elkaar;

h. voorschriften die beogen aan de burger procedurele waarborgen te bieden ten aanzien van het gebruik van bevoegdheden door de overheid.

2. Ook worden zoveel mogelijk in de wet opgenomen voorschriften omtrent het bestaan van financiële aanspraken jegens de overheid, de kring van voor die aanspraken in aanmerking komende personen en de verschillende elementen die bij de bepaling van de uit te keren bedragen een rol moeten spelen, tenzij de

143. Zie ook de toelichting: "Hoofdelementen zijn in ieder geval de reikwijdte en de structurele elementen van de regeling. Veelal zullen daartoe ook de voornaamste duurzame normen behoren. Het kan echter uit een oogpunt van toegankelijke regelgeving beter zijn om in de wet over een bepaald ondlerwerp geen materiële normen op te nemen, maar aan de lagere wetgever over te laten een integrale materiële regeling tot stand te brengen." Het primaat van de wetgever impliceert volgens het Eindrapport (p.45) dat tenminste de 'reikwijdte, de structurele elementen en de woornaamste duurzame normen' van een regeling in de wet dienen te staan. Het kabinet onderschreef dit standpunt, maar was van oordeel dat niet steeds zou kunnen vaststaan wat de 'voornaamste duurzame normen" inhouden (20038, nr 2, p.6). De 'reikwijdte en structurelle elementen' worden in deze aanwijzing 'hoofdelementen' genoemd. De uitzondering die bij deze (en andere) aanwijzingen wordt gemaakt voor rechtspositionele regelingen woor overheidspersoneel bevreemdt: er zijn verschillende regelingen (Ambtenarenwet, ARAB) die duidelijk cen extern karakter hebben, algemeen verbindende woorschriften bevatten en derhalve vallen onder Aanwijzingen voor de regelgeving. 


\section{Hoofdistuk 9}

financiele aanspraken slechs zeer tijdelijk of incidenteel van aard zijn dan wel het slechts om een zeer beperkt aantal gevallen gaat. ${ }^{144}$

Aanwijzingen die inhoudelijk op delegatie betrekking hebben zijn naast. Aanwijzing 22: Aanwijzing 23 (over het grondwettelijk delegatieverbod); Aanwijzing 25 (delegatie dient zo nauwkeurig en concreet mogelijk begrensd te zijn) en Aanwijzing 26 (delegatie aan de minister wordt beperkt tot "voorschriften van administratieve aard, uitwerking van de details van een regeling, voorschriften die dikwijls wijziging behoeven en voorschriften waarvan te voorzien is dat zij mogelijk met grote spoed moeten worden vastgesteld").

\subsubsection{Stout 1994}

Tien jaar na het verschijnen van de dissertatie van Van der Vlies verschijnt er opnieuw een rechtstheoretische beschouwing over de betekenis van het legaliteitsbeginsel en de invulling van een materieel wetsbegrip: een juridisch proefschrift van Stout. ${ }^{145}$ Volgens haar dienen de volgende kernelementen in beginsel in de formele wet opgenomen te worden. In de eerste plaats is dat het orgaan dat een bevoegdheid ontvangt. Daarnaast dient de wet de 'politiek-principiële hoofdelementen van beleid' te bevatten (die Stout uitsplitst in het aangeven van de strekking van de bestuurlijke bevoegdheid, en het stellen van de belangrijkste materiële normen). ${ }^{146}$ Ook behoort de wijze waarop de besluitvorming in procedureel opzicht gestalte krijgt in de wet zelf thuis. Daaronder vallen aspecten als het openstellen van rechtsbescherming, het bepalen aan welke voorwaarden die rechtsbescherming dient te voldoen, en 'het scheppen van een besluitvormingskader voor het bestuur'. ${ }^{147}$

Haar voorstel yoor de kernelementen is 'geïnspireerd door de literatuur". ${ }^{148} \mathrm{De}$ verschillende kernelementen zijn onder andere terug te vinden in het rapport Orde in de regelgeving 1985 (zie paragraaf 9.4.2) en daarop voortbordurend de Aanwijzingen voor de regelgeving 1993 (zie paragraaf 9.4.3). In zoverre lijkt Stouts voorstel dan ook weinig aan reeds bestaande voorstellen voor een invulling van het materieel wetsbegrip toe te voegen.

144. Zite voor een uitwerking van het tweede lid de bepalingen over subsidies in de Algemene wet bestuursrecht.

145. H.D. Stout, De betekenissen van de wet, 1994. Besproken door Thom Holterman, Kernachtige wetgever, in NJB 1995, p.256-257.

146. Stout 1994, p. 240.

147. Stout 1994, p.241.

148. Stout 1994, p. 240 . 
Aan de vraag welke voorschriften gedelegeerd kunnen worden besteedt Stout, na de presentatie van de kernelementen, geen aandacht meer. Voor de hand liggend is echter dat het vaststellen van de hierboven weergegeven kernelementen niet voor delegatie in aanmerking komt. Dat behoort immers tot de exclusieve taak van de formele wetgever.

\subsubsection{Conclusie}

Het is niet eenvoudig om duidelijke, steeds toepasbare criteria te ontwikkelen voor de inhoud van een materieel wetsbegrip. De werkwijze van de Commissie Wetgevingsvraagstukken (die is overgenomen door de opstellers van de Aanwijzingen voor de regelgeving 1993) om een 'lijst' te maken van onderwerpen die zoveel mogelijk in de formele wet geregeld moeten worden, heeft als voordeel dat er in enig opzicht duidelijkheid wordt geschapen. Ook de opsomming in Aanwijzing 26 over te delegeren voorschriften aan de minister geeft houvast. Daarbij is van belang dat de Commissie die onderwerpen heeft opgenomen ${ }^{149}$, die naar haar oordeel van groot belang zijn voor de bescherming van de burger tegen niet wettelijk genormeerd bestuursoptreden. ${ }^{150}$

Hoe waardevol de opsomming in het rapport Orde in de regelgeving en de Aanwijzingen voor de regelgeving ook is, voorkomen moet worden dat zij gaat werken als een lijst-zonder-meer. Het mag niet zo zijn dat door het strak hanteren van de lijst problemen van wetgeving er door verdoezeld worden, en een (voortdurende) fundamentele herbezinning op de taak van de wetgever achterwege blijft. Het is overigens niet verwonderlijk dat die herbezinning moeilijk op gang komt bij 'de wetgever' zelf. Daarvoor lijkt enige afstand onontbeerlijk. Hier ligt dan wellicht op de eerste plaats ook een taak voor de wetenschap om in elk geval aanzetten voor discussie te formuleren.

De taak van de formele wetgever kan, gelet op de in deze paragraaf weergegeven voorstellen in de literatuur, omschreven worden als het nemen van ingrijpende besluiten. Ingrijpendheid kan daarbij nader ingevuld worden vanuit de achter grond van het klassieke legaliteitsbeginsel in samenhang met de concrete onderwerpen die genoemd zijn in het rapport Orde in de regelgeving, en de Aanwijzingen voor de regelgeving. Het gaat hierbij vrijwel steeds om zaken waarvan de regeling inbreuk kan maken op de vrijheid en eigendom van burgers of op andere wijze burgers benadelend kan treffen. Daarnaast is regeling bij of krachtens de

149. Zie ook de Aanwijzingen voor de regelgeving 1993.

150. Zie ook Stout 1994 in haar bespreking yan de voorstellen van de Commissie Wetgevings vraagstukken (p,235-239). 


\section{Hoofdstuk 9}

formele wet geboden wanneer de grondwettelijke delegatieterminologie dit eist. Daarop wordt in de volgende paragraaf nader ingegaan.

Ook de vraag welke criteria gelden om in een concreet geval bevoegdheden, of de regeling van een onderwerp, te mogen delegeren is niet eenvoudig te beantwoorden. Afgezien van onderwerpen waarbij het grondwettelijke delegatieverbod regeling eist door de formele wetgever zelf en delegatie dus niet is toegestaan (behoudens de regeling van detailpunten) kan door de mate van ingrijpendheid te bepalen geoordeeld worden of delegatie aan lagere organen is toegestaan. De ingrijpendheid kan worden vastgesteld aan de hand van het criterium "ingrijpende besluiten', met een nadere invulling vanuit het klassieke legaliteitsbeginsel en de concrete onderwerpen uit het rapport Orde in de regelgeving en de Aanwijzingen voor de regelgeving 1993. Daarbij geldt dat naarmate er in de formele wet meer normering van te delegeren bevoegdheden plaatsvindt, delegatie eerder aanvaardbaar is.

\subsection{De invloed van de delegatieterminologie op het legaliteits- beginsel en het materieel wetsbegrip}

\subsubsection{De relatie delegatieterminologie-legaliteitsbeginsel}

Door de invoering van de grondwettelijke delegatieterminologie is er een formele benadering van het legalliteitsbeginsel 'bij gekomen'. Een door de Grondwet aangewezen onderwerp behoeft wettelijke regeling, ongeacht of het ingrijpen in de vrijheid en eigendom van burgers betreft of niet. ${ }^{151}$ Bij de invoering van de delegatieterminologie bleek dat voor een aantal onderwerpen een wettelijke basis nodig zou zijn, die eerst later gecreèerd is. ${ }^{152}$

In de jurisprudentie die besproken is in hoofdstuk 6 bleek dat vooral de specifie$\mathrm{ke}$ wettelijke grondslag die nodig is voor het beperken van grondwettelijke

151. Zie ook Hirsch Ballin 1992, p.99: "Het legaliteitsbeginsel wordt formeel opgevat: tenzij de grondwett delegatie expliciet uitsluit door het gebruik van formuleringen als "bij de wet" of "volgens de wet", is aan het legaliteitsbeginsel voldaan in alle gevallen waarin de formele wet delegeert." Hij voegt eraan toe: "Dit leidt tot onvrede: onvrede ondat het "primaat wan de politiek' tekort komt, wanneer belangrijke regels feitelijk van de administratie afkomstig zijn." Zie ook paragraaf 4 .3.

152. Zoals voorschriften die inbreuk maken op bepaalde grondrechten van ambtenaren. $Z$ zijn in de artikelen 125a-125f Ambtenarenwet vastgelegd bij Wet van 20 april 1.988 , Stb. 229. 
grondrechten nogal eens ontbreekt. De rechter kan daarvoor nu wijzen op de verplichting die de grondwettelijke delegatieterminologie in dit kader heeft geschapen, zonder overigens in het kader van het legaliteitsbeginsel of het materieel wetsbegrip te hoeven motiveren waarom er een wettelijke basis voor de bestreden maatregel/regeling nodig is. ${ }^{153}$ Aangezien inbreuken op de vrijheid en eigendom van de burger zich vooral in het kader van grondrechten zullen voordoen, kan echter aangenomen worden dat (impliciet) ook de klassieke opvatting van het legaliteitsbeginsel wordt gehandhaafd.

\subsubsection{De relatie delegatieverbod-materieel wetsbegrip}

De omschrijving van het grondwettelijke delegatieverbod is ook als een beschrijving van een materieel wetsbegrip te zien: wezenlijke bepalingen horen in de formele wet thuis, de regeling van detailpunten kan aan lagere regelgevers overgelaten worden. ${ }^{154}$

In paragraaf 4.5 hebben we gezien dat de tegenwoordige opvattingen over het delegatievraagstuk in regeringsstukken (terughoudendheid met delegatie) en de uitleg van het grondwettelijke delegatieverbod naar elkaar aan het toegroeien zijn, zodat de betekenis van het delegatieverbod ook voor het delegatievraagstuk betekenis krijgt. ( $\mathrm{Zij}$ het dat het materiële wetsbegrip ('wezenlijke bepalingen in de formele wet; vaststelling van details in lagere regelingen') buiten de Grondwet om niet zo strikt zal worden toegepast, dan wanneer er een grondwettelijk delegatieverbod geldt.)

Daarnaast geldt de keuze van de grondwetgever om voor bepaalde onderwerpen een delegatieverbod op te nemen als een invulling van het materieel wets-

153. In sommige gevallen wees de rechter wel op de ingripendheid van de desbetreffende maatregel of regeling.

154. Zie ook Kortmann 1987a, p.29: "het komt erop neer dat bij een delegatieverbod de formele wetgever de 'belangrijke' beslissingen moet nemen en dat andere organen regelend dan wel beschikkend - zich slechts met details mogen bezig houden. Zo ontstaat een bepald type van een materieel wetsbegrip: de wetgever moet de belangrijke beslissingen memen, de rest is, ongeacht de inhoud, witwoering." 


\section{Hoofdstuk 9}

begrip. . $^{\text {ss }}$ Gezien de diversiteit van onderwerpen is hier echter geen samenhangend criterium te ontdekken.

\subsubsection{Conclusie}

We kunnen twee benaderingen van het legaliteitsbeginsel onderscheiden. De 'klassieke' benadering, waarbij vooral vanuil de positie van de burger wordt gekeken. grijpt het bestuur in in de vrijheid en eigendom van de burger, dan is darvoor een wettelijke grondslag nodig. Deze klassieke benadering krijgt een ruimere invulling wanneer ook voor presterend bestuurshandelen (zoals subsidiëring) een wettelijke grondslag wordt vereist.

155. Delegatie is verboden in: art. 2 lid 3 ; art. 2 lid 4 ; art. 4 ; art. 6 lid 1 ; art. 7 lid 1 ; art. 7 lid 3 eerste volzin; art. 8; art. 9 lid 1 ; art. 12 lid 2 ; art. 13 lid 1 ; art. 13 lid 2 ; art. 15 lid 2 tweede volzin; art. 17 ; art 28 lid 1 ; art. 29 lid 1 ; art. 30 lid 1 eerste volzin; art. 35 lid 3 eerste volzin; art. 37 lid 2 eerste volzin "eerste deel; art. 40 lid 1 tweede volzin, eerste deel; art. 40 lid 2 derde volzin; art. 49 ; art. 52 lid 2 ; art. 53 ; art. 54 lid 1; art. 54 lid 2 sub a; art. 57 lid 4 ; art. 60 ; art. 64 lid 4 eerste volzin; art. 65; art. 73 lid 1 tweede volzin; art. 73 lid 3 ; art. 74 lid 3 ; art. 74 lid 4 ; art. 75 lid 2 ; art. 77 lid 2 ; art. 77 lid 3 ; art. 78 lid 2; art. 80 lid 2; art. 89 lid 2 tweede volzin; art. 91 lid 1 tweede volzin; art. 91 lid 2; art. 103 lid 1, eerste wolzin; art. 103 lid 2 ; art. 105 lid 1; art. 108 lid 2 tweede volzin; art. 111; art. 112 lid 2 eerste volzin; art. 116 lid 1 ; art. 116 lid 3 ; art. 117 lid 2 ; art. 117 lid 3 ; art. 118 lid 2 ; art. 118 lid 3 ; art. 121 eerste volzin; art. 122 lid 1 eerste deel; art. 123 lid 1 ; art. 126; art. 127 eerste deel; art. 129 lid 2 ; art. 129 lid 4 ; art. 129 lid 5 eerste en tweede volzin; art 130; art. 132 lid 5 tweede volzin; art. 132 lid 6 eerste deel; art. 136; art. 137 lid 1; art. 138 lid 1 sub a en b; art. 142.

Delegatie is toegestaan in de artikelen: art. 2 lid 1; art. 2 lid 2; art. 6 lid 2 ; art. 7 lid 2 ; art. 7 lid 3 tweede volzin; art. 9 lid 2 ; art. 10 lid 1 ; art. 10 lid 2 ; art. 10 lid 3 ; art. 11 ; art. 12 lid 1 ; art. 14 lid 1 ; art. 14 lid 3 ; art. 15 lid 1 ; art. 18 lid 2 ; art. 19 lid 2 ; art. 19 lid 3 ; art. 20 lid 2 ; art. 20 lid 3 ; art. 32 derde volzin; art. 34 eerste volzin; art. 35 lid 4 eerste volzin; art. 36 ; art. 37 lid 4 tweede volzin; art. 39 ; art. 40 lid 1 eerste volzin en tweede volzin, tweede deel; art. 58; art. 59 ; art. 63 eerste volzin; art. 70 ; art. 74 lid 1 derde volzin; art. 74 lid 5 ; art. 75 lid 1 ; art. 77 lid 4 ; art. 78 lid 1 ; art. 79 lid 1 ; art. 79 lid 2 ; art. 79 lid 3 ; art. 80 lid 1 ; art. 88 eerste volzin; art. 89 lid 2 ?; art. 89 lid 3 eerste volzin; art. 92; art. 95; art. 103 lid 1 tweede zin; art. 104; art. 105 lid 4; art. 106; art. 107 lid 1 ; art. 107 lid 2 ; art. 108 lid 1 ; art. 109; art. 110; art. 112 lid 2 tweede volzin; art. 113 lid 2 ; art 113 lid 4 ; art. 116 lid 2 ; art. 116 lid 4 ; art. 117 lid 4 ; art. 122 lid 1 tweede deel; art. 122 lid 2 ; art. 123 lid 2 ; art. 124 lid 2 ; art. 125 lid 1 tweede volzin; art. 127 ; art. 132 lid 1 ; art. 132 lid 2 ; art. 132 lid 3 ; art. 132 lid 5 eerste volzin; art. 132 lid 6 tweede deel; art. 133 lid 1 ; art. 133 lid 2 ; art. 133 lid 3 ; art. 134 lid 1 ; art. 13.4 lid 2 ; art. 134 lid 3 eerste volzin; art. 135 eerste volzin.

(De artikelen 23 en 97 tot en met 102 zijn hierbij niet opgenomen omdat deze uit de 'oude' Grondwet stammen en de delegatieterminologie niet van toepassing is.) 
Daarnaast is een benadering vanuit de grondwetgever opgekomen. Bij de Grondwetsherziening van $1983 \mathrm{zijn}$ in de Grondwet veel opdrachten aan de wetgever opgenomen (waarbij de wetgever al dan niet van delegatie gebruik mag maken). Dat betekent dat een door de Grondwet aangewezen onderwerp wettelijke regeling behoeft, ongeacht de aard van het overheidshandelen.

Zodra er een wettelijke basis is, is aan het legaliteitsbeginsel voldaan, ongeacht in hoeverre het handelen wan de overheid in de wettelijke regeling wordt genormeerd. Dan is formeel aan het legaliteitsvereiste voldaan. Materieel echter kan het legaliteitsvereiste onder druk staan wanneer de formele wet bestuurshandelen niet of nauwelijks inhoudelijk normeert. Het bestuur kan dan zijn eigen normen stellen, bijvoorbeeld in de vorm van algemeen verbindende voorschriften wanneer er een regelgevende bevoegdheid is, of in de vorm van beleidsregels wanneer er een bestuursbevoegdheid is.

Beide benaderingen van het legaliteitsbeginsel komen naast elkaar voor, omdat ook buiten de sfeer van de Grondwet om, de overheid veelvuldig handelt.

\subsection{Samenvatting}

In dit hoofdstuk is aandacht besteed aan de vraag of er in de parlementaire stukken op de grondwetsherziening een bepaalde invulling van het legaliteitsbeginsel en materieel wetsbegrip ten grondslag ligt. Bij het invoeren van een grondwettelijke delegatieterminologie moet immers steeds vastgesteld worden welk (facet van een) onderwerp zo belangrijk is dat regeling bij formele wet vereist is (en derhalve een delegatieverbod dient te worden opgenomen) dan well bij welk onderwerp de formele wetgever ook andere organen mag inschakelen om dat onderwerp te regelen.

Daarbij geldt ten tijde van de parlementaire herziening als opvatting het klassieke legaliteitsbeginsel: burgers bindende regels behoren een formeel-wettelijke grondslag te hebben. Ook invloed zou kunnen uitoefenen het criterium dat de Hoge Raad in het Fluorideringsarrest (1973) formuleerde: ingrijpende besluiten behoren door de wet geregeld te worden.

In de Grondwet van 1983 zelf (waarbij in het bijzonder is gekeken naar artikel $81 \mathrm{Gw}$ ) is geen duidelijk formeel of materieel wetsbegrip neergelegd. Wel zijn van beide opvattingen sporen in de parlementaire stukken te vinden. De meeste auteurs zijn van mening dat artikel $81 \mathrm{Gw}$ een formele betekenis heeft: wetten worden samengesteld door regering en Staten-Generaal gezamenlijk. Artikel 81 $\mathrm{Gw}$ bepaalt niets over de inhoud van de wetten. Gelet op de tekst van artikel 81 $\mathrm{Gw}$ is veel voor deze opvatting te zeggen. Maar zo niet grondwettelijk, dan toch 


\section{Hoofdstuk 9}

in elk geval constitutioneel, is verdedigbaar dat er ook een materieel wetsbegrip ten grondslag ligt aan artikel $81 \mathrm{Gw}$, in die zin dat een formele wet zo veel mogelijke algemene regels bevat die op een ieder (of betrokkenen) gelijkelijk van toepassing zijn, en die bovendien belangrijke of ingrijpende besluiten vastlegt.

Een onderzoek naar criteria voor een materieel wetsbegrip in de parlementaire stukken levert weinig op: een consistent gebruik van criteria is er niet uit op te maken. Impliciet lijkt er consensus te zijn over het feit dat de formele wetgever belangrijke besluiten moet nemen. Slechts een enkele keer wordt naar het Fluorideringsarrest verwezen en het criterium 'ingrijpendheid.' In sommige gevallen is de voorgestelde delegatiebepaling door de Tweede Kamer geamendeerd, in die zin dat een delegatieverbod is opgenomen daar waar de regering delegatie had toegestaan.

In paragraaf 9.3 zijn opvattingen over het legaliteitsbeginsel en het materieel wetsbegrip behandeld $n a$ de invoering van de Grondwet van 1983. Ten aanzien van de betekenis van het legaliteitsbeginsel was de conclusie dat meer overheidshandelen onder de werking van het legaliteitsbeginsel wordt gebracht. Kern van het legaliteitsbeginsel is nog steeds de 'klassieke' invulling: voor bestuursoptreden dat ingrijpt in vrijheid en eigendom van burgers (waaronder de grondrechten) is een formeel-wettelijke grondslag nodig. Daarnaast wordt steeds meer voor bepaalde vormen van presterend overheidshandelen (zoals subsidiëring) een wettelijke basis geëist (zie ook het wetsvoorstel Derde tranche Awb). Voor al het overheidsoptreden een wettelijke grondslag eisen lijkt niet zinvol. Dat zou de werklast voor de formele wetgever onaanvaardbaar opschroeven, met als gevolg waarschijnlijk veel kaderwetgeving en blanco-delegatie, hetgeen in strijd is met de opvattingen over het delegatievraagstuk na 1983 om juist zuinig om te gaan met delegatie van regelgevende bevoegdheid.

Naast de theorievorming over de inhoud van het legaliteitsbeginsel zijn er enkele studies verschenen over een (nieuwe) invulling van het materieel wetsbegrip. Daaruit valt consensus af te leiden met betrekking tot de taak van de formele wetgever: de wetgever dient ingrijpende besluiten te nemen. Concrete onderwerpen die als 'ingrijpend' kunnen worden aangemerkt zijn genoemd in het rapport Orde in de regelgeving en de Aanwijzingen voor de regelgeving 1993. Zij kunnen dan ook dienen ter invulling van dit criterium. De mate van ingrijpendheid zal mede bepalen of en hoeveel ruimte er voor delegatie is. Daarbij geldt dat die delegatie eerder aanvaardbaar is naar mate de delegatieverlening behoorlijk genormeerd en begrensd is. 
De invoering van de grondwettelijke delegatieterminologie in de Grondwet van 1983 heeft met zich meegebracht dat voor veel onderwerpen regeling bij of krachtens formele wet vereist wordt: daarmee heeft het legaliteitsbeginsel een uitbreiding ondergaan. Dat betekent dat in sommige gevallen een formeel-wettelijke basis nodig is ook al betreft het de regeling van een onderwerp waarbij geen inbreuk wordt gemaakt op de vrijheid of eigendom van de burger. Het grondwettelijke delegatieverbod is op twee manieren van belang voor de inhoud van het materieel wetsbegrip. Dat is op de eerste plaats wegens de omschrijving van dat verbod: wezenlijke bepalingen van een onderwerp horen in de formele wet zelf thuis, de regeling van detailpunten kan worden gedelegeerd; daarbij kan voor wat 'wezenlijke bepalingen" zijn aangesloten worden bij de onderwerpen genoemd in het rapport Orde in de regelgeving en de Aanwijzingen voor de regelgeving. Op de tweede plaats blijkt uit de onderwerpen waarvoor een delegatieverbod geldt een keuze van de grondwetgever voor een bepaald soort materieel wetsbegrip. Gezien de diversiteit van onderwerpen waarvoor een delegatieverbod geldt zijn hier echter geen duidelijke criteria aan te ontlenen. 


\section{Hoofdstuk 10}

\section{Conclusies}

\subsection{Inleiding}

Het is tijd om de balans op te maken. In paragraaf 1.1 zijn vijf onderzoeksdoelen gesteld, die ik nog even in herinnering roep. Het eerste doel was om in deze studie te onderzoeken welke betekenis de grondwettelijke delegatieterminologie precies heeft en of de terminologie op consequente wijze in de Grondwet van 1983 is neergelegd. Ik bespreek de resultaten hiervan in paragraaf 10.2. Het tweede doel in dit onderzoek was om na te gaan hoe de ontwikkelingen in het delegatievraagstuk vóór en na 1983 waren en welke plaats de delegatieterminologie binnen die ontwikkeling heeft ingenomen (paragraaf 10:3). Het derde doel is omschreven als een onderzoek naar de manier waarop de formele wetgever en de rechter uitvoering geven aan de delegatieterminologie (paragraaf 10.4).

De vierde opdracht was om het delegatievraagstuk in het algemeen en de grondwettelijke delegatieterminologie in het bijzonder te confronteren met ontwikkelingen in het staats- en bestuursrecht. De volgende vraagstukken zijn daarbij onderzocht: het onderscheid regelgeving-uitvoering; het onderscheid algemeen verbindende voorschriften-beleidsregels; en de vraag naar de inhoud van het legaliteitsbeginsel en het materieel wetsbegrip. De belangrijkste bevindingen zijn bij elkaar gebracht in paragraaf 10.5 .

Het laatste onderzoeksdoel tenslotte was om te bezien of het gebruik van de grondwettelijke delegatieterminologie in de Grondwet van 1983 geslaagd te noemen is, en of het wenselijk is om bij een eventuele (algehele) volgende grondwetsherziening opnieuw een delegatieterminologie op te nemen. Daarbij wordt heel beknopt gewezen op andere ontwikkelingen die mogelijk hierop invloed kunnen uitoefenen (paragraaf 10.6).

\subsection{Betekenis en consequent gebruik van de grondwettelijke delegatieterminologie}

\subsubsection{Betekenis van de grondwettelijke delegatieterminologie}

De betekenis van de grondwettelijke delegatieterminologie is niet zonder meer afleidbaar uit de grondwettelijke bepalingen: daarvoor dienen de parlementaire stukken geraadpleegd te worden. De delegatieterminologie beoogt duidelijk te 
maken of overdracht van (regelgevende) bevoegdheid door de formele wetgever is toegestaan. Dit is het geval wanneer in een grondwetsbepaling één van de woorden 'regel' of 'regels' is gebruikt, of een vervoeging van het werkwoord 'regelen', dan wel đe term "bij of krachtens'. Is één van deze termen niet opgenomen dan is delegatie verboden. Dat betekent dat de formele wetgever slechts regelgevende bevoegdheid mag delegeren voor zover het de regeling van detailpunten betreft. Ook mag hij niet door middel van attributie van discretionaire bestuursbevoegdheid, of het gebruik van vage normen, de normstelling feitelijk aan een lager orgaan overlaten.

Met name de precieze invulling van het delegatieverbod leidde tot veel discussie. Zo was elke delegatie van regelgevende bevoegdheid bij een delegatieverbod verboden in het wetsontwerp op de grondrechten (een 'absoluut' delegatieverbod), terwijl in het wetsontwerp op de provincies en gemeenten delegatie van regelgevende bevoegdheid werd toegestaan voorzover het detailpunten betreft. De lezer blijft achter met de vraag welke opvatting de geldende is.

Door de invulling van het delegatieverbod in het wetsontwerp op de provincies en gemeenten op te vatten als een nuancering van het 'absolute' delegatieverbod wordt een manier gevonden om dit verschil in opvatting te overbruggen. ${ }^{2}$

Voor een inbreuk op een grondwettelijk geregeld grondrecht dient steeds een specifieke wettelijke grondslag aanwezig te zijn. Een basis in een verordening die

1. Zie paragraaf 4.2 .

2. Eenzelfde versnippering van 'motivering' (waar ik gemakshalve de uitleg van het grondwettelijke delegatieverbod onder schaar) kan plaatsvinden bij de behandeling van één wetsvoorstel. Om tegernoet te komen aan het ongemak voor de lezer (die zijn informatie dan uit verscliillende stukken moet halen, hetgeen een belasting van tijd en energie is) stelt Waaldijk voor om de gewijzigde memorie van toelichting in te voeren. (Waaldijk 1994, p.232. Zie voor zijn argumenten p.232-235.) Vanaf de aanvang van een behandeling van een wetsvoorstel dient aanvulting en/of wijziging in de motivering van een wetsvoorstel verwerkt te worden in een gewijzigde memorie van toelichting. Het grote voordeel is dat steeds in éen stuk de laatste stand van zaken weergegeven wordt. Dit voorstel voor een 'gewijzigde mernorie van toelichting' is bruikbaar voor ến wetsvoorstel. De grondwetsherziening is echter over meerdere wetsvoorstellen verdeeld. Een sluitende oplossing voor het hierboven geschetste probleem dat een uitleg van de delegatieterminologie platsvindt in meerdere wetswoorstellen biedt de gewijzigde memorie van toelichting niet. Op voorw hand is ook niet duidelijk hoe wel een afdoende 'systeem' opgezet kan worden. Het mooist zou zijn wanneer de door de regering (en door de Staten-Generaal over te nemen) voorgestelde uitleg van de grondwettelijke delegatieterminologie (slechts) in één stuk ((gewijzigde) memorie van toelichting) zou staan dat aan het begin van de parlementaire behandeling van de reeks herzieningsvoorstellen aan de orde is, en waarnaar in volgende herzieningsvoorstellen verwezen wordt. 
is vastgesteld krachtens de algemene verordenende bevoegdheid van provincies en gemeenten is niet voldoende.

De delegatieterminologie bepaalt niet in welke mate er gedelegeerd mag worden. Bij de interpretatie van de terminologie dient rekening gehouden te worden met het onderwerp, de strekking en historie van de bepaling. ${ }^{3}$

Zoals er goede redenen zijn om aan te nemen dat een formele wetgever zich door middel van wetgeving niet voor de toekomst kan binden ${ }^{4}$, geldt dat ook voor de grondwetgever waar het gaat om de betekenis van de delegatieterminologie zoals neergelegd in toelichtende stukken. Ook daar dient de vrijheid te bestaan om, na verloop van tijd, voor een andere invulling te kiezen of andere accenten te leggen, hoezeer dat misschien uit oogpunt van systematiek en duidelijkheid te betreuren valt.

Dit betekent dat de uitleg van de delegatieterminologie in de tijd (na inwerkingtreding van de Grondwet) kan evolueren. Vanuit de wetenschap, of vanuit de praktijk van wetgever of rechter, kan er behoefte ontstaan aan een andere invulling van de dellegatieterminologie.

Ik bepleit terughoudendheid in versoepeling van toepassing van de delegatieterminologie. De grondwettelijke delegatieterminologie is als systeem van competentievoorschriften opgezet en in vele grondwettelijke artikelen neergelegd. Het opnemen van een delegatieverbod biedt voor de burger de waarborg dat slechts de formele wetgever regelend kan optreden. Gezien het belang hiervan, vooral daar waar fundamentele rechten van burgers in het geding zijn zoals bij grondrechten, dient niet te snel aangenomen te worden dat afwijking van het delegatieverbod in een concreet geval mogelijk of noodzakelijk is.

Meer ruimte is er voor een ontwikkeling van opvattingen over de mate waarin gedelegeerd kan worden nu daarvoor in de parlementaire stukken (in de meeste gevallen) geen "harde" aanwijzingen zijn gegeven. Hier geldt dat ruimte is om de opvattingen over het delegatievraagstuk zoals die zich na 1983 ontwikkelen in acht te nemen. Na 1983 is steeds meer terughoudendheid met delegatie bepleit (zie ook paragraaf 10.3 .2 ).

Het belang van de grondwettelijke delegatieterminologie is overigens slechts relatief doordat veel wetgeving tot stand komt die niet rechtstreeks geënt is op een grondwetsartikel. Voor de wetgeving die buiten de Grondwet om tot stand komt, gelden de 'gewone regels" van het delegatievraagstuk (zie hoofdstuk 4).

3. Zie paragraaf 4.2 .

4. Waaldijk 1.994 , hoofdstuk 6 . 


\section{Hoofdstuk 10}

\subsubsection{Onduidelijkheid over het gebruik van delegatieterminologie}

Onduidelijkheid over de te hanteren delegatieterminologie is er niet alleen wegens een verschillende uitleg van de terminologie, maar ook wanneer de terminologie niet consequent wordt toegepast (zie paragraaf 5.3). In de huidige Grondwet is dat het geval in de artikelen 36 en 104. De daar gebruikte term 'krachtens' (in plaats van 'bij of krachtens') roept de vraag op of bedoeld is delegatie mogelijk te maken. Bij artikel 104 Gw geldt overigens dat de tekst van deze bepaling door amendering tot stand kwam. Het oorspronkelijke regeringsvoorstel bevatte wel de thans geldende delegatieterminologie.

Ook onduidelijkheid over het hanteren van delegatieterminologie is er bij de tekst van artikel $23 \mathrm{Gw}$ (onderwijs) en de artikelen 97-192 Gw (defensie). De herzieningsvoorstellen voor deze bepalingen sneuvelden bij de grondwetsherziening. Van deze onderwerpen zijn de artikelen uit de Grondwet naar de tekst van 1972 overgenomen. Bij deze artikelen is het de vraag of de uitleg van de delegatieterminologie erop kan worden toegepast. Uiterste voorzichtigheid past daar waar die delegatieterminologie (in belangrijke mate) aanleiding was om het herzieningsvoorstel van de regering te verwerpen, zoals bij artikel 23 Grondwet het geval was. De terminologie mag dan in elk geval niet gehanteerd worden op die punten waar de discussie zich heeft toegespitst. Breekpunt bij artikel 23 Grondwet was dat, wanneer delegatie werd toegestaan, niet alleen delegatie binnen de centrale overheid mogelijk zou zijn, maar ook delegatie van rijksniveau naar decentraal niveau. Wanneer onder de huidige Grondwet de formele wetgever delegatie zou overwegen is duidelijk dat met een beroep op de grondwettelijke delegatieterminologie delegatie naar gemeente of provincie niet zonder meer toelaatbaar is.

Opvallend is in dit verband dat de Centrale Raad van Beroep artikel 23 Grondwet in sommige uitspraken heeft geinterpreteerd alsof er wel sprake was van een geldende delegatieterminologie. ${ }^{5}$ Dit deed de Centrale Raad door bij een beperking van de vrijheid van onderwijs na te gaan of "overeenkomstig het in de Grondwet vervatte systeem, die beperking herleidbaar is tot een in artikel 23 Grondwet omschreven beperkingsbevoegdheid". (...) "De beperkingsbevoegdheden, welke met name in het tweede lid van artikel $23 \mathrm{Gr}$.w. kunnen worden gellezen, hebben niet in enige wettelijke regeling een zodanige uitwerking gevonden dat in een geval als het onderhavige van een met de Gr.w. corresponderende 
herleidbaarheid kan worden gesproken." ${ }^{6}$ De norm die de Centrale Raad dan ontwikkelt is dat een ambtenaar in de uitoefening van zijn grondrecht (in dit geval de vrijheid van onderwijs), niet zover mag gaan dat de vervulling van zijn functie of de goede functionering van de openbare dienst in volstrekt ontoelaatbare mate wordt aangetast.

Dit laatste criterium past in de jurisprudentie zoals die zich heeft ontwikkeld rond de handhaving van het grondwettelijk delegatieverbod: de rechter gaat hierbij steeds vaker over tot een afweging van de betrokken belangen (zie ook paragraaf 10.4.2).

\subsubsection{Een apart grondwetsartikel voor de delegatieterminologie?}

De delegatieterminologie heeft vooral waarde in de gevallen dat delegatie van regelgevende bevoegdheid wordt verboden, ondanks het feit dat formele wetgever en rechter soms moeite hebben om het delegatieverbod te handhaven (zie paragraaf 10.4). Daarin is een precieze omschrijving van het delegatieverbod noodzakelijk. Een ruim delegatieverbod verdient daarbij de voorkeur: wanneer delegatie verboden is mag geen regelgevende bevoegdheid overgedragen worden. ${ }^{7}$ Wel kunnen in zo'n geval bestuursbevoegdheden worden toegekend. Bij de uitoefening daarvan kunnen bestuursorganen gebruik maken van beleidsregels. Het beperken van (grondwettelijke) grondrechten, het creëren of toedelen van bevoegdheden en het opleggen van verplichtingen aan burgers is daarbij niet toegestaan en dient, wanneer het zich bij de regeling van een onderwerp voordoet, in de formele wet te geschieden. Deze invulling van het delegatieverbod lijkt gerechtvaardigd nu het immers gaat om onderwerpen, die de wezenlijke elementen van een regeling betreffen, en waarvan de grondwetgever volgens de uitleg van de grondwettelijke delegatieterminologie regeling door de formele wetgever heeft gewild.

Is het wenselijk dat de delegatieterminologie in een aparte Grondwetbepaling wordt neergelegd? Het zou de duidelijkheid voor de nog-niet-wetende lezer

6. CRvB \& augustus 1991, AB 1991,577; TAR 1991, 175 (over een politie-ambtenaar die als nevenwerkzaamheideen rijschool wil houden), verwijzend naar CRvB 16 november 1989 , AB 1991, 24; TAR 1990, 13, m.nt. Olde Kalter; AB 1991, 24, met kritische noot Hennekens.

7. Het onderscheid regelgevende bevoegdheid - bestuursbevoegdheid kan gemaakt worden zoals in deze studie in paragraaf 2.1 is gedaan: een regelgevende bevoegdheid houdt in de bevoegdheid om algemeen verbindende voorschriften te stellen; een bestuursbevoegdheid is een bevoegdheid wan een bestuursorgaan, uitgezonderd het stellen van algemeen verbindende voorschriften of het verrichten van rechterlijke handelingen. 
ongetwijfeld vergroten. Maar die duidelijkheid is slechts schijn zolang niet ook de precieze betekenis en omvang van de toegestane delegatie en het delegatieverbod daarbij worden opgenomen. Bij de omschrijving van die betekenis wordt gebruik gemaakt van begrippen zoals regelgevende bevoegdheid, bestuursbevoegdheid, algemeen verbindend voorschrift en beleidsregel. Hun betekenis is in de huidige rechtspraktijk niet vastomlijnd. Ze lenen zich dan ook niet goed voor grondwettelijke regeling. Fixatie van deze begrippen door middel van een grondwettelijke codificatie zou tekort doen aan de ontwikkelingen die zich ongetwijfeld $^{8}$ voordoen gedurende de decennia dat de Grondwet geldend recht is. Ook uit rechtsbeschermingsoogpunt verdient grondwettelijke codificatie geen aanbeveling. De 'handhaving' van de delegatieterminologie door de rechter kan immers niet plaats vinden zolang het toetsingsverbod in artikel $120 \mathrm{Gw}$ opgenomen blijft. De formele wetgever zelf dient op een juiste toepassing en invulling van de delegatieterminologie toe te zien.

\subsection{De ontwikkeling van het delegatievraagstuk voor en na 1983 en de plaats van de delegatieterminologie daarin}

\subsubsection{De ontwikkeling van het delegatievraagstuk voor 1983}

In hoofdstuk 3 is gekozen voor een schetsmatige aanpak van het delegatievraagstuk tot 1983. Aan de hand van enkele wetenschappelijke werken zijn de volgende lijnen zichtbaar geworden. Sinds de tweede helft van de vorige eeuw neemt de formele wetgever steeds meer zijn toevlucht tot delegatie. De anvankelijk heersende weerstand hiertegen, voortkomend uit het idee, dat de moeizaam op de Koning bevochten macht niet zomaar weer aan hem teruggegeven mag worden, maakt plaats voor het besef dat inschakeling van lagere regelgevers onontkoombaar is. Maar de theoretische onderbouwing van het delegatievraagstuk blijkt niet eenvoudig. Tegenstanders van delegatie proberen hun standpunt te redden door dat wat aan de Koning wordt overgelaten om te regelen, 'uitvoering' te noemen, hetgeen wel was toegestaan.

Wanneer delegatie meer en meer geoorloofd wordt geacht verschuift de aandacht van de theoretische onderbouwing naar het zoeken van waarborgen tegen te vergaande delegatie. Daarvoor zijn verschillende maatregelen voorgesteld. Zo wil Van der Pot in 1916 de ministeriële verantwoordelijkheid inzetten, met als consequentie dat het parlement het vertrouwen in een minister kan opzeggen

8. Zie bijvoorbeeld de ontwikkelingen rond het begrip 'beleidsregel" (paragraaf 8.2). 
wanneer de minister niet aan kritiek ter zake van gedelegeerde regelingen van het parlement tegemoet komt (zie paragraaf 3.3).

Anderen, zoals Stellinga in 1951, beogen delegatie te begrenzen om op die manier te voorkomen dat delegatie te ver reikt. Voor Stellinga houdt dat in dat de hoofdzaken in een formele wet zelf opgenomen dienen te worden, regeling van detailpunten kan worden gedelegeerd (paragraaf 3.4).

Soms ook wordt gekozen voor heel praktische oplossingen om theorie en praktijk met elkaar in overeenstemming te brengen. Dit speelt vooral wanneer door de rechter 'verboden delegatie' is geoordeeld. In sommige gevallen is daarop de tekst van de wet aangepast (bijvoorbeeld door de term 'bij of krachtens' op te nemen) waardoor de delegatie 'gelegaliseerd' wordt. De invoering van de grondwettelijke delegatieterminologie in 1983 vindt plaats in een fase waarin delegatie van regelgevende bevoegdheid op uitgebreide schaal plaatsvindt, terwijl niet steeds duidelijk is of de 'oude' Grondwet in de diverse bepalingen beoogde delegatie mogelijk te maken.

\subsubsection{De ontwikkeling van het delegatievraagstuk na 1983}

Met de invoering van de grondwettelijke delegatieterminologie in 1983 krijgt het delegatievraagstuk er een dimensie bij. Bij wetgeving ter uitvoering van een grondwettelijk geregeld onderwerp is van belang na te gaan of delegatie is toegestaan. Is dat het geval dan gelden krachtens de delegatieterminologie weinig beperkingen. Integendeel, het delegatiebegrip heeft juist een uitbreiding ondergaan ten opzichte van de opvattingen over het delegatievraagstuk voor 1983. Zo is delegatie niet alleen toegestaan binnen dezelfde bestuurskolom (bijvoorbeeld formele wet-algemene maatregel van bestuur-ministeriële regeling), maar kan er ook gedelegeerd worden van formele wet naar provinciale of gemeentelijke verordening (zie ook paragraaf 4.2). Ook de attributie van bestuursbevoegdheden door de formele wetgever valt onder het delegatiebegrip (de verhouding algemene regeling-concreet besluit). Als delegatie is verboden dan dient de formele wetgever zelf alle wezenlijke elementen van een onderwerp te regelen, slechts de regeling van detailpunten mag aan lagere organen overgelaten worden. In paragraaf 4.5 is ingegaan op de vraag of de ruimere invulling van het delegatiebegrip ook geldt voor het delegatievraagstuk buiten de Grondwet. De conclusie in die paragraaf was dat de verruiming van het delegatiebegrip alleen lijkt te gelden voor op de Grondwet gebaseerde wetten. De toedeling van bevoegdheden door de formele wet aan een decentraal orgaan zal, wanneer het een op de Grondwet gebaseerde wet is, delegatie genoemd kunnen worden. Dezelfde toedeling zal bij een niet op de Grondwet gebaseerde wet attributie heten. Het betreft slechts een verschillend etiket waaraan geen rechtsgevolgen zijn verbonden. 


\section{Hoofdstuk 10}

Als ontwikkeling in het denken over delegatie na 1983 buiten het grondwettelijk kader om valt te wijzen op diverse regeringsstukken waarin terughoudendheid met delegatie wordt bepleit (zie paragraaf 4.3). Deze opvatting komen we tegen in onder andere de Aanwijzingen voor de regelgeving 1993 en diverse kabinetsnota's en standpunten. Daarbij valt op dat het grondwettelijk delegatieverbod en de geoorloofdheid van delegatie in het algemeen naar elkaar toegroeien. Zowel bij een delegatieverbod als wanneer delegatie is toegestaan is de opvatting dat de formele wet de voornaamste normen en hoofdelementen van de regeling bevat. Bij de uitleg van de grondwettelijke delegatieterminologie is over de mate waarin gedelegeerd mag worden weinig bepaald. Om te voorkomen dat er twee 'soorten' delegatiebegrippen ontstaan te weten een grondwettelijk (waarbij het mogelijk is om ruim te delegeren) en een buiten-grondwettelijk (waarin terughoudendheid bij delegatie betracht moet worden) dienen ook voor het grondwettelijke delegatiebegrip de ontwikkelingen in het delegatievraagstuk na 1983 gevolgd te worden.

Of het theoretische uitgangspunt van terughoudendheid met delegatie in de praktijk voldoende gevolgd wordt moet nog worden afgewacht. Het lijkt er echter op dat het terugdringen van delegatie van regelgevende bevoegdheid een moeizame aangelegenheid is. Zo verzuchtte CDA-Tweede Kamerlid Van de Camp: "Iedere keer als de Tweede Kamer denkt 'nu hebben we een goede, bondige wet gemaakt als medewetgever", dan volgen er soms letterlijk kilo's algemene maatregelen van bestuur, ministerièle beschikkingen en andere uitvoeringsbesluiten. (...) Onze samenleving loopt onherroepelijk vast als de omvang van de editie Schuurman en Jordens opnieuw verdubbelt. Dat is immers de afgelopen zeveneneenhalf jaar gebeurd!"9

Het terugdringen van het aantal regels in formele wetten ${ }^{10}$ of gedelegeerde regelingen lijkt dus niet of maar moeizaam te lukken. Als het al lukt om het aantal algemeen verbindende voorschriften terug te dringen is het overigens de vraag

9. W.G.J.M. wan de Camp, Voortwarend wetgeven door de praktijk beschouwd, in RegelMaat 1994, p. 172.

10. Een kwantitatief overzicht van het aantal door de regering ingediende wetsvoorstellen geeft Visscher 1994, p. 1 14. Voor het jaar 1993 kan Tweede Kamervoorzitter Deetman geciteerd worden: "Dit jaar (1993, JD) zijn in totaal ingediend 284 wetsvoorstellen, waarvan 10 initiatiefvoorstellen. Et zijn afgedaan 321 voorstellen. In vergelijking met de voorgaande jaren zouden wij in zekere zin kunnen spreken van een topscore." Aangehaald bij Van de Camp 1994, p.168. Hoewel we voorzichtig moeten zijn met het interpreteren van deze cijfers (bij deze cijfers zal zeker meegespeeld hebben dat het kalenderjaar 1993 voor het kabinet Lubbers/Kok een 'oogstjaar' was) staat de stijging van het aantal wetten in 1993 nitet op zichzelf. 
of het probleem niet verlegd zal worden en de kennelijke behoefte aan regels vertaling zal vinden in een vloed van beleidsregels. Met andere woorden: het totaal aantal (uitvoerings)regels zal niet verminderen, maar wel het niveau waarop de regels gesteld worden.

Voor een substantiële vermindering van het aantal regels zal de overheid zich anders, en vooral ook minder, moeten gaan bezig houden met de samenleving. Slechts minder bemoeienis zal structureel minder regels opleveren. "Voorlopig lijken we aan een dergelijke cultuuromslag nog niet toe te zijn.

\subsection{Uitvoering van de delegatieterminologie door formele wetgever en rechter}

\subsubsection{Uitvoering van de delegatieterminologie door de wetgever}

Wanneer de Grondwet delegatie toestaat wordt daar door de formele wetgever in verschillende gevallen ruim gebruik van gemaakt (zie paragraaf 6.2). De functie van de delegatieterminologie hier is het meest erin gelegen om duidelijk te maken dat delegatie mogelijk is. Daarnaast kan de parlementaire behandeling van de desbetreffende bepaling aanknopingspunten bieden voor de gevallen dat er terughoudend met delegatie moet worden omgegaan, of ter zake van welke aspecten van een onderwerp er wel of toch geen delegatie mag plaatsvinden.

Van de mogelijkheid om te delegeren wordt in formele wetten (Vreemdelingenwet, Wet Persoonsregistraties) soms zoveel gebruik gemaakt dat de kwaliteit van de regelgeving onder druk staat. Harde conclusies zijn uit het in paragraaf 6.2 besprokenc echter niet te trekken nu slechts enkele uitvoeringswetten aan de orde zijn gesteld. Bovendien zegt een ruime mate van delegatie op zichzelf nog niets over de kwaliteit van de regelgeving en wordt hiermee ook geen waardering gegeven over de uitvoering van de delegatieterminologie.

De grondwettelijke uitvoeringswetgeving is zo talrijk dat bestudering van alle wetten en daarop gebaseerde regelingen in het kader van de in deze studie gestelde onderzoeksdoelen niet mogelijk was.

De meeste waarborgen voor de positie van de burger biedt de terminologie wanneer een delegatieverbod is opgenomen, zoals bij een aantal grondrechten. Het delegatieverbod betreft echter vaak slechts cen bepaald aspect van het desbetref-

11. Zo ook Schreuder-Vlasblom 1985, p.495-496. 
fende grondrecht. ${ }^{12}$ De formele wetgever blijkt in sommige gevallen moeite te hebben met de implementatie van het grondwettelijke delegatieverbod. Volgens de uitleg van het delegatieverbod is het namelijk niet toegestaan om discretionaire bestuursbevoegdheden te attribueren. Dit blijkt een moeilijke opdracht. In het bijzonder bij de wettelijke regeling van grondrechten doen zich problemen voor. Dat juist daar een strikte uitleg van het delegatieverbod opbreekt is niet verwonderlijk. De uitoefening van grondrechten vindt immers plaats in een enorme diversiteit van gevallen en omstandigheden die niet allemaal door de formele wetgever te voorzien en te regelen zijn. Inschakeling van lagere bestuursorganen om feitelijk gestalte te geven aan de invulling van grondrechten is onvermijdelijk. Wanneer een toegekende bevoegdheid discretionair is, ontstaat er spanning met het grondwettelijk delegatieverbod.

\subsubsection{Uitvoering van de delegatieterminologie door de rechter}

In de jurisprudentie waarin een grondwettelijk geregeld grondrecht centraal staat noemt de rechter slechts zelden dat hij voor de taak staat een delegatieverbod te handhaven. Veeleer omzeilt hij deze netelige kwestie en aanvaardt toch op enigerlei wijze beperkingen van dat grondrecht die niet tot een grondwettelijke beperkingsclausule te herleiden zijn (zie paragraaf 6.3). Daarbij neemt de belangenafweging een steeds grotere plaats in. In dat kader ontwikkelt de rechter in sommige gevallen ook eigen toetsingsnormen. Er is verschil van mening of hiermee niet in feite de leer van de 'algemene beperkingen' wordt aanvaard.

Een 'succes' is de grondwettelijke delegatieterminologie wanneer voor inbreuken op grondrechten een specifieke wettelijke grondslag noodzakelijk is. Dat geeft de rechter houvast bij de beoordeling of bepaalde regelingen, maatregelen of handelingen door de beugel kunnen. Daarbij lijkt de rechter in sommige gevallen tamelijk formeel te constateren dat een formeel-wettelijke basis ontbreekt terwijl die wel vereist is. Omdat het in de meeste gevallen echter om de uitoefening van een grondrecht gaat is waarschijnlijk impliciet wel een afweging van de bij de inbreuk op het desbetreffende grondrecht betrokken belangen aanwezig.

Een rechterlijk oordeel over te ruim uitgevoerde delegatic is mij niet bekend.

Overigens werkt het toetsingsverbod van artikel $120 \mathrm{Gw}$ en de daarop gebaseerde heersende leer dat strikt gebonden gedelegeerde regelgeving ook niet aan de Grondwet getoetst mag worden belemmerend voor een (rechterlijk) oordeel over de juiste uitvoering van de grondwettelijke dellegatieterminologie.

12. Zie bijwoorbeeld artikel $2 \mathrm{Gw}$ en Kortmann 1994, p.377. Veelal bieden in verdragen beschermde grondrechten meer bescherming. 


\subsection{Leerstukken}

\subsubsection{Het onderscheid regelgeving-uitvoering}

Uit hoofdstuk 7 bleek dat het vroeger veel gehanteerde onderscheid regelgevinguitvoering in het delegatievraagstuk in onbruik raakt. Het denken over bevoegdheden heeft de plaats ingenomen van het denken in functies. In deze studie is onderscheid gemaakt in regelgevende bevoegdheden en bestuursbevoegdheden. Het in onbruik raken van het onderscheid regelgeving-uitvoering is toe te juichen. Het is een onduidelijk onderscheid. De afbakening regelgevende bevoegdheid (als een bevoegdheid om algemeen verbindende voorschriften te stellen) en bestuursbevoegdheid (alle andere door een bestuursorgaan uit te voeren handelingen) biedt meer duidelijkheid. Uit hoofdstuk 7 bleek ook dat bestuursbevoegdheden ruimer mogen zijn dan bevoegdheden die eerder als 'uitvoerings'-bevoegdheid gekwalificeerd werden. Dat hangt samen met de opkomst van de beleidsregel waardoor bestuursbevoegdheden gestructureerd kunnen worden uitgeoefend. Dat is één ontwikkeling waardoor delegatieverlening in ruimere mate toelaatbaar, want toch begrensd werd geacht. (Een tweede ontwikkeling is dat het verschijnsel delegatie steeds meer geaccepteerd is.)

De consequentie in het denken over bevoegdheden is dat de formele wet en de daarop gebaseerde lagere wettelijke regeling duidelijkheid moeten verschaffen over de soort bevoegdheid die beoogd is in het leven te roepen. Dit geldt in elk geval zolang aan de uitoefening van een regelgevende of bestuursbevoegdheid verschillende consequenties zijn verbonden, zoals de soort regel die binnen een bevoegdheid gesteld kan worden.

Op verschillende manieren is geprobeerd die duidelijkheid te bewerkstelligen. Zo wordt well in de wettelijke regeling een bepaling opgenomen die de status van de uitvoeringsregels benoemt, bijvoorbeeld, Onze minister kan ter uitvoering van het bepaalde in de artikelen... (nadere) regels stellen. ${ }^{13}$ Beoogd is (in dit geval) om de minister regelgevende bevoegdheid te geven. Dergelijk taalgebruik wordt ook voorgesteld in de Aanwijzingen voor de regelgeving 1993. Zo wordt in Aanwijzing 30 voorgesteld om delegatie van regelgevende bevoegdheid aan de minister uit te drukken in de formule "bij ministeriële regeling' of 'bij regeling van Onze Minister van ...'.

13. Van der Vlies 1991, p.118-119. Zij voert als bezwar hiertegen an dat hiermee de bewoegdheid wan de minister nauwelijks genormeerd wordt, alleen aan het vereiste van een wettelijke grondslag wordt voldaan. 
In sommige gevallen is ook niet duidelijk of beoogd is een bepaalde bevoegdheid te attribueren, te delegeren of te mandateren. ${ }^{14}$ Het spreekt voor zich dat ook in dit opzicht naar zoveel mogelijk duidelijkheid moet worden gestreefd.

\subsubsection{Het onderscheid algemeen verbindende voorschriften-beleidsregels}

De beleidsregel makt een succesvolle ontwikkeling door in kwantitatief en kwalitatief opzicht. Bij de waardering van de beleidsregel speelt de erkenning door de Hoge Raad als rechtsregel alsmede de (toekomstige) wettelijke regeling in de Algemene wet bestuursrecht een belangrijke rol. Zowel in de Awb als in de jurisprudentie van de Hoge Raad wordt een beleidsregel nadrukkelijk onderscheiden van een algemeen verbindend voorschrift. Het handhaven van een onderscheid tussen beide soorten regels is van belang nu beleidsregels en algemeen verbindende voorschriften in sommige gevallen veel op elkaar lijken. Dat geldt in het bijzonder voor regels die in het kader van een aan een bestuursorgaan gedelegeerde regelgevende bevoegdheid of bestuursbevoegdheid tot stand komen. De stap om gelijkstelling te bepleiten ligt dan voor de hand (zie paragraaf 8.3.7).

14. Zie voor yoorbeelden van onduidelijk taalgebruik: (overdragen, delegeren, opdragen, toekennen, machtigen) Hennekens 1992, p.612;1992, p.642; Van Buuren in zijn noot onder ARRS 28 oktober 1988, AB 1989, 153). Ook in HR 18 januari 1991, NJ 1992, 638.(Leffers) was discussie over de gehanteerde terminologie. In dit arrest ging het om de Regeling verbod voedsel-en slachtafvallen (Stcrt 1986,66), gebaseerd op artikel 36 Veewet waarin is bepaald dat de minister van Landbouw en Visserij regelen kan stellen. Het Hof, AG Koopmans (verwijzend naar de Aanwijzingen voor de wetgevingstechniek) en de Hoge Raad oordeelden dat de terminologie "regelem stellen" voor aanduiding van delegatie algemeen gebruikelijk is en dat geen sprake was van te vergaande (of te ruim uitgevoerde) delegatie. In het cassatiemiddel bepleitte de Staat "dat de wetgever met de daarin vervatte delegatiebepaling niet beoogd heeft om de minister de bevoegdheid te verlenen, om een zo algemeen, ongeclausuleerd, (vrijwel) direct werkend en als blijvende bedoeld verbod als het onderhavige (...) uit te vaardigen (...)."

Zie ook de aanvankelijk onduidelijke terminologie in de nieuwe Politiewet (Kamerstukken 22562, Wet van 9 december 1993, Stb.724), besproken in AA september 1993, Katern p.2264): "in de eerste versie van het wetsontwerp was bepaald dat in het jaarlijkse beleidsplan zou worden aangegeven welke bevoegdheden met betrekking tot het beheer van een plaatselijk onderdeel van een politiekorps door de korpsbeheerder zou worden opgedragen aan de burgemeester van de betrokken gemeente. Aldus werd een beperkte overdracht van beheersbewoegdhedenvan de korpsbeheerderaan de lokale burgemeesters mogelijk. Niet duidelijk werd echter wat met de term 'opgedragen' bedoeld zou kunnen worden. In de Mw'T werd op dit punt noch de term 'delegatie" noch de term "mandaat" gebruikt. Evenmin werd duidelijk gemaakt aan welke bevoegdheden gedacht was. Middels een Nota van wijziging veranderde de regering het 'opgedragen' in "mandateren" of 'delegeren'." 
$\mathrm{Zo}$ is voorgesteld om beleidsregels de status van algemeen verbindend voorschrift te geven (Van der Vlies en Verheij) voorzover het ministeriële regels betreft gegeven in het kader van een wettelijk genormeerde beschikkingsbevoegdheid. Praktisch argument daarvoor is dat deze beleidsregels in de praktijk al als algemeen verbindend voorschrift werken. (Twee andere genoemde argumenten, namelijk dat op beleidsregels dan een bekendmakingsplicht rust, en dat ze door de Hoge Raad in cassatie te toetsen zijn, zijn inmiddels achterhaald. Beleidsregels moeten volgens Afdeling 3.6 Awb bekendgemaakt worden en sinds 1990 erkent de Hoge Raad onder bepaalde voorwaarden beleidsregels als recht in de zin van artikel 99 Wet RO.)

Omgekeerd is voorgesteld om de status van algemeen verbindend voorschrift te "verlagen' tot beleidsregel waar het gaat om regels die door bestuursorganen in het kader van een gedelegeerde bevoegdheid worden gesteld. Achtergrond hierbij is de gebrekkige democratische legitimatie van gedelegeerde algemeen verbindende voorschriften.

Een derde voorstel was om beleidsregels gedeeltelijk gelijk te stellen aan algemeen verbindende voorschriften namelijk voor zover er geen inbreuken worden gemaakt op (de klassieke invulling vano het legaliteitsbeginsel.

De waardering van de verschillende voorstellen hangt samen met de visie die men heeft op het legaliteitsbeginsel en materieel wetsbegrip (zie hoofdstuk 9 en paragraaf 10.5.3).

Ik hecht waarde aan een klassieke invulling van het legaliteitsbeginsel. Dat betekent dat er voor inbreuken op de vrijheid en eigendom van de burger steeds een specifieke wettelijke grondslag aangewezen moet kunnen worden. Hoe gebrekkig de democratische legitimatie van sommige gedelegeerde algemeen verbindende voorschriften ook is, het feit dat de formele wetgever bij de delegatieverlening is betrokken geeft (althans in theorie) enige waarborg voor de gestelde of te stellen regel. Naast deze klassieke invulling geldt dat het legaliteitsbeginsel ook geldt daar waar de grondwettelijke delegatieterminologie een regeling van een onderwerp bij of krachtens formele wet eist.

Een invulling van het legaliteitsbeginsel in die zin dat het optreden van (enig orgaan van) de overheid voldoende gelegitimeerd is wanneer het terug te voeren is op een algemene regel, zoals een beleidsregel, acht ik niet wenselijk. Daarmee wordt op voorhand afstand gedaan van een 'check' op de tot stand te komen 
regeling door Tweede en Eerste Kamer ${ }^{15}$ Slechts politieke verantwoordelijkheid en rechterlijke toetsing blijven dan over ter controle van de (uitvoering van de) regeling.

Een tweede bezwaar is dat de algemeenheid van een regel onder druk staat. Met de toenemende rechtsverfijning (vanuit de idee dat daardoor ook het rechtvaardigheidsgehalte van regelingen en uitvoeringsbeslissingen toeneemt) is aanvaard dat steeds meer regels een kleiner bereik hebben omdat ze gelden voor een kleinere doelgroep. Dit geldt ook voor algemeen verbindende voorschriften: het vereiste dat een algemeen verbindend voorschrift voor 'een ieder' geldt is vervangen door de eis dat 'betrokkenen' gebonden worden.

Dat leidt tot de conclusie dat we, wát we aan controle op de totstandkoming van een regeling hebben, dienen te behouden, inclusief parlementair toezicht vooraf, hoe onvolkomen soms ook. Voor inbreuken op vrijheid en eigendom van burgers, voor burgers belastende en of benadelende maatregelen, voor het beperken van (grondwettelijke) grondrechten of het attribueren of delegeren van bevoegdheden, dient dan ook een specifieke wettelijke basis aanwezig te zijn. Nu woor beleidsregels in het overgrote deel van de gevallen slechts een algemene wettelijke basis is (wanneer de voorgestelde regeling in de Awb in werking treedt) zijn beleidsregels niet geschikt voor regelingen die een inbreuk maken op het hier geschetste legaliteitsbeginsel.

Voor de hierboven beknopt geschetste voorstellen voor een gelijke status van beleidsregels en algemeen verbindende voorschriften betekent deze visie op het legaliteitsbeginsel het volgende. De gelijkstelling van beleidsregels aan algemeen verbindende voorschriften (voor zover het ministeriële regels betreft die gegeven worden in het kader van een wettelijk toegekende beschikkingsbevoegdheid) kan niet worden gevolgd voorzover in het kader van die beschikkingsbevoegdheid voorschriften worden gegeven die belastend of benadelend zijn voor de burger: voor die regels is een regelgevende bevoegdheid verplicht. Voor andere bepalingen is tegen eventuele gelijkstelling minder bezwaar. Het feit echter dat éen bevoegdheid aanleiding kan geven tot verschillende soorten regels (beleidsregels en algemeen verbindende voorschriften) werkt onduidelijkheid in de hand en is daarom niet wenselijk. Duidelijkheid is er wel wanneer wordt vastgehouden aan

15. Hoewel het vertrouwen in het "kunnen" van de formele wetgever niet door iedereen wordt gedeeld. Zo bijvoorbeeld E. Jurgens, in NJB 1993, De mythe van Meerenberg, p.1381-1386 (op dat tijdstip was Jurgens lid van de Tweedle Kamer), die pleit voor delegalisering: "In beginsel zou alles bij regeringsverordening geregeld mogen worden behalve datgene waarvoor een grond wetsbepaling, een wet of een kamerbesluit een wet vereist." De medewetgevende taak van de wetgever stelt, naar hij meent, weinig voor. 
de opvatting dat een bestuursbevoegdheid de bevoegdheid geeft tot het stellen van beleidsregels en een regelgevende bevoegdheid een bevoegdheid tot het stellen van algemeen verbindende voorschriften. Voor die regelgevende bevoegdheid dient dan een specifieke wettelijke basis te zijn.

Aan gelijkstelling van gedelegeerde algemeen verbindende voorschriften met beleidsregels kleeft het nadeel dat hierdoor de rechtszekerheid in geding komt. Dat gebeurt vooral wanneer dit voorstel zo wordt uitgewerkt dat steeds discussie over de toepasselijkheid van de regel in een (vermeend bijzonder) geval aan de orde is. Ook gevaar voor willekeur ligt op de loer. Een burger die beter met het bestuur kan onderhandelen over zijn positie en de van toepassing zijnde regels zal een gunstiger positie kunmen afdwingen dan een burger die op dit terrein minder getalenteerd is. Ook de werkdruk voor het bestuursapparaat zal door steeds terugkerende discussie met burgers sterk toenemen. Wanneer de klassieke invulling van het legaliteitsbeginsel hierop wordt toegepast betekent dat dat inbreuken op vrijheid of eigendom van burgers of belastende en benadelende maatregelen niet meer in een gedelegeerde regeling mogen worden neergelegd (die immers de status van beleidsregeling krijgt), maar dat deze bepalingen opgenomen moeten worden in een formele wet of provinciale of gemeentelijke verordening. De hiermee toenemende werkdruk voor parlement, provinciale staten en gemeenteraden is praktisch onwenselijk.

Een gedeeltelijke gelijkstelling van beleidsregels aan algemeen verbindende voorschriften namelijk voor zover beleidsregels geen inbreuk maken op de vrijheid en eigendom van de burgers geeft in de praktijk aanleiding tot onduidelijkheid. Zo kunnen sommige bepalingen uit een beleidsregeling aangemerkt worden als algemeen verbindend voorschrift, terwijl andere bepalingen die status niet krijgen omdat ze iets regelen wat aan een algemeen verbindend voorschrift is voorbehouden. Ze kunnen dan echter ook niet de status van beleidsregel krijgen. De regeling is in zoverre onverbindend.

De conclusie is dat geen enkele vorm van gelijke waardering van beleidsregels en algemeen verbindende voorschriften zo aantrekkelijk is dat invoering ervan dient te geschieden.

Gehele of gedeeltelijke gelijkstelling van beleidsregels en algemeen verbindende voorschriften heeft ook gevolgen voor het delegatievraagstuk en de delegatieterminologie. Zowel de opwaardering van beleidsregels tot algemeen verbindende voorschriften als de "degradatie" van algemeen verbindende voorschriften tot 


\section{Hoofdsiuk 10}

beleidsregels betekent dat het vraagstuk van delegatie van regelgevende bevoegdheid an betekenis verliest.

Wanneer beleidsregels de status van algemeen verbindend voorschrift krijgen is een (wettelijk toegekende) bestuursbevoegdheid voldoende om burgers bindende regels te kunnen stellen. Het is van belang om een wettelijke basis te blijven eisen voor de overdracht van bestuursbevoegdheid omdat daaruit nog enige democratische legitimatie voorvloeit. De gevolgen zullen minder verstrekkend zijn voor zover er ook minder beleidsregels gelijkgesteld worden (bijvoorbeeld wanneer de gelijkstelling alleen geldt voor ministeriële regels in het kader van een wettelijk toegekende beschikkingsbevoegdheid).

De omgekeerde situatie, algemeen verbindende voorschriften kwalificeren als beleidsregels, heeft eveneens belangrijke gevolgen voor het vraagstuk van delegatie van regelgevende bevoegdheid. Er blijft nauwelijks ruimte over om dit vraagstuk toe te passen als alle regels gesteld door bestuursorganen beleidregels worden. Met name heeft bijvoorbeeld delegatie van regelgevende bevoegdheid aản de minister dan geen zin meer. De door een minister te stellen regels mogen geen verplichtingen aan burgers opleggen, of grondrechten beperken. Die regels horen in de formele wet (of eventueel algemene maatregel van bestuur) thuis. Dat betekent onvermijdelijk een taakverzwaring voor de formele wetgever. Vanuit het delegatievraagstuk en de grondwettelijke delegatieterminologie is geen enkele vorm van gelijkstelling wenselijk.

\subsubsection{Het legaliteitsbeginsel en het materieel wetsbegrip}

De ontwikkeling van het legaliteitsbeginsel laat zien dat voor steeds meer handelen van de overheid een wettelijke basis verlangd wordt. Dat betekent meer werk voor de formele wetgever. Er bestaat gevaar voor kaderwetgeving: veel open normen en discretionaire bevoegdheden, die nauwelijks genormeerd zijn. Dit zou bovendien een tegenstrijdige beweging zijn met de bedoeling van regeringswege (zoals onder meer tot uiting komend in de Aanwijzingen voor de regelgeving 1993) om delegatie van regelgevende bevoegdheid terug te dringen en de belangrijkste normen in de formele wet zelf op te nemen (zie ook hoofdstuk 4). In de klassieke betekenis van het legaliteitsbeginsel heeft dit beginsel een materiële invulling: voor inbreuken op de vrijheid en eigendom van burgers is een wettelijke grondslag nodig. Door de invoering van de grondwettelijke delegatieterminologie komt daar een formele benadering bij: waar de Grond wet een wettelijke regeling van een onderwerp eist is een basis in een formele wet een vereiste, ook al is er geen sprake van een situatie die een inbreuk maakt op de vrijheid of eigendom van burgers. 
Opvattingen over het legaliteitsbeginsel en de inhoud van een materieel wetsbegrip klinken slechts sporadisch door in de parlementaire stukken op de grondwetsherziening. Een duidelijke opvatting over een materieel wetsbegrip is niet af te leiden uit de behandeling van het herzieningsvoorstell waarin onder meer artikel 81 Grondwet is opgenomen. Meer impliciet dan expliciet is de opvatting dat belangrijke onderwerpen bij formele wet dienen te worden geregeld. Daarbij komt meteen de vraag op wat belangrijk is. Nu daarvoor geen duidelijke criteria te geven zijn, en de invulling ervan sterk afhankelijk is van de politieke opvatting van de dag verdient de in de literatuur genoemde term ingrijpende besluiten de voorkeur. Ook deze term is vaag, maar net iets beter objectiveerbaar, hoewel elke nadere invulling aan kritiek zal blootstaan. De taak van de formele wetgever kan, op basis van de in paragraaf 9.3 besproken voorstellen, geformuleerd worden als het nemen van ingrijpende besluiten. Het criterium ingrijpend kan nader ingevuld worden vanuit de opvatting van het klassieke legaliteitsbeginsel (inbreuken op de vrijheid en eigendom van de burger behoeven een wettelijke grondslag) én met de concrete onderwerpen die zijn genoemd in het rapport Orde in de regelgeving en de Aanwijzingen voor de regelgeving 1993. Daarbij hangt van de mate van ingrijpendheid af of er delegatie kan plaatsvinden. Delegatie is sneller aanvaardbaar wanneer de delegatieverlening behoorlijk genormeerd en begrensd is.

De - rechtstheoretische - voorstellen voor de invulling van een materieel wetsbegrip komen mede voort uit een herbezinning op de taken van de overheid. Als reactie op de nog steeds toenemende regeldichtheid wordt gezocht naar een afbakening tussen die zaken die in elk geval overheidsbemoeienis behoeven (in de zin van regeling in een formele wet) en die zaken die de formele wetgever aan lagere bestuursorganen of burgers en maatschappelijke instanties zelf kan overlaten.

Overigens zal een dergelijke ontwikkeling zich niet alleen voltrekken vanuit wetenschappelijke ideeën, maar veeleer ook omdat bijvoorbeeld krimpendle financiële middelen tot cen taakvermindering noodzaken.

10.6 Evaluatie van de grondwettelijke delegatieterminologie; opnemen in de volgende Grondwet?

Het delegatievraagstuk is oud, maar aktucel. Vooralsnog lijken de pogingen om de bemoeienis van de overheid met de maatschappij terug te dringen nog slechts weinig vertaling te vinden in de kwantiteit en kwaliteit van de gestelde regels. 


\section{Hoofdstuk 10}

Heel veel zaken worden door de formele wetgever aangepakt waarbij deze onvermijdelijk ook moet terugtreden en (ruim) gebruik maakt van delegatie.

Het invoeren van de grondwettelijke delegatieterminologie in 1983, in het streven om in elk geval grondwettelijk duidelijk te maken of delegatie geoorloofd is, is in grote lijnen geslaagd te noemen. De gebruikte terminologie zelf is duidelijk (de woorden 'regels", 'regeling', 'regelen' en de term 'bij of krachtens'). Minder duidelijk is echter de precieze betekenis van de terminologie (met name de omvang van het delegatieverbod). Ook is de terminologie in sommige artikelen niet consequent opgenomen.

Formele wetgever en rechter hebben met de handhaving van het delegatieverbod de nodige moeite. Vooral het verbod van het opnemen van discretionaire bestuursbevoegdheden is problematisch. De formele wetgever ontkomt soms niet aan het opnemen van (min of meer discretionaire) bevoegdheden, de rechter loopt met een boogje om het delegatieverbod heen en ontwikkelt eigen toetsingscriteria hetgeen steeds meer neer komt op een belangenafweging in het concrete geval.

Ondanks het feit dat het delegatieverbod dogmatisch gezien niet steeds even goed uit de verf komt is opneming ervan in de Grondwet zinvol. Het noopt de formele wetgever in elk geval tot terughoudendheid op terreinen waar fundamentele zaken voor burgers in het geding zijn, zoals bij grondrechten. Het delegatieverbod biedt in die zin belangrijke waarborgen voor de burgers. De handhaving van het delegatieverbod door de rechter gebeurt weliswaar niet expliciet onder die noemer, maar het dwingt de rechter wel tot zorgvuldige toetsing van de uitgeoefende bestuursbevoegdheid.

Het is aardig om tot slot te speculeren over de vraag of bij een eventuele volgende integrale grondwetsherziening weer een grond wettelijke delegatieterminologie opgenomen moet worden. Het antwoord op deze vraag is afhankelijk van verschillende ontwikkelingen.

In elk geval de volgende ontwikkelingen hebben we kunnen waarnemen sinds de invoering van de delegatieterminologie in 1983. Op de eerste plaats is het onderscheid regelgeving-uitwoering, in die bewoordingen achterhaald. Het onderscheid zal dan ook niet meer bruikbaar zijn om in het kader van een delegatieverbod aan te duiden wanneer een bestuursbevoegdheid acceptabel is omdat hij slechts 'uitvoering' van de betreffende wettelijke regeling is.

Een tweede ontwikkeling is de opkomst van de beleidsregel. De beleidsregel is bezig zich een eigen plaats te verwerven naast het algemeen verbindend voorschrift. Voorlopig wordt het onderscheid tussen beide soorten regels gehandhaafd, maar wanneer beide soorten regels een gelijke status krijgen (hetgeen naar 
mijn oordeel, zoals betoogd, niet zou moeten), zal dat vrij ingrijpende gevolgen hebben voor het delegatievraagstuk en de delegatieterminologie.

Ook de invulling van het legaliteitsbeginsel en het materieel wetsbegrip kunnen consequenties hebben voor het delegatievraagstuk. Wanneer voor steeds meer overheidsoptreden een wettelijke basis wordt verlangd zal aan de mogelijkheid om te kunnen delegeren grote behoefte zijn. Daar staat tegenover dat in het denken over de inhoud van het materieel wetsbegrip de neiging is om de regeling van minder onderwerpen tot de taak van de formele wetgever te rekenen.

Ook andere vormen van regelen en besturen zijn onderwerp van studie, zoals symbolische wetgeving, ${ }^{16}$ communicatief bestuur, ${ }^{17}$ en onderhandelend bestuur ${ }^{18}$. Dergelijk overleg kan bijvoorbeeld uitmonden in het vastleggen van afspraken in convenanten. ${ }^{19}$

Achtergrond is steeds de constatering dat de traditionele wijze van regelen en besturen niet meer voldoet in de huidige samenleving. Maatschappelijke instanties en burgers dienen meer betrokken te worden bij de vraag of een regeling tot stand moet komen, in welke vorm en met welke inhoud. Dit lijkt een aantrekkelijk uitgangspunt. Het is echter niet ondenkbaar dat het legaliteitsbeginsel onder druk komt te staan wanneer voor burgers ingrijpend en benadelend handelen zonder wettelijke grondslag wordt vastgelegd. Het is immers de vraag of bestuur en burger steeds in gelijkwaardige onderhandelingsposities zijn waardoor de burger zich vrijwillig aan dergelijke regelingen onderwerpt.

Maar ook al verschuift besturen in de richting van onderhandelend besturen, dan zal er nog steeds plaats zijn voor en behoefte zijn aan optreden door de formele wetgever. En zolang er formele wetten uitgevaardigd worden (en regelingen op decentraal niveau) zal er behoefte zijn aan delegatie. Vooral gelet op het delegatieverbod heeft de grondwettelijke delegatieterminologie in het delegatievraagstuk een nuttige functie. Gezien de stand van dit onderzoek beantwoord ik de vraag

16. Zie bijvoorbeeld W.J. Witteveen, P. van Seters en G. van Roermund, redactie, Wat maakt de wet symbolisch?, W.E.J. Tjeenk Willink Zwolle 1991.

17. Zie bijvoorbeeld W.J. Witteveen, Delegeren is communiceren, Preadvies voor de Vereniging voor wetgeving en wetgevingsbeleid, in Delegatie van wetgevende bevoegdheid, Samsom H.D. Tjeenk Willink Alphen aan den Rijn 1992, p.46-97.

18. Zie bijvoorbeeld H.D. Stout en A.J. Hoekema (red.), Onderhandelend bestuur, W.E.J. Tjeenk Willink Zwolle 1994 en H.D. Stout en A.J. Hoekema, Onderhandelend Bestuur, W.E.J. Tjeenk Willink. Zwolle 1994, en het verslag over een gehouden studiedag over dit onderwerp in NJB 1995, p.796-798.

19. Zie bijvoorbeeld $W$. Konijnenbelt, Convenanten met de gemeenten: fluiten in het schemerduister, Lemma Utrecht 1992; S.E. Zijlstra, Convenanten. W.E.J. Tjeenk Willink Zwolle 1994; B. Peeters, Convenanten, in het bijzonder milieuconvenanten, W.E.J. Tjeenk Willink Zwolle 1994. 
of in een komende Grondwet een delegatieterminologie moet worden opgenomen dan ook (voorzichtig) bevestigend.

Ten slotte. Het delegatievraagstuk gaat over macht. De invoering van de grondwettelijke delegatieterminologie heeft daarbij vooral de aandacht gevestigd op een evenwichtige verdeling van die macht. Het gaat om de bevoegdheid van de één (de formele wetgever of het bestuur) om over de ander (de burger) wat te zeggen te hebben.

De verdeling van die macht is niet eenvoudig. Dat wat in het belang is van doortastende, slagvaardige en flexibele bestuurders, wil nog wel eens botsen met het belang van de burger die de schade aan inbreuken op vrijheid en eigendom zo veel mogelijk beperkt wil zien.

In die gevallen kan de grondwettelijke delegatieterminologie een blok aan het been van 'de overheid' zijn.

De geschiedenis van het delegatievraagstuk voor 1983, maar ook de nog betrekkelijk korte historie van de grondwettelijke delegatieterminologie, waarbij formele wetgever, bestuurders en rechters in sommige gevallen met de uitvoering ervan worstelen, laat zien dat het thema van de botsende belangen steeds weer terug keert.

Daarbij zijn gelukkig steeds de contouren van het legaliteitsbeginsel en ruimer, de rechtsstaat, zichtbaar. Dat is een groot goed. Het fundament van onze rechtsstaat is de moeite waard om door te ploeteren bij het steeds weer zoeken naar nieuwe evenwichten in machtsverdeling. De grondwettelijke delegatieterminologie draagt daar, in het bijzonder wat het delegatieverbod bij grondrechten betreft, een belangrijke steen aan bij. 


\section{Samenvatting}

In deze studie staan de Grondwet en delegatie centraal. De tekst van de 'oude' Grondwet gaf geen duidelijk antwoord op de vraag of de formele wetgever regelgevende bevoegdheid mocht delegeren. Bij de totstandkoming van de 'nieuwe' Grondwet in 1983 is beoogd die onduidelijkheid weg te nemen door het invoeren van een grondwettelijke delegatieterminologie.

Bij een evaluatie van deze delegatieterminologie wordt het delegatievraagstuk in constitutioneel perspectief geplaatst.

In hoofdstuk 2 zijn enkele werkdefinities gegeven. Voor deze studie belangrijke definities zijn de omschrijvingen van regelgevende bevoegdheid ('de bevoegdheid om algemeen verbindende voorschriften te stellen') en bestuursbevoegdheid ('een bevoegdheid van een bestuursorgaan uitgezonderd het stellen van algemeen verbindende voorschriften en het plegen van rechterlijke handelingen'.) In dit hoofdstuk is tevens aandacht besteed aan attributie-delegatie-mandaat en aan de regeling van delegatie en mandaat in het wetsvoorstel Derde tranche Algemene wet bestuursrecht.

In hoofdstuk 3 is aan de hand van enkele dissertaties een schets van het delegatievraagstuk tot 1983 gegeven. In de vorige eeuw ging de discussie vooral over de vraag of delegatie aan de Koning wel kon worden toegestaan. Wanneer - in theorie - delegatie verboden werd geacht, werd het begrip uitvoering soms erg opgerekt, zodat alles wat niet formele wetgeving was, als uitvoering werd betiteld (ook al zouden wij het materieel als regelgeving beschouwen).

In deze eeuw is delegatie van regelgevende bevoegdheid op zich zelf niet meer zo omstreden, maar gaat het om het afbakenen van de grenzen van toegestane delegatie. De delegatieterminologie in de Grondwet van 1983 is daar min of meer een uitzondering op: de terminologie geeft aan bij welke grondwettelijk geregelde onderwerpen delegatie is verboden of toegestaan. Over de grenzen van de delegatie bepaalt de terminologie vrijwel niets.

De precieze betekenis van de terminologie komt aan bod in hoofdstuk 4. De betekenis ervan is behandeld in twee wetsvoorstellen: het absolute delegatieverbod (elke delegatie van regelgevende bevoegdheid is verboden), neergelegd in het wetsvoorstel op de grondrechten (Kamerstukken 13872), wordt genuanceerd in het wetsvoorstel op de provincies en gemeenten (Kamerstukken 13990). De 


\section{Samenvatting}

betekenis van de delegatieterminologie kan dan als volgt omschreven worden: delegatie is toegestaan wanneer de term 'bij of krachtens', een vorm van het werkwoord 'regelen' of een van de woorden 'regels' of 'regeling' wordt gebruikt. De mate waarin de wetgever van dellegatie gebruikt maakt is hierdoor niet bepaald. Wanneer delegatie is toegestaan mag een grondrecht alleen beperkt worden wanneer daarvoor een specifieke wettelijke basis is aan te wijzen. Voor provinciale en gemeentelijke besturen biedt de algemene verordenende bevoegdheid onvoldoende basis.

Een delegatieverbod houdt in dat de formele wetgever wezenlijke bepalingen in de wet zelf dient vast te leggen. De regeling van detailpunten mag overgelaten worden aan lagere regelgevers. De wetgever mag niet door het attribueren van discretionaire bestuursbevoegdheden of het gebruik van vage normen in feite de normstelling aan lagere organen overlaten.

De delegatieterminologie geldt niet voor de grondwetsartikelen die zijn overgenomen uit de 'oude' Grondwet nadat het betreffende herzieningsvoorstel was verworpen (zie hoofdstuk 5). Dat zijn artikel $23 \mathrm{Gw}$ (onderwijs) en de artikelen 97$102 \mathrm{Gw}$ (defensie) Ook is de terminologie niet op consequente wijze in de artikelen 36 en $104 \mathrm{Gw}$ opgenomen.

Met name de uitvoering en handhaving van het delegatieverbod plaatst de formele wetgever en de rechter voor problemen, in het bijzonder bij de bepalingen over grondrechten (hoofdstuk 6). De formele wetgever ontkomt in sommige gevallen niet aan het opnemen van discretionaire bestuursbevoegdheden waardoor de normstelling niet in de formele wet maar feitelijk door het bestuursorgaan plaatsvindt. Daar waar delegatie van regelgevende bevoegdheid is toegestaan wordt er in sommige gevallen ruim gebruik van gemaakt.

Voor inbreuken op grondrechten dient in veel gevallen een wettelijke basis te zijn. Het ontbreken van die basis is voor de rechter aanleiding om de betwiste regeling onverbindend of de bestreden maatregel onrechtmatig te achten.

Voor de burger liggen hier dan ook de belangrijkste waarborgen van de delegatieterminologie: de vereiste wettelijke basis voor inbreuken op grondrechten, waarbij een delegatieverbod de meest vergaande bescherming biedt.

Bij het delegatievraagstuk is van oudsher een scheiding gemaakt tussen regelgeving en uitvoering. Uit hoofdstuk 7 is duidelijk geworden dat dit onderscheid als zodanig niet meer in de jurisprudentie gehanteerd wordt. Nu is van belang of er een bevoegdheid is tot het stellen van algemeen verbindende voorschriften. Is dat niet het geval dan worden de in het geding zijnde regels gekwalificeerd als beleidsregels. Deze regels hebben zich de afgelopen decennia in toenemende mate 
een plaats verworven binnen het juridische systeem. Zo zijn ze door de Hoge Raad erkend als recht in de zin van artikel 99 Wet RO en is in het wetsvoorstel Derde tranche Algemene wet bestuursrecht een codificatie van de regels beoogd (hoofdstuk 8). Beleidsregels lijken in sommige gevallen zoveel op algemeen verbindende voorschriften dat er praktisch gezien nog nauwelijks onderscheid lijkt. Gelijkstelling van beide soorten regels is echter niet wenselijk, gelet op de 'klassieke' invulling van het legaliteitsbeginsel, die inhoudt dat inbreuken op de vrijheid en eigendom van burgers een wettelijke grondslag behoeven. Beleidsregels kunnen niet dienen om burgers verplichtingen op te leggen, inbreuken op grondrechten te maken of bevoegdheden te attribueren of delegeren: daar is steeds een specifieke wettelijke basis voor nodig.

De parlementaire behandeling van de grondwetsherziening geeft geen duidelijke criteria voor de invulling van een materieel wetsbegrip te zien (hoofdstuk 9). Consensus is er over het feit dat 'belangrijke' zaken wettelijke regeling behoeven. In studies over het materieel wetsbegrip na 1983 is dat uitgewerkt tot de opvatting dat 'ingrijpende' besluiten genomen dienen te worden door de formele wetgever. Concrete onderwerpen daarvoor zijn genoemd in het rapport Orde in de regelgeving 1985 en de Aanwijzingen voor de regelgeving 1993. Van de mate van ingrijpendheid van het te nemen besluit hangt af of, en hoeveel, ruimte er is voor delegatie.

De conclusie is dat het invoeren van de grondwettelijke delegatieterminologie in de Grondwet van 1983 in grote lijnen geslaagd te noemen is (hoofdstuk 10). Vooral het grondwettelijke delegatieverbod in het kader van grondrechten biedt belangrijke waarborgen voor de burger. 
$\therefore \quad \because \cdots$

$\therefore \quad \therefore$

;

$\because$ 


\section{Summary}

The central theme of this dissertation is the Netherlands Constitution and delegation of legislative authority. The text of the old Constitution as amended in 1972 did not provide a clear answer to the question as to whether the legislature, i.e. Parliament and Government, could delegate its legislative authority. One of the aims of redrafting the Constitution in 1983 was to remove this uncertainty through the introduction of a constitutional delegation terminology. The author assesses this terminology and places the question of delegation in a constitutional perspective.

In Chapter 2, the author offers a number of tentative definitions. Of major relevance for this study are the definitions of the terms "regelgevende bevoegdheid: "the authority to impose universally binding rules" and "bestuursbevoegdheid":

"a power conferred upon an administrative body not including the authority to impose universally binding rules or the authority to perform judicial acts. "This chapter also discusses the triplet attributie-delegatie-mandaat (the granting of original authority-derived authority with responsibility- derived authority without responsibility) and the rules governing delegatie and mandaat in the Bill relating to the Third Section of the new Algemene wet bestuursrecht (General Administrative Code [Awb]).

Chapter 3 outlines the academic debate on delegation of legislative powers, up to 1983. For this purpose, the author has drawn on a number of dissertations. In the last century, the debate was primarily about whether legislative powers could be delegated to the King. If such delegation was deemed prohibited, the term "uitvoering" (implementation) was at times very broadly construed: everything that could not be qualified as a statute was considered implementation. Although, in many cases, delegating legislative authority no longer causes controversy, today's issues are defining the scope within which delegation is permitted and finding safeguards against excessive delegation. The delegation terminology of the 1983 Constitution first and foremost offers safeguards: the terms employed indicate which matters governed by the Constitution can be delegated. The terminology offers virtually no clues, however, as to the boundaries of delegation.

The meaning of the delegation terminology is discussed in Chapter 4. Two Bills deal with its meaning. The absolute prohibition against delegation, i.e. the prohi- 


\section{Summary}

bition against any delegation of legislative authority as laid down in the Bill relating to fundamental rights (Parliamentary Record 13872), has been softened in the Bill relating to provinces and municipalities (Parliamentary Record 13990). In consequence, the delegation terminology may be understood as follows: delegation is permitted any time the terms "bij of krachtens" (by or by virtue of), a form of the verb 'regelen' (regulate), or one of the words 'regels' or 'regeling' are used. This does not define the extent to which the legislature may make use of delegation. Where delegation is permitted, a fundamental right may be curtailed only if there exists a specific statutory foundation to do so. The general power conferred on provincial and municipal administrations to impose ordinances does not constitute an adequate basis for the restriction of fundamental rights.

The prohibition against delegation implies that the legislature must enact essential provisions. Regulation of details may be left to the lower authorities. The legislature may not leave law-making proper to lower authorities by conferring discretionary administrative powers on these or by the use of ill-defined terminology. After 1983, increasingly, voices can be heard advocating restraint in delegating legislative authority. This is also evidenced by the Aanwijzingen voor de regelgeving 1993 (1993 Official Legislative Drafting Manual).

The delegation terminology has no application to the constitutional articles that survived the 'old' Constitution after the proposed revision of these articles had been rejected (see Chapter 5). Articles 23 (education) and Articles 97-102 (defense) have been transferred from the old Constitution. Furthermore, in Articles 36 and 104 the delegation terminology has not been consistently employed.

The implementation and the enforcement of the prohibition against delegating legislative authority present problems for the legislature and the courts, especially with regard to fundamental rights (Chapter 6). In some cases, the legislature cannot avoid including discretionary administrative powers in a statute, resulting in de facto law-making by an administrative body. The courts have ruled that such powers do not contravene the prohibition against delegation, but do weigh the interests involved.

In many instances, restrictions of fundamental rights must be based on a statute. The absence of such statutory foundation prompts the courts to rule that the disputed rule is not binding or that the disputed action is unlawful.

Where delegation of legislative authority is permitted, occasionally, generous use is made of it. 
In case of restrictions of fundamental rights, the prohibition against delegation and the required statutory foundation constitute the major safeguards for the citizen where delegation terminology is concerned.

Traditionally, a distinction has been made between 'regelgeving' (statutory regulation) and 'uitvoering' (implementation). In Chapter 7, the author demonstrates that the distinction as such is no longer used in case law. At issue today is whether the lower authorities have the power to impose universally binding rules. If there is no such power, the rules in question are called 'beleidsregels' (policy rules). In recent decades, this type of rule has increasingly gained ground in the legal system of the Netherlands. Policy rules have been acknowledged as law, for instance, by the Netherlands Supreme Court within the meaning of Article 99 of the Judicial Organization Act (RO), while in the Third Section of the General Administrative Code (Awb) codification of these rules is envisaged (Chapter 8). In some instances, policy rules so closely resemble universally binding rules that, in practice, there seems to be hardly any difference between the two. Equating the two types of rule is not advisable, however, because in the classical conception of the legality principle any infringement on the freedom and property of citizens must be regulated by statute. Policy rules may not serve to impose obligations on citizens, to restrict fundamental rights or to assign or delegate powers; this always requires statutory regulation.

The Parliamentary debate on constitutional review has not yielded unequivocal criteria establishing what should be regulated by statute and what can be delegated (Chapter 9). There is a consensus that 'weighty' questions require statutory regulation. In studies investigating the action radius of statutory law conducted after 1983, the view has been developed that 'far-reaching' decisions must be taken by the legislature. The matters to be dealt with in this way are enumerated in the Report "Orde in de regelgeving 1985" (Order in regulation 1985) and the 1993 Official Legislative Drafting Manual. The impact of the measure to be taken determines whether and to what extent regulation can be delegated.

The conclusion of the author is that the introduction of delegation terminology into the Constitution of 1983 can be generally considered successful (Chapter 10). The constitutional prohibition against delegation, in particular, constitutes important safeguards for the citizen, especially where fundamental rights are concerned. 


\section{Aangehaalde literatuur}

\section{Aantrekkelijke gedachten 1993}

Aantrekkelijke gedachten, Beschouwingen over de Algemene wet bestuursrecht, vakgroep besturrstecht en bestuurskunde Rijksuniversiteit Groningen, I.L. Boxum, L.J.A. Damen, C. Lambers, J. de Ridder en B.C. Vis red., Kluwer Deventer 1993

Ackermans-Wijn 1984

J.C.E. Ackermans-Wijn, De betekenis van de term 'algemeen verbindende voorschrifien', Bijdrage aan de Staatsrechtconferentie 1984, stencill

\section{Addens $\mathbf{1 8 8 4}$}

H.N. Addens Gzn., Delegatie van wetgevende macht, L. van Giffen Groningen 1884

Akkermans/Koekkoek 1992

P.W.C. Akkermans, A.K. Koekkoek (red.), De Grondwet, Een artikelsgewijs commentanr, W.E.J. Tjeenk Willink Zwolle 1992, tweede druk

Angeren van 1978

J.A.M van Angeren, De parlementaire inbreng bij gedelegeerde wetgeving, in NJB 1978 , p. 349-355

\section{Bakker 1992}

R.E. Bakker, Beleidsregels, 'even the British do it better' in NJB 1992, p.1065-1067

Bakker e.a. 1993

R.E. Bakker, J.M.E. Derks, M.A. Heldeweg, B.M.J. van der Meulen, E. Ramakers, H.J. Simon en A.Q.C. Tak (sectie bestuursrecht Rijksuniversiteit Limburg), Beleidsregels: gebruiksacnwijzing wan bestuursbewoegdheid, in RegelMaat 1993, p.54-60

\section{Beaufort de 1989}

W.H. de Beaufort, Voorhangproceaures toegepast, in RegelMaat 1989, p.78-79

\section{Belinfante/de Reede 1991}

A.D. Belinfante, J.L. de Reede, Beginselen van Nederlands staatsrecht; Samsom H.D. Tjeenk Willink Alphen aar den Rijn 1991, lle herziene druk

\section{Berg van den 1992}

H.A, van den Berg, Toetsing van bestuarswetgeving door de administratieve rechter, in NJB 1992 , p.1233-1238

\section{Besselink 1992}

L.F.M. Besselink, Het Verdrag van Maastricht wijkt ook op andere punten af van de Grondwet en eveneens van het Statuut, in NJB 1992, p.864-865

\section{Boer de 1987}

I. de Boer, Grondwettelijke codificatie-opdracht en risicowansprakelijkheid: Paard van Troje in het ontwerp-Wet Bodembescherming, in AA 1987, p.470-477

Boer de 1992

J. de Boer, De elektronische schriftelijke worm, in NJB 1992, p.670-672

Boer de 1993

J. de Boer, 'Een constitutioneel lesje à $f 310$ miljoen', in NJB 1993, p. $50-51$ 


\section{Böhtlingk 1958}

F.R. Böhtlingk, De rechtsstuat Nederland, Samsom n.v. Aphen aan den Rijn 1958

Böhtlingk/Logemann 1966

F.R. Bohtlingk en J.H.A. Logemann, Het wetsbegrip in Nederland, Samsom Alphen aan den Rijn 1966

Bok 1984

A.J. Bok, Delegatie van wetgeving onder voorbehoud, in Bestuurswetenschappen 1984, p.162176

\section{Bok 1993}

A.J. Bok, Zorgualdige en afgewogen regelgeving in her licht wan de Algemene wet bestuursrecht, in NTB 1993, p.117-126

Bolt 1993

H. Bolt, Benaderingen in het bestuursrecht, in Aantrekkelijke gedachten 1993, p. 141-159

Bonnes 1994

J.M. Bonnes, De uitvoering van EG-verordeningen in Nederland, W.E.J. Tjeenk Willink Zwolle 1994

Bonnes 1995

J.M. Bonnes, EG-Rechtelike tips voor de decentrale wetgever, in RegelMaat 1995, p.42-48 Boxum e.a. 1993

J.L. Boxum, L.J.A. Damen, C. Lambers, J. de Ridder en B.C. Vis (red.), Aantrekkelijke gedachten, Beschouwingen over de Algemene wet bestuursrecht, Kluwer Deventer 1993

Brờring 1993a

H.E. Bröring, Beleidsregets, een beknopte biografie, in Aantrekkelijke gedachten 1993, p.387402

\section{Bröring 1993b}

H.E. Bröring, Richtlijnen, Kluwer Deventer 1993

\section{Brouwer 1992}

J.G. Brouwer, Wijkt het Unie-Verdrag van Maastricht af van de Grondwet of van het Statuut? in NJB 1992, p.861-862

Burg van der $1986 \mathrm{a}$

F.H. van der Burg, Reactie, in Bestuurswetenschappen 1986, p.332-335

Burg wan der $1986 \mathrm{~b}$

F.H. van der Burg, Een nieuw materieel wetsbegrip, in Bestuur en norm (Crince Le Roybundel), Kluwer Deventer 1986, p.57-72

Burg van der 1992

F.H. van der Burg, Mandad en delegatie, in NTB 1992, p.268-275

Burg van der 1993

F.H. van der Burg, Regelgeving en bestuur, W.E.J. Tjeenk Willink Zwolle 1993

\section{Burkens 1989}

M.C. Burkens, Algemene leerstukken van grondrechten naar nederlands constitutioneel recht, W.E.J. Tjeenk Willink Z wolle 1989

Burkens/Vermeulen 1992

M.C. Burkens en B.P. Vermeulen, Maastricht in strijd met de Grondwet?, in NJB 1992, p.861-862 


\section{Buifjs 1883}

J.T. Buijs, De Grondwet, toelichting en kritiek, T, Gouda Quint Arnhem 1883

\section{Damen 1987}

L.J.A. Damen, Ongeregetd en andoorzichtig bestuur, Kluwer Deventer 1987

Dekker den-van Bijsterveld 1991

S.C. den Dekker-van Bijsterveld, Gemeenten en algemene beperkingen van klassieke grondrechten, in De Gemeentestem 1991, nr 6925, p.382-386

\section{Derde tranche 1991}

Voorontwerp Algemene wet Bestuursrecht, Derde tranche, Commissie wetgeving algemene regels van bestuursrecht, Sdu Uitgeverij Den Haag 1991

Derde tranche de 1992

De derde tranche, Commentaar op het woorontwerp woor de devide tranche van de Algemene wet bestuursrecht, redactie Willem Konijnenbelt, Samsom H.D. Tjeenk Willink Alphen aan den Rijn 1992

Dölle 1988

A.H.M. Dölle, Over ongeschreven staatsrecht, Wolters-Noordhoff Groningen 1988

\section{Donner 1951}

A.M. Donner, Preadvies over delegatie, Handelingen NJV 1951 deel I, p.148-194, N.V. Uitgewers-maatschappij W.E.J. Tjeenk Willink Zwolle 1951

Donner 1977

A.M. Donner, lets over delegatie wan wetgevende bevoegdheid, in Verdambundel, Haarlem 1977 , p. $229-238$

\section{Donner 1980}

A.M. Donner, Wetgeving en rechtspraak, in Bestuurswetenschappen 1980, p.224-233

\section{Donner 1981a}

A.M. Donner, Grondwetsherzieming en staatsrechtsdogmatiek. lets over het materieel wetsbegrip. Bijlage bij de preadviezen voor het staatsrechtcongres 1981 over de grond wetsherziening Donner 1981b

A.M. Donner, Beantwoording Rechtsvraag (125) staatsrecht, in Ars Aequi 1981, p.380-383 Donner 1987

A.M. Donner, Nederlands bestuarsrecht, Algemeen deel, Samsom H.D. Tjeenk Willink Alphen aan den Rijn 1987, vijfde druk

\section{Driel van 1956}

J.M.C. van Driel, De ministeriele verordening, NV Uitgeversmaatschappij W.E.J. Tjeenk Willink Zwolle 1956

\section{Dute 1994}

J.C.J. Dute, De wetgeving ter bestrijding van infectieziekten, Ars Aequi Libri Nijmegen 1994 Duynstee 1959

F.J.F.M. Duynstee, Bespreking van J. van der Hoeven, De plaats van de grondwet in het constitutionele recht, in R.M.Themis 1959, p.304-319

\section{Eindrapport Commissie Cals/Donner}

Eindrapport van de Staatscommissie van advies inzake de Growdwet en de Kieswet, Den Haag 1971

Eindrapport Commissie Van Schaik

Eindrapport van de Staatscommissie tot herziening wan de Grondwet, Den Haag 1954 


\section{Aangehaalde literatuur}

\section{Llainga 1992}

D.J. Elzinga, Recensie van A.D. Belinfante, J.L. de Reede, Beginselen van Nederlands staatsrecht, Sarnsom H.D. Tjeenk Willink Alphen aan den Rijn 1991. 1 e herziene druk, in R.M. Themis 1992, p.338-340

\section{Eijkern van 1964}

W.I. wan Eijkern, Delegatie vaw wetgevende bevoegdheid, in Vereniging voor de vergelijkende studie wan het recht van België en Nederland, Jaarboek 1963-1964, N.V. Uitgewersmij. W.E.J. Tjeenk Willink Zwolle, p.38-58

\section{Eijlander 1993}

Ph. Eillander, De wet stellen, W.E.J. Tjeenk Willink Zwolle 1993

\section{Ejlander/Voermans 1993}

Ph. Eijlander en W. Voermans, Nieuwe aanwizingen voor de regelgeving, in N.JB 1993, p. $169-174$

Flier van der 1993

J. van der Flier, Verslag van studieochtend: wel of niet wettelijke basis voor Aanwijzingen?, in RegelMat 1993, p.86-92

\section{Flinterman 1983}

C. Flinterman, Delegatie van wetgevende bevoegdheid: enkele recente Amerikaanse ontwikkelingen, in Staatkundig Jaarboek $1983-1984$, W. E.J. Tjeenk Willink Zwolle 1983, p.73-83

Gelein Vitringa van 1917

J. van Gelein Vitringa, Recensie van C.W. wan der Pot, Wet en Algemeene maatregel van bestuur in het Nederlandsche Staatsrecht, Leiden 1916, in Rechtsgeteerd Magazijn 1917, p. $330-343$

\section{Gemeente en regelgeving 1993}

Gemeente en regelgeving, P. de Heer, VNG Den Haag 1993

\section{Gerbranda/Kroes 1991}

Tj. Gerbranda en M. Kroes, Grondrechten evaluatie-onderzoek, deelrapporten, Stichting NJCM-Boekerij Leiden $199 \|$

\section{Gerbranda/Kroes 1993}

Tj. Gerbranda en M. Kroes, Grondrechtenevaluatie-onderzoek, Eindrapport, Stichting NJCMBoekerij 22 Leiden 1993

\section{Goede de/van den Brink 1986}

B. de Goede en H. van den Brink, Beeld van her Nederlands bestuursrecht, VUGA Uitgeverij "s Gravenhage 1986, vijfde druk

\section{Goorden 1990}

C.P.J. Goorden, Rechtsbevoegdheid in het bestuurstech, W. E.J. Tjeenk Willink Zwolle 1990 Goordien 1992

C.P.J. Goorden, Beleidsregels bij mandaat en delegatie, in NTB 1992, p. 163-168

\section{Goorden 1993}

C.P.J. Goorden, Bestuurlijke organisatie, in NTB 1993, p.224-235

Groot delvari Rossum 1993

G. R.J. de Groot en A.A. van Rossum, Mandaat en volmacht, in R. M. Themis 1993, p. 127-141 Groot de/van der Meulen/van Rossum 1994

G.R.J. de Groot, B.M.J. van der Meulen en A.A. van Rossum, Subsidies, beleidsregels, bestuursorganen, in NJB 1994, p.1193-1200 


\section{Haan de/Drupsteen/Fernhout I 1986}

P. de Haan, Th.G. Drupsteen en R. Fernhout, Besturusrecht in de sociale rechtsstaat, Deel I Ontwikkeling, Organisatie, Instrumentarium, Kluwer Deventer 1986, derde druk

\section{Handelingen NJV 1951}

Handelingen der Nederlandse Juristen-Vereniging 1951 deel II, Beraadslaging over her onderwerp 'Delegatie',p.86-153, N.V. Uitgevers-maatschappij W.E.J. Tjeenk Willink Zwolle 1952 Hasselt van 1987

Van Hasselt, Verzameling van Nederlandse Staarsregelingenen Grondwetten, Samsom uitgeverij Alphen aan den Rijn 1987, zeventiende druk

\section{Heida 1984}

H.P. Heida, Enkele constitutionele aspecten van wetgeving , in Kracht van wet (Van Eijkernbundel), W.E.J. Tjeenk Willink Zwolle 1984, p.33-48

\section{Helleweg 1995}

M.A. Heldeweg, Beleidsregels: nar een nieuwe catechismus voor "ambtelike bujbels'?, in NTB 1995, p.81-93

\section{Hennekens 1992}

H.Ph.J.A.M. Hennekens, Delegatie en mandaat in het licht van het voorontwerp van de Algemene wet bestuursrecht (I) in De Gemeentestem (1992) 6955, p.609-616 en (II) in De Gemeentestem 6956 (1992), p.641-647

\section{Hennekens 1994}

H.Ph.J.A.M. Hennekens, Het onderwijs: een aanhoudende zorg wan Grondwet tot praktijk (1) in De Gemeentestem 6985 (1994), p.173-179 en (II) in De Gemeentestem 6986 (1994), p.201207

\section{Heringa 1985}

A.W. Heringa, Concept-voorstel van een wet openbare manifestaties 1985 , in NJCM-Bulletin 1985, p. $156-164$

\section{Heringa 1987}

A.W. Heringa, Grondwet en delegatie, in RegelMaat 1987, p.76-79

Heringa 1992a

A.W. Heringa $a_{\text {D }}$ De verdragen van Macastricht in strija met de Grondwet. Goedkeuring met twee derde meerderhela?, in NJB 1992, p.749-752

Heringa $1992 \mathrm{~b}$

A.W. Heringa, Naschrift, in NJB 1992, p.865-866

\section{Heringa/Zwart 1991}

A.W. Heringa en T. Zwart, De Nederlandse Grondwet, W.E.J. Tjeenk Willink Zwolle 1991 . derde herziene druk (wan Grond wet 1983)

\section{Heuvel van den 1982}

J.H, van den Heuvel, Wetgeving belicht, Deventer 1982

Hirsch Ballin 1985

E.M.H. Hirsch Ballin, Annotatie bij Afd. Rechtspraak Raad van State 26 januari 1984, AB 1984, 384 (Koninklijk tehuis voor oud-militairen 'Bronbeek') in AA 1985, p.633-641

Hirsch Ballin 1986

E.M.H. Hirsch Ballin, Recht op beleidsregels en beleidsregels als recht, in AA 1986, p.493501 


\section{Aangehaalde literatuur}

\section{Hirsch Ballin 1989}

E.M.H. Hirsch Ballin, Het grondrecht op wrijheid en de wet, Samsom H.D. Tjeenk Willink Alphen aan den Rijn 1989

\section{Hirsch Ballin 1992}

E.M.H. Hirsch Ballin, Toespraak van de Minister van Justitie, in Delegatie van wetgevende bevoegdheid, Samsom HD. Tjeenk Willink Alphen aan den Rijn 1992, p.99-107

Hoeven wan der 1985

J. van der Hoeven, Recensie wan dissertatie van Van der Vlies, in TvO 1985, p.54-55

Hoeven wan der 1988

J. van der Hoeven, De plaats van de grondwet in het constitutionele recht, Aangevulde heruitgave, W.E.J. Tjenk Willink Zwolle 1988

\section{Hoorweg 1985}

H.J. Hoorweg, Delegatie, in Interpretatie in het staatsrecht, red. P. W.C. Akkermans en C.J. Bakx, Erasmusuniwersiteit Rotterdam 1985, p.67-83

\section{Huart 1928}

F.J.A. Huart, Hef delegatievraagstuk en de herziening der gemeentewet, in Gemeentebestuur $1928, p .565-590$

\section{Hijmians 1993}

H. Hijmans, Het amendement Van der Vaart/Kaetje: over het primaat van de ministeriële regeling, in RegelMaat 1993, p.213-214

Taarverslag Hoge Raad 1991-1992

Toelichting op de Jaarcijfers 1991-1992, Hoge Raad der Nederlanden, 's Grawenhage 1993 Jeukens 1978

H.J.M. Jeukens, De grondwetgever in pat-stelling, in Macht en onmacht van de wetgever, Kluwer Deventer 1978, p. $1-10$

Jong de 1993

J.P. de Jong, Legisprudentie. Noot bij advies Raad wan State over een voorstel van wet tot wijziging van de Wet op de Studiefinanciering, in RegelMaat 1993, p.71-76

\section{Kistenkas 1991}

F.H. Kistenkas, Naraen growdrechtelike ewenredigheidstoetsing, in De Gemeentestem 1991 , nr $6925, p .377-382$

Kle:ijn 1992

G.P. Kleijn, Beleidsregels in de derde tranche wan de Awb, in Bestuurswetenschappen 1992 , 0.296-303

\section{Kobussen 1991}

M. Kobussen, De wrihheid wan de overheid. W.E.J. Tjeenk Willink Zwolle 1991

Koekkoek/Konijnenbelt 1982

A.K. Koekkoek/W. Konijnenbelt, Het raam wan hoofdstuk I van de herziene Grondwet, in Grondrechten (Jeukensbundel), Nijmegen 1982, p. 1-39

Konijnenbelt 1982

W. Konijnenbelt, Donner en her materiele wetsbegrip, in NJB 1982, p.653-655

Konijnenbelt 1986

W. Konijnenbelt, De Grondwet als rechtsnorm, afscheidscollege Tilburg 1986 


\section{Konijmenbelt $1992 \mathrm{a}$}

W. Konijnenbelt, Résumé, Hoofdlynen van administratief rech in her perspectief van de Algemene wet bestuursrech, Uitgeverij Lemma BV Utrecht 1992, derde druk

\section{Konijnenbelt $1992 \mathrm{~b}$}

W. Konijnenbelt, Attributie, delegatie en mandaat in de Algemene wet bestuursrech, in De derde tranche, Commentas op het voorontwerp voor de derde tranche van de Algemene wet bestuursrecht, redactie Willem Konijnenbelt, Samsom H.D. Tjeenk Willink Alphen aan den Rijn 1992, p.6-22

\section{Konijnenbelt 1993}

W. Konijnenbelt, Herzie de Gemeentewet!, in De Gemeentestem 6961, p.117-121

\section{Koopmans 1983}

T. Koopmans, Compendium van het staatsrecht, Kluwer Deventer 1983, vierde druk

\section{Koopmans 1994}

Koopmans', Compendium van het staatsrecht, Kluwer Deventer 1994, zevende druk, bewerkt door Th.L. Bennekom, A.W. Heringa, T. Koopmans, R.E. de Winter

Kortmann 1976

C.A.J.M. Kortmann, De woorden van de wet, Kluwer Deventer 1976

\section{Kortmann 1979}

C.A.J.M. Kortmann, Behoorlijke wergeving, in Regel en praktijk (Van Wijnbergenbundel), W.E.J. Tjeenk Willink Zwolle 1979, p.63-74

\section{Kortmann 1980}

C.A.J.M. Kortmann, Lagere wetgeving en uitwoering, in Bestuurs wetenschappen 1980 , p.202212

\section{Kortmann 1987a}

C.A.J.M. Kortmann, De Grondwetsherzieningen 1983 en 1987, Kluwer Deventer 1987. tweede druk

\section{Kortmann 1987b}

C.A.J.M. Kortmann, Avanti rijp voor de sloop? Wet en recht in artikel 99 RO, in R.M. Themis 1987, p. $369-382$

\section{Kortmann 1989}

C.A.I.M. Kortmann, Delegatie onder voorbehoud, in RegelMaat 1989 , p.98=100

Kortmann 1990

C.A.J.M. Kortmann, Van eendagsvlieg naar insectenplaag?, in RegelMaat 1990, p.68-71 Kortmann 1991

C.A.J.M. Kortmann, De vorm van implementatie van EG-recht, in RegelMaat 1991, p.47-48 Kortmann 1992

C.A.J.M. Kortmann, De verdragen van Mastricht niet in strijd met de Grondwet, in NJB $1992,0.862$

\section{Kortmann 1994}

C.A.J.M. Kortmann, Constitutioneel recht, Kluwer Deventer 1994, tweade druk.

\section{Kortmann 1995}

C.A.J.M. Kortmann, Delegatie, beleidsregels en decentralisatie, in De Gemeentestem 1995. no $7006, \mathrm{p} .165$

Kreveld van 1983

J.H. van Kreveld, Beleidsregels in het recht, Kluwer Deventer 1983 


\section{Aangehaalde literatuur}

\section{Kreveld van 1985}

J.H. van Kreveld, Her verkleinen van de jwidische verschillen tussen beleidsregels en daarnee werwante wettelijke voorschriften, in Staatkundig Jaarboek 1985, A. W. Heringa e.a. (red.), Kobra Amsterdam 1985, p.293-320

\section{Kreveld van 1988}

JH. van Kreveld, Verdere inbouw wan beleidsregels in het recht, in NTB 1988, p.189-196

Kuiper/Boxum 1993

G.M. Kuper en J.L. Boxum, Het begrip bestuursorgaan in de Algemene wet bestuursrecht. in Aantrekkelijke gedachten 1993, p.275-290

Langbroek e.a. 1992

P.M. Langbroek, M.S.E. Wulffraat-van Dijk, G.H. Hagelstein, N.M. Spelt, G.H. Addink en M.J. Sluijs, Bouwen aan de Algemene wet bestuursrecht; in NJB 1992, p.473-477

\section{Leemans 1962}

W.F. Leemans, Figuren als overdracht, machtiging en opdracht met betrekking tor bestuursbevoegdheden, VAR-preadvies, H.D. Tjeenk Willink \& Zoon N.V. Haarlem 1962, p.1 80

\section{Logemamn 1958}

J.H.A. Logemann, Feit en Recht in her Staatsleven, in Socialisme en Democratie 1958, p.417430

\section{Lubberdink 1993}

H.G. Lubberdink, De Awb: hoedster van de individuele vrijheid?, in Aantrekkelijke gedachten 1993, p. $131-139$

\section{Marseveen van 1991}

Henc van Maarseveen, Bevoegdheid, in Algemene begrippen staatsrecht, red. Th. Holterman e.a., W.E.J. Tjeenk Willink Zwolle 1991, derde geheel therziene druk, p.63-87

Male van 1988

R.M. van Male, Rechter en bestuurswetgeving, W.E.J. Tjeenk Willink Zwolle 1988 Male van 1992

RM. van Male, Besluiten van algemene strekking in het nieuwe bestuursprocesrecht; een aarzelende stap vooruit, in Nieuw bestuursprocesrecht, J.B.J.M. ten Berge e.a. (red.), Kluwer Deventer 1992 ; p. 23-46

\section{Male van, in Akkermans/Koekkoek 1992}

R.M. van Male, Commentaar op artikel $89 \mathrm{Gw}$, in Akkermans/Koekkoek 1992, P.W.C. Akkermans, A.K. Koekkoek (red.), De Grondwet, Een artikelsgewijs commentaar, W.E.J. Tjeenk Willink Zwolle 1992, tweede druk, p.781-830

\section{Mazell 1992}

R.G. Mazel, Delegatie van wetgevende bevoegdheid; de inhoud van het wetsbegrip, Preadwies voor de Vereniging voor wetgeving en wetgevingsbeleid, in Delegatie van wetgevende bevoegdheid, Samsom H.D. Tjeenk Willink Alphen aan den Rijn 1992, p.9-45

\section{Meij die 1990}

J.M. de Meij, Inleiding tot het staatsrechten het bestuursrecht, Wolters-Noordhoff Groningen 1990 , derde druk

\section{Mejuer 1987}

A. Meijer, De burgemeester in (mood)roestand, in NJB 1987, p.237-242

\section{Mentink 1989}

D. Mentink, Orde in onderwijsbeleid, Kluwer Deventer 1989 
Meulen vain der e.a. 1991

B. van der Meulen, E. Steyger, M. Heldeweg, R. Bakker, R. Cobben en T. Tak, Besturisbevoegdheid als bron wan recht?, in NTB 1991, p.133-141

Michiels 1993

F.C.M.A. Michiels; Beleidsregels in de Algemene wet bestuursrech, in De Gemeentestem 6967 (1993), p.309-314

Moor de-van Vugt e.a. 1992

J.C. de Moor-van Vugt, J.M. Bonnes, W.J.M. Voermans en V.J.J.M. Bekkers, Implementatieproblemen: gekissebis in het vooronder?, in NJB 1992, p.601-607

Nicolaï 1992

P. Nicolaï, Beleidsregels, in De derde tranche, Commentaar op het voorontwerp voor de derde tranche van de Algemene wet bestuursrecht, redactie Willem Konijnenbelt, Samsom H.D. Tjeenk Willink Alphen aan den Rijn 1992; p.82-102

Nicolaï/Olivier 1991

P. Nicolaï en B.K. Olivier, Bestuursrech, Factotum Amsterdam 1991, tweede druk

Nicollai/Olivier 1992

P. NicolailB.K. Olivier, Bestuursrech, bewerkt door L.J.A. Damen en H. Troostwijk, Factotum Amsterdam 1992, derde herziene druk

Nicolaï e.a. 1994

P. Nicolaï, B.K. Olivier, L.J.A. Damen, H. Troostwijk, Bestuursrecht, Factotum Amsterdam 1994, wijfde herziene druk

Olde Kalter 1988

C.J.G. Olde Kalter, Wetgeving betreffende het recht het land te verlaten en het habeas corpusbeginsel in witzonderingstoestanden(veiligheidsinternering), in De wetgeving ter uitwoering van hoofdstuk I van de Grondwet, Zwolle 1988, p.35-59

Ommeren van 1991

F.J. wan Ommeren, Door de overheid gehanteerde algemene voorwaarden en het recht in de zin van art. 99 Wet $R O$, in NTB 1991, p.54-61

Oostenbrink 1978

J.J, Oostenbrink, Kanttekeningen bij de wetmatigheid wan het bestuw, Bujiten \& Schipperheijn Amsterdam 1978

\section{Oostenbrink 1986}

J.J. Oostenbrink, Met ministerieel mandaat, in Bestuur en norm (Crince Le Roy bundel), Kluwer Deventer 1986, p.171-179

Ordle in de regelgeving $\mathbf{1 9 8 5}$

Orde in de regelgeving, Eindrapport van de Commissie Wetgevingsvraagstukken, Staatsuitgeverij 's Gravenhage 1985

Oud 1970

P.J. Oud, Het constitutioneel recht wan het koninkrijk der nederlanden $I_{\mathrm{t}}$ W.E.I. Tjeenk Willink Zwolle 1970, tweede druk

\section{Oudshoorn 1992}

J.C. Oudshoorn, Delegatie en mandaat in de derde tranche, in Bestuurswetenschappen 1992 , p. 2711.276 


\section{Phat 1962}

W.M J.C. Phaf, Figuren als overdracht, machiging, en opdrach met betrekking tot bestuursbevoegdheden, VAR-preadvies, H.D. Tjeenk Willink \& Zoon N.V. Haarlem 1962, p.81-109 Polak 1993

J.M. Polak, De Aanwizingen voor de regelgeving. in NJB 1993, p.1396-1399

Pot wan der 1916

C.W. van der Pot, Wet en Algemeene matregel van bestun in het Nederlandsche Staatsrecht, Leiden, 1916

Pot van der/Donner 1972

C.W. van der Pot en A.M. Donner, Handboek van het Nederlandse staatsrecht, W. E.J. Tjeenk Willink Zwolle 1972, negende druk

Pot van der/Donner 1983

C. W. van der Pot en A.M. Donner, Handboek vam het Nederlandse staatsrecht, W.E.J. Tjeenk Willink Zwolle 1983 , elfde druk

Pot van der/Donner/Prakke 1989

C.W. van der Pot, A.M. Donner en L. Prakke, Handboek van het Nederlandse staatsrecht, W.E.J. Tjeenk Willink Zwolle 1989, twaalfde druk

Proeve 1966

Proeve van een nieuwe grondwet, "s Gravenhage 1966

Raad voor het binnenlands bestuur 1992

Raad voor het binnenlands bestuur, Adves over het voorontwerp van de derde tranche Algemene wet bestuurstecht, "s Gravenhage, mei 1992

Rapport ABAR 1973

Rapport Algemene bepalingen van administratief recht "H.D. Tjeenk Willink Groningen 1973, vierde druk

\section{Rapport ABAR 1984}

Rapport Algemene bepalingen van administraitef recht, Samsom H.D. Tjeenk Willink Alphen aan den Rijn 1984, vijfde druk

Rapport bijzondere commissie Vraagpunten 1990

Rapport bijzondere commissie Vraagpunten; Sraatkundige, bestuurijke en staatsrechtelijke vernieuwing. Kamerstukken 21427, SDU uitgeverij "s Gravenhage 1990

\section{Rapport Commissie Prins 1965}

Rapport van de commissie delegatie en mandaat van bestuursbevoegdheden. VAR geschrift LV, H.D. Tjeenk Willink \& Zoon N. V. Haarlem 1965

Regelgeving centrale overheid 1987

Regelgeving centrale overheid" Wetgevingsvraagstukken. Kabinetsstandpunt inzake "Orde in de regelgeving' 1985. Kamerstukken 1986-1987, 20038, 's Gravenhage 1987

Rirlder de 1993

J. de Ridder, Legistatief toezich in de $V S_{\text {n }}$ in Aantrekkelijke gedachten 1993, p. 223-240 Rijnen 1982

A.Ch.M. Rijnen, Niet in de nieuwe Grondwet opgenomen grondrechen, in Grondrechten (Jeukensbundel), Nijmegen 1982, p.506-533

\section{Ruiter 1986a}

D.W.P. Ruiter, Beleidsregels zijn algemeen verbindende voorschriften, in Bestuurswetenschappen 1986, p. 65.70 


\section{Ruiter $1986 \mathrm{~b}$}

D.W.P. Ruiter, Welke visie is riskanter?, in Bestwurswetenschappen 1986, p.503.505 Schegget ter/Herweijer 1993

H.J. ter Schegget en M. Herweijer, Hiëranchie in de regeling van mandaat en delegatie bij horizontaal bestuur? " in Aantrekkelijke gedachten 1993, p.307-320

Scheltema 1975

M. Scheltema, De vrijheid van overheidsorganen om publiekrechtelijke bevoegdheden door anderen te Laten uitoefenen, in Vrịheid en Recht (E.H. 's Jacobbundel), W.E.J. Tjeenk Willink Zwolle $1975, p .235-246$

Scheltema 1979

M. Scheltema, Preadvies, Dient verandering te worden gebrach in het proces van wergeving?, Handelingen NJW 1979, W.E.J. Tjeenk Willink Zwolle 1979, p.63-134

Schellema 1982

M. Scheltema, Bestuursrecht: Is het bestuur wetgever in eigen zaak?, in W.F. de Gaay Fortman (red.) Problemen van wetgeving, Kluwer Deventer 1982, p. 131-143

Schelltema 1984

M. Scheltema, De partijdige wetgever, Kluwer Deventer 1984

Scheltema 1988

M. Scheltema, Advies aan de Parlementaire Enquêtecommissie Bouwsubsidies, Kamerstukken II 1987-198:8, 19623, nr 30, p.453 e.v.

Scheltema 1989

M. Scheltema, De rechtsstaat, in De rechtsstat herdacht, W. E.J. Tjeenk Willink Zwolle 1989, p.11-25

Schreuder-Vlasblom 1985

M. Schreuder-Vlasblom, Recensie van I.C. van der Vhies, Het wetsbegrip en beginselen wan behoorlijke regelgeving, Vuga uitgeverij BV, 's-Gravenhage 1984 in RM Themis 1985, p.493500

\section{Schreuder-Vlasblom 1987}

M. Schreuder-VIasblom, De harde wet en haar zachte kant; enige opmerkingen over hardheidsclausules, in Bestuurswetenschappen 1987, p.100-117

Schreuder-Vlasblom 1992

M. Schreuder-Vlasblom, De werbindende krach wam rechtsregels, in Bestuurswetenschappen $\llbracket 992-\llbracket$, p. $25-41$

Sectie staats- en bestuursrecht KUB 1992

Sectie staats- en bestuursrecht KUB, Beleidsregels geregeld?, in NTB 1992, p.253.267

Sewandono $1992 \mathrm{a}$

I. Sewandono, Opinie, in N.JB 1992, p.264-265

Sewandono $1992 \mathrm{~b}$

I. Sewandono, Algemeen wetgevingsbeleid moet orde in delegatie van regelgeving gaan brengen, Verslag van het symposium van 19 mart 1992 van de Vereniging voor wetgeving en wetgevingsbeleid, in Bestuurswetenschappen 1992, p. 357-364

Simon 1993

H.J. Simon, Publiekrecht of privaatrecht? Een geschiktheidsonderzoek aan de hand van het nutsmaximalisatiebeginsel toegespitst op het gebruik wan het privaatrecht door het bestuur, W.E.J. Tjeenk Willink Zwolle 1993 


\section{Aangehaalde literatuur}

\section{Spill ter/Tak 1981}

F.W. ter Spill en A.Q.C. Tak, Onwetnatig bestuw, H.D. Tjeenk Wilink Alphen aan den Rijn 1981 (VAR-geschrift LXXXVI)

\section{Stellinga 1951}

J.R. Stellinga "Preadvies over delegatie, Handelingen NJV 1951 deel I, p.110-147, N.V. Uitgevers-maatschappij W.E.J. Tjeenk Willink Zwolle 1951

\section{Stout 1994}

H.D. Stout, De betekenissen van de wet, W.E.J. Tjeenk Willink Zwolle 1994

\section{Stroink 1978}

F.A.M. Stroink, Deconcentratie, Vuga-Boekerij 's-Gravenhage 1978

\section{Stroink 1983}

F.A.M. Stroink, Het beginsel van de wetmatigheid van bestuur en het begrip uitvoering, in TvO 1983, p.204-206

\section{Stroink 1992}

F.A.M. Stroink, Regeling delegatie in derde tranche Algemene wet bestutursrechtondoordacht, in NJB 1992, p.478-479

\section{Stroink/Steenbeek 1993}

F.A.M. Stroink en J.G. Steenbeek, Inleiding in het staats-en bestuursrecht, Sansom H.D. Tjeenk Willink Alphen aan den Rijn 1993, vierde druk

\section{Tak 1992}

A.Q.C. Tak, De ongewenste discussie, in Nieuw bestuursprocesrecht, Kluwer Deventer 1992, p. $67-84$

\section{Tak 1994}

A.Q.C. Tak, De Algemene wet bestuursrecht (het nieuwe bestuursprocesrecht), W.E.J. Tjeenk Willink Zwolle 1994 , derde druk

\section{Triepel 1942}

H. Triepel, Delegation und Mandat im öffentlichen Recht, W. Kohlhammer Verlag Stuttgart und Berlin 1942

\section{Tweede rapport Commissie Cals/Donner}

Tweede rapport wan de Staatscommissie vam advies inzake de Grondwet en de Kieswet, Den Hadg 1969

\section{Veltman 1994}

J. Veltmain, Algemene wet bestuursrecht, in RegelMaat 1994, p.116-133

Vereniging wan Gemeentesecretarissen in Nederland 1987

Verenigung van Gemeentesecretarissen in Nederlland, Een mogelijke aanpak wan "delegatie en mandaat", 's Gravenhage 1987

\section{Verhalen over de Grondwet 1993}

Verhalen over de Grondwet, A.W. Heringa, C.H.A. Litjens en R. E. de Winter, Sdu Juridische \& Fiscale Uitgeverij 's-Gravenhage 1993

Verheij, L. 1992

L.F.M. Verheij. Horizontale werking van grondrechten, in het bijonder wan het recht op privacy, W.E.J. Tjeenk Willink Zwolle 1992

Verheij 1985

Nico Verheij, Regelgeving door ministers: een pleidooi voor duidelijkheid, in NJB 1985, p.1144-1148 


\section{Verheij 1989}

Nico Verheij, Conversie van onverbindende wettelike voorschriften in beleidsregels, in RegelMaat 1989 , p. $41-45$

\section{Verheij 1992a}

Nico Verheij, Algemene wet bestuursrecht in vogelvlucht, in Bestuurswetenschappen 1992. p.160-179

\section{Verheij 1992b}

Nico Verheij, Beleidsregels: een goede zaak, in NJB 1992, p. 1427

Vermeulen 1990

B.P. Vermeulen, Algemene beperkingen, redelijke witleg en redelijke toepassing van grondrechten, in RegelMaat 1990, p.78-85

Visscher 1994

G. Visscher, Parlementaire invlaed op wetgeving, Sdu Uitgeverij 's-Gravenhage 1994

\section{Vivien 1845}

M. Vivien, Etudes administratives 1 , Parijs 1845

\section{Vlies van der 1984}

I.C. van der Vlies, Het wetsbegrip en beginselen van behoorlijke regelgeving, Vuga uitgeverij BV 's-Gravenhage 1984

\section{Vlies van der 1986}

I.C. van der Vlies, Annotatie bij HR 31 mei 1985 en HR 11 oktober 1985, in RegelMaat 1986. p.71-75

\section{Vlies van der 1989}

I.C. van der Vlies, Het legaliteitsbeginsel en kwaliteit van de wetgeving, in Bestuur 1989 , p. $67-70$ en 76

\section{Vlies van der 1990}

I.C. van der Vlies, Meer recht in de zin van artikel 99 Wet RO, in NJB 1990, p.1147.1151

Vlies van der 1991

I.C. van der Vlies, Handboek wetgeving, W.E.J. Tjeenk Willink Zwolle 1991, tweede aruk Vlies van der 1993

I.C. van der Vlies, Op het spoor van de Awb, in Aantrekkelijke gedachten 1993, p.49-60

Vlies wan der 1994

I.C. van der Vlies, Delegatie, mandaat en de rechrsstad, in In de sfeer van administratief recht, redactie T. Hoogenboom en L.J.A. Damen, Uitgeverij Lemma BV Utrecht 1994 , p.409. 427

\section{VNG 1986}

Model-algemene plaatselijke verardening, VNG Uitgeverij 's Gravenhage 1986

Voorontwerp Algemene wet bestuursrecht 1991

Commissie wetgeving algemene regels wan bestuursecht, Voorontwerp Algemene wet bestharsrecht, Derde tranche, SDU Uitgeverij Den Haag 1991

Vos 1918

H. Vos, Recensie van C.W. van der Pot, Wet en Algemeene maatregel wan bestuur in het Nederlandsche Staatsrecht, Leiden 1916, in Weekblad van het Regt 10212 (1918)

Vos 1934

H. Vos, Rechtspraak en literatuur op de gemeentewet. A. W. Sijthoff's Uitgeverij Maatschappij NV Leiden 1934 


\section{Aangehaalde literatuur}

\section{Waaldijk 1994}

K. Waaldijk, Motiveringsplichten van de wetgever, Koninklijke Vermande BV Lelystad 1994 Wattel 1993

P.J. Wattel, No taxation without representation, in Verhalen over de Grondwet 1993, p.116121

\section{Van Wijk/Konijnenbelt 1990}

H.D. van Wijk, Hoofdstukken van administratief recht, bewerkt door W. Konijnembelt Uitgeverij Lemma b.y. Utrecht 1990 , zesde druk

Van Wijk/Konijnenbelt 1993

H.D. van Wijk, Hoofdstukken van adninistratiefrecht, bewerkt door W. Konijnenbelt en R.M. van Male, Uitgeverij Lemma b.v. Urrecht 1993 , achtste druk

\section{Van Wijk/Konijnenbelt/Van Male 1994}

H.D. van Wijk, Hoofdstukken vant administratiefrecht, bewerkt door W. Konijnenbelt en R.M. van Male, Uitgeverij Lernma b.y. Utrecht 1994, negende druk

\section{Witteveen 1992}

W.J. Witteveen, Delegeren is communiceren, Preadvies voor de Vereniging voor wetgeving en wetgevingsbeleid, in Delegatie van wetgevende bevoegdheid "Samsom H.D. Tjeenk Willink Alphen aan den Rijn 1992, p.46-97

Zicht op wetgeving 1991

Zicht op wetgeving, Kabinetsnota, Kamerstukken 1990-1991, 22008, nrs 1-2 


\section{Jurisprudentieregister}

\section{President Rechtbank}

Pres. Rb Assen 9 februari 1995, NA 1995, 130219

Pres. Rb Den Bosch 25 juni 1985, KG 1985, 217150

Pres. Rb Den Bosch 23 september 1994, JB 1994/298, mnt. FAMS 223

Pres. Rb Den Bosch 30 december 1994, NA 1995, 84; Gst. 1995, 7004, 4, m.nt. HH 223

Pres. Rb Breda 26 april 1995, JB 1995/168 27I

Pres. Rb Den Haag 22 juni 1982, NJ $1983,17544,188$

Pres. Rb Den Haag 12 september 1991, NJCM-Bulletin 1992, p.37-41, m.nt. A. Derks 153

Pres. Rb Den Haag 27 januari 1995, NA 1995, 10728

Pres. Rb Maastricht 12 oktober 1994, JB 1994/299, m.nt. R. Schlössels 222

Pres. Rb Rotterdam 12 december 1994, NA 1995, 83223

Pres. Rb Utrecht 31 augustus 1994, JB 1994/255, m.nt. FAMS 222

\section{Rechtbank}

Rb Almelo 5 augustus 1992, NJ 1993, 4323

Rb Arnhem 24 november 1978, NJ 1979, 203 117, 184

Rb Den Haag 18 januari 1995156

Rb Roemond 27 juli 1989, NJ 1990, 759152

Rb Roermond 28 oktober 1992, TAR 1993, 17279

Rb Roermond 3 januari 1995, NJCM-Bulletin 1995, p.431-438, m.nt. J.M.E. Derks 152

Rb Roermond 18 april 1995, JB 1995/135 271

$\mathrm{Rb}$ Utrecht 21 februari 1994, JB $1994 / 38 \quad 219$

Rb Utrecht 27 januari 1995, JB 1995/55, m.nt. FAMS 24

Rb Zwolle 11 maart 1993, TAR 1993, 133153

\section{Gerechtshof}

Hof Amsterdam 4 mei 1990, AB 199 $1,30 \quad 27,34$

Hof Arnhem 12 juli $1988, A B 1989,122, \mathrm{~m}$.nt. M.J. Sluys 152

Hof Den Haag 18 mei 1989, AB 1989, 411, m.nt. FHvdB 188

Hof Leeuwarden 5 oktober 1990, FED, afl. 2325, nr.8 /48

\section{Hoge Raad}

HR 13 januari 1879 , W. 433044,260

HR 5 maart 1883, W. $4893 \quad 165,167$ 


\section{Jurisprudentieregister}

HR 17 februart $1896, W .6769165,167,178$

HR 2 januari 1900 , W. $7386 \quad 174$

HR 30 appill 1900 , Gst. $2536 \quad 174$

HR 25 juni 1900, W. $7478165,167,168$

HR 24 december 1900, Gst. $2579 \quad 174$

HR 2 januari $1902, W: 7386 \quad 176$

HR 10 november 1902 ; W. 9834176

HR 30 okttober 1911 ; W. $9335 / 74$

HR 26 juni 1916, AB 1916, p.352 174, 176, 178

HR 6 januari 1919, NJ 1919, p.233 /74, 176

HR 10 juni 1919, NJ 1919, p.647 218, 219

HR 12 januari 1923, NJ 1923, blz.307 270

IIR 25 januari 1926, NJ 1926, blz.246, m.nt. Besier 186

HR 20 december 1928, w. 11935174

HR 19 januari 1931, NJ 1932, p.439 29, 187

HR 22 april 1932, W. $12441 \quad 174$

HR 8 mei 1953, NJ 1953, $61429,187,193$

HR 8 februari 1955, NJ 1955, 254117,184

HR 1 november 1955 , NJ 1956, 40175

HR 26 november 1957, NJ 1958, 5329,187

HR 18 oktober 1960 , NJ 1961,38176

HR 9 januari 1962, AB 1963, p.143 175

HR 1 april 1966, NJ 1966, 45523

HR 19 november 1968 , NJ 1969, 103175

HR 14 januari 1969, AB 1969, blz. 539176

HR 25 april $1969, \mathrm{NJ} 1969,30370,206,218$

HR 27 juni 1972, NJ 1972, 496175

HR 22 juni 1973, NJ 1973, 386, m.nt. Bloembergen; AB 1973, 187 ,

m.nt. Van der Hoeven 252

HR 23 november 1976, NJ 1977, 290184

HR 22 december 1976, NJ 1977, 114187

HR 11 januari 1977, NJ 1977, $46729,170,186,193$

HR 3 mei 1977. NJ1977, 536, m.nt. ThWvV 178

HR 29 november 1977, NJ 1978,565184

HR 9 mei 1978, NJ 1979, 25184

HR 28 juni 1979, AB 1979, 488, m.nt. Stellinga 218

HR 8 rebruati 1980, NJ 1981,334, m.nt. MS 278

HR 6 juni 1980, NJ 1981, 563 m.nt. MS 188

HR 20 maart 1981, NJ 1982, 183 188, 220

HR \ juli 4981 , NJ 1981,618185

HR 1 juli 1983, NJ 1984, 360117,184

HR 10 april 1984, NJ 1984,612 117, 184, 277

HR 5 oktober 1984, NJ 1985, $74 \quad 184$

HR 26 februari 1985, NJ 1985, $595 \quad 1177,185$

HR 24 mei 1985, NJ 1986,543184 
HR 24 mei 1985, NJ 1987, 1, m.nt. Brunner en Alkema 155

HR 31 mei 1985, NJ 1985, 648, AB 1985, 480, m.nt. FHudB 211

HR 25 september 1985, AB 1986,64 228

HR 11 oktober 1985 , AB 1986, 84, m.nt. FHvdB; NI 1986, 322, m.mt. MS 211

HR 11 februari 1986 , NJ 1986,673 , m.nt. ThWvV 149

HR 27 juni 1986, NJ 1987, 898, m.nt. MS; AB 1987, 241, m.nt. FHvdB 278

HR 9 december 1988, AB 1989, 121, m.nt. FHvdB 153

HR 2 februari 1990, NJ 1991, 289, m.nt. Alkema 155

HR 9 maart 1990 , NJ 1990,406184

HR 28 maart 1990, NJ 1991, $118190,193,211,212,226,227$

HR 19 juni 1990, NJ $1991,119190,211,212$

HR 29 juni 1990 , NJ $1991,120190,211$

HR 2 juli 1990 , NJ 1990, 751, m.nt. Sch 151

HR 18 januari 1991, NJ 1992, 638184,304

HR 8 februari 1991, RvdW 1991, 54153

HR 20 januari 1992, AB 1992, 282, m.nt. Van der Burg 215

HR 10 november 1992, NJ 1993, 197, m.nt. 't H 152

HR 5 februari 1993, AB 1993, 239 m.nt. FHvdB 227

HR 18 juni 1993, NJ 1994, 347, m.nt. EAA en CJHB 155

HR 8 oktober 1993, AB 1994, 299262

HR 13 september 1994, NJB-Kattern 1994, p.531, nt 211212

Commissie van Beroep protestants christelijk voorgezet onderwijs

23 juni 1982, AB 1983, 95188

\section{Voorzitter College van Beroep voor het bedrijfsleven}

Vz CBB 16 november 1990, AB 1991, 300, m.nt. Goorden 236

\section{College van Beroep voor het bedrijfsleven}

CBB 21 september 1990, AB 1991, 97278

CBB 21 september 1990, AB 1991, 98278

CBB 1 maart 1994, JB $1994 / 50 \mathrm{~m}$.nt. MAH 219

CBB 31 januari 1995, JB 1995/61 24

\section{Centrale Raad van Beroep}

CRvB 28 april 1978, Jurisprudentie onderwijswetten $1978 / 153 \quad 188$ CRvB 16 november 1989, AB 1991, 24, m.nt. HH 154

CRvB 26 april 1990, AB 1990, 448, m.nt. HH 233 


\section{Jurisprudentieregister}

CRvB 25 juli 1991 , AB 1991,656 , m.n. HH 34

CRVB 8 augustus 1991, AB 1991,577; TAR 1991, 175297

CRvB 30 januari 1992, TAR 1992,68,279

CRvB 6 februari 1992, TAR 1992, 80228

CRvB 10 december 1992, TAR 1993, 34153

CRwB II mant 1993, AB 1993, 341, m.nt. HH 24

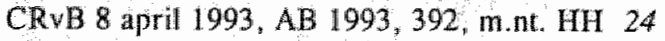

CRvB 28 april 1994, JB 1994/263 219, 237

CRvB II mei 1994, JB $1994 / 152 \mathrm{~m}$ nt. FAMS 216, 262

CRvB 10 november 1994, NJB-katern 1995, p.105, nr 223

CRvB 7 april 1995, JB $1995 / 124215$

\section{Koninklijk Besluit}

KB 19 januari $1979, \mathrm{AB} 1979,241 \quad 187$

KB 27 januari 1987, Stb.56 188

\section{Voorzitter Afdeling rechtspraak Raad van State}

Vz ARRS 1 november 1983, AB 1984, 489179

VI ARRS 16 oktober 1984, AB 1986, 224, m.nt. F.A. van Bakelen 189

VZ ARRS 30 jumi 1988, AB 1989, 438, m.nt. ICvdV 152

Vit ARRS 16 februari 1989, AB 1990, 9151

VZ ARRS 11 januari 1989, AB 1989, 42434

VI ARRS 17 april 1989, Gst. 1990,6895, 5 m.nt. B 27I

VZ ARRS 31 juli 1989, AB 1990, 31527,34

Vz ARRS 17 augustus 1990, Gst. $1991,6917,6271$

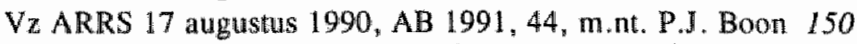

Vz ARRS 30 augustus $1990, \mathrm{AB} 1991,567 \quad 117,185$

Vx ARRS 18 oktober 1990, AB 1991, 193, m.nt. JHvdV 182

Vz ARRS 12 mei 1992, Gst. 6960, nr $227 I$

Vz ARRS 24 september 1992, AB 1993, 266, m.nt. NV 27

Vz ARRS 23 augustus 1993, AB 1994, 165228

\section{Afdeling rechtspraak Raad van State}

ARRS 2 november 1977, AB 1978, 55, m.nt. In 't Veld 225, 230

ARRS 7 aprill 1978, AB 1978, 474, m.nt. J.A. Borman 233

ARRS 8 april 1978, AB 1979, 222226

ARRS 17 mei 1978, AB 1978, 429233

ARRS 28 februari 1980, Gst. 1980, 6625, 8, m.nt. JMK 271

ARRS 11 maart 1980, AB 1980, 463220

ARRS 10 januari 1983, AB 1983, 306, m.nt. P.J. Boon 149, 233 
ARRS 2 september 1983, AB 1984, 245178

ARRS 26 januari 1984, AB 1984, 384226

ARRS 3 februari 1984, AB 1984,404 , m.nt. JHvdV 189

ARRS 24 februari 1984, AB 1984, 284, m.nt. JHvdV 189

ARRS 22 maart 1985, AB 1985, 471180

ARRS 7 jumi 1985 , AB 1985, 539, m.nt. JHvdV 181

ARRS 18 jumi 1985, AB 1985, 541, m.nt. JHvdV 180

ARRS 5 januari 1986, AB $1987,278 \mathrm{~m}$.nt. Van Buuren 21

ARRS 21 maart 1988, AB 1989, 14, m.nt. JHwdV 181

ARRS 28 oktober 1988, AB 1989, 153, m.nt. PvB 21

ARRS 29 oktober 1988, AB 1989, 153, m.nt. Van Buuren 21

ARRS 13 december 1990, Gst. 1991, 6920, nr 4 m.nt. HH 271

ARRS 4 juli 1991, AB 1991, 688, m.nt. JHvdV 237

ARRS 2 december 1991, AB 1992, 475, m.nt. $\mathbb{1}$. Sewandono 235

ARRS 17 december 1991, AB 1992,550, m.nt. JHvdV 34

ARRS 25 mei 1992, SEW 1993, p.257, m.nt. J.M. Bonnes 230, 234

ARRS 11 juni 1992, AA 1993, p.732-737 6. 221

ARRS 9 juli 1992, AB 1994, 61235

ARRS 7 augustus 1992, Gst. 6952, 4, m.nt. HH 237

ARRS 16 oktober 1992, AB 1993, 328, m.nt. PvB 21

ARRS 10 november 1992, AB 1993, 153 m.nt. NV 226

ARRS 23 maart 1993, AB 1993, 489, m.nt. S.E. Zijlstra 21, 29

ARRS 29 juli 1993, AB 1994, 3117

ARRS 26 augustus 1993, AB 1994, 199233

\section{Voorzitter Afdeling geschillen van bestuur Raad van State}

Vz AGRS 19 februari 1991, AB 1991, 305. m.nt. PJS 27

\section{Afdeling geschillen van bestuur Raad van State}

AGRS 20 november 1992, AB 1993, 241, m.nt. I. Sewandono 149

Afdeling bestuursrechtspraak Raad van State

ABRS 21 juni 1994, NJB 1994-katern, p.419, nr 29155

ABRS 27 oktober 1994, NJB-katern 1994, p.572-573, nr 45150

ABRS 5 januari 1995, NA 1995, 4527

Europees Hof voor de rechten van de mens

EHRM 26 april 1979, NJ $1980,146233,265$

EHRM 22 juni 1989, NJ 1992,705 265 
Jurisprudentieregister

Hof van Justitie Europese Gemeenschappen

HvJ EG 8 april 1976, 48/75, Royer, Jur. 1976, 497234

HvJ EG 6 mei 1980, 102/79, Commissie v. Belgiè, Jur. 1980, 1473235 


\section{Zakenregister}

Aanwijzingen inzake terughoudend heid met regelgeving

aanwijzing 7100,115

Aanwijzingen voor de regelgeving 1993

aanwijzing 2211

aanwijzing 3211,217

aanwijzing $17 \quad 194$

aanwijzing $19 \quad 219$

aanwijzing $22 \quad 104,116,282$

aanwijzing $23103,116,131,284$

aanwijzing $24116,131,282,283$

aanwijzing $25104,113,116,284$

aanwijzing $26105,131,199,284,285$

aanwijzing $27 \quad 105$

aanwijzing 28183,193

aanwijzing $30 \quad 183,303$

aanwijzing 3318,33

aanwijzing $36 \quad 119$

aanwijzing $38 \quad 120$

aanwijzing $40 \quad 120$

aanwijzing $42 \quad 120$

aanwijzingen 26-30 194

aanwijzing $328 \quad 130$

aanwijzing $339 \quad 130$

Aanwijzingen voor de wetgevingstechniek 1984

aanwijzing $5197,104,110$

aanwijzing $5297,104,128$

aanwijzing 5398

algemeen verbindend voorschrift 223,224

ornschrijuing 9,217

wettelijke grondslag 225

algemene maatregel van bestuur

zelfstandige 51,52

attributie

in wetsvoorstel Derde tranche Awb 30 van bestuursbevoegdheid 19,170

van regelgewende bevoegdheid 12

beleidsregel

en delegatieterminologie 243 en delegatievraagstuk 242

en grondwetsherziening 1983207

in jurisprudentie 179,212

in wetswoorstel Derde tranche Awb 212 , 214

inherente afwijkingsbewoegdheid 209 , 230,239

omschrijving 9

ontwikkeling $177,204-207,209$

recht in de zin van artikel 99 Wet RO 211

beleidsregel-algemeen verbindend voor schrift

gellikstelling $206,210,238-241,245$, $304,306,307$

gellijkstelling; gevolgen voor delegaticterminologie 243,244

overeenkomst; algemeenheid 227

overeenkomst; beroepsmogelijkheden 227

overeenkonst; toetsing 228

overeenkomst; totstandkoming 226

verschil; beperken van grondrecliten 232

verschil; implementatie van EG-regelgeving 234

verschil; inbreuk legaliteitsbeginsel 231

verschil; inherenteaf wijkingsbevoegdheid: 230

verschil; toedelen wan bevoegdheden 233 verschil; wettelijke grondslag 229

besluit van algemene strekking 221

bestuursbevoegdheid

discretionaire $137,138,166,189,209$, 274,302

en ongeschreven recht 270

en publieke taak-criterium 271

omschrijuing 6

bestuursorgaan 6

bevoegdheidstoedeling 9

conversie 235,237

delegatie

gecontroleerde $61,119,121$ 


\section{Zakenregister}

grenzen aan $54,56,60,62,115-117$, 184

in wetsvoorstel Derde tranche Awb 28 ongeoorloofde $167,168,186$

tijdelijke 120,121

van bestuursbevoegdheid 20

van regelgevende bevoegdheid 15,17 , $40,53,111,113,165,170,194,245$, 308

vereiste van goedkeuring bij wet 120

voorwardelijke 120,121

delegatieterminologie

betekenis $5,86,91,93,95,107,109$, 293

bij implementatie EG-regelgeving 130 . 132

en artikel $104 \mathrm{Gw}$ (belastingen) 128

en artikel $23 \mathrm{Gw} 296$

en artikel $23 \mathrm{Gw}$ (onderwijs) 125

en artikel 36 Gw (koninklijk gezag) 127

en artikelen 97-102 Gw (defensie) 127

en bevoegdheden van lagere owerheden 88,92

in de Aanwijzingen voor de regelgeving 1993103

in horizontale verhoudingen 155

relatie to wetsvoorstel Derde tranche Awb 36

delegatieverbod $86,95,97,103,137,138$, $143,144,158,165,169,245,273,287$, $294,295,301$

in jurisprudentie 149,302

reikwijdte $93,166,297$

delegatievraagstuk $7 I, 3 I I$

historie 39,298

ontwikkeling na $1983100,107,299$

EG-regelgeving

implementatie bij algemeen verbindend voorschrift 234

implementatie bij beleidsregel 234

implementatie en dellegatieterminollogie 130,132

formeel wetsbegrip $41,48,59$

in artikel 81 Gw? 252,254 grondrechten

horizontale verhoudingen en delegatieter-

minologie 155

leer van de algemene beperkingen 149 , 151

Grondwet 1887

artikell $5646,50,51,63,79$

Grondwet 1922

artikel $194 \quad 81$

Grondwet 1938

artikel 5761,63

artikel 11259,62

artikel $112 \mathrm{Gw} 54$

artikel 12454

Grondwet 1953

artikel $188 \quad 205$

Grondwet 1956

artikel 5772

Grondwet 1972

artikel $43 \quad 128$

artikel $56 \quad I I$

artikel $61 \quad 12$

artikel $62 \quad 12$

artikel $64 \quad 12$

artikel $97 \quad 12$

artikel $101 \quad 12$

artikel $188 \quad 129$

artikel $208 \quad 126$

Grondwet 1983

artikel 189,259

artikel $2 \quad 135,136,149$

artikel 3,89

artikel 589

artikel $689,90,103,137,150$

artikel $789,90,103,140,151,152,259$

artikel $8 \quad 89,273$

artikel $988-90,103,137,138$

artikell $1088,89,92,136,140,147,152$

artikel $11 \quad 136,147,152,155,256$

artikel $12 \quad 257$

artikel $15 \quad 153$

artikel $18 \quad 88,141,153,267$

artikel $19 \quad 153,267$

artikel $20 \quad 267$ 


\section{Zakenregister}

artikel $23103,125,154,296$

artikel $36 \quad 87,127$

artikel $37 \quad 15$

artikel $42 \quad 11$

artikel $53 \quad 257$

artikel 57259

artikel $60 \quad 12$

artikel $68 \quad 125$

artikel $79 \quad 142$

artikel $80 \quad 143$

artikel $8111,13,14,39,252,254,255$,

289,309

artikel $8968,87,116,117,127,217$,

$231,245,275$

artikel $9112,116,117,132,144$

artikel $95 \quad 144$

artikel $98 \quad 126$

artikel $99 \quad 126$

artikel $100 \quad 87,126,127$

artikel $102 \quad 126$

artikel $10498,1 / 4,128,148,205$

artikel $106 \quad 117$

artikel 10736,145

artikel 109267

artikel 111257

artikel 11211,103

artikel $113 \quad 11$

artikel $116 \quad 87,258$

artikel $120101,129,148,156$

artikel $122 \quad 258$

artikel $123 \quad 92$

artikel $12786,87,127$

artikel $13292,114,117,155,237$

artikel $135 \quad 258$

artikelen 97-102 126

legalliteitsbeginsel

en formele wetgever 249,272

en presterend overheidsoptreden 265 , 267

en privaatrechtelijk overheidsoptreden 267.269

formele benadering $286,289,308$

in 19 e euw 251

in jurisprudentie 277,278

klassieke opvatting 262, 305 materiële benadering 289

ruimere opvatting $263,270,275,278$, 308

mandaat

in wetsvoorstel Derde tranche Awb 24

ondertekenings - 25,27

van bestuursbevoegdheid 22

wan regelgevende bevoegdheid 18,33

materieel wetsbegrip 54

criteria 282,284

in artikel $81 \mathrm{Gw}$ ? $252,254,255$

ingrijpende besluiten $281,282,285,309$

materiële benadering 282,283

ministeriele regeling $64,66,68$

ondermandaat 23

in wetsvoorstel Derde tranche Awb 25

onderscheid

beleidsregel-algemeen verbindend voorschrift 304

regelgeving-uitvoering $8,90,92,163$, $164,166,193,200,303$

onderscheid regelgeving-uitwoering

formeel criterium 173,195

materieel criterium $173,196,198$

rechtsstaat 261,264

regelgevende bevoegdheid 306

omschrijving 6

van minister $183,185,188,238$

subdelegatie $18,29,66,69$

toetsing

wan gedelegeerde regelgeving 17,108 , 156

uitvoering

begrip $8,42,45,53,164,174,182$, 190,194

in jurisprudentie $174-176,178,186$

uitwoeringsregel $162,216,303$

uitwoeringswetgeving

en artikel $2 \mathrm{Gw} 135$

en artikelen 6 en 9 Gw 138

en artikel $10 \mathrm{GW} 140$

en artikel $18 \mathrm{GW} \quad 14 \mathrm{I}$

en artiket $79 \mathrm{Gw} 142$

en artikel $80 \mathrm{Gw} 143$

en artikelen 91 en $95 \mathrm{Gw} \quad 14$ 


\section{Zakenregister}

en artikel 107 ow 145

wetshegrip 251,252,254,255

Wetsvoorstel Derde tranche $A$ wb artikel $1: 3$ lid 49 artikel $1 \mathrm{~A} .1 .1,124$

artikel 1A.1.1.1a 25,26

artikel 1A.1.1.2 24, 26, 33

artikel $1 \mathrm{~A} .1 .4 .425$

artikel 1A.1.1.5 25

artikel $1 \mathrm{~A} .1 .1 .6 \quad 25$

artikel IA.1.1.724,25

artikel 1A.1.1.8 25

artikel 1A.1.11.925

artikel 1A.1.1.10 25

artikel $1 \mathrm{~A} .1 .1 .11 \quad 25,27$

artikel 1A.1.1.12 25 artikel 1A.1.2.1 28

artikel 1A.1.2.2 24, 28

artikel 1A.1.2.3 28, 29, 192

artikel 1.A.1.2.4 28

artikel 1A.1.2.5 16, 28

artikel 1.A.1.2.6 28

artikel 1A.1.2.7 28

artikel IA.1.2.8 28

artikel $4.4 .1 \quad 213,229,230$

artikel $4.4 .2 \quad 213$

artikel $4.4 .3 \quad 213$

artikel 4.4.4 21.3

artikel $4.4 .5213,214,216,230$

wettelijke grondslag $190,277,278$

algemene 155,306

specifieke 151,154,302,306 


\section{Curriculum vitae}

Johanna Maria Elisabeth (Annemiek) Derks werd geboren op 30 augustus 1960 te Nijmegen. Na het behalen van het diploma Gymnasium-B in 1978 aan de scholengemeenschap Jerusalem te Venray, rondde zij in 1984 de opleiding Schootmuziek-B aan het Maastrichts Conservatorium af. In datzelfde jaar begon zij met de opleiding Nederlands Recht an de Rijksuniversiteit Limburg die zij in 1988 cum laude afsloot. $\mathrm{Na}$ een jaar als medewerker onderwijs aan de Juridische Faculteit van de RL verbonden te zijn geweest, werd zij in september 1989 bij diezelfde faculteit aangesteld als Assistent in Opleiding.

Sinds augustus 1995 werkt zij bij de Griffie van het College van Besfuur aan de Rijksuniversiteit Limburg. 